UNIVERSIDAD DE SALAMANCA

Departamento de Estadística

Doctorado en Estadística Multivariante Aplicada

Tesis Doctoral

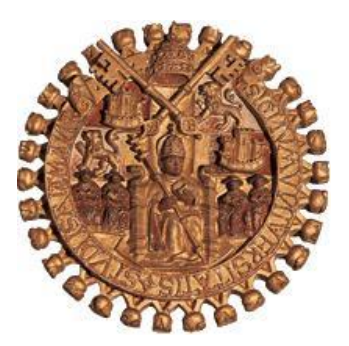

\title{
Análisis Multivariante de las Prácticas de Responsabilidad Social Corporativa y su Evolución en el Tiempo
}

\author{
Autor: Víctor Amor Esteban \\ Directoras: María Purificación Galindo Villardón \\ Isabel María García Sánchez
}





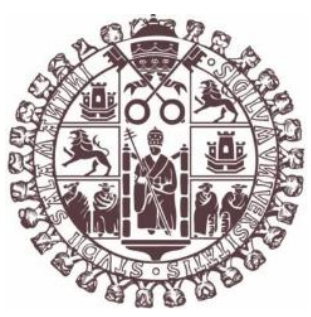

Dpto. de Estadística

Universidad de Salamanca

Dra. María Purificación Galindo Villardón

Catedrática de Universidad. Área de Estadística e Investigación Operativa Departamento de Estadística de la Universidad de Salamanca

y

Dra. Isabel María García Sánchez

Catedrática de Universidad. Área de Economía Financiera y Contabilidad Departamento de Administración y Economía de la Empresa de la Universidad de Salamanca

Certifican que D. Víctor Amor Esteban ha realizado en la Universidad de Salamanca, bajo su dirección, el trabajo que para optar al título de Doctor en Estadística Multivariante Aplicada, presenta con el título Análisis Multivariante de las Prácticas de Responsabilidad Social Corporativa y su Evolución en el Tiempo, autorizando expresamente su lectura y defensa.

Y para que conste, firman el presente certificado en Salamanca a _ de julio de 2018.

María Purificación Galindo Villardón Isabel María García Sánchez 



\section{ANÁLISIS MULTIVARIANTE DE LAS PRÁCTICAS DE RESPONSABILIDAD SOCIAL CORPORATIVA Y SU EVOLUCIÓN EN EL TIEMPO}

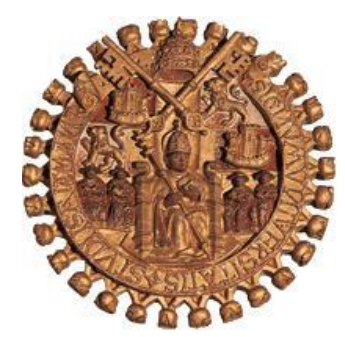

Dpto. de Estadística

Universidad de Salamanca
Trabajo para optar al título de Doctor en

Estadística Multivariante Aplicada por la Universidad de Salamanca

Presenta:

Víctor Amor Esteban

\section{Salamanca}





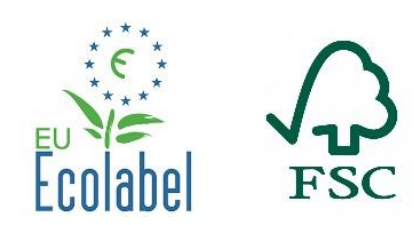

Esta tesis se ha impreso en papel 100\% ecológico 



\section{AGRADECIMIENTOS}

En primer lugar, quiero agradecer a todos los compañeros del Departamento de Estadística por conseguir con su trabajo que esto sea posible, por sus enseñanzas y su completa disposición para resolver cualquier problema; por permitirme formar parte de este gran grupo que no para de crecer y proponerse nuevas metas, indudablemente esa es la mejor enseñanza que me llevo.

Gracias a mis dos tutoras, la Dra. M ${ }^{a}$ Purificación Galindo Villardón -Catedrática en el Área de Estadística- y la Dra. Isabel María García Sánchez -Catedrática en el Área de Economía-, por haberme brindado la posibilidad de trabajar en un tema de gran impacto y trascendencia internacional como es la Responsabilidad Social Corporativa, por su orientación e instrucción durante estos años y, porque cinco minutos con ellas pueden ahorrarte días de trabajo. A Puri, aparte de poder trabajar a tu lado, hipnotizarme con tus enseñanzas o la facilidad y rapidez que tienes para resolver cualquier análisis independientemente de la técnica utilizada, tengo que agradecerte sobretodo aquella conversación antes de empezar el máster, yo había salido de la carrera y no tenía muy claro que debía hacer y tú me diste la confianza y el apoyo que necesitaba. Para mí, fue un punto de inflexión, un giro de $180^{\circ}$ en mi vida académica y, gracias a tu apoyo y tus consejos he podido afrontar retos que en la vida hubiera imaginado; espero haber reflejado mínimamente esa confianza ya que nunca pensé que podría llegar a escribir esta hoja, de verdad, GRACIAS. A Isabel, tengo que agradecerte la predisposición y amabilidad con la que me recibiste desde el primer día, fue muy fácil ganar esa pequeña confianza para que no fuera expresamente trabajo. Es realmente increíble tu conocimiento y experiencia en el tema, como manejas cada uno de los apartados y la destreza para encontrar siempre una solución rápida y precisa. Aunque para mí, el mayor mérito ha sido saber inculcarme parte de ese conocimiento ayudándome a entender, a través de la lectura de muchas investigaciones, qué es lo que los lectores buscan y como mostrárselo mediante los métodos estadísticos en un lenguaje asequible para el campo, de verdad, GRACIAS.

Por supuesto, quiero agradecer todo este camino a mi familia, quienes me han permitido llegar hasta aquí. A mis padres, con especial mención a mi madre y ya no solo por el trabajo sino porque siempre que tengo un problema, trate de lo que trate, marco el mismo número... pase lo que pase siempre tengo tu apoyo!!! No podía olvidarme de mi abuela, que será de las personas que más se alegre conmigo, gracias porque has sido como una segunda madre.

A mis amigos de Salamanca, por todos y cada uno de los momentos vividos, porque sin duda son lo mejor de todos estos años, sus amistades. Todos hemos conseguido logros académicos pasando por momentos difíciles, épocas de exámenes, nervios, tensión, etc. Pero sin dudarlo ni un segundo estoy seguro de que cualquiera si tuviera la opción volvería atrás para revivir todos esos momentos aun pagando el peaje de volver a superar los momentos difíciles. A mi hermano, que por supuesto le incluyo dentro de este párrafo, pero quiero destacar los partidos del Barça (hasta arriba de pepinillos), ya pronto salimos a verlos en directo.

En particular, agradecer a Armando por aquellas conversaciones en las que siempre tiene la palabra o el consejo más adecuado para el momento, gracias amigo me fuiste de especial ayuda, como tú ninguno. A Javi y a Angelillo, a Javi por aquel verano y esos meses de convivencia que sin duda me ayudaron a avanzar y, sobre todo por el ejido; y a Angelillo, ya ves que fácil nos ha sido siempre entendernos, esos vicios y comilonas, simplemente decirte que no cambien las cosas que sigan así años y años si hace falta, gracias hermano. A Cuba porque cada vez que nos vemos me supone una inyección de pura energía y positivismo siempre valorándome por encima de mis posibilidades jaja eres de esos amigos que espero no perder nunca la pista, un abrazo hermano y un saludito desde aquí para Alba. 
A mis compañeros de 'profesión' ya que nadie te puede entender mejor que aquellas personas que realizan tu misma labor. Apoyándonos en épocas de altibajos y ayudándonos los unos a los otros. Todas las conversaciones (aquellas de San Vicente con Nerea, por ejemplo), ya sea tomando una caña, en la azotea de un octavo, o en el parón de un acto, han sido de gran ayuda para la investigación ya que te aportan ideas o para desconectar, que en más de una ocasión es lo más importante, así que gracias a todos. Quiero destacar a varias personas. A mi amiga María, que la conozco desde el primer día que pisé una facultad y a día de hoy nos llevamos mejor que nunca, sabes que sin ti no hubiera sido posible nada de esto, muchísimas gracias. A mi amigo Domin, que después de diez años todavía recuerdo aquellas cervecillas en el o'hara's, buen Domin nada que ver todos estos años sin tu presencia. A Rodri y Pedrito por esas conversaciones alentándonos a no bajar el ritmo, me han ayudado mucho más de lo que os podéis imaginar, gracias y a seguir.

Por último, y no por ello menos importante sino todo lo contrario, gracias, gracias, gracias, a ti. Por demostrarme que quieres estar siempre a mi lado, tanto en las buenas como en las malas etapas. Para mí, eso es mucho más importante que el resto de cosas. Por estar siempre ahí y escucharme cuando lo necesito. Gracias por ser mi acompañante y mejor apoyo. 
"No dejes que tu pasado, sea cual sea, oscurezca tu visión de un futuro brillante."

Alex Rovira 



\section{Índice}

Introducción................................................................... 1

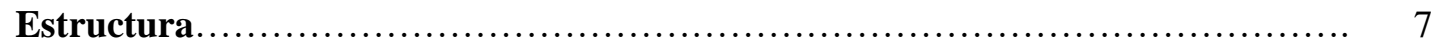

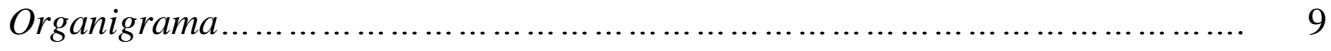

Breve Descripción por Capítulo .................................................. 17

Parte I. Comportamiento Empresarial Sostenible a Nivel Nacional 25

Capítulo I. El Efecto de la Identidad Nacional en el Comportamiento

Empresarial Sostenible.................................................. 27

Study of the Importance of National Identity in the Development of Corporate Social Responsibility Practices: a Multivariate Vision ................................ 29

Capitulo II. El Papel Influyente de los Valores Culturales en la Sostenibilidad Empresarial................................................................... 6

Cultural values on CSR patterns and evolution: A study from the biplot representation....

Capítulo III. El Sistema Legal como Factor Explicativo de las Prácticas de Responsabilidad Social Corporativa ......................................... Analysing the Effect of Legal System on Corporate Social Responsibility (CSR) at the Country Level, from a Multivariate Perspective .....................................

Capítulo IV. Propuesta de Indicador Nacional de Prácticas de Responsabilidad Social Corporativa.

A multivariate proposal for a National Corporate Social Responsibility Practices Index (NCSRPI) for international settings 
Capítulo V. Consistencia y Robustez de los Indicadores Nacionales de Sostenibilidad Empresarial.

Consistency and Robustness of the National Indicators of Business Sustainability through a Multivariate Vision....

Parte II. Comportamiento Empresarial Sostenible a Nivel Sectorial.

Capítulo VI. El Efecto de las Especificidades Sectoriales en la Responsabilidad Social Corporativa...

A Multivariate Vision of the Industry Specificity as an Explanatory Factor of Companies' Social Performance...

Capítulo VII. El Isomorfismo Mimético en la Sostenibilidad Empresarial .

Industry mimetic isomorphism and firm's sustainability based on the X-STATIS and HJ-biplot methods.....

Capítulo VIII. Propuesta de Indicador Sectorial de Prácticas de Responsabilidad Social Corporativa.

Useful information for stakeholder engagement: A multivariate proposal of an Industrial Corporate Social Responsibility Practices Index

Capítulo IX. Extensión y Utilidad del Indicador Sectorial de Sostenibilidad

An extension of the industrial corporate social responsibility practices index: New information for stakeholder engagement under a multivariate approach.

Parte III. Comportamiento Empresarial Sostenible a Nivel Empresa.

Capítulo X. Propuesta de Indicador de Prácticas de Responsabilidad Social Corporativa a Nivel Empresa.

Proposal for an Aggregate International Sustainability Index at the Organizational Level from CUR Matrix Decomposition

Conclusiones 


\section{Introducción}

La Responsabilidad Social Corporativa (en adelante, RSC) se remonta a la década de 1950, y "comprende las expectativas económicas, legales, éticas y discrecionales que la sociedad tiene de las organizaciones en un momento determinado" Carroll $(1979, \mathrm{p} 500)^{1}$, debido a la interrelación que existe entre los negocios y la sociedad. De acuerdo con Wood $(1991)^{2}$, es esta interrelación lo que conlleva a que la sociedad tenga ciertas expectativas sobre el comportamiento empresarial que van más allá de los resultados económicos.

Desde su comienzo hasta la actualidad han existido muchas definiciones y una gran cantidad de investigaciones tanto teóricas como empíricas, aun así, la conceptualización de la RSC es diversa y compleja porque no es una realidad física sino una construcción social, en la que cada individuo mira desde la óptica de sus conocimientos, capacidades e intereses. No obstante, existen varios componentes comunes, como lo es la referencia a tres dimensiones en el análisis de la actuación organizativa: económica -orientada a la búsqueda de una gestión transparente y la distribución correcta de la riqueza que se genera en la organización-; social-implica la necesidad de garantizar la equidad intergeneracional en aspectos sociales y calidad de vida-; y, medioambiental -enfocada a garantizar la sostenibilidad de los recursos medioambientales a lo largo del tiempo mediante la conservación de energía, reducción de residuos y contaminación o la limitación de ciertos recursos-; sin olvidar las relaciones con los stakeholders (parte interesada de la empresa: empleados, clientes, proveedores, accionistas, etc.) ante los que la empresa debe legitimarse, así como el carácter voluntario de estas responsabilidades. También está presente el carácter integrado de la RSC en la estrategia, políticas y operaciones. Con todo esto, la RSC puede ser vista como ese conjunto de responsabilidades que la empresa asume ante la sociedad, que irán cambiando, porque cambian las circunstancias y la misma sensibilidad de los actores.

En los últimos años, las demandas de los grupos de interés, los acuerdos gubernamentales a nivel mundial y las presiones de activistas han atraído una mayor cobertura de prensa sobre los impactos sociales y medioambientales de las grandes compañías, principalmente. A su vez, han comenzado a aparecer índices bursátiles de sostenibilidad, analistas y rankings que clasifican a las empresas según su desempeño en RSC, atrayendo una considerable publicidad y potenciales ventajas económicas y reputacionales para aquellas compañías mejor posicionadas. Como resultado, la RSC se ha convertido en una prioridad para las empresas de todo el mundo y en un área de estudio emergente en el ámbito académico, lo que se ha traducido en un número creciente de trabajos de investigación sobre el tema.

La RSC tiene la característica de ser una idea verdaderamente global, y sus características globales podrían dar lugar a la suposición de que la dinámica nacional o industrial es secundaria o incluso irrelevante; sin embargo, mientras que la RSC puede ser de naturaleza global, la investigación reciente sugiere que se aplica de manera diferente según los contextos

\footnotetext{
${ }^{1}$ Carroll, A. B. (1979). A three-dimensional conceptual model of corporate performance. Academy of management review, 4(4), 497-505.

${ }^{2}$ Wood, D. J. (1991). Corporate social performance revisited. Academy of management review, 16(4), 691718.
} 
institucionales con diferentes características sociales, económicas, culturales, jurídicas y políticas. Según Campbell (2007) ${ }^{3}$, las empresas son vistas como unidades económicas que operan dentro de contextos formados por un entramado de instituciones que afectan a su comportamiento e imponen expectativas sobre ellas. Este entorno institucional define 'las reglas del juego' en una sociedad o, más formalmente, las limitaciones ideadas humanamente que dan forma a la interacción social; o dicho de otra forma, el contexto institucional en el que opera la empresa establece una serie de oportunidades y barreras en la decisión de adoptar o mejorar su comportamiento sostenible. Siguiendo estas pautas, las organizaciones que operan en contextos similares, es decir, en entornos con estructuras institucionales paralelas, probablemente adoptarán patrones homogéneos de comportamiento socialmente responsable. DiMaggio and Powell $(1983)^{4}$ sostienen que este proceso mejora la estabilidad y la supervivencia de la empresa, facilita el poder político y la legitimidad institucional, y lo denominan 'isomorfismo'.

Las expectativas y reglas de comportamiento que provocan el isomorfismo empresarial provienen de presiones normativas, coercitivas y miméticas (Matten and Moon, 2008) ${ }^{5}$. Las presiones normativas se imponen formal o informalmente por grupos supra empresariales y / o se derivan de los valores culturales que prevalecen en el entorno en el que opera la empresa. El isomorfismo coercitivo hace referencia a las reglas, estándares o leyes que determinan el marco legal y / o profesional de las prácticas empresariales, pero también puede identificarse con las presiones que ejercen sobre la empresa los proveedores externos de recursos que fuerzan o limitan a la empresa a adoptar determinados comportamientos. El isomorfismo mimético es adoptado por compañías con baja tolerancia a la incertidumbre que, en lugar de diseñar un plan de acción propio, deciden imitar las prácticas empresariales de aquellas compañías líderes y reputadas, considerando que la simple imitación conduce a la legitimación de su actividad; las presiones miméticas son tradicionalmente asociadas con los sectores de actividad.

Un aspecto de vital importancia para la RSC es cuantificar toda esta información, para poder evaluar y medir el compromiso con la sostenibilidad de las empresas y, por ende, la comparación de resultados entre nacionalidades o sectores de actividad. Como se mencionó anteriormente, en los últimos años ha aparecido un creciente interés por parte de las compañías en la presentación y divulgación de informes de RSC, traduciéndose en diversos modelos de reportes, indicadores, estándares, etc., donde por regla general -mayoría de países- el reporte es voluntario y, de esta forma, la información es poco fiable ya que las corporaciones pueden seleccionar de manera arbitraria qué, cuánto y cómo informar y, mostrar únicamente aquellas actividades o estándares que las sitúen en un umbral positivo. Debido a este problema, actualmente es muy complicado utilizar medidas directas de las prácticas de RSC de las empresas porque las divulgaciones son voluntarias; consecuentemente, son incomparables porque no divulgan datos similares. Por lo tanto, a la hora de evaluar el desempeño global o las prácticas de RSC de una empresa es aconsejable obtener la información de agencias de calificación externa de conocida reputación: EIRIS, KLD, Bloomberg, ASSET4, etc.

A pesar de la existencia de investigaciones extensas e importantes sobre la RSC, relativamente pocos estudios han investigado los efectos de las condiciones institucionales sobre la conducta empresarial responsable de una manera internacional. De este modo, la mayoría presentan varias limitaciones que restringen la generalización de los resultados, como la reducción del número de países analizados, un único año de estudio, tomar en consideración solamente la información ambiental o contar exclusivamente con empresas pertenecientes a un único sector de actividad. Sobre la base de la teoría neo-institucional y el análisis institucional comparativo, esta tesis examina cómo los factores institucionales influyen en las prácticas de RSC mediante la adopción de un enfoque multi-región considerando una muestra de las grandes empresas internacionales que cotizan en bolsa y procedentes de todos los sectores de actividad, durante la

\footnotetext{
${ }^{3}$ Campbell, J. L. (2007). Why would corporations behave in socially responsible ways? An institutional theory of corporate social responsibility. Academy of management Review, 32(3), 946-967.

${ }^{4}$ DiMaggio, P., \& Powell, W. W. (1983). The iron cage revisited: Collective rationality and institutional isomorphism in organizational fields. American sociological review, 48(2), 147-160.

${ }^{5}$ Matten, D., \& Moon, J. (2008). "Implicit" and "explicit" CSR: A conceptual framework for a comparative understanding of corporate social responsibility. Academy of management Review, 33(2), 404-424.
} 
década 2004-2014. Con el objetivo de obtener información fiable y comparable utilizamos únicamente datos procedentes de una agencia reguladora gubernamental de calificación externa de gran prestigio internacional conocida como EIRIS (Ethical Investment Research Services). EIRIS es un proveedor global líder de investigación independiente sobre el desempeño ambiental, social y de gobierno (ESG) y, sus datos facilitan el estudio de las prácticas de RSC de las empresas abarcando las diferentes perspectivas de la sostenibilidad -medioambiente, derechos humanos, empleados (RSC interna), stakeholders (RSC externa) y códigos éticos-.

Dado el carácter multidimensional de los datos, es esencial analizarlos con técnicas que capturen este carácter multivariante. Tras una exhaustiva revisión bibliográfica sobre estudios de sostenibilidad de la empresa, hemos detectado que la mayoría se centran en análisis de regresión o análisis multivariantes individuales o de dos vías, aunque pocos; lo cual muestra una clara discordancia entre el crecimiento de las técnicas estadísticas multivariantes para la inspección de datos de tres vías y su uso en estas investigaciones, a pesar de que claramente los datos tienen esa estructura tridimensional: individuos, variables y tiempo. Los individuos se corresponden con las empresas, o en su defecto la agrupación de éstas en sus países de procedencia o el sector de actividad al que pertenecen; las variables hacen referencia a prácticas internaciones que evalúan el compromiso sostenible de las actividades de las compañías; y, el tiempo en relación a los años de estudio.

Durante muchos años, para comparar estructuras se analizaban por separado las diferentes tablas de datos y el investigador 'elucubraba' sobre las posibles relaciones entre las estructuras encontradas en cada una de las matrices. Hoy en día existen muchos métodos estadísticos para estudiar, de manera objetiva, las relaciones entre las estructuras; sin embargo, su uso no está generalizado. Por esta razón se considera de gran interés, tanto teórico como práctico, el uso de estas técnicas en aplicaciones más allá de la estadística. Así, el principal objetivo de esta investigación es la demostración de que estos métodos son de gran utilizad para la resolución de muchos problemas de sostenibilidad en el manejo de grandes volúmenes de datos y, que estas técnicas aportan una visión más completa del problema que los análisis multivariantes individuales.

Cuando disponemos de un gran volumen de datos, es importante identificar sus principales características subyacentes para conseguir una mejor comprensión del comportamiento de muchos procesos. La reducción de la dimensionalidad del problema ayuda a resumir la información capturada por un gran número de variables mediante un número más pequeño de variables latentes. Así, priorizando los resultados visuales en busca de un lenguaje más asequible para los investigadores del campo de la sostenibilidad mundial, el estudio comparado de estos métodos nos proporcionará soluciones de gran impacto social en un tema de trascendencia a nivel internacional como es la RSC. Estos métodos nos permitirán, a diferencia de los métodos estadísticos tradicionales - mediante los cuales se podría examinar cada año por separado y hacer un análisis comparativo de similitudes y diferencias-, trazar los resultados en un solo plano factorial, representando la estructura consenso de todos los años y, facilitando la visualización de patrones de comportamiento entre nuestros individuos (empresas, países o sectores) en referencia a sus valores en las prácticas internacionales de RSC en el periodo de estudio. Además, facilitan un estudio de las relaciones entre matrices, en nuestro caso, nos mostrarán las similitudes y diferencias de las estructuras encontradas entre los años y, un estudio de las trayectorias, mediante el cual es posible analizar la evolución durante los años de estudio de cada uno de nuestros individuos o variables.

De este modo, a partir de métodos estadísticos multivariantes pertenecientes a la familia de datos de tres vías, este documento lleva a cabo un estudio exhaustivo de las prácticas de RSC en sus diferentes dimensiones en empresas a nivel internacional, centrándose en las economías desarrolladas y, proporciona resultados respecto a las discrepancias más importantes a nivel nacional y sectorial, en la década 2004-2014. En términos generales, se examina la influencia de las características del país de origen y el sector de actividad al que pertenece una empresa, de manera global y específica para cada una de las dimensiones de RSC; a partir de un análisis XSTATICO (análisis compromiso de una serie de co-estructuras) se caracteriza la relevancia de las prácticas de RSC en todo el mundo teniendo en cuenta su agrupación en las dimensiones social y ambiental; mediante un análisis Tucker3 se buscan interacciones más profundas para clasificar 
cada uno de los países a estudio en función de sus fortalezas y debilidades en las prácticas de RSC; a través de la aplicación de un CO-X-STATIS (co-estructura de dos análisis compromiso) se evalúa la importancia que otorga cada sector de actividad a sus prácticas de RSC en relación a su compromiso social y ambiental, caracterizando éstos en función de sus valores en cada una de las prácticas. Además, se evalúa el rol que los factores institucionales desempeñan en las prácticas de RSC en alusión a las diferentes nacionalidades y sectores de actividad; esto se lleva a cabo con el uso de la técnica X-STATIS, la cual nos permite representar la estructura consenso de todos los años y, visualizar patrones de comportamiento de las empresas en función de sus sistemas culturales (presiones normativas), legales (coercitivas) o miméticas (impacto sectores de actividad); y, a partir de la estructura consenso calculada y los métodos biplot, se describen qué valores culturales presentan mayor influencia sobre la RSC y específicamente sobre qué dimensiones y, se identifica que países o sectores se ven más o menos afectados por los mismos; siguiendo esta metodología se realizan estos análisis para las medidas que cuantifican el funcionamiento del sistema legal y las fuerzas miméticas.

En base a las discrepancias institucionales encontradas, este documento propone unos índices compuestos agregados de prácticas de sostenibilidad empresarial a nivel nacional y sectorial que determinan el nivel de penetración de la RSC, lo que permite una comprensión holística del desarrollo de la RSC y sus raíces. Para su cálculo, se ha llevado a cabo un análisis factorial exploratorio y un análisis de la teoría de respuesta al ítem con el objetivo de estudiar las relaciones del conjunto original de prácticas seleccionadas y en base a ello, un análisis factorial confirmatorio para probar la confiabilidad de todas las prácticas de RSC que forman parte del indicador y la validez del constructo. El ranking obtenido por dichos indicadores está relacionado con la idoneidad del contexto institucional para las prácticas de RSC, por lo que cuanto mayor sea la puntuación del índice, más adecuado será el entorno para las prácticas de RSC. Estos indicadores son herramientas esenciales para las organizaciones y la administración pública, ya que proporcionan una visión internacional de la sostenibilidad de la empresa y una visión general del estado de los sectores de actividad. La disponibilidad de un valor de referencia para cada país o sector sobre las prácticas de RSC puede ser útil en los procesos de toma de decisiones para los administradores y políticos públicos. Más concretamente, estas puntuaciones y los rankings asociados brindan una visión de la realidad de los negocios; el manejo de estos datos permite identificar las prioridades y los factores estructurales de su crecimiento y facilita el diseño de políticas de impulso más precisas y efectivas para el desarrollo sostenible. En este sentido, los países y sectores con un comportamiento empresarial más deficiente en torno a la RSC tendrán la información suficiente para elegir las políticas específicas con las que superar esas deficiencias.

Como último punto de esta investigación se propone un índice agregado de sostenibilidad empresarial a nivel organizacional basando su construcción en un método novedoso de selección de individuos en el manejo de grandes cantidades de datos conocido como descomposición matricial CUR, enmarcado en el entorno del big data. Este método utiliza un procedimiento automático y objetivo otorgando a cada empresa un valor o puntuación conocido como leverage que hace referencia a su influencia estadística dentro del conjunto de datos y, a mayor leverage, mayor nivel de desarrollo sostenible. Los resultados de este indicador nos permiten identificar las empresas más potentes de cada país o sector de actividad o, por el contrario, las más rezagadas en tal aspecto. Esta información es estudiada y contrastada con los índices anteriores a nivel nacional y sectorial, corroborando su funcionamiento y utilidad. De este modo, queda abierta una bonita e interesante línea de investigación futura, ya que, por ejemplo, podríamos seleccionar únicamente las empresas punteras en desarrollo sostenible y analizar el rol que los gerentes de diferentes empresas, especialmente el CEO (Chief Executive Officer, en español hace referencia al director ejecutivo o director general), podrían desempeñar en la toma de decisiones de RSC. Igualmente, futuras investigaciones podrían estar orientadas a estudiar el papel de la personalidad del CEO de cada compañía ateniendo al sector de actividad, ya que, el CEO de una empresa dedicada al sector financiero probablemente no tendrá el mismo pensamiento que el de una empresa dedicada a la producción de petróleo y gas.

Organizativamente, la tesis se presenta estructurada por artículos, con un total de diez capítulos agrupados en tres partes. Previamente se presenta una sección titulada 'estructura' donde 
se muestra toda esta información de una manera ordenada y con un breve resumen del contenido por capítulo.

La primera parte se orienta a conocer la realidad nacional y el efecto de las presiones institucionales asociadas a la sostenibilidad empresarial y comprende los capítulos I - V. El capítulo I estudia la importancia de la identidad nacional de las empresas atendiendo exclusivamente a su país de origen; el capítulo II evidencia el valor influyente de los valores culturales de cada país en la sostenibilidad; en el capítulo III se analiza el sistema legal nacional como un factor explicativo de las prácticas de RSC; el siguiente capítulo IV propone un indicador nacional de RSC; y, en el capítulo V se prueba la consistencia y robustez de este indicador comparándolo con otras propuestas previas.

La segunda parte de esta tesis se centra en el estudio del comportamiento empresarial sostenible a nivel sectorial y se compone de los capítulos VI - IX. El capítulo VI muestra la relevancia de la especificidad del sector de actividad en la RSC; en el capítulo VII se examina la influencia del isomorfismo mimético; el capítulo VIII propone un indicador sectorial de RSC; y, en el capítulo IX se extiende el indicador anterior en los sub-sectores de actividad mostrando una visión más amplia de la sostenibilidad.

La tercera y última parte modifica el estudio y tratamiento de las prácticas de RSC. Así, frente a la versión agregada a nivel país o sector de las partes primera y segunda de esta tesis, se adopta un enfoque micro o desagregado, abordando el análisis y conocimiento de las prácticas de RSC a nivel empresa. Esta última parte está formada por un único capítulo, el capítulo X, donde se lleva a cabo la propuesta de un indicador de RSC a nivel empresa, mostrando las empresas líderes en desarrollo sostenible de los diferentes países o sectores y, dejando abierta una amplia línea de investigación futura. 


\section{Estructura}

En este epígrafe presentamos el contenido de nuestra investigación divido en tres partes y estructurado por capítulos, donde cada uno de ellos hace referencia a un artículo de investigación publicado o sometido a revisión en una revista de impacto del ámbito del desarrollo sostenible y la Responsabilidad Social Corporativa (RSC). Esta información es presentada de dos formas diferentes:

- En las siguientes páginas se muestra de una manera animada un breve resumen del propósito de la tesis, acompañado de un organigrama, en el cual se expone la división del documento en sus tres partes - nivel nacional, nivel sectorial y nivel empresa-, desglosando cada una de éstas en sus correspondientes capítulos. Para cada capítulo se despliega su objetivo, técnicas estadísticas empleadas, principales conclusiones y el estado del artículo de investigación en el cual desemboca la información.

- A continuación, se muestra esta misma información de una manera ordenada y con más detalle para cada uno de los capítulos, tratando todos los temas sintetizados en la introducción; dividida en las tres partes mencionadas: (i) la primera parte expone cómo las características institucionales del país de procedencia de las empresas tiene una fuerte relevancia en las prácticas de RSC y, se propone un índice nacional de sostenibilidad empresarial; comprende los capítulos I - V; (ii) la segunda muestra el rol influyente del entorno industrial donde opera la empresa, evidenciando las diferencias en sostenibilidad en función del sector de actividad y, se propone un índice sectorial de sostenibilidad empresarial; se constituye por los capítulos VI - IX; y, (iii) la tercera presenta un índice a nivel empresa que contrasta y corrobora los resultados obtenidos en las partes anteriores $\mathrm{y}$, deja abierta una interesante línea de investigación futura; formada únicamente por el capítulo $\mathrm{X}$. 


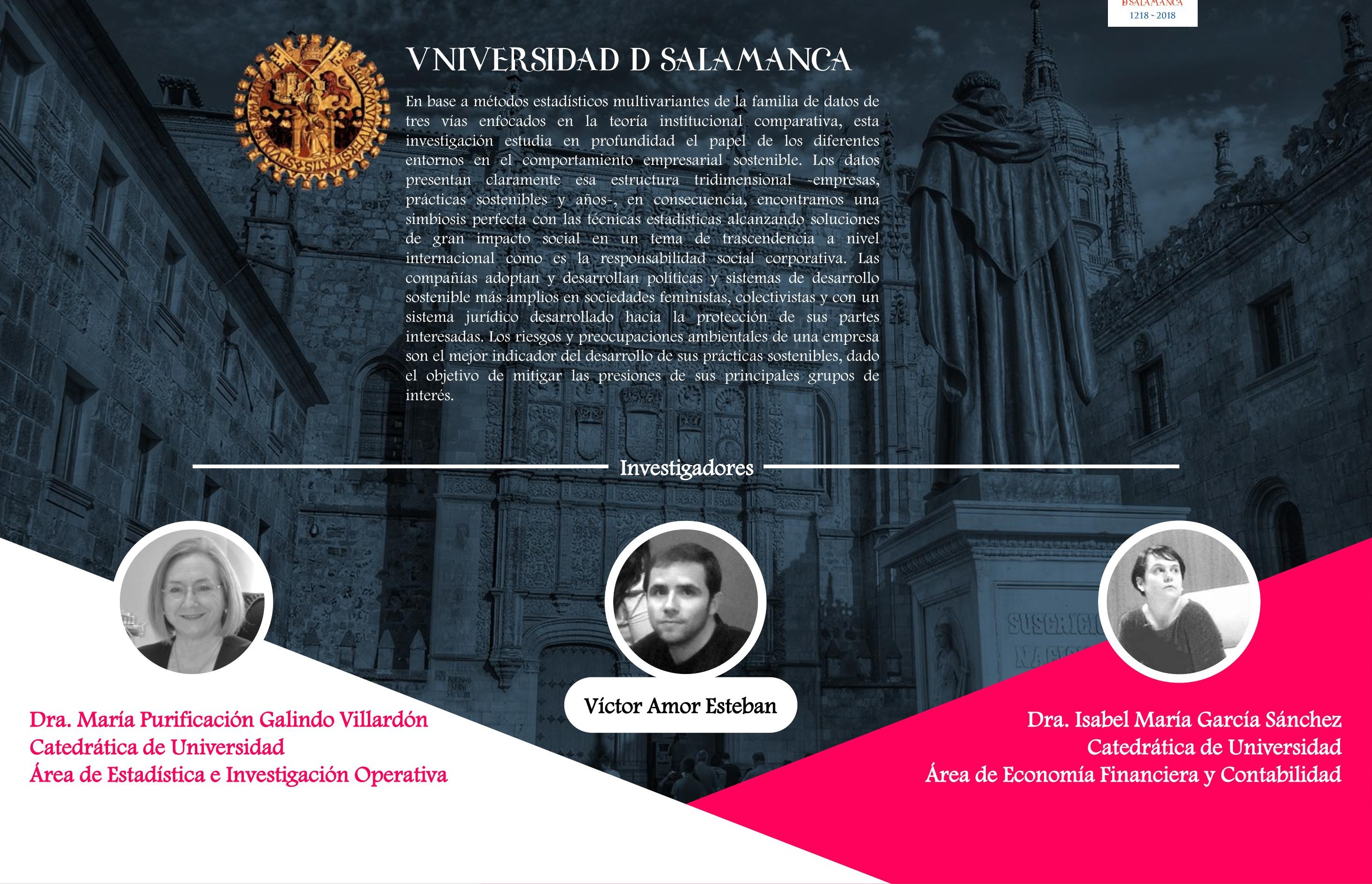





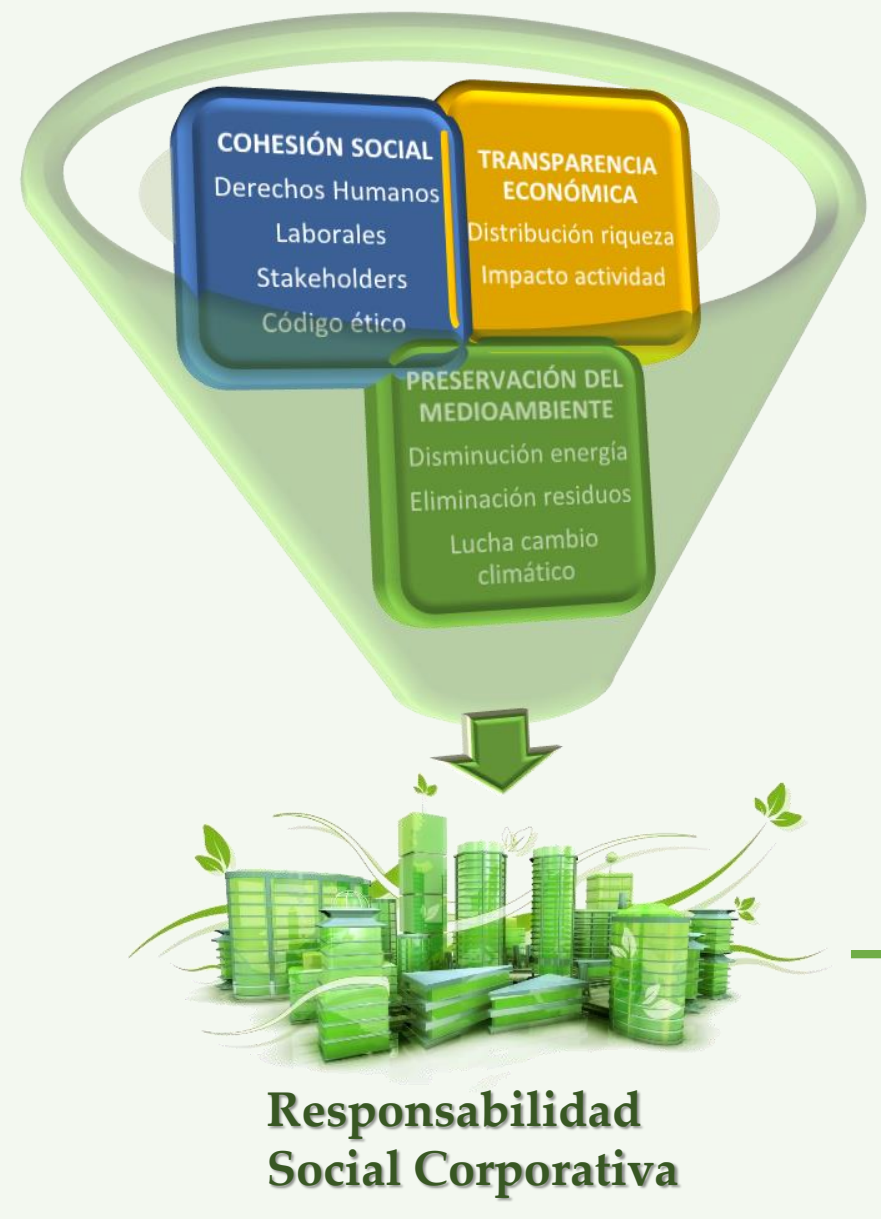

Parte I. Comportamiento Empresarial Sostenible a Nivel Nacional

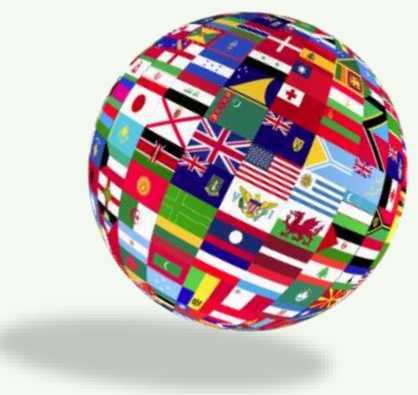

Parte II. Comportamiento Empresarial Sostenible a Nivel Sectorial

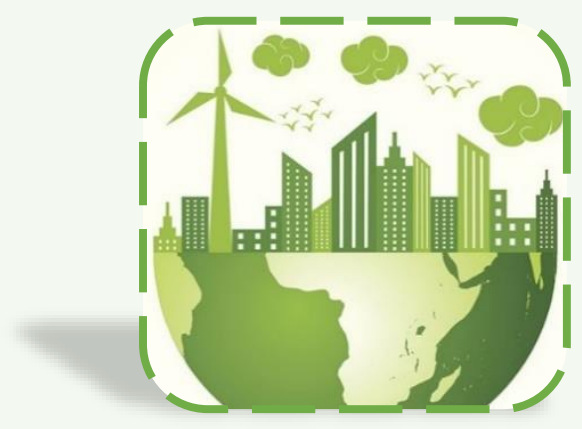

Parte III. Comportamiento Empresarial Sostenible a Nivel Empresa

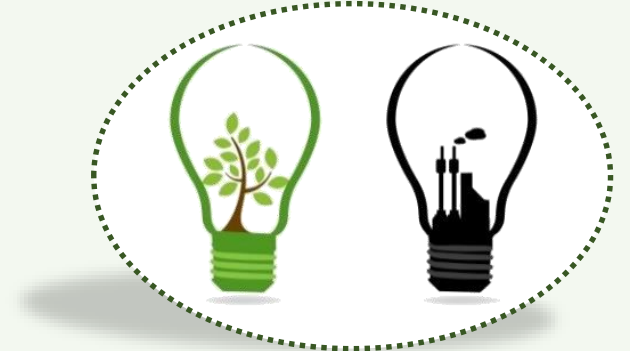

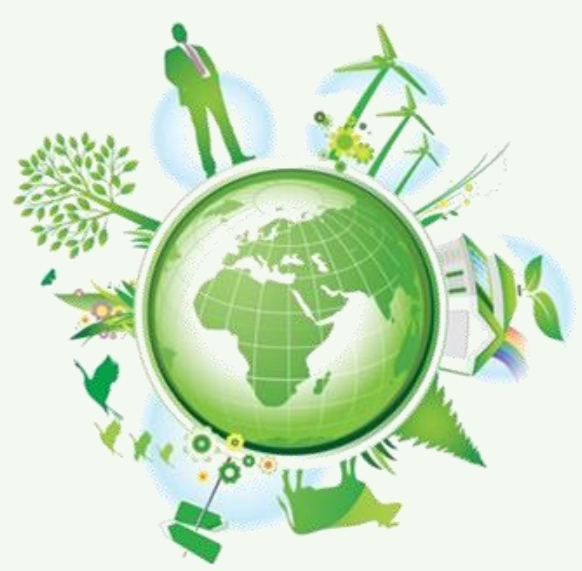

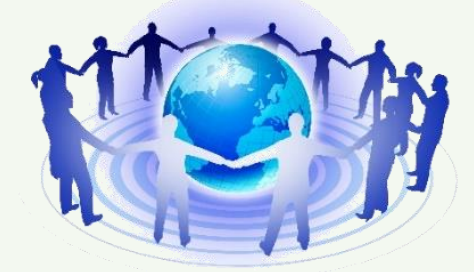





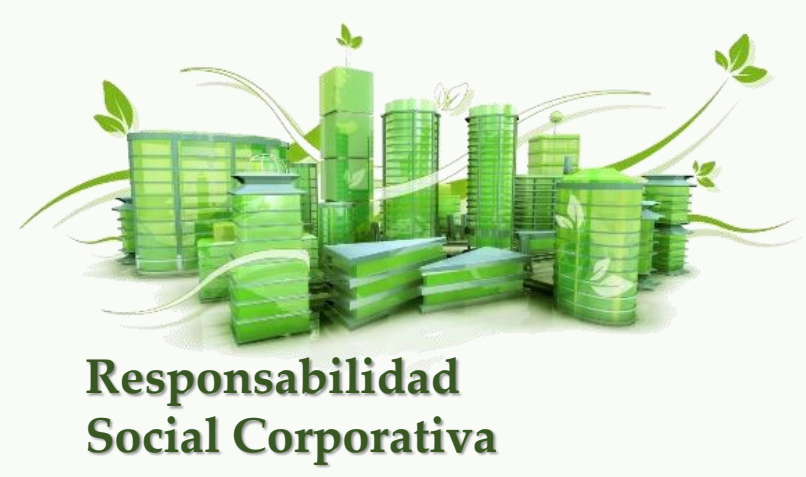

Parte I. Comportamiento Empresarial Sostenible a Nivel Nacional

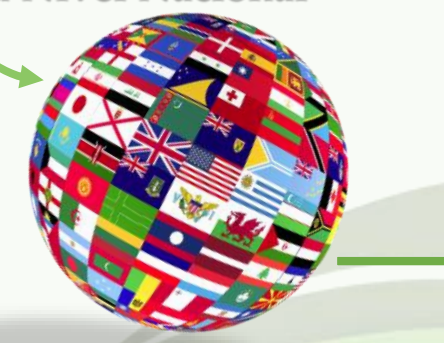

Parte II. Comportamiento Empresarial Sostenible a Nivel Sectorial

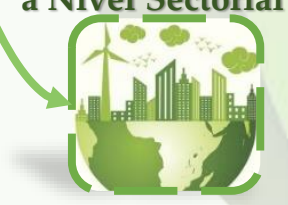

Parte III. Comportamiento Empresarial Sostenible a Nivel Empresa

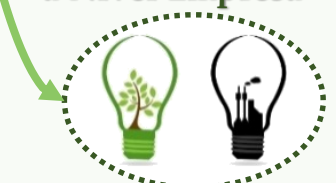

Capítulo I

El Efecto de la Identidad Nacional en el Comportamiento Empresarial Sostenible

Capítulo II

El Papel Influyente de los

Valores Culturales en

la Sostenibilidad

Empresarial

Capítulo III

El Sistema Legal

como Factor Explicativo

de las Prácticas de

Responsabilidad

Social Corporativa

Capítulo IV

Propuesta de

Indicador Nacional

de Prácticas de

Responsabilidad

Social Corporativa

Capítulo V

Consistencia y Robustez

de los Indicadores

Nacionales de

Sostenibilidad

Empresarial
Importancia País de Origen:

X-STATICO: relevancia prácticas RSC en todo el mundo

- Tucker3: relevancia prácticas RSC en referencia al país de origen

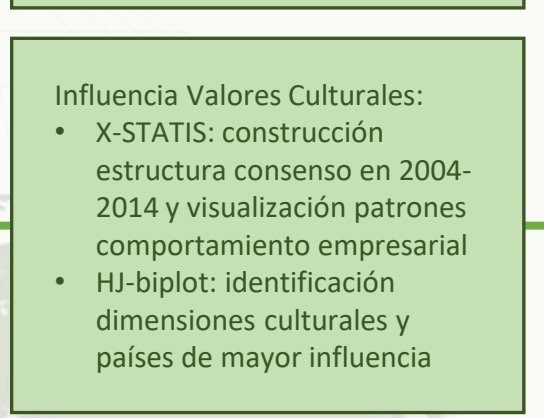

Relevancia Sistema Legal:

- X-STATIS: visualización empresas según su consenso en 2004-2014

- HJ-biplot: medidas del sistema legal con un papel más importante en la RSC y países específicos

Construcción Indicador Agregado:

- Análisis Factorial Exploratorio y Teoría de Respuesta al Ítem: selección prácticas relevantes con mayor información

Análisis Factorial

Confirmatorio: modelo resultante para la construcción del índice

Comparativa Índice Nacional RSC: Regresión lineal: alta similitud demostrando consistencia y robustez

Métodos biplot: explicación estructura índice propuesto a partir de otras iniciativas internacionales de RSC
Las instituciones nacionales y tradiciones ideológicas

distintivas determinan

las decisiones corporativas. Alto nivel de homogeneidad dentro del mismo continente $y$ mayor acorde a la proximidad geográfica entre países.
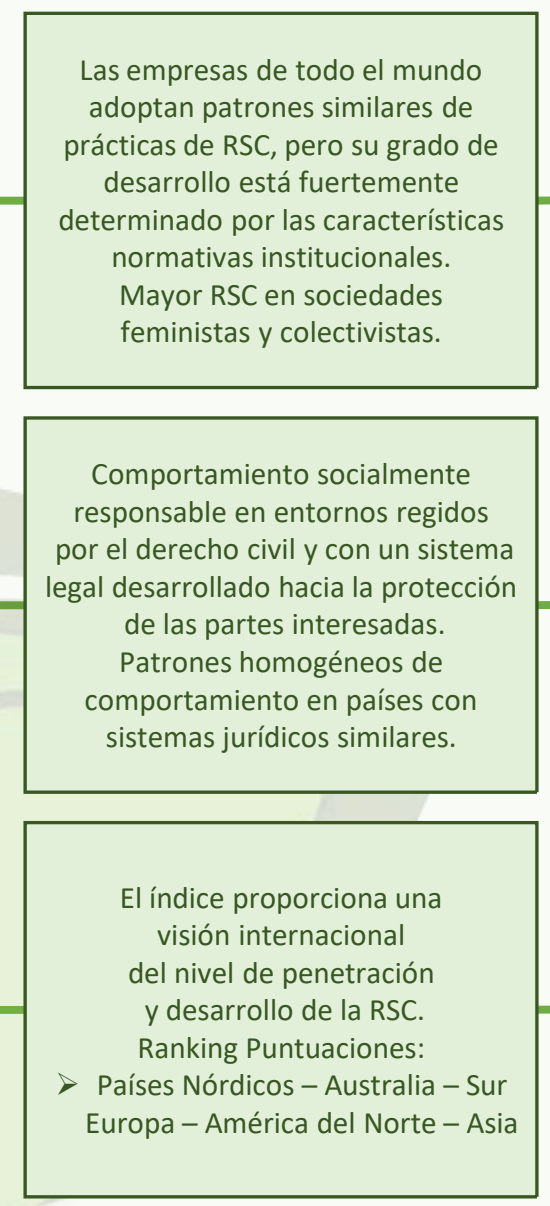

El índice propuesto se relaciona con estándares de gestión ambiental (ISO 14001); sistemas de salud y seguridad de empleados (OHSAS 18001);

compromisos del director general

(WBCSD y Global Compact); y,

con guías de reporte de dicha información (GRI).
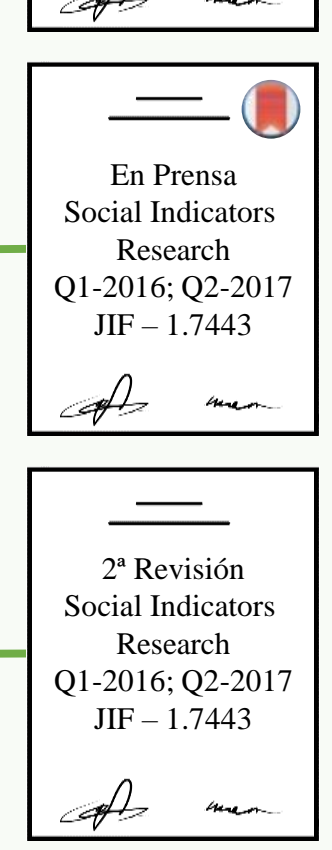

Aceptado

Administrative

Sciences

Open Access

Journal

D.
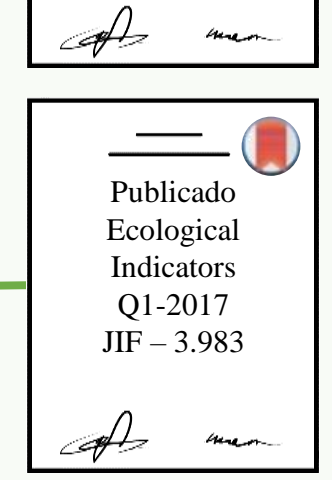

En Prensa

JIF -1.7443

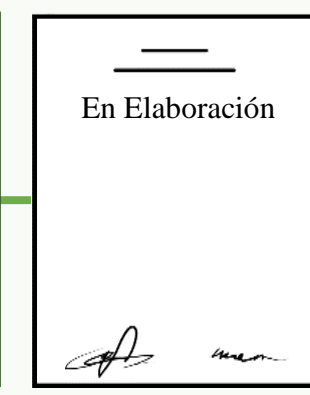



Responsabilidad

Social Corporativa

Parte II. Comportamiento Empresarial Sostenible

a Nivel Sectorial

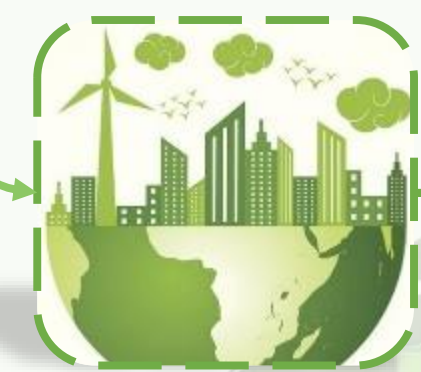

Parte III. Comportamiento Empresarial Sostenible a Nivel Empresa

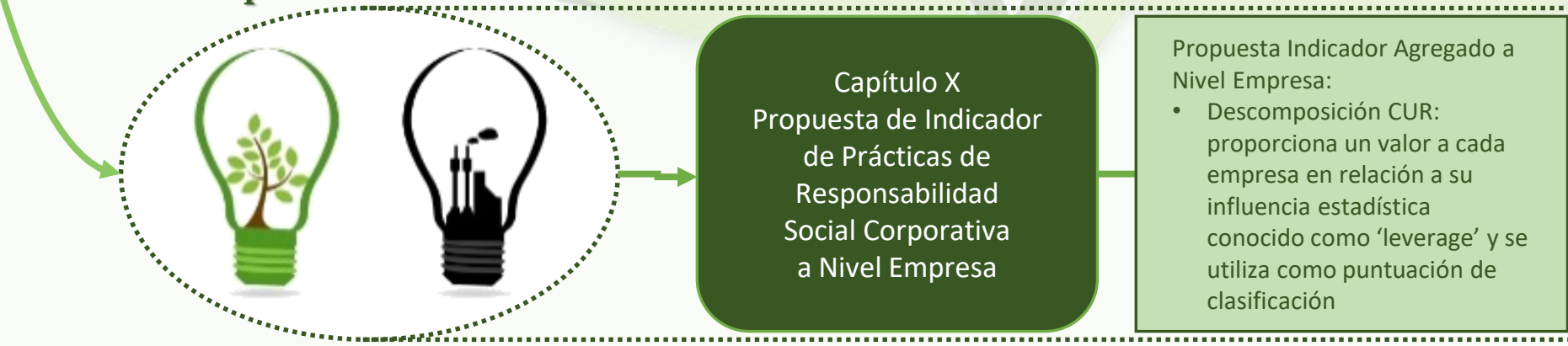

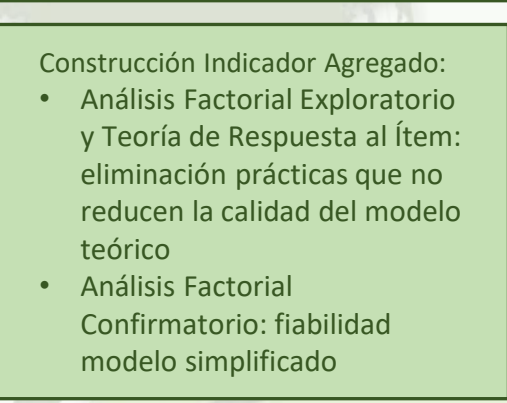

Extensión Indicador Agregado:

- Metodología similar:

extensión del índice sectorial a los sub-sectores que los forman

- MetaBiplot: comparación visualización global de la RSC a nivel sub-sectorial integración de los sectores y
Capítulo VI

El Efecto de las

Especificidades

Sectoriales en la

Responsabilidad

Social Corporativa

Capítulo VII

El sector de actividad es considerado el factor institucional con mayor capacidad explicativa en las prácticas

> Materias básicas y servicios públicos priorizan medioambiente; en petróleo y gas prevalecen los derechos humanos;

telecomunicaciones se centra en los derechos laborales. prácticas sociales en relación con su compromiso ambiental

Influencia Impacto Actividad:

- X-STATIS: comportamiento empresarial según el impacto de sus actividades en 20042014

en la Sostenibilidad

Empresarial

HJ-biplot: especificidad sectores acorde a su impacto ambiental y social

Capítulo VIII

Propuesta de Indicador Sectorial de Prácticas de

Responsabilidad

Social Corporativa

Capítulo IX

Extensión y Utilidad del Indicador Sectorial de

Sostenibilidad

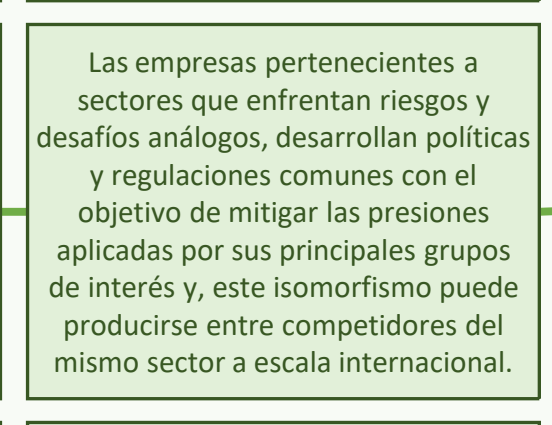

El índice permite una comprensión holística del desarrollo

de la RSC y sus raíces sectoriales.

Este índice junto a su desglose en las vertientes ambiental y social demuestra que los sectores más sostenibles son aquellos cuya actividad los lleva a ser considerados de alto impacto ambiental.

El índice proporciona una visión
global de la sostenibilidad
a nivel sub-sectorial.
Se determina el impacto ambiental
del sector como el mejor
indicador de prácticas de RSC.
Estos datos facilitan la orientación
hacia la promoción de políticas que
mejoren el comportamiento
empresarial sostenible.

En relación a otras medidas agregadas de RSC, se contrasta la utilidad de un novedoso método de selección de individuos enmarcado en el entorno del big data para la identificación de las empresas punteras en desarrollo sostenible $y$, la consiguiente construcción de un indicador compuesto agregado a partir de sus valores.
Aceptado

Capítulo Libro

Cambridge

Scholars

Publishing

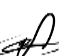

Af mem.
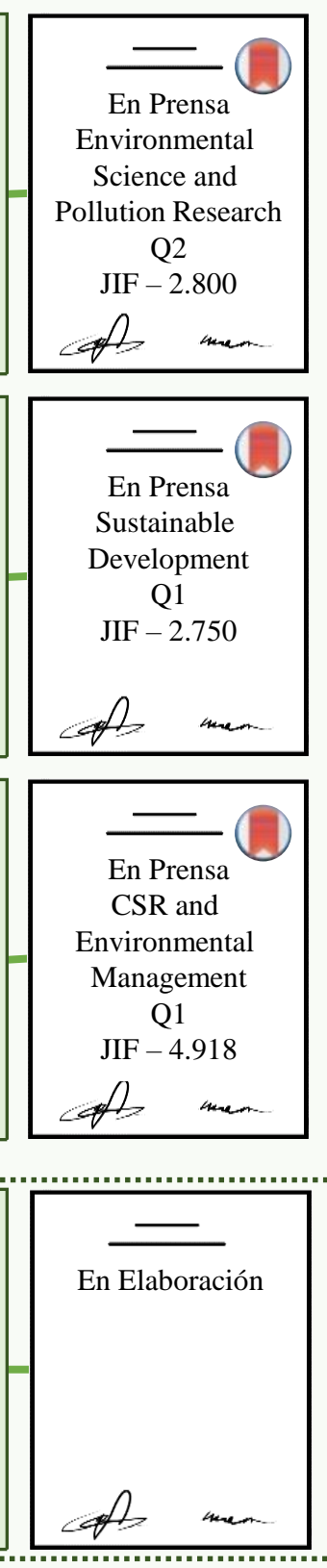



\title{
PARTE I. COMPORTAMIENTO EMPRESARIAL SOSTENIBLE A NIVEL NACIONAL
}

\author{
Capítulo I. El Efecto de la Identidad Nacional en el Comportamiento Empresarial \\ Sostenible
}

Las organizaciones suelen asociarse a las características institucionales de su país de origen. Es lo que se conoce como identidad nacional o efecto del país de origen. Las organizaciones multinacionales se esfuerzan por satisfacer las demandas de las partes interesadas locales y, al mismo tiempo, lograr consistencia global en su perfil de RSC; en consecuencia, la nacionalidad subyacente de la empresa se considera un factor clave para explicar la naturaleza del compromiso de las organizaciones con la RSC. Este capítulo, con una muestra internacional de empresas procedentes de 18 países diferentes y basado en métodos comparativos multivariantes, presenta una nueva y novedosa forma de mapear los patrones nacionales de RSC. En primer lugar, a partir de un análisis X-STATICO (compromiso de una serie de co-estructuras), se caracteriza la relevancia de las prácticas de RSC en todo el mundo. Una vez que el análisis de la RSC se ha establecido a nivel global, se lleva a cabo un análisis Tucker3 determinando el desarrollo y la evolución de estas prácticas de acuerdo con el país de origen de las empresas, ya que este método nos permite examinar relaciones entre interacciones más profundas. Los resultados muestran importantes discrepancias a nivel nacional: las empresas con sede en los países Nórdicos se presentan como líderes del desarrollo sostenible, priorizando sus prácticas en los temas sociales; las procedentes de Europa del Sur dan preferencia a los informes ambientales; y, en América del Norte, con un compromiso menor, otorgan mayor importancia a los problemas éticos. Por tanto, el país de origen es determinante de los patrones de RSC que adoptan sus empresas y de su evolución. Además, encontramos una elevada homogeneidad en las prácticas de RSC que han implementado las compañías cuyo país de origen se encuentra dentro de un mismo continente y existe una elevada proximidad geográfica entre ellos.

Toda esta información se presenta descrita y detallada de manera extensa en el artículo de investigación:

Study of the Importance of National Identity in the Development of Corporate Social Responsibility Practices: a Multivariate Vision

Estado: aceptado en Administrative Sciences - Open Access Journal (Indexada en el Emerging Sources Citation Index).

\section{Capitulo II. EI Papel Influyente de los Valores Culturales en la Sostenibilidad Empresarial}

Basado en la teoría institucional, este capítulo tiene como objetivo observar la influencia del sistema cultural en el grado de responsabilidad del comportamiento empresarial y examinar cómo el isomorfismo normativo influye en las prácticas de RSC a nivel país. Para su estudio utilizamos el modelo de Hofstede porque su grupo de dimensiones resalta las similitudes y diferencias culturales entre países, y medimos la RSC a lo largo de cinco indicadores que hacen referencia a las dimensiones ambientales y sociales. Este estudio contribuye a la literatura mediante la adopción de un enfoque de múltiples regiones considerando una muestra de 6600 observaciones de 600 empresas que cotizan en bolsa con sede en 18 países en Europa, América del Norte, Japón y Australia, durante el período 2004-2014.

Dado el carácter multidimensional de los datos, es esencial analizarlos con técnicas que capturen este carácter multivariante. A nivel empresa, trabajamos con un análisis X-STATIS, mediante el cual representamos la estructura consenso de todos los años separando las empresas en función de los valores culturales de sus países de procedencia, lo cual nos permite visualizar patrones de comportamiento con respecto a la RSC y diferenciar éstos en relación a sus sistemas culturales; $\mathrm{y}$, con datos a nivel país y mediante los métodos biplot, se describen qué dimensiones culturales del modelo de Hofstede presentan mayor influencia sobre la RSC y específicamente sobre qué indicadores. Además, es posible identificar qué países se ven más o menos afectados por estas dimensiones. 
Nuestra conclusión principal es que las dimensiones culturales ejercen presiones importantes sobre las empresas y su compromiso, por lo tanto, las empresas ubicadas en sociedades colectivistas y, aún más, en las feministas, se caracterizan por la búsqueda del bien común y hacen mayor hincapié en cuestiones sociales y ambientales, mostrando así las mejores prácticas de RSC. Finalmente, nuestros resultados demuestran que las empresas de todo el mundo adoptan patrones similares de prácticas de RSC, pero su grado de desarrollo está fuertemente determinado por las características normativas institucionales.

Toda esta información se presenta descrita y detallada de manera extensa en el artículo de investigación:

Cultural Values on CSR Patterns and Evolution: A Study from the Biplot Representation Estado: publicado en la revista Ecological Indicators (2017: Q1 - JIF:3.983).

\section{Capítulo III. El Sistema Legal como Factor Explicativo de las Prácticas de Responsabilidad Social Corporativa}

En este capítulo se analiza el efecto del isomorfismo coercitivo (sistema legal) en la RSC a nivel país utilizando las técnicas estadísticas multivariantes X-STATIS y HJ-biplot, que nos permiten capturar el papel que estas fuerzas institucionales juegan en la evolución y los patrones de comportamiento con respecto al compromiso con la sostenibilidad. La muestra para los análisis comprende las compañías listadas más grandes presentes en 18 países con un sesgo geográfico a favor de las empresas que operan en Europa (50.50\%), América del Norte (25.83\%), Japón (16.67\%) y Australia (7\%) sobre cinco indicadores sintéticos de RSC -medioambiente, derechos humanos, empleados, stakeholders y ética-, durante la década 2004-2014, lo que da lugar a unos datos de panel con 6600 observaciones. Los resultados demuestran que las fuerzas coercitivas tienen una influencia importante en el compromiso social y ambiental de las empresas. El análisis del sistema legal muestra que las empresas ubicadas en países regidos por el derecho civil tienen un mayor interés en las prácticas de RSC y la divulgación de información que las empresas en países de derecho común; es más probable que las empresas actúen de una manera socialmente responsable cuando operan en entornos institucionales con un sistema legal grande y desarrollado con orientación hacia la protección de las partes interesadas. En consecuencia, nuestros resultados muestran que las empresas que operan en países con sistemas jurídicos similares adoptan patrones homogéneos de comportamiento con respecto al compromiso con la sostenibilidad, pero sus grados de desarrollo están fuertemente determinados por las características institucionales coercitivas.

Toda esta información se presenta descrita y detallada de manera extensa en el artículo de investigación:

Analysing the Effect of Legal System on Corporate Social Responsibility (CSR) at the Country Level, from a Multivariate Perspective

Estado: en prensa en la revista Social Indicators Research (2016: Q1 - JIF:1.743; 2017: Q2 - JIF:1.648).

\section{Capítulo IV. Propuesta de Indicador Nacional de Prácticas de Responsabilidad Social Corporativa}

En este capítulo se propone un índice nacional de prácticas de RSC conocido como NCSRPI (National Corporate Social Responsibility Practices Index), que determina el nivel de penetración de la RSC en 29 países diferentes, considerando cada nación como un conjunto de factores institucionales. El NCSRPI se construye a través de un proceso de agregación estadística de 22 prácticas de RSC categorizadas en las dimensiones social y ambiental que se observan individualmente para cada empresa. El indicador compuesto resume y sintetiza toda la realidad empresarial a nivel nacional, proporcionando información relevante para evaluar los factores 
relacionados con el desempeño de la RSC y una visión del compromiso nacional con la sostenibilidad de la empresa. Además, se lleva a cabo una aplicación práctica del índice donde las puntuaciones de los países se estudian de acuerdo con sus características institucionales a partir de la evaluación del sistema legal, la cultura y la efectividad del gobierno. Con el uso de la técnica estadística multivariante $\mathrm{HJ}$-biplot presentamos de una manera visual las relaciones entre el NCSRPI y las medidas de los entornos institucionales que caracterizan a los países. En base a los resultados obtenidos consideraremos las discrepancias en las prácticas de RSC en relación a la idoneidad institucional del país de origen de las empresas; por lo tanto, cuanto mayor sea el valor del índice, más apropiado será el entorno del país para las prácticas de RSC. Los países europeos se presentan como líderes en cuestiones de responsabilidad social, destacando los países nórdicos; los países de América dan preferencia a cuestiones éticas y se ubican en la zona central y baja del ranking; y, los países pertenecientes al continente asiático, específicamente al sudeste asiático, están más rezagados a tal respecto. En consecuencia, las puntuaciones del NCSRPI nos permiten observar la variación agregada de la RSC explicada por las condiciones institucionales que distinguen la identidad nacional de cada país.

Toda esta información se presenta descrita y detallada de manera extensa en el artículo de investigación:

A Multivariate Proposal for a National Corporate Social Responsibility Practices Index (NCSRPI) for International Settings

Estado: sometido a $2^{\mathrm{a}}$ revisión en la revista Social Indicators Research (2016: Q1 JIF:1.743; 2017: Q2 - JIF:1.648).

\section{Capítulo V. Consistencia y Robustez de los Indicadores Nacionales de Sostenibilidad Empresarial}

En esta parte de la investigación se compara la utilidad y estructura de dos indicadores compuestos nacionales de sostenibilidad empresarial, (i) el NCSRI (National Corporate Social Responsibility Index) propuesto por Skoloudis et al. (2016), basado en datos nacionales sobre la suscripción, participación o inclusión en 16 iniciativas internacionales de RSC y (ii) el NCSRPI (National Corporate Social Responsibility Practices Index), basado en 22 prácticas reales de sostenibilidad categorizadas en las dimensiones social y ambiental que se definió en el capítulo previo. Metodológicamente, ambas propuestas presentan una estructura similar, con un alto grado de correlación que facilitan un ranking de países y el desarrollo de procesos benchmarking asociados a un conjunto de componentes agregados relacionados con temas de sostenibilidad que colectivamente evidencian el estado de compromiso y desarrollo de la RSC y describen el nivel de conducta empresarial responsable entre países.

Se demuestra la utilidad de estos índices que muestran con un enfoque macro que va más allá del nivel de la empresa como unidad de análisis, una comprensión global del desarrollo de la RSC con respecto a la raíz nacional, evitando problemas importantes asociados con la falta de datos y análisis comparativos que vinculen sistemáticamente la RSC con los contextos políticoeconómicos nacionales. A su vez, ambos evidencian que los países europeos y Australia son los más avanzados en temas de sostenibilidad y dentro de ellos, los países nórdicos son los que presentan la mayor actividad y prácticas más fuertes; el resto de países muestra prácticas débiles presentando una deficiente penetración de la RSC.

En este sentido, otorgamos una mayor utilidad y funcionalidad al índice de prácticas sostenibles NCSRPI, ya que, evalúa la sostenibilidad de la empresa de una manera más precisa a la inclusión o no en iniciativas internacionales -NCSRI-. Por tanto, situamos al índice de prácticas NCSRPI un paso por delante en tal aspecto, dado que, facilita no solo el conocimiento de las prácticas específicas llevadas a cabo sino también su nivel de compromiso en cada una de éstas a partir de una escala de 0-4, siendo 0-inadecuado y 4-excepcional. De este modo, el análisis profundo e individual de las prácticas permite el conocimiento de las presiones sobre el compromiso ambiental y social en los diferentes países y, se convierte en una herramienta esencial 
para el diseño y la elección correcta del enfoque en los procesos regulatorios hacia la promoción de políticas que mejoren el comportamiento empresarial sostenible.

Toda esta información se presenta descrita y detallada de manera extensa en el artículo de investigación:

Consistency and Robustness of the National Indicators of Business Sustainability through a Multivariate Vision

Estado: en elaboración.

\section{PARTE II. COMPORTAMIENTO EMPRESARIAL SOSTENIBLE A NIVEL SECTORIAL}

\section{Capítulo VI. El Efecto de las Especificidades Sectoriales en la Responsabilidad Social Corporativa}

Este capítulo se centra en analizar la importancia de la especificidad del sector de actividad en la sostenibilidad empresarial, corroborando que los grupos de interés locales y la sociedad en general perciben distintos riesgos tanto sociales como ambientales según la actividad económica que desarrollan las organizaciones, y este hecho se ve reflejado en las políticas e iniciativas de RSC adoptadas por las mismas. Para ello, se estudia el comportamiento de los diez principales sectores de actividad -atención a la salud, bienes de consumo, materias básicas, petróleo y gas, productos industriales, servicios al consumidor, servicios financieros, servicios públicos, tecnología y telecomunicaciones-, a partir de la codificación de una muestra de datos de 6600 observaciones de 600 grandes empresas internacionales cotizadas según la categoría 'industry' del 'Industry Classification Benchmark (ICB) system', para el periodo de tiempo 2004-2014. En base a diversos métodos estadísticos multivariantes se pone de manifiesto al sector como un factor institucional con capacidad explicativa en las prácticas de RSC demostrando que las empresas varían su comportamiento en función de los riesgos, presiones y expectativas específicas de cada sector. Así, puntualizamos como los sectores dedicados a las materias básicas y los servicios públicos, considerados de fuerte impacto sobre el medioambiente, presentan los niveles sostenibles más altos en esta dimensión; petróleo y gas focaliza sus esfuerzos en los derechos humanos ya que sus acciones tienen un fuerte impacto sobre la salud humana que claramente atenta contra los derechos de los ciudadanos; telecomunicaciones, con empresas más intensivas en personal, presenta preocupaciones sociales mayores a las ambientales priorizando sus prácticas hacia los derechos laborales y el trato con sus stakeholders; servicios financieros -enfocado a los empleados-y servicios al consumidor -orientado hacia los derechos humanos- se consideran los más retrasados en materia de RSC, sus empresas están menos vigiladas por los activistas y, por ende son menos competitivas en términos de prácticas sostenibles. Estos resultados dan respuesta a una de las preguntas más antiguas en el debate sobre la RSC, corroborando que las demandas sociales son un punto principal a tener en cuenta, inclusive en ciertos sectores las preocupaciones sociales superan a las ambientales.

Toda esta información se presenta descrita y detallada de manera extensa en el artículo de investigación:

A Multivariate Vision of the Industry Specificity as an Explanatory Factor of Companies' Social Performance

Estado: aceptado como capítulo del libro 'Corporate Social Responsibility Disclosure and Assurance: A Growing Market’ en la editorial Cambridge Scholars Publishing. 


\section{Capítulo VII. El Isomorfismo Mimético en la Sostenibilidad Empresarial}

Basado en la teoría neo-institucional y el análisis institucional comparativo, este trabajo estudia el papel que desempeñan las fuerzas miméticas en los patrones y la evolución del comportamiento con respecto a la sostenibilidad de la empresa. Los datos de panel se componen de 6600 observaciones de 600 grandes empresas cotizadas internacionales pertenecientes a 39 sub-sectores de actividad diferentes para el período 2004-2014. Mediante el empleo de los métodos estadísticos multivariantes HJ-biplot y X-STATIS, que proporcionan una visualización en un único plano factorial de una estructura de datos compleja, se puede observar que las fuerzas miméticas indican que las empresas que operan en sectores de alto impacto -sectores que operan bajo una mayor presión de sus grupos de interés-, enfrentan mayores riesgos sociales y ambientales y tienen puntuaciones más altas de RSC que las empresas de otros sectores. La adopción o el desarrollo de prácticas de RSC depende en gran medida del tipo de industria en la que opera la empresa, ya que la participación de los interesados en diferentes sectores industriales tiene diferentes áreas de preocupación. Por lo tanto, las empresas que operan en sectores más contaminantes, como minería, productos químicos o petróleo, otorgan mayor prioridad a la protección ambiental y defensa de los derechos humanos, mientras que otras empresas menos contaminantes involucradas en el sector de la comunicación se preocupan en mayor medida por problemas sociales, como la ética empresarial o los derechos de sus empleados. Finalmente, este documento evidencia que las empresas que operan en contextos similares, en sectores que enfrentan riesgos y desafíos análogos, probablemente desarrollen políticas y regulaciones comunes con el objetivo de mitigar las presiones aplicadas por sus principales grupos de interés $\mathrm{y}$, este isomorfismo puede producirse entre competidores del mismo sector a escala internacional.

Toda esta información se presenta descrita y detallada de manera extensa en el artículo de investigación:

Industry Mimetic Isomorphism and Firm's Sustainability based on the X-STATIS and HJbiplot Methods

Estado: en prensa en la revista Environmental Science and Pollution Research (2016: Q2 - JIF: 2.741; 2017: Q2 - JIF:2.800).

\section{Capítulo VIII. Propuesta de Indicador Sectorial de Prácticas de Responsabilidad Social Corporativa}

El trabajo presentado en este capítulo, en base en las discrepancias institucionales entre los diferentes tipos de industria, pretende ser pionero en la creación de un índice sectorial de prácticas de RSC, denominado ICSRPI (Industrial Corporate Social Responsibility Practices Index) que determine el nivel de penetración de la RSC en los diez sectores de actividad codificados según la categoría 'industry' del 'Industry Classification Benchmark (ICB) system', lo que permite una comprensión holística del desarrollo de la RSC y sus raíces sectoriales. El ICSRPI se construye a través de un proceso de agregación estadística de 23 prácticas de RSC categorizadas en las dimensiones social y ambiental que se observan individualmente para cada empresa. El desarrollo del ICSRPI junto a su desglose en las vertientes ambiental y social ha demostrado que los sectores más sostenibles son aquellos cuya actividad los lleva a ser considerados de alto impacto ambiental, ya que implementan políticas y sistemas de gestión ambiental más avanzadas. En este sentido, destacamos los sectores dedicados a materias básicas y servicios públicos; por el contrario, las compañías de sectores menos contaminantes, como los servicios financieros o servicios al consumidor, tienen puntuaciones más bajas, sin embargo, presentan altos valores en cuestiones sociales, dando mayor prioridad a la ética empresarial y los derechos de los empleados. Los hallazgos ofrecen un nuevo ámbito de estudio a los investigadores, exigiendo análisis más profundos de la especificidad del sector de actividad de la RSC y para identificar aún más los determinantes institucionales que dan forma a la sostenibilidad empresarial. Además, las discrepancias observadas a nivel sectorial muestran la utilidad del ICSRPI para simplificar y cuantificar las prácticas de RSC y proporcionar un valor útil para ser utilizado como referencia, 
ya que, conocer el nivel de compromiso con la sostenibilidad a nivel sectorial permite a las empresas que comienzan a operar en una nueva industria conocer los estándares mínimos de RSC que deben respetar. Asimismo, permite la realización de procesos de benchmarking dirigidos a la mejora continua de las decisiones y acciones empresariales.

Toda esta información se presenta descrita y detallada de manera extensa en el artículo de investigación:

Useful Information for Stakeholder Engagement: A Multivariate Proposal of an Industrial Corporate Social Responsibility Practices Index

Estado: en prensa en la revista Sustainable Development (2016: Q1 - JIF: 2.167; 2017: Q1 - JIF: 2.750).

\section{Capítulo IX. Extensión y Utilidad del Indicador Sectorial de Sostenibilidad}

El objetivo principal de este capítulo es ampliar el índice sectorial de prácticas de RSC estimado para los 10 principales sectores de actividad, conocido como ICSRPI (detallado en el capítulo VIII) a los 39 sub-sectores que los componen. Esta extensión proporciona información más detallada sobre las prácticas de RSC a nivel sectorial, especialmente sobre el desarrollo sostenible y las preocupaciones ambientales. Además, este estudio demuestra la utilidad del ICSRPI en investigaciones empíricas futuras al determinar el control del impacto que el isomorfismo mimético puede tener sobre el desarrollo de la RSC. Esto se consigue a través de la propuesta de una nueva medida, nombrada ICMT (Industry Classification and Mimetic Typologies, este nombre hace referencia a la clasificación de la industria en función de las tipologías miméticas) que determina el impacto general de la compañía en las dimensiones social y ambiental. Esta nueva medida otorga un valor de 1 a 5 a cada empresa en función del impacto de sus actividades y, por ende, a los sub-sectores y sectores de actividad. Las puntuaciones del ICSRPI son analizadas a partir de los valores de esta nueva medida llegando a la conclusión de que el impacto de una empresa, particularmente sus riesgos y preocupaciones ambientales, es el mejor indicador de sus prácticas de RSC.

Finalmente, profundizamos en los 10 sectores que conforman la clasificación del ICSRPI, caracterizando éstos a partir de las fortalezas y debilidades de los 39 sub-sectores de actividad que los componen en relación a las prácticas de RSC. Este estudio se realiza mediante un análisis MetaBiplot, que posibilita la obtención de una configuración consenso que integra las configuraciones resultantes de varios análisis biplot, mostrando en un único plano factorial los 39 sub-sectores y las 23 prácticas de RSC conjuntamente, consiguiendo una visión global de la sostenibilidad a nivel sub-sectorial.

Los resultados muestran que las empresas pertenecientes a los sub-sectores silvicultura y papel, minería, gas, agua y multiservicios, productores de petróleo y gas, tabaco y electricidad, muestran su predilección por las políticas y reportes ambientales, los derechos humanos y la participación de sus grupos de interés; y, las empresas menos contaminantes -bancos, seguros, telecomunicaciones, bienes inmobiliarios y minoristas-, se enfocan en las prácticas dirigidas a la formación de empleados y su promoción, políticas de igualdad de oportunidades y fomento de la diversidad, las buenas relaciones con clientes y proveedores y todo lo relacionado en la lucha por contrarrestar el soborno.

Estos resultados permiten comprender las presiones sobre el compromiso social y ambiental de los diferentes sectores y sub-sectores, facilitando así la orientación de los procesos regulatorios hacia la promoción de políticas que mejoren el comportamiento empresarial sostenible.

Toda esta información se presenta descrita y detallada de manera extensa en el artículo de investigación:

An Extension of the Industrial Corporate Social Responsibility Practices Index: New Information for Stakeholder Engagement under a Multivariate Approach

Estado: en prensa en la revista Corporate Social Responsibility and Environmental Management (2016: Q1 - JIF: 2.852; 2017: Q1 - JIF: 4.918). 


\section{PARTE III. COMPORTAMIENTO EMPRESARIAL SOSTENIBLE A NIVEL EMPRESA}

\section{Capítulo X. Propuesta de Indicador de Prácticas de Responsabilidad Social Corporativa a Nivel Empresa}

En esta última parte de la investigación se propone un índice agregado de sostenibilidad empresarial a nivel organizacional, además de examinar su consistencia con respecto a otras medidas agregadas de RSC. Para su construcción, se utiliza un método novedoso de selección de individuos en el manejo de grandes cantidades de datos conocido como descomposición matricial CUR, enmarcado en el entorno del big data. Este método utiliza un procedimiento automático y objetivo otorgando a cada empresa un valor o puntuación conocido como leverage que hace referencia a su influencia estadística dentro del conjunto de datos y, a mayor leverage, mayor nivel de desarrollo sostenible. Como segundo objetivo y con la información que brinda el índice agregado, se busca conocer las empresas más potentes de cada país o sector de actividad; analizando el compromiso en RSC a nivel nacional y sectorial. La muestra utilizada consiste en una muestra internacional de 2675 grandes empresas cotizadas de todos los sectores de actividad. Los resultados muestran la consistencia de las puntuaciones o leverage CUR como una medida agregada de RSC, confirmando mediante un análisis de correlación su coherencia con otras medidas agregadas de RSC. Además, los resultados del estudio confirman que las empresas se adaptan a las demandas o presiones procedentes de las partes interesadas en las diferentes áreas de interés, que son específicas de cada país y sector. Por lo tanto, revelamos cómo los países europeos muestran que están un paso por encima en términos sostenibles del resto de los países. En referencia al análisis por sector, este estudio muestra que las empresas más sostenibles se encuentran en sectores considerados de alto riesgo ambiental; las empresas utilizan la RSC para legitimar sus prácticas empresariales y como una forma de gestionar su reputación y responder a las expectativas de sus grupos de interés. Destacamos algunas empresas punteras en desarrollo sostenible como Norsk Hydro para la industria minera y metalúrgica en Noruega; Stora Enso en silvicultura y papel de Finlandia; Akzo Nobel para productos químicos en Países Bajos; BMW de automóviles y repuestos en Alemania; Generali en finanzas de Italia; Novartis en farmacéuticas de Suiza; BT Group en telecomunicaciones de Reino Unido; o Inditex en textiles para España, entre otras.

Toda esta información se presenta descrita y detallada de manera extensa en el artículo de investigación:

Proposal for an Aggregate International Sustainability Index at the Organizational Level from CUR Matrix Decomposition

Estado: en elaboración. 


\section{PARTE I}

\section{COMPORTAMIENTO EMPRESARIAL SOSTENIBLE A NIVEL NACIONAL}




\section{Capítulo I}

\section{El Efecto de la Identidad Nacional en el Comportamiento Empresarial Sostenible}

La Responsabilidad Social Corporativa (RSC) tiene la característica de ser una idea verdaderamente global, y sus características globales podrían dar lugar a la suposición de que la dinámica nacional es secundaria o incluso irrelevante; sin embargo, aunque la RSC puede ser de naturaleza global, investigaciones recientes sugieren que las instituciones nacionales duraderas y las tradiciones ideológicas distintivas determinan las decisiones corporativas.

Las compañías a menudo se asocian con las características institucionales del país, lo que se conoce como identidad nacional o efecto del país de origen. Los legados ideológicos e institucionales, así como la experiencia histórica, dirigen las prácticas y estrategias de las organizaciones. Las organizaciones multinacionales se esfuerzan por satisfacer las demandas de las partes interesadas locales y, al mismo tiempo, lograr consistencia global en su perfil de RSC; por lo tanto, el enfoque de las corporaciones respecto de la RSC está influenciado por el contexto institucional local y global, lo que resulta en un enfoque 'transnacional', donde las expectativas de las partes interesadas locales y globales están equilibradas. En consecuencia, la nacionalidad subyacente de la empresa se considera un factor clave para explicar la naturaleza del compromiso de las organizaciones con la RSC. Además, las multinacionales más globales están fuertemente enraizadas en su país de origen.

Para su estudio, analizamos la década 2004-2014 a partir de una muestra de 6600 observaciones procedentes de 600 empresas internacionales cotizadas en bolsa y procedentes de 18 países diferentes de las economías desarrolladas. Este trabajo en base a métodos comparativos multivariantes profundiza en el estudio del comportamiento empresarial sostenible al determinar el desarrollo y la evolución de las prácticas de RSC desde diferentes perspectivas medioambiente, derechos humanos, empleados, stakeholders y ética- según el país de origen de las empresas; y presenta una nueva y novedosa forma de mapear los patrones nacionales de RSC.

Como primer punto se caracteriza la relevancia de las prácticas de RSC en todo el mundo, esto es, conocer qué prácticas son las más demandadas por las empresas. A través de un análisis X-STATICO (co-inercia + X-STATIS), se procede a analizar la importancia de las dimensiones y sub-dimensiones de la RSC consideradas, estudiando las similitudes y diferencias que existen entre cada una de las prácticas, teniendo en cuenta su agrupación en las dimensiones ambiental y social. La principal ventaja de este método es que proporciona un compromiso de co-estructuras, es decir, primero verifica cómo coexisten los pares de variables (análisis de co-inercia) y luego obtiene una estructura de compromiso que representa estas relaciones y sus trayectorias, que muestran la evolución de cada una de estas prácticas durante los 11 años de estudio. Los resultados muestran que las empresas con mayores preocupaciones ambientales son las más sostenibles y, desarrollan con una prioridad similar o cercana a su compromiso ambiental, las prácticas dirigidas al desarrollo de sistemas de gestión en defensa de los derechos laborales y el mantenimiento de las buenas relaciones con sus grupos de interés (stakeholders), que surgen a partir del diálogo 
transparente y la participación de empleados y grupos de interés en el proceso de toma de decisiones.

Una vez que el análisis de la RSC se ha establecido a nivel global, determinamos el desarrollo y la evolución de estas prácticas de acuerdo con el país de origen de las empresas. A partir de un análisis Tucker3, examinamos las relaciones entre interacciones más profundas, buscando caracterizar cada uno de los países de origen de las empresas en relación con la relevancia de sus prácticas de RSC. El método Tucker3 abre un gran abanico de combinaciones entre las componentes de los diferentes modos (países-prácticas de RSC-años), permitiendo el análisis de relaciones entre componentes que probablemente no sean estudiadas por otros métodos (como el análisis de componentes principales donde normalmente se estudian únicamente las dos primeras componentes), cuya información por pequeña que pueda parecer puede llegar a explicar la dinámica de los datos o el porqué de determinadas situaciones; esto lo convierte en un método indudablemente atractivo a tener en cuenta. Este método nos permite caracterizar de forma individual a cada uno de los países de origen que forman parte de la muestra, según sus fortalezas (interacciones positivas) y sus debilidades (interacciones negativas) en cada una de las prácticas de RSC. Así, las empresas con sede en los países Nórdicos se presentan como líderes del desarrollo sostenible, priorizando sus prácticas en los temas sociales; aquellas procedentes de Europa del sur dan preferencia a los informes ambientales; y, en América del Norte muestran un compromiso menor, otorgando mayor importancia a los problemas éticos.

El hallazgo de importantes discrepancias nacionales corrobora que el país de origen de las empresas ofrece una serie de facilidades y barreras para el desarrollo de prácticas de RSC, lo cual contrasta la relevancia de la identidad nacional en el comportamiento sostenible de las empresas. En base a los resultados obtenidos podemos afirmar que el país de procedencia de las empresas es determinante de los patrones de RSC que adoptan y de su evolución. Además, podemos determinar que existe una elevada homogeneidad en las prácticas de RSC que han implementado las compañías cuyo país de origen se encuentra dentro de un mismo continente y existe una elevada proximidad geográfica entre ellos.

A continuación, presentamos toda esta información detallada de manera extensa en el artículo de investigación "Study of the Importance of National Identity in the Development of Corporate Social Responsibility Practices: a Multivariate Vision" aceptado en Administrative Sciences - Open Access Journal (Indexada en el Emerging Sources Citation Index). 
Research paper accepted:

Title: Study of the Importance of National Identity in the Development of Corporate Social Responsibility Practices: a Multivariate Vision

Authors: Víctor Amor-Esteban

$M^{\text {a }-P u r i f i c a c i o ́ n ~ G a l i n d o-V i l l a r d o ́ n ~}$

Fátima David

Journal: Administrative Sciences - Open Access Journal (indexed in Emerging Sources Citation Index) 

Article

\title{
Study of the Importance of National Identity in the Development of Corporate Social Responsibility Practices: A Multivariate Vision
}

\author{
Víctor Amor-Esteban ${ }^{1, *}$ (i),$M^{\text {a }}$-Purificación Galindo-Villardón ${ }^{1}$ (i) and Fátima David ${ }^{2}$ \\ 1 Department of Statistics, University of Salamanca, 37007 Salamanca, Spain; pgalindo@usal.es \\ 2 Escola Superior de Tecnologia e Gestão, Instituto Politécnico da Guarda, 6300-559 Guarda, Portugal; \\ sdavid@ipg.pt \\ * Correspondence: u105356@usal.es or victor_aes@hotmail.com
}

\begin{abstract}
Corporate Social Responsibility (CSR) has the characteristic of being a truly global idea, and its global features could give rise to the assumption that national dynamics are secondary or even irrelevant. However, while CSR policies may be of a global nature, recent research suggests that lasting national institutions and distinctive ideological traditions determine corporate decisions. In this study, we analysed the 2004-2014 decade from a panel data sample of 6600 observations from 600 large, internationally listed companies, and based on multivariate statistical methods, we contrasted the relevance of national identity in the sustainable behaviour of companies with the discovery of important national discrepancies, which corroborates that the country of origin of companies offers a series of facilities and barriers for the development of CSR practices. Companies, depending on different pressures and expectations, care about what is important in their own country. Thus, the corporations coming from Nordic countries-recognised as welfare states-are presented as the leaders in sustainable behaviour, highlighting in the social aspect the proper treatment of their employees and interest groups. They are followed a step below by companies whose country of origin is located in Southern Europe, which prioritise environmental reports. Organisations whose headquarters are centralized in North American countries are in a very delayed position, especially in environmental performance, giving greater preference to ethical issues.
\end{abstract}

Keywords: Corporate Social Responsibility (CSR); national identity; country of origin; multivariate statistics; social sustainability; sustainable development; environmental management

\section{Introduction}

Corporate Social Responsibility (hereafter CSR) dates back to the 1950s, which marks the modern era of CSR when formal writing on the subject began (Carroll 1999). Since then, there have been many definitions and a large amount of research, both theoretical and empirical; even so, CSR means something, but it is not always the same to everyone, as there is no widely accepted definition. Since the term was first used, debates have existed as to its meaning and key elements (Whetten et al. 2002; Davis 1973). Defining what CSR is an arduous and complex task, because it is not a physical reality but rather a social construction, in which each individual looks from the perspective of his or her own knowledge, skills, and interests. However, there are several common components, such as the reference to three areas of responsibility: economic, social, and environmental, without forgetting the interlocutors or stakeholders to whom the company is responsible, as well as the voluntary nature of these responsibilities. The integrated nature of CSR is also present in the strategy, policies, and operations of companies in order to adjust to social pressures and achieve a legitimacy that 
guarantees success and survival (Scott 1995; Oliver 1991; DiMaggio and Powell 1983). CSR can be seen as that set of responsibilities that the company assumes before society, which will change, because the circumstances and the sensitivity of the actors change.

Consequently, a universal definition of CSR is inherently problematic in view of the national differences in business systems, and the resulting differences in the contexts and functions of the various stakeholders in the same (Matten and Moon 2008). CSR has the characteristic of being a truly global idea, and its global features could give rise to the assumption that national dynamics are secondary or even irrelevant; however, while CSR may be of a global nature, recent research suggests that it is applied differently according to political, economic, social, legal, and cultural contexts (Gjølberg 2009).

Commonly, the term 'sustainability' is associated with caring for the environment, although the company and the environment are obliged to understand each other; that is, it is not conceived that a company that is considered as sustainable neglects its environmental processes; there are two other areas in which an organisation must be sustainable: the social one-with the aim of achieving an adequate relationship and fluid communication with the company's stakeholders, as well as the defence of the labour rights of its employees, and the economic one-with the aim of achieving a transparent management and correct distribution of the wealth that is generated. In this paper, based on panel data of 6600 observations from 600 listed firms arising from 18 countries, we show the national discrepancies in sustainability practices based on protection of the environment and social cohesion during the 2004-2014 decade. Through multivariate statistical methods, which enable us to identify the main underlying characteristics of a large volume of data and prioritise the visual results in search of a more accessible language for researchers in the field of global sustainability, we trace the results only in a factorial plane, representing the consensus structure of all of the years and facilitating the visualisation of countries' behaviour patterns in reference to the development of their CSR practices. More specifically, sustainable commitment at the national level is studied, focussing on the virtues and deficiencies according to the country of origin of the companies. (i) As a first step, through an X-STATICO analysis, the relevance of worldwide CSR practices is characterised, with the aim of establishing which practices are commonly the most demanded and developed by all companies, and finding those social practices with an importance similar or close to environmental ones. (ii) Secondly, based on an analysis of Tucker3, which examines the relationships between deeper interactions, the development and evolution of these practices is determined according to the country of origin of the companies, showing the importance of national identity in the development of them.

So, the main contribution of this document to the literature is the identification of the virtues and deficiencies in national sustainability systems, which will allow recognising where it is most necessary to adopt or improve CSR practices. Thus, the primary objective of the study is the usefulness of these data as an essential tool for politicians and public managers in the decision-making processes, facilitating the design of more effective policies through knowledge of the main concerns and expectations of the countries that lead to a greater CSR commitment.

The paper is organised into five additional sections following the introduction. The following section describes the theoretical background, focussing on the influence that the country of origin effect has on the sustainability of the company through international comparative studies. The next section details the data sample and describes the methodology used, providing a novel new way to map national CSR patterns with panel data sets. We continue to show the empirical results obtained with important national discrepancies on practices of corporate social responsibility, their discussion, and present the main conclusions of the study.

\section{Theoretical Background}

The ideological traditions and distinctive national institutions still shape and channel crucial corporate decisions; thereby, institutional theory is based on the assumption that, with respect to the same issue, two organisations may embrace different responsibilities, including when they operate 
outside their country of origin (Pauly and Reich 1997). Corporations are embedded within a broader social structure that has been long established within institutional theory; it encompasses different types of institutions, and exercises a significant influence on the decision making of companies (Gjølberg 2012; Ioannou and Serafeim 2012; Campbell 2007). Whitley (1992). We refer to this as the 'country of origin effect', where the national origin of that corporation plays an important role in the commitment level to CSR.

There is also extensive and important research focussed on the study of the influence of the characteristics of the institutional environment on the sustainable behaviour of companies, which, through comparative studies at an international level that address CSR issues, has found substantial differences in the practices of CSR between countries, as systematically explained by coercive and normative institutional pressures (Martínez-Ferrero and García-Sánchez 2016). Normative pressures emanate from the cultural values of the business environment, since, as a result of different cultural conditions - which imply different norms or forms of behaviour-local stakeholders show different expectations regarding business behaviour (Bustamante 2011). These investigations conclude that companies are more likely to behave in a socially responsible manner and show that they are more sensitive to the publication of CSR reports in feminist and collectivist societies, and, to a lesser extent, in societies with low power distance (in societies with low power distance, people strive to equalise the distribution of power and demand the justification of inequalities of power; on the contrary, a high power distance implies that it is distributed vertically, in an unequal way), orientation in the long term, tolerance to uncertainty, and high values of indulgence (Esteban et al. 2017; García-Sánchez et al. 2013; Ringov and Zollo 2007). Coercive pressures derive from rules, standards, or laws that determine the legal system of a country for the development of sustainability practices. There are numerous studies that evaluate the influence of these pressures on sustainable business behaviour, and conclude that companies located in countries regulated by civil law and with strong application of the law show greater interest in CSR practices and the dissemination of information than those governed by common law. The studies also show that those who operate in institutional environments with a large and developed legal system oriented to the protection of interest groups are more likely to act in a socially responsible manner (Amor-Esteban et al. 2017; García-Sánchez et al. 2016; Kolk and Perego 2010). In addition, other national institutional conditions, such as regulatory effectiveness, competitive conditions, and civic engagement, are very important factors and influence the CSR penetration (Halkos and Skouloudis 2016).

However, institutions are often associated with the characteristics of the country, which are collectively known as the national identity or country of origin. Ideological and institutional legacies, as well as historical experience, direct the practices and strategies of organisations (Pauly and Reich 1997). On the other hand, Filatotchev and Stahl (2015) argue that multinational organisations endeavour to meet the demands of local stakeholders and at the same time achieve global consistency in their CSR profile. Therefore, the corporations' approach to CSR is influenced by both the local and global institutional context, resulting in a 'transnational' approach, where the expectations of local and global stakeholders are balanced. Several researchers (Campbell 2007; Pauly and Reich 1997; Whitley 1992) have emphasised that distinctive ideological traditions and lasting national institutions determine corporate decisions. Consequently, the underlying nationality of the company is considered a key factor to explain the nature of the organisations' commitment to CSR. In addition, most global multinationals are strongly rooted in their country of origin (Noorderhaven and Harzing 2003).

This document does not affirm that the effect of the country of origin is the only factor that explains the CSR variation, but proposes that differences at the national level are a key factor that must be taken into account in understanding why organisations differ in their approach to CSR. This assumption is based on multiple examples of comparative studies between different countries, which illustrate clear differences between the interpretation and practice of CSR (Dypdahl 2015). Thus, behind this approach, Matten and Moon (2004), Habisch et al. (2005), Campbell (2006), and Lenssen et al. (2006) were the first authors to theorise about the relationship between CSR and national contexts. Matten and Moon (2004) 
suggested that CSR is applied differently according to the legal, economic, cultural, and political context in which the company operates; Habisch et al. (2005) corroborated this fact in their book Corporate social responsibility across Europe. Campbell (2006) demonstrated that the characteristics of the national context impose different expectations and pressures on business behaviour, so that companies develop their CSR practices according to these specific demands. Lenssen et al. (2006) mapped CSR patterns to national economic, social, and political institutions, since the different pressures faced by companies causes them to vary their behaviour in order to comply with the laws and professional guidelines of their environment.

In this sense, Welford (2004) showed that companies care about what is most important in their countries; thus, Hong Kong companies emphasise the internal aspects of CSR; Singaporean firms focus on external CSR; and Norwegian organisations give preference to social policies. More specifically, several investigations reveal these differences between two regions, a limited number of countries, or only one dimension. Maignan and Ralston (2002) pointed out that United States (US) companies have a lower commitment than European companies to environmental matters; however, they focus on codes of ethics and philanthropic CSR more broadly than the European firms. Aaronson (2003) showed that United Kingdom (UK) companies offer more extensive disclosures than US companies, since they have made national and global CSR a priority. Baskin (2006), in his study on CSR in emerging markets, and Jamali et al. (2009), in their assessment of managerial perspectives for CSR in three neighbouring Middle East countries (Lebanon, Syria and Jordan), support the institutional interaction between state policies, the discretionary activities of the private sector, and civil society activism to shape the penetration of CSR in national contexts. Tang and Li (2009) argued that there are significant differences between rule-based and relationship-based societies; in the former, companies tend to demonstrate a greater commitment to CSR. So, for example, among the BRIC countries (Brazil (B), Russia (R), India (I), and China (C)), companies from India, which is a rule-based society, take first place in good corporate practices, whereas the Chinese organisations, as China is one of the most authoritarian, occupy last place. Witt and Redding (2011) studied the social variations in CSR values of the top executives of five economies (Germany, Hong Kong, Japan, South Korea, and the US) and stated that the conceptualisation of CSR and the approach of stakeholders differ among the main executives of different institutional environments. Florini and Saleem (2011) and Grauel and Gotthardt (2016) showed the differences between countries in relation to the activities related to climate change, and according to their origin, legal regulation, and political systems, and pointed out that Japan, Spain, and France present very contrasting institutional characteristics with diverse judicial and legal traditions. Ariztía et al. (2014) presented how Chile and Brazil, as old developing countries, show an increasingly important role of CSR discourses and practices with ethical consumption activities.

The empirical examples suggest that CSR is influenced by the country of origin, and that the individual characteristics of the company are decisive for CSR also when the company has supervised operations (Bustamante 2011). These specific characteristics of the company, which are also known as 'company identity' or 'company personality', are considered a crucial component that influences the company's CSR agenda. Thereby, the first hypothesis of our research defends that there are significant differences in CSR business practices between companies based in different countries. Thus, Hypothesis $\mathrm{H} 1$ is proposed as follows:

H1: The country of origin of the companies determines the level of development and commitment to CSR practices.

In addition, the historical experience of the ideological and institutional legacies leads to thinking about the existence of similar patterns of business behaviour in companies whose headquarters are located in geographically close countries, and the existence of greater discrepancies in their profile or approach to CSR at greater distances among them. Therefore, Hypothesis $\mathrm{H} 2$ is proposed as follows:

H2: There is a high level of homogeneity in CSR practices implemented by companies whose country of origin is located within the same continent, and there is great geographical proximity between them. 
CSR as a corporate practice has been widely recognised in the last decade, and organisations around the world are increasingly committed to CSR, striving to achieve legitimacy for their corporate operations. This document, based on comparative multivariate methods, presents a new and novel way of mapping national CSR patterns and delves into the study of sustainable business behaviour by determining the development and evolution of CSR practices from different perspectives—environment, human rights, employees, stakeholders, ethics-according to the country of origin of the companies. This way characterises the advantages and barriers offered by each country during the 2004-2014 decade, showing the importance of national identity in the development of these practices. In addition, it analyses which social practices are most in demand, comparing their development with the environmental ones that naturally constitute the central part of sustainability.

\section{Materials and Methods}

\subsection{Population and Sample}

The target population considered corresponds to the largest listed companies internationally because they are the most active in terms of sustainability. The information was obtained from the database of Ethical Investment Research Services (EIRIS). We selected those companies with complete information and with a criterion of inclusion of a minimum of 10 companies per country during the 2004-2014 decade, which resulted in a final sample of 6600 observations of 600 listed companies from the main developed economies (Europe, 50.50\%; North America, 25.83\%; Japan, 16.67\%; and Australia, $7 \%$ ). Given that the objective of this work is to study the national root of sustainability, companies are grouped by their country of origin, giving rise to 18 different countries (see Table 1). Noteworthy is a bias in favour of companies from Japan, the United Kingdom, and the United States in line with the distribution of large listed companies available in EIRIS. The large firms are the most active in CSR and are models for small firms that operate in their country of origin; therefore, this information should not generate representativeness problems (Martínez-Ferrero and García-Sánchez 2016).

Table 1. Distribution of companies by country of origin.

\begin{tabular}{cccccccc}
\hline & Countries & Observations & $\%$ & & Countries & Observations & $\%$ \\
\hline 1 & Australia & 462 & 7.0 & 2 & Austria & 44 & 0.7 \\
3 & Belgium & 77 & 1.2 & 4 & Canada & 440 & 6.7 \\
5 & Denmark & 121 & 1.8 & 6 & Finland & 110 & 1.7 \\
7 & France & 429 & 6.5 & 8 & Germany & 407 & 6.2 \\
9 & Italy & 143 & 2.2 & 10 & Japan & 1100 & 16.6 \\
11 & Netherlands & 165 & 2.5 & 12 & Norway & 66 & 1.0 \\
13 & Portugal & 44 & 0.7 & 14 & Spain & 165 & 2.5 \\
15 & Sweden & 275 & 4.2 & 16 & Switzerland & 220 & 3.3 \\
17 & United Kingdom & 1067 & 16.1 & 18 & United States & 1265 & 19.1 \\
& & & & & Total & 6600 & 100.0 \\
\hline
\end{tabular}

It is important to consider the time factor, inasmuch as the period 2004-2014 marks the decade in which companies have assumed greater commitments in terms of sustainability. This period is considered as the most prolific period of corporate and academic CSR, due to the effect of technological development and the consequent access to information on corporate behaviour and the different pressures that actors can exercise (Martínez-Ferrero and García-Sánchez 2016).

\subsection{Variables}

The real sustainability practices that will be studied in depth and with which we will characterise the strengths and weaknesses of each of the countries studied in terms of sustainability are divided into two dimensions: environmental and social. The measures selected to quantify the sustainable business behaviour come from a government agency of external evaluation of known 
reputation under the name of EIRIS (Ethical Investment Research Services). EIRIS evaluates organisations' integration of social, environmental, and governance factors into their strategies, operations, and management-with a focus on promoting economic performance, responsible investment, and sustainable value creation. The evaluation takes into account the efficiency of managerial systems in implementing environmental, social, and governance objectives, in other words, the company's 'sustainability objectives'. This database provides multiple indicators in the different areas of sustainability, many of which are oriented to specific countries or certain activity sectors; however, a set of these measures is available for all countries and sectors, which are used on a recurrent basis to evaluate the environmental and social sustainable performance by numerous researchers (e.g., García-Sánchez and García-Meca 2017; Martínez-Ferrero and García-Sánchez 2016; León 2015; Boudt et al. 2013).

This set of measures consists of 28 CSR practices (see Table 2) that quantify the sustainable commitment of companies in a reliable way through the EIRIS data base, as well as in a precise way through each practice evaluating the level of commitment of the company on a scale of 0 to 4 (where 1-weak, 2-moderate, 3-good, and 4-exceptional). This quantification is also complete and balanced, since its evaluation includes the different approaches of the companies. These include the following. (i) The care and protection of the environment: the EIRIS agency makes reference to the preservation of the environment in relation to the waste disposal, decontamination, energy expenditure, or climate change through the valuation of the policies, systems, and reports, as well as the quantification of the impact of its commercial processes. (ii) Safeguarding human rights: the practices are aimed at evaluating the policies, systems, and reports of companies in the adoption of codes of conduct related to the elimination of forced or child labour, discrimination, or working conditions. (iii) The defence of employees' labour rights: these measures correspond to internal CSR, encompassing initiatives aimed at promoting equal opportunities and improving the quality of work, both contractual and physical, such as practices aimed at to maintain good health and safety conditions, employee participation, and work for the disabled or training. (iv) The deal with stakeholders: these variables refer to relationships with the external part of the company, such as practices aimed at maintaining good relations with customers, suppliers, consumers, or the community, among others, as well as encompassing initiatives that inform the impacts on the present and future of the company; in addition, they also refer to practices for fluid communication with all stakeholders, establishing a mutually beneficial relationship. (v) Business ethics: these refer to the policies and systems in place to combat political corruption and the establishment of ethical values that must be fulfiled in all areas of the company.

Table 2. Composition of Corporate Social Responsibility Practices. EIRIS: Ethical Investment Research Services.

\begin{tabular}{|c|c|c|}
\hline \multicolumn{3}{|r|}{ Environmental Dimension } \\
\hline \multicolumn{3}{|r|}{ Environment } \\
\hline ENV1 & Environmental policy & $\begin{array}{l}\text { How does EIRIS rate the company's environmental policy and } \\
\text { commitment? }\end{array}$ \\
\hline ENV2 & Environmental systems & How does EIRIS rate the company's environmental management system? \\
\hline ENV3 & Environmental reporting & How does EIRIS rate the company's environmental reporting? \\
\hline ENV4 & $\begin{array}{l}\text { Environmental } \\
\text { performance }\end{array}$ & $\begin{array}{l}\text { What level of improvements in environmental impact can the company } \\
\text { demonstrate? }\end{array}$ \\
\hline \multicolumn{3}{|r|}{ Social dimension } \\
\hline & & Human Rights \\
\hline HR1 & Human rights policy & What is the extent of policy addressing human rights issues? \\
\hline HR2 & Human rights systems & What is the extent of systems addressing human rights issues? \\
\hline HR3 & Human rights reporting & Does the company report on human rights issues? \\
\hline
\end{tabular}


Table 2. Cont.

\begin{tabular}{|c|c|c|}
\hline \multicolumn{3}{|r|}{ Employees } \\
\hline EMP1 & $\begin{array}{l}\text { Equal opportunities } \\
\text { (policy) }\end{array}$ & $\begin{array}{l}\text { How good is the company's policy on equal opportunity and diversity } \\
\text { issues? }\end{array}$ \\
\hline EMP2 & $\begin{array}{l}\text { Equal opportunities } \\
\text { (systems) }\end{array}$ & $\begin{array}{l}\text { How clear is the evidence of systems and practices to support equal } \\
\text { opportunities and diversity? }\end{array}$ \\
\hline EMP3 & Health and safety systems & How clear is the evidence of health and safety systems? \\
\hline EMP4 & $\begin{array}{l}\text { Trade unions and } \\
\text { employee participation }\end{array}$ & How clear is the evidence of systems that manage employee relations? \\
\hline EMP5 & Training & $\begin{array}{l}\text { How clear is the evidence of systems that support employee training and } \\
\text { development? }\end{array}$ \\
\hline EMP6 & Job creation and security & $\begin{array}{l}\text { How clear is the evidence of systems and practices that advance job } \\
\text { creation and security? }\end{array}$ \\
\hline \multicolumn{3}{|r|}{ Stakeholders } \\
\hline STH1 & Community relations & How clear is the company's commitment to community or charitable work? \\
\hline STH2 & $\begin{array}{l}\text { Customer/supplier } \\
\text { relations policy }\end{array}$ & $\begin{array}{l}\text { Does the Ccmpany have policies on maintaining good relations with } \\
\text { customers and/or suppliers? }\end{array}$ \\
\hline STH3 & Community involvement & $\begin{array}{l}\text { How clear is the evidence of systems that maintain good relations with the } \\
\text { community? }\end{array}$ \\
\hline STH4 & $\begin{array}{l}\text { Responsibility for } \\
\text { stakeholders }\end{array}$ & How many stakeholder issues have been allocated to board members? \\
\hline STH5 & Stakeholder engagement & What level of engagement with stakeholders is disclosed by the company? \\
\hline STH6 & Stakeholder policy & How good are the company's policies towards its stakeholders overall? \\
\hline STH7 & Stakeholder systems & $\begin{array}{l}\text { How good is the company's quantitative systems on stakeholder } \\
\text { relationships? }\end{array}$ \\
\hline STH8 & Stakeholder reporting & $\begin{array}{l}\text { How good are the company's management reporting for stakeholders } \\
\text { overall? }\end{array}$ \\
\hline & & Ethics and Governance \\
\hline ETH1 & Codes of ethics & Does the company have a code of ethics and, if so, how comprehensive is it? \\
\hline ETH2 & Codes of ethics systems & $\begin{array}{l}\text { Does the company have a system for implementing a code of ethics and, } \\
\text { if so, how comprehensive is it? }\end{array}$ \\
\hline ETH3 & \multirow{2}{*}{$\begin{array}{c}\text { Countering bribery policy } \\
\text { Countering bribery } \\
\text { systems }\end{array}$} & What is the extent of the company's policy for countering bribery? \\
\hline ETH4 & & What is the extent of the company's system for countering bribery? \\
\hline ETH5 & $\begin{array}{l}\text { Countering bribery } \\
\text { reporting }\end{array}$ & What is the extent of the company's reporting on countering bribery? \\
\hline ETH6 & Board practice & $\begin{array}{l}\text { How many of the core elements of corporate governance does the company } \\
\text { have? }\end{array}$ \\
\hline ETH7 & ESG risk management & $\begin{array}{l}\text { How well do the board and senior management address company-wide } \\
\text { ESG (Environmental, Social, and Governance) risks and opportunities? }\end{array}$ \\
\hline
\end{tabular}

\subsection{Statistical Multivariate Methods}

\subsubsection{X-STATICO Analysis}

Simier et al. (1999) and Thioulouse et al. (2004) presented what they call the STATICO method, which, in reality, is a combined study of a co-inertia analysis and a STATIS. In this research, we perform an X-STATICO analysis (co-inertia and X-STATIS, which are described below). The X-STATICO method is an efficient tool for the simultaneous analysis of a succession of pairs of tables. The flexibility of this technique comes partly from the co-inertia analysis, which maximises the squared covariance between the values of the individuals according to two different sets of variables. Figure 1 shows the procedure scheme on which the X-STATICO analysis is based. 


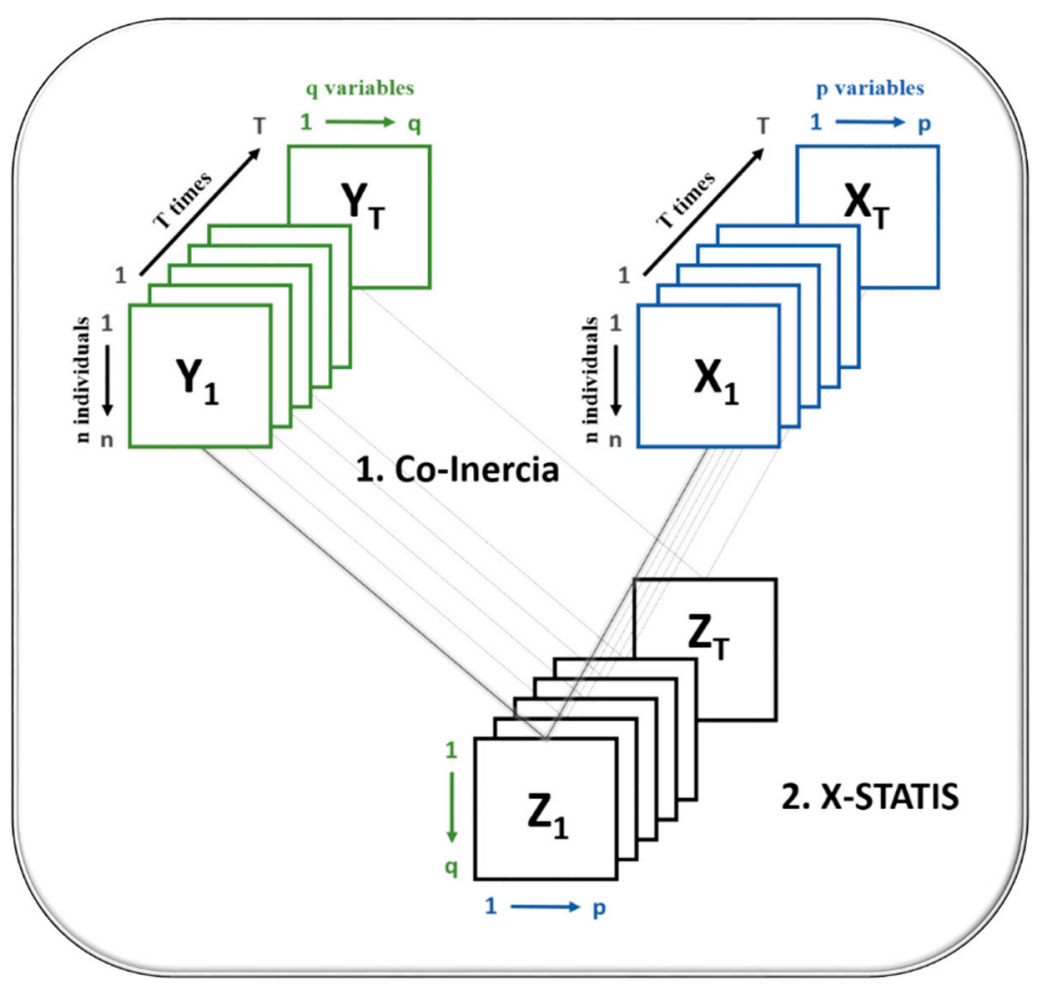

Figure 1. Diagram of procedure on which the X-STATICO analysis is based.

The data are arranged in two successions of $T$ tables where $t$ refers to the years 2004-2014; the first succession of $X_{t}$ tables correspond to the social commitment, and each $X_{t}$ matrix carries the information of $n$ individuals (countries) measured on $p$ variables (social practices); another succession of $Y_{t}$ tables with information on the same $n$ individuals measured on $q$ variables (environmental practices). In this way, we perform a co-inertia analysis (Dolédec and Chessel 1994) for each pair of tables $Y_{t}$ and $X_{t}$; this is a multivariate method that explores the covariance between two sets of data, and allows the finding of the common structure between two groups of variables on the same individuals. This is achieved by finding the successive axes of the two sets of data with maximum covariance, obtaining a succession of $Z_{t}$ crossed tables of $q x p$ dimensions; that is, each table contains the covariance between the environmental and social performance of countries, $Z_{t}=Y_{t}^{\prime} X_{t}$.

The next step is to perform an X-STATIS analysis (Jaffrenou 1978) on these $Z_{t}$ tables, where the rows refer to the practices that evaluate the environmental commitment of the companies and the columns correspond to those that measure their concern for social welfare (Figure 2). The STATIS family methods (Structuration de Tableaux A Trois Indices de la Statistique) are data analysis techniques that have been developed to extract the relevant information stored in three-way data tables; that is, several two-way matrices indexed by time (Escoufier 1976; L'Hermier des Plantes 1976). The essential idea of the STATIS methods is to look for a common structure to all matrices, which is called structure consensus or compromise; for it, scalar products are made between matrices capturing the statistically significant information. The X-STATIS is a technique belonging to the STATIS family, with a peculiarity, since, although it is only applicable to the set of matrices constituted by the same individuals and the same variables in $T$ times or occasions, it has the advantage of not losing the original information, since it does not use operators. Instead, it works directly with the matrices, which also makes its procedure easier and allows more representations. This method follows a three-stage scheme: (i) the interstructure study, (ii) the compromise analysis, and (iii) the intrastructure study. 


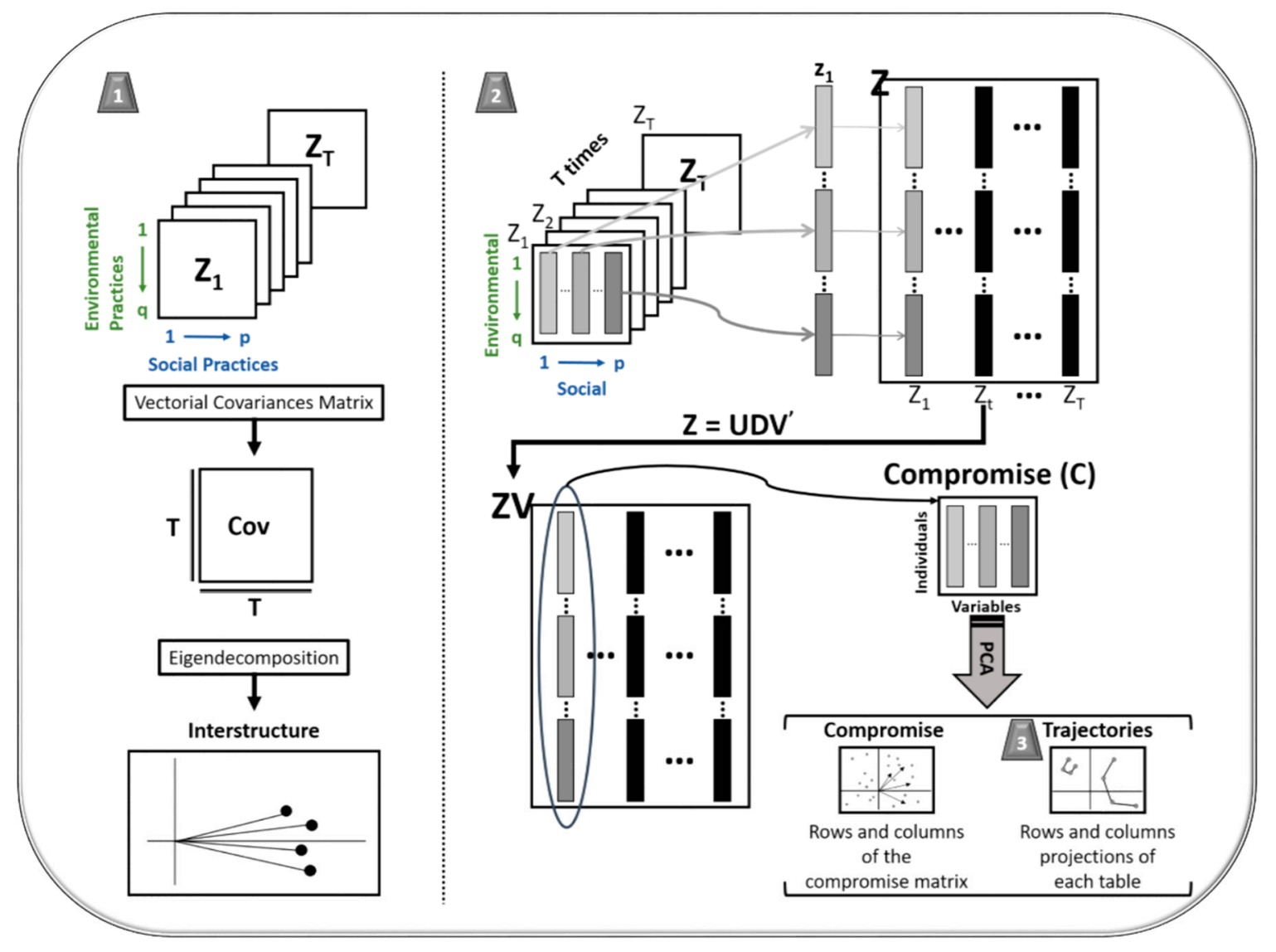

Figure 2. Scheme of procedure on which the X-STATIS analysis is based.

i The interstructure study: in the first stage, it is about studying the relationship between the different data tables, that is, a general comparison of the $T$ data tables' structure. For this, a matrix of vector covariances between tables is constructed, so that the element in row $t$ and column $l$ is $\operatorname{Covv}\left(Z_{t}, Z_{l}\right)=\operatorname{Traza}\left(Z_{t}^{\prime} D_{q} Z_{l} D_{p}\right)$, where $Z_{t}$ is the $t$-table of the sequence, and $D_{q}, D_{p}$ are the metrics for the rows and columns, respectively. Applying a decomposition in singular values to this matrix, we can reduce the dimensionality and represent this information in an Euclidean subspace of low dimension, in which each data table (years) is represented as a point. The distance between points is associated with similarity; that is, two close points correspond to two years of similar characteristics, and, if we join these points to coordinates origin, we can visualise an estimate of said similarity in terms of the angles between vectors, associating acute angles with strong similarities.

ii The compromise analysis: the second stage consists in the compromise analysis, where, through the vectorisation of the $Z_{t}$ matrices, that is, a linear transformation that converts each matrix into a column vector, concatenating the constituent columns of each matrix one on top of the other; so, if we have $T$ matrices, we have a new matrix of $T$ columns and $q x p$ rows, with $q$ being the number of individuals (our environmental practices) and $p$ being the number of variables (social practices) that, as we said, should be the same for each matrix. We call this matrix $Z$. From a decomposition in singular values of the matrix $Z$, we get a new matrix known as the $Z V$ matrix, from which we extract the first column that contains the factorial loads of the first eigenvector-which carries most of the information-and provides us with the information that all the matrices have in common, and, unfolding this vector, we obtain the compromise matrix (C). This matrix synthesises the information of each one of the $q$ individuals in the $p$ variables for the $T$ times or occasions, 'filtering the noise' and representing the statistically significant information: 
the stable structure of the data. If we apply a principal component analysis to this matrix, we can trace and interpret its structure, where environmental practices (rows of the compromise matrix) and social practices (columns of the compromise matrix) are represented, which refer to the information during the $T$ times. With this information, we can interpret the relationships between the variables of two types (environmental and social) based on how all of the countries behave in them through the compromise analysis.

iii The intrastructure study: in the third stage, we study the intrastructure (also known as trajectories). The compromise matrix obtained in the previous stage allows representing the commitment positions of each of the elements (environmental and social practices) that make up the different tables. These positions correspond to the average positions of the same. This gives us a compromise space for the projection of the elements of each of the starting matrices, that is, the projection of the environmental practices (rows) and social practices (columns) of each year (each table) in the compromise subspace. Let $V_{r}$ be the first $r$ eigenvectors of the compromise matrix. The coordinates of the rows of the $Z_{t}$ table are the rows of $Z_{t} D_{p} Z_{r}$, and the columns are the rows of $Z_{t}^{\prime} D_{q} U_{r}$, where $U_{r}$ are the first eigenvectors of $C D_{p} C^{\prime} D_{q}$. The trajectories provide information on the evolution of each of the elements (environmental and social practices), and show how each table differs from the stable structure. With all this information, we can determine the relevance of worldwide CSR practices, showing which practices are commonly the most demanded and developed by all companies, and find those social practices that are generally implemented within the company with a development that is similar or close to environmental practices.

The main advantage of this method is that it provides a compromise of co-structures; that is, it first verifies how the pairs of variables co-exist (co-inertia analysis) and then obtains a commitment structure that represents these relations and the trajectories during the $T$ times that show the evolution that is drawn on it. That is, the stable component of the variations in the relationships between the variables of two cubes is represented, which can be traced, and the graphical results can be very detailed.

\subsubsection{Tucker3 Analysis}

The Tucker3 model proposed by Tucker (1966) is the decomposition of data from a three-way array $X=x_{i j t}$, which means that the $t$ tablas (or matrices, which represent $t$ conditions) have $I$ rows and $J$ columns, where the first mode consists of $I$ subjects, the second is composed by $J$ variables, and the third one makes reference to the $T$ different times or conditions. The decomposition of this cube formed by the $X_{t}$ matrices has the following form (Kroonenberg 2008; Kiers and Kinderen 2003; Barbieri et al. 1999) (see Figure 3):

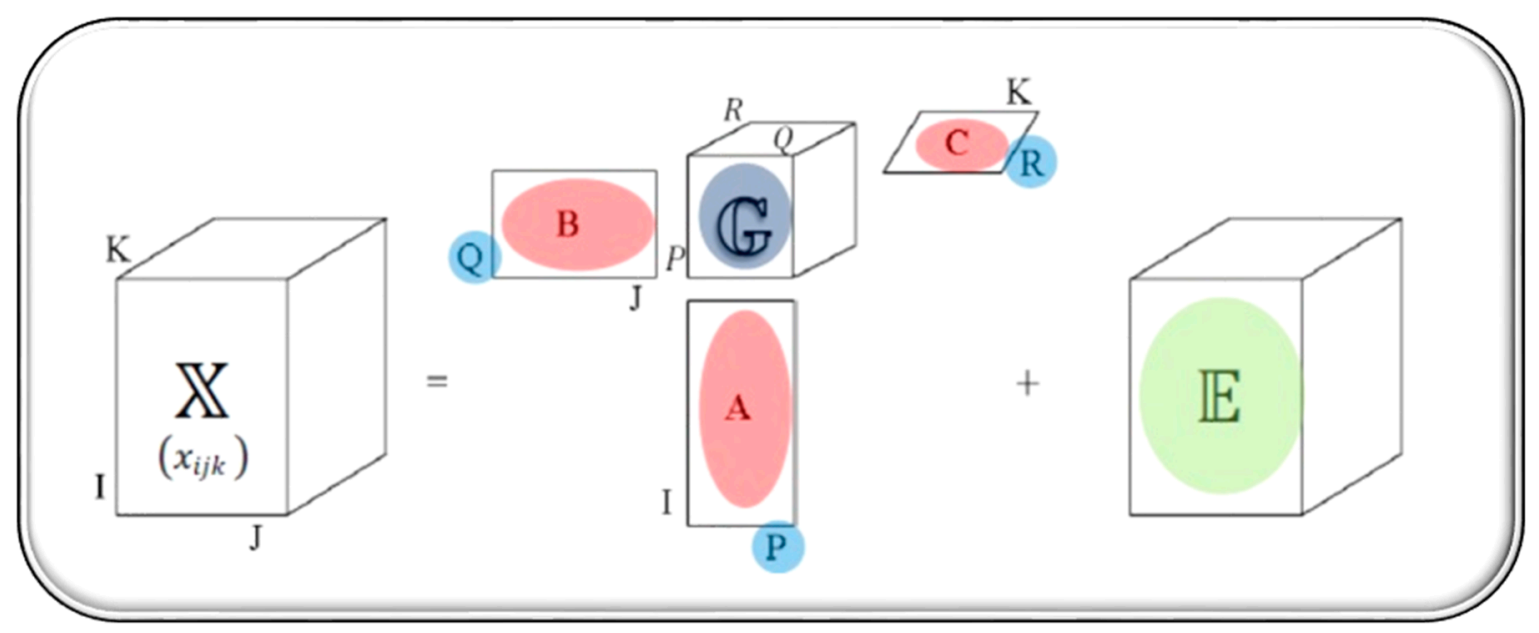

Figure 3. Scheme of procedure on which the Tucker3 analysis is based. 
where:

1. A, B, and C correspond to each of the modes with $I, J$, and $T$ dimensions, respectively, to describe the subject to analyse.

2. $\quad P, Q$, and $R$ refer to the number of components retained for each of the modes $\mathbf{A}, \mathbf{B}$, and $\mathbf{C}$, respectively, with $P \leq I, Q \leq J$, and $R \leq T$.

3. $E$ corresponds to the residual matrix associated with the description of $X$.

4. $G$ represents the central matrix known as the core matrix of $\boldsymbol{P} \times \boldsymbol{Q} \times \boldsymbol{R}$. dimensions, $G_{P \times Q \times R}$. This matrix represents the value by which the product of a single component is weighted, so that the value and sign of each element of this matrix provides information about the entity of the interaction between the components of the different modes. In addition, it contains the amount of variability explained by the combination of said components $(P, Q$, and $R)$.

Decomposition can be formulated as a factorisation of the $X_{I \times J \times T}$ three-way data matrix, such that, every element of our starting data cube $(X)$ can be decomposed with the following equation:

$$
x_{i j t}=\sum_{p=1}^{P} \sum_{q=1}^{Q} \sum_{r=1}^{R} a_{i p} b_{j q} c_{t r} g_{p q r}+e_{i j t}, \quad i=1, \ldots, I ; j=1, \ldots, J ; t=1, \ldots, T
$$

where:

1. $a_{i p} b_{j q}$, and $c_{t r}$ are the elements of the $A_{I \times P}, B_{J \times Q}$ and $C_{T \times R}$ charge matrices respectively, and $p, q, r$ denote the number of components in the modes $A, B$, and $C$.

2. $e_{i j t}$ is an element of the residual three-way matrix $E$, which denotes an error term associated with the description of $x_{i j t}$.

3. $g_{p q r}$ elements weigh the products among the $p$ components of the subjects (first mode, A), the $q$ components of the variables (second mode, B), and the $r$ components of the different conditions (third mode, C) and explain the interaction between the factors $p, q, r$ of each of the modes. Those elements are stored in the core matrix $G$, of dimensions $(P \times Q \times R)$. This matrix can be considered as a generalisation of the diagonal matrix of the eigenvalues obtained from the decomposition into the singular values of a two-way matrix (note that said singular value decomposition forms the basis of the generalisation of the methods for multiple-way arrays). In addition, the core matrix $\mathrm{G}$ is derived from the matrices of the three modes $A_{I \times P}, B_{J \times Q}$ and $C_{T \times R}$ as follows:

$$
g_{p q r}=\sum_{i=1}^{I} \sum_{j=1}^{J} \sum_{t=1}^{T} a_{i p} b_{j q} c_{t r} x_{i j t}
$$

The first step in the construction of this matrix is to select how many components we retain in each mode. The first fundamental point is that the components that we are going to retain in each of the modes do not have to have the same dimension. Normally, in principal components, we conserve the first two; in this model, it does not have to, and this is the fundamental point, since we can not only analyse the information that comes in the first components, but also the information that comes after them; the information that these components contribute is where the new information is really located that explains the dynamics of the data and the reason for certain phenomena.

When selecting the $P \times Q \times R$ model with which we are going to work, it is necessary to consider all of the combinations $P \times Q \times R$ with $P \leq I, Q \leq J$ y $\leq T$. There is no direct rule for choosing the number of components; we have to know the data and know that, since the more components we retain in each of the modes, the more complex we will have in the model, we must look at a great complexity of advantages and disadvantages. However, there are some restrictions incorporated in the model; in particular, the minimum product rule says that the product of the number of components in two modes must always be equal to or greater than that of the third modality, so that $P \times Q \geq R$, $P \times R \geq Q$ y $Q \times R \geq P$. 
Once all the possible combinations have been made, the combination that presents a sufficiently high percentage of explained variance and the simplest of the most stable ones is chosen. The sum of the number of its components is calculated for each of the models, $S=P+Q+R$, and, for each value of $S$, the one with the highest variance value explained is selected, or equivalently, a lower value of the residual sum of squares. In this way, we obtain a list in which each of the models has a value of $S$. In increasing order of $S$, the incremental quotient between the residual sum of squares and $S$ is calculated for each of the models, and we only remain with those models for which their value of the incremental quotient is similar to the next, that is, the more stable models. Finally, we would select for our analysis that model of the stable ones with a lower value of $S$, that is, the simplest among the most stable. We show in Figure 4, by way of example, where the models positioned in the polygonal line (blue) are those with the smallest values in relation to the residual sum of squares (vertical axis) for each value of $S$ (sum of components, horizontal axis); and the vertical line (purple) separates the most stable models (right) from the least stable models (left). So, for this particular case, the selected model would be the $3 \times 2 \times 3$ for being the simplest among the most stable.

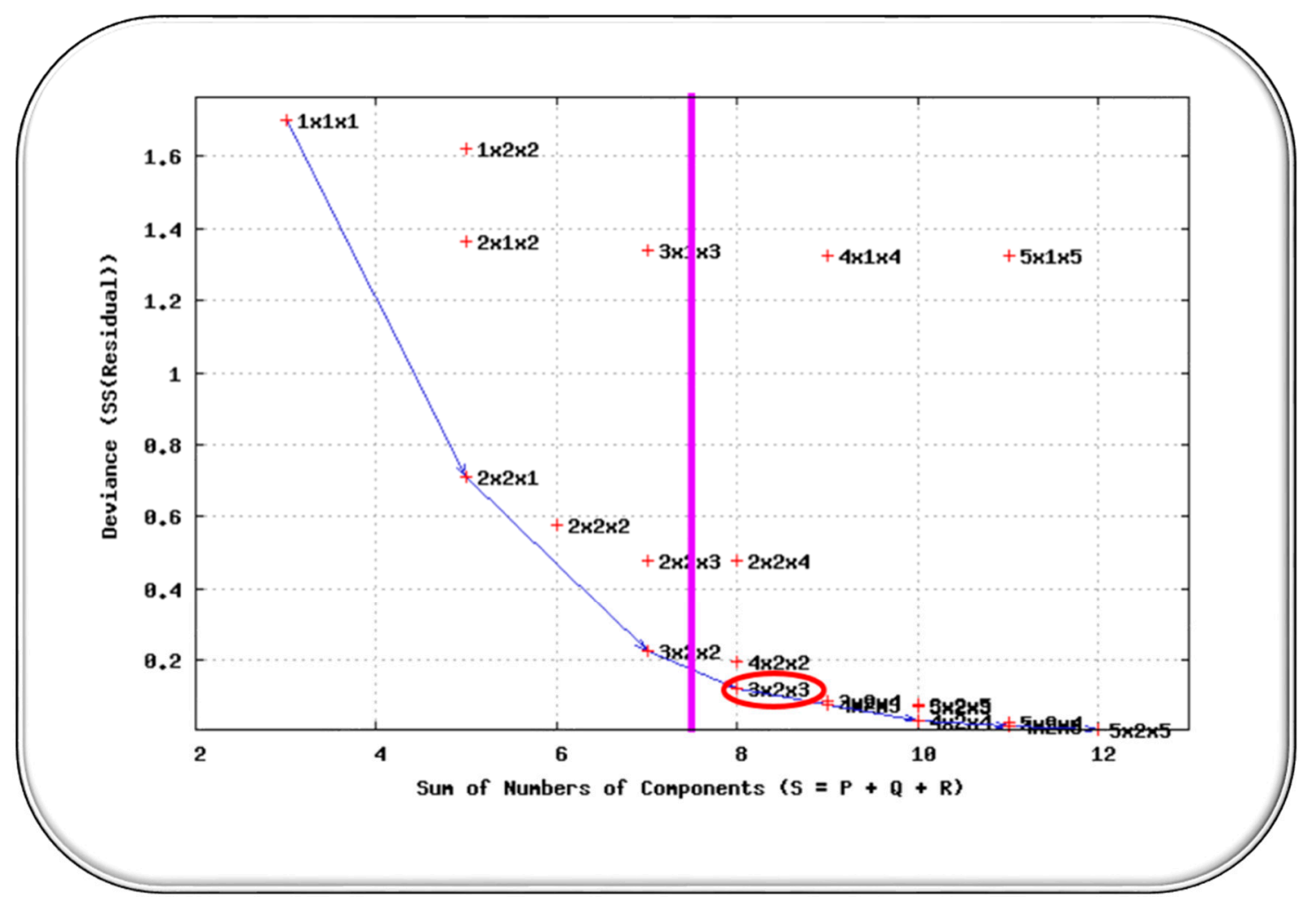

Figure 4. Example model selection of a Tucker3 analysis.

Once the number of components to be retained in each mode has been selected, that is, the values of $P, Q$ and $R$, we perform the analysis for the simplified model. The first step is to interpret the elements of the core matrix $G_{P \times Q \times R}$ that indicate the strength or weight of the relationships between the components of the different dimensions or modes and provide a value in reference to the amount of variance explained. Therefore, we stayed with those elements that explain more information.

Once we have selected the elements of the core matrix that we are going to study, we interpret each of them (e.g., $g_{312}$ would be an element composed of the third component of the first mode, the first component of the second mode, and the second component of the third mode). So, when interpreting the relationships between individuals, variables, and times, it does not only have a place if the element of $G$ presents a high value, but also the combination of the signs of the four factors of the term $a_{i p} b_{j q} c_{t r} g_{p q r}$. For example, if $g_{p q r}$ has a positive sign $\left(+g_{p q r}\right)$ and the product of the components 
$p t h$, qth and $r$ th of the first, second, and third modes, respectively, is also positive; then, the general effect of the term $g_{p q r}\left(a_{i p} b_{j q} c_{t r}\right)$ is positive. Symbolically, it is:

$$
[( \pm) \text { core }] \times[( \pm) P \times( \pm) Q \times( \pm) R]= \pm \text { interaction }
$$

Next, we show a diagram for the interpretation of the elements of the core matrix (see Figure 5).

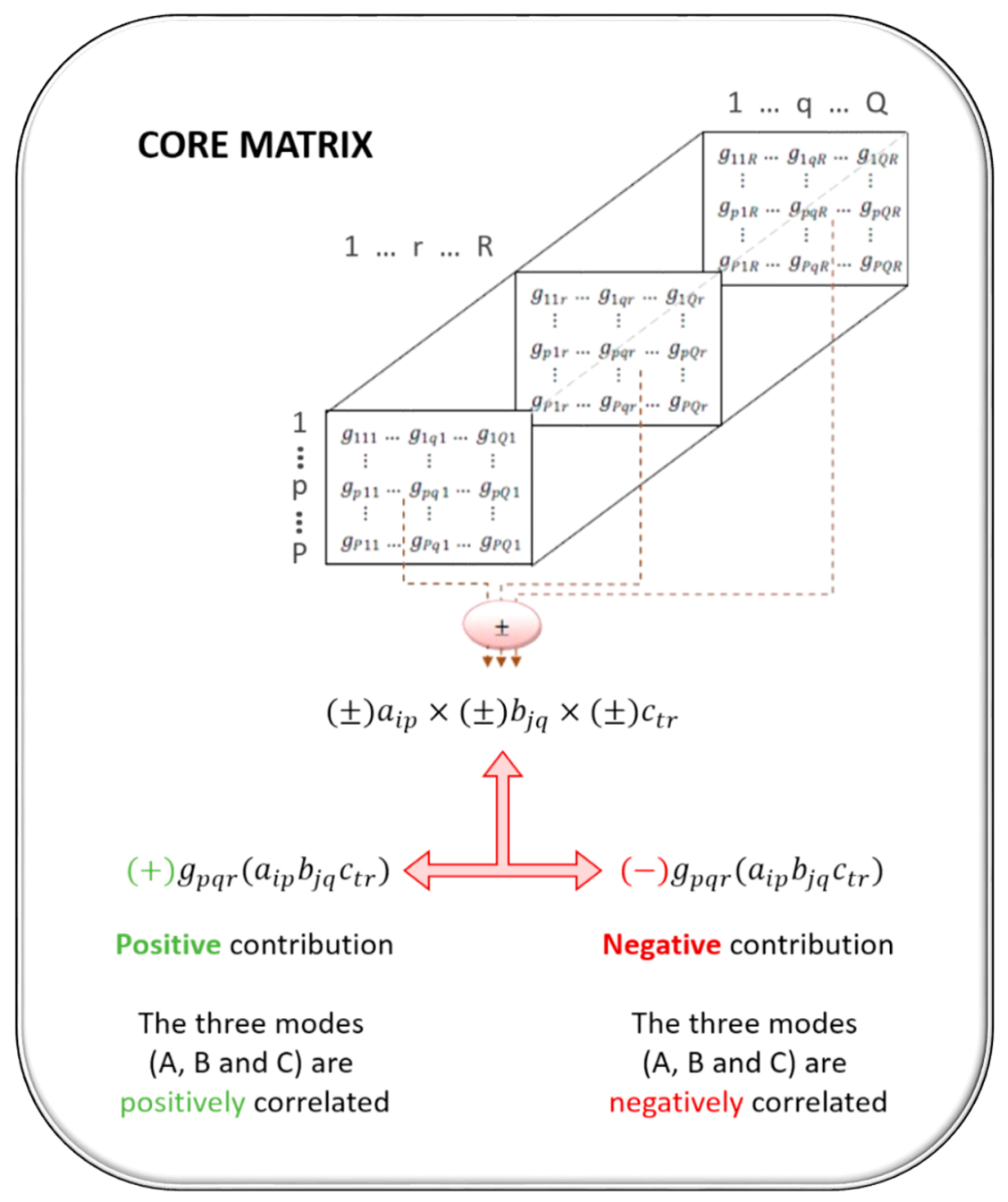

Figure 5. Interpretation diagram core matrix elements of a Tucker3 analysis.

In this investigation, the data present a three-way structure, where the A mode of subjects corresponds to the countries of origin of large international companies; the B mode of variables refers to international practices that assess the level of sustainability of companies; and, the C mode of times is in relation to the years of study, which in this case is the 2004-2014 decade. The fundamental objective of the use of this methodology is to examine the relationships between deeper interactions, seeking to characterise each of the countries of origin of the companies in relation to the development of their CSR practices.

A simple way to understand the interactions is in a visual way, so that three sub-graphics are displayed, one for each mode. Each sub-graphic represents two components in one way, one horizontally and one vertically; the countries are represented by circular flags, and CSR practices and the years are represented by vectors, all of them linked to the origin of coordinates. So, when studying each element, we must take into account each of the signs, since this method not only allows us to study the interaction, it also enables us to assess whether it is positive or negative and which 
rows (mode A) are the ones that interact with which columns (mode B) and at what times or conditions (mode C):

$>$ Sign of the elements that appear in the core matrix $\rightarrow(+/-)$ core

$>$ Sign of the elements in the studied component of the first mode $\mathrm{A} \rightarrow(+/-) \mathrm{P}$

$>$ Sign of the elements in the studied component of the second mode $\mathrm{B} \rightarrow(+/-) \mathrm{Q}$

$>$ Sign of the elements in the studied component of the third mode $\mathrm{C} \rightarrow(+/-) \mathrm{R}$

Any of the three-way study methods provides a more complete view of the problem than the individual multivariate analyses, but if we also use these techniques in a complementary way, we can benefit from the advantages of each of them. In this way, if in the previous section, we described the use of one of the STATIS methods to capture the multivariate character of the data highlighting its stable part, now, with the Tucker3 method, we emphasise the dynamic part, i.e., what has changed. More specifically, the Tucker3 method allows us, through the study of deeper interactions than those studied with other techniques, to characterise in an individual way each of the countries of origin that are part of the sample, according to their strengths (positive interactions) and weaknesses (negative interactions) in each of the CSR practices under study. In addition, it's possible to know if these interactions change during the study period, and if so, we can know specifically the years in which they occur.

\section{Results}

\subsection{Characterisation of the Relevance of CSR Practices Worldwide}

As a first step, through an X-STATICO analysis, we proceed to analyse the importance of the dimensions and sub-dimensions of the CSR considered, studying the similarities and differences that exist between each of the practices, taking into account their grouping in the established environmental and social dimensions. The data for this analysis are arranged in two cubes of 18 rows (the countries), with 11 repetitions (the years 2004-2014): a cube with four columns, corresponding to the environmental variables; and the other with 22 columns, indicating practices related to social welfare.

The first step of the X-STATICO analysis (Figure 6) is the realisation of a co-inertia analysis between each pair of tables of both cubes. With this analysis, we seek to find the agreement established between the countries from the point of view of their environmental practices and from the point of view of their social practices, so that it provides us with a matrix for each year in which their rows will be the environmental variables and the social ones their columns, thus facilitating the vision of the most important relationships between each pair of tables. The second step consists of carrying out an X-STATIS analysis whose objective is to highlight the stable structure throughout this decade, that is, to find a 'middle year' to represent each of the practices and their relationships in this structure stable, and show how each of these moves away from said structure.

The first result that this method provides us is an interstructure study of the X-STATIS analysis after performing the co-inertia analysis, which allows us to reduce the dimensionality and represent the information in an Euclidean subspace of low dimension, in which each year (data table) is represented as a point, and joining these points to coordinates' origin, we can visualise an estimate of said similarity in terms of the angles between vectors, associating acute angles with strong similarities (see Figure 7). This representation includes $83.18 \%$ of the total variability, and allows the interpretation of the similarities and differences between the years of study. This representation also indicates which of these acquire greater importance in the construction of the so-called compromise matrix, that is, those years that look more like an 'average year', which will highlight the stable part of the evolution of the data over time. 


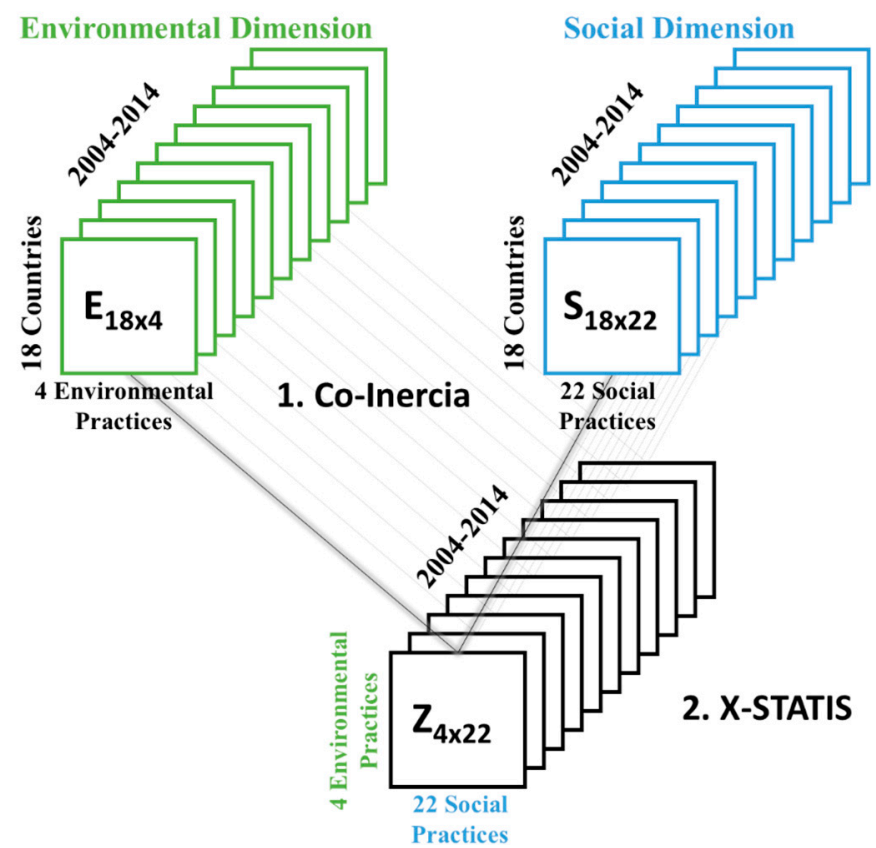

Figure 6. Diagram of the procedure of X-STATICO analysis.

Acute angles between vectors can be observed, that is, strong similarities between years, produced in a gradual way, since the first year of the study, 2004, is located in the lower part of the figure, and as the years increase, they increase their position until they reach 2014, which occupies the highest position. Therefore, we intuit a constant growth in the commitment of company sustainability in this decade of study. Also, the 'average year', which was most similar to the stable configuration, is seen for the years 2009 and 2010, which were those closest to the abscissa axis. They were also the intermediate years of the study, since as we said, the relations are produced in a gradual way.

The next step is the attainment of the compromise matrix, which summarises all of the information provided by each of the configurations, since this matrix is a global summary of all of the tables. Therefore, in the subspace created by this matrix, the relationships between environmental and social variables can be interpreted according to how all of the countries behave in them. This representation (Figure 8) collects $97 \%$ of the information, and in it, two figures can be visualised. The first, which is located on the left, corresponds to the environmental variables, which are identified as green, and the second is located on the right, and refers to the variables of social type, distinguished by colours according to their sub-dimensions. Thus, the red vectors refer to human rights, purple correspond to employees, orange are in relation to stakeholders, and blue are those referring to business ethics.

In relation to environmental practices, all of them are located in the right semi-plane (quadrants I and IV); with this information, we understand that the countries with the most sustainable companies would be positioned on the right side next to these variables, since it would be difficult to conceive that a country denominated as sustainable presented low values in environmental practices. In reference to social practices relevance, it is argued that those countries with strong demands for environmental practices give similar importance to practices aimed at the participation of both employees (EMP4) and stakeholders (STH5) in the decision making of the company; to the health and safety of these (EMP3), equal opportunities systems (EMP2), as well as training (EMP5) and job creation (EMP6); systems for the good management of stakeholders (STH7) to maintain good relations with the community (STH1), and information disclosure (STH8); all of them located in the right semi-plane (quadrants I and IV) and maintain a direct relationship with environmental variables. The rest of the variables have an inverse relationship with the environmental ones, such as equal opportunities policies (EMP1) or policies on stakeholders (STH6), and those related to human rights and ethics receive less importance. 


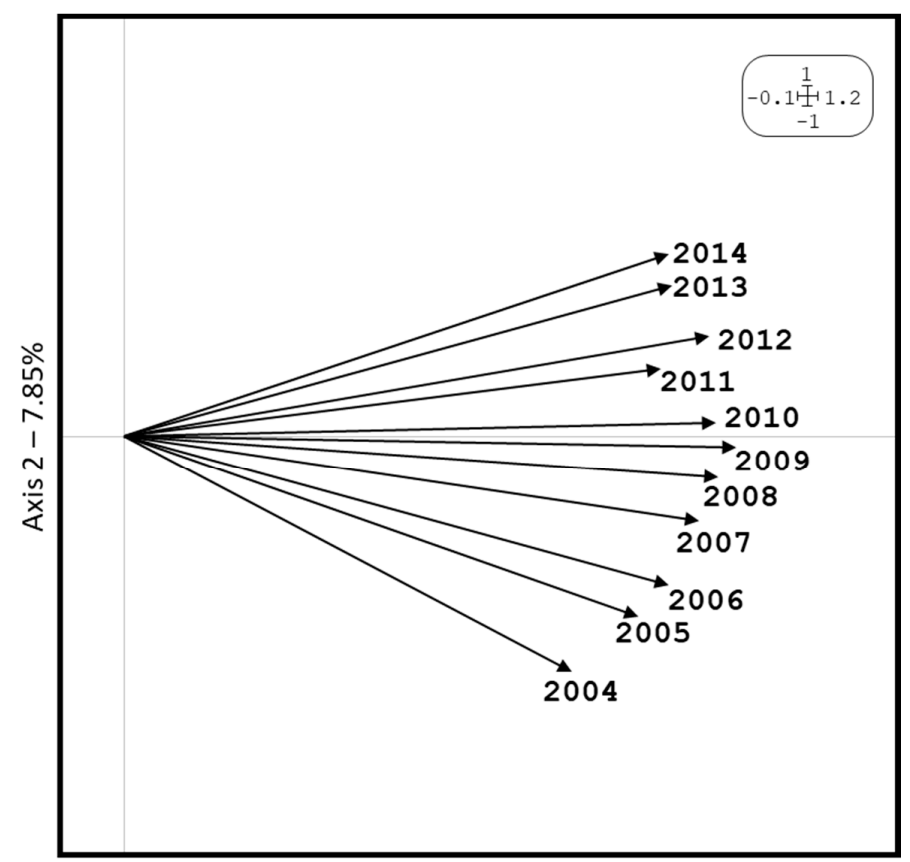

Axis $1-75.33 \%$

Figure 7. Factorial plane 1-2 representation with the ordering of the sampling years, interstructure study of the X-STATICO analysis.

In general terms, companies from all over the world give greater importance to their environmental levels, their relationships with their stakeholders, and the labour rights of their employees. This is because companies strive to achieve global consistency in their CSR profile, combined with the need to meet the demands of local stakeholders and trust with their employees, in order to achieve a proactive image of good prestige and social reputation and therefore, the economic advantages associated with this commitment.

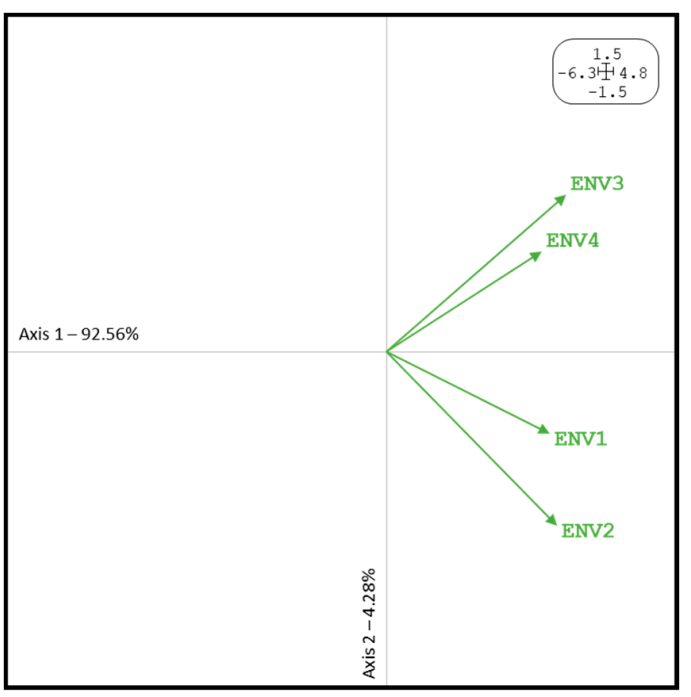

(a)

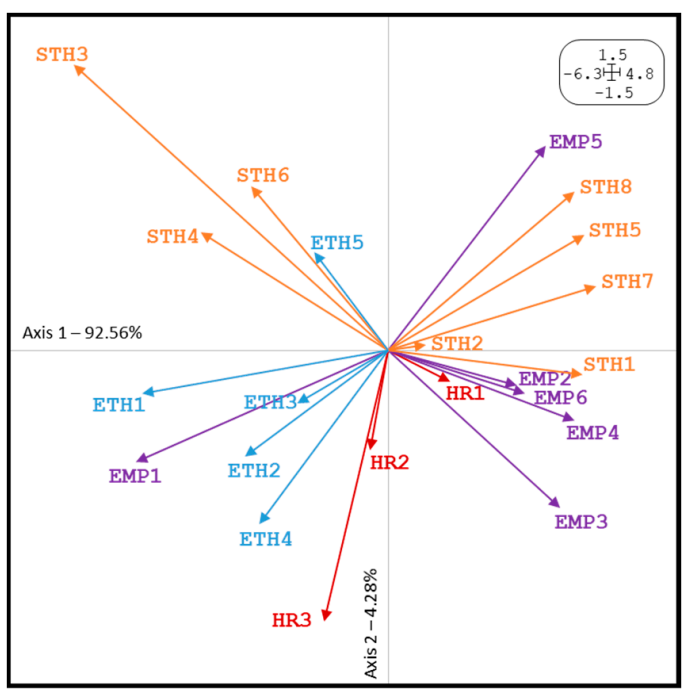

(b)

Figure 8. Compromise analysis of X-STATICO. (a) environmental practices; (b) social practices.

The third and last step of this analysis includes the intrastructure study, also known as trajectories, which allows us to interpret, by the projection of each one of the rows (environmental variables) and 
columns (social variables) of each of the starting tables (years) about the compromise subspace created, how these relationships vary over time. This representation (Figure 9) has been separated for each of the variables in order to obtain an individualised view; the vector represents the commitment position of each variable and the union of the points the trajectory from the first year of study (2004) to the last (2014). It can be observed that social practices that have a direct relationship with the environment, that is, those positioned in the right semi-plane (quadrants I and IV), show greater stability, with homogeneous locations occupying a similar position in the plane during this decade; this may be because these practices respond to the expectations of the stakeholders that are a very important part of the company and provide great reliability on the rights of their employees, creating an image of a responsible and concerned company on their part, internally as well as externally, workers, stakeholders, consumers, etc. Apparently, these practices have forged a place next to the environmental ones, acquiring an importance close to these, so that both consumers and any other interest group of the company no longer simply demand the protection of the environment, but also the development of systems oriented to labour rights and dealing with different stakeholders that arise from the employee relationships, transparent dialogue, and participation with stakeholders.

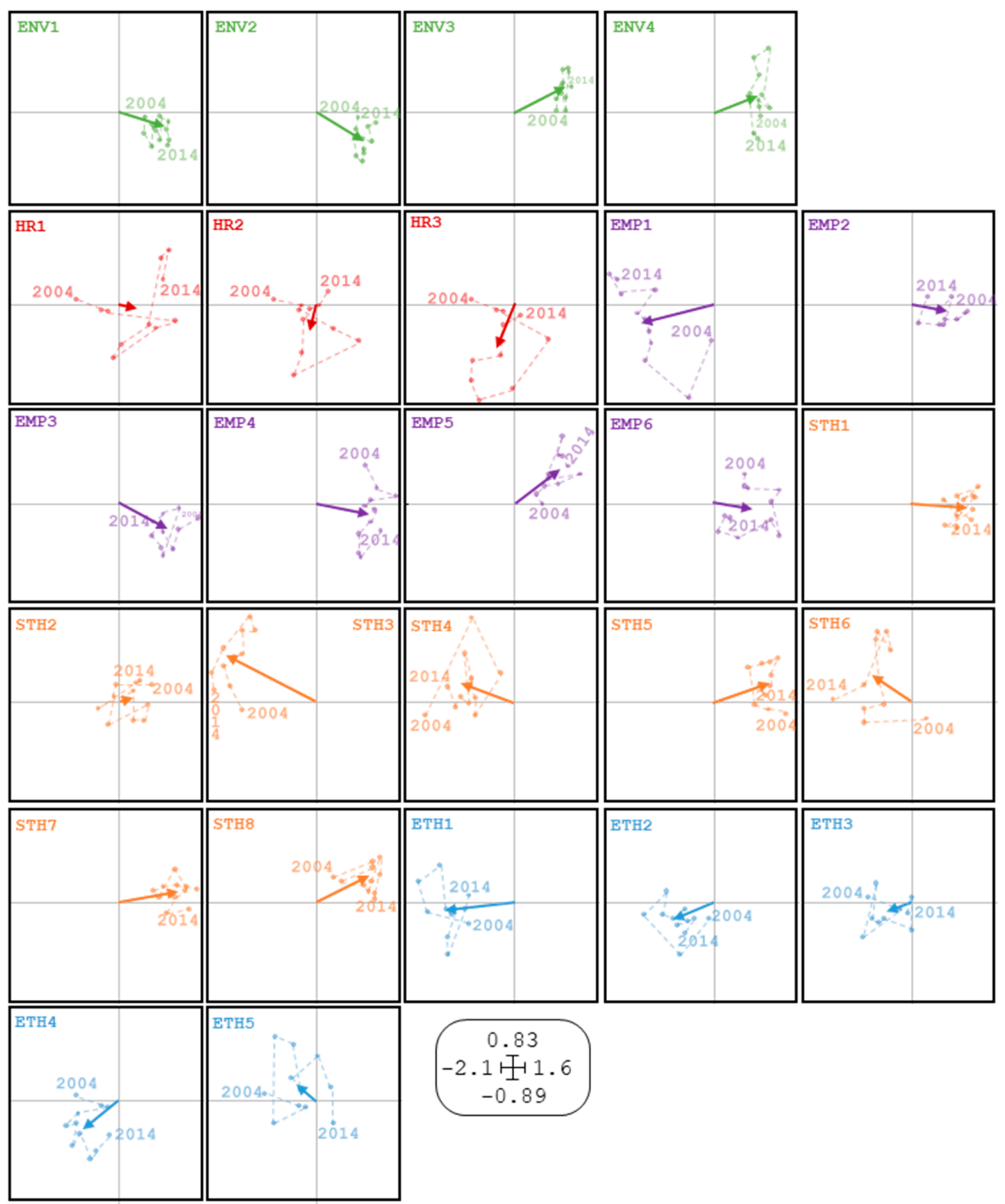

Figure 9. Corporate Social Responsibility (CSR) practical trajectories, X-STATICO analysis. 
We find the opposite situation in the rest of variables, those located in the left semi-plane (quadrants II and III), which extend over a large part of the plane, presenting great instability during these years, which explains why these practices are not the main requirement of both internal and external groups of companies. Given the possibility that they are not entrenched in some countries, in general, these variables refer to business ethics and acquire less importance than the rest. However, they will certainly have a place in certain companies, a priori; it is to be assumed in less polluting companies, given the inverse relationship with environmental practices.

\subsection{Characterisation of the Relevance of CSR Practices According to the Country of Origin}

Once the analysis of the CSR has been established at the global level, in this section, we determine the development and evolution of these practices, according to the country of origin of the companies. With a Tucker3 analysis, we examine the relationships between deeper interactions, seeking to characterise each of the countries of origin of the companies in relation to the relevance of their CSR practices. The data are arranged in a cube, composed of 11 matrices (the years, 2004-2014), and each contains 18 rows (countries) and 26 columns (CSR practices). The first step is to select the number of components to be retained for each of the modes (Figure 10), where mode A refers to the countries of dimension $\mathrm{I}=18$ and $\mathrm{P}$ components to retained; mode $\mathrm{B}$ refers to the countries of dimension $\mathrm{J}=26 \mathrm{CSR}$ practices and Q components to retained; and mode $\mathrm{C}$ refers to the years of study, dimension $\mathrm{K}=11$, and $\mathrm{R}$ components to retained. With the retained components, the core matrix $(\mathrm{G})$ is created to weight all of the possible combinations of these; plus, it contains the amount of variability explained for each of these combinations.

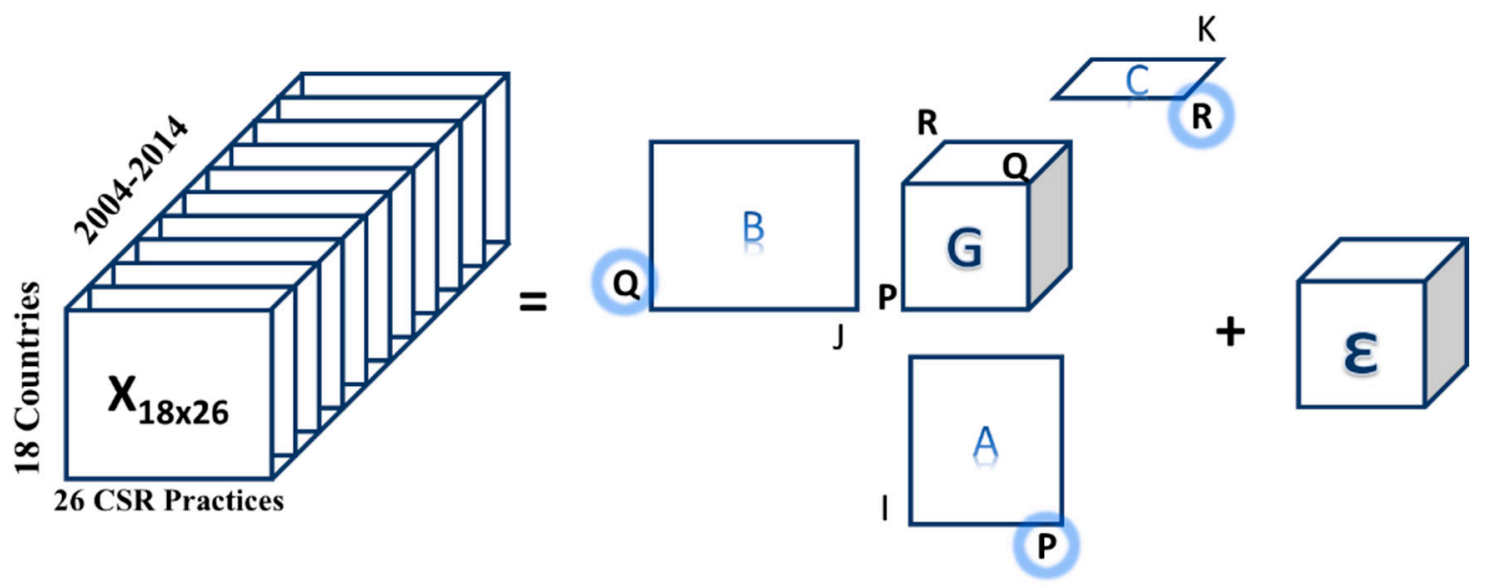

Figure 10. Diagram Procedure Tucker3 analysis.

For the selection of the components, we observe the first results that the method gives us; Table 3 shows us the results of all of the combinations of possible models according to the selection of the components of each mode, with the significant models marked with "*'; Table 4 shows us a summary of the previous table only with the significant models, that is, those models that have a better explained variance for a sum of the fixed components. 
Table 3. All Combinations of Possible Models, Tucker3 Analysis.

\begin{tabular}{|c|c|c|c|c|c|c|c|c|c|}
\hline \multicolumn{10}{|c|}{$\begin{array}{c}\text { Summary of All Permissible Analyses with Components Less Than } 5 \times 5 \times 5 \text {. Overall Fitted and Residual Sum of } \\
\text { Squares (SS) }\end{array}$} \\
\hline & $\begin{array}{l}\text { Model } \\
\text { Size }\end{array}$ & $\begin{array}{c}\text { Sum of } \\
\text { Components } \\
\text { (S) }\end{array}$ & $\begin{array}{l}\text { Best } \\
\text { given } \\
\mathrm{S}\end{array}$ & $\begin{array}{l}\text { Difference } \\
\text { in Prop. Fit }\end{array}$ & SS(Res) & $\begin{array}{l}\text { Proportional } \\
\text { SS (Fit) }\end{array}$ & $\begin{array}{l}\text { Proportional } \\
\text { SS (Res) }\end{array}$ & $\begin{array}{l}\text { Number of } \\
\text { Iterations }\end{array}$ & \\
\hline 1 & $1 \times 1 \times 1$ & 3 & * & 0.236 & 19.85989 & 0.2362 & 0.7638 & 19 & \\
\hline 2 & $1 \times 2 \times 2$ & 5 & & & 19.46644 & 0.2513 & 0.7487 & 24 & \\
\hline 3 & $1 \times 3 \times 3$ & 7 & & & 19.36555 & 0.2552 & 0.7448 & 31 & \\
\hline 4 & $1 \times 4 \times 4$ & 9 & & & 19.30520 & 0.2575 & 0.7425 & 30 & \\
\hline 5 & $1 \times 5 \times 5$ & 11 & & & 19.26906 & 0.2589 & 0.7411 & 38 & \\
\hline 6 & $2 \times 1 \times 2$ & 5 & & & 19.54406 & 0.2483 & 0.7517 & 24 & \\
\hline 7 & $2 \times 2 \times 1$ & 5 & * & 0.107 & 17.07668 & 0.3432 & 0.6568 & 50 & M \\
\hline 8 & $2 \times 2 \times 2$ & 6 & * & 0.011 & 16.80365 & 0.3537 & 0.6463 & 50 & M \\
\hline 9 & $2 \times 2 \times 3$ & 7 & & & 16.78106 & 0.3546 & 0.6454 & 50 & M \\
\hline 10 & $2 \times 2 \times 4$ & 8 & & & 16.77541 & 0.3548 & 0.6452 & 50 & M \\
\hline 11 & $2 \times 3 \times 2$ & 7 & & & 16.17405 & 0.3779 & 0.6221 & 50 & M \\
\hline 12 & $2 \times 3 \times 3$ & 8 & & & 16.13195 & 0.3795 & 0.6205 & 50 & $\mathrm{M}$ \\
\hline 13 & $2 \times 3 \times 4$ & 9 & & & 16.10693 & 0.3805 & 0.6195 & 50 & $\mathrm{M}$ \\
\hline 14 & $2 \times 3 \times 5$ & 10 & & & 16.10082 & 0.3807 & 0.6193 & 50 & M \\
\hline 15 & $2 \times 4 \times 2$ & 8 & & & 15.92783 & 0.3874 & 0.6126 & 50 & M \\
\hline 16 & $2 \times 4 \times 3$ & 9 & & & 15.83500 & 0.3910 & 0.6090 & 50 & M \\
\hline 17 & $2 \times 4 \times 4$ & 10 & & & 15.79969 & 0.3923 & 0.6077 & 50 & M \\
\hline 18 & $2 \times 4 \times 5$ & 11 & & & 15.78850 & 0.3928 & 0.6072 & 50 & M \\
\hline 19 & $2 \times 5 \times 3$ & 10 & & & 15.67887 & 0.3970 & 0.6030 & 50 & M \\
\hline 20 & $2 \times 5 \times 4$ & 11 & & & 15.61218 & 0.3995 & 0.6005 & 50 & M \\
\hline 21 & $2 \times 5 \times 5$ & 12 & & & 15.58446 & 0.4006 & 0.5994 & 50 & M \\
\hline 22 & $3 \times 1 \times 3$ & 7 & & & 19.47851 & 0.2508 & 0.7492 & 50 & $\mathrm{M}$ \\
\hline 23 & $3 \times 2 \times 2$ & 7 & & & 16.31406 & 0.3725 & 0.6275 & 33 & \\
\hline 24 & $3 \times 2 \times 3$ & 8 & & & 16.24297 & 0.3753 & 0.6247 & 27 & \\
\hline 25 & $3 \times 2 \times 4$ & 9 & & & 16.22352 & 0.3760 & 0.6240 & 50 & M \\
\hline 26 & $3 \times 2 \times 5$ & 10 & & & 16.20727 & 0.3766 & 0.6234 & 50 & M \\
\hline 27 & $3 \times 3 \times 1$ & 7 & * & 0.071 & 14.96000 & 0.4246 & 0.5754 & 50 & M \\
\hline 28 & $3 \times 3 \times 2$ & 8 & $*$ & 0.021 & 14.42526 & 0.4452 & 0.5548 & 50 & M \\
\hline 29 & $3 \times 3 \times 3$ & 9 & & & 14.35978 & 0.4477 & 0.5523 & 50 & $\mathrm{M}$ \\
\hline 30 & $3 \times 3 \times 4$ & 10 & & & 14.33347 & 0.4487 & 0.5513 & 50 & M \\
\hline 31 & $3 \times 3 \times 5$ & 11 & & & 14.31549 & 0.4494 & 0.5506 & 50 & M \\
\hline 32 & $3 \times 4 \times 2$ & 9 & & & 13.73359 & 0.4718 & 0.5282 & 50 & M \\
\hline 33 & $3 \times 4 \times 3$ & 10 & & & 13.64108 & 0.4753 & 0.5247 & 50 & M \\
\hline 34 & $3 \times 4 \times 4$ & 11 & & & 13.60055 & 0.4769 & 0.5231 & 50 & $\mathrm{M}$ \\
\hline 35 & $3 \times 4 \times 5$ & 12 & & & 13.57635 & 0.4778 & 0.5222 & 50 & $\mathrm{M}$ \\
\hline 36 & $3 \times 5 \times 2$ & 10 & & & 13.11528 & 0.4956 & 0.5044 & 50 & M \\
\hline 37 & $3 \times 5 \times 3$ & 11 & & & 13.01122 & 0.4996 & 0.5004 & 50 & M \\
\hline 38 & $3 \times 5 \times 4$ & 12 & & & 12.95215 & 0.5018 & 0.4982 & 50 & M \\
\hline 39 & $3 \times 5 \times 5$ & 13 & & & 12.91216 & 0.5034 & 0.4966 & 50 & M \\
\hline 40 & $4 \times 1 \times 4$ & 9 & & & 19.42840 & 0.2528 & 0.7472 & 50 & M \\
\hline 41 & $4 \times 2 \times 2$ & 8 & & & 16.07294 & 0.3818 & 0.6182 & 34 & \\
\hline 42 & $4 \times 2 \times 3$ & 9 & & & 15.99050 & 0.3850 & 0.6150 & 35 & \\
\hline 43 & $4 \times 2 \times 4$ & 10 & & & 15.96533 & 0.3859 & 0.6141 & 50 & M \\
\hline 44 & $4 \times 2 \times 5$ & 11 & & & 15.94740 & 0.3866 & 0.6134 & 50 & M \\
\hline 45 & $4 \times 3 \times 2$ & 9 & & & 13.92007 & 0.4646 & 0.5354 & 50 & M \\
\hline 46 & $4 \times 3 \times 3$ & 10 & & & 13.81635 & 0.4686 & 0.5314 & 50 & $\mathrm{M}$ \\
\hline 47 & $4 \times 3 \times 4$ & 11 & & & 13.77297 & 0.4703 & 0.5297 & 50 & $\mathrm{M}$ \\
\hline 48 & $4 \times 3 \times 5$ & 12 & & & 13.75182 & 0.4711 & 0.5289 & 50 & M \\
\hline 49 & $4 \times 4 \times 1$ & 9 & * & 0.032 & 13.58059 & 0.4777 & 0.5223 & 50 & M \\
\hline 50 & $4 \times 4 \times 2$ & 10 & * & 0.039 & 12.55889 & 0.5170 & 0.4830 & 50 & M \\
\hline 51 & $4 \times 4 \times 3$ & 11 & & & 12.44025 & 0.5215 & 0.4785 & 50 & M \\
\hline 52 & $4 \times 4 \times 4$ & 12 & & & 12.35933 & 0.5246 & 0.4754 & 50 & M \\
\hline 53 & $4 \times 4 \times 5$ & 13 & & & 12.33007 & 0.5258 & 0.4742 & 50 & M \\
\hline 54 & $4 \times 5 \times 2$ & 11 & * & 0.030 & 11.76955 & 0.5473 & 0.4527 & 50 & M \\
\hline 55 & $4 \times 5 \times 3$ & 12 & & & 11.62559 & 0.5529 & 0.4471 & 50 & M \\
\hline 56 & $4 \times 5 \times 4$ & 13 & & & 11.53261 & 0.5564 & 0.4436 & 50 & M \\
\hline 57 & $4 \times 5 \times 5$ & 14 & & & 11.48448 & 0.5583 & 0.4417 & 50 & $\mathrm{M}$ \\
\hline 58 & $5 \times 1 \times 5$ & 11 & & & 19.40379 & 0.2537 & 0.7463 & 50 & $\mathrm{M}$ \\
\hline
\end{tabular}


Table 3. Cont.

\begin{tabular}{|c|c|c|c|c|c|c|c|c|c|}
\hline \multicolumn{10}{|c|}{$\begin{array}{c}\text { Summary of All Permissible Analyses with Components Less Than } 5 \times 5 \times 5 \text {. Overall Fitted and Residual Sum of } \\
\text { Squares (SS) }\end{array}$} \\
\hline & $\begin{array}{l}\text { Model } \\
\text { Size }\end{array}$ & $\begin{array}{c}\text { Sum of } \\
\text { Components } \\
\text { (S) }\end{array}$ & $\begin{array}{l}\text { Best } \\
\text { given } \\
\mathrm{S}\end{array}$ & $\begin{array}{l}\text { Difference } \\
\text { in Prop. Fit }\end{array}$ & SS(Res) & $\begin{array}{l}\text { Proportional } \\
\text { SS (Fit) }\end{array}$ & $\begin{array}{l}\text { Proportional } \\
\text { SS (Res) }\end{array}$ & $\begin{array}{l}\text { Number of } \\
\text { Iterations }\end{array}$ & \\
\hline 59 & $5 \times 2 \times 3$ & 10 & & & 15.88905 & 0.3889 & 0.6111 & 32 & \\
\hline 60 & $5 \times 2 \times 4$ & 11 & & & 15.84346 & 0.3906 & 0.6094 & 33 & \\
\hline 61 & $5 \times 2 \times 5$ & 12 & & & 15.82271 & 0.3914 & 0.6086 & 50 & $\mathrm{M}$ \\
\hline 62 & $5 \times 3 \times 2$ & 10 & & & 13.75725 & 0.4709 & 0.5291 & 50 & M \\
\hline 63 & $5 \times 3 \times 3$ & 11 & & & 13.61220 & 0.4765 & 0.5235 & 50 & $\mathrm{M}$ \\
\hline 64 & $5 \times 3 \times 4$ & 12 & & & 13.55278 & 0.4787 & 0.5213 & 50 & $\mathrm{M}$ \\
\hline 65 & $5 \times 3 \times 5$ & 13 & & & 13.52812 & 0.4797 & 0.5203 & 50 & $\mathrm{M}$ \\
\hline 66 & $5 \times 4 \times 2$ & 11 & & & 12.18121 & 0.5315 & 0.4685 & 50 & $\mathrm{M}$ \\
\hline 67 & $5 \times 4 \times 3$ & 12 & & & 12.04418 & 0.5368 & 0.4632 & 50 & M \\
\hline 68 & $5 \times 4 \times 4$ & 13 & & & 11.93868 & 0.5408 & 0.4592 & 50 & M \\
\hline 69 & $5 \times 4 \times 5$ & 14 & & & 11.89604 & 0.5425 & 0.4575 & 50 & M \\
\hline 70 & $5 \times 5 \times 1$ & 11 & & & 12.37526 & 0.5240 & 0.4760 & 50 & $\mathrm{M}$ \\
\hline 71 & $5 \times 5 \times 2$ & 12 & * & 0.029 & 11.01160 & 0.5765 & 0.4235 & 50 & $\mathrm{M}$ \\
\hline 72 & $5 \times 5 \times 3$ & 13 & * & 0.006 & 10.85058 & 0.5827 & 0.4173 & 50 & $\mathrm{M}$ \\
\hline 73 & $5 \times 5 \times 4$ & 14 & * & 0.006 & 10.70568 & 0.5882 & 0.4118 & 50 & M \\
\hline 74 & $5 \times 5 \times 5$ & 15 & * & 0.001 & 10.66897 & 0.5897 & 0.4103 & 50 & $\mathrm{M}$ \\
\hline
\end{tabular}

Note: ${ }^{*}=$ best solution for a given value of the sum of number of components. $\mathrm{M}=$ maximum number of iterations was reached.

Table 4. Combinations with Better Fit, Tucker3 Analysis.

\begin{tabular}{ccccc}
\hline & Sum of Components & Model Size & Difference in Prop. Fit & Prop. SS (Fit) \\
\hline 1 & 3 & $1 \times 1 \times 1$ & 0.23616 & 0.2362 \\
7 & 5 & $2 \times 2 \times 1$ & 0.10705 & 0.3432 \\
8 & 6 & $2 \times 2 \times 2$ & 0.01050 & 0.3537 \\
27 & 7 & $3 \times 3 \times 1$ & 0.07091 & 0.4246 \\
28 & 8 & $3 \times 3 \times 2$ & 0.02057 & 0.4452 \\
49 & 9 & $4 \times 4 \times 1$ & 0.03249 & 0.4777 \\
50 & 10 & $4 \times 4 \times 2$ & 0.03930 & 0.5170 \\
54 & 11 & $4 \times 5 \times 2$ & 0.03036 & 0.5473 \\
71 & 12 & $5 \times 5 \times 2$ & 0.02915 & 0.5765 \\
72 & 13 & $5 \times 5 \times 3$ & 0.00619 & 0.5827 \\
73 & 14 & $5 \times 5 \times 4$ & 0.00557 & 0.5882 \\
74 & 15 & $5 \times 5 \times 5$ & 0.00141 & 0.5897 \\
\hline
\end{tabular}

Table 4 shows the models with the best fit, a priori, the selected model results from the $5 \times 5 \times 2$ combination, since the greatest amount of variability is sought, and the difference in the adjustment of the following models is insignificant (around 1\%). Another interesting option would be to choose the previous model resulting from the combination $4 \times 5 \times 2$, since its proportion would only decrease by $3 \%$, and we would have a component that is less in the first mode. In addition, to facilitate the selection of the model, you can use the so-called 'scree plot' in which all of the possible models are represented based on the sum of the number of its components against the residual sum of squares (Figure 11). It can be seen that the chosen model $5 \times 5 \times 2$ has the lowest sum of residual squares for those models that have the same sum of the number of components; in addition, it is the first of the most stable, since, in the later ones, the reduction in the sum of residual square is negligible. 


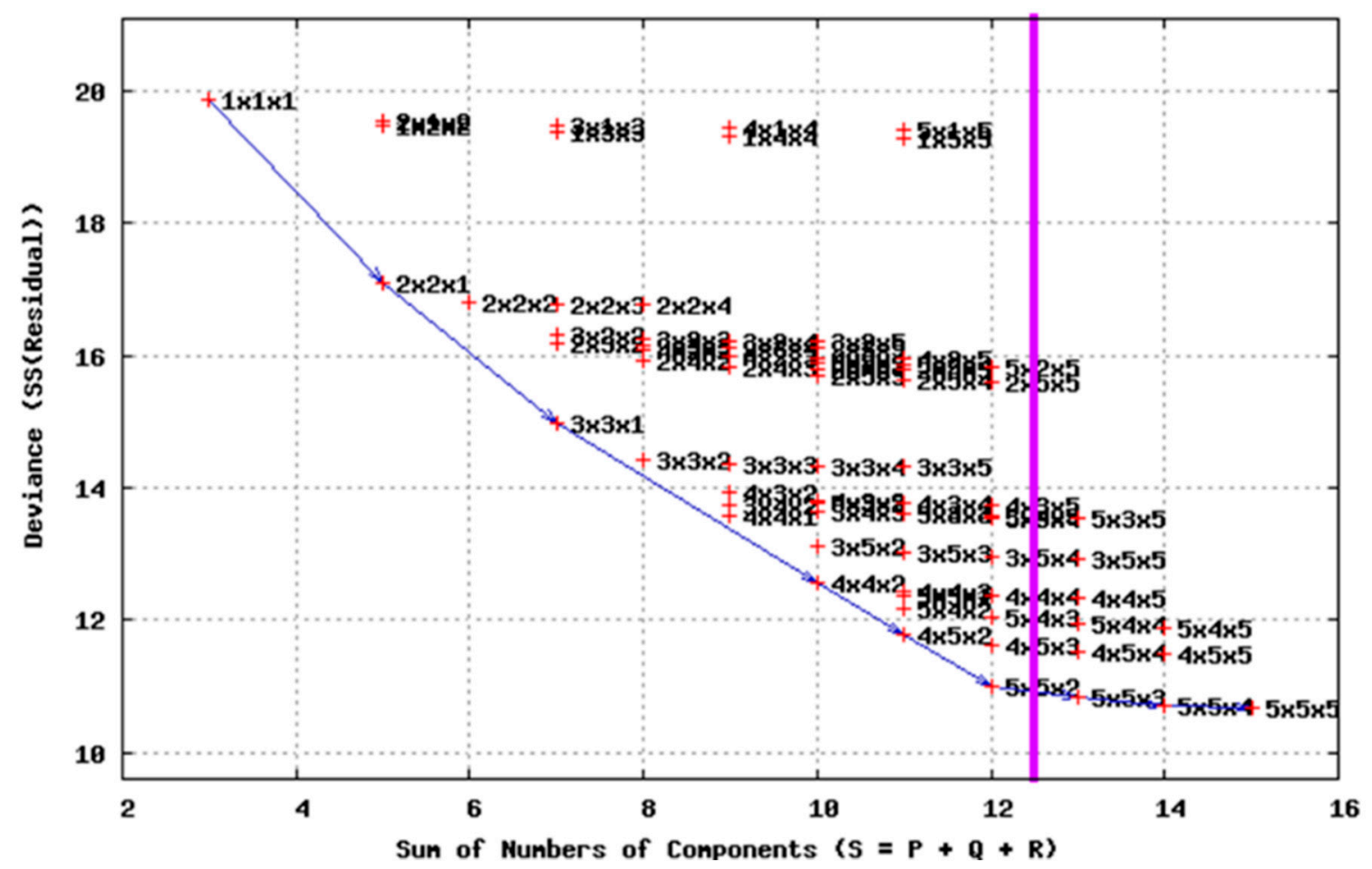

Figure 11. Model selection graph, Tucker3 analysis.

Once the model is selected, we perform the same analysis, but setting the number of components to be retained in each mode as $5 \times 5 \times 2$. One of the first results obtained are those of Table 5 , which represents the amount of variance explained by each of the components retained in each of the modes.

Table 5. Variance Explained by Modes and Total, Tucker3 Analysis.

\begin{tabular}{lccccccc}
\hline \multirow{2}{*}{ Mode } & \multirow{2}{*}{ Variance Total } & \multicolumn{5}{c}{ Components by Mode } \\
\cline { 3 - 8 } & & $\mathbf{1}$ & $\mathbf{2}$ & $\mathbf{3}$ & $\mathbf{4}$ & $\mathbf{5}$ \\
\hline A & Countries & 0.576 & 0.243 & 0.125 & 0.102 & 0.065 & 0.041 \\
B & CSR Practices & 0.576 & 0.241 & 0.128 & 0.087 & 0.063 & 0.057 \\
C & Years & 0.576 & 0.498 & 0.079 & & & \\
\hline \multicolumn{2}{l}{ Total variance explained } & 0.576 & & & & & \\
\hline
\end{tabular}

It can be seen that we obtained an amount of $57.60 \%$ of the information, which is a percentage high enough, considering that a cube of $18 \times 26 \times 11$ has been reduced to one of $5 \times 5 \times 2$. The next step is the analysis of the core matrix (Table 6), where we obtain the values of the residual sum of squares and the percentages of variance explained for each of the combinations of the components retained by mode. When identifying those elements of the core matrix that we are interested in interpreting, we select those with a higher percentage of variability, which will be the ones that provide us with the greatest amount of information. In addition, in the sum of squares, the signs are shown to interpret the interactions between the components. 
Table 6. Core Matrix, Tucker3 Analysis.

\begin{tabular}{|c|c|c|c|c|c|c|c|c|c|c|c|c|}
\hline \multirow{2}{*}{\multicolumn{3}{|c|}{ CORE MATRIX }} & \multicolumn{5}{|c|}{ Mode 2 Components } & \multicolumn{5}{|c|}{ Mode 2 Components } \\
\hline & & & \multicolumn{5}{|c|}{ Sum of Residual Squares } & \multicolumn{5}{|c|}{ Variance Explained (\%) } \\
\hline & & & 1 & 2 & 3 & 4 & 5 & 1 & 2 & 3 & 4 & 5 \\
\hline \multirow{5}{*}{$\begin{array}{c}\text { Mode 3, } \\
\text { Component } 1\end{array}$} & \multirow{5}{*}{$\begin{array}{l}\text { Mode } 1 \\
\text { components }\end{array}$} & 1 & 2.45 & -0.09 & 0.03 & -0.09 & -0.06 & 23.20 & 0.00 & 0.00 & 0.00 & 0.00 \\
\hline & & 2 & 0.09 & 1.46 & -0.62 & -0.16 & -0.01 & 0.00 & 8.30 & 1.50 & 0.10 & 0.00 \\
\hline & & 3 & -0.07 & 0.64 & 1.15 & -0.65 & -0.01 & 0.00 & 1.50 & 5.10 & 1.60 & 0.00 \\
\hline & & 4 & 0.05 & 0.09 & -0.40 & -0.47 & 0.89 & 0.00 & 0.00 & 0.60 & 0.90 & 3.00 \\
\hline & & 5 & 0.08 & 0.22 & 0.41 & 0.71 & 0.53 & 0.00 & 0.20 & 0.60 & 2.00 & 1.10 \\
\hline \multirow{5}{*}{$\begin{array}{c}\text { Mode 3, } \\
\text { Component } 2\end{array}$} & \multirow{5}{*}{$\begin{array}{l}\text { Mode } 1 \\
\text { components }\end{array}$} & 1 & -0.24 & -0.10 & 0.23 & 0.03 & 0.38 & 0.20 & 0.00 & 0.20 & 0.00 & 0.60 \\
\hline & & 2 & 0.21 & 0.60 & -0.01 & 0.53 & 0.06 & 0.20 & 1.40 & 0.00 & 1.10 & 0.00 \\
\hline & & 3 & 0.23 & -0.48 & -0.05 & -0.19 & 0.44 & 0.20 & 0.90 & 0.00 & 0.10 & 0.80 \\
\hline & & 4 & -0.27 & -0.32 & -0.42 & -0.36 & -0.18 & 0.30 & 0.40 & 0.70 & 0.50 & 0.10 \\
\hline & & 5 & 0.01 & 0.12 & 0.00 & -0.02 & -0.21 & 0.00 & 0.10 & 0.00 & 0.00 & 0.20 \\
\hline
\end{tabular}

Those elements selected for interpretation have been highlighted, obtaining an explained variance of $41.60 \%$. Next, we analyse each of the elements, showing the graphical results for the three modes, so each graph will represent two components in one way, one horizontally and one vertically; and, together with the results obtained from the core matrix, the interactions between countries, CSR practices, and years will be interpreted.

The first element of the core matrix that is interpreted is G111, in which we analyse the first component of each mode (Figure 12); this element absorbs $23.20 \%$ of the total variability. Given that this element is positive (2.45), those countries that are located in the right semi-plane (quadrants I and IV), that is, those that obtain positive values in the first component of mode A, as shown in the first figure, present a positive interaction with the practices of CSR that are also located in the right semi-plane (quadrants I and IV) of the second figure (positive values in the first component of mode B) in all of the years of study, since all of them obtain positive coordinates by positioning themselves in the right part of the third figure.

Core matrix element $(+) \times$ Countries $(+) \times$ CSR Practices $(+) \times$ Years $(+)=$ Interaction $(+)$

Although depending on the country of origin of the companies, we can identify specific characteristics in the development and evolution of CSR practices, the analyses carried out allow us to speak of highly similar patterns for those companies whose headquarters are located in geographically close countries. In this sense, the commentary on the results obtained will be made for groups of countries whose companies show similar sustainable behaviour. Thus, for these groups of countries, the main characteristics observed in the development of CSR will be determined.

Thus, during the 2004-2014 decade, companies whose country of origin is located in southwestern Europe (Portugal, Spain, France, Belgium), as well as in Finland and Denmark, prioritise their practices in environmental issues, as well as systems that promote equal opportunities, participation, and training of their employees (EMP2, EMP4, EMP5), and good community relations, participation, systems, and reports on their stakeholders (STH1, STH5, STH7, and STH8).

In the same way, observing the opposite semi-planes, that is, the countries and practices with negative coordinates in the first components of their modes, it is evident for all of the years that the companies whose headquarters are centralised in North American countries, such as the United States and Canada, stand out for their high values in those practices aimed at ethical issues and human rights, as well as policies in favour of equal opportunities (EMP1) and policies towards their stakeholders (STH6), or the importance of these as board members (STH4) and relations with the community (STH3).

Core matrix element $(+) \times$ Countries $(-) \times$ CSR Practices $(-) \times$ Years $(+)=$ Interaction $(+)$ 


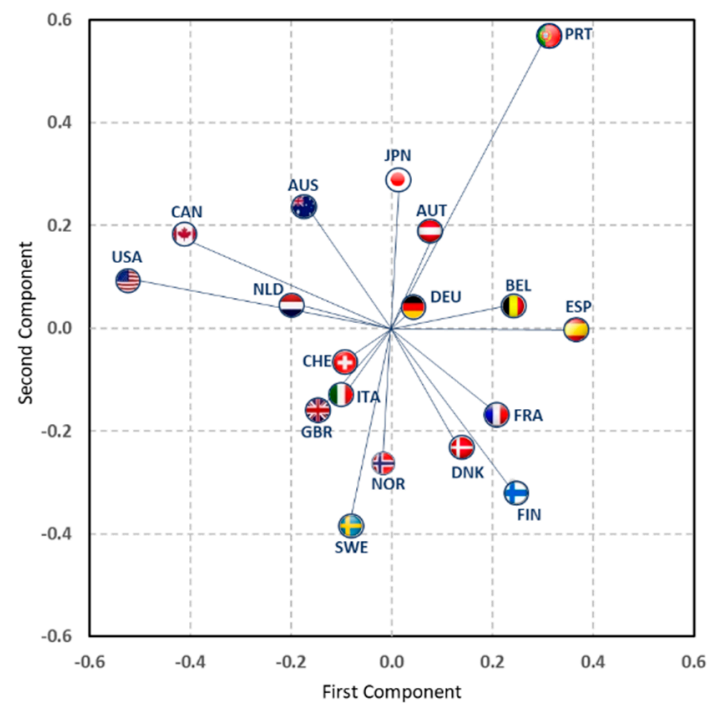

(a)

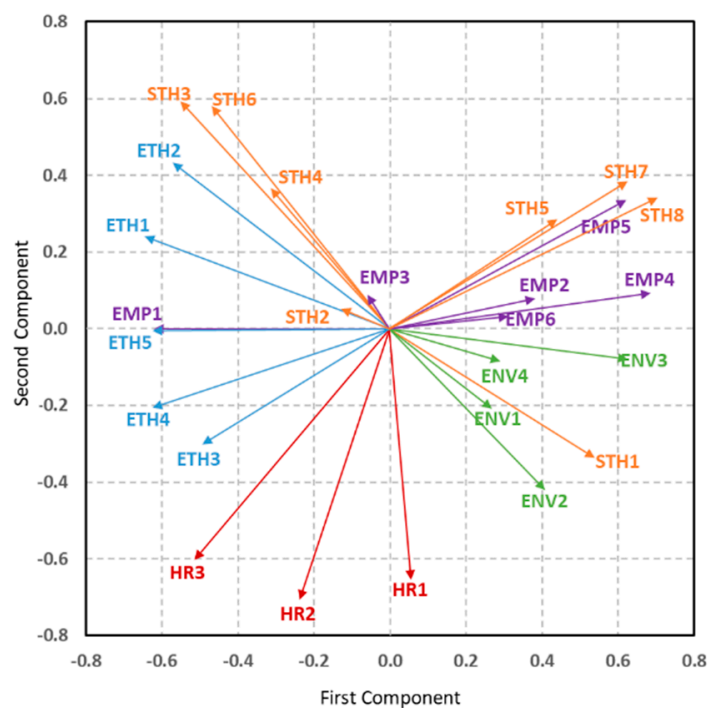

(b)

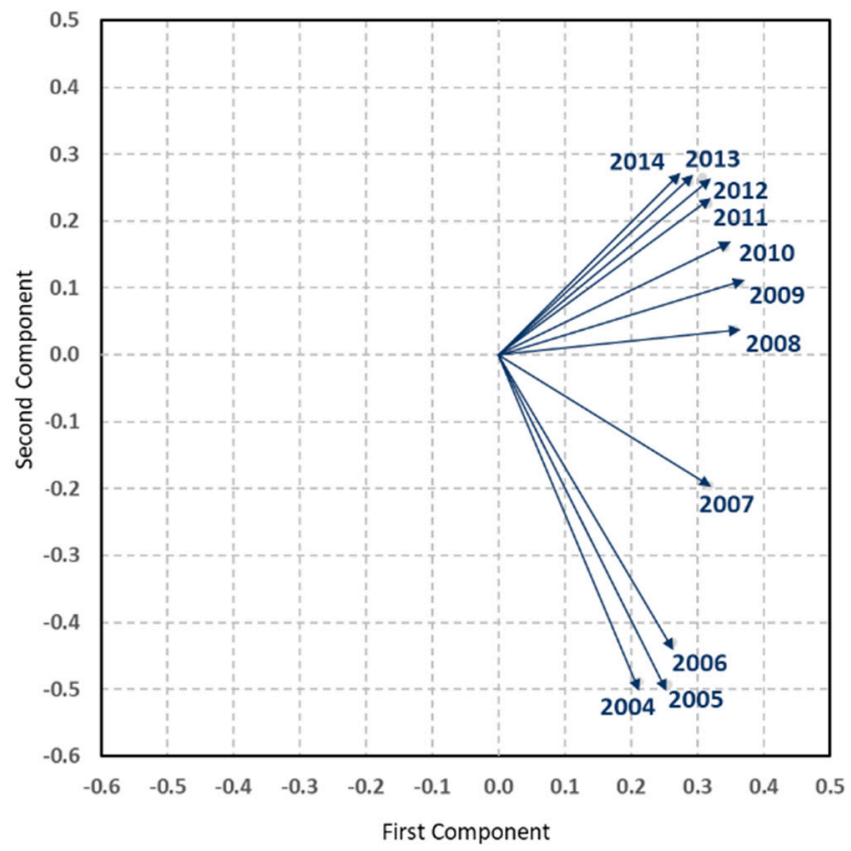

(c)

Figure 12. Graphics for the interpretation of the G111 and G221 elements of core matrix, Tucker3 analysis. (a) countries; (b) CSR practices; (c) years.

It should be noted that the structure found for the first components of the three modes has a very high degree of similarity when compared to the results of the X-STATICO analysis (see Figure 8), where we observe that the variable 'equal opportunities policy (EMP1)' is the one that is separated from the rest of the practices in relation to dealing with employees, also losing its relationship with the environment; we find the same case with the variables towards the interest groups, 'community involvement (STH3)', 'responsibility for stakeholders (STH4)', and 'stakeholders policy (STH6)'; likewise, we find the low degree of correlation of the ethical variables and of human rights with the environment. This shows that these methods should be used in a complementary way to obtain results that benefit from the advantages of each of them, since they provide results from different points of view with a strong degree of coherence. 
The second element of the core matrix that is interpreted is G221. This element absorbs $8.30 \%$ of information, and, since it is formed by the second component of the first and second modes and the first of the third, it is interpreted with the same figure as in the previous case (Figure 12), with the difference that now, we observe the second components in the first two modes, that is, the vertical axes in countries and CSR practices. Thus, with this being the positive element (1.46), in all of those years, those countries and practices located in the upper semi-plane (quadrants I and II) have a positive interaction.

Core matrix element $(+) \times$ Countries $(+) \times$ CSR Practices $(+) \times$ Years $(+)=$ Interaction $(+)$

That is, in all of the years of study, the firms in Portugal emphasise the training of their employees (EMP5), the participation of the community, policies, systems, and reports in favour of the participation and responsibility of the stakeholders (STH3-4-5-6-7-8), and in the implementation of a code of business ethics (ETH2).

In the same way, observing the opposite semi-planes, in all of the years of study, the companies coming from in the Nordic countries-Denmark, Finland, Norway, and Sweden-stand out for presenting the highest levels in the practices related to human rights (policy, system, and report, HR1-2-3), good measures to counteract bribery (policy, system, and report, ETH3-4-5), strong practices in the environment, and a strong commitment to the community (STH1).

Core matrix element $(+) \times$ Countries $(-) \times$ CSR Practices $(-) \times$ Years $(+)=$ Interaction $(+)$

The third element of the core matrix that is interpreted is G331, which is the third component of the first and second modes, and the first component of the third mode (Figure 13); this element absorbs $5.10 \%$ of the total variability. Given that this element is positive (1.15), those countries that obtain positive values in the third component, that is, those that are located in the upper semi-plane (quadrants I and II), present a positive interaction with CSR practices that are also located in the upper semi-plane (quadrants I and II) of the second figure, or vice versa in all of the years of study, since all of them obtain positive coordinates by positioning themselves in the right part of the third figure.

Core matrix element $(+) \times$ Countries $(-) \times$ CSR Practices $(-) \times$ Years $(+)=$ Interaction $(+)$

Thus, in all of the years of study, the organisations based in Japan and Austria have focussed mainly on environmental systems and reports (ENV2-3); in addition to the participation of their employees (EMP4) and the responsibility of their stakeholders (STH4) in decision-making processes, and systems and reports in the fight to counteract bribery (ETH4-5).

The fourth and fifth elements of the core matrix are interpreted are G451 and G541, which collect $3.00 \%$ and $2.00 \%$ information, respectively. The results of these elements should only be interpreted after knowing the results of the other elements of the core matrix with greater variance, understanding that these results explain less obvious differences between countries, CSR practices, and years. 


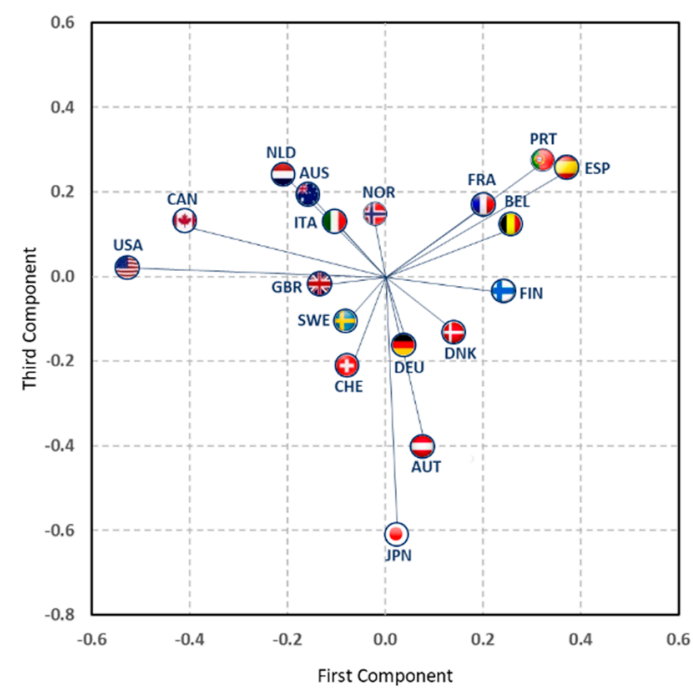

(a)

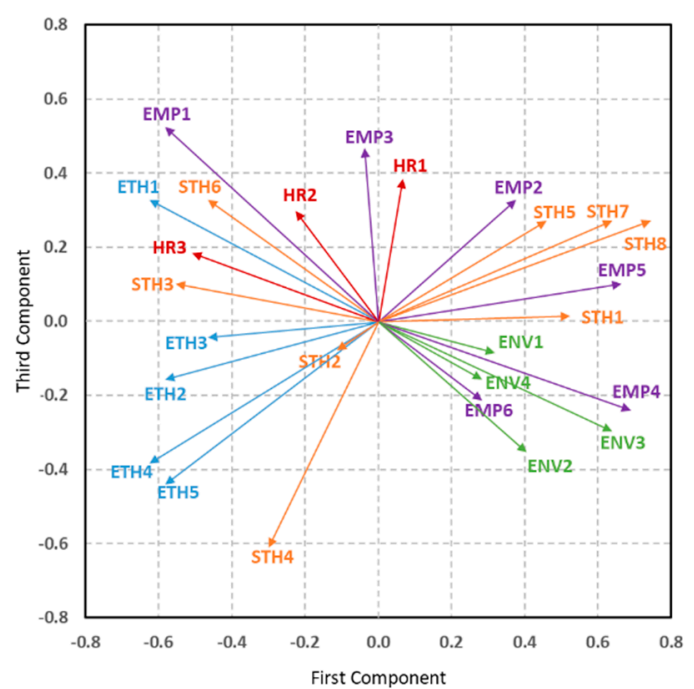

(b)

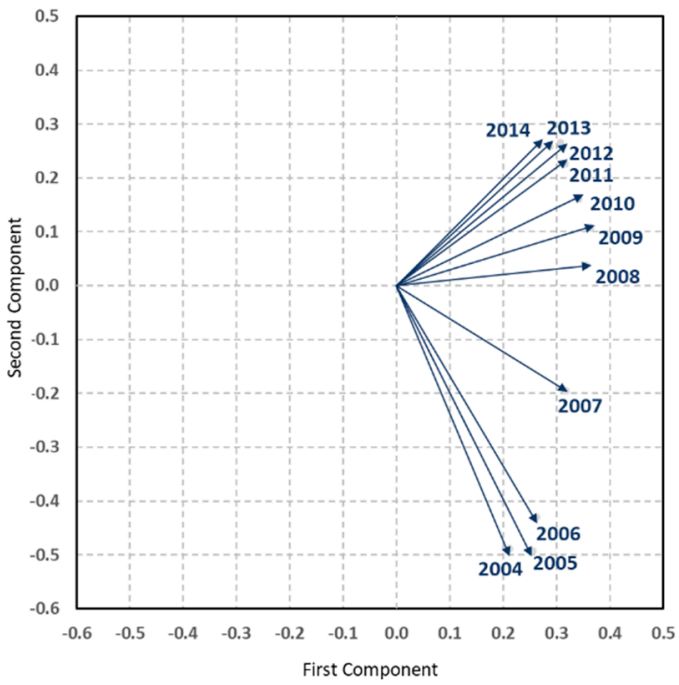

(c)

Figure 13. Graphics for the interpretation of the G331 element of core matrix, Tucker3 analysis. (a) countries; (b) CSR practices; (c) years.

Element G451 interprets the fourth component of the first mode, the fifth of the second mode, and the first of the third mode (Figure 14). Since this element is positive (0.89), the countries that receive positive coordinates in the fourth component, that is, those located in the upper semi-plane, present during all the years of study a positive interaction with those practices equally situated in the upper semi-plane.

Core matrix element $(+) \times$ Countries $(+) \times$ CSR Practices $(+) \times$ Years $(+)=$ Interaction $(+)$ 


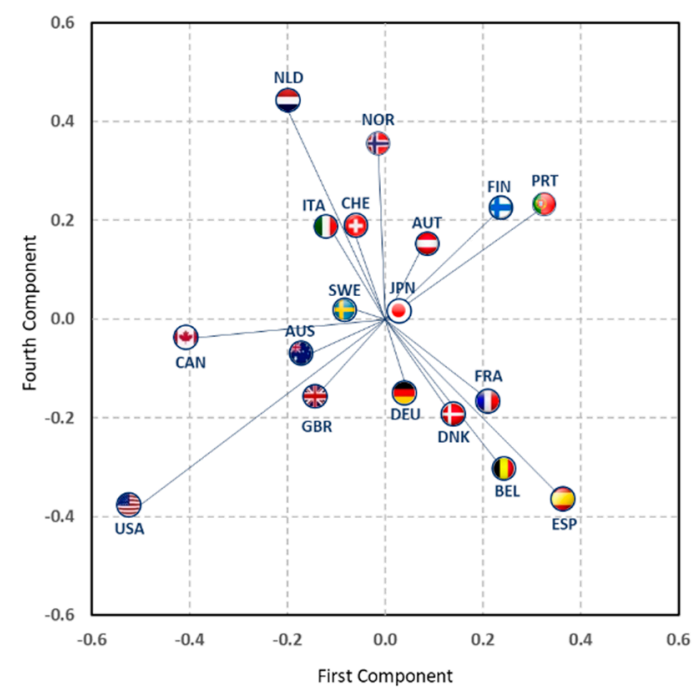

(a)

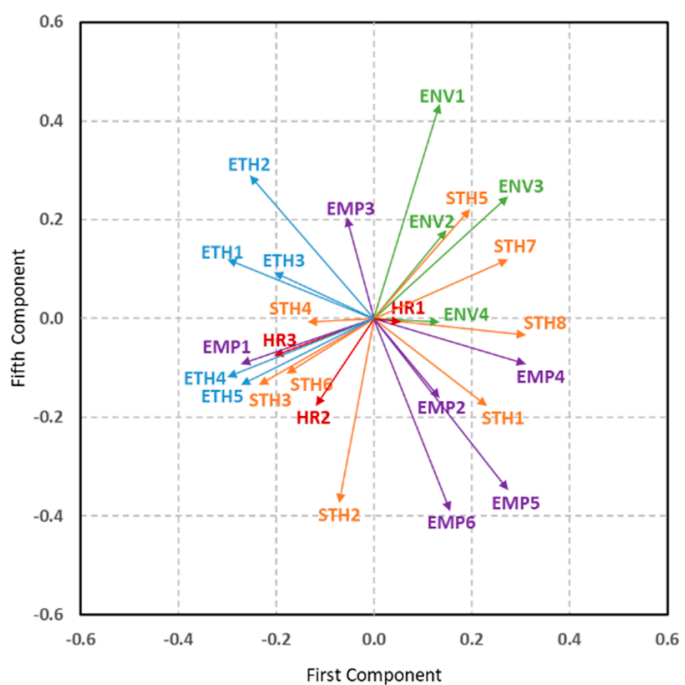

(b)

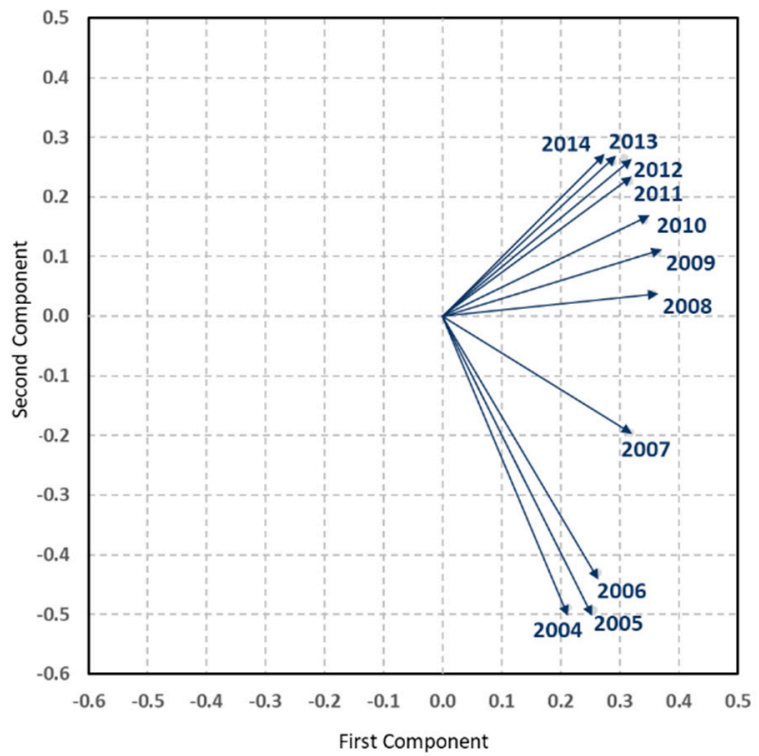

(c)

Figure 14. Graphics for the interpretation of the G451 element of core matrix, Tucker3 analysis.

(a) countries; (b) CSR practices; (c) years.

In this way, in all of the years of study, the companies whose country of origin is either the Netherlands or Norway attach great importance to environmental policies and reports (ENV1-3), the health and safety of their employees (EMP3), the participation of their stakeholders (STH5), and the systems for the implementation of a code of ethics (ETH2).

Element G541 interprets the fifth component of the first mode, the fourth of the second mode, and the first of the third mode (Figure 15). Since this element is positive (0.71), the countries that receive negative coordinates in the fifth component, that is, those located in the lower semi-plane, present during all of the years of study a positive interaction with those practices that are also located in the lower semi-plane.

Core matrix element $(+) \times$ Countries $(-) \times$ CSR Practices $(-) \times$ Years $(+)=$ Interaction $(+)$ 


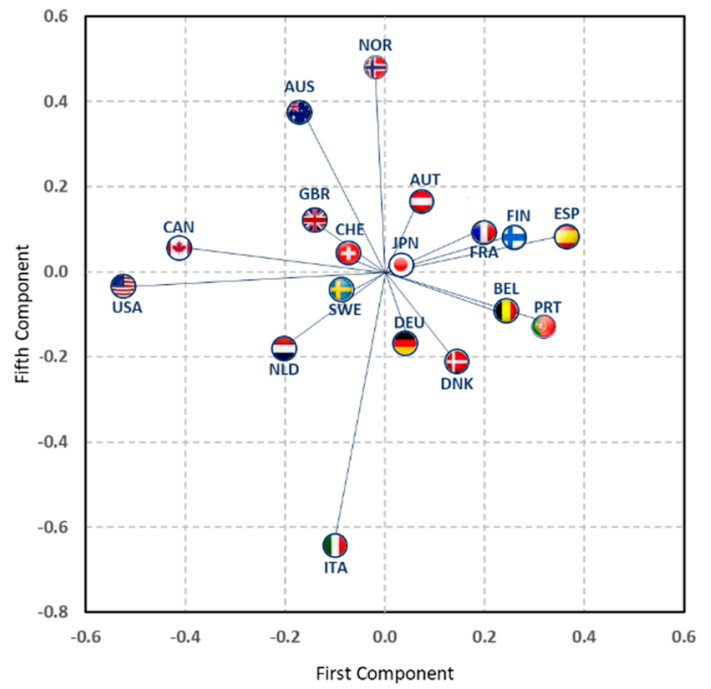

(a)

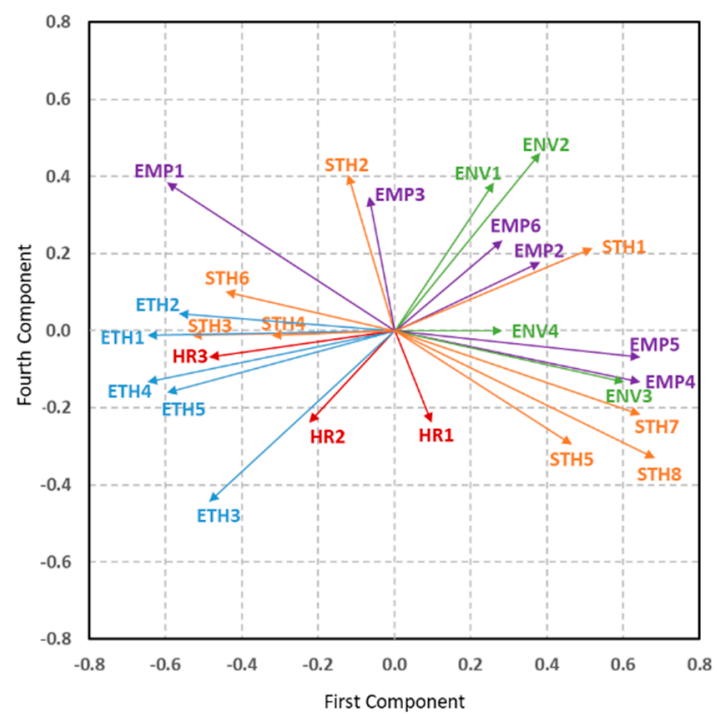

(b)

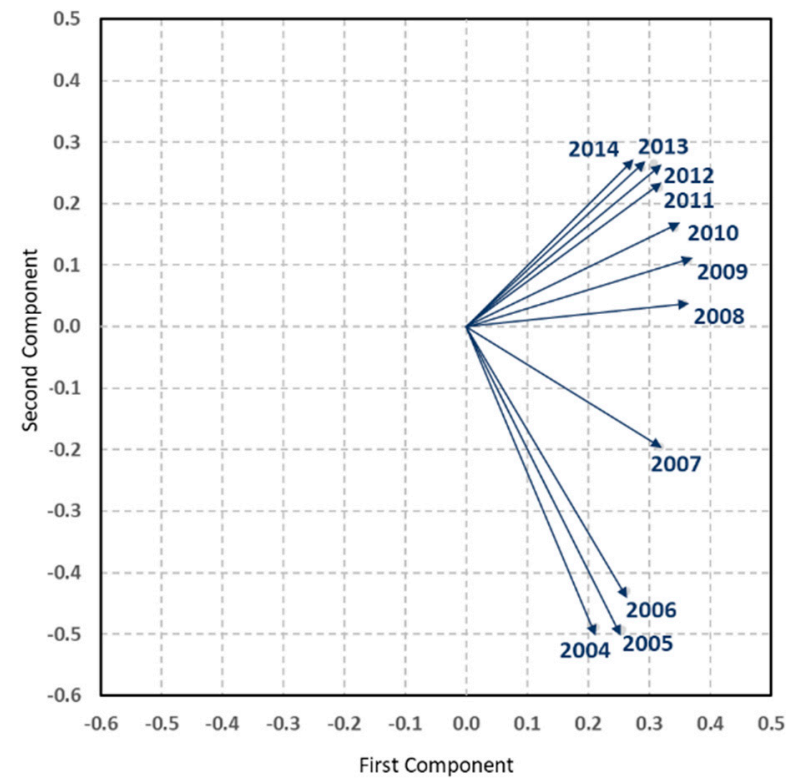

(c)

Figure 15. Graphics for the interpretation of the G541 element of core matrix, Tucker3 analysis. (a) countries; (b) CSR practices; (c) years.

That is, in all of the years of study, the corporations based in Italy emphasise their CSR practices in human rights policies and systems (HR1 and HR2), the greater participation of their stakeholders and reports on them (STH5 and STH8), as well as policies to counter bribery (ETH3).

\section{Discussion}

Although we are accustomed to associating sustainability with the care and preservation of the environment, there are two more areas that an organisation must take care of in order to be considered as sustainable: the social one-with the aim of achieving an adequate relationship and a fluid communication with the people who they are related to it-and the economic one, with the aim of achieving transparent management and a correct distribution of the wealth that is generated. This research works with the environmental and social dimensions, and corroborates that environmental policies, systems, and reports naturally occupy the central part of the company's 
sustainability, since a company that neglects its environmental processes cannot be considered as sustainable, without forgetting, in addition, the social pressure to disclose bad environmental news (Ekelenburg 2016; Casey and Grenier 2014; Semenova and Hassel 2008).

In reference to the social dimension of company sustainability, a large part of the practices aimed at maintaining good external relations with stakeholders acquire a similar importance or close to the environmental commitment; these practices have forged a place next to the environmental commitment, and are demanded in most countries. This is so because the CSR is based on the policies and voluntary activities arising from the expectations and pressures from the stakeholders (Matten and Moon 2008; Carroll 1991). These expectations come from the environment where the company operates and are specific to it, so if companies want to receive the approval of the society in which they are immersed, they must meet the behavioural standards imposed by those expectations (García-Sánchez et al. 2013; Campbell 2007). A similar situation occurs with practices aimed at defending the labour rights of the company's employees, such as health and safety conditions, participation, and training; the companies develop these practices in order to demonstrate that the commitment to their employees goes beyond the levels of protection established by the regulations. In this way, the company can be considered proactive and gain in reputation or social prestige, thus obtaining associated economic advantages related to the growth and survival of the company (Jackson and Apostolakou 2010). The opposite situation occurs with practices related to business ethics, such as those aimed at the implementation of a code of ethics or policies in the fight against bribery; these practices receive less importance than the rest, and may not be entrenched in certain countries or industries. However, they surely have a place in certain companies, which, a priori, is to be assumed in less polluting companies, such as the banking and financial services (Weber 2014; Scholtens 2011; Belu 2009).

This research contrasts the relevance of national identity in the sustainable behaviour of companies with the finding of important national discrepancies, corroborating that companies are concerned with what is important in their countries of origin based on the different pressures and expectations received. Thus, companies coming from European countries are one step above the rest, highlighting those based in the Nordic countries_recognised as welfare states-as leaders in company sustainability with the highest levels in all practices (Welford 2005) and greater predominance in the social aspect, emphasising the human rights of their citizens and the fight against bribery; they are also known for occupying the first positions in the Corruption Perception Index, obviously due to its absence. The next highest commitment is found in companies whose country of origin is located in Southern Europe, partly because they present a weaker legal system than the previous ones (García-Sánchez et al. 2016). Companies in these countries prioritise environmental reports and show a predilection for systems that promote equal opportunities, the participation and training of their employees, as well as systems to maintain good relations with customers and suppliers. In reference to organisations from non-European countries, it should be noted that companies based in Japan only focus on environmental concerns, leaving aside the other practices (Ortas et al. 2015). Finally, in relation to corporations whose headquarters are centralised in North American countries-Canada and the United States-present a lagging position in comparison with their European counterparts in sustainability terms, as other researchers have previously discovered for microdata (Purdy et al. 2010; Matten and Moon 2008; Welford 2004), especially in environmental issues, since companies in these countries give preference to practices aimed at ethical issues.

\section{Conclusions}

The results show that the companies with the greatest concern in environmental issues, which are the most sustainable, develop with a similar or close priority to these the practices aimed at the development of management systems for labour rights and dealing with different stakeholders, which arise from the employee relationships, as well as transparent dialogue and participation with stakeholders. The practices referring to business ethics acquire a lesser importance for the companies. A great instability is observed in its trajectory during this decade, which explains that said practices 
are not the main requirement of the groups that are both internal and external of the companies, given the possibility that they are not entrenched in some countries; however, they can be accommodated in certain companies, such as those aimed at financial services whose environmental concern is less.

In this research, we contrast the relevance of national identity in the sustainable behaviour of corporations with the finding of important national discrepancies, which corroborates that the country of origin of companies offers a series of facilities and barriers for the development of CSR practices. Based on the results obtained, we can affirm that the country in which the firms are located is a determinant of the CSR patterns they adopt and their evolution. In addition, we can determine that there is a high level of homogeneity in the CSR practices implemented by organisations whose country of origin is located within the same continent, and there is a high geographical proximity between them. Thus, European companies are a step above in sustainability terms of the rest of countries, especially in environmental performance, more specifically:

The corporations coming from the Nordic countries, highlighting Finland and Norway, are considered the foremost in sustainability terms, presenting the highest levels of human rights practices (policy, system, and report), the fight to counter bribery (policy, system, and report), strong environmental practices, and a strong commitment to the community. Firms based in Switzerland and the Netherlands present characteristics close to these countries, highlighting the latter in human rights and ethics.

Companies whose country of origin is located in Southern Europe-Portugal, Spain, and France-prioritise their practices in environmental matters, systems that promote equal opportunities, the participation and training of their employees, as well as good relations with clients and suppliers and the systems towards the interest groups and their participation.

Other organisations based in Italy - a country that is not very prominent in the study-emphasise their practices in human rights policies and systems, the greater participation of their interest groups, and reports on them, as well as policies to counteract bribery.

Firms whose country of origin is Japan only focus on environmental concerns, leaving aside other practices. Companies based in Austria present low values in the study, giving preference to their performance and environmental reports, the participation of their employees, and the responsibility of their stakeholders in decision-making processes, systems, and reports in the fight to counteract the bribe.

- Companies whose headquarters are centralised in North America countries, such as the United States and Canada, are in an inferior position to other countries in relation to their environmental practices, employees, or stakeholders; however, they improve their levels in those practices aimed at ethical issues and of human rights, with low but similar results to those found for companies of other countries, as well as policies in favour of equal opportunities and policies towards their interest groups, or the importance of these as members of the council and relations with the community.

The main contribution to the literature of this document is the usefulness of these data as an essential tool for politicians and public managers in decision-making processes, since they facilitate the observation of the economic, environmental, and social progress of each country, smoothing the road to sustainable development with medium and long-term projections. The availability of these data allows the identification of the structural drivers of growth and the establishment of priorities that allow the design of more effective policies that lead to a greater CSR commitment. The identification of virtues and deficiencies in national sustainability systems allows us to recognise where it is most necessary to adopt or improve CSR practices. These analyses can also be of great help to company managers in their own CSR strategic decisions, as it helps them understand the existing pressures on the environmental and social commitments of those foreign markets in which they decide to diversify their commercial activities. 
This document presents limitations that will be considered by the authors in future lines of research. Although one of the main contributions of the study is the use of an international database, the sample is restricted to certain specific countries due to the limited information available in the different databases. In the same way, based on the results obtained, an interesting line of research is opened in order to carry out an individual follow-up of companies from leading countries in sustainable development and, on the contrary, based on those with a deficit in their CSR commercial behaviour, facilitating a comparative study of the role that the managers of the companies, especially the chief executive officer (CEO), could play in the CSR decision making. In this way, one could understand the incentives that lead the CEOs of the companies to invest in CSR practices in the long term in search of improvements in the sustainability of the commercial actions, and the knowledge of this study would help promote the strengths and correct the environmental and social deficiencies derived from economic activity.

Moreover, this document proposes that differences at the national level-the so-called effect of the country of origin-are a key factor that must be taken into account to understand why corporations differ in their approach to CSR; however, it is not reasonable to assume that national states could serve alone as the primary unit of analysis, since there are several factors at the company level that influence the practice of CSR, including the internal organisational structure and the industry in which they operate, as well as the characteristics of leadership, the composition of the board, and the size of the company. Accordingly, future work will be oriented towards analysing these limitations that may well be considered by the authors in future lines of research.

Author Contributions: Conceptualization, Formal Analysis and Writing-Original Draft, V.A.-E.; Methodology, Resources and Supervision, M.-P.G.-V.; Conceptualization, Investigation and Supervision, F.D.

Funding: This research received no external funding.

Conflicts of Interest: The authors declare no conflict of interest.

\section{References}

Aaronson, Susan Ariel. 2003. Corporate Responsibility in the Global Village: The British Role Model and the American Laggard. Business and Society Review 108: 309-38. [CrossRef]

Amor-Esteban, Víctor, Isabel-María García-Sánchez, and Ma-Purificación Galindo-Villardón. 2017. Analysing the Effect of Legal System on Corporate Social Responsibility (CSR) at the Country Level, from a Multivariate Perspective. Social Indicators Research n.d. , 1-18.

Ariztía, Tomas, Dorothea Kleine, S. L. Maria das Graças, Nurjk Agloni, Rita Afonso, and Roberto Bartholo. 2014. Ethical Consumption in Brazil and Chile: Institutional Contexts and Development Trajectories. Journal of Cleaner Production 63: 84-92. [CrossRef]

Barbieri, P., C. A. Andersson, D. L. Massart, S. Predonzani, G. Adami, and E. Reisenhofer. 1999. Modeling Bio-Geochemical Interactions in the Surface Waters of the Gulf of Trieste by Three-Way Principal Component Analysis (PCA). Analytica Chimica Acta 398: 227-35. [CrossRef]

Baskin, Jeremy. 2006. Corporate Responsibility in Emerging Markets. Journal of Corporate Citizenship 24: 29-47. [CrossRef]

Belu, Constantin. 2009. Ranking Corporations Based on Sustainable and Socially Responsible Practices. A Data Envelopment Analysis (DEA) Approach. Sustainable Development 17: 257-68. [CrossRef]

Boudt, Kris, Jonathan Cornelissen, and Christophe Croux. 2013. The Impact of a Sustainability Constraint on the Mean-Tracking Error Efficient Frontier. Economics Letters 119: 255-60. [CrossRef]

Bustamante, Silke. 2011. Localization vs. Standardization: Global Approaches to CSR Management in Mulitinational Companies. Institute of Management. Available online: http:/ /institut-ina.de/wp-content/ uploads/2015/05/2011_03_CSR-multinational-companies.pdf (accessed on 18 April 2018).

Campbell, John L. 2006. Institutional Analysis and the Paradox of Corporate Social Responsibility. American Behavioral Scientist 49: 925-38. [CrossRef]

Campbell, John L. 2007. Why Would Corporations Behave in Socially Responsible Ways? An Institutional Theory of Corporate Social Responsibility. Academy of Management Review 32: 946-67. [CrossRef] 
Carroll, Archie B. 1999. Corporate Social Responsibility Evolution of a Definitional Construct. Business E Society 38: 268-95.

Carroll, Archie B. 1991. The Pyramid of Corporate Social Responsibility: Toward the Moral Management of Organizational Stakeholders. Business Horizons 34: 39-48. [CrossRef]

Casey, Ryan J., and Jonathan H. Grenier. 2014. Understanding and Contributing to the Enigma of Corporate Social Responsibility (CSR) Assurance in the United States. Auditing: A Journal of Practice E Theory 34: 97-130.

Davis, Keith. 1973. The Case for and against Business Assumption of Social Responsibilities. Academy of Management Journal 16: 312-22.

DiMaggio, Paul, and Walter W. Powell. 1983. The Iron Cage Revisited: Collective Rationality and Institutional Isomorphism in Organizational Fields. American Sociological Review 48: 147-60. [CrossRef]

Dolédec, Sylvain, and Daniel Chessel. 1994. Co-Inertia Analysis: An Alternative Method for Studying Species-Environment Relationships. Freshwater Biology 31: 277-94. [CrossRef]

Dypdahl, Kristin. 2015. CSR and the Country of Origin Effect in Multinational Corporations-An Comparativ and Contextual Analysis of Brazilian and Norwegian MNCs in the Oil and Gas Industries. Master's thesis, Utrecht University, Utrecht, The Netherlands.

Ekelenburg, Matthijs van. 2016. Determinants of Voluntary External Assurance on Corporate Sustainability Reports: A Comparison between Europe and North America. Available online: http://theses.ubn.ru.nl/ handle/123456789/1684 (accessed on 20 April 2018).

Escoufier, Yves. 1976. Opérateur Associé à Un Tableau de Données. In Annales de l'INSEE. París: ADRES, pp. 165-79. Available online: http://www.jstor.org/stable/20075217 (accessed on 17 April 2018).

Esteban, Victor Amor, Ma Purificacion Galindo Villardon, and Isabel Maria Garcia Sanchez. 2017. Cultural Values on CSR Patterns and Evolution: A Study from the Biplot Representation. Ecological Indicators 81: 18-29. [CrossRef]

Filatotchev, Igor, and Günter K. Stahl. 2015. Towards Transnational CSR. Corporate Social Responsibility Approaches and Governance Solutions for Multinational Corporations. Organizational Dynamics 44: 121-29. [CrossRef]

Florini, Ann, and Saleena Saleem. 2011. Information Disclosure in Global Energy Governance. Global Policy 2: 144-54. [CrossRef]

García-Sánchez, Isabel-Maria, Beatriz Cuadrado-Ballesteros, and Jose-Valeriano Frias-Aceituno. 2016. Impact of the Institutional Macro Context on the Voluntary Disclosure of CSR Information. Long Range Planning 49: 15-35. [CrossRef]

García-Sánchez, Isabel-María, and Emma García-Meca. 2017. CSR Engagement and Earnings Quality in Banks. The Moderating Role of Institutional Factors. Corporate Social Responsibility and Environmental Management 24: 145-58. [CrossRef]

García-Sánchez, Isabel-María, Lázaro Rodríguez-Ariza, and José-Valeriano Frías-Aceituno. 2013. The Cultural System and Integrated Reporting. International Business Review 22: 828-38. [CrossRef]

Gjølberg, Maria. 2009. Measuring the Immeasurable? Scandinavian Journal of Management 25: 10-22. [CrossRef]

Gjølberg, Maria. 2012. The Political Economy of Corporate Social Responsibility (CSR). Ph.D. dissertation, University of Oslo, Oslo, Norway.

Grauel, Jonas, and Daniel Gotthardt. 2016. The Relevance of National Contexts for Carbon Disclosure Decisions of Stock-Listed Companies: A Multilevel Analysis. Journal of Cleaner Production 133: 1204-17. [CrossRef]

Habisch, André, Jan Jonker, Martina Wegner, and René Schmidpeter. 2005. Corporate Social Responsibility across Europe. Berlin: Springer. Available online: https:/ / books.google.nl/books?hl=es\&lr=\&id=4tu5VKLfy2UC\&oi= fnd\&pg=PA1\&dq=Habisch, + A., +Jonker,,+ J.,+\%26+Wegner, + M.+(2005).+Corporate+social+responsibility+ across+Europe.+Berlin:+Springer.\&ots=hCT_ZjTDHZ\&sig=GRtqhd9oGcQpZ6tdl1gHGSA_Nhk (accessed on 18 April 2018).

Halkos, George, and Antonis Skouloudis. 2016. National CSR and Institutional Conditions: An Exploratory Study. Journal of Cleaner Production 139: 1150-56. [CrossRef]

Ioannou, Ioannis, and George Serafeim. 2012. What Drives Corporate Social Performance? The Role of Nation-Level Institutions. Journal of International Business Studies 43: 834-64. [CrossRef]

Jackson, Gregory, and Androniki Apostolakou. 2010. Corporate Social Responsibility in Western Europe: An Institutional Mirror or Substitute? Journal of Business Ethics 94: 371-94. [CrossRef] 
Jaffrenou, Pierre-Alain. 1978. Sur l'analyse Des Familles Finies de Variables Vectorielles: Bases Algébriques et Application à La Description Statistique. Ph.D. Thèse, Université de Lyon, Lyon, France.

Jamali, Dima, Yusuf Sidani, and Khalil El-Asmar. 2009. A Three Country Comparative Analysis of Managerial CSR Perspectives: Insights from Lebanon, Syria and Jordan. Journal of Business Ethics 85: 173-92. [CrossRef]

Kiers, Henk A. L., and Albert Kinderen. 2003. A Fast Method for Choosing the Numbers of Components in Tucker3 Analysis. British Journal of Mathematical and Statistical Psychology 56: 119-25. [CrossRef] [PubMed]

Kolk, Ans, and Paolo Perego. 2010. Determinants of the Adoption of Sustainability Assurance Statements: An International Investigation. Business Strategy and the Environment 19: 182-98. [CrossRef]

Kroonenberg, Pieter M. 2008. Applied Multiway Data Analysis. Hoboken: John Wiley \& Sons, vol. 702.

Lenssen, Gilbert, Wojciech Gasdparski, Boleslaw Rok, Peter Lacy, Atle Midttun, Kristian Gautesen, and Maria Gjølberg. 2006. The Political Economy of CSR in Western Europe. Corporate Governance: The International Journal of Business in Society 6: 369-85.

León, Juan Ángel Poyatos. 2015. Análisis de la Relación Causal de la Responsabilidad Social Corporativa y la Performance Financiera de las Empresas. Ph.D. dissertation, Universitat Politècnica de València, València, Spain, March 31. [CrossRef]

L'Hermier des Plantes, H. 1976. Structuration Des Tableauya Trois Indices de La Statistique. Thése de 3eme Cycle. Montpellier: Université Montpellier II.

Maignan, Isabelle, and David A. Ralston. 2002. Corporate Social Responsibility in Europe and the US: Insights from Businesses' Self-Presentations. Journal of International Business Studies 33: 497-514. [CrossRef]

Martínez-Ferrero, Jennifer, and Isabel-María García-Sánchez. 2016. Coercive, Normative and Mimetic Isomorphism as Determinants of the Voluntary Assurance of Sustainability Reports. International Business Review 26: 102-18. [CrossRef]

Matten, Dirk, and Jeremy Moon. 2008. 'Implicit' and 'Explicit' CSR: A Conceptual Framework for a Comparative Understanding of Corporate Social Responsibility. Academy of Management Review 33: 404-24. [CrossRef]

Matten, Dirk, and Jeremy Moon. 2004. Implicit and Explicit CSR. A Conceptual Framework to Understand CSR in Europe. ICCSR Research Paper Series 29: 1-27.

Noorderhaven, Niels G., and Anne-Wil Harzing. 2003. The 'Country-of-Origin Effect' in Multinational Corporations: Sources, Mechanisms and Moderating Conditions. In Management and International Review. Berlin: Springer, pp. 47-66.

Oliver, Christine. 1991. Strategic Responses to Institutional Processes. Academy of Management Review 16: 145-79. [CrossRef]

Ortas, Eduardo, Igor Álvarez, Jacques Jaussaud, and Ainhoa Garayar. 2015. The Impact of Institutional and Social Context on Corporate Environmental, Social and Governance Performance of Companies Committed to Voluntary Corporate Social Responsibility Initiatives. Journal of Cleaner Production 108: 673-84. [CrossRef]

Pauly, Louis W., and Simon Reich. 1997. National Structures and Multinational Corporate Behavior: Enduring Differences in the Age of Globalization. International Organization 51: 1-30. [CrossRef]

Purdy, Jill M., Elizabeth A. Alexander, and Stern Neill. 2010. The Impact of National Institutional Context on Social Practices: Comparing Finnish and US Business Communities. European Journal of International Management 4: 234-56. [CrossRef]

Ringov, Dimo, and Maurizio Zollo. 2007. The Impact of National Culture on Corporate Social Performance. Edited by Gilbert Lenssen. Corporate Governance: The International Journal of Business in Society 7: 476-85. [CrossRef]

Scholtens, Bert. 2011. Corporate Social Responsibility in the International Insurance Industry. Sustainable Development 19: 143-56. [CrossRef]

Scott, W. Richard. 1995. Institutions and Organizations. Foundations for Organizational Science. London: SAGE Publication.

Semenova, Natalia, and Lars G. Hassel. 2008. Financial Outcomes of Environmental Risk and Opportunity for US Companies. Sustainable Development 16: 195-212. [CrossRef]

Simier, Monique, L. Blanc, Frédéric Pellegrin, and Daniel Nandris. 1999. Approche Simultanée de \$ K \$ Couples de Tableaux: Application à l'étude Des Relations Pathologie Végétale-Environnement. Revue de Statistique Appliquée 47: 31-46.

Tang, Lu, and Hongmei Li. 2009. Corporate Social Responsibility Communication of Chinese and Global Corporations in China. Public Relations Review 35: 199-212. [CrossRef] 
Thioulouse, Jean, Monique Simier, and Daniel Chessel. 2004. Simultaneous Analysis of a Sequence of Paired Ecological Tables. Ecology 85: 272-83. [CrossRef]

Tucker, Ledyard R. 1966. Some Mathematical Notes on Three-Mode Factor Analysis. Psychometrika 31: $279-311$. [CrossRef] [PubMed]

Weber, Jessica Lee. 2014. Corporate Social Responsibility Disclosure Level, External Assurance and Cost of Equity Capital. University of Colorado at Boulder. Available online: http:/ / gradworks.umi.com/36/35/3635946. html (accessed on 20 April 2018).

Welford, Richard. 2004. Corporate Social Responsibility in Europe and Asia: Critical Elements and Best Practice. The Journal of Corporate Citizenship 13: 31-47. [CrossRef]

Welford, Richard. 2005. Corporate Social Responsibility in Europe, North America and Asia: 2004 Survey Results. The Journal of Corporate Citizenship 17: 33-52. [CrossRef]

Whetten, David A., Gordon Rands, and Paul Godfrey. 2002. What Are the Responsibilities of Business to Society. In Handbook of Strategy and Management. London: SAGE, pp. 373-408.

Whitley, Richard. 1992. European Business Systems: Firms and Markets in Their National Contexts. Newcastle upon Tyne: SAGE.

Witt, Michael A., and Gordon Redding. 2011. The Spirits of Corporate Social Responsibility: Senior Executive Perceptions of the Role of the Firm in Society in Germany, Hong Kong, Japan, South Korea and the USA. Socio-Economic Review 10: 109-34. [CrossRef]

(C) 2018 by the authors. Licensee MDPI, Basel, Switzerland. This article is an open access article distributed under the terms and conditions of the Creative Commons Attribution (CC BY) license (http:/ / creativecommons.org/licenses/by/4.0/). 





\section{Capítulo II}

\section{El Papel Influyente de los Valores Culturales en la Sostenibilidad Empresarial}

La sostenibilidad empresarial está interrelacionada en muchos aspectos con el proceso de globalización, por lo que obtiene el sello de ser una idea verdaderamente global, siempre preocupada por garantizar sus dimensiones humanas, sociales y ambientales. Sin embargo, aunque la RSC puede ser de naturaleza global, varios investigadores sugieren que se aplica de manera diferente en los diversos contextos culturales, legales, sociales y económicos.

Las instituciones son factores clave para comprender la naturaleza de las prácticas de RSC y pueden considerarse como las 'reglas del juego', por lo que las empresas de un país específico desarrollan determinadas conductas. Concentrarse en las diferentes instituciones puede ayudarnos a comprender qué incentivos y restricciones tienen las empresas en sus macro ambientes, en lugar de considerar la RSC como puramente voluntaria. El presente trabajo, basado en la teoría institucional y la teoría de las partes interesadas, tiene como objetivo observar la influencia del sistema cultural en el grado de responsabilidad del comportamiento empresarial.

La cultura se traduce en presiones normativas que detectan las dimensiones prescriptivas, evaluativas y obligatorias en la vida social, es decir, dando instrucciones o normas sobre cómo las personas deben actuar y juzgar, o determinar la idoneidad de las acciones y las obligaciones moralmente restrictivas. La cultura puede definirse como un programa colectivo de la mente que distingue a las personas de un país de las de los demás. En esta investigación utilizamos el modelo de las dimensiones culturales de Hofstede, comúnmente utilizado por otros autores para analizar el impacto del sistema cultural en el contexto macro-social. Los valores culturales de Hofstede destacan las similitudes y diferencias entre los países en función de cinco dimensiones: alta / baja distancia en el poder; individualismo / colectivismo; masculinidad / feminidad; aversión / tolerancia a la incertidumbre; y, orientación a corto / largo plazo.

Los valores culturales en cada país determinan la propensión de las empresas a adoptar ciertos niveles de sostenibilidad, ya que los diferentes valores culturales del entorno o contexto en el que opera la empresa desempeñan un papel importante en las expectativas de las partes interesadas. De modo que, las organizaciones que operan en contextos similares, es decir, en países con valores culturales parejos, probablemente adoptarán patrones de comportamiento de RSC homogéneos. Este proceso mejora la estabilidad y la supervivencia de la empresa, facilita el poder político y la legitimidad institucional, y se denomina 'isomorfismo normativo'.

Este estudio contribuye a la literatura mediante la adopción de un enfoque a nivel mundial considerando una muestra de 6600 observaciones de 600 empresas que cotizan en bolsa con sede en 18 países de Europa, América del Norte, Japón y Australia, durante el período 2004-2014. A 
diferencia del capítulo anterior, en lugar de trabajar con las practicas individuales de sostenibilidad, éstas son agrupadas en cinco indicadores sintéticos de RSC -medioambiente, derechos humanos, empleados, stakeholders y ética- asociados con las dimensiones sociales y ambientales. Trabajamos de esta manera con el objetivo de corregir la divergencia en el comportamiento empresarial dentro de la misma línea de acción en términos de sostenibilidad, que puede no observarse si los ítems fueran analizados de manera individual. La agregación de las prácticas de RSC proporciona una mayor simplicidad en el análisis de los resultados, lo que permite una determinación más precisa de las implicaciones que puedan derivarse.

Dado el carácter multidimensional de los datos, es esencial analizarlos con técnicas que capturen este carácter multivariante. En primer lugar, trabajamos con todas las empresas, mediante la aplicación de un análisis X-STATIS calculamos la estructura consenso de todos los años y, la representamos separando las empresas en función de los valores culturales de sus países de procedencia, lo cual nos permite visualizar patrones de comportamiento con respecto a la RSC y diferenciar éstos en relación a sus sistemas culturales. En segundo lugar, trabajando con datos a nivel país y los métodos biplot, se describen qué dimensiones culturales del modelo de Hofstede presentan mayor influencia sobre la RSC y específicamente sobre qué indicadores. Además, es posible observar qué países se ven más o menos afectados por estas dimensiones.

Los resultados ponen de manifiesto que las dimensiones culturales ejercen presiones importantes sobre las empresas y su compromiso y, evidencian que las empresas ubicadas en sociedades colectivistas y, aún más, en las feministas, se caracterizan por la búsqueda del bien común y hacen mayor hincapié en cuestiones sociales y ambientales, mostrando las mejores prácticas de RSC. En relación a los países, los datos apuntan a una mayor actividad en el norte que en el sur de Europa y, muestran que las empresas responden a lo que es importante en sus propios países; por ejemplo, los países nórdicos dan prioridad a las políticas sociales, mientras que las empresas japonesas están más comprometidas con el medio ambiente. Finalmente, nuestros resultados demuestran que las empresas de todo el mundo adoptan patrones similares de prácticas de RSC, pero su grado de desarrollo está fuertemente determinado por las características institucionales normativas.

A continuación, presentamos toda esta información detallada de manera extensa en el artículo de investigación "Cultural values on CSR patterns and evolution: A study from the biplot representation" publicado en la revista Ecological Indicators (2017: Q1 - JIF:3.983). 
Research paper published:

Title: Cultural values on CSR patterns and evolution: A study from the biplot representation

Authors: Víctor Amor-Esteban

Ma-Purificación Galindo-Villardón

Isabel-María García-Sánchez

Journal: Ecological Indicators, 81, 18-29

\begin{tabular}{c|c|c|c|c} 
Year & Category Name & $\begin{array}{c}\text { Total Journals } \\
\text { in Category }\end{array}$ & $\begin{array}{c}\text { Journal Rank } \\
\text { in Category }\end{array}$ & $\begin{array}{c}\text { Quartile } \\
\text { in Category }\end{array}$ \\
\hline 2017 & Environmental Sciences & 241 & 48 & Q1
\end{tabular}

* Journal Impact Factor: 3.983; 5 Year Impact Factor: 4.391.

* Publisher: Elsevier Science BV

* Google scholar cites:

APA Esteban, V. A., Villardón, M. P. G., \& Sánchez, I. M. G. (2017). Cultural values on CSR patterns and evolution: A study from the biplot representation. Ecological indicators, 81, 18-29.

ISO ESTEBAN, Víctor Amor; VILLARDÓN, Ma Purificación Galindo; SÁNCHEZ, Isabel

690 María García. Cultural values on CSR patterns and evolution: A study from the biplot representation. Ecological indicators, 2017, vol. 81, p. 18-29.

Esteban, Víctor Amor, M ${ }^{a}$ Purificación Galindo Villardón, and Isabel María García

MLA Sánchez. "Cultural values on CSR patterns and evolution: A study from the biplot representation." Ecological indicators 81 (2017): 18-29.

*The paper is numbered independently and includes pages 71-82 (12) of the global document. 

Original Articles

\title{
Cultural values on CSR patterns and evolution: A study from the biplot representation
}

\author{
Víctor Amor Esteban ${ }^{\mathrm{a}, *}, \mathrm{M}^{\mathrm{a}}$ Purificación Galindo Villardón ${ }^{\mathrm{a}}$, Isabel María García Sánchez \\ a Department of Statistics, Campus Miguel de Unamuno, c/Alfonso X El Sabio s/n, University of Salamanca, 37007 Salamanca, Spain \\ b Department of Business Administration, Campus Miguel de Unamuno, Faculty of Economics, University of Salamanca, 37007 Salamanca, Spain
}

\section{A R T I C L E I N F O}

\section{Keywords:}

Corporate Social Responsibility (CSR)

Normative forces

CSR engagement

X-STATIS

HJ-biplot

\begin{abstract}
A B S T R A C T
Based on institutional and stakeholder theory, this study aims to observe the influence the cultural system has on the degree of responsibility of business behaviour and examines how normative isomorphism influences the Corporate Social Responsibility practices at the country level. We use the Hofstede model because its dimension group highlights the cultural similarities and differences between countries, and we measure CSR along five indicators referring to environmental and social dimensions. This study contributes to the literature by adopting a multi-region approach considering a sample of 6600 observations of 600 publicly-listed companies headquartered in 18 countries in Europe, North America, Japan and Australia, during the period 2004-2014. Given the multidimensional character of the data, we use the exploratory statistical techniques X-STATIS and HJbiplot, since this allows us to approximate a large group of variables in a low-dimensional space, providing us with a useful visualisation of the structure of the data of the sample relative to the variables. Our main conclusion is that cultural dimensions exert important pressures on firms and their commitment, so, companies located in collectivist societies and, even more, in feminist ones, are characterised by the pursuit of the common good and place greater emphasis on social and environmental issues, thereby showing best CSR practices. Overall, the data does point to more activity in Northern than in Southern Europe, and show that companies respond to what is important in their own countries; for example, the Nordic countries give priority to social policies, while Japanese companies are more committed to the environment. Finally, our results evidence that companies worldwide adopt similar patterns of CSR practices, but their degree of development is strongly determined by the normative institutional characteristics.
\end{abstract}

\section{Introduction}

Corporate Social Responsibility (CSR) has expanded since the 1990s as an emerging area of organisational management study, and, in the scope of mitigation, the umbrella term of responsible business conduct has gained attention on the global scale (Halkos and Skouloudis, 2016; Lozano, 2012; Wood, 2010). Nowadays, CSR is actively promoted by institutions such as the United Nations, the OECD and the World Bank, among other key global institutions. In addition, an emerging "epistemic CSR community" can be discerned, which is central to the development of the global discourse, consisting of a set of collective ideas and shared references as well as specific and identifiable CSR practices, such as reporting standards or certification schemes. This community is made up of academic institutions, non-governmental organisation leaders and research groups. Thus, corporate social responsibility is interrelated with the process of globalization in many aspects, so that it obtains the hallmark of being a truly global idea, always concerned with ensuring its human and environmental dimensions (Gjølberg, 2009; Ruggie, 2008). Nevertheless, although CSR may be of a global nature, as mentioned, several researchers suggest that it is applied differently in different cultural, legal, social and economic contexts.

These general institutional factors define the context in which firms interact with their stakeholders, who have different expectations regarding business behaviour as a result of different cultural conditions involving different values, norms and practices (Bustamante, 2011; Carroll, 1979). In the cultural system, the humanistic orientation, gender equity and institutional collectivism are some of the different dimensions that reflect essentially important differences in the social dimension of CSR (Baskin, 2006) as well as in environmental issues (Barkemeyer, 2007), because countries with different cultural systems perceive the prevalence of these aspects with respect to the economic one in many diverse ways (Maignan, 2001).

There is extensive and important research on CSR; however,

\footnotetext{
* Corresponding author.

E-mail address: victor_aes@hotmail.com (V.A. Esteban).
} 
relatively few studies investigate the effects of institutional conditions on responsible business conduct (Jackson and Apostolakou, 2010; Aguilera et al., 2007). Other studies, such as those by Chen and Bouvain (2009), Lattemann et al. (2009), van der Laan Smith et al. (2005), Xiao et al. (2005) and Holland and Boon Foo (2003), present several limitations that restrict the generalisation of the results, such as the reduced number of countries analysed or the consideration of only environmental information (Aerts et al., 2006; Cormier et al., 2005) or firms in only one sector (Adelopo et al., 2013). This paper compares the practices and disclosure of information about CSR in its different dimensions in companies from several countries belonging to different sectors.

The present work, based on institutional theory and stakeholder theory, aims to observe the influence of the cultural system on the degree of responsibility of business behaviour. This paper contributes to the literature by evaluating several countries through a sample of large listed corporations headquartered in 18 countries in Europe, North America, Japan and Australia, instead of following a single-country or a two-region approach, such as those used by Perez-Batres et al. (2011) and Xiao et al. (2005), across the years 2004-2014. We measure CSR with five indicators - human rights, employees, stakeholders, ethics and environment - that refer to social and environmental dimensions. Our paper analyses the role that institutional forces play in the commitment to sustainability, specifically the impact of normative forces, that is, the different country cultural characteristics.

Given the multidimensional character of the data that make up CSR, it is essential to analyse it with techniques that capture its multivariate character. In this article we use the X-STATIS (Jaffrenou, 1978) and the HJ-biplot (Galindo, 1986) exploratory statistical techniques for such data analysis. From traditional statistical methods one could examine each year separately and make a comparative analysis of similarities and differences; however, the X-STATIS allows us to represent the results in a single factorial plane, representing the consensus structure of all years and, thus, visualizing the behavioural patterns of companies in relation to their CSR practices. To classify countries according to their CSR practices and their normative characteristics, certain techniques could be used, for example, a cluster analysis; but in that case, we would find the patterns but not the variables that characterise the groups; or a principal component analysis, but, it does not provide a simultaneous representation. For this reason, a biplot representation has been chosen, and among its possibilities, we use the HJ-biplot; it has the highest reliability, because of individuals and variables can be superimposed on the same reference system with optimal representation quality.

The paper is structured as follows. In the following section, we describe the institutional features considered in the analysis; accordingly, disaggregated information allows us to expand the framework of neo-institutional theory to analyse the effect that normative pressures have on various aspects of CSR. Subsequently, we provide details of the data and statistical methods used, describe the empirical results obtained and discuss them. Finally, we present our main conclusions regarding the findings.

\section{Normative isomorphism and cultural systems}

On the basis of the above, due to the resulting differences in the roles of the various stakeholders according to the different institutional contexts, there is no universal definition of CSR (Matten and Moon, 2008). On this line Matten and Moon (2004) research is among the first to theorise on the theoretical relation between CSR and national contexts, and Habisch et al. (2005), in their book "Corporate social responsibility across Europe", published a year later, reinforce the theory that CSR is contingent on national contexts. Lenssen et al. (2006) map the current patterns of CSR to the national political and economic institutions established decades ago.

Institutions are key factors in understanding the nature of CSR practices (Jones and Nisbet, 2011) and can be seen as the "rules of the game", so companies within a specific country develop certain behaviours (Thelen, 1999). Concentrating on the different institutions can help us to comprehend which incentives and constraints the firms have in their macro-environments, instead of considering CSR as purely voluntary (e.g., Dennis Jr, 2011; Matten and Crane, 2005; Windsor, 2004). Several authors theorise on two different sources of CSR: the first is known as coercive and is based on rules and standards that are usually codified and mandatory, and the second is known as normative, referring to the promotion of firms' CSR policies and activities by the perceived expectations of stakeholders (Matten and Moon, 2008; Carroll, 1991). Thereby, organisations that operate in similar contexts, that is, in countries with similar institutional structures, will probably adopt homogeneous CSR behaviour patterns. DiMaggio and Powell (1983) argue that this process enhances company stability and survival, facilitating political power and institutional legitimacy, and name it "isomorphism".

In relation to normative isomorphism, the stakeholder theory determines the role that stakeholders could play in CSR development. A stakeholder is defined as "any group or individual who can affect or is affected by the achievement of an organisation's purpose" (Freeman, 1984), which allows us to define a new image of a company that, through the production of goods and services, wants to satisfy the needs of the different groups that constitute it and on which it depends for its survival (Fernández, 2003). As a result of different cultural conditions involving different norms, values and practices, local interest groups have different expectations regarding business behaviour (Bustamante, 2011; Carroll, 1979).

Culture can be defined as a collective programme of the mind, which is highly invisible, sub-conscious and difficult to change (Hofstede, 1983), affecting the behaviour of citizens and corporations (Vitell et al., 2003), Moreover, the ethics of decision-making processes is expected to have a significant influence (Su, 2006; Singhapakdi et al., 1994), on managers' behaviour, the organisational structure and the business performance, since it will generate an orientation towards entrepreneurial behaviour that is more or less sustainable (Boyd and Richerson, 2005), and this contributes to determining the commitment that the companies will show in relation to their economic, social and environmental actions.

Culture translates into normative pressures, which detect the prescriptive, evaluative and obligatory dimensions in social life, that is, giving instructions or norms on how people should act and judging or determining the suitability of actions and the morally restrictive obligations (Scott, 2001). According to Minkov (2007) and Hofstede (1983), culture can be defined as a collective programme of the mind that distinguishes the people of one country from those of others. Several models have been developed, such as the Hofstede, GLOBE or Schwartz models, which can help us to understand the societal values that distinguish countries from each other; accordingly, these values are grouped into clusters, as in Hofstede's dimensions of national culture. In this paper, and due to their dimensions being proposed by other models (de Mooij and Hofstede, 2010) we use the Hofstede Model. This model based on the dimensions proposed by Hofstede (2001) is often used by other authors to analyse the impact of the cultural system on the macrosocial context, for example Frías-Aceituno et al. (2013), García-Sánchez et al. (2013), Williams and Zinkin (2008), Ringov and Zollo (2007), Christie et al. (2003), Vitell et al. (2003) and Maignan (2001), and to predict the business ethics or CSR parameters. Adaptations of these parameters to analyse the influence on CSR disclosure practices are also used by Kim and Kim (2010), Orij (2010) and van der Laan Smith et al. (2005).

Hofstede's national work was realized in the 1960s for IBM. To identify the basic values of citizens and distinguish these values between countries, Hofstede proposed four dimensions, which are referred to as "differences"; however, other authors, such as van der Laan Smith et al. (2005), use the term "dimensions". Hofstede's cultural 
value dimensions highlighting the similarities and differences between countries consist of power distance, individualism/collectivism, masculinity/femininity and uncertainty avoidance (Hofstede, 2001). Sometime afterwards, Hofstede and Hofstede (2005) proposed a fifth dimension: a long-term versus short-term orientation towards life.

The power distance dimension indicates the level of hierarchy in a society; a high power distance translates into a society with different levels of power status, in which power positions are vertically stratified, which is associated with low employee involvement in decision-making processes. Individualism/collectivism refers to the importance that individuals give to the collective entity; societies in which collectivism prevails are formed by citizens who have stronger links with society, since they think more of themselves as a member of a group (Hofstede, 2001, p. 225). The dimension of masculinity/femininity makes reference to the role that gender plays in a society. Societies that focus on material success are often assumed to be masculine, because they are assertive and hard; on the contrary, the most modest societies and those concerned with quality of life are considered to be feminine (Hofstede, 2001, p. 297). Uncertainty avoidance presents a culture's level of tolerance of uncertainty; a society conforming to a greater number of codified and obligatory norms and rules imposed on individuals is less supportive of uncertainty. Finally, the dimension of long-/short-term orientation explains that societies with a short orientation present pastand present-oriented values and societies with a long-term orientation present future-oriented values (Hofstede and Hofstede, 2005).

The cultural values in each country determine a propensity in companies to adopt certain sustainability behaviour, since the different environments or contexts in which the company operates or equivalently different cultural values play an important role in the expectations of stakeholders. Therefore, in societies with a low power distance, feminist and collectivist orientation and a good level of tolerance of uncertainty, firms are expected to show greater commitment to sustainability (Garcia-Sanchez et al., 2016; Frías-Aceituno et al., 2013; Ringov and Zollo, 2007), in the same way as societies with long-term orientation (Garcia-Sanchez et al., 2016). It is expected that in these societies the behaviour of companies is based on practices that promote greater transparency, that is, disclosure of information through an integrated report that provides a wide range of information that stakeholders and investors can evaluate in a precise, clear and comparable manner.

From the above, the specific research questions that we propose in this paper ask whether firms adopt homogeneous behaviour patterns regarding their CSR practices when operating in countries with similar cultural systems and whether these normative pressures influence the evolution or degree of business compromise with CSR. More concretely, taking into account the Hofstede model, because its dimension groups highlight the cultural similarities and differences between countries (Hofstede and Hofstede, 2005), it is possible to determine the effect of the cultural dimensions proposed by this author.

\section{Data and research methods}

\subsection{Sample}

We started from a set of panel data taken from the world's leading companies with their financial and CSR data obtained from the Thomson One Analytic and EIRIS databases. The sample we used comprised 6600 observations from 600 publicly-listed companies from 18 different countries during the period 2004-2014, highlighting four predominant geographic areas: Europe (50.50\%, 3333 observations, 14 countries), North America (25.83\%, 1705 observations, 2 countries), Japan (16.67\%, 1100 observations) and Australia (7\%, 462 observations) (see Table 1). It is necessary to take into account the time factor, since the development of CSR in the 2004-2014 decade was extremely important owing to the effect of technological development and freedom of the press and, indirectly, of the ability to access information
Table 1

Distribution of the samples, by countries.

\begin{tabular}{llll}
\hline & & Frequency & \\
\cline { 4 - 4 } Countries & & Absolute & Relative (\%) \\
\cline { 4 - 4 } 1 & & & \\
2 & Australia & 462 & 7,0 \\
3 & Austria & 44 & 0,7 \\
4 & Belgium & 77 & 1,2 \\
5 & Canada & 440 & 6,7 \\
6 & Denmark & 121 & 1,8 \\
7 & Finland & 110 & 1,7 \\
8 & France & 429 & 6,5 \\
9 & Germany & 407 & 6,2 \\
10 & Italy & 143 & 2,2 \\
11 & Japan & 1100 & 16,6 \\
12 & Netherlands & 165 & 2,5 \\
13 & Norway & 66 & 1,0 \\
14 & Portugal & 44 & 0,7 \\
15 & Spain & 165 & 2,5 \\
16 & Sweden & 275 & 4,2 \\
17 & Switzerland & 220 & 3,3 \\
18 & UK & 1067 & 16,1 \\
& USA & 1265 & 19,1 \\
& Total & 6600 & 100,0 \\
\hline & & &
\end{tabular}

about corporate behaviour and about the pressure that different stakeholders are able to exercise (Martínez-Ferrero and GarcíaSánchez, 2016).

\subsection{Variables for analysis}

We used five indicators to measure the performance of CSR: "human rights", "employees", "stakeholders" and "ethics", regarding the social dimension, and "environment", related to the environmental dimension. The CSR performance was obtained from the EIRIS database and includes information on 26 items that evaluate the development and commitment to sustainability of each company by a scale of $0-4$, being "O-Inadequate", "1-Weak", "2-Moderate", "3-Good" and "4-Exceptional"; each indicator gets its value from the average of the items that form it, and each one is composed of a different number of items, as shown in Table 2. These items are mainly linked to the social, ethical and environmental CSR dimensions and represent the company's level of commitment to stakeholders, the policies and practices it implements to support equal opportunities and human rights, its health systems and safety at work procedures, its relationships with customers, suppliers and employees, its impact on the environment and its systems and policies for environmental management. Specifically, indicators of the social dimension refer to corporate impact in the community (Hubbard, 2009), including support for human rights, philanthropic behaviour, equal opportunities, employee relations and participation and the development of economic and social well-being. The environmental dimension is associated to the development of policies and systems to economise natural resources and to control the effects of business activities on the environment, in terms of waste, air emissions and chemical residues (Hubbard, 2009).

In order to represent normative institutional forces, we used the Hofstede model because its five dimensions group highlights the cultural similarities and differences between countries (Hofstede and Hofstede, 2005), these are numerical variables whose values were obtained on the website Geert Hofstede ${ }^{\mathrm{TM}}$ Cultural Dimensions. According to the literature, in societies with a low power distance, feminist, collectivist, with a good level of tolerance to uncertainty and long term orientation, are expected that their companies show a greater commitment to sustainability. Thus, the chosen variables represent cultural values for those who promote CSR information; these variables are "long term" measured using the corresponding Hofstede indexes, "femininity" (inverse measure of masculinity), "collectivism" (inverse 
Table 2

Descriptive CSR indicators.

\begin{tabular}{|c|c|c|c|c|}
\hline \multicolumn{3}{|c|}{ Social performance } & \multirow{2}{*}{$\frac{\text { Mean }}{\mathbf{0 , 9 8}}$} & \multirow{2}{*}{$\frac{S D}{\mathbf{0 , 8 7}}$} \\
\hline Humar & Rights & & & \\
\hline HR1 & Human Rights policy & What is the extent of policy addressing human rights issues? & 1,37 & 1,11 \\
\hline HR2 & Human Rights systems & What is the extent of systems addressing human rights issues? & 1,00 & 0,93 \\
\hline HR3 & Human Rights reporting & Does the Company report on human rights issues? & 0,58 & 0,81 \\
\hline \multicolumn{3}{|c|}{ Employees } & 1,09 & 0,56 \\
\hline Emp1 & Equal opportunities (policy) & How good is the Company's policy on equal opportunity and diversity issues? & 1,94 & 0,96 \\
\hline Emp2 & Equal opportunities (systems) & How clear is the evidence of systems and practices to support equal opportunities and diversity? & 1,00 & 0,81 \\
\hline Emp3 & Health \& safety systems & How clear is the evidence of health \& safety systems? & 1,27 & 0,79 \\
\hline Emp4 & Trade unions and employee participation & How clear is the evidence of systems to manage employee relations? & 0,89 & 0,88 \\
\hline Emp5 & Training & How clear is the evidence of systems to support employee training and development? & 0,81 & 0,73 \\
\hline Emp6 & Job creation and security & How clear is the evidence of systems and practices to advance job creation and security? & 0,64 & 0,64 \\
\hline \multicolumn{3}{|c|}{ Stakeholders } & 1,55 & 0,76 \\
\hline Sth1 & Customer/supplier relations & How clear is the Company's commitment to community or charitable work? & 1,70 & 0,68 \\
\hline Sth2 & Customer/supplier relations (policy) & Does the Company have policies on maintaining good relations with customers and/or suppliers? & 1,38 & 0,99 \\
\hline Sth3 & Community involvement & How clear is the evidence of systems to maintain good relations with customers and/or suppliers? & 1,47 & 0,93 \\
\hline Sth4 & Responsibility for stakeholders & How many stakeholder issues have been allocated to board members? & 1,25 & 1,21 \\
\hline Sth5 & Stakeholder engagement & What level of engagement with stakeholders is disclosed by the Company? & 1,46 & 1,04 \\
\hline Sth6 & Stakeholder policy & How good are the Company's policies towards its stakeholders overall? & 1,93 & 0,89 \\
\hline Sth7 & Stakeholder systems & How good are the Company's management systems for stakeholders overall? & 1,84 & 1,05 \\
\hline Sth8 & Stakeholder reporting & How good is the Company's quantitative reporting on stakeholder relationships? & 1,66 & 1,15 \\
\hline Ethics & & & 1,76 & 0,88 \\
\hline Eth1 & Codes of ethics & Does the Company have a code of ethics and, if so, how comprehensive is it? & 3,12 & 1,15 \\
\hline Eth2 & Codes of ethics systems & Does the Company have a system for implementing a code of ethics and, if so, how comprehensive is it? & 2,76 & 1,18 \\
\hline Eth3 & Countering bribery policy & What is the extent of the Company's policy for countering bribery? & 2,07 & 1,10 \\
\hline Eth4 & Countering bribery systems & What is the extent of the Company's system for countering bribery? & 1,75 & 0,89 \\
\hline Eth5 & Countering bribery reporting & What is the extent of the Company's reporting on countering bribery? & 0,87 & 0,64 \\
\hline \multicolumn{3}{|c|}{ Environmental performance } & Mean & SD \\
\hline \multicolumn{3}{|c|}{ Environment } & 1,74 & 1,11 \\
\hline Env1 & Environmental policy & How does EIRIS rate the Company's environmental policy and commitment? & 2,25 & 1,29 \\
\hline Env2 & Environmental management & How does EIRIS rate the Company's environmental management system? & 2,40 & 1,48 \\
\hline Env3 & Environmental reporting & How does EIRIS rate the Company's environmental reporting? & 1,29 & 1,40 \\
\hline Env4 & Environmental performance & What level of improvements in environmental impact can the Company demonstrate? & 1,04 & 1,18 \\
\hline
\end{tabular}

of individualism), "uncertainty tolerance" (inverse of uncertainty avoidance) and "low power distance" (inverse of power distance). The values of these variables are taken to create the variable "Culture", which was created by calculating the average value of these five dimensions in order to observe the global effect and thus highlight the similarities and differences between countries according to their cultural development.

\subsection{Statistical analysis}

\subsubsection{Partial triadic analysis (X-STATIS)}

The analysis X-STATIS (Jaffrenou, 1978) is a STATIS family method (Escoufier, 1976; L'Hermier des Plantes, 1976) able to analyse a threeway table (600 companies, 5 CSR indicators and 11 years, 2004-2014). It is an exploratory tool which main goal is to summarize the $\mathrm{k}$ data tables in a single called "compromise", which constitutes a global summary of the set of tables, therefore, it is a matrix that summarizes all the information provided by all the configurations, in our case over time, likewise as analyse the relationship between these data tables. Its development is divided into three steps: the study of the interstructure, the compromise analysis and the study of the intrastructure.

Steps of X-STATIS (see Fig. 1):

- The first step is the study of the interstructure; it is a question of studying the relation between the different tables, that is to say an overall comparison of the structure of the $\mathrm{k}$ data tables. For this, a scalar product matrix between tables is built, so the element in row $\mathrm{k}$ and column 1 is $\operatorname{Covv}\left(\mathrm{X}_{\mathrm{k}}, \mathrm{X}_{1}\right)=\operatorname{Tr}\left(X_{k}^{t} D_{n} X_{l} D_{p}\right)$, where $\mathrm{X}_{\mathrm{k}}$ is the kth table of the sequence and $D_{n}, D_{p}$ are the two metrics for the rows and columns, respectively.

- The second step is the analysis of the compromise, where through the vectorisation of the $\mathrm{k}$ matrices, that is, a linear transformation which converts each matrix into a column vector, stacking the columns of each matrix on top of one another, so that if we have $\mathrm{k}$ matrices, we will have a new matrix of $\mathrm{k}$ columns and nxp rows; this matrix we call $\mathrm{Z}$. From the principal components analysis of this matrix, we obtain the matrix $\mathrm{ZV}$; we extract the first main address that is collected in the first column and by unfolding this first column, we construct the compromise matrix.

- The third step is the study of the intrastructure (the trajectories) is obtained by the projection of the rows and columns of each table in the compromise subspace. Let $V_{r}$ be the first $r$ eigenvectors matrix from the compromise analysis. The coordinates of the rows of table $\mathrm{X}_{\mathrm{k}}$ are the rows of $\mathrm{X}_{\mathrm{k}} \mathrm{D}_{\mathrm{p}} \mathrm{V}_{\mathrm{r}}$, and the columns are the rows of $X_{k}^{t} D_{n} U_{r}$, $\mathrm{U}_{\mathrm{r}}$, being the first $\mathrm{r}$ eigenvectors of $X_{c} D_{p} X_{c}^{t} D_{n}$.

For this paper, the main goal of the X-STATIS analysis is to extract a multivariate structure showing the different years 2004-2014:

- The interstructure analysis allows reduce the dimensionality and represent each data matrix (each year) as a point in the lowdimensional Euclidean subspace. A small distance between points indicates similarity, and, if we connect each point with the origin of coordinates, we will have an estimate of the correlation evaluating the angles between vectors (acute angles are associated in a positive correlation), and will indicate that the CSR indicators maintain their behaviour over time with respect to the companies studied.

- The compromise analysis allows construct a matrix which contains 

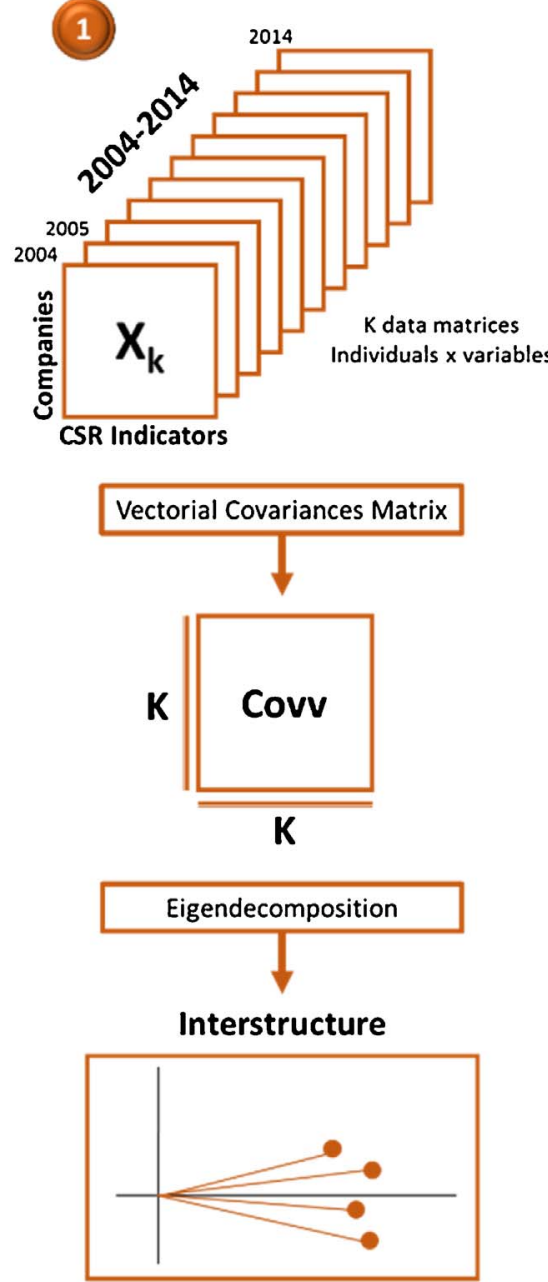
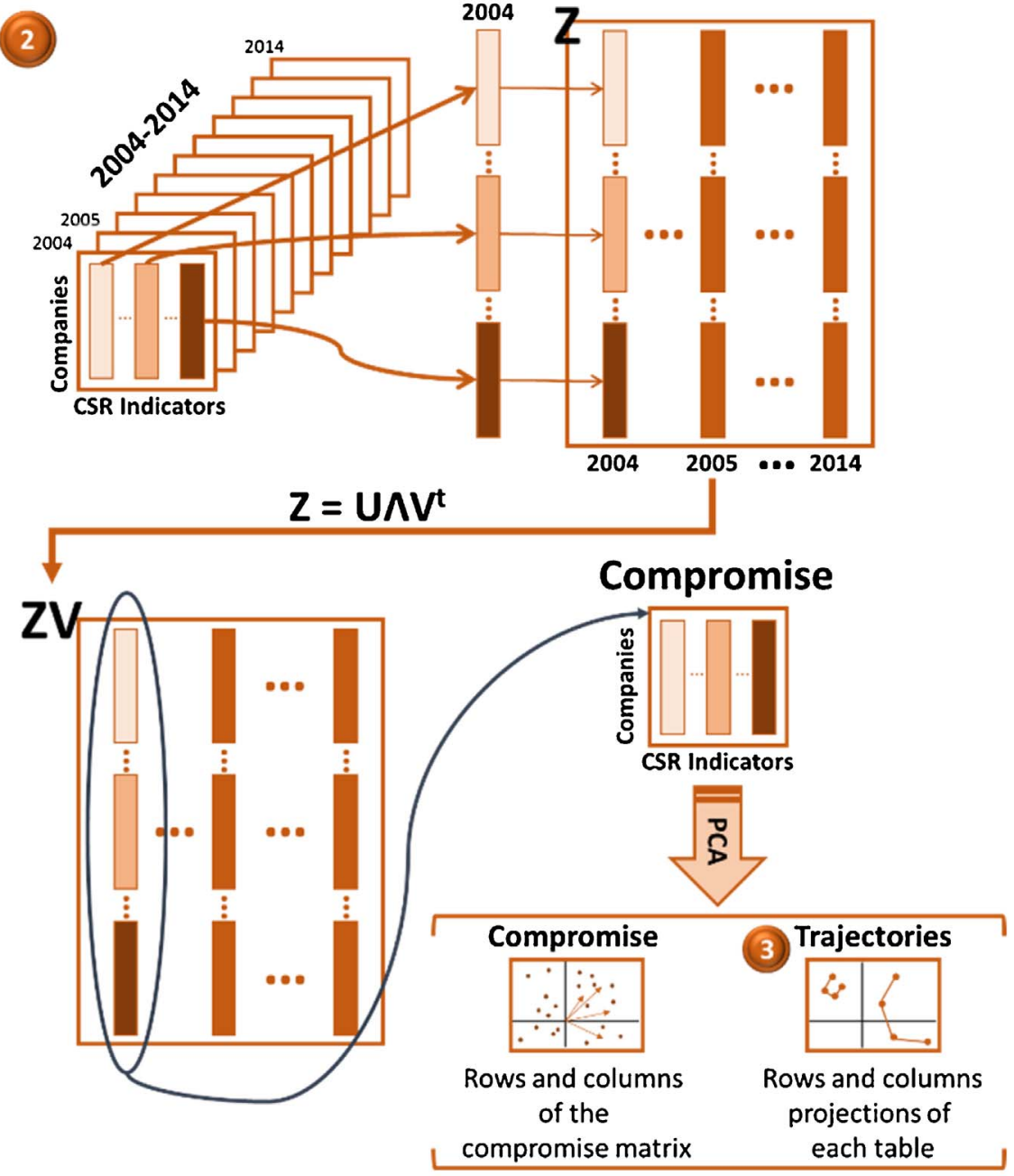

Fig. 1. X-STATIS flow chart and compromise table. the values for each company that synthesise the information in each of the CSR indicators in the 11 years of the study, which is known by the name "compromise". Therefore, the compromise step "filters" the noise and represents the statistically significant information, the stable structure, which can then be plotted to interpret that structure.

- The third step is the study of the intrastructure, also known as trajectories, which allows represent the individuals and variables of each one of the tables by the projection of the rows and columns of each table on the compromise subspace. In this study, we did not work with trajectories because we had a large number of companies, and the purpose of this methodology would be to follow the course, the evolution of enterprises individually, which was not a goal of this work; however, it may be interesting for future research to keep track of certain companies, progresses or changes that may appear in certain years or periods of time.

\subsubsection{HJ-biplot}

A biplot is a graphical representation of multivariate data, in the same way that a scatter diagram shows the joint distribution of two variables, a biplot represents three or more variables Gabriel (1971). The HJ-biplot (Galindo, 1986) is a multivariate graphic display of a matrix $\mathrm{X}_{\mathrm{nxp}}$. Let $\mathrm{X}=\mathrm{UDV}^{\mathrm{T}}$ be the usual singular value decomposition (SVD) of $\mathrm{X}$ with $\mathrm{U}$ and $\mathrm{V}$ orthogonal matrices and $\mathrm{D}=\operatorname{diag}\left(\lambda_{1}, \ldots, \lambda_{\mathrm{p}}\right)$ containing the singular values. Let $\mathrm{J}$ and $\mathrm{H}$ be the matrices of the first two columns of UD and VD, respectively. This method aims for the simultaneous interpretation of the relationships between individuals (rows) that are usually displayed as points and variables (columns) as vectors on a two-dimensional plot of the data table X. Accordingly, by means of markers $j_{i}=\left(j_{i}, \ldots, j_{n}\right)$ for its rows and $h_{j}=\left(h_{j}, \ldots, h_{n}\right)$ for its columns, both markers can be superimposed in the same reference system with optimal quality of representation.

For this paper, the main goal of the HJ-biplot is to describe the relations between the rows (countries) and columns (CSR indicators and cultural system variables) following the guidelines for the interpretation of the elements of the HJ-biplot:

- to identify clusters of samples with similar profiles, i.e., the distance between individuals (row markers) as dissimilarities between them, less distance meaning less dissimilarity, so countries that are closer to other countries are more similar.

- to evaluate the relationships between variables, the relationships of CSR indicators, normative forces and the relationships between them, i.e. the cosines of the angles formed by the column vectors, since small acute angles are associated with high positive correlations between variables; likewise, the length of a column vector (variables) approximates its standard deviation.

- to rank the different countries according to CSR indicators and normative forces, which will be achieved by ordering the individuals with respect to the variables through the order found in the orthogonal projections of the row markers (countries) on the column markers (variables).

Note that only the points and vectors with good quality of 


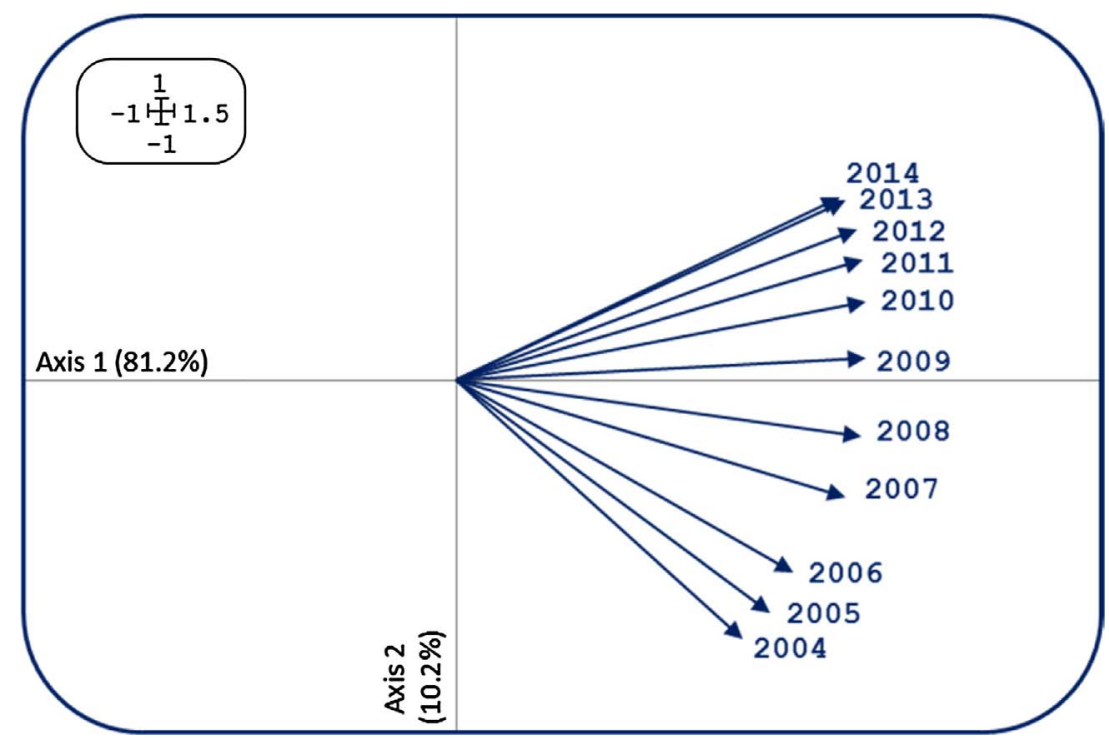

Fig. 2. Representing the ordination of sampling years with the factorial plane 1-2 of the study of interstructure according to X-STATIS analysis.

representation can be interpreted correctly in the subspace observed. All the calculations processed in the HJ-biplot analysis as well as in the graphs were performed using the software developed by VicenteVillardón (2010), which is available from http://biplot.usal.es/ classicalbiplot/

\section{Empirical results and discussion}

In this section, we are going to study the effect or the influence of the normative forces on the social and environmental performance in CSR matters of our firms in the decade 2004-2014. We begin by comparing the structures of the years by the study of interstructure of a $\mathrm{X}$-STATIS analysis, which provides a graphical estimate of the vector correlation coefficient between matrices, i.e. between years (see Fig. 2), where we find short angles between vectors, that is, strong relationships which are produced gradually; thus, we intuit a growth in the commitment to sustainability. This representation shows similar structures between years and collects more than $91 \%$ of the information with the factorial plane $1-2$.

The following is the construction of the compromise matrix, which constitutes a global summary of the set of tables, therefore, it is a matrix that summarizes all the information provided by all the configurations. Thus, in the compromise subspace created by this matrix, each company is represented by a value that synthesises the information of the 11 years of the study on these variables; in this way, we can investigate the behaviour of each company with respect to the others, capturing the multivariate information of that period, "filtering" the noise and keeping the information statistically significant. This repre-

Table 3

Weight and Representation of each matrix on compromise.

\begin{tabular}{lll}
\hline Axis & Weights & $\operatorname{Cos}^{2}$ \\
\hline 2004 & $2,30 \mathrm{E}+02$ & 0,523 \\
2005 & $2,48 \mathrm{E}+02$ & 0,590 \\
2006 & $2,56 \mathrm{E}+02$ & 0,620 \\
2007 & $3,16 \mathrm{E}+02$ & 0,695 \\
2008 & $3,25 \mathrm{E}+02$ & 0,734 \\
2009 & $3,28 \mathrm{E}+02$ & 0,757 \\
2010 & $3,28 \mathrm{E}+02$ & 0,757 \\
2011 & $3,26 \mathrm{E}+02$ & 0,750 \\
2012 & $3,21 \mathrm{E}+02$ & 0,736 \\
2013 & $3,12 \mathrm{E}+02$ & 0,699 \\
2014 & $3,06 \mathrm{E}+02$ & 0,676 \\
\hline
\end{tabular}

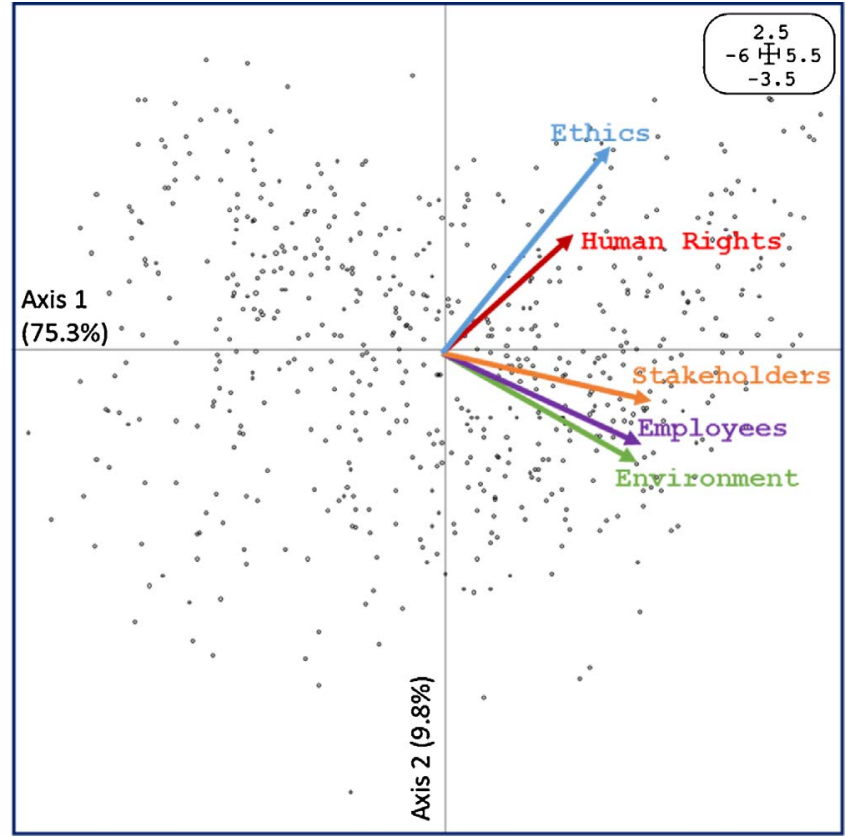

Fig. 3. Compromise analysis representing all the companies and all the CSR indicators.

sentation collects more than $85 \%$ of the information with the first two axes, and all the matrices obtain similar weights in the construction of the compromise (Table 3, "Weights" column) and good representation in that subspace (Table 3, " $\operatorname{Cos}^{2}$ " column), somewhat smaller for the first three years.

Consequently, we are presenting the factorial plane 1-2 that brings us close to the totality of the information in this representation (see Fig. 3), visualizing the position of our 600 companies in the period 2004-2014 in reference to the five variables used to measure the commitment to sustainability. Companies are scattered throughout the graph, presenting a great variability; in addition, we observed a strong relationship between "stakeholders", "employees" and "environment" located in the 4th quadrant: on the other hand, there was a strong relationship between "ethics" and "human rights" in the 1st. quadrant.

To evaluate the influence of normative forces (cultural systems) on the commitment to sustainability, we used the Hofstede variables promoting this commitment, namely "femininity", "collectivism", "uncertainty tolerance", "low power distance" and "long term": it is 


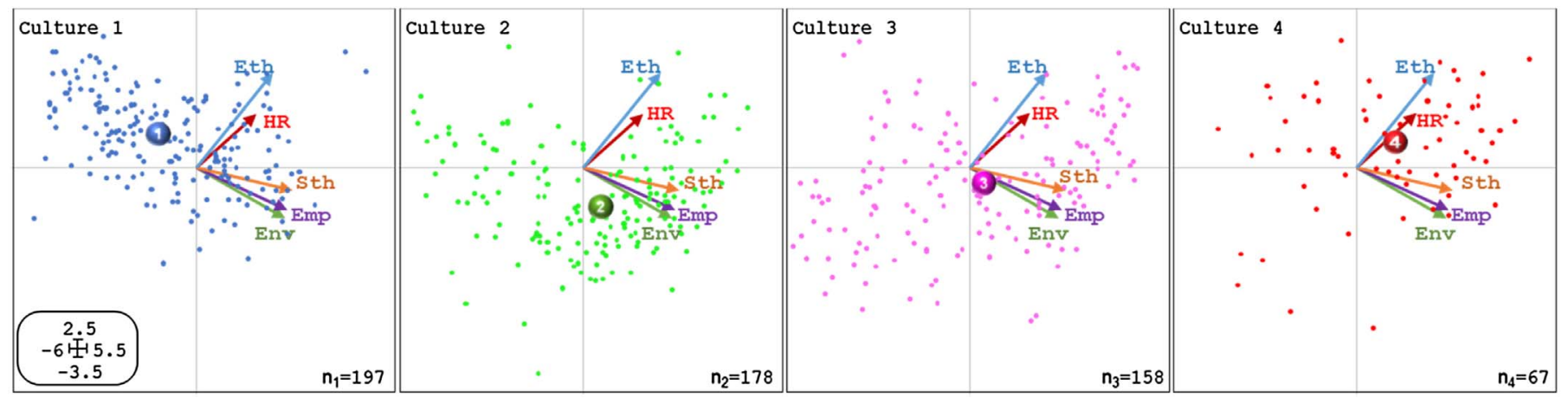

Fig. 4. Compromise analysis representing all the companies and all the CSR indicators, split into four levels of development (cultural typologies).

therefore expected that countries with higher values in these variables are the most developed culturally and therefore show greater commitment to sustainability. To do this, we used the "Culture" variable, which is an average of these five variables, so each country in the study receives a numerical value of cultural development, and thus their companies: using the $\mathrm{p}_{25}, \mathrm{p}_{50}$ and $\mathrm{p}_{75}$ percentiles in this variable, we fragmented the sample into four typologies of levels of development, being the fourth typology the one of greater development. This way, we regarded patterns of behaviour referring to CSR according to the degree of development of the cultural system in each country. For this, we projected the companies in the compromise subspace produced by $\mathrm{X}$ STATIS, separating them into the four levels of development for better viewing (see Fig. 4).

All CSR indicators are located on the right side of the graph, so that companies located more to the right side show greater commitment to sustainability, as this latent axis (horizontal) is a combination of the five CSR indicators; in reference to the vertical axis, companies located in the top of the graph give greater priority to ethical issues ("Eth") and human rights ("HR"), which are strongly interrelated, and those located at the bottom give higher priority to environment ("Env"), employee ("Emp") and stakeholder ("Sth") issues. In regards to the companies (points), there are no different patterns of behaviour between companies for belonging to one typology or another, i.e. companies are positioned in a dispersed manner in any typology, which means that in each typology (different cultural development), we found companies with varying degrees of CSR commitment and approaches. However, we found differences in the degree of CSR evolution of businesses by typology, that is, most of the companies of the fourth typology (higher cultural development) are located on the right side, resulting in a greater commitment to sustainability; most companies of the first typology (less developed) are located on the left side, indicating less commitment. The second and third typology show their companies very dispersed, highlighting a large part of the companies of the second in the fourth quadrant, giving greater importance to their environmental practices. Finally, the circle with the number corresponding to each typology shows the centroid, i.e. the midpoint of companies of each typology, so that companies in the first typology focus their practices on ethical issues, as most parts are located close to the ethics variable ("Eth"); on the contrary, the second typology places more emphasis on environmental, employee and stakeholder practices.

To better appreciate the differences between typologies according to the degree of CSR evolution, we complement this analysis with five graphics of Parallel Coordinates (Inselberg, 1992) corresponding to the five CSR indicators. It is a display system that can represent $\mathrm{n}$ dimensions in a two-dimensional system, in which each vertical axis corresponds to a variable, the years of study in our case, and the horizontal lines represent the joint values of typologies in each year (see Fig. 5).

Companies operating in culturally more developed countries show greater commitment to sustainability in each one of the CSR indices of the study, as we see the fourth typology is the one with the highest values, with the largest difference found in the human rights practices. This order is maintained in "human rights", "stakeholders" and "employees"; in "ethics", the first typology, with the lowest commitment to CSR and being the least developed one, is positioned third in the last year of study, intercalated in the above years with the others; this is because a large part of these companies prioritise ethical issues (see Fig. 4). In "environment", the second typology is positioned second in the last year, interspersed with the others in previous years, mainly because most of these companies prioritise environmental issues (see Fig. 4). Based on these results, we assume that there has been a large increase in CSR during the years 2004-2014.

Applying the HJ-Biplot to data at country level allows us to investigate the typologies. This way, can be approximated in a lowdimensional space, two dimensions, our set of variables, providing a useful visualisation of the structure of the countries of the sample relative to CSR indicators and variables that measure their cultural development. Therefore, we can find relationships between these variables and characterise countries according to their cultural development and commitment to sustainability simultaneously. For a correct implementation of the HJ-biplot are essential several measures, specifically, eigenvalues and explained variance; and to know the variables responsible for the position of axes, the relative contribution of the factor to the element (see Table 4).

The first two axes of the analysis explained $63 \%$ of data variability; we used the factorial plane 1-2 to represent all this information in the following figure (Fig. 6).

The circular flags represent the relative position of each country with respect to the variables; the value obtained by each country is the average of the companies in the period 2004-2014. The interpretation of the variables is based on the angles between vectors, such that the variables that form small angles are variables with similar behaviours (correlated). Among the variables used to measure the cultural development of a country (discontinuous vectors), we highlight "femininity" and "collectivism", which are those that have a relationship with the CSR variables; specifically, we found a strong relationship between "femininity" and "ethics" and "human rights" and a somewhat smaller relationship with the remaining CSR variables. In the case of "collectivism", there was the strongest relationship with "environment", "employees" and "stakeholders" and a small relationship with "human rights" and "ethics". This information means that companies that place greater emphasis on sustainable issues, such as ethics, concern for public good or good governance, are those that operate in countries made up of collectivist citizens and even more so in feminist countries. This is because individuals in these societies emphasise the quality of life in contrast to the search for material benefit of a more individual nature, which translates into the managers of the companies being interested in responding partly to the economic demands and partly to the environmental and social demands of stakeholders, implying greater commitment to sustainability.

On the contrary, the preference for uncertainty or risk, short or long-term orientation and the existence of a greater or lesser power 


\section{Ethics}

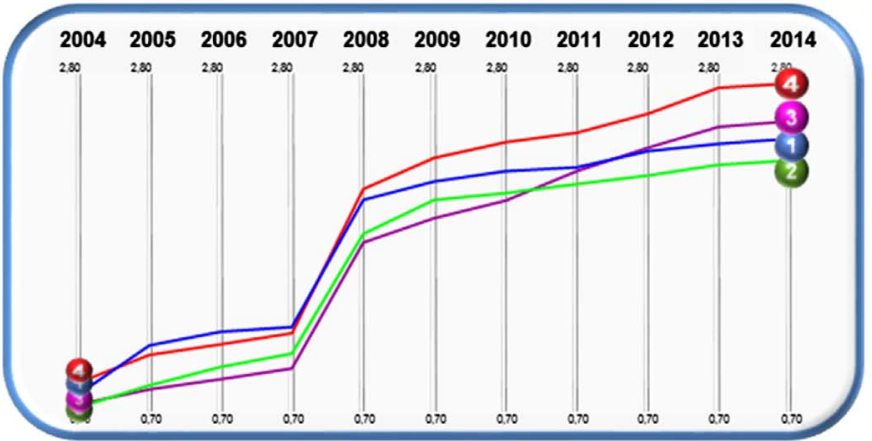

Stakeholders

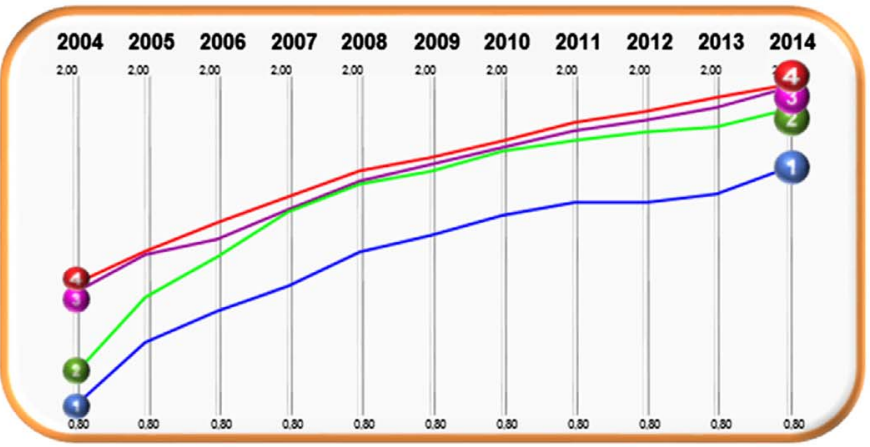

\section{Human Rights}

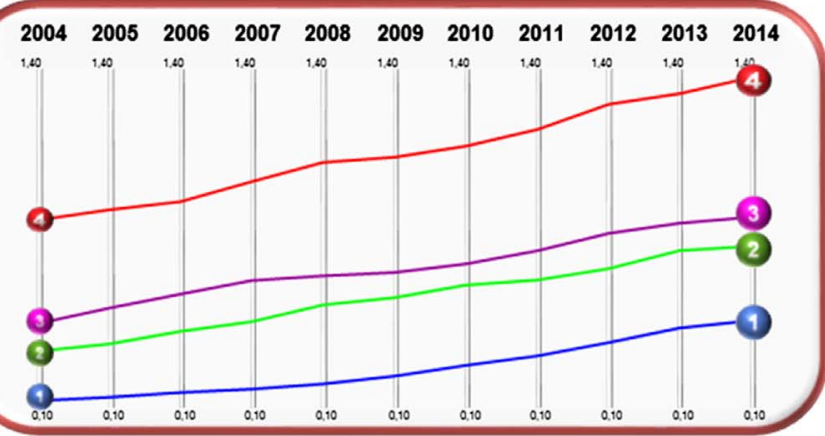

Employees

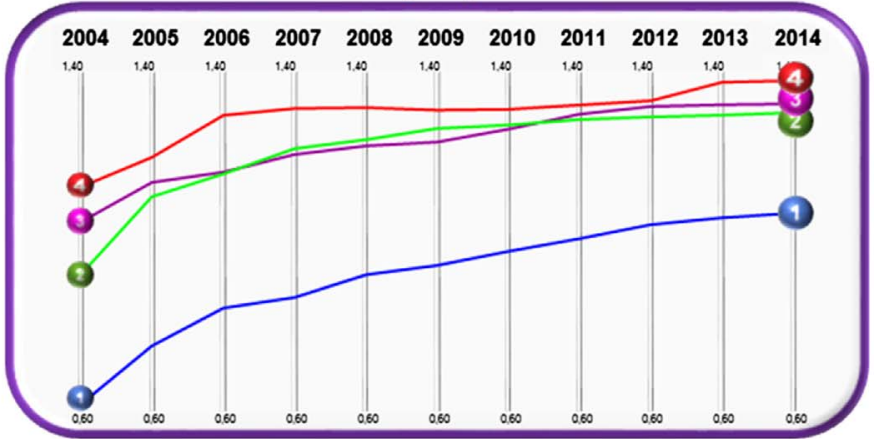

\section{Environment}

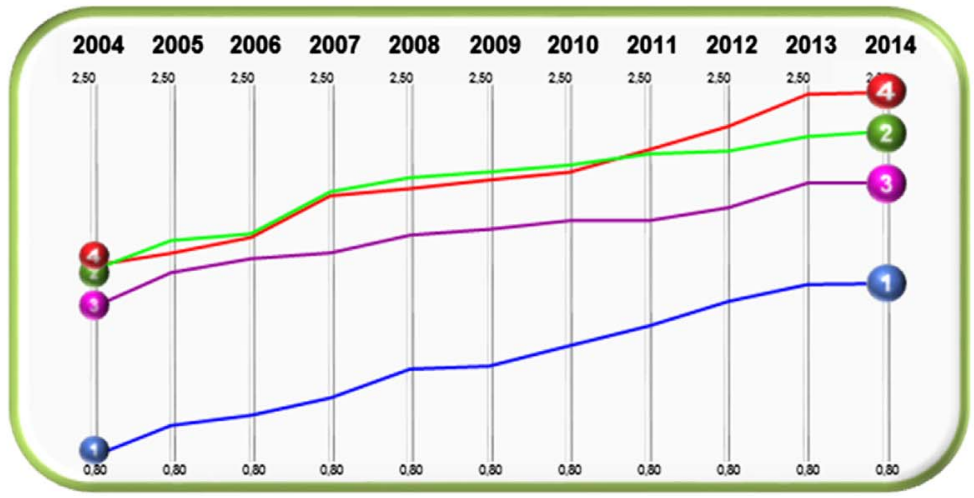

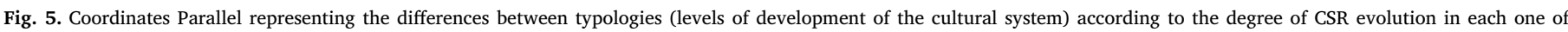
indicators.

Table 4

Relative contribution of the factor to the element.

\begin{tabular}{lll}
\hline Variables & Axis 1 & Axis 2 \\
\hline Uncertainty Tolerance & 217 & 695 \\
Low Power Distance & 112 & 397 \\
Ethics & 107 & 306 \\
Femininity & 188 & 496 \\
Human Rights & 498 & 271 \\
Employees & 824 & 1 \\
Stakeholders & 727 & 2 \\
Environment & 586 & 4 \\
Collectivism & 334 & 221 \\
Long Term & 39 & 271
\end{tabular}

distance are not determining factors, which indicates that power stratification or more or less regulation does not influence the implementation of CSR practices. Previous studies observe that stakeholders in these countries could be more interested in economic issues as opposed to integrated financial and non-financial information
(Garcia-Sanchez et al., 2016).

The countries located near a variable (vector) have predominant values for that variable, so the countries are significant in explaining the variable and the variable is essential for the countries. All the countries obtained good-quality representation or goodness of fit, which was somewhat smaller for Italy, Switzerland and Austria, regarding the variables. In Table 4 it can be seen that the "employees", "stakeholders" and "environment" variables contribute substantially to axis 1 but make a low contribution to axis 2; therefore, the latent horizontal axis is largely explained by these variables that measure the countries' commitment to CSR. The remaining CSR variables, "ethics" and "human rights", are located in the first quadrant, which means that the countries that are located next to the right side of the graph in the first quadrant are those with a greater commitment to sustainability.

Thus, as mentioned in the previous analysis, the fourth typology (Norway, the Netherlands, Finland, Sweden and Denmark) is the one with the highest values of the study. These countries received the highest values in "femininity", which is the variable that exerts the greatest influence on sustainability; however, these countries have low 


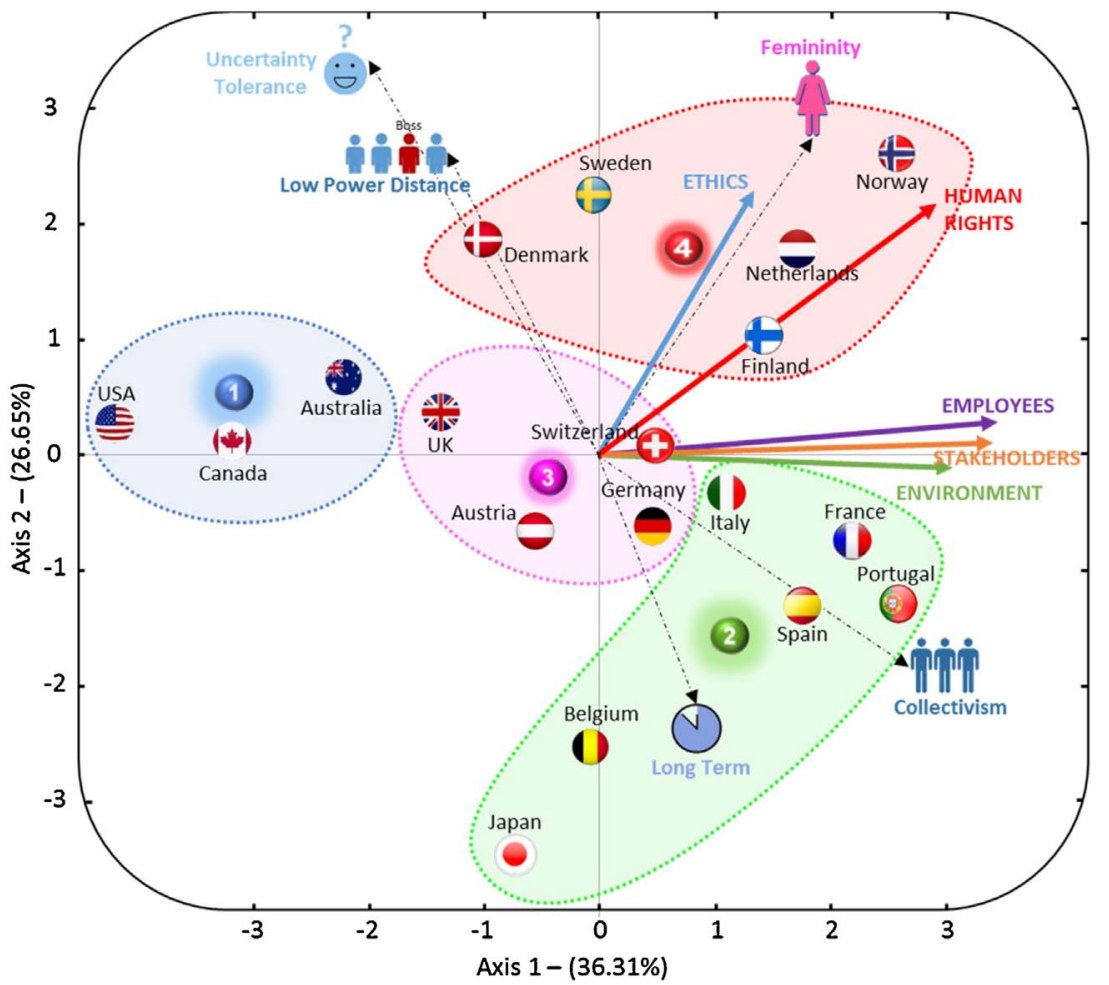

Fig. 6. HJ-biplot factorial plane 1-2 representing all the countries and all variables, regarding to cultural system (discontinuous vectors) and CSR indicators (continuous vectors).

\section{Culture 4}
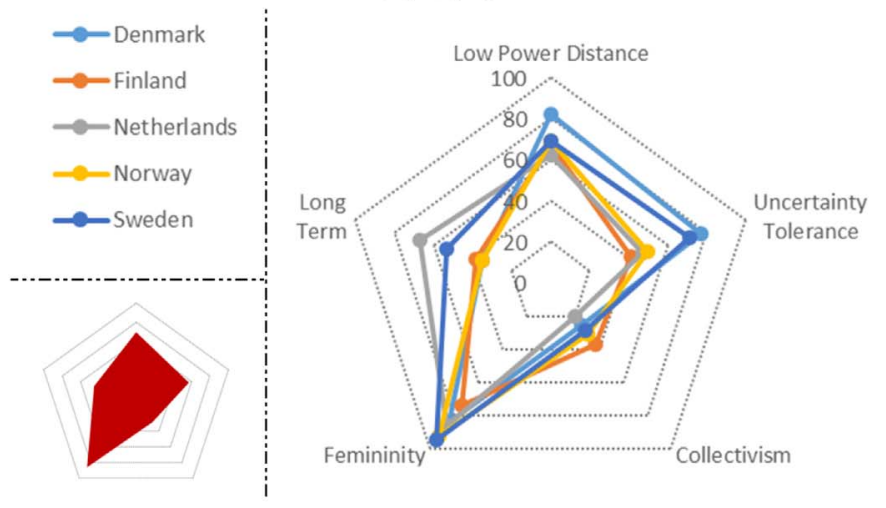

\section{Culture 2}

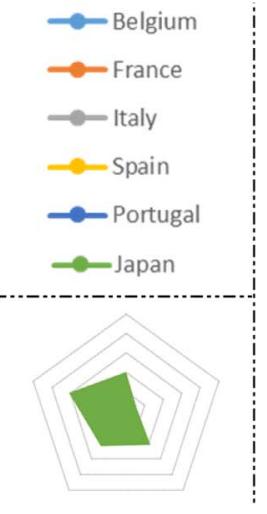

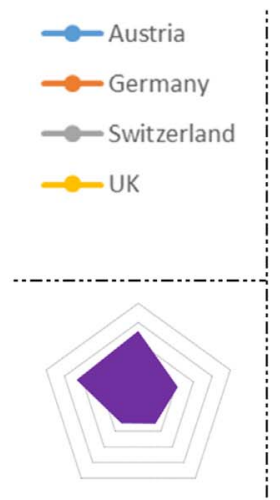

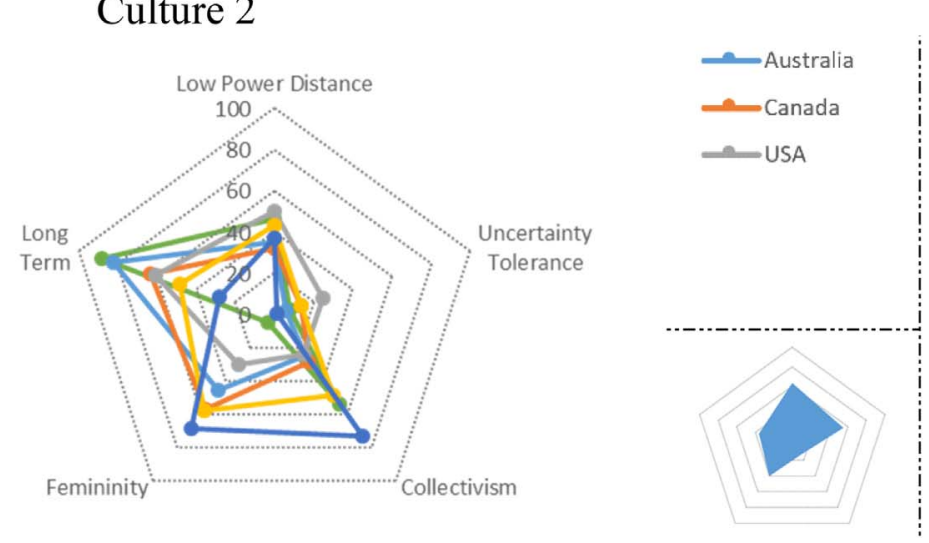

Fig. 7. Typologies Hofstede Dimensions.

\section{Culture 3}

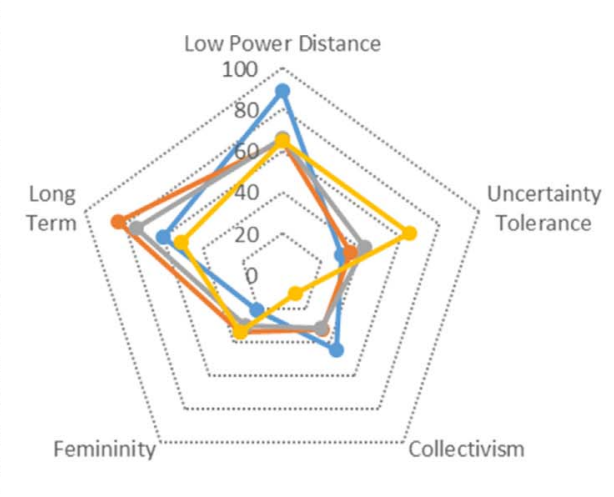

\section{Culture 1}

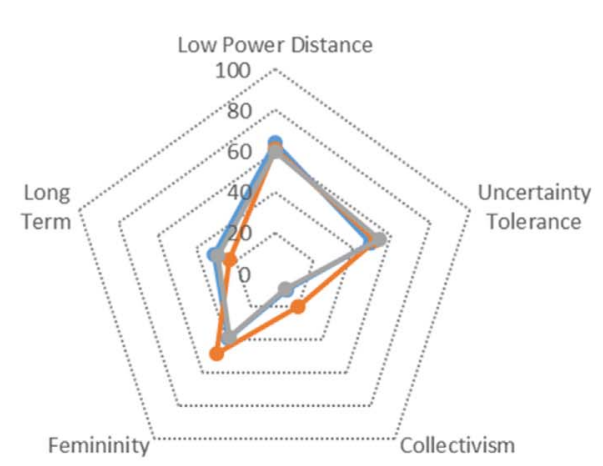


values of collectivism and are characterised by low power distance. These citizens are seen as equals, striving to achieve individual objectives that are not always economic goals. This stands in contrast, for example, to the USA, which ranks first in individualism but scores medium high on power distance, making it a less socially orientated country (Orij, 2010; van der Laan Smith et al., 2005).

The third typology (Switzerland, Germany, Austria and the UK) and the second one (Italy, France, Spain, Portugal, Belgium and Japan) showed very close values in the previous analyses, including the latter being superior in relation to "environment" (see Fig. 5), which is because the cultural value of the five variables is greater in the third typology. However, the second typology obtained somewhat higher values for "femininity" and "collectivism" (see Fig. 7), which are the variables that truly influence the CSR, yet it is driven by the low values of Japan, as Japanese companies are only committed to the environment. This leads us to the same conclusion as Welford (2004), namely that companies respond to what is important in their own countries. For example, the Nordic countries give priority to social policies. In general, our results indicate the existence of greater activity in Northern Europe than Southern Europe; this may be due to the links to the development of the economic system as well as the effect that the historical trend towards a more liberal democracy may have.

Finally, the first typology (Australia, Canada and the USA) presents the lowest values in the CSR study. In the case of Australia, listed companies should disclose the corporate governance practices of the company and explain any deviations from the best practices established by the corporate governance board of the stock exchange, since its regulatory regime is similar to that found in several European countries (Baughn et al., 2007; Kimber and Lipton, 2005). Canada shows greater commitment to sustainability than the USA; however, compared with the main European countries, both seem to lag far behind in this regard (Purdy et al., 2010; Matten and Moon, 2008; Welford, 2004). One of the reasons for European companies being more accepting of government involvement in CSR than companies in the USA is the institutional arrangements emphasising collective action between the state, the civil society and the companies(Aaronson and Reeves, 2002).

Accordingly, the results obtained show that firms adopt homogeneous degrees of CSR commitment to sustainability when operating in countries with similar cultural systems, although the pattern is similar worldwide. This happens because of firms' shared need to meet the same stakeholders' expectations due to the influence of the cultural system, since, when we speak of similar countries, we refer to a congruence of management values, norms and practices derived from their shared culture. These results support the evidence reported by authors such as Garcia-Sanchez et al. (2016), García-Sánchez et al. (2013), Fernandez-Feijoo et al. (2011), Adams and Kuasirikun (2000), Neu et al. (1998), Salter and Niswander (1995) and Langlois and Schlegelmilch (1990), among others, for various types of business reports.

\section{Conclusions}

This paper analyses the role that institutional forces play in the commitment to sustainability, specifically the impact of normative forces, that is, cultural systems at the country level. In general our results indicate that a strong institutional macro context improves CSR practices in the environmental and social dimensions. More specifically, strong cultural systems are associated with an increased commitment to sustainability.

Our central conclusion is that the commitment of sustainability of companies is considerably influenced by cultural dimensions. The analysis of the five Hofstede dimensions in our study partially supports the global evidence. Accordingly, companies that place greater emphasis on sustainable issues, such as ethics, concern for public good or good governance, are those that operate in countries made up of collectivist citizens and even more so in feminist countries, thereby showing the best CSR practices. On the contrary, a preference for uncertainty or risk, short or long-term orientation and the existence of a greater or lesser power distance are not determining factors.

Regarding the countries included in this study, in general greater activity is found in Northern Europe than in Southern Europe. This is in agreement with the findings of Welford (2005), who state that the more developed a country is, the greater the intensity of its CSR practices, in addition to the historical tendency towards a more liberal democracy in the north. Firms respond to what is important in their own countries; for example, the Nordic countries give priority to social policies, while Japanese companies are more committed to the environment. Referring to the countries of North America, Canada shows greater commitment than the USA; however, compared with the main European countries, both seem to lag far behind in this regard. Consequently, the results obtained show that firms adopt homogeneous degrees of CSR commitment to sustainability when operating in countries with similar cultural systems, which is due to the shared need of firms to meet the same stakeholders' expectations due to the influence of the cultural system, since, when we speak of similar countries, we refer to a congruence of management values, norms and practices derived from their shared culture.

This paper contributes to the literature by evaluating several countries, specifically eighteen, instead of following a single-country or two-region approach, in other words by adopting an international approach (Weber, 2014; Hodge et al., 2009; Xiao et al., 2005). By analysing the decade 2004-2014, that is, several years instead of a single year (Hodge et al., 2009; Perego, 2009), our study contributes to updating the time period analysed in previous studies (Tower et al., 2012; Kolk and Perego, 2010; Simnett et al., 2009). Additionally, there is a methodological contribution based on the use of exploratory statistical techniques such as: (i) the X-STATIS that allows to represent the results in a single factorial plane that represents the consensus structure of all years and thus, visualizing the behavioural patterns of companies in relation to their CSR practices, and (ii) through a HJbiplot representation that allows to classify countries according to their CSR practices and their normative characteristics. In this regard, our evidence reports that, worldwide, companies adopt similar patterns of CSR practices, however their degrees of development are strongly determined by the normative institutional characteristics.

This article evidences the existence of a globalized conception of the commitments and practices that are framed under the CSR; it also shows significant differences in the levels of business sustainability development according to the regions and countries of origin of the companies analysed. At this respect, institutional theory and, more specifically, normative isomorphism, show that companies from different countries adopt different levels of CSR practices as a result of the discrepancies in institutional efficiency between countries. In the same way, companies that operate in a common scenario of compromise show similar commitments to CSR.

These findings suggest that they can be useful in identifying those countries that are the most deficient in their CSR business behaviour and in helping them to overcome those deficiencies. With regard to companies, these results will help to provide an understanding of the differential pressures for social and environmental behaviour and the importance of investing in CSR when entering foreign markets or diversifying their business activities. In addition, knowledge of international variations in CSR practices in different institutional contexts will be important for investors, when formulating their expectations about the type and level of business commitment, and for managers, who must keep in mind the existence of these institutional factors to review and adjust their CSR practices with the aim of being accepted as legitimate actors in the different markets. Thus, all these issues should lead managers to consider the impacts of corporate activities on their decision-making processes and guide them towards the promotion of policies that improve sustainable business behaviour.

Future research is necessary to overcome several limitations of this 
study. The use of an international database, although it is one of the contributions of the study, can generate divergence of information, for example due to the existence of different corporate governance systems. The sample was restricted to certain specific countries because of the limited information available in the different databases used. Likewise, it may be interesting for future research to keep track of certain companies individually to identify the progress or changes that may appear in certain years or periods of time.

\section{References}

Aaronson, S.A., Reeves, J., 2002. The European response to public demands for global corporate responsibility. National Policy Association U. S. A.

Adams, C.A., Kuasirikun, N., 2000. A comparative analysis of corporate reporting on ethical issues by UK and German chemical and pharmaceutical companies. Eur. Account. Rev. 9, 53-79. http://dx.doi.org/10.1080/096381800407941.

Adelopo, I., Moure, R.C., Obalola, M., 2013. On the Effects of Legal and Cultural Institutions on Corporate Social Disclosures by Banks. De Montfort University.

Aerts, W., Cormier, D., Magnan, M., 2006. Intra-industry imitation in corporate environmental reporting: an international perspective. J. Account. Public Policy 25, 299-331.

Aguilera, R.V., Rupp, D.E., Williams, C.A., Ganapathi, J., 2007. Putting the S back in corporate social responsibility: a multilevel theory of social change in organizations. Acad. Manage. Rev. 32, 836-863.

Barkemeyer, R., 2007. Legitimacy as a Key Driver and Determinant of CSR in Developing Countries. (Pap. For.).

Baskin, J., 2006. Corporate responsibility in emerging markets. J. Corp. Citizsh. 24, $29-47$.

Baughn, C.C., Bodie (Dusty), N.L., McIntosh, J.C., 2007. Corporate social and environmental responsibility in Asian countries and other geographical regions. Corp. Soc. Responsib. Environ. Manag. 14, 189-205. http://dx.doi.org/10.1002/csr.160.

Boyd, R., Richerson, P.J., 2005. Solving the puzzle of human cooperation. Evol. Cult. $105-132$.

Bustamante, S., 2011. Localization Vs. Standardization: Global Approaches to CSR Management in Mulitinational Companies. Institute of Management.

Carroll, A.B., 1979. A Three-Dimensional Conceptual Model of Corporate Performance. Acad. Manag. Rev. 4, 497-505. http://dx.doi.org/10.5465/AMR.1979.4498296.

Carroll, A.B., 1991. The pyramid of corporate social responsibility: toward the moral management of organizational stakeholders. Bus. Horiz. 34, 39-48.

Chen, S., Bouvain, P., 2009. Is corporate responsibility converging? A comparison of corporate responsibility reporting in the USA, UK, Australia, and Germany. J. Bus. Ethics 87, 299-317. http://dx.doi.org/10.1007/s10551-008-9794-0.

Christie, P.M.J., Kwon, I.-W.G., Stoeberl, P.A., Baumhart, R., 2003. A cross-cultural comparison of ethical attitudes of business managers: India Korea and the United States. J. Bus. Ethics 46, 263-287.

Cormier, D., Magnan, M., Van Velthoven, B., 2005. Environmental disclosure quality in large German companies: economic incentives, public pressures or institutional conditions? Eur. Account. Rev. 14, 3-39.

de Mooij, M., Hofstede, G., 2010. The Hofstede model: applications to global branding and advertising strategy and research. Int. J. Advert. 29, 85. http://dx.doi.org/10. 2501/S026504870920104X.

Dennis Jr, W.J., 2011. Entrepreneurship, small business and public policy levers. J. Small Bus. Manag. 49, 92-106.

Escoufier, Y., 1976. Opérateur associé à un tableau de données. Annales de l'INSEE. JSTORpp. 165-179.

Fernández, J.M.R., 2003. El gobierno de la empresa: un enfoque alternativo. Ediciones AKAL.

Fernandez-Feijoo, B., Romero, S., Ruiz, S., 2011. Information systems for sustainability: hofstede's cultural differences in the perception of a quality measure for sustainability reports. International Conference on ENTERprise Information Systems 54-62 (Springer).

Frías-Aceituno, J.-V., Rodríguez-Ariza, L., González-Bravo, M.-I., 2013. The effect of societal values on local government transparency: applying hofstede's cultural dimmensions. Lex Localis 11, 829 .

Freeman, E.R., 1984. Strategic Management. Pitman, Boston, MA.

Gabriel, K.R., 1971. The biplot graphic display of matrices with application to principal component analysis. Biometrika 58, 453-467.

Galindo, M.P., 1986. Una alternativa de representación simultánea: HJ-Biplot. Qüestiió $10,1$.

García-Sánchez, I.-M., Rodríguez-Ariza, L., Frías-Aceituno, J.-V., 2013. The cultural system and integrated reporting. Int. Bus. Rev. 22, 828-838. http://dx.doi.org/10. 1016/j.ibusrev.2013.01.007.

Garcia-Sanchez, I.-M., Cuadrado-Ballesteros, B., Frias-Aceituno, J.-V., 2016. Impact of the institutional macro context on the voluntary disclosure of CSR information. Long Range Plann. 49, 15-35. http://dx.doi.org/10.1016/j.lrp.2015.02.004.

Gjølberg, M., 2009. Measuring the immeasurable? Scand. J. Manag. 25, 10-22. http://dx. doi.org/10.1016/j.scaman.2008.10.003.

Habisch, A., Jonker, J., Wegner, M., Schmidpeter, R., 2005. Corporate Social Responsibility Across Europe. Springer Science \& Business Media.

Halkos, G., Skouloudis, A., 2016. National CSR and institutional conditions: an exploratory study. J. Clean. Prod. 139, 1150-1156. http://dx.doi.org/10.1016/j. jclepro.2016.07.047.
Hodge, K., Subramaniam, N., Stewart, J., 2009. Assurance of sustainability reports: impact on report users' confidence and perceptions of information credibility. Aust. Account. Rev. 19, 178-194.

Hofstede, G., Hofstede, G.J., 2005. Cultures and Organizations, Software of the Mind: Intercultural Cooperation and Its Importance for Survival. McGraw-Hill, London, New Delhi, New York.

Hofstede, G., 1983. The cultural relativity of organizational practices and theories. J. Int. Bus. Stud. 14, 75-89. http://dx.doi.org/10.1057/palgrave.jibs.8490867.

Hofstede, G., 2001. Cultural Consequences. Sage Publ., Thousand Oaks CA.

Holland, L., Boon Foo, Y., 2003. Differences in environmental reporting practices in the UK and the US: the legal and regulatory context. Br. Account. Rev. 35, 1-18. http:// dx.doi.org/10.1016/S0890-8389(02)00127-0.

Hubbard, G., 2009. Measuring organizational performance: beyond the triple bottom line. Bus. Strategy Environ. 18, 177-191.

Inselberg, A., 1992. The Plane R2 with Coordinate Parallel. Dep. Tel Aviv Univ. Isr. (Comput. Sci. Appl. Math.).

Jackson, G., Apostolakou, A., 2010. Corporate social responsibility in Western Europe: an institutional mirror or substitute? J. Bus Ethics 94, 371-394. http://dx.doi.org/10. 1007/s10551-009-0269-8.

Jaffrenou, P.-A., 1978. Sur l'analyse des familles finies de variables vectorielles: bases algébriques et application à la description statistique.

Jones, B., Nisbet, P., 2011. Shareholder value versus stakeholder values: CSR and financialization in global food firms. Socio-Econ. Rev. 9, 287-314.

Kim, Y., Kim, S.-Y., 2010. The influence of cultural values on perceptions of corporate social responsibility: application of hofstede's dimensions to Korean public relations practitioners. J. Bus. Ethics 91, 485-500. http://dx.doi.org/10.1007/s10551-0090095-z.

Kimber, D., Lipton, P., 2005. Corporate governance and business ethics in the Asia-Pacific region. Bus. Soc. 44, 178-210.

Kolk, A., Perego, P., 2010. Determinants of the adoption of sustainability assurance statements: an international investigation. Bus. Strategy Environ. 19, 182-198.

L'Hermier des Plantes, H., 1976. Structuration des tableauya trois indices de la statistique. Thése de 3eme cycle. Université Montpellier II.

Langlois, C.C., Schlegelmilch, B.B., 1990. Do corporate codes of ethics reflect nationa character? Evidence from Europe and the United States. J. Int. Bus. Stud. 21, 519-539. http://dx.doi.org/10.1057/palgrave.jibs.8490340.

Lattemann, C., Fetscherin, M., Alon, I., Li, S., Schneider, A.-M., 2009. CSR communication intensity in Chinese and Indian multinational companies. Corp. Gov. Int. Rev. 17, 426-442.

Lenssen, G., Gasdparski, W., Rok, B., Lacy, P., Midttun, A., Gautesen, K., Gjølberg, M., 2006. The political economy of CSR in Western Europe. Corp. Gov. Int. J. Bus. Soc. 6 , 369-385.

Lozano, R., 2012. Towards better embedding sustainability into companies' systems: an analysis of voluntary corporate initiatives. J. Clean. Prod. 25, 14-26.

Maignan, I., 2001. Consumers' perceptions of corporate social responsibilities: a crosscultural comparison. J. Bus. Ethics 30, 57-72.

Martínez-Ferrero, J., García-Sánchez, I.-M., 2017. Coercive, normative and mimetic isomorphism as determinants of the voluntary assurance of sustainability reports. Int. Bus. Rev. 26 (1), 102-118.

Matten, D., Crane, A., 2005. Corporate citizenship: toward an extended theoretical conceptualization. Acad. Manage. Rev. 30, 166-179.

Matten, D., Moon, J., 2004. Implicit and Explicit CSR A Conceptual Framework to Understand CSR in Europe. ICCSRpp. 29 (Res. Pap. Ser.).

Matten, D., Moon, J., 2008. Implicit and explicit CSR: a conceptual framework for a comparative understanding of corporate social responsibility. Acad. Manag. Rev. 33 404-424.

Minkov, M., 2007. What Makes Us Different and Similar: A New Interpretation of the World Values Survey and Other Cross-cultural Data. Klasika i Stil Publishing House.

Neu, D., Warsame, H., Pedwell, K., 1998. Managing public impressions: environmental disclosures in annual reports. Account. Organ. Soc. 23, 265-282. http://dx.doi.org/ 10.1016/S0361-3682(97)00008-1.

Orij, R., 2010. Corporate social disclosures in the context of national cultures and stakeholder theory. Account. Audit. Account. J. 23, 868-889. http://dx.doi.org/10. 1108/09513571011080162.

Perego, P., 2009. Causes and consequences of choosing different assurance providers: an international study of sustainability reporting. Int. J. Manag. 26, 412.

Perez-Batres, L.A., Miller, V.V., Pisani, M.J., 2011. Institutionalizing sustainability: an empirical study of corporate registration and commitment to the United Nations global compact guidelines. J. Clean. Prod. 19, 843-851. http://dx.doi.org/10.1016/j. jclepro.2010.06.003.

Purdy, J.M., Alexander, E.A., Neill, S., 2010. The impact of national institutional context on social practices: comparing Finnish and US business communities. Eur. J. Int. Manag. 4, 234-256.

Ringov, D., Zollo, M., 2007. The impact of national culture on corporate social performance. Corp. Gov. Int. J. Bus. Soc. 7, 476-485. http://dx.doi.org/10.1108/ 14720700710820551.

Ruggie, J.G., 2008. Taking embedded liberalism global: the corporate connection. Embed. Glob. Mark. Endur. Chall. 231-238.

Salter, S.B., Niswander, F., 1995. Cultural influence on the development of accounting systems internationally: a test of Gray's [1988] theory. J. Int. Bus. Stud. 26, 379-397.

Scott, W.R., 2001. Institutions and Organizations. Sage.

Simnett, R., Vanstraelen, A., Chua, W.F., 2009. Assurance on sustainability reports: an international comparison. Account. Rev. 84, 937-967. http://dx.doi.org/10.2308/ accr.2009.84.3.937.

Singhapakdi, A., Vitell, S.J., Leelakulthanit, O., 1994. A cross-cultural study of moral philosophies, ethical perceptions and judgements: a comparison of american and thai 
marketers. Int. Mark. Rev. 11, 65-78. http://dx.doi.org/10.1108/

02651339410073015.

Su, S.-H., 2006. Cultural differences in determining the ethical perception and decisionmaking of future accounting professionals: a comparison between accounting students from Taiwan and the United States. J. Am. Acad. Bus. 9, 147-158.

Thelen, K., 1999. Historical institutionalism in comparative politics. Annu. Rev. Polit. Sci. 2, 369-404.

Tower, G., Rusmin, R., others, 2012. Legitimising corporate sustainability reporting throughout the world. Aust. Account. Bus. Finance J. 6, 19.

van der Laan Smith, J., Adhikari, A., Tondkar, R.H., 2005. Exploring differences in social disclosures internationally: a stakeholder perspective. J. Account. Public Policy 24 123-151. http://dx.doi.org/10.1016/j.jaccpubpol.2004.12.007.

Vicente-Villardón, J.L., 2010. MULTBIPLOT: A Package for Multivariate Analysis Using Biplots. Mathlab Softw. Biplot Usal EsClassicalBiplotindex Html.

Vitell, S.J., Paolillo, J.G.P., Thomas, J.L., Philosophy Documentation Center, 2003. The perceived role of ethics and social responsibility: a study of marketing professionals. Bus. Ethics Q. 13, 63-86. http://dx.doi.org/10.5840/beq20031315.

Weber, J.L., 2014. Corporate Social Responsibility Disclosure Level, External Assurance and Cost of Equity Capital. University Of Colorado At Boulder.
Welford, R., 2004. Corporate social responsibility in Europe and Asia: critical elements and best practice. J. Corp. Citizsh. 31 .

Welford, R., 2005. Corporate social responsibility in europe, North America and asia: 2004 survey results. J. Corp. Citizsh. 33.

Williams, G., Zinkin, J., 2008. The effect of culture on consumers' willingness to punish irresponsible corporate behaviour: applying Hofstede's typology to the punishment aspect of corporate social responsibility. Bus. Ethics Eur. Rev. 17, 210-226. http://dx. doi.org/10.1111/j.1467-8608.2008.00532.x.

Windsor, D., 2004. Global corporate social responsibility: international regimes and the constellation of corruption, poverty, and violence. In: In: Hooker, J., Madsen (Eds.), International corporate responsibility: exploring the issues. International

Management series, volume 3. Carnegine Mellon University Press, Pittsburg, pp. 43-67.

Wood, D.J., 2010. Measuring corporate social performance: a review. Int. J. Manag. Rev. $12,50-84$.

Xiao, J.Z., Gao, S.S., Heravi, S., Cheung, Y.C., 2005. The impact of social and economic development on corporate social and environmental disclosure in Hong Kong and the UK. Adv. Int. Account. 18, 219-243. 




\section{Capítulo III}

\section{El Sistema Legal como Factor Explicativo de las Prácticas de Responsabilidad Social Corporativa}

El desarrollo empresarial sostenible hace referencia a las prácticas de las compañías que involucran iniciativas que benefician a la sociedad. La evolución y los patrones de comportamiento con respecto a la RSC varían sustancialmente entre países, por lo que es necesario investigar más a fondo la influencia de la diversidad institucional. Este trabajo enfoca la atención en la dimensión coercitiva del entorno institucional, analizando el impacto que la fortaleza y la eficiencia de los sistemas legales tiene en la adopción y desarrollo de prácticas de RSC.

El isomorfismo coercitivo hace referencia a las reglas, estándares o leyes que determinan el marco legal y / o profesional de las prácticas empresariales, pero también puede identificarse con las presiones que ejercen sobre la empresa los proveedores externos de recursos que fuerzan o limitan a la empresa a adoptar determinados comportamientos. Para su estudio, numerosos investigadores comparan las empresas con sede en países regidos por el derecho común, donde buscan maximizar la riqueza de los accionistas y, empresas en países de derecho civil, donde presentan una estructura de gobierno empresarial más orientada a las partes interesadas. La supervivencia de la empresa depende en gran medida de las relaciones con las partes interesadas; e, independientemente de que estén a favor de la empresa o quieran rescindir su relación para penalizar un comportamiento inadecuado, deben estar informadas no solo del impacto económico sino también del impacto ambiental y el desempeño social de la organización. Por lo tanto, el término transparencia corporativa no debe estancarse en los estados financieros, sino que debe ampliarse a otros temas, como los aspectos ambientales y sociales del comportamiento corporativo, y debe presentarse en una forma integrada. En consecuencia, las normas legales y sociales de diferentes países están relacionadas con la orientación de las partes interesadas, el bienestar de los empleados y el trato de las minorías como una parte importante de las actividades de RSC.

En consecuencia, para cuantificar toda esta información, clasificaremos las empresas en función del derecho que rige su país (0-derecho común, 1-derecho civil); emplearemos una variable numérica nombrada 'Stake law' como una medida de la orientación hacia las partes interesadas, que capta el entorno legal de un país con referencia a la protección de los derechos y beneficios laborales; $y$, por último, utilizaremos 'CSR law' como otra medida de orientación haica las partes interesadas, que captura la existencia de leyes de divulgación relacionadas con la RSC. Esta información es evaluada sobre las compañías listadas más grandes presentes en 18 países con un sesgo geográfico a favor de las empresas que operan en Europa (50.50\%), América del 
Norte (25.83\%), Japón (16.67\%) y Australia (7\%) sobre cinco indicadores sintéticos de RSC medioambiente, derechos humanos, empleados, stakeholders y ética-, y durante la década 20042014, lo que da lugar a unos datos de panel con 6600 observaciones.

Los análisis se realizaron con técnicas estadísticas multivariantes con el fin de conseguir capturar el carácter multidimensional de los datos. A nivel empresa, éstas se codifican en cuatro niveles o tipologías en relación al funcionamiento de su sistema legal para observar su influencia en la RSC. Para ello, se lleva a cabo un análisis X-STATIS de las 600 empresas durante el periodo 2004-2014, calculando la estructura consenso y representando en un único plano factorial la información sintetizada de las 600 empresas sobre sus prácticas de RSC en dicho periodo. Una vez hecho esto, separamos las empresas según el nivel de desarrollo de su sistema legal y buscamos diferencias en los patrones de comportamiento con respecto al compromiso con la sostenibilidad. A nivel país, agrupando las empresas por su país de procedencia y, con la aplicación de un HJ-biplot se describen qué medidas de las empleadas para cuantificar el desarrollo del sistema legal de los países presentan un papel más importante en el desarrollo de prácticas de RSC y específicamente sobre qué indicadores tienen una influencia mayor. Además, es posible observar qué países se ven más o menos afectados por todas estas medidas de manera simultánea, tanto los indicadores de RSC como las medidas del sistema legal.

Los resultados demuestran que las fuerzas coercitivas tienen una influencia importante en el compromiso social y ambiental de las empresas. El análisis del sistema legal muestra que las empresas ubicadas en países regidos por el derecho civil tienen un mayor interés en las prácticas de RSC y la divulgación de información que las empresas en países de derecho común; es más probable que las empresas actúen de una manera socialmente responsable cuando operan en entornos institucionales con un sistema legal grande y desarrollado con orientación hacia la protección de las partes interesadas. En consecuencia, nuestros resultados muestran que las empresas que operan en países con sistemas jurídicos similares adoptan comportamientos homogéneos con respecto al compromiso con la sostenibilidad, pero sus grados de desarrollo están fuertemente determinados por las características institucionales coercitivas.

A continuación, presentamos toda esta información detallada de manera extensa en el artículo de investigación "Analysing the Effect of Legal System on Corporate Social Responsibility (CSR) at the Country Level, from a Multivariate Perspective" actualmente en prensa en la revista Social Indicators Research (2016: Q1 - JIF:1.743; 2017: Q2 - JIF:1.648). 
Research paper in press:

Title: Analysing the Effect of Legal System on Corporate Social Responsibility (CSR) at the Country Level, from a Multivariate Perspective

Authors: Víctor Amor-Esteban

Isabel-María García-Sánchez

Ma-Purificación Galindo-Villardón

Journal: Social Indicators Research, 1-18

\begin{tabular}{c|c|c|c|c} 
Year & Category Name & $\begin{array}{c}\text { Total Journals } \\
\text { in Category }\end{array}$ & $\begin{array}{c}\text { Journal Rank } \\
\text { in Category }\end{array}$ & $\begin{array}{c}\text { Quartile } \\
\text { in Category }\end{array}$ \\
\hline 2016 & Social Sciences, Interdisciplinary & 96 & 15 & Q1 \\
\hline 2017 & Social Sciences, Interdisciplinary & 98 & 27 & Q2
\end{tabular}

* Journal Impact Factor: 2016 - 1.743; 2017 - 1.648; 5 Year Impact Factor: 2.207.

* Publisher: Springer

* Google scholar cites:

\begin{tabular}{l|l} 
APA & $\begin{array}{l}\text { Amor-Esteban, V., García-Sánchez, I. M., \& Galindo-Villardón, M. P. (2017). } \\
\text { Analysing the Effect of Legal System on Corporate Social Responsibility (CSR) at } \\
\text { the Country Level, from a Multivariate Perspective. Social Indicators Research, 1- } \\
18 .\end{array}$ \\
\hline ISO & $\begin{array}{l}\text { AMOR-ESTEBAN, Víctor; GARCÍA-SÁNCHEZ, Isabel-María; GALINDO- } \\
\text { VILLARDÓN, Ma-Purificación. Analysing the Effect of Legal System on Corporate } \\
\text { Social Responsibility (CSR) at the Country Level, from a Multivariate } \\
\text { Perspective. Social Indicators Research, 2017, p. 1-18. }\end{array}$ \\
\hline MLA & $\begin{array}{l}\text { Amor-Esteban, Víctor, Isabel-María García-Sánchez, and Ma-Purificación Galindo- } \\
\text { Villardón. "Analysing the Effect of Legal System on Corporate Social Responsibility } \\
\text { (CSR) at the Country Level, from a Multivariate Perspective." Social Indicators } \\
\text { Research (2017): 1-18. }\end{array}$
\end{tabular}

*The paper is numbered independently and includes pages 89-106 (18) of the global document. 



\title{
Analysing the Effect of Legal System on Corporate Social Responsibility (CSR) at the Country Level, from a Multivariate Perspective
}

\author{
Víctor Amor-Esteban ${ }^{1}$ - Isabel-María García-Sánchez ${ }^{2}$ • \\ Márificación Galindo-Villardón $^{1}$
}

Accepted: 21 October 2017

(C) Springer Science+Business Media B.V. 2017

\begin{abstract}
In this paper, we analyse the effect of coercive isomorphism (legal system) on Corporate Social Responsibility (CSR) at the country level by using the multivariate statistical techniques X-STATIS and HJ-biplot, which allow us to capture the role that these institutional forces play in the evolution and patterns of behaviour regarding the commitment to sustainability. The results evidence that coercive forces have an important influence on the social and environmental commitment of companies. Analysis of the legal system shows that firms located in civil law countries have a greater interest in their CSR practices and in disclosing information than companies in common law countries; the most likely companies to act in a responsible way are those operating in institutional environments with a large and developed legal system oriented towards stakeholder protection. Consequently, our results show that companies operating in countries with similar legal systems adopt homogeneous patterns of behaviour regarding the commitment to sustainability, but their degrees of development are strongly determined by the coercive institutional characteristics.
\end{abstract}

Keywords Corporate Social Responsibility (CSR) - Coercive forces · Commitment to sustainability $\cdot$ X-STATIS $\cdot$ HJ-biplot

Víctor Amor-Esteban

victor_aes@hotmail.com

Isabel-María García-Sánchez

lajefa@usal.es

$M^{\mathrm{a}}$-Purificación Galindo-Villardón

pgalindo@usal.es

1 Department of Statistics, Campus Miguel de Unamuno, C/Alfonso X El Sabio s/n, University of Salamanca, 37007 Salamanca, Spain

2 Department of Business Administration, Campus Miguel de Unamuno, Faculty of Economics, University of Salamanca, 37007 Salamanca, Spain 


\section{Introduction}

Corporate Social Responsibility (CSR) refers to business practices involving initiatives that benefit society. The evolution and patterns of behaviour regarding CSR vary substantially across countries (e.g. Jamali et al. 2009; Hartman et al. 2007), so it is necessary to investigate further the influence of institutional diversity between countries on CSR. The postulates of institutional theory argue that business behaviour is usually homogeneous as a result of the expectations and norms of action that the institutional environments in which companies operate impose on them and that they must necessarily satisfy in order to legitimize and ensure their long-term survival (Campbell 2007; North 1990).

The expectations and rules of behaviour that provoke the business isomorphism come from normative, coercive and mimetic pressures (DiMaggio and Powell 1983). The former are imposed, formally or informally, by supra-business groups and/or derived from the cultural values prevailing in the environment in which the company operates. The rules, standards or laws that determine the legal and/or professional framework of business practices are known as coercive isomorphism (Matten and Moon 2004). Mimetic isomorphism is associated with the imitation of the practices that the most admired and successful companies perform and which, on the one hand, legitimize the company and, on the other hand, reduce the uncertainty in the decision-making processes of companies with a follower role (Matten and Moon 2004).

In relation to this isomorphism, several studies highlight the importance of the "coercive isomorphism" resulting from pressures exerted on organisations both formally and informally by other organisations on which they are dependent, such as the legal regulatory system within which organisations function (DiMaggio and Powell 1983). Accordingly, in the CSR research sphere, one would expect that the weakness or strength of the legal system acts as an influential institutional factor in the demand for CSR development.

The academic interest in CSR evolution, its determinants and consequences has shown an exponential growth in the last decades and there is currently a huge interest in deepening the impact that the institutional environment has on sustainable enterprise engagement (Jackson and Apostolakou 2010; Aguilera et al. 2007). In general, the studies-e.g., Chen and Bouvain (2009), Lattemann et al. (2009), van der Laan Smith et al. (2005), Xiao et al. (2005) and Holland and Boon Foo (2003) — are characterized by facing this challenge in research by comparing a small number of countries or a single CSR dimension-e.g., Aerts et al. (2006), Cormier et al. (2005)—for companies operating in a single sector-e.g., Adelopo et al. (2013) - , which makes it difficult to obtain generalizable results in environments other than those considered.

In order to overcome these limitations, this paper will analyse the social and environmental practices of CSR for a sample of companies operating in different countries and in different sectors. More specifically, in order to obtain more precise results, this paper focuses attention on the coercive dimension of the institutional environment, analysing the impact that the strength and efficiency of legal systems have on the adoption and development of CSR practices, comparing common versus civil law countries and examining the strength of the enforcement mechanism breakdown as a proxy for the strength of the legal system.

Due to the multidimensional characteristics of the data-that is, the study of business CSR practices in the social and environmental dimensions in the decade 2004-2014-we consider the use of exploratory statistical multidimensional techniques as the X-STATIS (Jaffrenou 1978) and HJ-biplot (Galindo 1986) essential to capture this multivariate character. Thereby, (1) the X-STATIS allows us to visualize the behaviour patterns of firms 
in reference to their CSR practices by the construction and plotting in a factorial plane of the compromise matrix - that is, the consensus structure of all years; and (2) the HJ-biplot allows us to classify the companies' origin countries in relation to their CSR practices and their legal system characteristics.

The paper is organized in five sections. In the next section, we describe the effect that coercive pressures exercise on business sustainability according to our institutional theoretical framework. We continue with the description of the sample, models and statistical techniques that we use in order to contrast the hypothesis. In section four, we present the results obtained. Our last section is concluding remarks, in which we establish the main implications of our analysis.

\section{Coercive Isomorphism and Legal Systems}

Coercive isomorphism refers to the norms, laws or external rules that give legitimacy to different practices (Matten and Moon 2004) but can also identify with the pressures on companies' external resource providers that force or limit their adoption of certain behaviours. Since the work of La Porta et al. (1998), researchers have analysed the legal system by comparing civil and common law systems (Adelopo et al. 2013; García-Sánchez et al. 2013; Simnett et al. 2009; Ball et al. 2000). According to these investigators, firms in common law countries aim to maximise shareholder wealth; however, companies in civil law countries present a more stakeholder-oriented corporate governance structure (Ekelenburg 2016). The protection of investors is more important in common law countries, since its main purpose is to raise the prices of shares and dividends (Kolk and Perego 2010; Ball et al. 2000; La Porta et al. 1997). By contrast, economic benefits are not the sole purpose of corporations in civil law countries; companies have social concerns, so other stakeholders, such as those related to social welfare (e.g. society, suppliers, employees) are at least as important as shareholders (Kolk and Perego 2010).

Several authors (Ortas et al. 2015; Kolk and Perego 2010; van der Laan Smith et al. 2005) in a similar context provide evidence that firms from civil law countries (stakeholder orientation) issue more corporate environmental reports with higher quality than companies from common law countries (shareholder orientation), because the companies from civil law countries are more sensitive to stakeholders' needs (Simnett et al. 2009; Ball et al. 2000). These countries enact laws to protect the rights of different stakeholders, like employees; by contrast, common law countries enact laws to protect the shareholders (Lorenzo et al. 2013).

The survival of the company depends to a great extent on the relations with stakeholders. Whether they are in favour of the company or want to withdraw their loan to penalize inadequate behaviour, they must be informed not only of the economic impact but also of the environmental impact and social performance of this corporation (Hess 2008). Therefore, the term corporate transparency should not be left to stagnate in the financial statements but should be expanded to other issues, such as the environmental and social aspects of corporate behaviour (Gray et al. 1987), and it should be presented in an integrated form (Frias-Aceituno et al. 2013).

Consequently, the legal and social norms of different countries are related to stakeholder orientation, the welfare of employees and minorities being an important part of CSR activities. Therefore, we use "Stake Law" as a measure of stakeholder orientation (Dhaliwal et al. 2012), which captures a country's legal environment with reference to the 
protection of labour rights and benefits. The social expectations regarding CSR issues are reflected in a country's laws and regulations on CSR disclosure (Kagan et al. 2003). There are laws that require the issuance of reports on policies and environmental and social activities directed at commercial companies and/or pension funds, corresponding to high expectations regarding the corporate social performance of stakeholders. Thus, we use "CSR Law" as the other stakeholder orientation measure, which captures the existence of CSR-related disclosure laws.

All these arguments lead us to think in the same way as Campbell (2006), who argues that firms operating in institutional settings with a strong and developed legal system, that is, important coercive pressures and regulations oriented towards stakeholders' protection, are most likely to act in a responsible manner and report on their behaviour. GarcíaSánchez et al. (2013), in their analysis of the impact of the legal system on the relevance of the information contained in sustainability reports, show that companies located in civil law countries have a greater interest in the disclosure of information about CSR standards than companies in common law countries; this line of work also contains Ball et al. (2000). Consequently, it can be expected that those companies from civil law countries with an orientation towards stakeholders are more likely to show greater commitment to sustainability.

The specific objective of this paper is to highlight the role that institutional coercive forces have in the development of CSR, considering that companies operating in environments with similar legal and judicial systems adopt homogeneous behaviour patterns with respect to their CSR practices, influencing their evolution.

\section{Research Methods}

\subsection{Population and Sample}

The target population considered in this study corresponds to all listed companies whose economic and financial information is included in the Thomson ONE Analytics database. Subsequently, the information extracted for these companies was our final sample of 6600 observations corresponding to the 600 companies for the period 2004-2014.

The companies selected are the companies that show greater commitment to CSR (Martínez-Ferrero and García-Sánchez 2016), especially in the channelled time period, being considered the most prolific in the development of CSR at the enterprise level (Martínez-Ferrero and García-Sánchez 2016).

In Table 1 it can be seen that the available information allows the use of a balanced panel of the largest listed companies present in 18 countries with a geographical bias in favour of those firms operating in Europe (50.50\%), North America (25.83\%), Japan $(16.67 \%)$ and Australia (7\%).

\subsection{Variables for Analysis}

The information on CSR business practices has been extracted from the EIRIS database. Specifically, CSR will be measured by the aggregation of 26 individually weighted items scored $0-4$, a score that identifies an increasing scale from an inadequate commitment to an exceptional one, identifying at the intermediate scale those weak, moderate or good commitments. 
Table 1 Distribution of companies according to their headquarters countries

\begin{tabular}{llcc}
\hline Countries & & \multicolumn{2}{c}{ Frequency } \\
\cline { 3 - 4 } & & Absolute & Relative (\%) \\
\hline 1 & Australia & 462 & 7.0 \\
2 & Austria & 44 & 0.7 \\
3 & Belgium & 77 & 1.2 \\
4 & Canada & 440 & 6.7 \\
5 & Denmark & 121 & 1.8 \\
6 & Finland & 110 & 1.7 \\
7 & France & 429 & 6.5 \\
8 & Germany & 407 & 6.2 \\
9 & Italy & 143 & 2.2 \\
10 & Japan & 1100 & 16.6 \\
11 & Netherlands & 165 & 2.5 \\
12 & Norway & 66 & 1.0 \\
13 & Portugal & 44 & 0.7 \\
14 & Spain & 165 & 2.5 \\
15 & Sweden & 275 & 4.2 \\
16 & Switzerland & 220 & 3.3 \\
17 & UK & 1067 & 16.1 \\
18 & USA & 1265 & 19.1 \\
& Total & 6600 & 100.0 \\
\hline & & &
\end{tabular}

The 26 items, in order to correct the divergence in business behaviour within the same line of action in terms of sustainability, which may not be observed if the items were analysed in an individualized way, are grouped into five synthetic indicators of CSR associated with the social and environmental dimensions. The social dimension incorporates actions related to human rights, employees, stakeholders and ethics. Table 2 shows the main descriptive statistics of CSR practices and dimensions.

The aggregation of CSR practices into sub-dimensions and dimensions provides greater simplicity in the analysis of results, allowing a more precise determination of the implications that may arise from it (Martínez-Ferrero and García-Sánchez 2016; Garcia-Sanchez et al. 2015).

For coercive forces, to characterise the legal system of the countries in the sample, we used three variables. "Civil Law" is a dummy variable, for which countries governed by civil law receive the value 1 and countries governed by common law receive the value 0 (La Porta et al. 1998). "Stake Law" is a measure of stakeholder orientation, which captures a country's legal environment with reference to protecting labour rights and benefits; it is a numerical variable that presents an average value of the following three indices from Botero et al. (2003) and one index from La Porta et al. (2004): the first measure, employment laws, refers to the protection of employment and labour based on the cost and dismissal procedures, the cost of an increase in the hours worked and alternative contracts of employment; the second, social security laws, is an indication of social security benefits that includes unemployment, sickness, disability, old age and death benefits; the third, collective relations laws, captures the protection of collective relations regarding collective disputes and labour union power; and the fourth, human rights laws, measures the human 
Table 2 Corporate social responsibility performance composition

Mean SD

Social performance

Human rights

$0.98 \quad 0.87$

HR1 Human rights policy

What is the extent of policy addressing human rights

$1.37 \quad 1.11$ issues?

HR2 Human rights systems What is the extent of systems addressing human rights issues?

HR3 Human rights reporting

Does the company report on human rights issues?

Employees

Emp1 Equal opportunities (policy)

Emp2 Equal opportunities (systems)

Emp3 Health and safety systems

Emp4 Trade unions and employee participation

Emp5 Training

Emp6 Job creation and security

How good is the company's policy on equal opportunity

1.940 .96 and diversity issues?

How clear is the evidence of systems and practices to

$1.00 \quad 0.81$

support equal opportunities and diversity?

How clear is the evidence of health \& safety systems?

How clear is the evidence of systems to manage employee relations?

How clear is the evidence of systems to support employee training and development?

How clear is the evidence of systems and practices to advance job creation and security?

Stakeholders

Sth1 Community relations

How clear is the company's commitment to community or charitable work?

Sth2 Customer/supplier relations (policy)

Does the company have policies on maintaining good relations with customers and/or suppliers?

How clear is the evidence of systems to maintain good $\quad \begin{array}{ll}1.47 & 0.93\end{array}$

Community
involvement

Sth4 Responsibility for stakeholders

Sth5 Stakeholder engagement

Sth6 Stakeholder policy relations with customers and/or suppliers?

How many stakeholder issues have been allocated to board members?

What level of engagement with stakeholders is disclosed by the company?

How good are the company's policies towards its stakeholders overall?

Sth7 Stakeholder systems

How good are the company's management systems for

Sth8 Stakeholder reporting stakeholders overall? stakeholder relationships?

Ethics

Does the company have a code of ethics and, if so, how

Eth1 Codes of ethics comprehensive is it?

Eth2 Codes of ethics systems

Eth3 Countering bribery policy

Eth4 Countering bribery systems

Does the company have a system for implementing a code

2.76 of ethics and, if so, how comprehensive is it?

What is the extent of the company's policy for countering bribery?

What is the extent of the company's system for countering $\quad \begin{array}{ll}1.75 & 0.89\end{array}$ bribery? 
Table 2 continued

\begin{tabular}{|c|c|c|c|c|}
\hline & & & Mean & $\mathrm{SD}$ \\
\hline Eth5 & $\begin{array}{l}\text { Countering bribery } \\
\text { reporting }\end{array}$ & $\begin{array}{l}\text { What is the extent of the company's reporting on } \\
\text { countering bribery? }\end{array}$ & 0.87 & 0.64 \\
\hline \multicolumn{5}{|c|}{ Environmental performance } \\
\hline \multicolumn{3}{|c|}{ Environment } & 1.74 & 1.11 \\
\hline Env1 & Environmental policy & $\begin{array}{l}\text { How does EIRIS rate the company's environmental policy } \\
\text { and commitment? }\end{array}$ & 2.25 & 1.29 \\
\hline Env2 & $\begin{array}{r}\text { Environmental } \\
\text { management }\end{array}$ & $\begin{array}{l}\text { How does EIRIS rate the company's environmental } \\
\text { management system? }\end{array}$ & 2.40 & 1.48 \\
\hline Env3 & $\begin{array}{l}\text { Environmental } \\
\text { reporting }\end{array}$ & $\begin{array}{l}\text { How does EIRIS rate the company's environmental } \\
\text { reporting? }\end{array}$ & 1.29 & 1.40 \\
\hline Env4 & $\begin{array}{c}\text { Environmental } \\
\text { performance }\end{array}$ & $\begin{array}{l}\text { What level of improvements in environmental impact can } \\
\text { the company demonstrate? }\end{array}$ & 1.04 & 1.18 \\
\hline
\end{tabular}

rights protection. The average value of these four indices indicates stakeholder orientation, with a higher value presenting greater stakeholder orientation. "CSR Law" is another measure of stakeholder orientation, which captures the existence of CSR-related disclosure laws; it is a categorical variable equalling 1 when the country's mandatory disclosure requirement is only for industrial firms or only for pension funds, 2 if this requirement is for both industrial firms and pension funds and 0 otherwise.

\subsection{Multivariate Analysis}

\subsubsection{The X-STATIS Technique}

The X-STATIS technique (Jaffrenou 1978) is suitable to study three-way data-that is, the CSR practices of 600 companies during the 2004-2014 period. It is a data analysis technique belonging to the STATIS family method (Escoufier 1976; L'Hermier des Plantes 1976) that has been developed to extract the relevant information stored in three-way data tables. It is an exploratory tool that consists of three phases: the interstructure, the compromise and the intrastructure. Focusing on our objectives, we will only apply the first two.

The first phase is the study of the interstructure. As a first step, the structure of $k$ matrices is compared: a matrix of scalar products between the $k$ data tables is constructed so the element in row $k$ and column 1 is $\operatorname{Covv}\left(X_{k}, X_{1}\right)=\operatorname{Tr}\left(X_{k}^{t} D_{n} X_{1} D_{p}\right)$, where $X_{k}$ is the $k$ th table of the sequence and $\mathrm{D}_{\mathrm{n}}$ and $\mathrm{D}_{\mathrm{p}}$ are the two metrics for the rows and columns, respectively. The second phase comprises the construction and analysis of the compromise matrix, which synthesizes and summarizes the common structure of the $k$ matrices, filtering the noise and representing the statistically relevant information. For this construction, a vectorization of each of one of the $k$ matrices is performed-i.e. each matrix is converted into a column vector by a linear transformation: these vectors are stacked on top of one another, construing the matrix $\mathrm{Z}$. A singular value decomposition is applied to this matrix, resulting in the matrix $\mathrm{ZV}$. We pick the first eigenvector of that matrix and through unfolding this vector we construct the compromise matrix. Finally, if we apply a principal components analysis to this matrix, we can plot the averages for the variables and individuals and interpret its structure (Fig. 1). 
For this study, the principal purpose of the X-STATIS analysis is to extract a multivariate structure showing the different years 2004-2014. By the study of interstructure, we can plot the matrix of scalar products between $k$ data tables and, in this way, compare the structure of the $k$ matrices (years), so each data matrix is represented as a point in a lowdimensional Euclidean subspace. Connecting each point with the origin of the coordinates, we obtain an estimation of the correlation between each pair of matrices - thus, a small distance between points and acute angles are associated with high positive correlation, similarity among years, which will indicate that the variables (CSR indicators) maintain their behaviour over time with regard to the individuals (companies) studied. In the second phase, we construct the compromise matrix, which summarizes the structure of the $k$ matrices: this matrix contains the values that synthesise the information that comprise the 11 years of the study pertaining to each company in relation to the CSR indicators. In this way, we can plot that structure and represent the statistically relevant information to visualize the behaviour patterns of firms in reference to their CSR practices.

All the calculations processed in the X-STATIS analysis and in the graphs are performed using the ADE-4 software (Thioulouse et al. 1997).
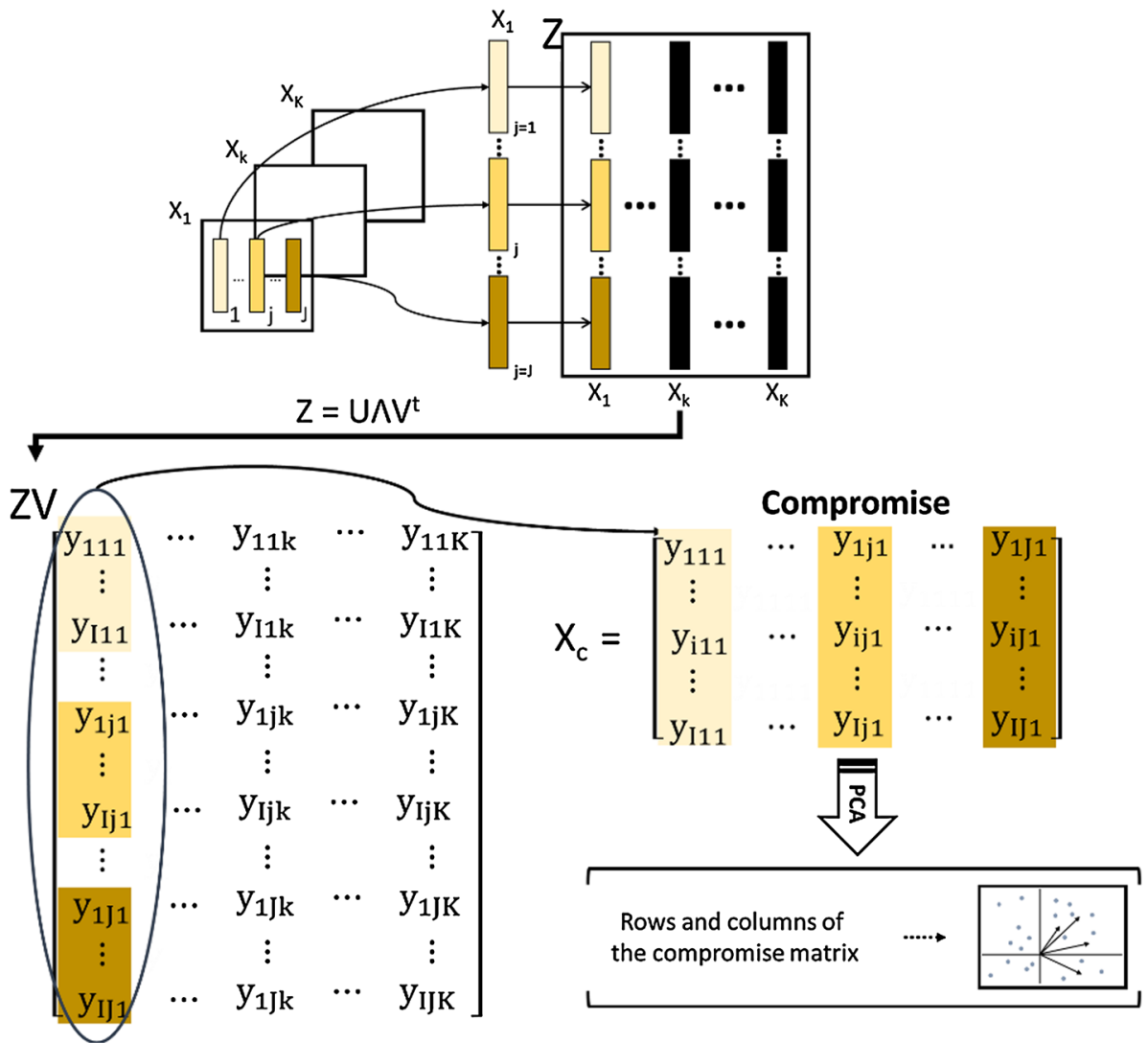

Fig. 1 X-STATIS compromise analysis scheme 


\subsubsection{The HJ-Biplot Technique}

Biplots (Gabriel 1971) are statistical exploratory multidimensional techniques that represent the joint structure of the individuals (headquarters countries of companies) and variables (CSR practices and measures of country legal systems) of a multivariate data matrix X. The HJ-biplot (Galindo 1986) is a representation in a low dimensional space of a matrix $X_{\text {nxp }}$. Let $X=U V^{\mathrm{T}}$ be the usual singular value decomposition (SVD) of $X$ with $U$ and $\mathrm{V}$ orthogonal matrices and $\mathrm{D}=\operatorname{diag}\left(\lambda_{1}, \ldots, \lambda_{\mathrm{p}}\right)$ containing the singular values. Let $\mathrm{J}$ and $\mathrm{H}$ be the matrices of the first two columns of UD and VD, respectively. This method allows, by the suitable selection of markers, $\mathrm{j}_{\mathrm{i}}=\left(\mathrm{j}_{\mathrm{i}}, \ldots, \mathrm{j}_{\mathrm{n}}\right)$ for its rows and $\mathrm{h}_{\mathrm{j}}=\left(\mathrm{h}_{\mathrm{j}}, \ldots, \mathrm{h}_{\mathrm{n}}\right)$ for its columns, to represent simultaneously in the same Euclidean space the rows and columns with the highest quality of representation.

For this study, the principal purpose of the HJ-biplot analysis is to extract and describe the relationships between CSR practices and legal system variables, and classify the headquarters countries of companies according to these. For its interpretation, we have to keep several guidelines going, so row markers (countries) are represented as points and column markers (variables) as vectors. In this way, we can visualize a set of countries with similar behaviours-i.e. interpret the distance between points as similarity, so that countries closer to other countries present similar profiles. To describe the relationships between CSR practices and legal system measures, acute angles between vectors are associated with a high positive correlation. To classify the countries in reference to CSR practices and legal system measures - i.e. by the orthogonal projections of the points (countries) on the vectors (variables) - we can order the different countries in relation to each variable. Note that the countries and variables can only be interpreted correctly with good quality of representation in the subspace observed.

All the processes and representations performed in the HJ-biplot analysis are implemented by the software MultBiplot (Vicente-Villardón 2010).

\section{Results of Empirical Analysis and Discussion}

In this section, the influence or effect of the coercive forces on the environmental and social performance in CSR practices of 600 firms in the decade 2004-2014 is evaluated. As a fist point, we compare the structures of the years by studying the inter-structure of an X-STATIS analysis that provides a graphical estimate of the vector correlation coefficient between years (data tables) (see Fig. 2). By observing the angles formed among vectors (acute angles are associated with positive correlation), we found relationships produced in a gradual manner between the years of study: thus the years present similar structures and we infer a growth in CSR practices in the indicated period. This representation connects with the factorial plane 1-2, accounting for more than $91 \%$ of variability.

The next step comprises the construction and analysis of the compromise matrix, which synthesizes and summarizes the common structure of all the matrices. This matrix contains the company's values in relation to the mentioned variables, synthesized for the 11 years of study. In this way, we plot the structure of this matrix to investigate and compare the behaviour of each company in reference to the rest, capturing the multivariate information of that period, filtering the noise and representing the statistically relevant information. This representation with the first two axes collects approximately $85 \%$ of the variability. All the matrices receive a good quality of representation (Table 3, "Cos ${ }^{2 "}$ column) and 


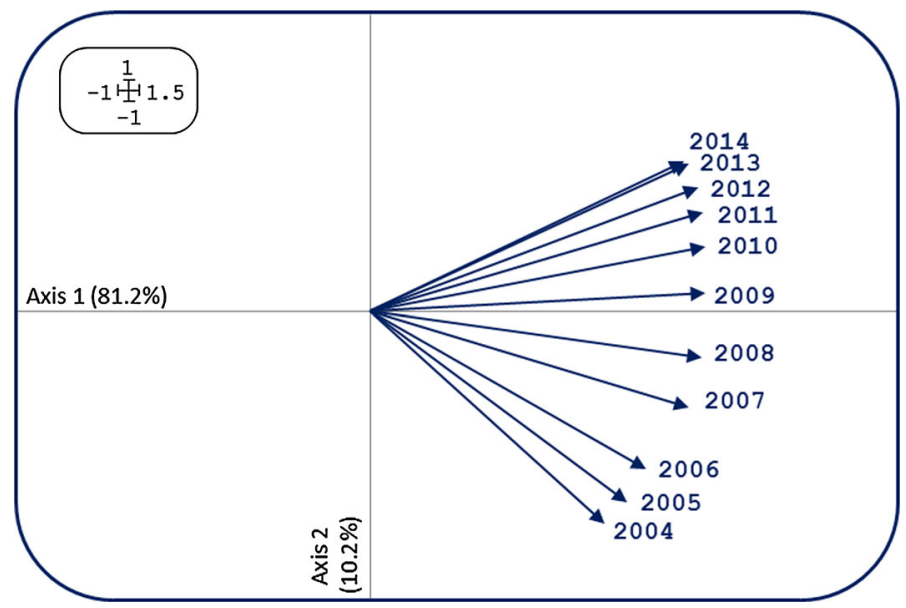

Fig. 2 Graphical estimate of the vector correlation coefficient between years, X-STATIS interstructure analysis

Table 3 Weights of the matrices (years) and their quality of representation on compromise analysis

\begin{tabular}{llllll}
\hline Axis & Weights & $\operatorname{Cos}^{2}$ & Axis & Weights & $\operatorname{Cos}^{2}$ \\
\hline 2004 & $2.30 \mathrm{E}+02$ & 0.523 & 2010 & $3.28 \mathrm{E}+02$ & 0.757 \\
2005 & $2.48 \mathrm{E}+02$ & 0.590 & 2011 & $3.26 \mathrm{E}+02$ & 0.750 \\
2006 & $2.56 \mathrm{E}+02$ & 0.620 & 2012 & $3.21 \mathrm{E}+02$ & 0.736 \\
2007 & $3.16 \mathrm{E}+02$ & 0.695 & 2013 & $3.12 \mathrm{E}+02$ & 0.699 \\
2008 & $3.25 \mathrm{E}+02$ & 0.734 & 2014 & $3.06 \mathrm{E}+02$ & 0.676 \\
2009 & $3.28 \mathrm{E}+02$ & 0.757 & & & \\
\hline
\end{tabular}

obtain similar weights for the construction (Table 3, "Weights" column), somewhat smaller for the first three.

Subsequently, with factorial plane 1-2 of compromise subspace, we present the position of our 600 firms in the decade 2004-2014 in relation to the five variables that measure the CSR practices (see Fig. 3). The firms are scattered throughout the plane, presenting high variability; in addition, the graph shows two dimensions, one related to ethics and human rights in the first quadrant, the other related to stakeholders, employees and environment, located in the fourth quadrant.

To evaluate the effects of coercive forces on the commitment to sustainability, we used the variables "Civil Law", which identifies whether a country is governed by the civil or common law, "Stake Law", where a higher value indicates a greater stakeholder's orientation and "CSR Law", which captures the existence of disclosure laws. According to the literature, these variables promote commitment to sustainability, i.e. it is expected that those countries who obtain high values in these variables show greater commitment. To test this, we created the "Legal" variable, which is the sum of these three variables, thus each country of study receives a value in reference to its legal system and therefore its companies. By using percentiles (25th, 50th and 75th) in this variable, we divided the sample into four typologies according to levels of development of their legal system, the fourth being the most developed. Thereby, we visualized the behavioural patterns of companies with respect to CSR practices according to the degree of development of the 


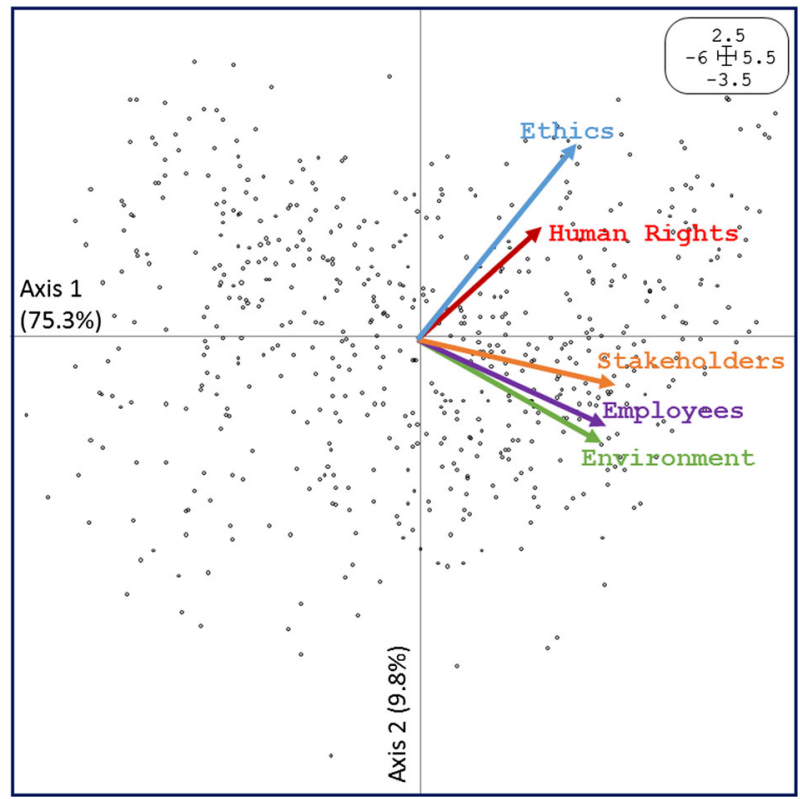

Fig. 3 Factorial plane 1-2 of compromise subspace, representing the position of 600 firms in relation to the five indicators that measure the CSR practices

legal system of their headquarters countries. For that, firms were projected in the subspace generated by a compromise analysis of X-STATIS, partitioning them in the four typologies for a better understanding (see Fig. 4).

The five indicators that measure CSR practices position their vectors to the right, so that firms situated more to the right present a greater CSR commitment. In this way, the horizontal latent axis can be seen as a combination of these indicators. Regarding the vertical latent axis, firms situated in the lower part of the graph give higher preference to stakeholders ("Sth"), employees ("Emp") and the environment ("Env"); on the other hand, those situated in the top part show greater interest in human rights ("HR") and ethical issues ("Eth"). Regarding the companies, we observed high variability, with companies being scattered throughout the graph. We can therefore say that companies worldwide adopt similar CSR commitment, regardless of the legal system that characterizes their country of origin. However, taking into account our legal system classification, we found companies with varying degrees of CSR commitment. More concretely, we

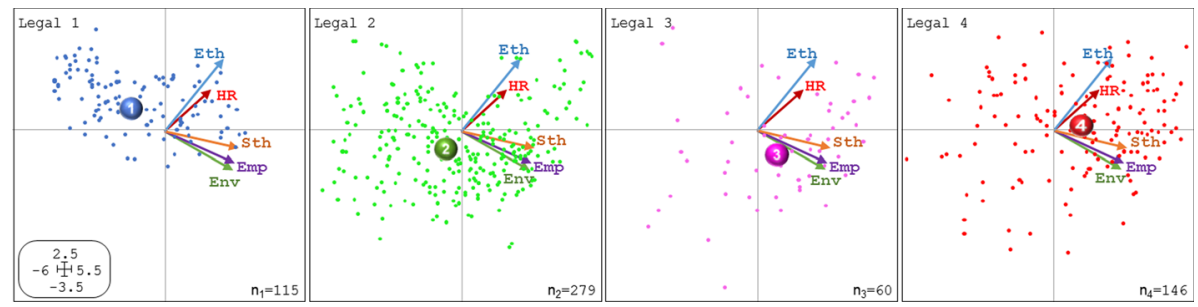

Fig. 4 Factorial plane 1-2 of compromise subspace, divided into four typologies according to levels of development of their legal system 
found differences in the degree of CSR evolution of businesses by typology: specifically, when most of the companies are located in the left or right side of the graph, it can be noted that the fourth and third typologies (which are those with the most developed legal system) have most of their businesses on the right side, indicating greater commitment. We also noted that companies in the first typology were mostly located in the second quadrant, which means that their priorities are ethical and human rights issues, yet their commitment to sustainability appears to be well behind the rest of the typologies. In conclusion, we observe that there is a trend in the centres of the clouds, showing higher average degrees of CSR for companies belonging to countries with advanced legal systems.

With the aim of delving into the differences among typologies regarding the degree of CSR evolution, we applied a parallel coordinates (Inselberg 1992), graph to each of the CSR indicators, being a technique that allows us to visualize k-dimensions in a twodimensional system. So, a point in a k-dimensional space (typologies values on CSR indicators) is transformed into a polygonal line through $\mathrm{k}$ parallel axes (our years of study) (see Fig. 5).

Companies operating in countries with further development of the legal system show a greater commitment to sustainability in each one of the CSR indices of the study, as the higher development typologies (fourth and third) have the highest CSR values. With one notable difference to the remaining ones, both typologies have similar values in all CSR indexes, with the fourth typology being positioned first, except for "Environment", which

Ethics

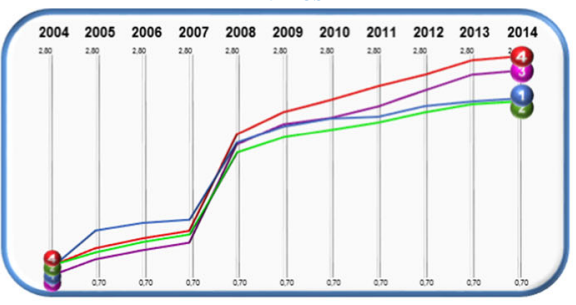

Stakeholders

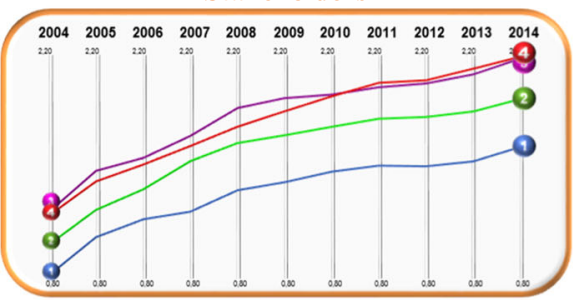

Environment

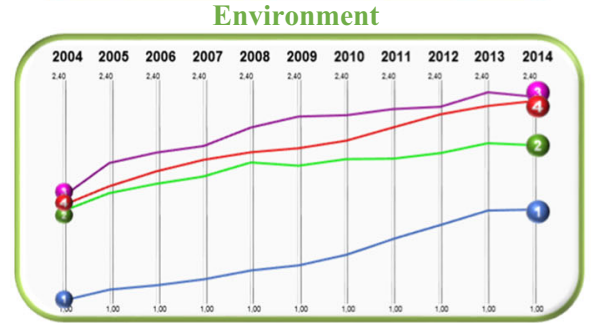

Human Rights

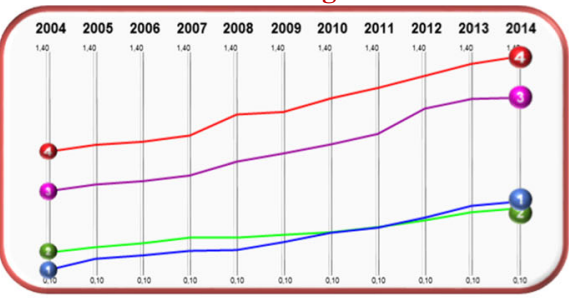

Employees

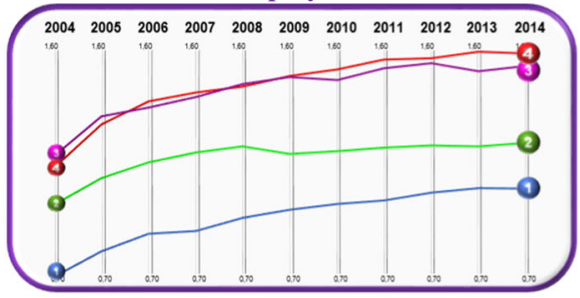

Fig. 5 Coordinates of parallel graphs: evolution of typologies (levels of development of the legal system) in each CSR indicator during the years 2004-2014 
was overtaken by the third. With respect to the typologies of less development, the second typology obtained higher values in "Stakeholders", "Employees" and "Environment" and, similar to the first typology, in "Ethics" and "Human Rights" values, albeit somewhat lower in the recent years of this study, most likely because most companies of the first typology prioritise in ethical and human rights issues (Fig. 4). In short, all companies bet on the same CSR practices (common patterns) but, according to the legal system in the country of origin, show a greater or lesser commitment to them (development degrees). These differences in the development of CSR practices observed between different legal systems are constant over time-i.e. the evolution of CSR patterns differs between legal systems but is common within them in the analysed period.

Subsequently, the application of an HJ-biplot, working with data at country level, allowed us to investigate within the typologies. This method allows us to plot the structure of headquarters countries of companies in relation to our set of variables in a low dimensional space, with the aim of characterizing countries in accordance with their legal system development and commitment to CSR practices simultaneously. For the application of the HJ-biplot in the right way, several quality measures are essential-specifically, eigenvalue and explained variance, and the relative contribution of the factor to the element (see Table 4) which explains the importance of each variable for the position of axes.

The factorial plane 1-2 of this representation collects $69 \%$ of the total information. All of this information is represented in Fig. 6.

The countries are represented by circular flags and their position on the graph is according to the CSR indicators and variables that evaluate the legal system. The value responsible for the position of each one is the average value of firms of each country in the 2004-2014 period in each one of the variables. By observing the angles formed by the variables, those with small acute angles indicate high positive correlation, highlight "Stake Law" and "Civil Law", as they are positively interrelated as well as related with all CSR variables. The strongest relationship was found between "Civil Law" and "Environment"; "Stake Law" was strongly related with the four variables that measure the commitment of companies to social practices ("Ethics", "Human Rights", "Employees", "Stakeholders") and slightly related with "Environment".

In order to analyse the typologies or the countries that form them, it is interesting to know that all of the countries obtained a good quality representation, which was somehow smaller for Denmark and Belgium. Table 4 shows that all variables, except "CSR Law", highly contribute to axis 1 and only slightly to axis 2, somewhat less for the variable "Ethics"; therefore, the horizontal latent axis is largely explained by these variables, so that those countries governed by civil law ("Civil Law") and greater stakeholder

Table 4 Relative contribution of the factor to the element

\begin{tabular}{lcc}
\hline Variables & Axis 1 & Axis 2 \\
\hline CSR Law & 2 & 711 \\
Ethics & 185 & 131 \\
Human rights & 650 & 69 \\
Stake Law & 800 & 40 \\
Employees & 766 & 3 \\
Stakeholders & 589 & 6 \\
Environment & 698 & 89 \\
Civil Law & 658 & 98 \\
\hline
\end{tabular}




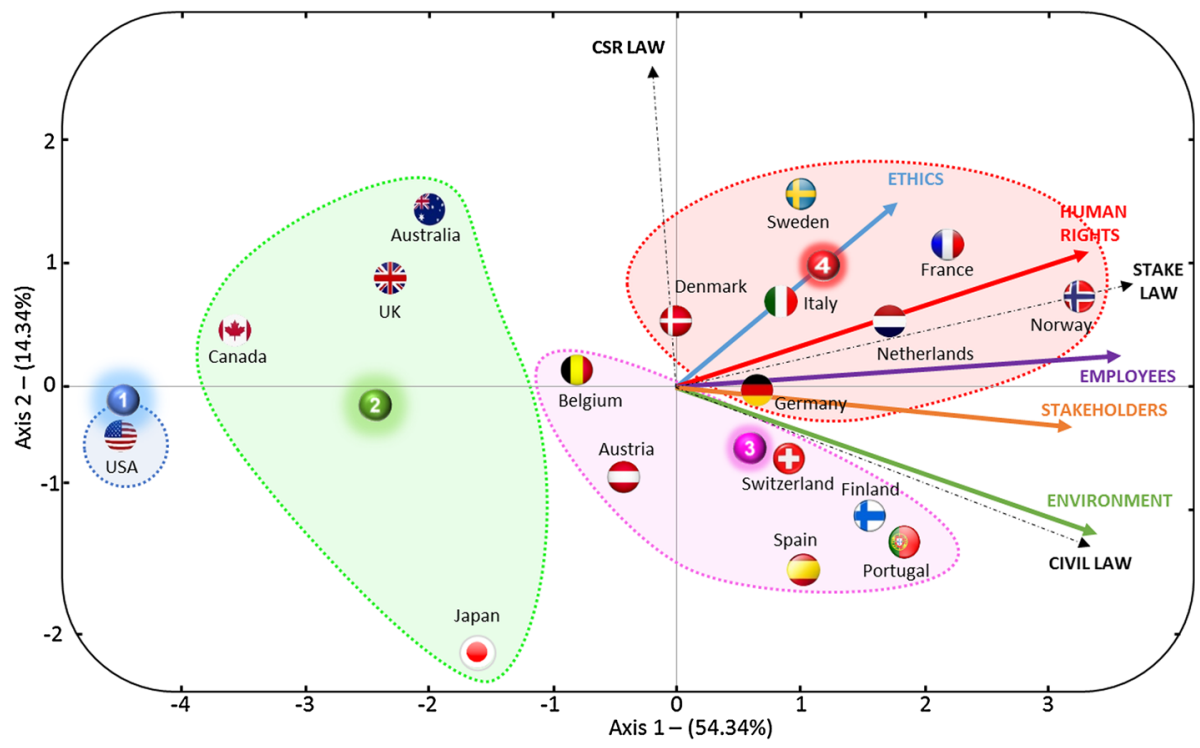

Fig. 6 Factorial plane 1-2 of HJ-biplot showing the position of the 18 headquarters countries of companies in relation to the CSR indicators (continuous vectors) and legal system (discontinuous vectors)

orientation ("Stake Law") are positioned on the right side of the graph. Since these variables are positively related to CSR indicators, these countries show a greater commitment to sustainability, emphasising the social practices in the upper area and giving higher priority to environmental issues in the lower area.

As mentioned in the previous analysis, the fourth and third typologies have very high values in terms of their CSR practices compared with those of the second and first typologies. This is mainly because these typologies are both formed by European countries governed by civil law and greater stakeholder orientation, unlike the other typologies, which are formed by countries governed by common law and greater shareholder orientation, except for Japan. Our results are in agreement with those found by Campbell (2006), who argue that firms operating in institutional settings with a strong and developed legal system, that is, important coercive pressures and regulations with an orientation towards stakeholders' protection, are most likely to act in a responsible manner and report on their behaviour. Similarly, García-Sánchez et al. (2013), in their analysis of the impact of the legal system on the relevance of the information contained in sustainability reports, show that companies operating in civil law countries have a greater interest in disclosing information about CSR standards than companies in common law countries. Several authors (Ortas et al. 2015; Kolk and Perego 2010; van der Laan Smith et al. 2005) in a similar context provide evidence that companies from civil law countries (stakeholder orientation) issue more corporate environmental reports with higher quality than companies from common law countries (shareholder orientation), because the companies from civil law countries are more sensitive to stakeholders' needs (Simnett et al. 2009; Ball et al. 2000). This is in line with the work of Ball et al. (2000), who describes common law countries as countries with shareholder orientation, which are characterised by a further development of laws protecting shareholders (Lorenzo et al. 2013), more dispensed ownership structures and poor government intervention in markets (Adelopo et al. 2013). 
On the contrary, civil law countries, considered as countries with stakeholder orientation (Ball et al. 2000), have a higher concentration of ownership in banks, and financial institutions play a much more important role than in common law countries. Another difference is the high level of protection of the rights of employees in civil law countries (Adelopo et al. 2013; Ferner and Quintanilla 1998). Thus, employers in continental European countries tend to consider employees as part of their strategic strength and resources of the company and are more willing to invest in their training and development (Ferner and Quintanilla 1998).

It is noteworthy that in our study countries with a higher stakeholder orientation, relevant to the fourth typology, show greater commitment to sustainability, emphasising their practices regarding social issues ("Ethics", "Human Rights", "Employees" and "Stakeholders"). The countries that make up the third typology, with somewhat smaller values in their stakeholder orientation than the fourth typology, give higher priority to environmental issues ("Environment"). Accordingly, the results obtained show that firms adopt homogeneous degrees of CSR commitment to sustainability when operating in countries with similar legal systems, although the patterns are similar worldwide.

\section{Conclusions}

This paper focuses on the analysis of the role that the coercive institutional forces that characterize the country of origin of companies play in the development of CSR practices. Specifically, it has been observed that strong coercive institutional contexts assume that the evolution of the commitments that companies have acquired in social and environmental issues evolve isomorphically. However, these characteristics of the institutional environment do not influence the adopted practices, being internationally common among the large listed companies.

Our main conclusion is that coercive forces have an important influence on the social and environmental commitment of companies. An analysis of the legal system shows that firms located in civil law countries have a greater interest in their CSR practices and in disclosing information than companies in common law countries; the most likely ones to act in a responsible way are the companies operating in institutional environments with a large and developed legal system oriented towards stakeholder protection. Consequently, the results show that firms adopt homogeneous degrees of CSR commitment to sustainability when operating in countries with similar legal systems.

Our evidence contributes to previous literature by adopting a multi-country international approach, expanding existing evidence on the comparisons of two countries (Weber 2014; Hodge et al. 2009; Xiao et al. 2005). In addition, our analysis has a multi-period approach, overcoming the disadvantages of cross-sectional analyses that do not allow controlling unobservable heterogeneity (Hodge et al. 2009; Perego 2009). Furthermore, the analysis of the 2004-2014 period contributes to update the results obtained in previous studies (Tower and Rusmin 2012; Kolk and Perego 2010; Simnett et al. 2009). Finally, a more subtle contribution is methodological. The use of exploratory statistical techniques such as the $\mathrm{X}$-STATIS allows us to visualize the behaviour patterns of firms in reference to their CSR practices by the construction and plotting in a factorial plane of the compromise matrix, which represents the consensus structure of all years, while the HJ-biplot allows us to classify the companies' origin countries in relation to their CSR practices and their legal system characteristics. In this sense, our results offer evidence that companies worldwide 
adopt similar patterns of CSR practices but that their degrees of development are strongly determined by the coercive institutional characteristics.

Our results show possible decisions that can be taken at the country level by political leaders and responsible public administrations in order to promote sustainability in the business world. At the corporate level, our evidence allows companies to know the coercive pressures that social and environmental issues can support in those geographic environments which they expect to enter according to their strategy of geographic diversification. Even for companies without internationalization strategies, the results obtained allow managers to specify the actions they undertake in order to legitimize themselves before their stakeholders and the society in which they operate. In addition, knowing the CSR practices of large companies and their temporal evolution facilitates decision-making processes in the securities market by providing information to investors that allows them to formulate their expectations on the level of corporate commitment to CSR.

This paper presents limitations that should be taken into account in future research. The need to consider possible divergences within the institutional environments that have been determined in this study should be noted especially. In this sense, although coercive institutional pressures may be similar, the possible differences caused by the typologies of corporate governance prevailing in each environment and relevant in terms of business sustainability have not been controlled. In this sense, future work should be oriented towards analysis of the interaction between the different characteristics of the macroenvironment.

\section{References}

Adelopo, I., Moure, R. C., \& Obalola, M. (2013). On the effects of legal and cultural institutions on corporate social disclosures by banks. Leicester: De Montfort University.

Aerts, W., Cormier, D., \& Magnan, M. (2006). Intra-industry imitation in corporate environmental reporting: An international perspective. Journal of Accounting and Public Policy, 25, 299-331.

Aguilera, R. V., Rupp, D. E., Williams, C. A., \& Ganapathi, J. (2007). Putting the S back in corporate social responsibility: A multilevel theory of social change in organizations. Academy of Management Review, 32, 836-863.

Ball, R., Kothari, S. P., \& Robin, A. (2000). The effect of international institutional factors on properties of accounting earnings. Journal of Accounting and Economics, 29, 1-51.

Botero, J. C., Djankov, S., La Porta, R., López de Silanes, F., \& Shleifer, A. (2003). The regulation of labor. Pap: NBER Work.

Campbell, J. L. (2006). Institutional analysis and the paradox of corporate social responsibility. American Behavioral Scientist, 49, 925-938. https://doi.org/10.1177/0002764205285172.

Campbell, J. L. (2007). Why would corporations behave in socially responsible ways? An institutional theory of corporate social responsibility. Academy of Management Review, 32, 946-967.

Chen, S., \& Bouvain, P. (2009). Is corporate responsibility converging? A comparison of corporate responsibility reporting in the USA, UK, Australia, and Germany. Journal of Business Ethics, 87, 299-317. https://doi.org/10.1007/s10551-008-9794-0.

Cormier, D., Magnan, M., \& Van Velthoven, B. (2005). Environmental disclosure quality in large German companies: Economic incentives, public pressures or institutional conditions? European Accounting Review, 14, 3-39.

Dhaliwal, D. S., Radhakrishnan, S., Tsang, A., \& Yang, Y. G. (2012). Nonfinancial disclosure and analyst forecast accuracy: International evidence on corporate social responsibility disclosure. The Accounting Review, 87, 723-759.

DiMaggio, P., \& Powell, W. W. (1983). The iron cage revisited: Collective rationality and institutional isomorphism in organizational fields. American Sociological Review, 48, 147-160.

Escoufier, Y. (1976). Opérateur associé à un tableau de données. In Annales de l'INSEE (pp. 165-179). JSTOR. 
Ferner, A., \& Quintanilla, J. (1998). Multinationals, national business systems and HRM: The enduring influence of national identity or a process of “Anglo-Saxonization". International Journal of Human Resource Management, 9, 710-731. https://doi.org/10.1080/095851998340973.

Frias-Aceituno, J. V., Rodriguez-Ariza, L., \& Garcia-Sanchez, I. M. (2013). The role of the board in the dissemination of integrated corporate social reporting. Corporate Social Responsibility and Environmental Management, 20, 219-233.

Gabriel, K. R. (1971). The biplot graphic display of matrices with application to principal component analysis. Biometrika, 58, 453-467.

Galindo, M. P. (1986). Una alternativa de representacion simultanea: HJ-Biplot. Qüestiió 1986 (Vol. 10 Núm 1).

Garcia-Sanchez, I.-M., Cuadrado-Ballesteros, B., \& Frias-Aceituno, J.-V. (2015). Impact of the institutional macro context on the voluntary disclosure of CSR information. Long Range Planning, 30, 1e21.

García-Sánchez, I.-M., Rodríguez-Ariza, L., \& Frías-Aceituno, J.-V. (2013). The cultural system and integrated reporting. International Business Review, 22, 828-838. https://doi.org/10.1016/j.ibusrev. 2013.01.007.

Gray, R., Owen, D., \& Maunders, K. (1987). Corporate social reporting: Accounting and accountability. Upper Saddle River: Prentice-Hall International.

Hartman, L. P., Rubin, R. S., \& Dhanda, K. K. (2007). The communication of corporate social responsibility: United States and European Union multinational corporations. Journal of Business Ethics, 74, 373-389.

Hess, D. (2008). The three pillars of corporate social reporting as new governance regulation: Disclosure, dialogue, and development. Business Ethics Quarterly, 18, 447-482.

Hodge, K., Subramaniam, N., \& Stewart, J. (2009). Assurance of sustainability reports: Impact on report users' confidence and perceptions of information credibility. Australian Accounting Review, 19, $178-194$.

Holland, L., \& Boon Foo, Y. (2003). Differences in environmental reporting practices in the UK and the US: The legal and regulatory context. The British Accounting Review, 35, 1-18. https://doi.org/10.1016/ S0890-8389(02)00127-0.

Inselberg, A. (1992). The plane R2 with coordinate parallel. Computer Science and Applied Mathematics Departments Tel Aviv, University, Israel.

Jackson, G., \& Apostolakou, A. (2010). Corporate social responsibility in Western Europe: An institutional mirror or substitute? Journal of Business Ethics, 94, 371-394. https://doi.org/10.1007/s10551-0090269-8.

Jaffrenou, P.-A. (1978). Sur l'analyse des familles finies de variables vectorielles: Bases algébriques et application à la description statistique. Thèse de Troisième Cycle, Université de Lyon, France.

Jamali, D., Sidani, Y., \& El-Asmar, K. (2009). A three country comparative analysis of managerial CSR perspectives: Insights from Lebanon, Syria and Jordan. The Journal of Business Ethics, 85, 173-192.

Kagan, R. A., Gunningham, N., \& Thornton, D. (2003). Explaining corporate environmental performance: How does regulation matter? Law \& Society Review, 37, 51-90.

Kolk, A., \& Perego, P. (2010). Determinants of the adoption of sustainability assurance statements: An international investigation. Business Strategy and the Environment, 19, 182-198.

L'Hermier des Plantes, H. (1976). Structuration des tableauya trois indices de la statistique. Thése de 3eme cycle, Université Montpellier II.

La Porta, R., Lopez-de-Silanes, F., Pop-Eleches, C., \& Shleifer, A. (2004). Judicial Checks and Balances, 112. Journal of Political Economy, 445, 448-449.

La Porta, R., Lopez-De-Silanes, F., Shleifer, A., \& Vishny, R. W. (1997). Legal determinants of external finance. Journal of Finance, 52, 1131-1150. https://doi.org/10.1111/j.1540-6261.1997.tb02727.x.

La Porta, R., Lopez-de-Silanes, F., Shleifer, A., Vishny, R. W., Levitt, S. D., Andreoni, J., et al. (1998). Law and finance law and finance. J. Polit. Econ., 106, 1113-1155.

Lattemann, C., Fetscherin, M., Alon, I., Li, S., \& Schneider, A.-M. (2009). CSR communication intensity in Chinese and Indian multinational companies. Corporate Governance: An International Review, 17, 426-442.

Lorenzo, J. M. P., Sánchez, I. M. G., \& Zaballos, A. B. (2013). El impacto del sistema cultural en la transparencia corporativa. Revista Europea de Dirección y Economía de la Empresa, 22, 143-154.

Martínez-Ferrero, J., \& García-Sánchez, I.-M. (2016). Coercive, normative and mimetic isomorphism as determinants of the voluntary assurance of sustainability reports. Int: International Business Review. https://doi.org/10.1016/j.ibusrev.2016.05.009.

Matten, D., \& Moon, J. (2004). Implicit and explicit CSR. A conceptual framework to understand CSR in Europe. In ICCSR Research Paper Series (Vol. 29). 
North, D. C. (1990). Institutions, institutional change and economic performance. Cambridge: Cambridge University Press.

Ortas, E., Álvarez, I., Jaussaud, J., \& Garayar, A. (2015). The impact of institutional and social context on corporate environmental, social and governance performance of companies committed to voluntary corporate social responsibility initiatives. Journal of Cleaner Production, 108, 673-684. https://doi. org/10.1016/j.jclepro.2015.06.089.

Perego, P. (2009). Causes and consequences of choosing different assurance providers: An international study of sustainability reporting. International Journal of Management, 26, 412.

Simnett, R., Vanstraelen, A., \& Chua, W. F. (2009). Assurance on sustainability reports: An international comparison. The Accounting Review, 84, 937-967. https://doi.org/10.2308/accr.2009.84.3.937.

Thioulouse, J., Chessel, D., Dole, S., \& Olivier, J.-M. (1997). ADE-4: A multivariate analysis and graphical display software. Statistics and Computing, 7, 75-83.

Tower, G., \& Rusmin, R. (2012). Legitimising corporate sustainability reporting throughout the world. Australasian Accounting Business \& Finance Journal, 6, 19.

van der Laan Smith, J., Adhikari, A., \& Tondkar, R. H. (2005). Exploring differences in social disclosures internationally: A stakeholder perspective. Journal of Accounting and Public Policy, 24, 123-151. https://doi.org/10.1016/j.jaccpubpol.2004.12.007.

van Ekelenburg, M (2016). Determinants of voluntary external assurance on corporate sustainability reports: A comparison between Europe and North America.

Vicente-Villardón, J. L. (2010). MULTBIPLOT: A package for multivariate analysis using biplots. Mathlab Softw. Biplot Usal EsClassicalBiplotindex Html.

Weber, J. L. (2014). Corporate social responsibility disclosure level, external assurance and cost of equity capital. Boulder: University of Colorado at Boulder.

Xiao, J. Z., Gao, S. S., Heravi, S., \& Cheung, Y. C. (2005). The impact of social and economic development on corporate social and environmental disclosure in Hong Kong and the UK. Advances in International Accounting, 18, 219-243. 




\section{Capítulo IV}

\section{Propuesta de Indicador Nacional de Prácticas de Responsabilidad Social Corporativa}

La responsabilidad social corporativa es una estrategia empresarial esencial para garantizar la supervivencia de la empresa. La relevancia que ha adquirido en las últimas décadas ha sido acompañada por un crecimiento exponencial en el número de investigadores interesados en su evolución, determinantes e impactos. Aunque, en general, la RSC proviene de una decisión empresarial voluntaria estrechamente vinculada a la visibilidad de la empresa, la disponibilidad de fondos, etc., numerosos estudios han demostrado el papel que las instituciones públicas a nivel nacional juegan en su adopción y desarrollo.

En este sentido, ha surgido una corriente enfocada en el diseño de indicadores agregados o compuestos que permiten la determinación del nivel de compromiso empresarial con la RSC, para que las autoridades públicas encargadas de la toma de decisiones puedan diseñar políticas adecuadas para promover la sostenibilidad de las empresas como un componente esencial del desarrollo sostenible. En este sentido, el objetivo principal de esta parte de la investigación es el diseño de un indicador compuesto nacional basado en la medición de prácticas de sostenibilidad reales abarcando las diferentes perspectivas del desarrollo sostenible de las empresas medioambiente, derechos humanos, empleados, stakeholders y ética-, y recibe el nombre de National Corporate Social Responsibility Practices Index y el acrónimo NCSRPI (en español, índice nacional de prácticas de responsabilidad social corporativa).

Específicamente, el NCSRPI se constituye de los valores de 1459 empresas con cotización internacional de 29 países diferentes de las economías desarrolladas para el año 2014, en relación a 22 prácticas de RSC que evalúan el compromiso sostenible de cada empresa desde diferentes perspectivas: medioambiente, derechos humanos, empleados, stakeholders y ética. El índice está basado en un proceso metodológico estructurado en torno a siete fases: (i) el desarrollo de un marco teórico sobre el contexto institucional nacional y las dimensiones de la RSC, describiendo la interrelación entre los elementos en el contexto; (ii) la selección de las prácticas de RSC que determinen un alto nivel de calidad según su pertinencia, puntualidad, accesibilidad y consistencia analítica; (iii) la imputación de datos faltantes; (iv) la eliminación de aquellas prácticas que no reducen la calidad del modelo teórico, a partir de métodos estadísticos multivariantes; (v) la estandarización de los datos; (vi) la ponderación de las prácticas que conforman el modelo final; y (vii) la agregación de los valores de las prácticas de RSC usando una suma ponderada para derivar las puntuaciones nacionales de RSC.

El NCSRPI cuantifica y simplifica los datos de RSC y a través de un enfoque macro que va más allá del nivel de la empresa como unidad de análisis proporciona una comprensión global del desarrollo de la RSC considerando las raíces nacionales de la compañía. A su vez, facilita el ranking de países y el desarrollo de procesos de benchmarking asociados a un conjunto de 
componentes relacionados con temas de sostenibilidad social y ambiental, que colectivamente demuestran el estado de compromiso y desarrollo de la RSC y describen el nivel de conducta empresarial responsable entre países. Asimismo, el NCSRPI es útil para comparar el desempeño de RSC en diferentes países al proporcionar una visión internacional de la evolución de la RSC.

Una vez construido, se lleva a cabo una aplicación práctica del índice donde las puntuaciones de los países se estudian de acuerdo con sus características institucionales a partir de la evaluación del sistema legal, la cultura y la efectividad del gobierno. Con el uso de la técnica estadística multivariante HJ-biplot presentamos de una manera visual las relaciones entre el NCSRPI y las medidas de los entornos institucionales que caracterizan a los países. Siguiendo las pautas para su interpretación, este método nos permite conocer qué características del entorno institucional tienen una mayor influencia en las prácticas de RSC, identificar conjuntos de países y zonas geográficas con características institucionales similares y, caracterizar cada país en relación con su entorno y su valor en el NCSRPI simultáneamente.

Los resultados de este estudio tratan de arrojar luz sobre la heterogeneidad de la RSC y concluyen que las discrepancias entre países se deben a la variabilidad de la eficiencia institucional, ya que el entorno institucional en cada país establece para sus empresas una serie de oportunidades y barreras en su decisión de adoptar o mejorar sus prácticas de RSC. De esta forma, consideraremos las discrepancias en las prácticas de RSC en relación a la idoneidad institucional del país de origen de las empresas; por lo tanto, cuanto mayor sea el valor del índice, más apropiado será el entorno del país para las prácticas de RSC. Por lo tanto, las puntuaciones del NCSRPI nos permitirán observar la variación agregada de la RSC explicada por las condiciones institucionales que distinguen la identidad nacional de cada país.

Así, los países nórdicos se presentan como líderes en sostenibilidad empresarial, caracterizados por ser sociedades feministas gobernadas por el derecho civil y por una tendencia histórica hacia una democracia más liberal, donde el poder se distribuye de manera equitativa y se implementan medidas firmes para proteger a los trabajadores y las prestaciones de la seguridad social, además de ser considerados países de alto desarrollo humano y alta indulgencia. En un segundo escalón se posicionan los países del sur de Europa, en parte porque tienen sistemas legales más débiles, pero se distinguen por sus fuertes medidas de protección de las relaciones colectivas y laborales, así como los derechos humanos; también se consideran sociedades feministas y se rigen por el derecho civil. En la zona central nos encontramos a Japón, Canadá y Estados Unidos con puntuaciones próximas a cero. Por último, nos encontramos a Malasia, Singapur y Hong Kong; si bien, estos países tienen un alto nivel de desarrollo, son sociedades colectivistas y tienen una gran tolerancia a la incertidumbre, también presentan las peores prácticas del estudio, esto puede deberse al hecho de que estos países se rigen por el derecho común, tienen democracias imperfectas y una distribución desigual del poder, prestan poca atención a la protección del trabajador y las relaciones colectivas, y no son pro-feministas.

Un indicador agregado de las prácticas de RSC para cada país es una herramienta esencial para los políticos y gerentes públicos en los procesos de toma de decisiones. Específicamente, el NCSRPI brinda información sobre la realidad empresarial, permitiendo la observación del progreso económico, social y ambiental de cada país, facilitando la proyección a medio y largo plazo. La disponibilidad de estos datos permite la identificación de los impulsores estructurales de crecimiento y el establecimiento de prioridades que permitan el diseño de políticas más efectivas para el desarrollo sostenible de la empresa.

Por otro lado, la información ofrecida permite realizar un análisis de benchmarking de desempeño económico, ambiental y social en diferentes países, favoreciendo procesos que buscan descubrir las acciones que conducen a un mayor compromiso con la RSC. Estos análisis pueden ser utilizados, además de por políticos y líderes empresariales, por gerentes de empresas en sus propias decisiones estratégicas sobre RSC y para comprender las presiones existentes sobre los compromisos sociales y ambientales de esos mercados extranjeros en los que deciden diversificar sus actividades empresariales.

A continuación, presentamos toda esta información detallada de manera extensa en el artículo de investigación "A multivariate proposal for a National Corporate Social Responsibility Practices Index (NCSRPI) for international settings" sometido a $2^{\text {a }}$ revisión en la revista Social Indicators Research (2016: Q1 - JIF:1.743; 2017: Q2 - JIF:1.648). 


\section{Research paper submitted to 2 nd revision:}

Title: A multivariate proposal for a National Corporate Social Responsibility Practices Index (NCSRPI) for international settings

Authors: Víctor Amor-Esteban

Ma-Purificación Galindo-Villardón

Isabel-María García-Sánchez

Journal: Social Indicators Research

\begin{tabular}{c|c|c|c|c} 
Year & Category Name & $\begin{array}{c}\text { Total Journals } \\
\text { in Category }\end{array}$ & $\begin{array}{c}\text { Journal Rank } \\
\text { in Category }\end{array}$ & $\begin{array}{c}\text { Quartile } \\
\text { in Category }\end{array}$ \\
\hline 2016 & Social Sciences, Interdisciplinary & 96 & 15 & Q1 \\
\hline 2017 & Social Sciences, Interdisciplinary & 98 & 27 & Q2
\end{tabular}

* Journal Impact Factor: 2016 - 1.743; 2017 - 1.648; 5 Year Impact Factor: 2.207.

* Publisher: Springer

* Google scholar cites: 



\title{
A multivariate proposal for a National Corporate Social Responsibility Practices Index (NCSRPI) for international settings
}

\begin{abstract}
This paper proposes a National Corporate Social Responsibility Practices Index (NCSRPI) that determines the level of penetration of corporate social responsibility (CSR) in 29 different countries, considering each nation as a set of institutional factors. The NCSRPI is built through a statistical aggregation process of $22 \mathrm{CSR}$ practices categorized into the social and environmental dimensions that are individually observed for each company. The composite indicator summarizes and synthesizes the entire business reality at the country level, providing pertinent information to evaluate factors related to CSR performance and a vision of national commitment to company sustainability. The results provided by the NCSRPI show that companies around the world adopt similar patterns of behaviour in relation to their CSR practices, but with different levels of evolution. Thus, European countries present themselves as the leaders in issues of social responsibility, the countries of America give preference to ethical issues, and countries belonging to the Asian continent, specifically to Southeast Asia, are shown to be the most laggardly in this regard. In conclusion, the institutional environment in each country establishes for firms a series of opportunities and barriers in their decision to adopt or improve their CSR practices.
\end{abstract}

Keywords: corporate social responsibility (CSR); national CSR; sustainable development; environmental management; social sustainability; composite index.

\section{Introduction}

Corporate Social Responsibility (CSR) is an essential business strategy to ensure the survival of companies. The relevance it has acquired in recent decades has been accompanied by an exponential growth in the number of researchers interested in its evolution, determinants and impacts (Wood, 2010). Although, in general, CSR comes from a voluntary business decision closely linked to the visibility of the company, the availability of funds, etc., numerous studies have shown the role that public institutions at the national level play in its adoption and development (Amor-Esteban et al., 2017; Demirbag et al., 2017).

In this sense, a current has emerged focused on the design of aggregate or composite indicators that allow the determination of the level of business commitment to CSR - Lenssen et al. (2006), Gjølberg (2009), Halkos and Skouloudis (2016) and Skouloudis et al. (2016) - so that the decision-making public authorities can design adequate policies to promote company sustainability ${ }^{1}$ as an essential component of sustainable development. Specifically, these authors have developed a national CSR index known as the National Corporate Social Responsibility Index. These indices are based on national data about underwriting, participation, or inclusion in different international CSR initiatives, such as the Global 100 Most Sustainable Corporations, Global Compact, or Global Reporting Initiative, among others.

These aggregate indices have a limitation linked to the data that is incorporated in each of the individual indicators. For example, these indicators reflect the number of companies in each country that have an ISO 14000 certification, disclose according to the GRI, etc. However, these indices do not control for whether the companies included in each item meet the necessary criteria of the other items analysed. Therefore, the information they provide is based on an individualised approach to specific CSR practices adopted by different companies, not allowing observation of the global commitment that each company has to CSR.

In this sense, the main goal of this research is the design of a national composite indicator based on the measurement of real sustainability practices for a sample of companies from different countries, whose data are available in the Ethical Investment Research Services (EIRIS) database,

\footnotetext{
${ }^{1}$ We use the terms "sustainable business behaviour", "company sustainability" and "CSR practices" interchangeably throughout the paper
} 
evaluating on a scale from 0 to 4 the sustainable commitment of each company; this will be known as the National Corporate Social Responsibility Practices Index (NCSRPI).

Specifically, the NCSRPI will be formed from the values of 1459 internationally listed companies from 29 different countries of developed economies for the year 2014, regarding 22 CSR practices that assess the sustainable commitment of each company from different perspectives - environment, human rights, employees, stakeholders, and ethics - based on a methodological process structured around seven phases (Nardo et al., 2005; OECD, 2008; Dobbie and Dail, 2013) These phases comprise: (i) the development of a theoretical framework for the national institutional context; (ii) the selection of CSR practices that determine a high level of quality according to their relevance, timeliness, accessibility, and analytical consistency; (iii) the imputation of missing data; (iv) the elimination of those practices that reduce the quality of the theoretical model; (v) the standardisation of the data; (vi) the weighting of the practices that make up the final index; and (vii) the aggregation of the CSR practices' scores using a weighted sum to derive national CSR scores.

The NCSRPI provides an overview of CSR practices around the world and presents a ranking of countries based on the development of CSR practices by their companies. Likewise, a practical application of the index will be carried out and the scores of the countries will be studied according to their institutional characteristics and by evaluating the legal system, the culture and the effectiveness of the government. In this way, we will consider the discrepancies in CSR practices in relation to the institutional suitability of the country of origin of the companies; therefore, the higher the score of the index, the more appropriate the country's environment for CSR practices. Thus, the NCSRPI scores will allow us to observe the aggregate variation of CSR explained by the institutional conditions that distinguish the national identity of each country.

Comparative studies which address CSR have found substantial differences in CSR practices between countries, systematically explained by coercive pressures emanating from standards, laws or rules that determine the professional and legal systems for the development of practices (Amor-Esteban et al., 2017; Demirbag et al., 2017), and normative, stemming from formal and informal pressures exerted by supraorganisations or imposed by the cultural values of the business environment (García-Sánchez et al., 2013; Esteban et al., 2017; Gallego-Álvarez and Ortas, 2017). Thus, institutional theory shows that firms from different countries, as a result of discrepancies in institutional efficiency, adopt different levels of CSR practices and, more specifically, that a strong macro institutional context improves CSR practices in the social and environmental dimensions. Likewise, firms show similar commitments when operating in a common scenario (Colwell and Joshi, 2013; Duran and Bajo, 2014; Mar Miras-Rodríguez et al., 2015; García-Sánchez et al., 2016; García-Sánchez and García-Meca, 2017).

In this paper, the institutional pressures that exist in each national context are determined with reference to the country of origin's legal system, the culture and the government's effectiveness. The results obtained confirm the relationships observed in previous studies, guaranteeing the relevance of the NCSRPI to decision-making processes at a macroeconomic level.

\section{Theoretical Background}

Concern to preserve the environment, and respect for human and social rights, has grown exponentially over the last decades, with particular attention to the commitment made by the private sector (Ruggie, 2008). This corporate commitment, termed corporate social responsibility (CSR), began in the United States (Carroll, 1999) and gained ground in the last decade of the twentieth century and the beginning of the twenty-first (Barnea and Rubin, 2010), denoting concrete and identifiable practices such as certification systems, information standards, and investment criteria, among others (Gjølberg, 2009). Currently, CSR is actively promoted by institutions such as the United Nations (UN), the Organization for Economic Co-operation and Development (OECD), and the World Bank, with the aim of generating a collective idea of sustainable practices and a set of shared experiences, where it is possible to affirm that, for Western society today, good ethics are good business (Van Beurden and Gössling, 2008). 
Despite the existence of a globalised conception of practices and commitments that come under the umbrella of CSR, levels of company sustainability present significant differences according to their countries and regions of origin, as many researchers have revealed. In this sense, institutional theory predicts that companies from different countries adopt different CSR practices and priorities (Welford, 2004, 2005) as a consequence of discrepancies in institutional efficiency between countries (Halkos and Skouloudis, 2016), explained differently by the legal, social, economic, cultural, legal, and political contexts (Ortas et al., 2015). In this sense, the obligation to study the influence of institutional conditions on responsible corporate behaviour seems unquestionable (Aguilera et al., 2007; Jackson and Apostolakou, 2010).

Matten and Moon (2004), Habisch et al. (2005), Campbell (2006) and Lenssen et al. (2006) were the first authors to theorize about the relationship between CSR and national contexts. Empirically, Matten and Moon (2008) and Jackson and Apostolakou (2010) argue that, in AngloSaxon countries, firms tend to engage more explicitly in voluntary CSR practices, while those from coordinated market economies fostered their CSR practices by formal institutions. Baskin (2006) and Jamali et al. (2009) support the institutional interaction between civil society activism, private sector discretionary activities, and state policies in configuring CSR penetration among national contexts. Witt and Redding (2011) observe that the conceptualization of CSR and the focus of stakeholder groups differ among top executives from different institutional settings. Florini and Saleem (2011) and Grauel and Gotthardt (2016) show that activities related to climate change differ widely among countries according to their political systems, as well as legal regulation and origin, and point out that France, Spain, and Japan, which contain the majority of companies committed to the United Nations Global Compact (UNGC), have very contrasting institutional features (Masahiko, 1988), with diverse judicial and legal traditions (Amann et al., 2007). Other documents have identified the importance of institutions to explain specific aspects of CSR, such as human resource management (Edelman and Suchman, 1997), environmental performance (Bansal and Roth, 2000), community relations (Guthrie and McQuarrie, 2004; Chen and Bouvain, 2009; García-Sánchez et al., 2016), or the quality of the CSR reports (Kolk and Perego, 2010; Frías-Aceituno et al., 2013; García-Sánchez et al., 2013, 2016).

On the other hand, based on institutional theory, firms in the same country are more likely to present similar CSR practices, since they have similar priorities. However, either in the presence of legal norms or beliefs in which firms carry out their CSR activities, the different institutional contexts of countries show different expectations at the corporation level regarding commitment to sustainability; in addition, mimetic convergence causes existing firms to mimic the CSR practices of their counterparts (Ortas et al., 2015). In other words, companies operating in a common commitment scenario show the same commitments to CSR.

In this sense, Welford (2004) points out that firms concern to what is most relevant in their own countries: so, in Norway, companies are more likely to light on social policies; in Singapore, companies emphasize the external aspects of CSR; and in Hong Kong, companies focus on internal CSR. Maignan and Ralston (2002) find that US companies focus on philanthropic CSR and codes of ethics in a broader way than continental European companies, but US firms present a lower compromise on environmental issues. Aaronson (2003) points out that the United States and Britain adopt different approaches to CSR despite having similar political and business cultures; this can be due to the fact that British corporations have made national and global CSR a priority and it is therefore expected that these organizations will offer more extensive disclosures than US companies, and with better coordinated information. Ariztía et al. (2014) indicate that Brazil and Chile have increasingly activities of ethical consumption being these old developing countries.

The results of these studies have led several authors-i.e., Lenssen et al. (2006), Gjølberg (2009), Halkos and Skouloudis (2016) and Skouloudis et al. (2016) — to adopt a new approach, analysing the effect that the institutional context has on CSR penetration by creating a national CSR index that allows observation of the aggregate CSR variation explained by the link of institutional conditions that distinguish the national identity of each country. The National Corporate Social Responsibility Index avoids major problems associated with the lack of comparative data and analysis that systematically link CSR with national political-economic contexts. 
Lenssen et al. (2006) developed a measure of CSR engagement by correlating the national economic and political institutions with resulting of CSR models, based on a set of items grouped into four categories. In this vein, Gjølberg (2009) based on nine leading and global CSR initiatives and twenty countries builds a national indicator and observes that national differences is determined also by non-ethical factors, such as the degree to which businesses are socially integrated in society and susceptible to public scorn, in relation at CSR success. Skouloudis et al. (2016) expand the Gjølberg index to assess national CSR and observe a large variation across countries, where most of them are presenting as laggard countries in relation of global CSR initiatives, which is translate as a poor CSR penetration.

Halkos and Skouloudis (2016) show that is necessary in-depth studies the influence of the institutional conditions in CSR, such as wide qualitative analyses to explain regional discrepancies on groups of countries, or using refined statistical techniques of CSR penetration. Furthermore, evaluating the influence of informal institutions on CSR, such as religious beliefs and cultural traits, will help us to understand the nexus between socially responsible business behaviour and national institutions.

These papers present several limitations associated with the theoretical and methodological conception in the creation of a national CSR index. Specifically, these indicators are based on national data on underwriting, participation, or inclusion in different international CSR initiatives, best-in-class indices, social and environmental standards, and ethical investment indices (see Table 1). Each of these 'components' is computed by the number of companies ratifying the specific CSR 'variable'. Its addition creates global CSR engagement rankings or indicators that do not accurately measure the level of CSR practices in each company.

In order to correct these limitations, this paper proposes a National Corporate Social Responsibility Practices Index (NCSRPI) which determines the level of CSR penetration. This index is formed by the measurement of 22 CSR practices which evaluate the sustainability of the company in a more precise way to the inclusion or not in international initiatives, because it is possible to know the level of commitment of the company in each practice on a scale of $0-4$ ( $0=$ inadequate to $4=$ exceptional). These practices are distributed across the five most important issues in sustainability terms: the protection of the environment, the preservation of human rights, internal relations (i.e., everything related to employees), external relations or compliance with stakeholder pressures, and business ethics. Through a methodological process of statistical aggregation based on multivariate methods, we combine the practices into an indicator that summarises and synthesises all the information in general terms.

Using a macro approach that goes beyond the level of the company as a unit of analysis, the proposed NCSRPI provides a global understanding of CSR development which also considers the company's national roots. In turn, it facilitates the ranking of countries and the development of benchmarking processes associated with a set of added components pertaining to issues of social and environmental sustainability, which collectively demonstrate the state of commitment to and development of CSR and describe the level of responsible business conduct between countries. The NCSRPI quantifies and simplifies CSR data. Likewise, the NCSRPI is useful to compare the CSR performance in different countries by providing a national view of CSR evolution. 
Table 1. International CSR initiatives included in the assessment to devise the National Corporate Social Responsibility Index

\begin{tabular}{|c|c|c|c|c|}
\hline Author & \multicolumn{4}{|c|}{ International CSR initiatives } \\
\hline Lenssen et al. (2006) & $\begin{array}{l}\text { Developed a measure of CSR engagement by correlating the na } \\
\text { grouped into four categories. } \\
1 \text { SRI (Socially Responsible Investment) analyses: } \\
\text { - Dow Jones Sustainability Index (DJSI) } \\
\text { - FTSE4Good Index } \\
2 \text { Industrial Membership in Corporate Responsibility Commun } \\
\text { - UN Global Compact } \\
\text { - World Business Council for Sustainable Developm } \\
\text { (WBCSD) }\end{array}$ & ies: & $\begin{array}{l}\text { economic and politic } \\
\qquad \begin{array}{rr} \\
\mathbf{4} & \mathrm{Co} \\
\end{array}\end{array}$ & $\begin{array}{l}\text { 1 institutions with resulting of CSR models, based on a set of items } \\
\text { Dorate Responsibility Reporting: } \\
\text { - Global Reporting Initiative (GRI) } \\
\text { KPMG CR reporting } \\
\text { - ISO } 14001\end{array}$ \\
\hline Gjølberg (2009) & $\begin{array}{l}\text { Based on nine leading global CSR initiatives within two relevan } \\
\begin{array}{l}\text { Results-oriented initiatives: require documented CSR } \\
\text { achievements, narrowly directed towards businesses }\end{array}\end{array}$ & $\begin{array}{l}\text { dimer } \\
1 \\
2 \\
3 \\
4 \\
5 \\
6 \\
7 \\
8 \\
9\end{array}$ & $\begin{array}{l}\text { Sions: results-orient } \\
\text { Dow Jones Sustainal } \\
\text { FTSE4Good } \\
\text { Global } 100 \text { Most Su: } \\
\text { SustainAbility } 100 \text { b } \\
\text { KPMG Reporting St } \\
\text { World Business Cou } \\
\text { ISO } 14000 \\
\text { Global Compact } \\
\text { Global Reporting Ini }\end{array}$ & $\begin{array}{l}\text { versus process-oriented initiatives. } \\
\text { ility Index (DJSI) } \\
\text { ainable Companies } \\
\text { st reports } \\
\text { vey } \\
\text { cil for Sustainable Development (WBCSD) } \\
\text { iative (GRI) }\end{array}$ \\
\hline Skouloudis et al. (2016) & $\begin{array}{ll}\text { Expanded the Gjølberg index to a composite construct of natio } \\
\text { standards, 'best-in-class' rankings, and ethical investment stock } \\
1 & \text { ISO } 14001 \\
2 & \text { OHSAS } 18001 \\
3 & \text { SA } 8000 \\
4 & \text { Global Reporting Initiative (GRI) } \\
5 & \text { Global Compact } \\
6 & \text { World Business Council for Sustainable Development } \\
7 & \text { Carbon Disclosure Project } \\
8 & \text { Greenhouse Gas Protocol }\end{array}$ & $\begin{array}{l}\text { al CS } \\
\text { xchan }\end{array}$ & $\begin{array}{l}\text { Re evaluation from a } \\
\text { ge indices. } \\
\qquad \\
10 \\
11 \\
12 \\
13 \\
14 \\
15 \\
16\end{array}$ & $\begin{array}{l}\text { series of } 16 \text { international CSR initiatives, environmental and social } \\
\text { KPMG triennial survey on CSR reporting } \\
\text { Ethibel Sustainability Index } \\
\text { FTSE4Good Global Index } \\
\text { Dow Jones Sustainability } \\
\text { ECPI Global ESG Alpha Equity Index } \\
\text { MSCI World ESG Index } \\
\text { Ethisphere's World's Most Ethical (WME) companies } \\
\text { Global } 100 \text { Most Sustainable Companies }\end{array}$ \\
\hline
\end{tabular}




\section{Method. A proposal for a composite national CSR indicator: the NCSRPI}

In order to create in-depth knowledge about CSR development at the international level, we use reliable and complete information about different social and environmental practices at the company level. We will add this as an indicator to synthesise all the information into a single index whose value can be used as a reference and facilitate a vision of the current reality and its evolution. In the literature, this type of index is known as an aggregate composite indicator and it shows latent real information. This represents an important tool for the communication of scientific and technical information, as well as being useful for evaluating situations or decisions (Paruolo et al., 2013). The proposed NCSRPI will provide a holistic understanding of the development of CSR and its national roots.

The design of a measure of national CSR penetration implies that companies' CSR practices can be aggregated into a single indicator which summarises them in a global way, synthesising all the information that each one represents. The methodological process for the creation of this composite indicator is structured around seven stages (Nardo et al., 2005; OECD, 2008; Dobbie and Dail, 2013): the development of a theoretical framework (Section 2); the selection of variables (3.2); input of missing data (3.3); removal of variables (3.4); data standardisation (3.5); weighing (3.6); and aggregation (3.7).

Prior to the development of the methodological process for the construction of the indicator, we present origins and structure of the data.

\subsection{Population and sample}

The main objective of this research is the construction of an indicator which shows a comparison between the level of development of CSR in different countries and geographical areas based on the development of CSR practices in the companies of that country. To do this, we selected the largest listed companies internationally as the target population because they are the most active companies in terms of sustainability (Martínez-Ferrero and García-Sánchez, 2016). This information was obtained from the Ethical Investment Research Services (EIRIS) database. EIRIS is a leading global provider of independent research into the social, environmental, and governance (ESG) performance of firms. EIRIS is an independent research organisation serving investors. It provides non-financial information on enterprises' social, environmental, and ethical policies and practices. It provides comprehensive research on over 3000 firms globally. It offers comparable, consistent data on over 110 different ESG areas, including human rights and supply chain labour standards, board practice, managing environmental and climate change impacts, bribery and corruption (for more, see http://www.vigeo-eiris.com/).

Of all the variables available in this database, we selected 28 practices $^{2}$ that provide complete information on company sustainability, which we explain in the following section. We chose only those companies with complete information for these selected CSR practices and we included a minimum of 10 companies per country; the total sample corresponds to 1459 internationally listed companies from 29 developed countries (see Table 2 - Panel A). The sample consists of four predominant geographical areas: Asia $(37.4 \%, 546$ organisations, 10 countries), Europe (34.7\%, 506 companies, 14 countries), America (25.4\%, 370 firms, 4 countries), and Oceania (2.5\%, 37 Australian companies). A bias in favour of companies operating in the United States, Japan and the United Kingdom, consistent with the type of large listed companies whose information is available in EIRIS, should be noted. This information should not lead to representativeness

\footnotetext{
${ }^{2}$ The EIRIS database has a higher number of CSR dimensions, but most of these are specific to one or two sectors (sometimes specific countries) which are not available for the others. In addition, several items are the same measures with different levels of response. Thus, the 28 items are those common to all companies and to all countries. These items are those more frequently used in empirical papers (i.e., Martínez-Ferrero and García-Sánchez 2016; Amor-Esteban et al. 2017; Cuadrado-Ballesteros et al. 2017; Esteban et al. 2017; García-Sánchez and García-Meca 2017).
} 
problems because large companies are the most active in CSR, and are models for the smaller companies operating in their country of origin (Martínez-Ferrero and García-Sánchez, 2016).

It is important to mention the distribution of the companies by their sector of activity, because this could distort the results by countries. The companies were grouped according to the 10 main industries, consistent with the coding of the Industry Classification Benchmark system, and the descriptive ones show a structure similar to reality, highlighting the number of companies that operate in industrial $(24.7 \%)$, consumer goods $(17.0 \%)$ and financial $(14.1 \%)$ industries; the remaining sectors have a percentage close to $10 \%$, smaller for companies belonging to the telecommunications and utilities sector (see Table 2 - Panel B). In addition, a cross-table between countries and sectors is shown, revealing the number of companies by sector in each country (see Table 2 - Panel C).

Finally, it should be noted that the data was selected for the year 2014. This year was selected due to the fact that in the decade 2004-2014 an extremely important CSR development occurred, because of greater access to information about corporate behaviour, the freedom of the press, the effect of technological developments, and greater knowledge about the pressure that different actors can exert. The decade 2004-2014 marks the decade in which companies assumed greater commitments in terms of sustainability and is considered to be the most relevant period for corporate and academic CSR studies (Martínez-Ferrero and García-Sánchez, 2016); thus, evaluation of the year 2014 implies measurement of an accumulation of all the commercial efforts made in that period. 
Table 2. Sample distribution

Panel A: Distribution of companies by country

\begin{tabular}{llllllll} 
& Country & $\mathrm{n}^{\mathbf{0}}$ & $\%$ & & Country & $\mathrm{n}^{\text {o }}$ & $\%$ \\
\hline 1 & Australia & 37 & 2.5 & 16 & Malaysia & 14 & 1.0 \\
2 & Austria & 11 & 0.8 & 17 & México & 11 & 0.8 \\
3 & Belgium & 12 & 0.8 & 18 & Netherlands & 24 & 1.6 \\
4 & Brazil & 13 & 0.9 & 19 & Norway & 11 & 0.8 \\
5 & Canada & 23 & 1.6 & 20 & Russia & 14 & 1.0 \\
6 & China & 26 & 1.8 & 21 & Singapore & 27 & 1.9 \\
7 & Denmark & 12 & 0.8 & 22 & South Korea & 97 & 6.6 \\
8 & Finland & 17 & 1.2 & 23 & Spain & 25 & 1.7 \\
9 & France & 76 & 5.2 & 24 & Sweden & 29 & 2.0 \\
10 & Germany & 64 & 4.4 & 25 & Switzerland & 35 & 2.4 \\
11 & Hong Kong & 73 & 5.0 & 26 & Thailand & 11 & 0.8 \\
12 & India & 21 & 1.4 & 27 & Turkey & 10 & 0.7 \\
13 & Israel & 13 & 0.9 & 28 & United Kingdom & 152 & 10.4 \\
14 & Italy & 24 & 1.6 & 29 & United States & 323 & 22.1 \\
15 & Japan & 254 & 17.4 & & Total & 1459 & 100.0
\end{tabular}

\begin{tabular}{llll}
\hline \multicolumn{3}{l}{ Panel B: Distribution of companies by industry } \\
& Industry & $\mathrm{n}^{\text {o }}$ & $\%$ \\
\hline 1 & Basic Materials & 144 & 9.9 \\
2 & Consumer Goods & 248 & 17.0 \\
3 & Consumer Services & 135 & 9.3 \\
4 & Financials & 205 & 14.1 \\
5 & Health Care & 94 & 6.4 \\
6 & Industrials & 361 & 24.7 \\
7 & Oil \& Gas & 95 & 6.5 \\
8 & Technology & 104 & 7.1 \\
9 & Telecommunications & 40 & 2.7 \\
10 & Utilities & 33 & 2.3 \\
\hline & Total & 1459 & 100.0
\end{tabular}

Panel C: Distribution of companies by country and industry

Country / Industry Basic Materials Consumer Goods Consumer Services Financials Health Care Industrials Oil \& Gas Technology Telecommunications Utilities Total

\begin{tabular}{ll}
\hline 1 & Australia \\
2 & Austria \\
3 & Belgium \\
4 & Brazil \\
5 & Canada \\
6 & China \\
7 & Denmark \\
8 & Finland \\
9 & France \\
10 & Germany \\
11 & Hong Kong \\
12 & India \\
13 & Israel \\
14 & Italy \\
15 & Japan \\
16 & Malaysia
\end{tabular}

16 Malaysia

$\begin{array}{ccc}6 & 2 & 3 \\ 1 & 0 & 0 \\ 2 & 1 & 3 \\ 2 & 4 & 0 \\ 8 & 2 & 2 \\ 3 & 5 & 0 \\ 0 & 1 & 0 \\ 3 & 2 & 1 \\ 4 & 13 & 11 \\ 9 & 17 & 5 \\ 1 & 11 & 18 \\ 2 & 3 & 0 \\ 2 & 2 & 0 \\ 1 & 6 & 4 \\ 33 & 69 & 16 \\ 1 & 1 & 1\end{array}$

3
0
3
0
2
0
0
1
11
5
18
0
0
4
16
1

8
4
4
3
4
6
0
0
9
6
21
4
5
6
15
4

$\begin{array}{cc}4 & 8 \\ 0 & 3 \\ 1 & 0 \\ 0 & \\ 0 & 1 \\ 0 & 6 \\ 7 & 6 \\ 1 & 3 \\ 5 & 6 \\ 6 & 20 \\ 0 & 14 \\ 2 & 9 \\ 1 & 3 \\ 0 & 1 \\ 19 & 4 \\ 0 & 75\end{array}$

$\begin{array}{ccc}8 & 4 & 0 \\ 3 & 1 & 0 \\ 0 & 0 & 0 \\ 1 & 1 & 0 \\ 3 & 3 & 1 \\ 6 & 2 & 1 \\ 3 & 1 & 0 \\ 6 & 1 & 1 \\ 20 & 3 & 5 \\ 14 & 0 & 5 \\ 9 & 2 & 4 \\ 3 & 2 & 1 \\ 1 & 1 & 1 \\ 4 & 2 & 0 \\ 75 & 5 & 16 \\ 2 & 1 & 0\end{array}$

$\begin{array}{cccc}0 & 1 & 1 & 37 \\ 0 & 1 & 1 & 11 \\ 0 & 1 & 0 & 12 \\ 0 & 1 & 1 & 13 \\ 1 & 0 & 0 & 23 \\ 1 & 1 & 2 & 26 \\ 0 & 0 & 0 & 12 \\ 1 & 1 & 1 & 17 \\ 5 & 1 & 5 & 76 \\ 5 & 0 & 2 & 64 \\ 4 & 2 & 5 & 73 \\ 1 & 1 & 3 & 21 \\ 1 & 0 & 0 & 13 \\ 0 & 0 & 1 & 24 \\ 16 & 3 & 3 & 254 \\ 0 & 3 & 1 & 14\end{array}$




\begin{tabular}{|c|c|c|c|c|c|c|c|c|c|c|c|c|}
\hline 17 & Mexico & 3 & 3 & 2 & 0 & 0 & 2 & 0 & 0 & 1 & 0 & 11 \\
\hline 18 & Netherlands & 3 & 4 & 2 & 1 & 0 & 8 & 2 & 3 & 1 & 0 & 24 \\
\hline 19 & Norway & 2 & 1 & 1 & 1 & 0 & 0 & 5 & 0 & 1 & 0 & 11 \\
\hline 20 & Russia & 3 & 0 & 1 & 2 & 0 & 0 & 5 & 0 & 2 & 1 & 14 \\
\hline 21 & Singapore & 0 & 2 & 2 & 10 & 0 & 9 & 3 & 0 & 1 & 0 & 27 \\
\hline 22 & South Korea & 11 & 19 & 6 & 17 & 0 & 30 & 4 & 5 & 3 & 2 & 97 \\
\hline 23 & Spain & 0 & 1 & 3 & 4 & 0 & 9 & 3 & 1 & 2 & 2 & 25 \\
\hline 24 & Sweden & 3 & 4 & 2 & 6 & 1 & 9 & 1 & 1 & 2 & 0 & 29 \\
\hline 25 & Switzerland & 3 & 5 & 1 & 5 & 6 & 12 & 1 & 1 & 1 & 0 & 35 \\
\hline 26 & Thailand & 0 & 1 & 1 & 3 & 1 & 1 & 3 & 0 & 1 & 0 & 11 \\
\hline 27 & Turkey & 0 & 0 & 0 & 6 & 0 & 2 & 0 & 0 & 2 & 0 & 10 \\
\hline 28 & United Kingdom & 17 & 15 & 17 & 17 & 5 & 54 & 16 & 7 & 3 & 1 & 152 \\
\hline 29 & United States & 21 & 54 & 33 & 34 & 35 & 67 & 23 & 51 & 4 & 1 & 323 \\
\hline & Total & 144 & 248 & 135 & 205 & 94 & 361 & 95 & 104 & 40 & 33 & 1459 \\
\hline
\end{tabular}




\subsection{Selection of variables}

In the second phase, the selection of CSR practices was carried out; that is, the set of measures were chosen to form the NCSRPI, based on relevance, timeliness, accessibility, and analytical consistency, because these determine the quality of the composite indicator. In order to assess the national CSR by adopting a multi-region approach for a sample of 1459 large listed companies based in 29 countries, a composite construction of national CSR assessment was developed using the country level data from a set of 28 global CSR practices for the year 2014.

The set of 28 CSR practices that we chose was obtained from the EIRIS database, which offers a wide range of measures that evaluate the sustainability of the company, and were specifically selected because they are the variables that are commonly used in research works to measure social and environmental performance (e.g.: Boudt et al., 2013; León, 2015; MartínezFerrero and García-Sánchez, 2016; Amor-Esteban et. al, 2017; Esteban et. al, 2017; GarcíaSánchez and García-Meca, 2017).

These issues represent the level of company engagement with their stakeholders and relate primarily to environmental protection, social well-being, and ethical and governance CSR dimensions. The environmental performance comprises the practices related to policies and systems to control the effects of commercial activities in caring for the environment, such as the fight against climate change, the elimination of waste, the reduction of atmospheric emissions or the economisation of natural resources, and practices that report all this information. Social performance refers to corporate impact on the community and includes practices to preserve and protect human rights; practices in relation to labour rights with policies and systems that promote equal opportunities, participation and training of employees, and systems aimed at improving health and safety conditions; practices to maintain good relations with customers, suppliers and the community; policies, systems and reports which address stakeholder pressures as well as CSR participation and responsibility; practices to evaluate the company's ethics code and everything related to counteracting bribery; and the board's practice and ESG risk management (see Table 3). In addition, it is possible to know not only if the company is committed to a practice, but also the level of development of that commitment, because these measures evaluate on a scale of $0-4$, where 0 is inadequate, 1 is weak, 2 is moderate, 3 is good, and 4 is exceptional.

Table 3. Corporate social responsibility performance composition

Environmental performance

Environment

ENV1 Environmental policy

ENV2 Environmental systems

ENV3 Environmental reporting

ENV4 Environmental performance
How does EIRIS rate the Company's environmental policy and commitment?

How does EIRIS rate the Company's environmental management system? How does EIRIS rate the Company's environmental reporting?

What level of improvements in environmental impact can the Company demonstrate?

Social performance

Human Rights

HR1 Human Rights policy

HR2 Human Rights systems

HR3 Human Rights reporting

Employees

EMP1 Equal opportunities (policy)

EMP2 Equal opportunities

EMP3 Health \& safety systems

EMP4 Trade unions and employee participation

EMP5 Training
What is the extent of policy addressing human rights issues?

What is the extent of systems addressing human rights issues?

Does the Company report on human rights issues?

How good is the Company's policy on equal opportunity and diversity issues?

How clear is the evidence of systems and practices to support equal opportunities and diversity?

How clear is the evidence of health \& safety systems?

How clear is the evidence of systems to manage employee relations?

How clear is the evidence of systems to support employee training and development? 
EMP6 Job creation and security

Stakeholders

STH1 Community relations
STH2 Customer/supplier relations
policy

STH3 Community involvement

STH4 Responsibility for

stakeholders

STH5 Stakeholder engagement

STH6 Stakeholder policy

STH7 Stakeholder systems

STH8 Stakeholder reporting

Ethics and Governance

$\begin{array}{ll}\text { ETH1 } & \text { Codes of ethics } \\ \text { ETH2 } & \text { Codes of ethics systems } \\ \text { ETH3 } & \text { Countering bribery policy } \\ \text { ETH4 } & \text { Countering bribery systems } \\ \text { ETH5 } & \text { Countering bribery reporting } \\ \text { ETH6 } & \text { Board practice }\end{array}$

ETH7 ESG risk management
How clear is the evidence of systems and practices to advance job creation and security?

How clear is the Company's commitment to community or charitable work?

Does the Company have policies on maintaining good relations with customers and/or suppliers?

How clear is the evidence of systems to maintain good relations with community?

How many stakeholder issues have been allocated to board members?

What level of engagement with stakeholders is disclosed by the Company? How good are the Company's policies towards its stakeholders overall?

How good is the Company's quantitative systems on stakeholder relationships?

How good are the Company's management reporting for stakeholders overall?

Does the Company have a code of ethics and, if so, how comprehensive is it?

Does the Company have a system for implementing a code of ethics and, if so, how comprehensive is it?

What is the extent of the Company's policy for countering bribery?

What is the extent of the Company's system for countering bribery?

What is the extent of the Company's reporting on countering bribery?

How many of the core elements of corporate governance does the Company have?

How well do the board and senior management address Company-wide ESG (Environmental, Social and Governance) risks and opportunities?

\subsection{Imputation of missing data}

According to Soto and Schuschny (2009) it is possible to make artificial imputation of data without altering its structure when the lost data does not exceed $15 \%$ of the information. If this amount is exceeded, the distance between observed and unobserved data can produce biases and complications in the processing and analysis of the data, compromising the quality and robustness of the results (Horton and Lipsitz, 2001). Our sample of data was selected with the criterion that all the reports should be complete; this is one of the advantages of our index over the composite indicators previously proposed.

\subsection{Removal of variables: multivariate analysis}

Multivariate analysis is an essential task that consists of checking and verifying the relationships between variables in order to make the best methodological decisions about their normalisation, weighting and aggregation processes (OECD, 2008). We statistically analysed the original set of 28 CSR practices to avoid the error of selection of independent variables that do not present links between variables and eliminate those that provide duplicate information, because these can distort the results of the study. In order to do this, an item response theory analysis was carried out to study the discriminatory power of the practices. A factorial analysis using the principal components method was also conducted with the aim of summarising in a latent variable most of the of the information acquired by these practices. By compiling both results, it was possible to optimally select the set of 22 practices that best summarises and synthesises all the information, and eliminate those that reduce the quality of the theoretical model. 


\subsubsection{Analysis of the discriminatory power of CSR practices}

We analyse which practices have greater discriminating power. For this, we use the item response theory (IRT) that allows us to perform a disaggregated analysis of the different practices (items). The probability of responding to a response category of an item $i$ at a given level of the latent construct is known as the item response function, or item characteristic curve (ICC). Among the different one-dimensional models for ordered polytomic data, one which has most received attention to date is the graduated response model of Samejima (1969). This model is an extension of the logistic model of two parameters for the case in which the response to the item is polytomic. The model is based on the differences between the functions of accumulated categorical responses: for an item with $m$ categorical responses, there will be $m-1$ cumulative dichotomies. For an item of five categories, the first cumulative curve represents the probability that an individual will select one category against the four highest categories; the second is between individuals who selected category 2 or a lower category versus category 3 or a higher category, and so on. The individual response curves are obtained as differences from the accumulated ones. For a detailed study of the model, see Samejima (1972) and Van Der Linden and Hambleton (1997).

The item information function indicates the amount of information contributed by the item and at what level this information is provided, so that, to greater pending more information. The information of the item is the inverse of the variability of the maximum likelihood estimator of $\theta$ in each level. The items with the greatest power to discriminate have high information, while items with less power to discriminate have less information. More information on these concepts can be found in Muniz (1997).

The most commonly used parameter estimation procedure is the maximum likelihood method, whereby the estimators are estimated in successive iterations. For the estimation of the characteristic curves and item information, there are many computer programs: in our case, we have used MultiLog (Thissen, 1991).

We start by showing the total information curve (Fig. 1), in which the information function (blue line) and the standard error (red line) are represented for the 28 CSR practices. Analysing Fig. 1, the maximum information is 35.000 ; this means that in each of the 28 practices that compose this information, the expected average is 1.250 .

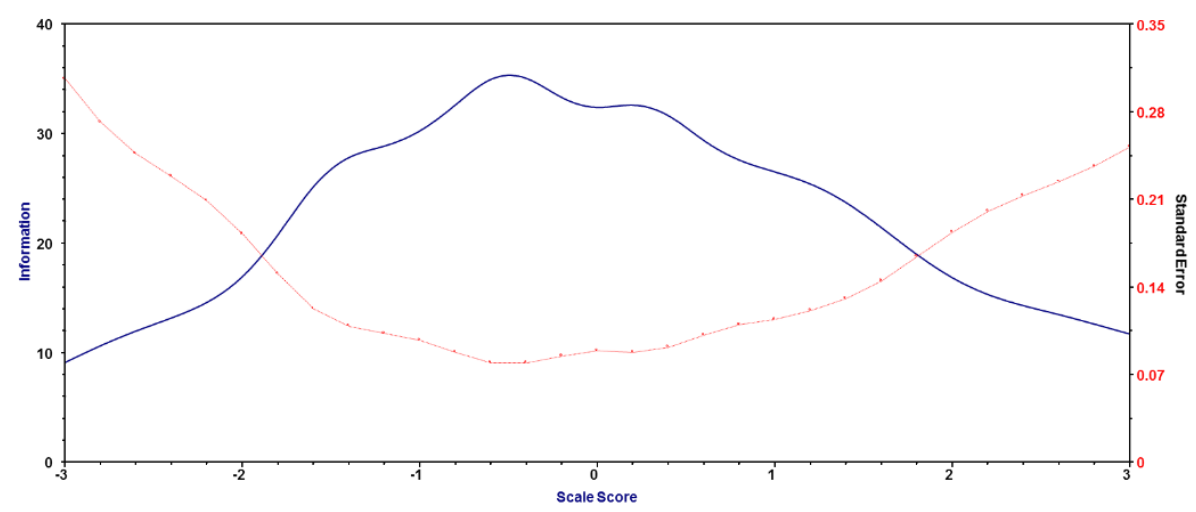

Fig. 1. Test total information and measurement error

In Fig. 2, the information curves of the 28 practices (items) that theoretically compose the global dimension of CSR are represented. Those items whose information is above the expected average are shown in green; contoured in green are those with values close to but below the average; and without highlight are the practices with values well below the average, the candidates to leave the model. 


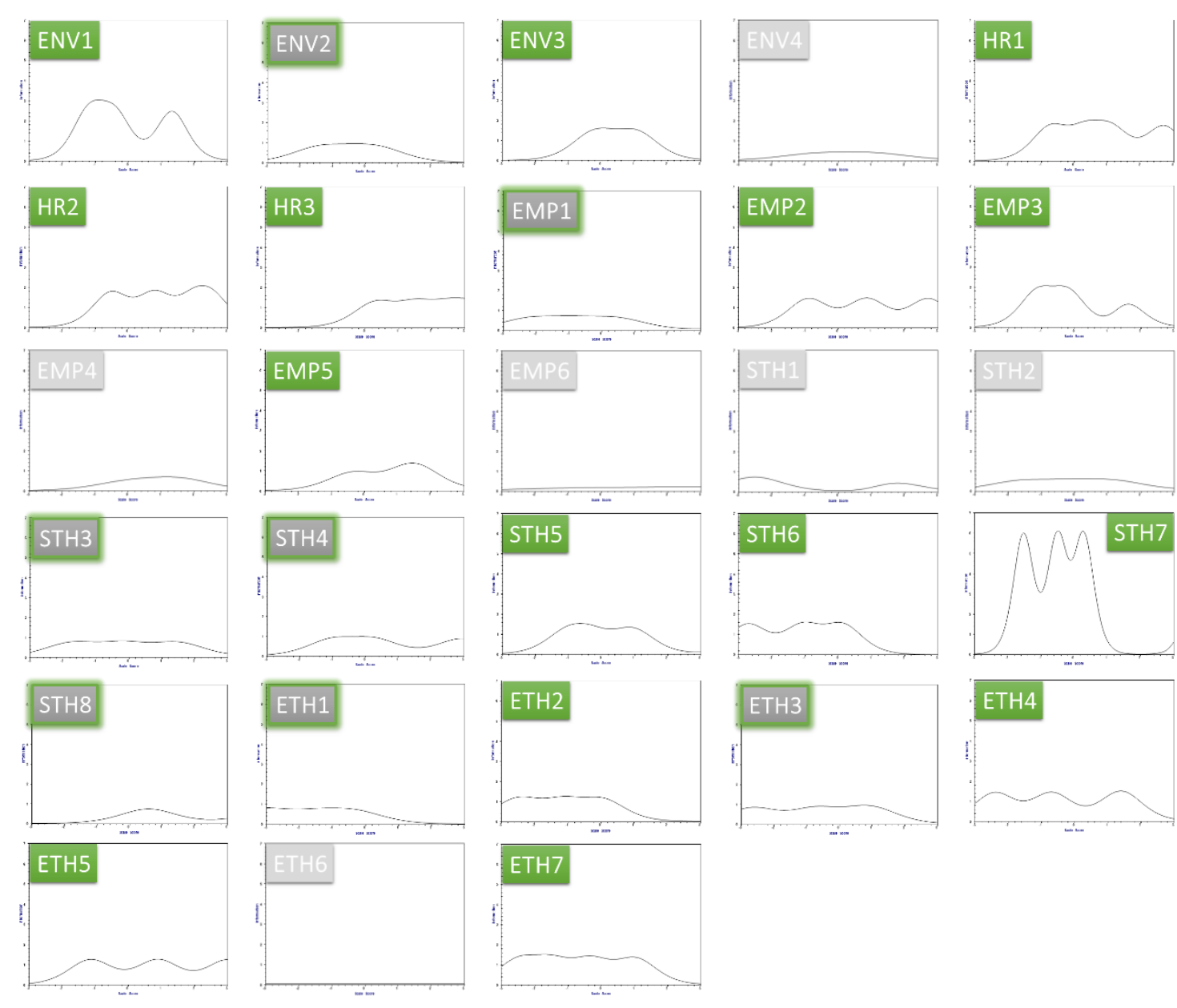

Fig. 2. Information function of each of the CSR practices

From the previous analyses, it can be determined that the practices of environmental performance (ENV4), trade unions and employee participation (EMP4), job creation and security (EMP6), community relations (STH1), customer/supplier relations policy (STH2) and board practice (ETH6) have the lowest values in the information function; that is, they have a very small discriminatory power and, therefore, these practices can be eliminated from the model.

\subsubsection{Analysis of the factorial structure of CSR practices}

We studied the factorial structure of the data through the application of an exploratory factor analysis (EFA) with the principal components method. Prior to this, we used (i) the Kaiser-MeyerOlkin sample adequacy index $(K M O=0.940)$ and (ii) the Bartlett sphericity test ( $p$-value $<0.000)$. In this sense, both measures showed good sample adequacy and an appropriate correlation between the practices, indicating that the data are adequate for the application of factorial analysis.

The first main axis absorbs 43.4 percent of the variance and the first three 56.2 percent. It is therefore the first axis which captures most of the information. The Table 4 shows that all items have their highest loads on this axis, except for "Board Practice (ETH6)" which gets its highest score in factor 2 with a value of 0.259 . This information means that all the practices are related to a single dimension and, therefore, it is very appropriate to combine the results in a single measure: the NCSRPI. For better reliability of our results, we applied bootstrap resampling with $n=1000$ replicates, which revealed the stability of the load factors. In addition, a column with the maximum values of the information function of each practice in the item response theory (IRT) has been added. Thus, compiling both results, we can select the optimal set of practices that best synthesises and summarises all this information. 


\begin{tabular}{|c|c|c|c|c|c|}
\hline & \multirow[b]{2}{*}{ CSR Practices (Items) } & \multicolumn{3}{|c|}{ EFA Factor 1} & \multirow{2}{*}{$\begin{array}{c}\text { IRT Maximum } \\
\text { Information Value }\end{array}$} \\
\hline & & $\begin{array}{l}\text { Sample } \\
\text { Est. }\end{array}$ & $\begin{array}{l}\text { Bootstrap } \\
\text { Mean Est. }\end{array}$ & $\begin{array}{c}\text { Bootstrap } \\
\text { SD Est. }\end{array}$ & \\
\hline ENV1 & Environmental policy & 0.807 & 0.806 & 0.010 & 3.026 \\
\hline ENV2 & Environmental systems & 0.675 & 0.675 & 0.014 & 0.957 \\
\hline ENV3 & Environmental reporting & 0.685 & 0.685 & 0.013 & 1.608 \\
\hline ENV4 & Environmental performance & 0.474 & 0.474 & 0.020 & 0.461 \\
\hline HR1 & Human Rights policy & 0.741 & 0.741 & 0.010 & 2.036 \\
\hline HR2 & Human Rights systems & 0.712 & 0.711 & 0.011 & 2.095 \\
\hline HR3 & Human Rights reporting & 0.565 & 0.564 & 0.013 & 1.480 \\
\hline EMP1 & Equal opportunities (policy) & 0.636 & 0.636 & 0.013 & 0.737 \\
\hline EMP2 & Equal opportunities (systems) & 0.700 & 0.699 & 0.014 & 1.474 \\
\hline EMP3 & Health \& safety systems & 0.712 & 0.712 & 0.014 & 2.058 \\
\hline EMP4 & Trade unions and employee participation & 0.491 & 0.492 & 0.018 & 0.679 \\
\hline EMP5 & Training & 0.595 & 0.595 & 0.017 & 1.372 \\
\hline EMP6 & Job creation and security & 0.359 & 0.357 & 0.022 & 0.228 \\
\hline STH1 & Community relations & 0.371 & 0.370 & 0.020 & 0.639 \\
\hline STH2 & Customer/supplier relations policy & 0.588 & 0.587 & 0.017 & 0.640 \\
\hline STH3 & Community involvement & 0.633 & 0.632 & 0.015 & 0.830 \\
\hline STH4 & Responsibility for stakeholders & 0.605 & 0.605 & 0.016 & 0.999 \\
\hline STH5 & Stakeholder engagement & 0.735 & 0.735 & 0.012 & 1.531 \\
\hline STH6 & Stakeholder policy & 0.755 & 0.755 & 0.011 & 1.614 \\
\hline STH7 & Stakeholder systems & 0.894 & 0.894 & 0.006 & 6.009 \\
\hline STH8 & Stakeholder reporting & $\mathbf{0 . 7 5 0}$ & 0.749 & 0.012 & 0.732 \\
\hline ETH1 & Codes of ethics & 0.612 & 0.611 & 0.013 & 0.829 \\
\hline ETH2 & Codes of ethics systems & 0.706 & 0.705 & 0.011 & 1.271 \\
\hline ЕТН3 & Countering bribery policy & 0.621 & 0.620 & 0.014 & 0.967 \\
\hline ETH4 & Countering bribery systems & 0.673 & 0.672 & 0.013 & 1.504 \\
\hline ETH5 & Countering bribery reporting & 0.668 & 0.667 & 0.013 & 1.255 \\
\hline ETH6 & Board practice & 0.054 & 0.054 & 0.024 & 0.048 \\
\hline ETH7 & ESG risk management & $\mathbf{0 . 7 3 8}$ & 0.738 & 0.011 & 1.520 \\
\hline
\end{tabular}

These techniques express results with different meanings; even so, very consistent results are obtained - that is, those practices that obtain the highest loads in the EFA present the points of greater information in the IRT, such as the stakeholders systems (STH7), environmental policies (ENV1), and human rights policies and systems (HR1, HR2); on the other hand, those practices that present factorial loads less than 0.600 in the EFA present little information in the IRT $(<0.700)$ and these practices are excluded from the analysis (see practices not highlighted in Table 4). With the elimination of these variables, we sought to simplify the theoretical model of the 28 CSR practices with the aim that the global sustainability score of a company should be balanced and not enhanced by any specific characteristic.

The two variables eliminated in the dimension that collects employees' rights - trade unions and employee participation (EMP4) and job creation and security (EMP6), which measure the level of development of systems designed to manage relationships with employees, work, and safety - have a strong relationship with the practice of training and participation (EMP5), which evaluates support systems for training and development of employees. The latter practice includes the two previous items and, according to the statistical analysis, it has a greater explanatory capacity. Therefore, when evaluating the commitment of a company in the training of its employees, we only use practical training (EMP5) because if we kept the three practices, a company with a strong commitment in this characteristic would have a greatly increased score.

A similar situation can be found in the other variables excluded from the model. Environmental performance (ENV4) measures the level of environmental performance; hence, it is redundant because it is consistent with the information in the other environmental variables and it can be eliminated.

In relation to the stakeholders, - the dimension that assesses the company's commitment to external relations - it is possible to discard community relations (STH1) and policies to maintain 
good relations with customers and suppliers (STH2), because of the strong relationship they have with community involvement (STH3) which includes the information of both; this item it determines the commitment of the company to maintain good external relations and, in addition, it presents greater variability in the study.

Finally, we excluded the practice regarding board compliance (ETH6) in the dimension of business ethics. This information is collected by ESG risk management practices (ETH7), which measures the commitment of the board and senior management when dealing with risks and opportunities of ESG.

\subsection{Data standardization}

For the comparison or aggregation of values, a standardisation process is necessary in case the measures applied use a different scale. In this way, we avoid the influence of atypical values and we unify the range and measure of the variables so that they are comparable (Freudenberg, 2003). This phase is not necessary in our research because the selected CSR practices evaluate the companies' commitment to sustainability on the same scale of $0-4$, where $0=$ inadequate, $1=$ weak, $2=$ moderate, $3=$ good, and $4=$ exceptional.

\subsection{Weighting}

This phase entails the attribution of weights to each of the practices in reference to the individual importance of each in relation to the set. This relevance will be determined through the regression weights obtained by a confirmatory factorial analysis of the model composed of the practices selected in the previous phase.

\subsubsection{Confirmatory factorial analysis of the simplified model}

The selection of a methodology for attribution of weights is a very important phase in the construction of comparative values. In this sense, taking into account the best methodologies of attribution of weights, it was decided to assigned weight to the CSR practices through the standardized regression coefficients of a confirmatory factor analysis (CFA) of the simplified model. In this way, we tested the validity of the construct and the reliability of the set of practices selected to be combined in the NCSRPI (Martínez Arias et al., 2006). Researchers use numerous indicators of goodness of fit to evaluate a model; we show some of these more common indices in Table 5.

Table 5. Indicators of goodness of fit of simplified model

\begin{tabular}{ccccccc}
\hline \multicolumn{3}{c}{$\begin{array}{c}\text { Indicators of incremental } \\
\text { goodness of fit }\end{array}$} & $\begin{array}{c}\text { Indicators of residual } \\
\text { goodness of fit }\end{array}$ & $\begin{array}{c}\text { Root mean square error } \\
\text { of approximation }\end{array}$ \\
\hline NFI & TLI & IFI & CFI & RFI & SRMSR & RMSEA \\
0.936 & 0.930 & 0.944 & 0.944 & 0.921 & 0.0434 & 0.069 \\
\hline
\end{tabular}

In relation to the indicators of incremental goodness of fit- the Normed Fit Index (NFI), Non-Normed Fit Index (NNFI, also known as the Tucker-Lewis coefficient, TLI), Incremental Fit Index (IFI), Comparative Fit Index (CFI), and Relative Fit Index (RFI) - most authors state that in order to accept a model as valid, at least three of these five indicators must exceed 0.9 (Hu and Bentler, 1999; Yu and Muthen, 2002). According to residual goodness of fit, an average of the residuals calculated on the correlation matrix (standardized root mean squared residuals, SRMSR) should be less than 0.08 , where the lower the value, the better the fit of the model. In reference to the root mean square error of approximation (RMSEA), the authors mention that the model may be considered valid if this value is less than 0.08; based on experience, Browne et al. (1993) suggest that a RMSEA of 0.05 or less indicates a "perfect fit".

Based on the above, we can say that the fit of our model is valid: all the indicators exceed the minimum so that they are considered acceptable in the direction of the good adjustment. Thus, 
with the application of a bootstrap resampling with $n=1000$ replicates, we present the estimation and the confidence intervals to 95 percent of the standardized regression coefficients of our model. These weights are those we will use to weight our practices in the construction of the NCSRPI. As can be seen in Table 6, all practices selected are highly significant ( $\mathrm{p}$ value $<0.01$ ), which means that all have an important function in the index and give great reliability about the stability and precision of our results.

Table 6. Standardized regression weights of simplified model

\begin{tabular}{llllllll}
\hline \multicolumn{1}{c}{ CSR Practices } & \multicolumn{2}{c}{ Parameter } & Estimate & Lower & Upper & p-value \\
\hline Environmental policy & ENV1 & $\leftarrow$ & CSR & 0.804 & 0.784 & 0.823 & 0.002 \\
Environmental systems & ENV2 & $\leftarrow$ & CSR & 0.655 & 0.622 & 0.686 & 0.002 \\
Environmental reporting & ENV3 & $\leftarrow$ & CSR & 0.685 & 0.657 & 0.712 & 0.002 \\
Human Rights policy & HR1 & $\leftarrow$ & CSR & 0.710 & 0.682 & 0.735 & 0.002 \\
Human Rights systems & HR2 & $\leftarrow$ & CSR & 0.673 & 0.644 & 0.700 & 0.002 \\
Human Rights reporting & HR3 & $\leftarrow$ & CSR & 0.532 & 0.494 & 0.564 & 0.003 \\
Equal opportunities (policy) & EMP1 & $\leftarrow$ & CSR & 0.609 & 0.574 & 0.641 & 0.002 \\
Equal opportunities (systems) & EMP2 & $\leftarrow$ & CSR & 0.690 & 0.659 & 0.723 & 0.002 \\
Health \& safety systems & EMP3 & $\leftarrow$ & CSR & 0.715 & 0.688 & 0.741 & 0.002 \\
Training & EMP5 & $\leftarrow$ & CSR & 0.584 & 0.548 & 0.620 & 0.002 \\
Community involvement & STH3 & $\leftarrow$ & CSR & 0.623 & 0.589 & 0.653 & 0.002 \\
Responsibility for stakeholders & STH4 & $\leftarrow$ & CSR & 0.630 & 0.596 & 0.664 & 0.002 \\
Stakeholder engagement & STH5 & $\leftarrow$ & CSR & 0.744 & 0.716 & 0.768 & 0.002 \\
Stakeholder policy & STH6 & $\leftarrow$ & CSR & 0.724 & 0.693 & 0.746 & 0.004 \\
Stakeholder systems & STH7 & $\leftarrow$ & CSR & 0.860 & 0.845 & 0.875 & 0.003 \\
Stakeholder reporting & STH8 & $\leftarrow$ & CSR & 0.733 & 0.705 & 0.756 & 0.002 \\
Codes of ethics & ETH1 & $\leftarrow$ & CSR & 0.575 & 0.536 & 0.612 & 0.002 \\
Codes of ethics systems & ETH2 & $\leftarrow$ & CSR & 0.682 & 0.650 & 0.710 & 0.003 \\
Countering bribery policy & ETH3 & $\leftarrow$ & CSR & 0.593 & 0.556 & 0.629 & 0.001 \\
Countering bribery systems & ETH4 & $\leftarrow$ & CSR & 0.656 & 0.624 & 0.686 & 0.002 \\
Countering bribery reporting & ETH5 & $\leftarrow$ & CSR & 0.662 & 0.631 & 0.692 & 0.002 \\
ESG risk management & ETH7 & $\leftarrow$ & CSR & 0.755 & 0.728 & 0.778 & 0.003 \\
\hline
\end{tabular}

As described in the previous sections, according to our theoretical model, we began with complete and accurate information on CSR practices at a company level synthesised in 28 variables from the EIRIS database. Through a methodological process based on multivariate statistical techniques, we selected the set of practices that best summarised and synthesised all the information and, we eliminated practices that from an empirical point of view did not provide information and, in turn, reduced the quality of the model theoretically. The results give rise to a simplified model of 22 CSR practices that will provide an overall CSR score, balanced according to the different elements of business performance: environment, human rights, employees, stakeholders, and ethics.

The next step is the attribution of weights to each of these practices according to their importance with regard to sustainable commitment. For this, we selected the standardised regression weights of our simplified model, since it is these values that adjust the covariance between the variables; that is, they minimise the differences between the covariances observed in the sample and the covariances predicted by the structural model, allowing the construction of the model, which reveals the validity of the construct and the reliability of each of the selected practices to be combined in the NCSRPI. Thus, the scores received by each practice reflect its importance for the latent variable, CSR, in addition to being interpretable in terms of correlation.

These weights are responsible for verifying our model and corroborating the suitability of these practices in the measurement of company sustainability. Their selection was not based solely on this criterion, but these values are also congruent with the previous literature and the criteria of other researchers, adequately representing the real situation of CSR. Thus, the practices that refer to stakeholders and those related to environmental protection are the most transcendental, highlighting the creation of systems to maintain good relations with stakeholders, 
since CSR is based on voluntary activities and policies motivated by expectations of stakeholders (Carroll, 1991; Matten and Moon, 2008); these expectations are specific to the environment of the company and must comply with the standards of behaviour if they want to receive the approval of the society in which they are immersed (Campbell, 2007; García-Sánchez et al, 2013). Environmental policies have a strong importance because a company considered to be sustainable does not show disregard for the environment, especially because of the effect that news about environmental impacts has on corporate reputation (Semenova and Hassel, 2008; Casey and Grenier, 2014; Ekelenburg, 2016). We also highlight compliance with recommendations about internal corporate governance due to its high impact on CSR practices, measured through the ESG risk management practice (Rodriguez-Dominguez et al., 2009; Cuadrado-Ballesteros et al., 2017) and health and safety systems and equal opportunities, as well as human rights policies. Companies adhere to all these CSR practices in order to be considered proactive, demonstrating that their commitment goes beyond the levels of protection established by the regulations. This commitment can be very useful to achieve vital social objectives such as prestige or a good reputation and, therefore, the economic advantages associated with the survival and growth of the company (Jackson and Apostolakou, 2010). All the practices previously mentioned have a significance close to or greater than 0.70 . Practices aimed at systems such as the implementation of a code of ethics, human rights, environment, and the fight against bribery have a significance of between 0.65-0.70. Finally, those practices that receive less importance, around 0.60, are policies to counteract bribery, promote equal opportunities, codes of ethics, and employee training. The differences between the weights that each practice receives are small, because this classification simply seeks to give a plus to practices established which have been demanded and developed by the companies, but without decompensating the final result.

\subsection{Aggregation}

The final phase of the formation of the composite indicator is the aggregation process and implies take into account the individual weight of each practice in reference to its importance into the set. In this sense, a methodology similar to that used by Skouloudis et al. (2016) will be used, consisting of the aggregation of presence ratios relativized by GDP. Unlike these authors, however, the NCSRPI is not based on the average number of companies present in the practices analysed: it is based on the fact that for each of the CSR practices, the difference between the average of the sustainability level of the selected country and the average of the sustainability level of all the countries that form part of the rating is calculated. These relationships are corrected and normalized for GDP PPP rates - that is, the GDP of each country is divided by the sum of the GDPs of all countries in the sample. We used GDP in order to obtain a relativized score because economic development of a country is an unquestionable determinant of the number of companies in the country and their economic status. Both factors are especially relevant in CSR development. In the latest stage of this calculation method, the aggregation of the scores of each practice is done by a weighted sum with the standardized regression weights obtained in the confirmatory factor analysis (see Table 6) to derive a national level index (Equation 1).

National CSR practices index $=\sum_{i=1}^{22} p_{i}\left(\begin{array}{c}\begin{array}{c}\text { Average level of sustainability of practice } X_{i} \text { from country } A \\ - \\ \text { Average level of sustainability of practice } X_{i} \\ \text { from all sample countries }\end{array} \\ \frac{\text { GDP PPP country A }}{\text { Total GDPPPP of all sample countries }}\end{array}\right)$

Equation 1. The aggregation method for obtaining the national CSR practices scores

In order to test the usefulness of the NCSRPI, a practical application has been made. The results present a comparison of the countries analysed by ranking - that is, values close to 0 are associated with countries that do not stand out in the study; positive values represent countries with the best CSR practices, greater commitment to company sustainability in social issues, and 
environmental concerns; and negative values depict those countries in the study that are slower in adopting this commitment, the most lagging in CSR.

\section{Empirical results and discussion}

\subsection{Practical application}

The results synthesized in Table 7 evidence that European Union (EU) countries have a greater commitment to sustainability by presenting the best CSR practices, the highest positive values; in contrast, most non-EU countries seem to be far behind in this area, with Southeast Asian countries having the worst practices in the study. Such results would support the evidence reported by Skouloudis et al. (2016) regarding the poor penetration of CSR and a large variation between countries, where most of them are presenting as laggard countries in relation of global CSR initiatives. In addition, it should be noted that the country-level results obtained in the NCSRPI macro indicator are similar to the empirical evidence obtained for micro data in previous studies.

Table 7. National Corporate Social Responsibility Practices Index (NCSRPI)

\begin{tabular}{|c|c|c|c|c|c|c|c|c|}
\hline & Country & NCSRPI & & Country & NCSRPI & & Country & NCSRPI \\
\hline 1 & Finland & 21.00 & 11 & United Kingdom & 0.94 & 21 & India & -0.83 \\
\hline 2 & Denmark & 11.25 & 12 & Belgium & 0.86 & 22 & China & -0.84 \\
\hline 3 & Sweden & 10.27 & 13 & Germany & 0.82 & 23 & Mexico & -2.33 \\
\hline 4 & Norway & 9.56 & 14 & Japan & 0.23 & 24 & Turkey & -3.06 \\
\hline 5 & Netherlands & 5.81 & 15 & Canada & 0.10 & 25 & Russia & -3.30 \\
\hline 6 & Switzerland & 5.06 & 16 & United States & -0.18 & 26 & Thailand & -4.93 \\
\hline 7 & Australia & 3.81 & 17 & Brazil & -0.35 & 27 & Malaysia & -16.48 \\
\hline 8 & Spain & 3.33 & 18 & South Korea & -0.58 & 28 & Singapore & -21.93 \\
\hline 9 & France & 1.80 & 19 & Austria & -0.64 & 29 & Hong Kong & -29.17 \\
\hline 10 & Italy & 1.04 & 20 & Israel & -0.68 & & & \\
\hline
\end{tabular}

The scores shown by the NCSRPI country ranking refer to the development of CSR practices by their companies. The biases of companies by country and sector that we have commented on when defining the empirical sample suggest the possible existence of limitations in the construction of the indicator. In this sense, in order to provide robustness to the NCSRPI indicator, in the following section we will test our model using sample companies paired by country and sector. This analysis will allow us to check the model's functionality by comparing the scores obtained.

Once the robustness of the NCSRPI has been validated, we will proceed to address the second objective of this paper, by explaining the differences found between countries according to their institutional environments. This complementary objective will allow us to guarantee the coherence of the information provided by the indicator with the results obtained in previous studies, allowing the generalisation of its use in decision-making processes and in research carried out in universities. This second objective will be addressed using a HJ-biplot analysis.

\subsection{Robust results analysis}

The data sample used to create the NCSRPI is characterised by a significant presence of companies from the United States, the United Kingdom and Japan. In addition, it includes some of the main oil producers, such as the United States, Russia, China, Canada and Mexico; these countries obtain negative NCSRPI scores and this can lead to confusion when thinking about the great influence that the scores of these companies could have on the overall rating of the country. Another example is that it is mainly European countries specialised in sectors such as finance or manufacturing that obtain positive NCSRPI scores. It was already possible to check in the sample (see Table 2) that countries present their companies with a uniform distribution by sectors; However, in order to verify the reliability of our model and ensure the robustness of the results, 
in this section we reduce the sample without losing the proportion of companies distributed by sector in each country and we match the number of companies per country as much as possible, reaching a balanced sample with a low level of dispersion.

Table 9 shows the new data sample composed of 416 companies for the same 29 countries. In "Panel A. Distribution of companies by country", it is possible to observe how all countries have a similar number of companies in the range of $2.4 \%$ to $4.6 \%$. In "Panel B. Distribution of companies by industry", we obtain a structure similar to the main sample, with the largest number of companies in the finance sector $(16.30 \%)$ and a smaller presence of companies in the health care sector $(5.50 \%)$. In "Panel C. Distribution of companies by country and industry", we display the proportion of companies with the highest number of active industries per country.

The results of the NCSRPI indicator for the new sample are synthesised in Table 8. It can be observed that they show a high degree of similarity with those obtained for the initial sample, with each country occupying the same position in the associated rankings. The column entitled "NCSRPI" shows the scores obtained in the main sample, the column "Replica" shows the scores for the reduced sample, and the column "Difference" gives us the difference between both scores. It can be observed that all countries suffer a small variation in their score - an inevitable effect given that each company has a particular behaviour and many of them have been eliminated. However, the differences between countries are maintained, emphasising national identity as a strong explanatory factor of CSR practices. These ratings show the functionality of the model and give greater precision and robustness to the results.

Table 8. National Corporate Social Responsibility Practices Index (NCSRPI) of robust analysis

\begin{tabular}{llllllllll}
\hline & Country & NCSRPI & Replica & Difference & & Country & NCSRPI & Replica & Difference \\
\hline 1 & Finland & 21.00 & 20.78 & -0.22 & 16 & United States & -0.18 & -0.15 & 0.03 \\
2 & Denmark & 11.25 & 11.07 & -0.18 & 17 & Brazil & -0.35 & -0.37 & -0.02 \\
3 & Sweden & 10.27 & 9.53 & -0.74 & 18 & South Korea & -0.58 & -0.71 & -0.13 \\
4 & Norway & 9.56 & 9.41 & -0.15 & 19 & Austria & -0.64 & -0.76 & -0.12 \\
5 & Netherlands & 5.81 & 7.28 & 1.47 & 20 & Israel & -0.68 & -0.85 & -0.17 \\
6 & Switzerland & 5.06 & 7.27 & 2.21 & 21 & India & -0.83 & -0.89 & -0.06 \\
7 & Australia & 3.81 & 3.52 & -0.29 & 22 & China & -0.84 & -0.90 & -0.06 \\
8 & Spain & 3.33 & 3.48 & 0.15 & 23 & Mexico & -2.33 & -2.35 & -0.02 \\
9 & France & 1.80 & 1.80 & 0.00 & 24 & Turkey & -3.06 & -3.09 & -0.03 \\
10 & Italy & 1.04 & 1.51 & 0.47 & 25 & Russia & -3.30 & -3.31 & -0.01 \\
11 & United Kingdom & 0.94 & 1.37 & 0.43 & 26 & Thailand & -4.93 & -4.97 & -0.04 \\
12 & Belgium & 0.86 & 1.14 & 0.28 & 27 & Malaysia & -16.48 & -16.54 & -0.06 \\
13 & Germany & 0.82 & 0.29 & -0.53 & 28 & Singapore & -21.93 & -17.78 & 4.15 \\
14 & Japan & 0.23 & 0.26 & 0.03 & 29 & Hong Kong & -29.17 & -30.89 & -1.72 \\
15 & Canada & 0.10 & 0.24 & 0.14 & & & & & \\
\hline
\end{tabular}

\subsection{Institutional environment, NCSRPI and national identity}

In this section we study the scores of the countries according to their institutional characteristics, evaluating the legal system, the culture and government effectiveness. In this way, we will consider national discrepancies in CSR practices in relation to the institutional suitability of the country of origin of the companies.

The voluntary and proactive practices posed by CSR constructs, which form part of the broader spectrum of activities related to the interaction between the company and society, are widely defined by the institutional conditions of countries. The institutional terrain suggest that business responsibility is determined by the expectations and demands of society as are carried out by country's formal and informal institutions. It is therefore necessary to compare the results that companies have adopted in these practices in their country and the economic and social area to which they belong (Searcy, 2014).

In accordance with García-Sánchez et al. (2013) and Amor-Esteban et al. (2017), the institutional environment of each country is determined by the characteristics of the legal system, the government's effectiveness and the predominant cultural values in society. 
Table 9. Sample distribution of robust analysis

Panel A: Distribution of companies by country

\begin{tabular}{llllllll} 
& Country & $\mathrm{n}^{\circ}$ & $\%$ & & Country & $\mathrm{n}^{\mathbf{0}}$ & $\%$ \\
\hline 1 & Australia & 16 & 3.8 & 16 & Malaysia & 14 & 3.4 \\
2 & Austria & 11 & 2.6 & 17 & Mexico & 11 & 2.6 \\
3 & Belgium & 11 & 2.6 & 18 & Netherlands & 18 & 4.3 \\
4 & Brazil & 13 & 3.1 & 19 & Norway & 11 & 2.6 \\
5 & Canada & 15 & 3.6 & 20 & Russia & 14 & 3.4 \\
6 & China & 13 & 3.1 & 21 & Singapore & 12 & 2.9 \\
7 & Denmark & 12 & 2.9 & 22 & South Korea & 17 & 4.1 \\
8 & Finland & 17 & 4.1 & 23 & Spain & 18 & 4.3 \\
9 & France & 19 & 4.6 & 24 & Sweden & 16 & 3.8 \\
10 & Germany & 15 & 3.6 & 25 & Switzerland & 14 & 3.4 \\
11 & Hong Kong & 16 & 3.8 & 26 & Thailand & 11 & 2.6 \\
12 & India & 15 & 3.6 & 27 & Turkey & 10 & 2.4 \\
13 & Israel & 13 & 3.1 & 28 & United Kingdom & 15 & 3.6 \\
14 & Italy & 16 & 3.8 & 29 & United States & 16 & 3.8 \\
15 & Japan & 17 & 4.1 & & Total & 416 & 100.0
\end{tabular}

\begin{tabular}{llll}
\hline \multicolumn{3}{l}{ Panel B: Distribution of companies by industry } \\
& Industry & $\mathrm{n}^{\mathbf{0}}$ & $\%$ \\
\hline 1 & Basic Materials & 50 & 12.0 \\
2 & Consumer Goods & 49 & 11.8 \\
3 & Consumer Services & 42 & 10.1 \\
4 & Financials & 68 & 16.3 \\
5 & Health Care & 23 & 5.5 \\
6 & Industrials & 55 & 13.2 \\
7 & Oil \& Gas & 51 & 12.3 \\
8 & Technology & 19 & 4.6 \\
9 & Telecommunications & 34 & 8.2 \\
10 & Utilities & 25 & 6.0 \\
\hline & Total & 416 & 100.0
\end{tabular}

Panel C: Distribution of companies by country and industry

Country / Industry Basic Materials Consumer Goods Consumer Services Financials Health Care Industrials Oil \& Gas Technology Telecommunications Utilities Total

\begin{tabular}{|c|c|c|c|c|c|c|c|c|c|c|c|c|}
\hline 1 & Australia & 2 & 2 & 3 & 2 & 1 & 2 & 2 & 0 & 1 & 1 & 16 \\
\hline 2 & Austria & 1 & 0 & 0 & 4 & 0 & 3 & 1 & 0 & 1 & 1 & 11 \\
\hline 3 & Belgium & 2 & 1 & 2 & 4 & 1 & 0 & 0 & 0 & 1 & 0 & 11 \\
\hline 4 & Brazil & 2 & 4 & 0 & 3 & 0 & 1 & 1 & 0 & 1 & 1 & 13 \\
\hline 5 & Canada & 2 & 2 & 2 & 3 & 0 & 2 & 3 & 1 & 0 & 0 & 15 \\
\hline 6 & China & 2 & 1 & 0 & 2 & 0 & 2 & 2 & 1 & 1 & 2 & 13 \\
\hline 7 & Denmark & 0 & 1 & 0 & 0 & 7 & 3 & 1 & 0 & 0 & 0 & 12 \\
\hline 8 & Finland & 3 & 2 & 1 & 0 & 1 & 6 & 1 & 1 & 1 & 1 & 17 \\
\hline 9 & France & 2 & 2 & 2 & 2 & 2 & 2 & 3 & 1 & 1 & 2 & 19 \\
\hline 10 & Germany & 2 & 2 & 2 & 2 & 1 & 2 & 0 & 2 & 0 & 2 & 15 \\
\hline 11 & Hong Kong & 1 & 2 & 2 & 2 & 0 & 2 & 2 & 1 & 2 & 2 & 16 \\
\hline 12 & India & 2 & 2 & 0 & 2 & 2 & 1 & 2 & 1 & 1 & 2 & 15 \\
\hline 13 & Israel & 2 & 2 & 0 & 5 & 1 & 1 & 1 & 1 & 0 & 0 & 13 \\
\hline 14 & Italy & 1 & 2 & 4 & 2 & 0 & 4 & 2 & 0 & 0 & 1 & 16 \\
\hline 15 & Japan & 2 & 2 & 2 & 2 & 1 & 2 & 2 & 1 & 1 & 2 & 17 \\
\hline 16 & Malaysia & 1 & 1 & 1 & 4 & 0 & 2 & 1 & 0 & 3 & 1 & 14 \\
\hline
\end{tabular}




\begin{tabular}{|c|c|c|c|c|c|c|c|c|c|c|c|c|}
\hline 17 & Mexico & 3 & 3 & 2 & 0 & 0 & 2 & 0 & 0 & 1 & 0 & 11 \\
\hline 18 & Netherlands & 3 & 4 & 2 & 1 & 0 & 2 & 2 & 3 & 1 & 0 & 18 \\
\hline 19 & Norway & 2 & 1 & 1 & 1 & 0 & 0 & 5 & 0 & 1 & 0 & 11 \\
\hline 20 & Russia & 3 & 0 & 1 & 2 & 0 & 0 & 5 & 0 & 2 & 1 & 14 \\
\hline 21 & Singapore & 0 & 2 & 2 & 2 & 0 & 2 & 3 & 0 & 1 & 0 & 12 \\
\hline 22 & South Korea & 2 & 2 & 2 & 2 & 0 & 2 & 2 & 1 & 2 & 2 & 17 \\
\hline 23 & Spain & 0 & 1 & 3 & 4 & 0 & 2 & 3 & 1 & 2 & 2 & 18 \\
\hline 24 & Sweden & 3 & 2 & 2 & 2 & 1 & 2 & 1 & 1 & 2 & 0 & 16 \\
\hline 25 & Switzerland & 3 & 2 & 1 & 2 & 2 & 1 & 1 & 1 & 1 & 0 & 14 \\
\hline 26 & Thailand & 0 & 1 & 1 & 3 & 1 & 1 & 3 & 0 & 1 & 0 & 11 \\
\hline 27 & Turkey & 0 & 0 & 0 & 6 & 0 & 2 & 0 & 0 & 2 & 0 & 10 \\
\hline 28 & United Kingdom & 2 & 1 & 2 & 2 & 1 & 2 & 1 & 1 & 2 & 1 & 15 \\
\hline 29 & United States & 2 & 2 & 2 & 2 & 1 & 2 & 1 & 1 & 2 & 1 & 16 \\
\hline & Total & 50 & 49 & 42 & 68 & 23 & 55 & 51 & 19 & 34 & 25 & 416 \\
\hline
\end{tabular}


To quantify the functioning of a country's legal system, we will draw on the four indices used in the work of Dhaliwal et al. (2012). These authors evaluate the legal environment mainly with respect to the protection of labour rights. The first index, called social security laws, is a numerical measure of the benefits of social security based on the benefits granted by the country due to illness, disability, unemployment, old age, and death. The second index, called human rights laws, is a numerical variable which refers to the protection of human rights. The third is entitled employment laws and is based on dismissal procedures, alternative contracts, and costs of increasing hours worked; it quantifies the protection of employment and the worker. The fourth is called the collective relations laws, which is also a numerical variable that captures the protection of collective relations based on union power and collective disputes. In addition, we use a final variable, civil law, taken from La Porta et al. (1998), for which countries governed by common law receive a value of 0 and those governed by civil law receive a value of 1 , since those countries governed by civil law present a stronger orientation towards their stakeholders (GarcíaSánchez et al., 2013; Amor-Esteban et al., 2017).

To evaluate government effectiveness in each country, we will use three indices, all of which are treated as numerical variables. The Economist Intelligence Unit's Democracy Index provides a global vision of the state of democracy based on five categories: electoral process and pluralism; civil liberties; the functioning of the government; political participation; and political culture. The Human Development Index (HDI) is an indicator of human development by country, prepared by the United Nations Development Programme (UNDP) based on three dimensions: health, education and standard of living. The Government Effectiveness Index developed by the Worldwide Governance Indicators (WGI) project measures the quality of public services, the civil service and its independence from political pressures, the quality of the formulation and implementation of policies, and the credibility of the government's commitment to established policies.

To evaluate culture, we use the Hofstede model because its grouping of dimensions highlights the similarities and cultural differences between countries (Hofstede and Hofstede, 2005). Culture can be defined as a collective programme of the mind, which is highly invisible, subconscious and difficult to change (Hofstede, 1983), that affects citizens' and businesses' behaviours (Vitell et al., 2003). The variables that we will use refer to the values of the six cultural dimensions proposed by Hofstede that are available on the Geert Hofstede ${ }^{\mathrm{TM}}$ cultural dimensions' website; all of these are numerical variables. In accordance with several studies, our measures will be: femininity, indulgence, uncertainty tolerance, collectivism, low power distance, and longterm orientation, because societies with high values in these variables promote the best CSR practices (Ringov and Zollo, 2007; Frías-Aceituno et al., 2013; García-Sánchez et al., 2016; Esteban et al., 2017).

In order to discover relationships between the NCSRPI and the measures of the institutional environments that characterise the countries, we use the HJ-biplot multivariate method (Galindo, 1986). The HJ-biplot is a multivariate graphical visualization of a $X_{n x p}$ matrix. Let $X=U D V^{\prime}$ the decomposition into singular values of $X$ with orthogonal matrices $U, V$ and $D=$ $\operatorname{diag}\left(\lambda_{1}, \ldots, \lambda_{p}\right)$ which contains the singular values. Let $J$ and $H$ the matrices of the first two columns of $U D$ and $V D$, respectively. The objective of this method is the simultaneous representation of the relationships between variables (columns, NCSRPI and institutional environment variables) as vectors and individuals (rows, countries) that are generally shown as points in a two-dimensional chart of the $\mathrm{X}$ data table. Consequently, by means of markers $h_{j}=$ $\left(h_{j}, \ldots, h_{p}\right)$ for columns and $j_{i}=\left(j_{i}, \ldots, j_{n}\right)$ for rows, both markers can be superimposed on the same reference system with optimal rendering quality.

A biplot is like a scatter diagram that shows the joint distribution of two variables, but actually represents three or more variables and, following the guidelines for its interpretation, this method allows us to: (i) know which characteristics of the institutional environment have a greater influence on CSR practices, examining the angles between vectors because acute angles translate into positive correlations; (ii) identify sets of countries and geographic zones with similar institutional characteristics - the similarity is associated with the proximity of the points in the plane; and (iii) characterise each country in relation to its environment and its score on the NCSRPI simultaneously through the orthogonal projections of the countries on the variables. 
In Fig. 3 the factorial plane 1-2 is represented, which collects about $60 \%$ of the information and obtains an optimal representation for countries and variables; we can see that all of these are separated from the centre of gravity. It should be noted that the civil law variable works as an illustrative variable, since it is a qualitative variable while the rest are numerical; that is, the subspace has been constructed and this variable is projected in order to compare its behaviour with the others. All these calculations were processed using MultBiplot software (VicenteVillardón, 2010).

The HJ-biplot representation provides an approximation of the values of the 29 countries studied in reference to the NCSRPI and the measures that evaluate the legal system, culture and government of these countries. In first place, we can see that most of these measures are positioned around the NCSRPI, which corroborates the influence of the institutional environment of the country of origin of the company in the development of CSR practices. More specifically, it is possible to determine that the pressures to adopt or improve CSR practices come mainly from strong legal systems, since these variables are located closest to the NCSRPI; thus, we have "employment laws", "civil law", "collective relations laws" and "social security laws". In reference to culture, we find more sustainable business behaviour in feminist societies and, to a lesser extent, in those countries with a low power distance and high values of indulgence. Finally, in relation to the government, the countries with a stronger democracy show better sustainable commitments; it should be noted that as we have only included countries from developed economies, the differences in the HDI scores (Human Development Index) and the Government Effectiveness index are very small and, therefore, we suspect that if we increase the number of sample countries, we would find a stronger relationship with the NCSRPI than the current one.

In relation to the countries, we have simply linked to visual effects those that are positioned closely and we have marked the projection of its centroid with the NCSRPI, distinguishing them in three colours that refer to the three columns of classification (see Table 7). The European countries demonstrate far more sustainability when compared with the rest of the world. Within Europe, the data point to greater activity in Northern Europe (Welford, 2005), where the Nordic countries present themselves as leaders in company sustainability, characterised by being feminist societies governed by civil law or by a historical tendency towards a more liberal democracy, where power is evenly distributed and strong measures are in place to protect the worker and social security benefits, in addition to being considered countries of high human development and high indulgence. Following the Nordic countries, we find the Netherlands and Switzerland which have similar characteristics. The next positions are occupied by Southern European countries (Spain, France and Italy), partly because they have weaker legal systems (García-Sánchez et al., 2016), but are distinguished by their strong measures in protection of collective and worker relations, as well as human rights; they are also considered feminist societies and are governed by civil law. Finally, the lowest scores were obtained by Belgium, Germany, and Austria. Germany is considered to be a CSR laggard compared with its European counterparts, since the country's high level of social integration and the favourable economic climate at the national level have contributed to reduced demand for CSR in the country, which is why German companies have maintained a widely ambivalent position towards CSR practices (Jackson and Apostolakou, 2010). This effect could be also applied to Scandinavian countries, which, in turn, are showed as leaders in the European CSR context. However, their differences could be explained by the existence of higher legal requirements (i.e., higher values in social securities laws) in Scandinavian countries. In this vein, Kinderman (2008) affirmed that, "the consequence of the stringent standards of binding regulation in Germany is that German business-led CSR takes on a distinctively libertarian meaning: responsibility yes, but in exchange for great freedom". In Germany, CSR initiatives have emerged alongside the discourse of shareholder value and have gone hand-in-hand with calls for deregulation or positions against social partnership.

In reference to the countries that are not part of the EU, all of them present scores close to 0 or negative (in the plane close to the origin of coordinates and in the opposite direction to the NCSRPI vector), except for Australia which is positioned above countries such as Spain. This may be due to the fact that its regulatory regime is similar to that found in some European countries - especially in relation to corporate transparency (Kimber and Lipton, 2005; Baughn et al., 2007) - and the United Kingdom (included in this group because his institutional 
characteristics are more similar to Australia and North America than to European countries), which has established guidelines for international CSR governance for its companies and organisations and which scores above Germany. Japan is presented as the country with the best CSR in the Asian continent with a positive score close to 0. Japan is geographically similar to South Korea - a country with a negative score - and both are considered collectivist societies with long-term orientations; however, Japan is governed by civil law and South Korea by common law. In the American continent, Canada presents the best practices, demonstrating a greater commitment than the United States; however, compared to the main European countries, both seem to lag far behind in relation to company sustainability issues. As other researchers have previously discovered from microdata (Welford, 2004; Matten and Moon, 2008; Purdy et al., 2010), these countries, together with Australia and the United Kingdom - the low area of the map - are characterised by a high level of human development, indulgence and great government effectiveness; however, these countries are governed by common law and its measures for the protection of the worker and collective relations are weak. In addition, these are not considered to be feminist societies. Of the other countries with the lowest NCSRPI scores, in the first quadrant we find India, China, Mexico, Turkey, Russia, and Thailand. In general terms, their low scores can be explained by the fact that although they are collectivist countries with long-term orientations, they are also characterised by being the least developed countries in the study, having low positions in the democracy index, with vertically stratified power, weak legal systems and little government effectiveness. In the fourth quadrant we find Malaysia, Singapore and Hong Kong. Although these countries have a high level of development, are collectivist societies and have a great uncertainty tolerance, they embody the worst practices in this study, which may be due to the fact that these countries are governed by common law, have imperfect democracies and an unequal distribution of power, pay little attention to worker protection and collective relations, and are not pro-feminist.

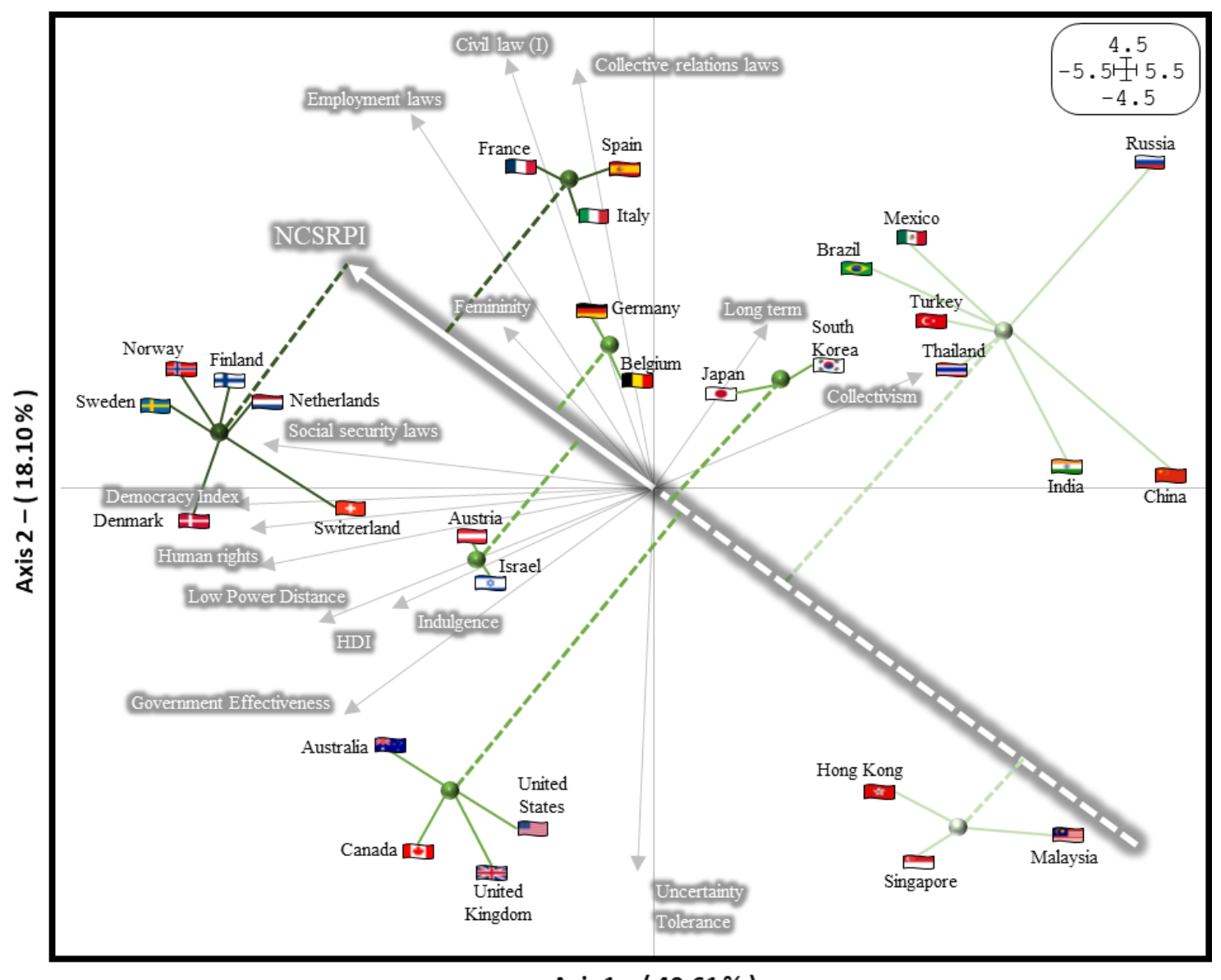

Axis $1-(40.61 \%)$

Fig. 3. Joint representation of the NCSRPI and Institutional Environments, factorial plane 1-2 of the HJ-biplot 
Then, with the purpose of studying whether the sampled countries grouped in four geographical areas show the same interest in social and environmental issues, we disaggregate information showing by continent the values in each of the practices that make up the index (Fig. 4), marked with on green the indicators on the protection of the environment; regarding to social issues, red denotes human rights advocacy, employee rights are in purple; concern over expectations of stakeholders is in orange; and business ethics are marked blue. These results show that companies around the world adopt similar patterns of behaviour in relation to their CSR practices, but with different levels of evolution, since, as we can see, the scheme obtained is similar for the four continents. The greatest similarity is found between Europe and Oceania, but this is because the values of Oceania are only the values of Australia, a country whose regulatory regime, as mentioned earlier, is similar to that found in some European countries; its schemes are those that present the strongest values since they are the leaders in issues of social responsibility. For the case of America, we find a smaller scheme, giving preference to ethical issues, and lastly the countries of Asia are shown as the most laggardly in this aspect.
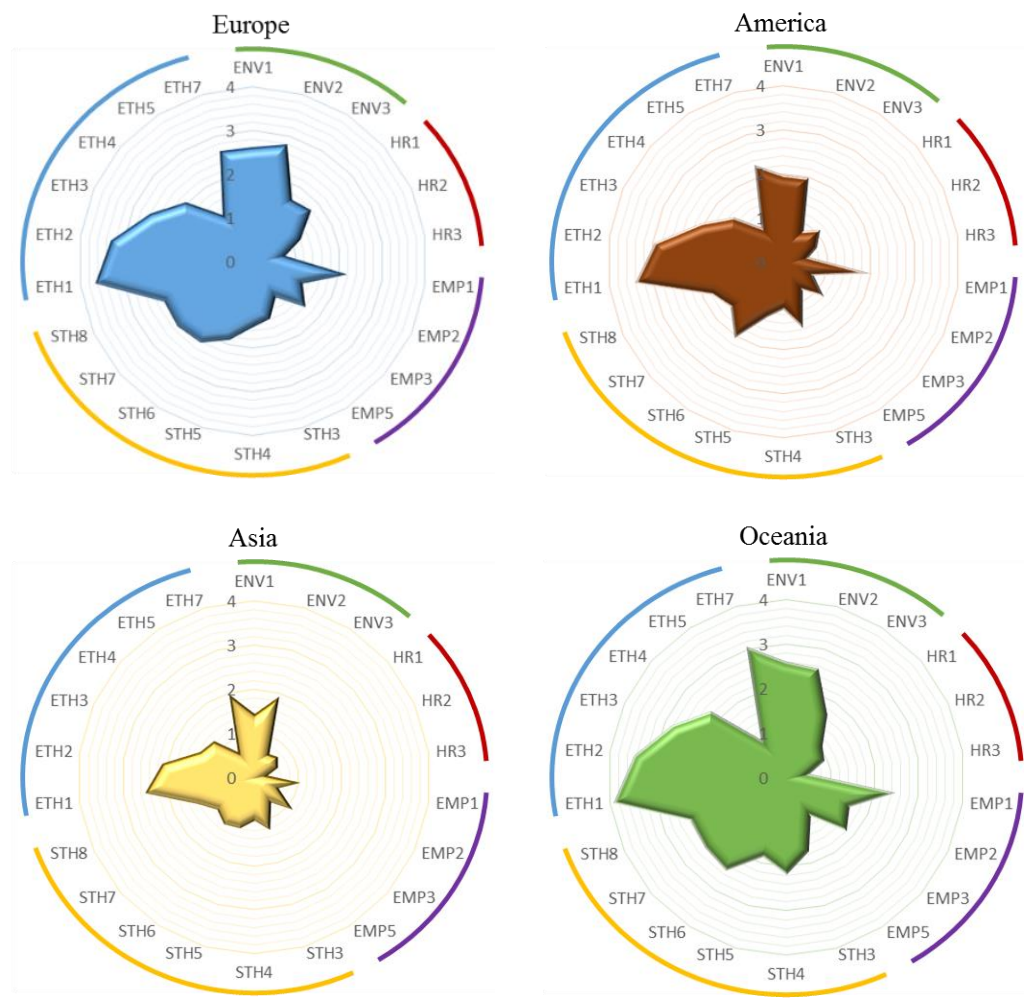

Fig. 4. Radial profiles by geographical area representing the CSR practices

The NCSRPI shows the heterogeneity of CSR in the 29 countries analysed, providing empirical conclusions on the degree to which institutions at country level influence the adoption or improvement of business sustainability. The differences or discrepancies between countries attributed to the variability of institutional efficiency (Chen and Bouvain, 2009; Jackson and Apostolakou, 2010) show that companies behave as economic units that operate within contexts composed by the union of a series of institutional conditions that impose different expectations on them defining their behaviour (Campbell et al., 1991). The principal discrepancies in the institutional conditions are in the different cultural, legal, socio-political and financial contexts (Aerts et al., 2006). From the perspective of neo-institutional theory, these differences imply different pressures on firms. Campbell (2006) argues that organizations in a strong institutional environment are more likely to behave in a socially responsible manner, as this determines whether corporations need to comply with the existing rules and the professional standards of their environment. Different pressures on companies could lead to changes in their behaviour (Campbell, 2007), including in respect of the disclosure of social and environmental information (Adelopo et al., 2013). In conclusion, the institutional environment in each country establishes 
for firms a series of opportunities and barriers in their decision to adopt or improve their CSR practices.

Finally, with the Fig. 5 represents the world map plotted according to NCSRPI scores. The darker the shade, the greater the commitment to sustainability of companies. The grey colour represents those countries that were not considered in the study.

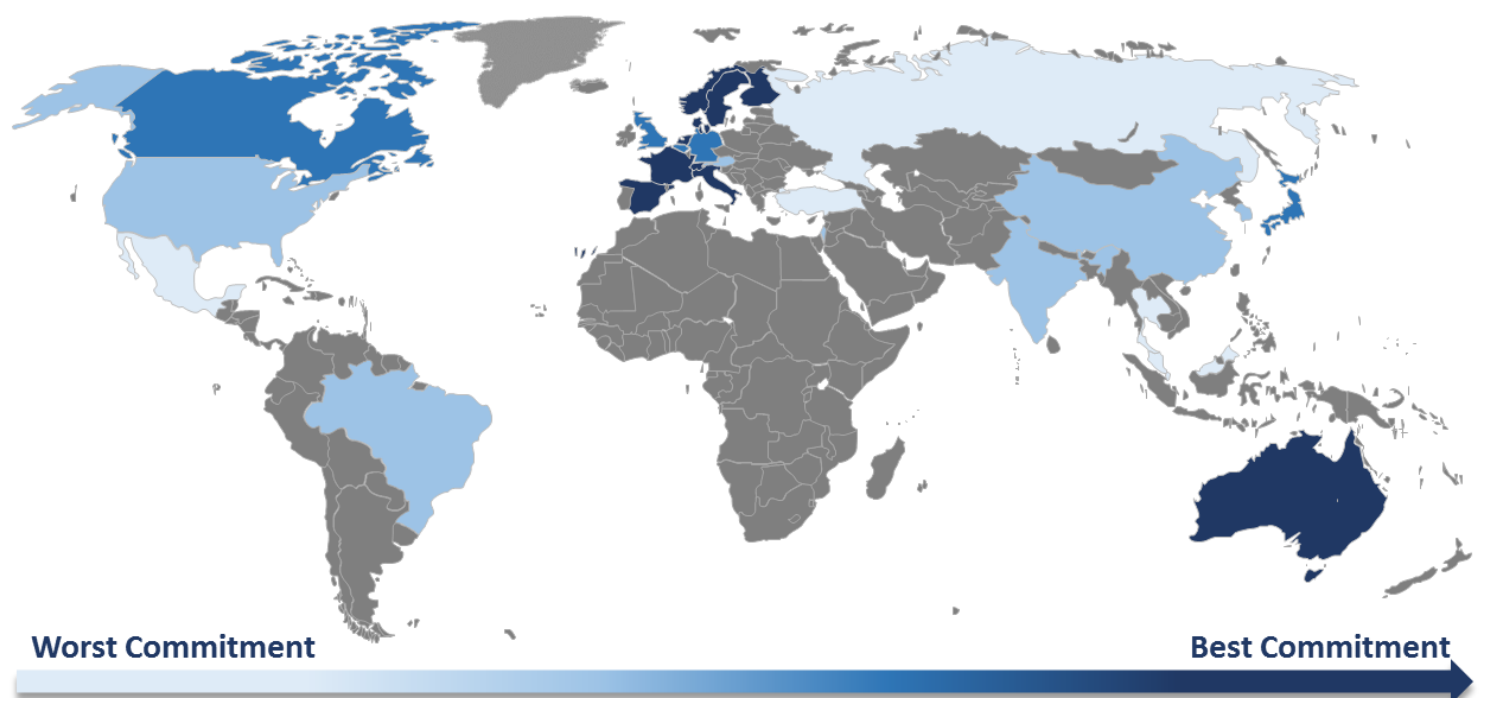

Fig. 5. NCSRPI world map (2014)

\section{Conclusions}

In this research, a National Corporate Social Responsibility Practices Index (NCSRPI) was designed to measure national corporate social responsibility, consisting of the aggregation of 22 practices coming from five CSR dimensions. The NCSRPI is a tool built to assess national company sustainability management by providing relevant information to assist the stakeholder in making decisions based on countries' CSR commitment, identifying the strengths and weaknesses in the national sustainability systems to recognize where is most necessary adopt or improve the CSR policies and systems.

In addition, this study tries to shed light on the heterogeneity of CSR in 29 countries and concludes that the discrepancies between countries are due to the variability of institutional efficiency, since the institutional environment in each country establishes for its firms a series of opportunities and barriers in their decision to adopt or improve their CSR practices.

In general, our results show that companies around the world adopt similar patterns of behaviour respect to their CSR practices, but with different levels of evolution. Thus, European countries present themselves as the leaders in issues of social responsibility, the countries of America give preference to ethical issues, and countries belonging to the Asian continent, specifically to Southeast Asia, are shown to be the most laggardly in this regard.

We conclude that commitment to company sustainability is related mainly to the development of the country's legal system orientation with regard to labour rights; thus, the countries of northern Europe, specifically the Nordic countries, lead the ranking, because they are recognised for their historical trend towards a more liberal democracy. The Nordic countries are followed by the Netherlands, Switzerland, and Australia, which present a regulatory regime in accordance with those found in some European countries. In the central part of the ranking stands Germany, a country considered to be a CSR laggard in comparison with other European countries. Japan is the country with the best CSR practices in Asia; its firms show a greater commitment to environmental protection. Canada, the country with the highest commitment to sustainability in North America has similar practices to the USA, but shows greater commitment; however, both seem to be far behind in comparison with the major European countries in this regard. The rest of the countries in the ranking seem to be far behind in sustainability measures, with those in 
Southeast Asia (Thailand, Malaysia, Singapore, Hong Kong) having the lowest sustainability commitment and the worst practices.

Our NCSRPI is also useful for public administrations and companies. An aggregate indicator of CSR practices for each country is an essential tool for politicians and public managers in decision-making processes. Specifically, the NCSRPI provides information on the business reality, allowing observation of the economic, social and environmental progress of each country, facilitating projection in the medium and long terms. The availability of these data allows the identification of the structural drivers of growth and the establishment of priorities that allow the design of more effective policies that compel company sustainability. Also, countries that have a CSR business behaviour deficit could design actions to overcome those deficiencies.

On the other hand, the information provided makes it possible to carry out a benchmarking analysis of economic, environmental and social performances in different countries, favouring processes that aim to discover the actions that lead to a greater commitment to CSR. These analyses can be used by - in addition to politicians and business leaders - managers of companies in their own strategic decisions about CSR and for understanding the existing pressures on the social and environmental commitments of those foreign markets in which they decide to diversify their business activities.

\section{References}

Aaronson, S.A. (2003). Corporate responsibility in the global village: The British role model and the American laggard. Bus. Soc. Rev. 108, 309-338.

Adelopo, I., Moure, R.C., Obalola, M. (2013). On the Effects of Legal and Cultural Institutions on Corporate Social Disclosures by Banks. Leicester, De Montfort University.

Aerts, W., Cormier, D., Magnan, M. (2006). Intra-industry imitation in corporate environmental reporting: An international perspective. J. Account. Public Policy 25, 299-331.

Aguilera, R.V., Rupp, D.E., Williams, C.A., Ganapathi, J. (2007). Putting the S back in corporate social responsibility: A multilevel theory of social change in organizations. Acad. Manage. Rev. 32, 836863.

Amann, B., Caby, J., Jaussaud, J., Pineiro, J. (2007). Shareholder activism for corporate social responsibility: Law and practice in the United States, Japan, France and Spain. New Corp. Account.-Corp. Soc. Responsib. Law.

Amor-Esteban, V., García-Sánchez, I.-M., Galindo-Villardón, M.-P. (2017). Analysing the Effect of Legal System on Corporate Social Responsibility (CSR) at the Country Level, from a Multivariate Perspective. Soc. Indic. Res. 1-18.

Ariztía, T., Kleine, D., Maria das Graças, S.L., Agloni, N., Afonso, R., Bartholo, R. (2014). Ethical consumption in Brazil and Chile: Institutional contexts and development trajectories. J. Clean. Prod. 63, 84-92.

Bansal, P., Roth, K. (2000). Why companies go green: A model of ecological responsiveness. Acad. Manage. J. 43, 717-736.

Barnea, A., Rubin, A. (2010). Corporate Social Responsibility as a Conflict Between Shareholders. J. Bus. Ethics 97, 71-86. https://doi.org/10.1007/s10551-010-0496-z.

Baskin, J. (2006). Corporate responsibility in emerging markets. J. Corp. Citizsh. 24, 29-47.

Baughn, C.C., Bodie, N.L., McIntosh, J.C. (2007). Corporate social and environmental responsibility in Asian countries and other geographical regions. Corp. Soc. Responsib. Environ. Manag. 14, 189205. https://doi.org/10.1002/csr.160.

Boudt, K., Cornelissen, J., Croux, C. (2013). The impact of a sustainability constraint on the mean-tracking error efficient frontier. Econ. Lett. 119, 255-260. https://doi.org/10.1016/j.econlet.2013.03.020.

Browne, M.W., Cudeck, R., Bollen, K.A., Long, J.S. (1993). Alternative ways of assessing model fit. Sage Focus Ed. 154, 136-136.

Campbell, J.L. (2007). Why would corporations behave in socially responsible ways? An institutional theory of corporate social responsibility. Acad. Manage. Rev. 32, 946-967. https://doi.org/10.5465/AMR.2007.25275684.

Campbell, J.L. (2006). Institutional Analysis and the Paradox of Corporate Social Responsibility. Am. Behav. Sci. 49, 925-938. https://doi.org/10.1177/0002764205285172.

Campbell, J.L., Hollingsworth, J.R., Lindberg, L.N. (1991). Governance of the American economy. (Vol. 5). Cambridge University Press. 
Carroll, A.B. (1999). Corporate social responsibility evolution of a definitional construct. Bus. Soc. 38, 268-295.

Casey, R.J., Grenier, J.H. (2014). Understanding and contributing to the enigma of corporate social responsibility (CSR) assurance in the United States. Audit. J. Pract. Theory 34, 97-130.

Chen, S., Bouvain, P. (2009). Is Corporate Responsibility Converging? A Comparison of Corporate Responsibility Reporting in the USA, UK, Australia, and Germany. J. Bus. Ethics 87, 299-317. https://doi.org/10.1007/s10551-008-9794-0.

Colwell, S.R., Joshi, A.W. (2013). Corporate ecological responsiveness: Antecedent effects of institutional pressure and top management commitment and their impact on organizational performance. Bus. Strategy Environ. 22, 73-91.

Cuadrado-Ballesteros, B., García-Sánchez, I.-M., Martínez-Ferrero, J. (2017). The impact of board structure on CSR practices on the international scale. Eur. J. Int. Manag. 11, 633-659.

Demirbag, M., Wood, G., Makhmadshoev, D., Rymkevich, O. (2017). Varieties of CSR: institutions and socially responsible behaviour. Int. Bus. Rev. 26(6), 1064-1074.

Dhaliwal, D.S., Radhakrishnan, S., Tsang, A., Yang, Y.G. (2012). Nonfinancial disclosure and analyst forecast accuracy: International evidence on corporate social responsibility disclosure. Account. Rev. 87, 723-759.

Dobbie, M.J., Dail, D. (2013). Robustness and sensitivity of weighting and aggregation in constructing composite indices. Ecol. Indic. 29, 270-277.

Duran, J.J., Bajo, N. (2014). Institutions as determinant factors of corporate responsibility strategies of multinational firms. Corp. Soc. Responsib. Environ. Manag. 21, 301-317.

Edelman, L.B., Suchman, M.C. (1997). The legal environments of organizations. Annu. Rev. Sociol. 23, 479-515.

Ekelenburg, M.V. (2016). Determinants of voluntary external assurance on corporate sustainability reports: A comparison between Europe and North America. Netherlands, Radboud University.

Esteban, V.A., Villardon, M.P.G., Sánchez, I.M.G. (2017). Cultural values on CSR patterns and evolution: A study from the biplot representation. Ecol. Indic. 81, 18-29. https://doi.org/10.1016/j.ecolind.2017.05.051.

Florini, A., Saleem, S. (2011). Information disclosure in global energy governance. Glob. Policy 2, 144154.

Freudenberg, M. (2003). Composite indicators of country performance.

Frías-Aceituno, J., Rodríguez-Ariza, L., González-Bravo, M.-I. (2013). The Effect of Societal Values on Local Government Transparency: Applying Hofstede's Cultural Dimmensions. Lex Localis - J. Local Self-Gov. 11. https://doi.org/10.4335/11.4.829-850(2013).

Galindo, M.P. (1986). Una alternativa de representacion simultanea: HJ-Biplot. Qüestiió 10(1), 13-23.

Gallego-Álvarez, I., Ortas, E. (2017). Corporate environmental sustainability reporting in the context of national cultures: A quantile regression approach. Int. Bus. Rev. 26, 337-353.

García-Sánchez, I.-M., Cuadrado-Ballesteros, B., Frías-Aceituno, J.-V. (2016). Impact of the Institutional Macro Context on the Voluntary Disclosure of CSR Information. Long Range Plann. 49, 15-35. https://doi.org/10.1016/j.lrp.2015.02.004.

García-Sánchez, I.-M., García-Meca, E. (2017). CSR engagement and earnings quality in banks. The moderating role of institutional factors. Corp. Soc. Responsib. Environ. Manag. 24, 145-158.

García-Sánchez, I.-M., Rodríguez-Ariza, L., Frías-Aceituno, J.-V. (2013). The cultural system and integrated reporting. Int. Bus. Rev. 22, 828-838. https://doi.org/10.1016/j.ibusrev.2013.01.007.

Gjølberg, M. (2009). Measuring the immeasurable? Scand. J. Manag. 25, 10-22. https://doi.org/10.1016/j.scaman.2008.10.003.

Grauel, J., Gotthardt, D. (2016). The relevance of national contexts for carbon disclosure decisions of stocklisted companies: a multilevel analysis. J. Clean. Prod. 133, 1204-1217.

Guthrie, D., McQuarrie, M. (2004). Corporate investment, social innovation, and community change: the local political economy of low-income housing development. N. Y. Univ.

Habisch, A., Jonker, J., Wegner, M., Schmidpeter, R. (2005). Corporate social responsibility across Europe. Springer Science \& Business Media.

Halkos, G., Skouloudis, A. (2016). National CSR and institutional conditions: An exploratory study. J. Clean. Prod. 139, 1150-1156. https://doi.org/10.1016/j.jclepro.2016.07.047.

Hofstede, G. (1983). The Cultural Relativity of Organizational Practices and Theories. J. Int. Bus. Stud. 14, 75-89. https://doi.org/10.1057/palgrave.jibs.8490867.

Hofstede, G., Hofstede, G.J. (2005). Cultures and Organizations, Software of the Mind: Intercultural Cooperation and Its Importance for Survival, McGraw-Hill: London, New Delhi, New York.

Horton, N.J., Lipsitz, S.R. (2001). Multiple imputation in practice: comparison of software packages for regression models with missing variables. Am. Stat. 55, 244-254. 
Hu, L., Bentler, P.M. (1999). Cutoff criteria for fit indexes in covariance structure analysis: Conventional criteria versus new alternatives. Struct. Equ. Model. Multidiscip. J. 6, 1-55.

Jackson, G., Apostolakou, A. (2010). Corporate Social Responsibility in Western Europe: An Institutional Mirror or Substitute? J. Bus. Ethics 94, 371-394. https://doi.org/10.1007/s10551-009-0269-8.

Jamali, D., Sidani, Y., El-Asmar, K. (2009). A three country comparative analysis of managerial CSR perspectives: Insights from Lebanon, Syria and Jordan. J. Bus. Ethics 85, 173-192.

Kimber, D., Lipton, P. (2005). Corporate governance and business ethics in the Asia-Pacific region. Bus. Soc. $44,178-210$.

Kinderman, D.P. (2008). The Political Economy of Corporate Responsibility in Germany, 1995-2008. SSRN Electron. J. https://doi.org/10.2139/ssrn.2229690

Kolk, A., Perego, P. (2010). Determinants of the adoption of sustainability assurance statements: An international investigation. Bus. Strategy Environ. 19(3), 182-198.

La Porta, R., Lopez-de-Silanes, F., Shleifer, A., Vishny, R. W., Levitt, S. D., Andreoni, J., et al. (1998). Law and finance law and finance. J. Polit. Econ. 106, 1113-1155.

Lenssen, G., Gasdparski, W., Rok, B., Lacy, P., Midttun, A., Gautesen, K., Gjølberg, M. (2006). The political economy of CSR in Western Europe. Corp. Gov. Int. J. Bus. Soc. 6, 369-385.

León, J.Á.P. (2015). Análisis de la relación causal de la responsabilidad social corporativa y la performance financiera de las empresas. https://doi.org/10.4995/Thesis/10251/48517.

Maignan, I., Ralston, D.A. (2002). Corporate social responsibility in Europe and the US: Insights from businesses' self-presentations. J. Int. Bus. Stud. 33, 497-514.

Mar Miras-Rodríguez, M., Carrasco-Gallego, A., Escobar-Pérez, B. (2015). Are socially responsible behaviours paid off equally? A Cross-cultural analysis. Corp. Soc. Responsib. Environ. Manag. 22, 237-256.

Martínez Arias, R., Hernández-Lloreda, M.J., Hernández-Lloreda, M.V. (2006). Psicometría. Madr. Alianza Editor.

Martínez-Ferrero, J., García-Sánchez, I.-M. (2016). Coercive, normative and mimetic isomorphism as determinants of the voluntary assurance of sustainability reports. Int. Bus. Rev. 26(1), 102-118. https://doi.org/10.1016/j.ibusrev.2016.05.009.

Masahiko, A. (1988). Information, Incentives, and bargaining in the Japanese Economy. New York, Cambridge University Press.

Matten, D., Moon, J. (2008). "Implicit" and "explicit" CSR: a conceptual framework for a comparative understanding of corporate social responsibility. Acad. Manage. Rev. 33, 404-424.

Matten, D., Moon, J. (2004). Implicit and explicit CSR. A conceptual framework to understand CSR in Europe. ICCSR Res. Pap. Ser. 29.

Muṇiz, J. (1997). Introducción a la teoría de respuesta a los ítems [Introduction to item response theory]. Madr. Pirámide.

Nardo, M., Saisana, M., Saltelli, A., Tarantola, S. (2005). A Tools for Composite Indicators Building. Joint Research Centre European Commission. Inst. Prot. Secur. Citiz. Econom. Stat. Support Antifraud Unit Ispra.

OECD (2008). Handbook on constructing composite indicators: Methodology and user guide. OECD publishing.

Ortas, E., Álvarez, I., Jaussaud, J., Garayar, A. (2015). The impact of institutional and social context on corporate environmental, social and governance performance of companies committed to voluntary corporate social responsibility initiatives. J. Clean. Prod. 108, 673-684. https://doi.org/10.1016/j.jclepro.2015.06.089.

Paruolo, P., Saisana, M., Saltelli, A. (2013). Ratings and rankings: voodoo or science? J. R. Stat. Soc. Ser. A Stat. Soc. 176, 609-634.

Purdy, J.M., Alexander, E.A., Neill, S. (2010). The impact of national institutional context on social practices: Comparing Finnish and US business communities. Eur. J. Int. Manag. 4, 234-256.

Ringov, D., Zollo, M. (2007). The impact of national culture on corporate social performance. Corp. Gov. Int. J. Bus. Soc. 7, 476-485. https://doi.org/10.1108/14720700710820551.

Rodriguez-Dominguez, L., Gallego-Alvarez, I., García-Sánchez, I.M. (2009). Corporate governance and codes of ethics. J. Bus. Ethics 90, 187.

Ruggie, J.G. (2008). Taking embedded liberalism global: The corporate connection. Embed. Glob. Mark. Endur. Chall. 231-238.

Samejima, F. (1972). A general model for free-response data. Psychom. Monogr. Suppl.

Samejima, F. (1969). Estimation of latent ability using a response pattern of graded scores. Psychom. Monogr. Suppl.

Searcy, C. (2014). Measuring enterprise sustainability. Bus. Strategy Environ. 25(2), 120-133. 
Semenova, N., Hassel, L.G. (2008). Financial outcomes of environmental risk and opportunity for US companies. Sustain. Dev. 16, 195-212.

Skouloudis, A., Isaac, D., Evaggelinos, K. (2016). Revisiting the national corporate social responsibility index. Int. J. Sustain. Dev. World Ecol. 23, 61-70.

Soto, H., Schuschny, A.R. (2009). Guía metodológica: Diseño de indicadores compuestos de desarrollo sostenible.

Thissen, D. (1991). MULTILOG: Multiple Category Item Analysis and test scoring using Item Response Theory (Version 7.0. 3). Chicago, IL: Scientific Software International. Inc.

Van Beurden, P., Gössling, T. (2008). The worth of values-a literature review on the relation between corporate social and financial performance. J. Bus. Ethics 82, 407.

Van Der Linden, W.J., Hambleton, R.K. (1997). Item response theory: Brief history, common models, and extensions, in: Handbook of Modern Item Response Theory. Springer, pp. 1-28.

Vicente-Villardón, J.L. (2010). MULTBIPLOT: A package for multivariate analysis using biplots. Mathlab Softw. Biplot Usal EsClassicalBiplotindex Html.

Vitell, S. J., Paolillo, J. G., \& Thomas, J. L. (2003). The Perceived Role of Ethics and Social Responsibility: A Study of Marketing Professionals. Bus. Ethics Q. 13, 63-86. https://doi.org/10.5840/beq20031315.

Welford, R. (2005). Corporate social responsibility in Europe, North America and Asia: 2004 survey results. J. Corp. Citizsh. 17, 33-52.

Welford, R. (2004). Corporate social responsibility in Europe and Asia: Critical elements and best practice. J. Corp. Citizsh. 13, 31.

Witt, M.A., Redding, G. (2011). The spirits of corporate social responsibility: Senior executive perceptions of the role of the firm in society in Germany, Hong Kong, Japan, South Korea and the USA. SocioEcon. Rev. 10, 109-134.

Wood, D.J. (2010). Measuring corporate social performance: A review. Int. J. Manag. Rev. 12, 50-84.

Yu, C.Y., Muthen, B. (2002). Evaluation of model fit indices for latent variable models with categorical and continuous outcomes, in: Annual Meeting of the American Educational Research Association, New Orleans, LA. 




\section{Capítulo V}

\section{Consistencia y Robustez de los Indicadores Nacionales de Sostenibilidad Empresarial}

El concepto de responsabilidad social empresarial ha adquirido una creciente atención a nivel mundial expandiéndose de forma exponencial a lo largo de las últimas décadas. La extensa literatura se refiere principalmente al análisis a nivel de empresa dentro de un país y hay investigaciones limitadas a nivel inter-países. Si bien existe una extensa literatura de casos de estudio a nivel nacional sobre los aspectos específicos de la RSC, es escasa la literatura sobre la composición de un índice de RSC a nivel país que permita comparaciones significativas entre países. Los autores más trascendentes en esta corriente fueron Lenssen et al. $(2006)^{1}$ pioneros en la creación de un indicador nacional de RSC apoyado en la correlación de las instituciones económicas y políticas nacionales con los modelos de RSC resultantes, a través de un conjunto de ítems agrupados en cuatro categorías. En esta línea, Gjølberg $(2009)^{2}$ construye un indicador nacional basado en nueve iniciativas líderes y globales de RSC y veinte países. Skouloudis et al. $(2016)^{3}$ amplían el índice de Gjølberg trabajando con países de todas las regiones geográficas del mundo en el año 2012 para evaluar la RSC nacional y observan una gran variación entre países, donde la mayoría se presentan como países rezagados en relación con las iniciativas globales de RSC, lo que se traduce en una penetración de RSC deficiente. Nombraron a este índice NCSRI (National Corporate Social Responsibility Index).

Basándonos en su trabajo, actualizamos este índice para el año 2014. Siguiendo el proceso metodológico, el NCSRI compuesto se basa en datos nacionales sobre la suscripción, participación o inclusión en 16 iniciativas internacionales de RSC (ej.: Carbon Disclosure Project, Dow Jones Sustainability World Enlarged Index, FTSE4Good Global Index etc.), esto es, el número de empresas por país que ratifican o cumplen el estándar de la iniciativa. Esta información se calcula con el objetivo de realizar un estudio comparativo con el índice propuesto en el capítulo anterior, el NCSRPI (National Corporate Social Responsibility Practices Index). El NCSRPI se construye a través de un proceso de agregación estadística de 22 prácticas de RSC categorizadas en las dimensiones social y ambiental que se observan individualmente para cada empresa.

Previamente al estudio comparativo, se corrobora la utilidad del NCSRI creado para el año 2014, estudiando el grado de coherencia con el índice anterior creado para el 2012. Los resultados

\footnotetext{
${ }^{1}$ Lenssen, G., Gasdparski, W., Rok, B., Lacy, P., Midttun, A., Gautesen, K., Gjølberg, M. (2006). The political economy of CSR in Western Europe. Corp. Gov. Int. J. Bus. Soc. 6, 369-385.

${ }^{2}$ Gjølberg, M. (2009). Measuring the immeasurable? Scand. J. Manag. 25, 10-22. https://doi.org/10.1016/j.scaman.2008.10.003.

${ }^{3}$ Skouloudis, A., Isaac, D., Evaggelinos, K. (2016). Revisiting the national corporate social responsibility index. Int. J. Sustain. Dev. World Ecol. 23, 61-70.
} 
muestran un alto grado de similitud, manteniéndose la estructura central con ligeros cambios; entre ellos, el aumento de la proporción de empresas activas en RSC durante estos dos años. Como siguiente paso se comparan estos resultados con el índice formado por las prácticas de RSC que hemos propuesto en el capítulo previo, el NCSRPI. Los resultados evidencian fuertes similitudes entre ambos índices, con un alto grado de correlación, por ello, el siguiente objetivo de la investigación es profundizar en estos índices estudiando la estructura dentro de cada uno de ellos.

En base a métodos estadísticos exploratorios, como el HJ-biplot, el cual nos permite aproximar un gran grupo de variables en un espacio de baja dimensión proporcionándonos una visualización útil de la estructura de los datos, se estudia el comportamiento de estos índices en función de las variables empleadas por el otro. Se realiza una representación biplot de cada uno de los índices de manera interna:

(i) se representan los valores que toman los países en cada una de las 16 iniciativas internacionales de RSC y, sobre este subespacio creado se proyecta de forma ilustrativa el índice de prácticas de RSC -el NCSRPI- de manera que podemos observar qué iniciativas son capaces de explicar la estructura encontrada en el índice de prácticas. Los resultados muestran que el NCSRPI se siente mayormente identificado con la certificación ISO 14001 (estándar de gestión ambiental), la norma OHSAS 18001 (sistema de gestión de seguridad y salud ocupacional), el WBCSD (World Business Council for Sustainable Development, organización global dirigida por los CEO de más de 200 empresas líderes), el Global Compact (derechos humanos, leyes laborales y medidas anticorrupción), y el GRI (Global Reporting Initiative, hace referencia al cambio climático, los derechos humanos, la gobernanza y el bienestar social).

(ii) se representan los valores que toman los países en cada una de las 22 prácticas de RSC $\mathrm{y}$, sobre este subespacio creado se proyecta de forma ilustrativa el índice de iniciativas de RSC el NCSRI- de manera que podemos observar qué prácticas de RSC son capaces de explicar la estructura encontrada en el índice de iniciativas. Los resultados muestran que el NCSRI se siente principalmente identificado con los sistemas de gestión, como son los dirigidos a la igualdad de oportunidades y fomento de la diversidad; los designados a los problemas ambientales; los orientados a la gestión de los stakeholders; los destinados a la seguridad y salud laboral; sistemas y reportes en la lucha contra el soborno y a favor de la implantación de códigos éticos. Las políticas e informes reciben menor importancia.

Estos hallazgos demuestran la utilidad de los indicadores nacionales de sostenibilidad para facilitar la planificación de varias acciones de mejora y proporcionar información relevante sobre temas ambientales y sociales para guiar a los gerentes o partes interesadas en sus procesos de toma de decisiones. A su vez, facilitan un ranking de países y el desarrollo de procesos benchmarking asociados a un conjunto de componentes agregados relacionados con temas de sostenibilidad, como son la preservación del medioambiente, la defensa de los derechos humanos y laborales, las relaciones externas de la organización y, la ética empresarial, que colectivamente evidencian el estado de compromiso y desarrollo de la RSC y describen el nivel de conducta empresarial responsable entre países, lo cual permite identificar los países más deficientes en términos de sus sistemas de sostenibilidad y, poder aplicar las medidas correctas para superar dichas deficiencias. A nivel de empresa, estos resultados facilitan la comprensión de las diferentes presiones para el comportamiento social y ambiental en los diversos mercados extranjeros.

En este sentido, otorgamos una mayor utilidad y funcionalidad al índice de prácticas sostenibles NCSRPI, ya que, evalúa la sostenibilidad de la empresa de una manera más precisa a la inclusión o no en iniciativas internacionales -NCSRI-. Por tanto, situamos al índice de prácticas NCSRPI un paso por delante en tal aspecto, dado que, facilita no solo el conocimiento de las prácticas específicas llevadas a cabo sino también su nivel de compromiso en cada una de éstas a partir de una escala de 0-4, siendo 0-inadecuado y 4-excepcional. De este modo, el análisis profundo e individual de las prácticas permite el conocimiento de las presiones sobre el compromiso ambiental y social en los diferentes países y, se convierte en una herramienta esencial para el diseño y la elección correcta del enfoque en los procesos regulatorios hacia la promoción de políticas que mejoren el comportamiento empresarial sostenible.

A continuación, presentamos toda esta información detallada de manera extensa en el artículo de investigación "Consistency and Robustness of the National Indicators of Business Sustainability through a Multivariate Vision" actualmente en proceso de elaboración. 
Research paper in elaboration process:

Title: Consistency and Robustness of the National Indicators of Business Sustainability through a Multivariate Vision

Authors: Víctor Amor-Esteban

Ma'-Purificación Galindo-Villardón

Isabel-María García-Sánchez

Journal: in elaboration process

*The paper is numbered independently and includes pages 149-162 (14) of the global document. 



\title{
Consistency and Robustness of the National Indicators of Business Sustainability through a Multivariate Vision
}

\begin{abstract}
This research compares the usefulness and structure of two national composite corporate sustainability indicators, (i) the NCSRI (National Corporate Social Responsibility Index), based on national data on subscription, participation or inclusion in 16 international CSR initiatives and (ii) the NCSRPI (National Corporate Social Responsibility Practices Index), based on 22 real sustainability practices categorized in the social and environmental dimensions. Methodologically, both proposals present a similar structure, with a high degree of correlation that facilitates a ranking of countries and the development of benchmarking processes associated with a set of aggregate components related to sustainability issues that collectively demonstrate the state of commitment and development of CSR and describe the level of responsible business conduct between countries.

It is demonstrated that these indices allow, with a macro approach that goes beyond the level of the company as a unit of analysis, a global understanding of the development of CSR with respect to the national environment, avoiding important problems associated with the lack of data and comparative analyses that systematically link CSR with national political-economic contexts. In turn, both indices show that European countries and Australia are the most advanced in terms of sustainability and within them, the Nordic countries demonstrate the most activity and stronger practices; the remaining countries show weak practices presenting a poor penetration of CSR.
\end{abstract}

Keywords: corporate social responsibility (CSR); national CSR; composite index; sustainable development; stakeholder engagement; multivariate statistics.

\section{Introduction}

The concept of corporate social responsibility (CSR) has gained increasing attention worldwide, expanding exponentially over the last decades (Wood, 2010). The extensive literature refers mainly to company-level analysis within a country and there is limited research at intercountry level. Why are companies in some countries more socially responsible than companies in other countries?

Institutional theory sees corporations as embedded in a nexus of formal and informal rules (North, 1990) imposed by a network of institutions that affect their behaviour and impose expectations on them (Campbell, 2007). Thus, a comparative analysis between countries allows introducing the effect of the country as a significant institutional dimension.

Comparative studies that address CSR issues have found substantial differences in CSR practices between countries, systematically explained by coercive and normative institutional pressures (Esteban et al., 2017; García-Sánchez and García-Meca, 2017; García-Sánchez et al., 2016; Mar Miras-Rodríguez et al., 2015; Duran and Bajo, 2014; Colwell and Joshi, 2013), These studies show that a macro institutional context with a strong development of their cultural values and the functionality of the legal system improve company sustainability in social and environmental dimensions; thus, in function of the differences in institutional efficiency, organizations from different countries show discrepancies in their CSR levels, moreover, corporations from countries with parallel institutional characteristics present similar sustainability commitments.

Based on this evidence, certain academics - Halkos and Skouloudis (2016), Skouloudis et al. (2016), Gjølberg (2009) and Lenssen et al. (2006) - adopted a different approach, analysing the role that institutional context plays on CSR penetration by the construction of a national CSR index that allows to observe the aggregate variation of CSR explained by the relation to the institutional conditions that distinguish the national identity of each country, known as the National Corporate Social Responsibility Index (NCSRI). These indicators are based on national data on the subscription, inclusion or participation in diverse international CSR initiatives; later, 
a new national index dealing with real sustainability practices is proposed, but with a limited number of countries, called as the National Corporate Social Responsibility Practices Index (NCSRPI) (detailed in the previous chapter).

The objective of this research is to verify the convergence and utility of these national sustainability indexes, since they avoid important problems associated with the lack of data and comparative analysis that systematically link CSR with national political-economic contexts. Also, based on exploratory statistical methods, such as the HJ-biplot, which facilitates an approximate in a low-dimensional space of a large group of variables providing us with a useful visualization of the structure of the data, we will study the behaviour of each index in reference to the variables used by the other, highlighting the strongest associations between CSR practices and the NCSRI; as well as emphasizing the correlations between international CSR initiatives and the NCSRPI.

\section{NCSRI and NCSRPI - National Indicators of Business Sustainability}

Although there is an extensive literature of case studies at the national level on the specific aspects of CSR, there is little literature on the composition of a CSR index at the country level that allows meaningful comparisons between countries (Skouloudis and Evangelinos, 2012). The most momentous authors in this stream were Lenssen et al. (2006) pioneers in the creation of a national CSR indicator supported by the correlation of national economic and political institutions with the resulting CSR models, through a set of items grouped into four categories. In a similar vein, Gjølberg (2009), builds a national indicator based on nine leading and global CSR initiatives and twenty countries. Skouloudis et al. (2016) expand the Gjølberg index by working with countries from all geographic regions of the world in 2012 to assess national CSR and observe a great variation among countries, where most of them appear as lagging countries in relation to global CSR initiatives; which translates as a poor CSR penetration.

Based on their work, we update this index for 2014. Following the methodological process, the composite NCSRI is based on national data on subscription, inclusion or participation in 16 international CSR initiatives (see Annex A), best-in-class indices, social and environmental standards and ethical investment indices (Carbon Disclosure Project, Dow Jones Sustainability World Enlarged Index, ECPI Global ESG Alpha Equity Index, Ethibel Sustainability Index, FTSE4Good Global Index, Global 100 Most Sustainable Corporations, Global Compact, Global Reporting Initiative, Greenhouse Gas Protocol, ISO 14001, KPMG triennial survey on CSR reporting, MSCI World ESG Index, OHSAS 18001, SA 8000, World Business Council for Sustainable Development, World's Most Ethical Companies). Each of these 'components' is calculated by the number of companies per country that ratify the specific CSR 'variable' and a 'limit value' of inclusion in at least four CSR 'sub-indices' (that is, the ratings of countries that appeared in less than four initiatives were excluded from the analysis). This gave rise to a global vision of sustainability in relation to the CSR penetration in 83 countries around the world.

For the construction of the aggregate indicator, the ratio between the number of corporations in each country and the total number of organizations in the 83 countries was calculated for each of the aforementioned sub-indices (variables). Then, with the aim of correcting and normalizing these relations, they are divided by the GDP ratio of each country and the GDP of the 83 countries. In the next step, with the aim of preserving the variation between them and avoiding biased results, the ratios obtained by countries are transformed using the natural logarithm of these values. Finally, the values by country in each of the 16 CSR initiatives is aggregated through a summation and we already have the aggregated values of national sustainability (Equation 1).

National CSR Index

$$
=\sum_{i=1}^{16}\left(\frac{\frac{\text { Number of companies in indicator } X_{i} \text { from country } A}{\text { Total Number of companies in indicator } X_{i} \text { from all sample countries }}}{\frac{G D P \text { PPP country } A}{\text { Total GDP PPP of all sample countries }}}\right)
$$


Following this line of research, a National Corporate Social Responsibility Practices Index (NCSRPI) is proposed in the previous chapter, which determines the level of CSR penetration formed by the real sustainability practices of a sample of 1,459 companies from 29 different countries, considering each nation as a set of institutional factors. For this, the national business behaviour of a series of 22 practices categorized in the social and environmental dimensions of sustainability is studied (see Annex B), adopting the national business systems approach developed by Whitley (1999), who considers that the system of a country is determined by the historical development of its institutions. This information is extracted from the EIRIS database, a source of data from numerous investigations (e.g., Martínez-Ferrero and García-Sánchez, 2016).

The composite NCSRPI is based on a statistical process conformed by seven stages (Dobbie and Dail, 2013; OECD, 2008) for the year 2014, which comprise (i) a first phase with a theoretical framework detailing the interrelation of CSR dimensions and institutional contexts; (ii) a second phase with the choice of CSR measures or practices that determine the commitment of the company to sustainability in relation to its accessibility, analytical consistency and punctuality; (iii) the imputation if necessary of missing data; (iv) the exclusion of those practices that do not reduce the quality of the theoretical model based on a statistical analysis about the relationship of them; (v) the standardization if necessary of the data so that they are comparable to each other; (vi) the completion of a confirmatory factor analysis of the practices finally chosen and the attribution of weights from the standardized regression weights obtained in the final model; and (vii) the aggregation of the values through a weighted sum of these practices by Equation 2. This formula is based on the weighted sum of the 22 practices that finally make up the index and, for each of the CSR practices, we work with the difference between the average value of the companies in each country and the average value of the companies in all the countries. Then, with the aim of correcting and normalizing these relations, they are divided by the GDP ratio of each country and the GDP of all the countries. Finally, the values by country in each of the 22 CSR practices are aggregated through a weighted sum with the standardized regression weights of the final model to derive values of national sustainability.

National CSR Practices Index

$$
=\sum_{i=1}^{22} p_{i}\left(\begin{array}{c}
\begin{array}{c}
\text { Average level of sustainability of practice } X_{i} \text { from country } A \\
-
\end{array} \\
\text { Average level of sustainability of practice } X_{i} \text { from all sample countries } \\
\frac{G D P P P P \text { country } A}{\text { Total GDP PPP of all sample countries }}
\end{array}\right)
$$

Equation 2. The aggregation method for obtaining the national CSR practices scores

\section{Method}

\subsection{HJ-biplot analysis}

Biplots (Gabriel, 1971) are statistical exploration methods for the inspection of data matrices, a biplot represents three or more variables in the same way that a scatter diagram shows the joint distribution of two variables. The HJ-biplot (Galindo, 1986) is a multivariate representation of a matrix $X_{n x p}$ that, by the proper selection of markers $h_{j}=\left(h_{j}, \ldots, h_{p}\right)$ for its columns and $j_{i}=\left(j_{i}, \ldots, j_{n}\right)$ for its rows, provides the presentation with optimum quality of representation of both markers in the same reference system of low dimension. Let $X=U V^{\mathrm{T}}$ the singular value decomposition (SVD) of $\mathrm{X}$ with $\mathrm{U}$ and $\mathrm{V}$ orthogonal matrices and $\mathrm{D}=\operatorname{diag}\left(\lambda_{1}, \ldots, \lambda_{\mathrm{p}}\right)$ that contains the singular values. Let $\mathrm{J}$ and $\mathrm{H}$ be the matrices of the first two columns of UD and VD, respectively.

In the HJ-biplot representation, countries are represented as points (row markers) in a subspace of low dimension, and international CSR practices / initiatives as vectors (column markers). For this research, the main objective of this analysis is to extract and describe in a visual way the structure of the data, so that, taking into account the rules of interpretation, this method allows us to: (i) check the existing relationships between CSR practices and the NCSRI, that is, highlighting CSR practices that explain a greater variability of the national sustainability index, 
which will be those that form the smallest angles with the index, since acute angles are translated in positive correlations; in the same way, we will emphasize the international CSR initiatives that are most identified with the national index of sustainability practices, the NCSRPI; (ii) in reference to the countries (points in the representation), we can identify sets or geographic zones with a similar sustainable behaviour, since close points in the plane are associated with a strong similarity; and (iii) characterize countries that more strongly demand CSR practices or initiatives, this will be done through the orthogonal projections of the points (countries) on the vectors (CSR variables). All the calculations and representations involved in this HJ-biplot analysis were processed with the MultBiplot software (Vicente-Villardón, 2010).

\section{Results of the Empirical Analysis and Discussion}

As a first point, we will corroborate the usefulness of the NCSRI created for the year 2014, and for this, we quantify the coherence of this indicator through the Pearson correlation coefficient with the NCSRI of 2012 (Skouloudis et al., 2016), which has a value of 0.726 associated with a highly significant p-value (0.000). Likewise, a linear regression analysis was carried out (Fig. I), where the concentration of the different countries in the graph near the regression line is indicative of the importance of the linear association between the pair of indices, thus, $53 \%$ of the variability of the NCSRI in 2014 is explained by the NCSRI in 2012 ( $\mathrm{p}$-value $=0.000$ and $\mathrm{r}^{2}=0.527$ ). The labels used follow the ISO 3166-1 country code system.

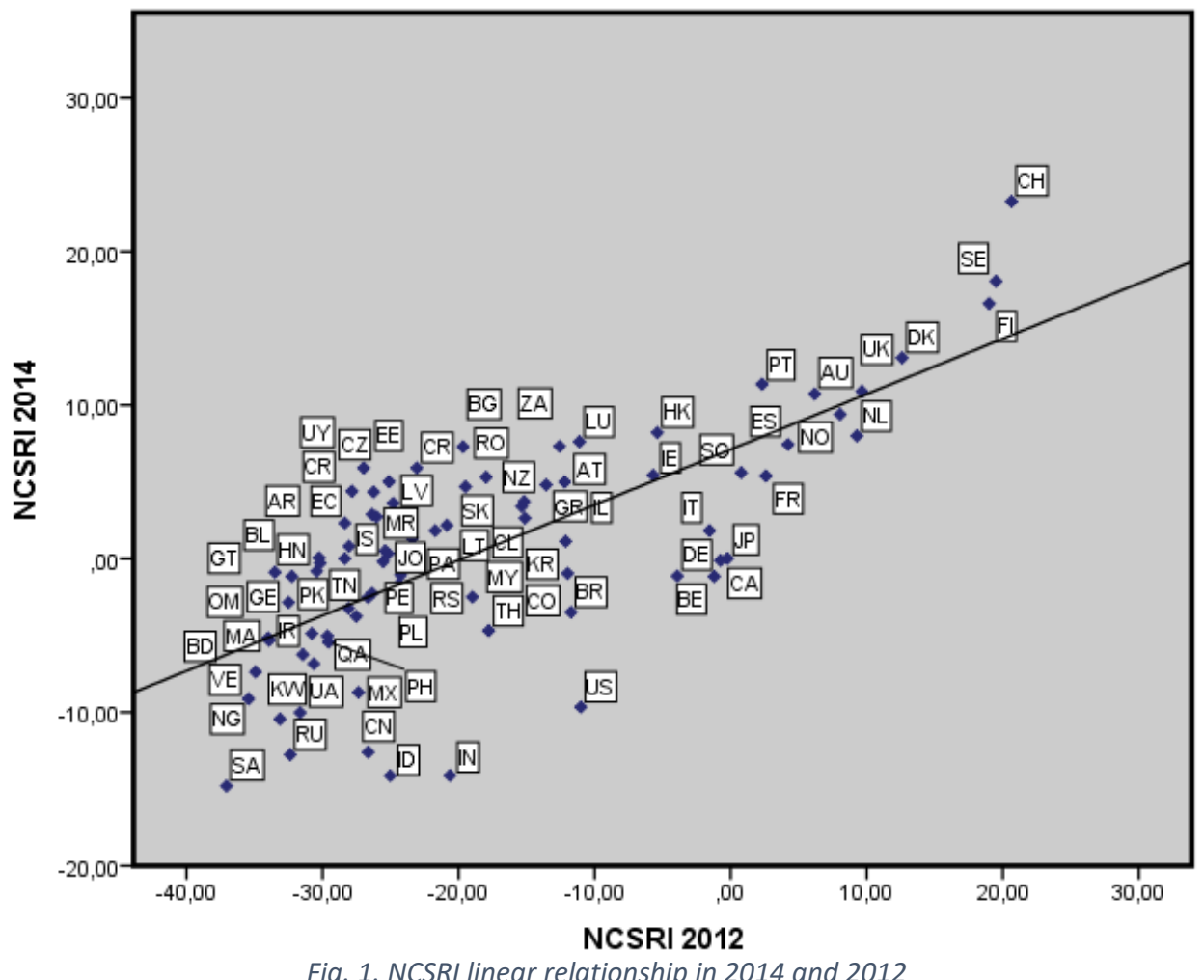

Fig. 1. NCSRI linear relationship in 2014 and 2012

It is necessary to take the time factor into account, since it is important to highlight that the 2014 year election for the creation of indicators is relevant because the 2004-2014 decade is considered one of the most prolific periods for the CSR commitment of companies, partly due to the fact that during this period the knowledge of the pressure that the different interested parties could exercise was facilitated and there was greater access to information about corporate behaviour due to greater press freedom and technological development. In this way, the measurement of the 2014 year implies the joint evaluation of an accumulation of all the commercial efforts made in that period (Martínez-Ferrero and García-Sánchez, 2016). The results of the NCSRI in 2014 summarized in Table 1 show a greater proportion of organizations active 
in CSR than in 2012. The countries of the European Union (EU) are still the leaders of this ranking showing great differences in relation to the rest of the world, which translates into a greater commitment to sustainability, Switzerland ranks first, followed by Nordic nations Sweden, Finland and Denmark; in reference to non-European countries we find positive values corresponding to the East Asia and Pacific region in Australia, Hong Kong and Singapore; Japan and Canada receive a score of approximately zero, while Germany and the United States receive negative ratings; the lowest score of the evaluation is obtained by Saudi Arabia.

\begin{tabular}{|c|c|c|c|c|c|c|c|c|}
\hline Rank & Country & NCSRI 2014 & & & & & & \\
\hline 1 & Switzerland & 23.27 & 29 & Greece & 3.41 & 57 & Poland & -2.25 \\
\hline 2 & Sweden & 18.07 & 30 & Iceland & 2.88 & 58 & Malaysia & -2.49 \\
\hline 3 & Finland & 16.62 & 31 & Mauritius & 2.73 & 59 & Peru & -2.52 \\
\hline 4 & Denmark & 13.08 & 32 & Chile & 2.64 & 60 & Oman & -2.84 \\
\hline 5 & Portugal & 11.37 & 33 & Argentina & 2.32 & 61 & Pakistan & -3.23 \\
\hline 6 & United Kingdom & 10.90 & 34 & Lithuania & 2.18 & 62 & Brazil & -3.48 \\
\hline 7 & Australia & 10.73 & 35 & Slovenia & 1.91 & 63 & Kazakhstan & -3.75 \\
\hline 8 & Norway & 9.40 & 36 & Italy & 1.83 & 64 & Thailand & -4.68 \\
\hline 9 & Hong Kong & 8.21 & 37 & Slovak Republic & 1.83 & 65 & Kenya & -4.87 \\
\hline 10 & Netherlands & 8.00 & 38 & Panama & 1.32 & 66 & Qatar & -5.03 \\
\hline 11 & Luxembourg & 7.62 & 39 & South Korea & 1.13 & 67 & Iran, Islamic Rep. & -5.16 \\
\hline 12 & Spain & 7.44 & 40 & Ecuador & 0.81 & 68 & Morocco & -5.31 \\
\hline 13 & South Africa & 7.32 & 41 & Bahrain & 0.51 & 69 & Philippines & -5.43 \\
\hline 14 & Bulgaria & 7.29 & 42 & Jordan & 0.33 & 70 & Turkey & -5.71 \\
\hline 15 & Uruguay & 5.91 & 43 & Tunisia & 0.06 & 71 & Egypt, Arab Rep. & -6.24 \\
\hline 16 & Croatia & 5.91 & 44 & Japan & 0.01 & 72 & Kuwait & -6.84 \\
\hline 17 & Singapore & 5.60 & 45 & Bolivia & 0.01 & 73 & Bangladesh & -7.37 \\
\hline 18 & Ireland & 5.44 & 46 & Canada & -0.11 & 74 & Mexico & -8.70 \\
\hline 19 & France & 5.39 & 47 & Vietnam & -0.19 & 75 & Venezuela, RB & -9.12 \\
\hline 20 & Romania & 5.31 & 48 & Belarus & -0.29 & 76 & United States & -9.65 \\
\hline 21 & Estonia & 5.02 & 49 & Honduras & -0.81 & 77 & Ukraine & -10.02 \\
\hline 22 & Austria & 5.00 & 50 & Guatemala & -0.88 & 78 & Nigeria & -10.44 \\
\hline 23 & Israel & 4.81 & 51 & Colombia & -0.96 & 79 & China & -12.59 \\
\hline 24 & Hungary & 4.69 & 52 & Serbia & -1.06 & 80 & Russian Federation & -12.76 \\
\hline 25 & Costa Rica & 4.40 & 53 & Germany & -1.12 & 81 & India & -14.11 \\
\hline 26 & Czech Republic & 4.35 & 54 & Belgium & -1.15 & 82 & Indonesia & -14.13 \\
\hline 27 & New Zealand & 3.72 & 55 & Georgia & -1.15 & 83 & Saudi Arabia & -14.80 \\
\hline 28 & Latvia & 3.62 & 56 & Sri Lanka & -1.66 & & & \\
\hline
\end{tabular}

The next step is the comparison of these results with the index formed by CSR practices, the NCSRPI (see Table 2), which underlines that the countries of the European Union (EU) have a greater sustainability commitment by demonstrating the best CSR practices, the Nordic countries being those that present the highest positive values. In contrast, most of the non-EU countries seem to be lagging behind in this area, Japan and Canada obtain a score close to zero again and Thailand ranks last in the ranking. To do this, we select only those countries for which we have information about the proportion of companies active in international CSR initiatives and their values in CSR practices. This resulted in information from 26 countries among the developed economies, Europe, North America, Oceania and certain well-developed Asian countries. Following the Pearson correlation coefficient, we found strong bonds between both indices (Pearson's $r=0.727 \mathrm{p}$-value $=0.000$ ), and a linear regression analysis was carried out where the prediction line accompanied by the intervals shows $95 \%$ confidence (Fig. 2).

\begin{tabular}{lllllllll}
\hline Rank & Country & NCSRPI 2014 & & & & & \\
\hline 1 & Finland & 21.00 & 10 & Italy & 1.04 & 19 & Austria \\
2 & Denmark & 11.25 & 11 & United Kingdom & 0.94 & 20 & Israel & -0.64 \\
3 & Sweden & 10.27 & 12 & Belgium & 0.86 & 21 & India & -0.68 \\
4 & Norway & 9.56 & 13 & Germany & 0.82 & 22 & China & -0.83 \\
5 & Netherlands & 5.81 & 14 & Japan & 0.23 & 23 & Mexico & -2.33 \\
6 & Switzerland & 5.06 & 15 & Canada & 0.10 & 24 & Turkey & -3.06 \\
7 & Australia & 3.81 & 16 & United States & -0.18 & 25 & Russia & -3.30 \\
8 & Spain & 3.33 & 17 & Brazil & $-0,35$ & 26 & Thailand & -4.93 \\
9 & France & 1.80 & 18 & South Korea & -0.58 & & & \\
\hline
\end{tabular}

Table 2. National Corporate Social Responsibility Practices Index 2014 


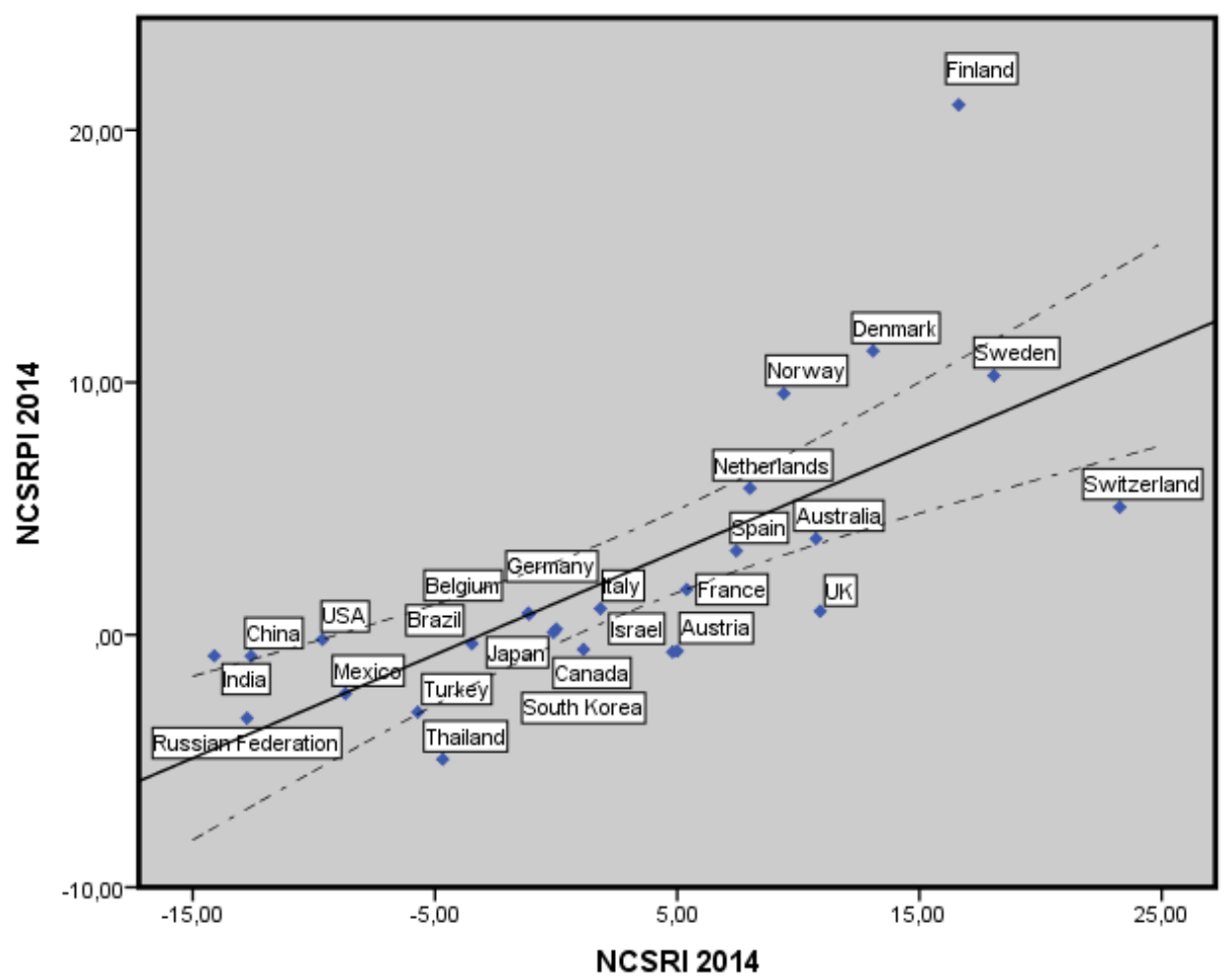

Fig. 2. Linear relationship NCSRI and NCSRPI in 2014

Both indices have strong similarities, with a high degree of correlation, therefore, the next objective of the research is to deepen these indices by studying the structure within each one, so that we can characterize the 26 countries studied in reference to 16 international initiatives and 22 CSR practices; as well as, the relationships of all of them with both indices, analysing the similarities and differences between them. It will be carried out through two HJ-biplot representations, the first will refer to the relationship of the national sustainability practices index, the NCSRPI, with international CSR initiatives (Fig. 3) and the second to the relationship of the national sustainability index, the NCSRI, with CSR practices (Fig. 4). Prior to the representations, several measures are essential, more concretely, the eigenvalues and variance explained, and the relative contribution of the factor to the element (Table 3), through which we can know the variables responsible for the position of the axes.

The first representation refers to the structure within the sustainability index, which includes $62 \%$ variability with the first two axes. The subspace is created around the proportion of active companies in the 26 countries studied in relation to 16 international CSR initiatives, and on this subspace, we project the sustainability practices index (NCSRPI) in order to find those that better identify, that is, see which initiatives can explain in a some extent the ranking found in CSR practices. The strongest associations of the NCSRPI are found with ISO 14001 certification, which is a standard of environmental management systems that sets a framework for any company to follow providing security to the management, employees and stakeholders on the environmental impact; and with the OHSAS 18001 standard, an occupational health and safety management system to control health and safety risks at work; that is, countries with greater environmental concerns and that are more committed to working conditions have the strongest CSR levels. These sub-indices make reference to the practices of environmental performance and labour health and safety. This information is of great relevance since it agrees with the study of the sustainability sectorial of Amor-Esteban et al. (2018), where they show that companies belonging to sectors with greater environmental risks, composed of the most polluting organizations and with higher labour risks, present the highest CSR levels. We find another strong relationship with WBCSD (World Business Council for Sustainable Development), a global organization led by the CEOs of more than 200 leading companies working together to accelerate the transition to a sustainable world; the Global Compact, a voluntary initiative based on the CEOs' commitment to implementing universally accepted principles on the protection of human 
rights, labour standards and anti-corruption measures, and taking measures to support the UN's (United Nations) objectives; and the GRI (Global Reporting Initiative), an initiative that helps companies and governments around the world to understand and communicate their impact on critical sustainability issues such as climate change, human rights, governance and social welfare. In conclusion, according to the CSR sub-indexes, the sustainability practices ranking (NCSRPI) is based on those companies with the highest environmental and labour risks, that are concerned about their human rights and anti-corruption measures, which due to the social pressure to disclose bad environmental news, seek the adoption or improvement of their practices to manage and increase user confidence and thus respond to the expectations of stakeholders (Ekelenburg, 2016; Casey and Grenier, 2014; Peters and Romi, 2014; Jackson and Apostolakou, 2010; Simnett et al., 2009).

In reference to the countries, the results are consistent, that is, the countries that present the best practices (see Table 2) are placed on the right side next to the variables presenting higher proportions of active companies in the different CSR sub-indexes. Most of these countries are European, as other researchers have previously found for microdata (Purdy et al., 2010; Matten and Moon, 2008; Welford, 2004), Likewise, higher CSR levels are observed in northern than in southern Europe, according to the conclusions of Welford (2005), who affirms that the intensity of corporate CSR practices is linked to the development of a country and also highlights the historical trend towards a more liberal democracy in the North. Thus, Finland and Denmark stand out in the mentioned initiatives, characterized by their environmental performance and occupational safety; Sweden and Switzerland appear in most subscripts, as those that take the leading role on the horizontal axis, the Global 100, FTSE4Good, DJSI and ESI which include the largest leading companies in terms of sustainability of various indices; the MSCI and ECPI ESG in reference to ESG risks; the Carbon Disclosure Project and GHGP which impose the disclosure of environmental information with respect to greenhouse gas emissions - here we note that Australia is also located, since its regulatory regime is similar to that of several European countries (Baughn et al., 2007; Kimber and Lipton, 2005); WME and KPMG in the designation of the most ethical companies in the world and CSR disclosure practices respectively, where North America stands out with Canada and the USA. The remaining countries located on the left show a lower commitment to sustainability, among them we find Germany, a country considered a laggard in CSR compared to its European counterparts, since its high level of social integration and favourable economic situation at the national level helps to reduce public demand for CSR in the country, so that German companies have maintained a widely ambivalent position towards CSR activities (Jackson and Apostolakou, 2010), and lastly Russia and India.

The second representation refers to the structure within the index of sustainability practices (Fig. 4), which includes a $72 \%$ variability with the first two axes. The subspace is created based on the values of the 26 countries studied in relation to 22 sustainability practices categorized in the social and environmental dimensions, and on this subspace we project the sustainability index (NCSRI) in order to find those practices that better identify with it, and to some extent explain the ranking it presents. The NCSRI maintains the strongest links with CSR practices related to systems, such as those aimed at equal opportunities and promotion of diversity, environmental management systems, a framework or method used to guide an organization to achieve and maintain a functioning in accordance with established goals and respond effectively to changes in regulatory, social, financial and competitive pressures, as well as environmental risks, management systems of stakeholders, those aimed at safety and health work focused on showing a commitment beyond the levels of protection established by regulations, systems and reports to counteract bribery, and systems for implementing a code of ethics. In summary, according to CSR practices, the NCSRI sustainability ranking is based on the most ethical companies in the world, leaders in environmental management, with strong systems towards stakeholders, health and safety at work, in line with diversity and in the fight to counter bribery.

In relation to the position of the countries, the structure found is similar to the previous one, the European countries are the strongest in sustainability, among them, we also find Australia; within Europe, the strongest practices are found in the north, particularly in the Nordic countries, thus, Finland and Denmark stand out in terms of human rights and the environment, in the ESG risks and participation of their stakeholders; others like Sweden, Norway, Netherlands and 
Switzerland focus more on practices aimed at business ethics, health and safety at work, or systems to promote equal opportunities; most other countries appear to lag behind them in terms of sustainability, with the lowest commitment from Turkey, Russia and Thailand.

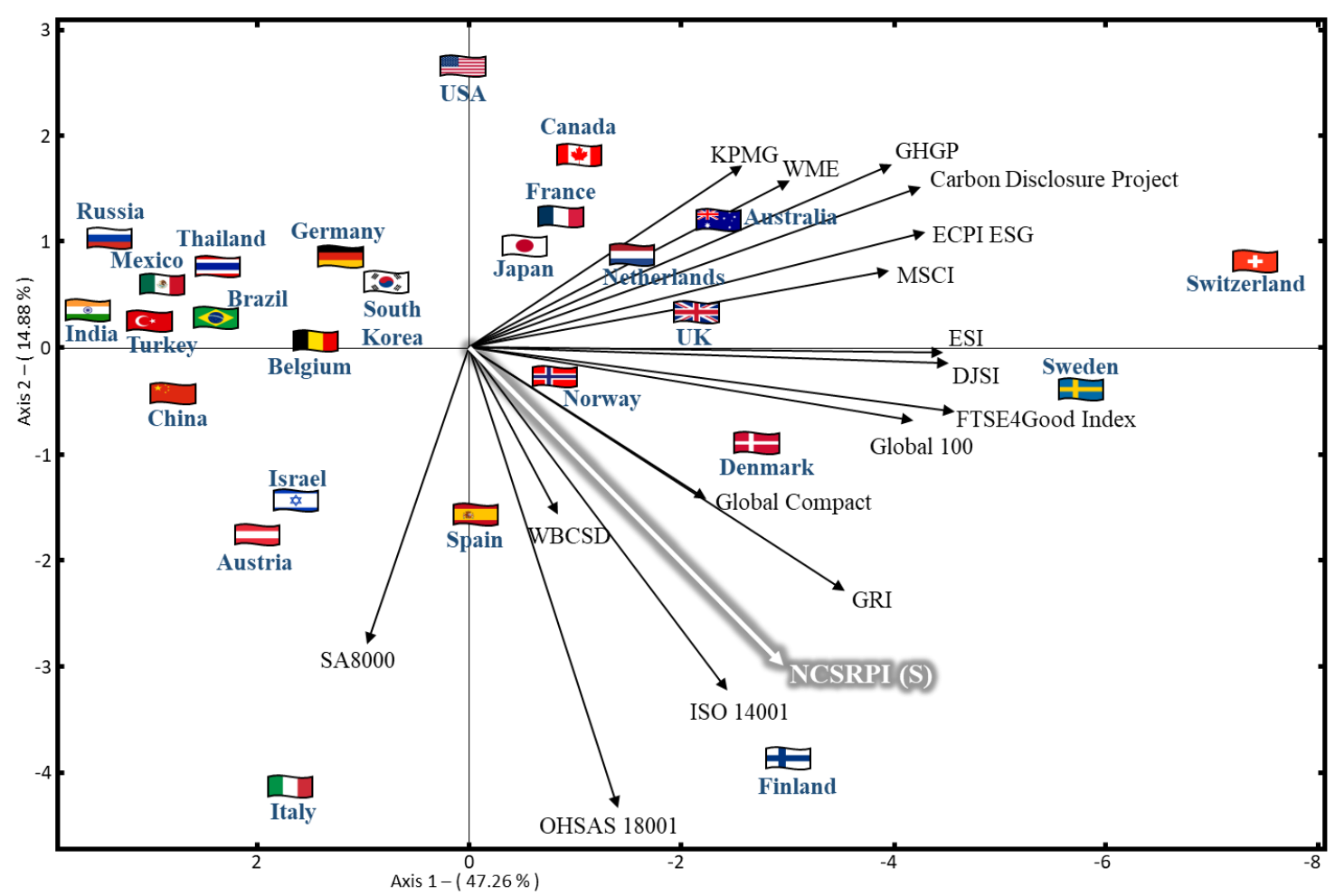

Fig. 3. Factorial plane 1-2 of the HJ-biplot, relationship of the NCSRPI (S) with the sub-indexes of NCSRI

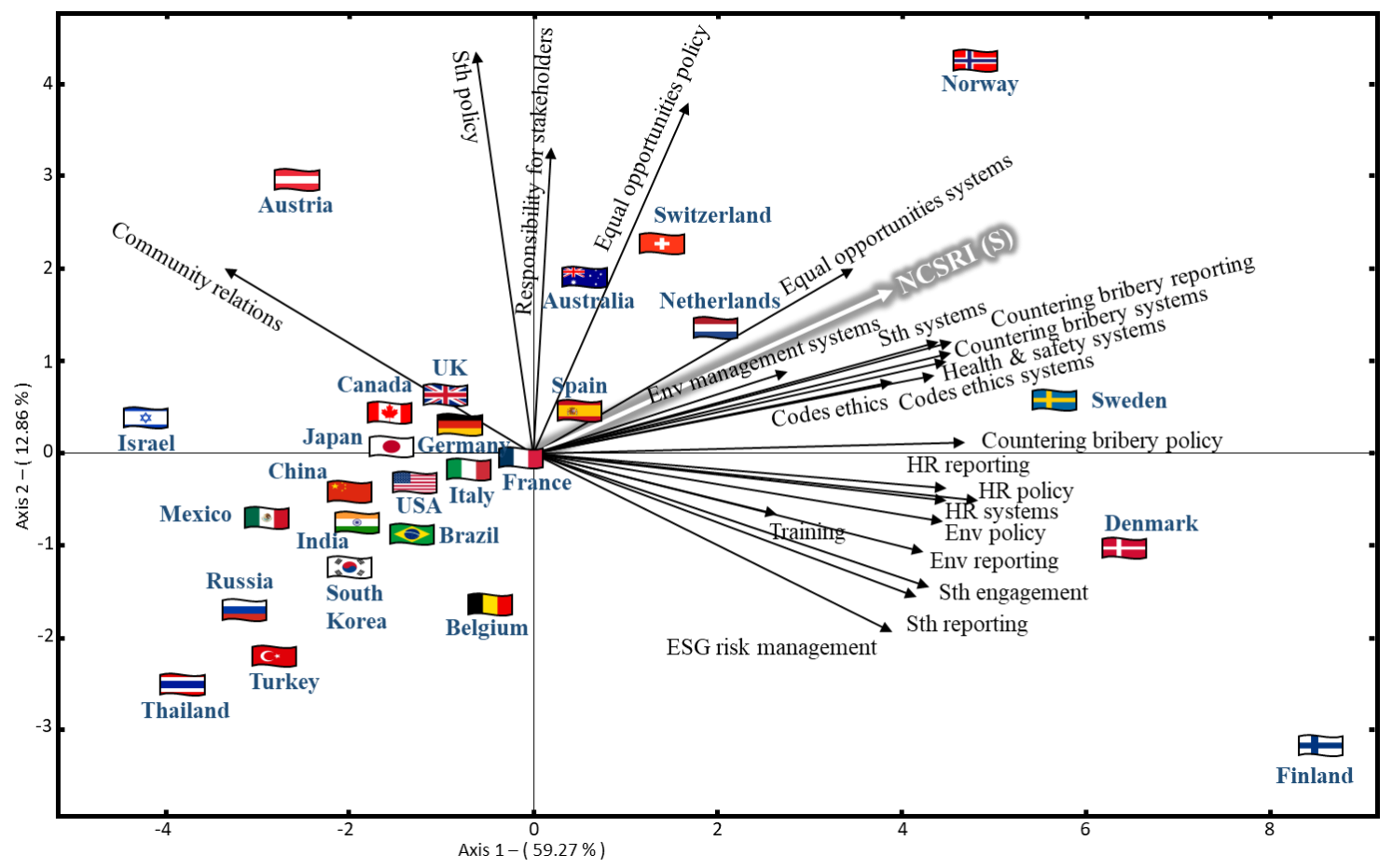

Fig. 4. Factorial plane 1-2 of the HJ-biplot, relationship of the NCSRI (S) with the CSR practices of NCSRPI 


\begin{tabular}{|c|c|c|c|c|c|}
\hline CSR practices & Axis 1 & Axis 2 & CSR initiatives & Axis 1 & Axis 2 \\
\hline Environmental Policy & 779 & 11 & ISO 14001 & 237 & 408 \\
\hline Environmental management & 360 & 25 & OHSAS 18001 & 79 & 745 \\
\hline Environmental reporting & 731 & 44 & SA8000 & 37 & 304 \\
\hline Human Rights Policy & 792 & 8 & GRI & 498 & 212 \\
\hline Human Rights Systems & 921 & 10 & Global Compact & 201 & 83 \\
\hline Human Rights Reporting & 712 & 7 & WBCSD & 27 & 100 \\
\hline Equal opportunities policy & 116 & 585 & Carbon Disclosure Project & 723 & 92 \\
\hline Equal opportunities systems & 480 & 176 & GHGP & 633 & 119 \\
\hline Health \& safety systems & 757 & 35 & KPMG & 260 & 116 \\
\hline Training & 197 & 22 & ESI & 787 & 0 \\
\hline Community involvement & 438 & 154 & FTSE4Good Index & 831 & 14 \\
\hline Responsibility for stakeholders & 2 & 453 & DJSI & 814 & 0 \\
\hline Stakeholder engagement & 738 & 84 & ECPI ESG & 742 & 48 \\
\hline Stakeholder policy & 15 & 749 & MSCI & 631 & 20 \\
\hline Stakeholder systems & 815 & 53 & WME & 367 & 101 \\
\hline Stakeholder reporting & 692 & 101 & Global 100 & 694 & 18 \\
\hline Codes of ethics & 719 & 36 & NCSRPI (S) & 493 & 220 \\
\hline Codes of ethics systems & 729 & 34 & & & \\
\hline Countering bribery policy & 887 & 0 & & & \\
\hline Countering bribery systems & 791 & 43 & & & \\
\hline Countering bribery reporting & 765 & 50 & & & \\
\hline ESG risk management & 603 & 148 & & & \\
\hline NCSRI $(S)$ & 470 & 157 & & & \\
\hline
\end{tabular}

\section{Conclusions}

A national index of business sustainability, with a macro approach that goes beyond the level of the company as a unit of analysis, allows a global understanding of the development of CSR with respect to the national environment, avoiding important problems associated with the lack of data and comparative analyses that systematically link CSR with national political-economic contexts. At the same time, it facilitates a ranking of countries and the development of benchmarking processes associated with a set of aggregate components related to sustainability issues, such as the preservation of the environment, the defence of human rights, the external relations of the organization, and business ethics, which collectively demonstrate the state of CSR development and commitment and describe the level of responsible business conduct among countries.

The national sustainability indexes analysed in this research, the NCSRI (National Corporate Social Responsibility Index), based on national data on subscription, inclusion or participation in 16 international CSR initiatives and the NCSRPI (National Corporate Social Responsibility Practices Index), based on 22 real sustainability practices categorized in the social and environmental dimensions, present a similar structure, with a high degree of correlation; thus, both show that the European countries and Australia, that has a regulatory regime, in relation to corporate transparency, similar to that found in some European countries especially, are the most advanced in sustainability issues and within them, the Nordic countries demonstrate the highest activity and the strongest practices; the remaining countries show weak practices presenting a poor penetration of CSR, among them is Germany, a country considered a laggard in CSR in comparison with its European counterparts, since its high level of social integration and favourable economic climate at national level contributes to reducing the public demand for CSR in the country, so that German companies have maintained a widely ambivalent position towards CSR activities; Japan, Canada and USA as leaders of their respective continents but with a commitment far behind their European counterparts; and countries like Russia, Turkey or Thailand as the laggards in this aspect.

Also, based on exploratory statistical methods, such as the HJ-biplot, which allows us to approximate a large group of variables in a low-dimensional space providing us with a useful visualization of the data structure, we studied the behaviour of these indexes in function of the 
variables used by the other index; thus, according to international CSR initiatives, the sustainability practices ranking (NCSRPI) is based on those companies with the highest environmental and labour risks, concerned about their human rights and with anti-corruption measures, which due to the social pressure to disclose bad environmental news, seek the adoption or improvement of their practices to manage and increase user confidence and thus respond to the expectations of their stakeholders; and according to CSR practices, the sustainability ranking (NCSRI) is based on the most ethical companies in the world, leaders in environmental management, with strong systems towards stakeholders, health and safety at work, in line with diversity and in the fight to counter bribery.

These concluding observations demonstrate the utility of national sustainability indicators to identify the most deficient countries in terms of their sustainability systems. The handling of these data will help to determine the priorities and structural drivers of their growth, which allows to guide stakeholders and managers in the design of sustainable development and to promote policies that are more precise and effective in their decision-making processes. At company level, these results facilitate knowledge of the different pressures for environmental and social behaviour.

\section{References}

Adelopo, I., Moure, R.C., Obalola, M., 2013. On the Effects of Legal and Cultural Institutions on Corporate Social Disclosures by Banks. De Montfort University.

Aerts, W., Cormier, D., Magnan, M., 2006. Intra-industry imitation in corporate environmental reporting: An international perspective. Journal of Accounting and public Policy 25, 299-331.

Amor-Esteban, V., Galindo-Villardón, M.-P., García-Sánchez, I.-M., 2018. Useful information for stakeholder engagement: A multivariate proposal of an Industrial Corporate Social Responsibility Practices Index. Sustainable Development. https://doi.org/10.1002/sd.1732

Baughn, C.C., (Dusty) Bodie, N.L., McIntosh, J.C., 2007. Corporate social and environmental responsibility in Asian countries and other geographical regions. Corporate Social Responsibility and Environmental Management 14, 189-205. doi:10.1002/csr.160

Campbell, J.L., 2007. Why would corporations behave in socially responsible ways? an institutional theory of corporate social responsibility. Academy of Management Review 32, 946-967. doi:10.5465/AMR.2007.25275684

Campbell, J.L., 2006. Institutional Analysis and the Paradox of Corporate Social Responsibility. American Behavioral Scientist 49, 925-938. doi:10.1177/0002764205285172

Casey, R.J., Grenier, J.H., 2014. Understanding and contributing to the enigma of corporate social responsibility (CSR) assurance in the United States. Auditing: A Journal of Practice \& Theory 34, 97-130.

Chen, S., Bouvain, P., 2009. Is Corporate Responsibility Converging? A Comparison of Corporate Responsibility Reporting in the USA, UK, Australia, and Germany. Journal of Business Ethics 87, 299-317. doi:10.1007/s10551-008-9794-0

Colwell, S.R., Joshi, A.W., 2013. Corporate ecological responsiveness: Antecedent effects of institutional pressure and top management commitment and their impact on organizational performance. Business Strategy and the Environment 22, 73-91.

Dobbie, M.J., Dail, D., 2013. Robustness and sensitivity of weighting and aggregation in constructing composite indices. Ecological Indicators 29, 270-277.

Duran, J.J., Bajo, N., 2014. Institutions as determinant factors of corporate responsibility strategies of multinational firms. Corporate Social Responsibility and Environmental Management 21, 301317.

Ekelenburg, M.V., 2016. Determinants of voluntary external assurance on corporate sustainability reports: A comparison between Europe and North America. Netherlands: Radboud University.

Esteban, V.A., Villardón, M.P.G., Sánchez, I.M.G., 2017. Cultural values on CSR patterns and evolution: A study from the biplot representation. Ecological Indicators 81, 18-29. doi:10.1016/j.ecolind.2017.05.051

Gabriel, K.R., 1971. The biplot graphic display of matrices with application to principal component analysis. Biometrika 58, 453-467.

Galindo, M.P., 1986. Una alternativa de representacion simultanea: HJ-Biplot. Qüestiió 10, 1. 
García-Sánchez, I.-M., Cuadrado-Ballesteros, B., Frías-Aceituno, J.-V., 2016. Impact of the Institutional Macro Context on the Voluntary Disclosure of CSR Information. Long Range Planning 49, 1535. doi:10.1016/j.lrp.2015.02.004

García-Sánchez, I.-M., García-Meca, E., 2017. CSR engagement and earnings quality in banks. The moderating role of institutional factors. Corporate Social Responsibility and Environmental Management 24, 145-158.

Gjølberg, M., 2009. Measuring the immeasurable? Scandinavian Journal of Management 25, 10-22. doi:10.1016/j.scaman.2008.10.003

Halkos, G., Skouloudis, A., 2016. National CSR and institutional conditions: An exploratory study. Journal of Cleaner Production 139, 1150-1156. doi:10.1016/j.jclepro.2016.07.047

Jackson, G., Apostolakou, A., 2010. Corporate Social Responsibility in Western Europe: An Institutional Mirror or Substitute? Journal of Business Ethics 94, 371-394. doi:10.1007/s10551-009-0269-8

Kimber, D., Lipton, P., 2005. Corporate governance and business ethics in the Asia-Pacific region. Business \& Society 44, 178-210.

Lenssen, G., Gasdparski, W., Rok, B., Lacy, P., Midttun, A., Gautesen, K., Gjølberg, M., 2006. The political economy of CSR in Western Europe. Corporate Governance: The international journal of business in society $6,369-385$.

Mar Miras-Rodríguez, M., Carrasco-Gallego, A., Escobar-Pérez, B., 2015. Are socially responsible behaviors paid off equally? A Cross-cultural analysis. Corporate Social Responsibility and Environmental Management 22, 237-256.

Martínez-Ferrero, J., García-Sánchez, I.-M., 2016. Coercive, normative and mimetic isomorphism as determinants of the voluntary assurance of sustainability reports. International Business Review. doi:10.1016/j.ibusrev.2016.05.009

Matten, D., Moon, J., 2008. "Implicit" and "explicit" CSR: a conceptual framework for a comparative understanding of corporate social responsibility. Academy of management Review 33, 404-424.

North, D.C., 1990. Institutions, Institutional Change and Economic Performance. Cambridge: Cambridge University Press.

OECD, 2008. Handbook on constructing composite indicators: Methodology and user guide. OECD publishing.

Peters, G.F., Romi, A.M., 2014. The association between sustainability governance characteristics and the assurance of corporate sustainability reports. Auditing: A Journal of Practice \& Theory 34, $163-$ 198.

Purdy, J.M., Alexander, E.A., Neill, S., 2010. The impact of national institutional context on social practices: Comparing Finnish and US business communities. European Journal of International Management 4, 234-256.

Simnett, R., Vanstraelen, A., Chua, W.F., 2009. Assurance on Sustainability Reports: An International Comparison. The Accounting Review 84, 937-967. doi:10.2308/accr.2009.84.3.937

Skouloudis, A., Evangelinos, K., 2012. A research design for mapping national CSR terrains. International Journal of Sustainable Development \& World Ecology 19, 130-143.

Skouloudis, A., Isaac, D., Evaggelinos, K., 2016. Revisiting the national corporate social responsibility index. International Journal of Sustainable Development \& World Ecology 23, 61-70.

Vicente-Villardón, J.L., 2010. Multbiplot: A package for multivariate analysis using biplots. Departamento de Estadística. Universidad de Salamanca. http://biplot.usal.es/ClassicalBiplot/index.html.

Welford, R., 2005. Corporate social responsibility in Europe, North America and Asia: 2004 survey results. The Journal of Corporate Citizenship 17, 33-52.

Welford, R., 2004. Corporate social responsibility in Europe and Asia: Critical elements and best practice. The Journal of Corporate Citizenship 13, 31.

Whitley, R., 1999. Divergent capitalisms: The social structuring and change of business systems. OUP Oxford.

Wood, D.J., 2010. Measuring corporate social performance: A review. International Journal of Management Reviews 12, 50-84. 
Annex A. The sub-indices, qualifications and standards that make up the construction of the national corporate social responsibility index (NCSRI).

\begin{tabular}{l|l}
\hline CSR initiatives & \\
\hline Carbon Disclosure Project & \\
\hline Dow Jones Sustainability & \\
\hline World Enlarged Index &
\end{tabular}

World Enlarged Index

ECPI Global ESG Alpha

Equity Index

Ethibel Sutainability Index Excellence Global

Ethisphere WME

Description and functionality

Carbon Disclosure Project (CDP) is an international, non-profit organization that works in cooperation with market forces in order to motivate companies to measure, manage and disclose vital environmental information with respect to their greenhouse gas emissions and ultimately to take action in reducing them. The indicator refers to the number of companies per country included in the Global 500 Climate Change Report 2012 which have responded to CDP's questionnaire and provided relevant information.

The Dow Jones Sustainability World Enlarged Index (DJSI World Enlarged) tracks the performance of the top $20 \%$ of the 2500 largest companies in the S\&P Global Broad Market Index which lead in terms of corporate sustainability. These companies are assessed by RobecoSAM using an annual corporate sustainability assessment. The indicator refers to the constituents of the DJSI World Enlarged.

The ECPI Global ESG Alpha Equity Index is composed of the 100 highest market capitalization and highest Environmental, Social and Governance rated and liquid companies. The indicator refers to the constituents of the ECPI Global ESG Alpha Equity.

The Ethibel Sustainability Index (ESI) Excellence Global contains a variable number of shares, collects the best-in-class companies with respect to CSR/sustainability across sectors and regions in Europe, North America and Asia Pacific. It is a free-float weighted index, designed to approximate the sector weights on the S\&P Global 1200. The indicator refers to the constituents of the ESI Excellence Global.

The World's Most Ethical (WME) companies designation, developed by the Ethisphere Institute, recognizes companies that promote ethical business standards and practices internally, exceed legal compliance minimums and shape future industry standards by promoting best practices. At the heart of the evaluation and selection process for Ethisphere's WME companies is a proprietary rating system. The indicator refers to the firms which are included in the WME list.

The FTSE4Good Global Index, created by FTSE International and Ethical Research Services (EIRIS) has been designed to objectively measure

FTSE4Good Global Index the performance of companies around the world that meet globally recognised corporate responsibility standards. It is one of the world's premier indices for socially responsible investing. The indicator refers to the constituents of the FTSE4Good Global.

\section{Global 100}

The Global 100 Most Sustainable Corporations in the World is a sustainability equity index, maintained by the Corporate Knights advisory group and calculated by Solactive, a German index provider. The indicator refers to the constituents which are included in the Global 100.

Global Compact The Global Compact, developed by the United Nations, is a strategic policy initiative inviting companies to embrace, support and enact, within Principles their sphere of influence, a set of ten universally-accepted principles pertaining to human rights protection, labour standards, benign environmental management and anti-corruption measures. The indicator refers to the total number of companies per country which are formally endorsing the initiative.

The Global Reporting Initiative (GRI) Guidelines offer a set of reporting principles, standard disclosures and an implementation manual for preparing sustainability reports by organizations, regardless of their size, sector or location. The Guidelines also offer an international reference

Global Reporting Initiative Guidelines

Greenhouse Gas Protocol for all those interested in the disclosure of governance approach and of the environmental, social and economic performance and impacts of organizations. The indicator refers to the total number of sustainability reports published in the year of reference and registered to GRI's Disclosure Database.

The Greenhouse Gas Protocol (GHG Protocol) is an accounting tool for quantifying and managing greenhouse gas emissions with the overall aim of contributing to credible and effective programs for tackling climate change. It offers the accounting framework for nearly every GHG 
standard and program in the world as well as hundreds of GHG inventories prepared by individual companies. The indicator refers to the corporate users of the GHG Protocol per country.

ISO 14001 is an environmental management system standard developed by the by the International Organization for Standardization (ISO) which maps out a framework that an organization can follow to set up an effective environmental management system. It can be used by any organization regardless of its activity or sector. It can provide assurance to company management, employees as well as external stakeholders that environmental impact is being measured and improved. The indicator refers to the total number of organizations per country certified to the standard.

KPMG Int. Survey of

Corporate Resp. KPMG'S International Survey of Corporate Responsibility Reporting is a detailed analysis of corporate nonfinancial reporting and includes a Reporting descriptive assessment of the current status of the CSR/sustainability disclosure practices among the 100 largest companies in selected countries (N100). The indicator refers to the number of N100 companies per country that report on corporate responsibility is sues.

The MSCI World ESG Index, a member of the MSCI Global Sustainability indices, consists of large and mid cap companies and provides , constituents of the MSCI World ESG

OHSAS 18001 is an occupational health and safety management system standard developed by the Occupational Health and Safety Advisory Services (OHSAS) Project Group. It is intended to help organizations to control occupational health and safety risks. It was developed in response to widespread demand for a recognized standard against which health and safety performance can be assessed and certified. The indicator refers to the total number of organizations per country certified to the standard.

OHSAS 18001

The SA8000 standard is an auditable certification standard for decent workplaces developed by the Social Accountability International (SAI)

SA8000 It reflects a management systems approach by setting out policies and procedures that protect the basic human rights of employees and socially acceptable practices in the workplace are continuously maintained. The indicator refers to the total number of facilities per country certified to the standard.

World Business Council The World Business Council for Sustainable Development (WBCSD) is a global association of companies that aims to promote strategic issues linked to sustainable development and corporate responsibility. It offers a platform for firms to share knowledge, experience and best

Development

practices, to advocate the business positions on such issues among various forums, in cooperation with governmental bodies, NGOs and intergovernmental organizations. The indicator refers to the number of companies per country which are members of WBCSD.

Source: Halkos and Skouloudis (2016) 
Annex B. Sustainability measures from the EIRIS database that constitute the national corporate social responsibility practices index (NCSRPI).

According to the information contained in the EIRIS database, businesses' CSR practices will be determined from 22 items weighted $0-4$, which identify inadequate, weak, moderate, good and exceptional levels of CSR. These 22 items correspond to measures of CSR results associated with social and environmental dimensions. Within the social dimension, we group actions related to human rights, employees, stakeholders and ethics.

Environmental performance

\section{Environment}

ENV1 Environmental policy

ENV2 Environmental policy

ENV3 Environmental reporting

\section{Social performance}

\section{Human Rights}

HR1 Human Rights policy

HR2 Human Rights systems

HR3 Human Rights reporting

Employees

EMP1 Equal opportunities policy

EMP2 Equal opportunities systen

EMP3 Health \& safety system

EMP5 Training

Stakeholders

STH3 Community involvement

STH4 Responsibility for stakeholders

STH5 Stakeholder engagemen

STH6 Stakeholder policy

STH7 Stakeholder systems

STH8 Stakeholder reporting

Ethics and Governance

ETH1 Codes of ethics

ETH2 Codes of ethics systems

ETH3 Countering bribery policy

ETH4 Countering bribery systems

ETH5 Countering bribery reporting

ETH7 ESG risk management
How does EIRIS rate the Company's environmental policy and commitment?

How does EIRIS rate the Company's environmental management system?

How does EIRIS rate the Company's environmental reporting?

What is the extent of policy addressing human rights issues?

What is the extent of systems addressing human rights issues?

Does the Company report on human rights issues?

How good is the Company's policy on equal opportunity and diversity issues?

How clear is the evidence of systems and practices to support equal opportunities and diversity?

How clear is the evidence of health \& safety systems?

How clear is the evidence of systems to support employee training and development?

How clear is the evidence of systems to maintain good relations with community?

How many stakeholder issues have been allocated to board members?

What level of engagement with stakeholders is disclosed by the Company?

How good are the Company's policies towards its stakeholders overall?

How good is the Company's quantitative systems on stakeholder relationships?

How good are the Company's management reporting for stakeholders overall?

Does the Company have a code of ethics and, if so, how comprehensive is it?

Does the Company have a system for implementing a code of ethics and, if so, how comprehensive is it?

What is the extent of the Company's policy for countering bribery?

What is the extent of the Company's system for countering bribery?

What is the extent of the Company's reporting on countering bribery?

How well do the board and senior management address Company-wide ESG (Environmental, Social and Governance) risks and opportunities? 




\section{PARTE II}

\section{COMPORTAMIENTO \\ EMPRESARIAL SOSTENIBLE A NIVEL SECTORIAL}




\section{Capítulo VI}

\section{El Efecto de las Especificidades Sectoriales en la Responsabilidad Social Corporativa}

Existe un creciente interés a nivel internacional por la responsabilidad social corporativa, en particular, de las grandes empresas multinacionales a las que se les exige un compromiso cada vez mayor y medidas que prevengan la contaminación medioambiental, las violaciones de los derechos humanos o los comportamientos poco éticos. Esto ha generado que la preocupación sobre responsabilidad social ya no sea un hecho aislado sino una práctica habitual, en particular, entre las empresas más grandes. La extensa investigación que existe en el ámbito de la RSC, la gestión estratégica o los negocios internacionales ha evidenciado que la procedencia de las empresas es un factor relevante porque afecta a la forma en que éstas interaccionan con el gobierno, sus clientes, proveedores, empleados y la sociedad, así como a su comportamiento en asuntos éticos.

La mayoría de este tipo de estudios que abordan la relación entre la sostenibilidad de la empresa y los diferentes contextos, olvida el efecto que puede tener el sector de actividad sobre el comportamiento empresarial. No obstante, aunque pocas, ciertas investigaciones han revelado que el sector puede definirse como un campo organizacional del que surgen presiones institucionales, debido a que las empresas en función del sector al que pertenezcan enfrentan diferentes riesgos ante la sociedad, con diferentes presiones como pueden ser las que ejercen los proveedores externos de recursos que fuerzan o limitan a la empresa a adoptar determinados comportamientos. Además, la supervivencia de la empresa depende de su éxito en la gestión de las relaciones con las partes interesadas, cuyas preocupaciones varían en función del sector en el que operen y, el concepto actual de transparencia no solo cubre la parte económica, sino que se amplía a los aspectos sociales y ambientales de la conducta corporativa, en este sentido, la reputación empresarial no es solo definida por el nivel de éxito sino también por el nivel de aceptación social.

La RSC puede, por tanto, convertirse en una característica institucionalizada de las estructuras de gestión sectoriales, ya sea como resultado de regulaciones coercitivas de las autoridades gubernamentales, presiones normativas creadas por ONG o el comportamiento del consumidor, o a través de sus propios esfuerzos por imitar de forma proactiva a los competidores en el sector para proteger su reputación. Es importante destacar que este tipo de presiones sectoriales no deben ser consideradas como estrictamente de alcance nacional, sino que pueden producir isomorfismo entre los competidores del mismo sector a escala internacional.

Esta parte de la investigación se centra en analizar la industria como un factor institucional con capacidad explicativa sobre la sostenibilidad de la empresa. Para ello, se estudia el comportamiento de los diez principales sectores de actividad -atención a la salud, bienes de consumo, materias básicas, petróleo y gas, productos industriales, servicios al consumidor, servicios financieros, servicios públicos, tecnología y telecomunicaciones-, a partir de la 
codificación de una muestra de datos de 6600 observaciones de 600 grandes empresas internacionales cotizadas según la categoría 'industry' del 'Industry Classification Benchmark (ICB) system', para el periodo de tiempo 2004-2014. El desarrollo sostenible de estas empresas se evalúa a partir de 26 prácticas de RSC que abarcan la sostenibilidad desde la dimensión ambiental (prácticas en medioambiente) y la dimensión social (prácticas en derechos humanos, empleados, stakeholders y ética).

El principal objetivo de este capítulo de la investigación es interpretar la importancia que otorga cada sector a las prácticas que evalúan el bienestar social en relación a su compromiso ambiental y, por ende, su caracterización en función de cada una de las prácticas de RSC. Para ello, dividimos los datos en sub-dimensiones: medioambiente (ENV), derechos humanos (HR), empleados (EMP), stakeholders (STH), ética (ETH); y aplicamos un análisis CO-X-STATIS (XSTATIS + co-inercia) tratando éstas por pares, lo que dará lugar a cuatro análisis: (i) ENV-HR, (ii) ENV-EMP, (iii) ENV-STH, (iv) ENV-ETH. El método CO-X-STATIS es un análisis de coinercia del compromiso de dos sucesiones de tablas, por tanto, destaca las relaciones entre dos estructuras estables. De este modo, el resultado final del análisis nos proporciona un plano donde vienen representados cada uno de los diez sectores de actividad mediante un vector, donde el inicio marca la posición de acuerdo a la ordenación de la matriz de prácticas ambientales y, el extremo del vector marca la posición de acuerdo a la ordenación de la matriz de prácticas sociales (derechos humanos, empleados, stakeholders o ética). Por tanto, los resultados que proporciona esta técnica nos permite conocer la importancia que otorga cada sector a las sub-dimensiones sociales en comparación con su compromiso ambiental y, caracterizar cada uno de ellos en función de sus fortalezas y debilidades en relación a las 26 prácticas de RSC individuales.

Así, es posible puntualizar como los sectores dedicados a las materias básicas y los servicios públicos, considerados de fuerte impacto sobre el medioambiente, presentan los niveles ambientales más sostenibles; petróleo y gas focaliza sus esfuerzos en los derechos humanos ya que sus acciones tienen un fuerte impacto sobre la salud humana que claramente atenta contra los derechos de los ciudadanos; telecomunicaciones, con empresas más intensivas en personal, presenta preocupaciones sociales mayores a las ambientales priorizando sus prácticas hacia los derechos laborales y el trato con sus stakeholders; servicios financieros -enfocado a los empleados-y servicios al consumidor -orientado hacia los derechos humanos- se consideran los más retrasados en materia de RSC, sus empresas están menos controladas por el público y, por ende son menos competitivas en términos de prácticas sostenibles.

A raíz de los resultados obtenidos, es posible comprobar la existencia de importantes discrepancias sectoriales, debidas a que los grupos de interés específicos de cada sector y la sociedad en general perciben distintos riesgos tanto sociales como ambientales según la actividad económica que desarrollan las organizaciones, hecho que se ve reflejado en las prácticas de RSC adoptadas por las mismas. De modo que, las empresas adoptan políticas y sistemas de RSC más codificados y explícitos del sector en el que operan con el objetivo de mejorar su imagen controlando los estándares con los que deben cumplir para ser considerados proactivos y ver así aumentado sus beneficios. Además, estos análisis dan respuesta a una de las preguntas más antiguas en el debate sobre la RSC, corroborando que las demandas sociales son un punto principal a tener en cuenta, ya que en ciertas empresas las preocupaciones sociales superan las ambientales.

A continuación, presentamos toda esta información detallada de manera extensa en el artículo de investigación "A Multivariate Vision of the Industry Specificity as an Explanatory Factor of Companies' Social Performance" aceptado como capítulo del libro 'Corporate Social Responsibility Disclosure and Assurance: A Growing Market' en la editorial Cambridge Scholars Publishing. 
Research paper accepted as book chapter:

Title: A Multivariate Vision of the Industry Specificity as an Explanatory Factor of Companies' Social Performance

Authors: Víctor Amor-Esteban

Ma'-Purificación Galindo-Villardón

Fátima David

Journal: Cambridge Scholars Publishing

Book entitled 'Corporate Social Responsibility Disclosure and Assurance: A Growing Market' 



\title{
CHAPTER ONE
}

\section{A MUlTIVARIATE VISION OF THE INDUSTRY SPECIFICITY AS AN EXPLANATORY FACTOR OF COMPANIES' SOCIAL PERFORMANCE}

\author{
VÍCTOR AMOR-ESTEBAN, \\ Ma-PURIFICACIÓN GALINDO-VILLARDÓN, \\ AND FÁTIMA DAVID
}

\begin{abstract}
This paper focuses on analysing the importance of the industry specificity with regard to company sustainability. It corroborates the hypothesis that local interest groups - and society in general - perceive different social and environmental risks according to the economic activity developed by the organizations. This fact is reflected in the Corporate Social Responsibility (CSR) policies and initiatives adopted by them. For this, the behaviour of the data set's ten main industries is studied from the coding of a data sample of 6,600 observations of 600 large international companies. These companies were listed according to the industry category of the Industry Classification Benchmark (ICB) system, for the 2004-2014 time period. Based on multivariate statistical methods, the industry is shown as being an institutional factor with an explanatory capacity in terms of CSR practices. This demonstrates that companies vary their behaviour according to the risks, pressures, and specific expectations of each industry. Thus, we point out how the industries dedicated to basic materials and utilities, which are considered to have a strong impact on the environment, present the highest environmental levels. Oil and gas companies focus their efforts on human rights, since their actions have a strong impact on human health. Telecommunications, along with personal-intensive companies, presents social concerns as being greater than environmental ones - prioritizing their practices towards labour rights and stakeholders deals. Financial services
\end{abstract}


(focused on employees) and consumer services (oriented towards human rights) are considered as being the most delayed in CSR terms. Their companies are comparatively less studied by the public, since they are not considered to have a strong impact on the environment, and are therefore less competitive in terms of sustainable practices. These results answer one of the oldest questions in the CSR debate, corroborating that social demands are a main point to be taken into account. Even in certain industries, social concerns outweigh environmental concerns.

Keywords: Corporate Social Responsibility (CSR), industry specificity, social performance, multivariate statistics, company sustainability, environmental management

\section{Introduction}

There is a growing international interest in Corporate Social Responsibility (CSR) - in particular, of the large multinational companies that are being asked for an ever-increasing commitment and measures to prevent environmental pollution, human rights violations, and unethical behaviour. This has generated the conclusion that concern about social responsibility is no longer an isolated event but a common practice, in particular, between larger companies (KPMG, 2011). Wood (1991) suggested that 'the basic idea of corporate social responsibility is that business and society are interwoven rather than being distinct entities; therefore, society has certain expectations for appropriate business behaviour and outcomes'.

Company sustainability and the dissemination of information in the environmental and social dimensions has been studied in an increasing number of investigations over the last decades (Deegan and Gordon, 1996; Deegan et al., 2002; Habisch et al., 2005; Welford, 2005; Aguilera et al., 2006; Chen and Bouvain, 2009). In this line of research, many studies show that although CSR has the stamp of being a truly global idea, it is applied in a different way by different companies, depending on the institutional characteristics of the environment in which they operate (Campbell, 2007; Gjølberg, 2009). This is because the different political, economic, legal, and cultural contexts offer a series of facilities for or barriers to sustainable development (Ortas et al., 2015; Halkos and Skouloudis, 2016). In general, most of these studies focus on analysing the country as being the institutional factor with the greatest explanatory capacity in terms of company sustainability. This points mainly to the normative pressures that make reference both to the differences in the cultural values of the countries 
(Ringov and Zollo, 2007; García-Sánchez et al., 2013) and to the coercive pressures corresponded to the functioning of the legal system (Kolk and Perego, 2010; Demirbag et al., 2017). However, few investigations have revealed that the industry can be defined as an organizational field from which institutional pressures arise (Aerts et al., 2006), because companies depending on the industry in which they operate face different risks to society, with different expectations of their stakeholders and consumer behaviour. A good example is the oil companies sector, considered as having a greater risk and impact on the environment than other companies, such as banking or financial services, have (Jackson and Apostolakou, 2010). Stakeholders will impose greater pressure on the oil companies to get them to adopt CSR policies aimed at protecting the environment and at protecting the health and safety of their employees.

This research focuses on analysing the industry as an institutional factor with an explanatory capacity on company sustainability. For this, the behaviour of the ten main industries - Basic Materials, Utilities, Oil \& Gas, Industrials, Consumer Goods, Technology, Health Care, Telecommunications, Financials, and Consumer Services - is studied. This is based on the coding of a data sample of 6,600 observations of 600 large international companies listed according to the industry category of the Industry Classification Benchmark (ICB) system, for the 2004-2014 time period. The main objective is the characterization of each of the industries based on their sustainable commitment through the study of 26 CSR practices that encompass sustainability from different perspectivees environment, human rights, employees, stakeholders, and ethics - seeking to find important discrepancies that corroborate the relevance of the industry in socially responsible behaviour. In addition, we direct the research towards answering one of the oldest questions in the debate on CSR: the question of whether it is worthwhile for organizations to pay attention to social demands. All of this will be carried out through a multivariate statistical analysis known as CO-X-STATIS, through which we will study the co-structure of the social sub-dimensions with regard to the environment. That is, we will interpret the importance that each industry gives to social practices as compared to their environmental commitment.

This work is structured as follows: The first section, which refers to the theoretical background, is focused on CSR and institutional contexts. The second details the structure of the data and describes the methodology used. The following sections present the results obtained from the empirical 
analysis; a discussion of those results; and the main conclusions of the study.

\section{Theoretical Framework}

\subsection{Corporate Social Responsibility (CSR) and Institutional Contexts}

The extensive research that exists in the field of CSR, strategic management, or international business has shown that the origin of companies is a relevant factor because it affects the way they interact with the government, its customers, suppliers, employees, and society (Kolk, 2005). The so-called 'country of origin effect' (Sethi and Elango, 1999) which consists of the resources of the countries as their government policies, cultural values, and institutional laws - is exerting a different pressure on companies. As far as social responsibility is concerned, these differences can be very relevant - since it has been found that companies improve their sustainable commitment in response to expectations and social pressures to obtain or maintain their legitimacy (Ortas et al., 2015).

In this sense, several authors demonstrate the importance of institutional characteristics at the national level as a very influential role in the sustainable commitment of companies, as systematically explained by normative and coercive pressures (Martínez-Ferrero and García-Sánchez, 2016). The authors study the relevance of normative pressures by referring to the cultural values of each country (values obtained from the Geert Hofstede TM website). They do so because, according to the cultural dimensions of Hofstede (2001), local stakeholders, as a result of different cultural conditions, have different expectations regarding business behavior. Thus, previous research has shown that companies show a greater interest in sustainability in countries characterized as feminist and collectivist - and, to a lesser extent, in countries with long-term orientation, low power distance, indulgent and tolerant to uncertainty (Frías-Aceituno et al., 2013; García-Sánchez et al., 2013; Mar Miras-Rodríguez et al., 2015; García-Sánchez et al., 2016; Esteban et al., 2017; Halkos and Skouloudis, 2017). In relation to coercive pressures, these correspond to laws, norms, and standards that define the legal system of a country. Additionally, among the main measures for analyzing the role of the legal system, the authors focus on whether it is governed by the civil law - or, on the contrary, whether it is governed by common law; or if the orientation of the country is more directed towards stakeholders or shareholders. Among other 
Factor of Companies' Social Performance

characteristics, they are also based on civic commitment, regulatory effectiveness, or competitive conditions. Thus, previous research shows that companies are more likely to behave in a socially responsible way when they belong to countries with a strong application of the law, governed by civil law and with a legal system oriented towards stakeholders protection (Perego, 2009; Kolk and Perego, 2010; Boiral and Gendron, 2011; Zhou et al., 2013; García-Sánchez et al., 2016; Halkos and Skouloudis, 2016; García-Sánchez and García-Meca, 2017; Amor-Esteban et al., 2017; Demirbag et al., 2017).

Most such studies, which address the relationship between the sustainability of the company and institutional contexts, forget the effect that the industry can have on business behaviour. However, few investigations have revealed that the industry can be defined as an organizational field from which institutional pressures arise (Aerts et al., 2006). This is because companies depending on the industry in which they operate face different risks to society, with different pressures such as those exerted by external suppliers of resources that force or limit the company to adopt certain behaviours (Mizruchi and Fein, 1999). In addition, company survival depends on its success in managing relationships with interested parties (Hess, 2008), whose concerns vary depending on the industry to which they belong. This is due to the current concept of transparency which not only covers the economic part, but which extends to the social and environmental aspects of corporate behaviour (Gray et al., 1987; Frías-Aceituno et al., 2013). Accordingly, productive efficiency is not only defined by the level of success but also by the level of social acceptance (Ortas et al., 2015).

In this line of reasoning, several authors show that as a result of more demanding regulations and specific pressures exerted by the main interest groups of each industry, there are important differences in sustainability reports between companies from different industries (Branco and Rodrigues, 2008; Parsa and Deng, 2008; Wanderley et al., 2008; Bayoud et al., 2012; Young and Marais, 2012). Thus, companies belonging to the same industry will face similar challenges and, therefore, are likely to develop a similar pattern of behaviour with respect to CSR standards, norms, and practices - which implies a degree of convergence in their sustainability commitments (DiMaggio, 1991). That is, companies can disclose information or adopt CSR initiatives due to the fact that their competitors are doing so; they may be motivated to follow the behaviour carried out by another organization that is accepted as being a leader or a model of their industry, with the aim of acquiring social legitimacy (Larrinaga, 2007). 
In addition, the market characteristics of certain industries can explain possible differences with respect to CSR practices adopted by companies differences associated with consumer preferences and demands. (Park et al., 2014). Therefore, consumers behave differently in each industry depending on the risks that are perceived by society. For example, oil companies are perceived by consumers as being high risk in relation to their impact on environmental issues, as well as the health and safety conditions of employees. Therefore, these actors are comparatively more likely to pressure oil companies to adopt CSR policies. In addition, companies that are choosing the rules themselves and are controlling their own activities instead of leaving that responsibility to the State could have more to gain by being considered proactive. Precisely because of their impact on society and because of the scrutiny given to them by government or stakeholders, companies within such industries - higher risk; more polluting - will tend to adopt more codified and explicit CSR policies. CSR can, therefore, become an institutionalized feature of industrial management structures. This could either be as a result of coercive regulations of government authorities, regulatory pressures created by NGOs, or consumer behaviour, or through their own efforts to imitate proactively to competitors in the industry to protect their reputation. It is important to note that this type of industrial pressure should not be considered as being strictly national, but can produce isomorphism among the competitors of the same industry on an international scale (Jackson and Apostolakou, 2010).

Previous research analysing the relationship between CSR and institutional contexts only analyses the influence of national characteristics; and few of them study the industry specificity. This work shows the industry as an institutional factor with an explanatory capacity on company sustainability. To do this, we will conduct a comparative multivariate analysis, characterizing each industry according to its strengths and deficiencies. The characterization is based around 26 CSR practices that encompass environmental and social issues - human rights, employees, stakeholders, and ethics - . The analysis shows the most important industrial discrepancies and, therefore, demonstrates that companies vary their behaviour according to the risks, pressures, and specific expectations of each industry. In addition, we will interpret the importance that each industry gives to social practices in comparison with its environmental commitment. 
Factor of Companies' Social Performance

\section{Methodology}

\subsection{Population and Sample}

In sustainable terms, the most active companies correspond to the largest companies internationally listed on the stock exchange - and, therefore, this will be our target population (Martínez-Ferrero and García-Sánchez, 2016). The information about these companies was taken from the Ethical Investment Research Services (EIRIS) database (an independent research organization that provides non-financial information on the environmental, ethical, and social practices and policies of companies). The largest number of companies was selected, with the sole criterion being that their reports were complete-since one of the main problems of the sustainable rating agencies is the loss of data. This research refers to the 2004-2014 decade with a final sample of 600 listed organizations per year, which makes a total of 6,600 observations of international origin with a predominance of the data coming from four geographical areas: Europe, North America, Japan, and Australia, with percentages of 50.50, 25.83, 16.67, and 7.00, respectively. In view of the objectives of the work, we will group companies according to the industry category of the Industry Classification Benchmark (ICB) system. We will study the industrial roots of sustainability through the data of the ten main industries (see Table 1). The distribution finding a comparatively greater number of companies in industries related to industrial products (18.80\%), financial services (17.30\%), and consumer goods (13.50\%). The rest have proportions close to $10 \%$, with a smaller number of companies being focused on technology, utilities, and telecommunications.

Table 1. Distribution of companies by industry, following the Industry Classification Benchmark (ICB) system

\begin{tabular}{|c|c|c|c|}
\hline & & \multicolumn{2}{|c|}{ Frequencies } \\
\hline \multicolumn{2}{|c|}{ Industry } & Absolute & Relative (\%) \\
\hline 1 & Basic Materials & 704 & 10.7 \\
\hline 2 & Consumer Goods & 891 & 13.5 \\
\hline 3 & Consumer Services & 792 & 12.0 \\
\hline 4 & Financials & 1144 & 17.3 \\
\hline 5 & Health Care & 495 & 7.5 \\
\hline 6 & Industrials & 1243 & 18.8 \\
\hline 7 & Oil \& Gas & 462 & 7.0 \\
\hline
\end{tabular}




\begin{tabular}{llll}
8 & Technology & 319 & 4.8 \\
9 & Telecommunications & 264 & 4.0 \\
10 & Utilities & 286 & 4.3 \\
\hline & Total & $\mathbf{6 , 6 0 0}$ & $\mathbf{1 0 0 . 0}$ \\
\hline
\end{tabular}

It is important to highlight that the selection of the 2004-2014 period is due to the fact that this decade marks the most prolific period of the academic and corporate CSR. In this period, companies - due to great advances in technological development or due to a greater facility of accessing information on corporate behaviour - have taken comparatively greater risks in terms of sustainability (Martínez-Ferrero and García-Sánchez, 2016).

\subsection{CSR practices_-Variables to Quantify Sustainable Commitment}

In order to quantify sustainable business behaviour in a complete, balanced, and reliable way, companies were selected with information from 26 CSR practices-which evaluate the development and commitment to sustainability on a scale of 0-4, being '0-Inadequate', '1-Weak', '2-Moderate', '3-Good', and '4-Exceptional'. These practices include many possible aspects that a company can encompass in its commitment to sustainability in terms of social and environmental dimensions. The social dimension is made up of four sub-dimensions:

- Human rights - a dimension which includes policies, systems, and reports in the struggle for the defence of citizens' rights;

- Employees - a dimension constituted by practices that evaluate the policies and systems of the company when promoting equal opportunities and better working conditions, such as the health and safety of its employees, their training and the creation of employment;

- Stakeholders - a dimension which includes everything related to maintaining the company's good external relations; the treatment of the company in relation to the community, customers, consumers, contractors, suppliers, etc. As well as maintaining those stakeholders' responsibilities related to their participation in the decision-making process; and 
Factor of Companies' Social Performance

- Ethics - a dimension that includes practices which value the existence of a code of ethics in the company and its policies, systems, and reports in the fight against bribery.

The environmental dimension implies policies, systems, and reports oriented towards the care and preservation of the environment (Table 2). The specific selection of these practices was due to the fact that they are commonly used in research work to analyse the social and environmental performance of companies (Boudt et al., 2013; León, 2015; MartínezFerrero and García-Sánchez, 2016; García-Sánchez and García-Meca, 2017).

\section{Table 2. CSR practices-measures to quantify sustainable business behaviour}

\begin{tabular}{c} 
Social dimension \\
Human Rights \\
\hline Human Rights policy / What is the extent of the Company's policy addressing \\
\\
human rights issues? \\
Human Rights systems $/$ What is the extent of systems addressing human rights \\
issues?
\end{tabular}

Employees

\begin{tabular}{|c|c|c|}
\hline Equal opportunities policy & I & $\begin{array}{l}\text { How good is the Company's policy on equal } \\
\text { opportunity and diversity issues? }\end{array}$ \\
\hline Equal opportunities systems & l & $\begin{array}{l}\text { How clear is the evidence of systems and practices to } \\
\text { support equal opportunities and diversity? }\end{array}$ \\
\hline Health & l & How clear is the evidence of health \& safety systems? \\
\hline $\begin{array}{r}\text { Trade unions and employee } \\
\text { participation }\end{array}$ & I & $\begin{array}{l}\text { How clear is the evidence of systems to manage } \\
\text { employee relations? }\end{array}$ \\
\hline Training & I & $\begin{array}{l}\text { How clear is the evidence of systems to support } \\
\text { employee training and development? }\end{array}$ \\
\hline Job creation and security & I & $\begin{array}{l}\text { How clear is the evidence of systems and practices to } \\
\text { advance job creation and security? }\end{array}$ \\
\hline
\end{tabular}

Stakeholders

\begin{tabular}{|c|c|c|}
\hline Community relations & I & $\begin{array}{l}\text { How clear is the Company's commitment to } \\
\text { community or charitable work? }\end{array}$ \\
\hline $\begin{array}{r}\text { Customer/supplier relations } \\
\text { policy }\end{array}$ & I & $\begin{array}{l}\text { Does the Company have policies on maintaining good } \\
\text { relations with customers and/or suppliers? }\end{array}$ \\
\hline Community involvement & I & $\begin{array}{l}\text { How clear is the evidence of systems to maintain good } \\
\text { relations with the community? }\end{array}$ \\
\hline $\begin{array}{r}\text { Responsibility for } \\
\text { stakeholders }\end{array}$ & I & $\begin{array}{l}\text { How many stakeholder issues have been allocated to } \\
\text { board members? }\end{array}$ \\
\hline Stakeholder engagement & l & $\begin{array}{l}\text { What level of engagement with stakeholders is } \\
\text { disclosed by the Company? }\end{array}$ \\
\hline
\end{tabular}




$\begin{array}{ccl}\text { Stakeholder policy } & / & \begin{array}{l}\text { How good are the Company's policies towards its } \\ \text { stakeholders overall? }\end{array} \\ \text { Stakeholder systems } & / \quad \begin{array}{l}\text { How good is the Company's quantitative systems on } \\ \text { stakeholder relationships? }\end{array} \\ \text { Stakeholder reporting } / & \begin{array}{l}\text { How good are the Company's management reporting } \\ \text { for stakeholders overall? }\end{array}\end{array}$

Ethics

\begin{tabular}{|c|c|c|}
\hline Codes of ethics & I & $\begin{array}{l}\text { Does the Company have a code of ethics - and if so, } \\
\text { how comprehensive is it? }\end{array}$ \\
\hline Codes of ethics systems & I & $\begin{array}{l}\text { Does the Company have a system for implementing a } \\
\text { code of ethics - and if so, how comprehensive is it? }\end{array}$ \\
\hline Countering bribery policy & I & $\begin{array}{l}\text { What is the extent of the Company's policy for } \\
\text { countering bribery? }\end{array}$ \\
\hline Countering bribery systems & I & $\begin{array}{l}\text { What is the extent of the Company's system for } \\
\text { countering bribery? }\end{array}$ \\
\hline $\begin{array}{r}\text { Countering bribery } \\
\text { reporting }\end{array}$ & I & $\begin{array}{l}\text { What is the extent of the Company's reporting on } \\
\text { countering bribery? }\end{array}$ \\
\hline
\end{tabular}

Environmental dimension

\begin{tabular}{ccl}
\hline \multicolumn{2}{c}{ Environment } \\
\hline Environmental policy & $/$ & $\begin{array}{l}\text { How does EIRIS rate the Company's environmental } \\
\text { policy and commitment? }\end{array}$ \\
Environmental systems & $/$ & $\begin{array}{l}\text { How does EIRIS rate the Company's environmental } \\
\text { management system? }\end{array}$ \\
Environmental reporting & $/$ & $\begin{array}{l}\text { How does EIRIS rate the Company's environmental } \\
\text { reporting? }\end{array}$ \\
Environmental performance & $/$ & $\begin{array}{l}\text { What level of improvements in environmental impact } \\
\text { can the Company demonstrate? }\end{array}$ \\
\hline
\end{tabular}

\subsection{Statistical Multivariate Analysis}

\subsubsection{CO-X-STATIS Method}

Thiolouse (2011) presents the COSTATIS, which is a technique that combines STATIS and co-inertia analyses. In this investigation, a CO-XSTATIS analysis (X-STATIS and co-inertia, which we describe below) is performed. This method is used to simultaneously analyse two successions of tables with the same variables within each sequence and between the same individuals in both sequences. It is based on the co-inertia analysis of two compromise tables (a matrix that summarizes a set of matrices). The first step is to use two X-STATIS analyses, one for each succession, to calculate the two compromise tables; the second step consists of a co-inertia analysis to examine the relationships between these two compromises. 
Factor of Companies' Social Performance

Figure 1 shows the procedure scheme on which the CO-X-STATIS is based, where a pair of sequences of $T$ tables is used. $Y_{t}$ is a sequence of $T$ tables with information on $n$ individuals measured on $q$ variables; and $X_{t}$ is another sequence of $T$ tables that measures the same $n$ individuals on $p$ variables. A X-STATIS analysis is applied to each sequence, obtaining a compromise matrix $Y_{C}$ representative of $Y_{t}$ tables and another $X_{C}$ representative of $X_{t}$ tables. On these two compromise matrices, $Y_{C}$ and $X_{C}$, a co-inertia analysis is carried out, obtaining the matrix of cross products $Z=Y_{C}^{\prime} D_{n} X_{C}$ through which it is possible to study the co-structure of these two compromises.

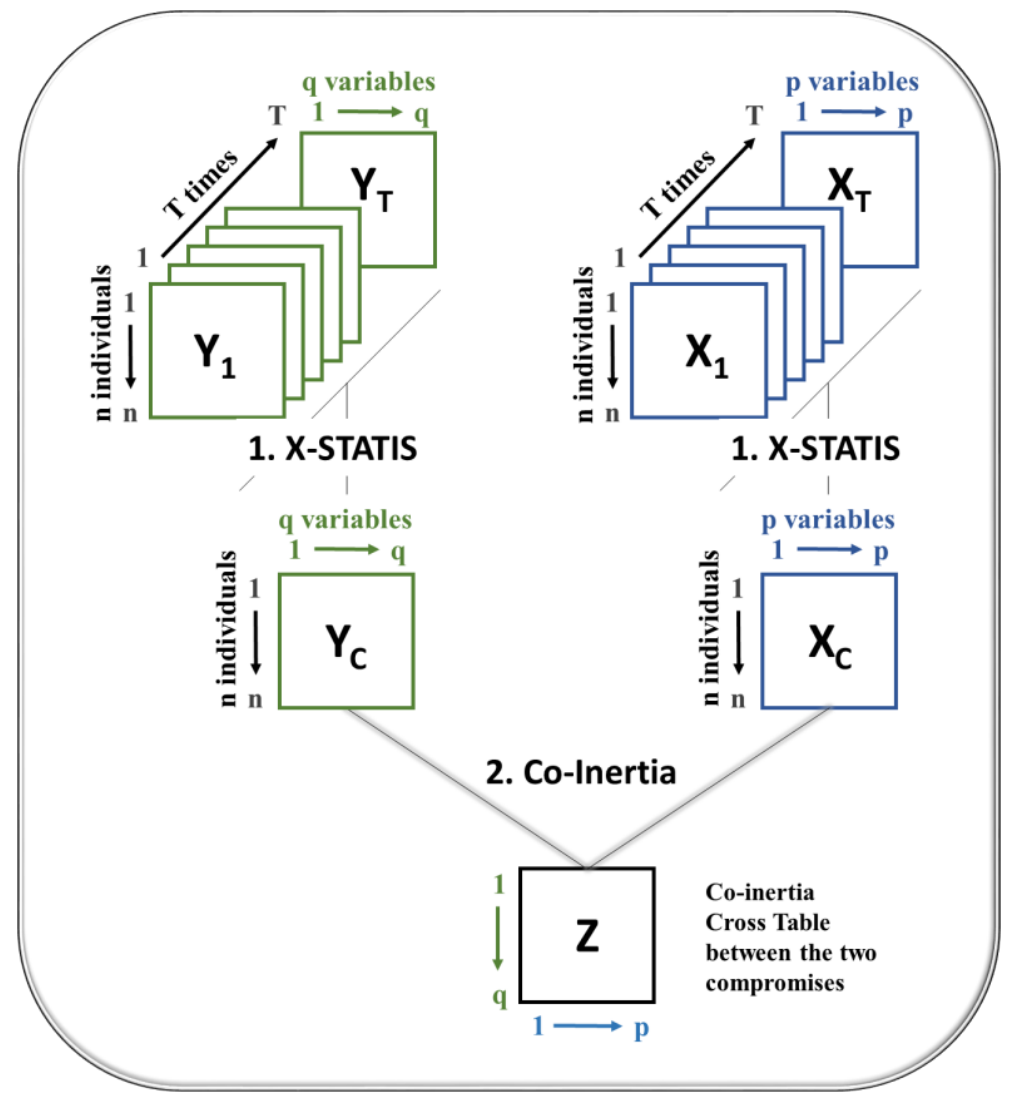

Figure 1. Outline of the CO-X-STATIS analysis 
In this research, the CO-X-STATIS analysis is used to interpret the importance that each industry gives to the practices that evaluate social welfare in relation to its environmental commitment and, therefore, its characterization according to each of CSR practices. This will be done through a comparison of the environmental dimension (Env) with each of the social sub-dimensions - human rights (HR), employees (Emp), stakeholders (Sth), and ethics (Eth) - trying these in pairs, which will result in four CO-X-STATIS analyses (Env-HR, Env-Emp, Env-Sth, and EnvEth). In any of these four analyses, the data will be arranged in two successions of $T$ tables where $t$ will refer to the years 2004-2014. The first succession of $X_{t}$ tables will correspond to the social commitment, and each $X_{t}$ matrix will carry the information of $n$ individuals (industries) measures on $p$ variables (social practices referring to a single sub-dimension) and another succession of $Y_{t}$ tables with information on the same $n$ individuals measures on $q$ variables (environmental practices). The first step is the application of an X-STATIS analysis to each succession.

The STATIS - Structuration de Tableaux A Trois Indices de la Statisquefamily methods was developed by L'Hermier des Plantes (1976), although the theoretical basis of these methods belong to Escoufier (1976). In synthesis, the STATIS methods consist of making a study of the relationship between the $T$ matrices so as to later determine a compromise matrix, which is the closest of all the $T$ original matrices and is representative of all of them, and which is obtained from scalar products between configurations. In this work, however, we use the X-STATIS method (Jaffrenou, 1978). This is a method within the STATIS family with the difference that it is only applicable to successions of tables with the same individuals and the same variables (since it has the advantage of working directly with the original matrices without using operators provided that it is in compliance with the said condition). Thus, the procedure of this method is simpler and provides more representations. It follows the same scheme of the STATIS methods, which (as a general rule) are composed of three stages: interstructure, compromise, and intrastructure. However, in view of the objectives of this study, we will only focus on the first two stages.

(i) Interstructure (see Figure 2): In this stage, the relationship between the different tables is studied by comparing their structure in a global way. For this, a matrix of vectorial covariances between tables is constructed, so that the element in row $t$ and column $l$ is $\operatorname{Covv}\left(X_{t}, X_{l}\right)=\operatorname{Traza}\left(X_{t}^{\prime} D_{n} X_{l} D_{p}\right)$ where $X_{t}$ is the t-table of the sequence and $D_{n}, D_{p}$ are the two metrics for the rows and columns, respectively. This will lead to a matrix $T x T$ where 
each value will represent the covariance between two tables (years in this study). From the decomposition of this matrix into singular values, we look for a Euclidean representation in low dimension where each matrix (each year) is represented as a point in the plane. Thus, the proximity between two points will correspond to two tables of similar structures. In this way, the study of the interstructure will allow us to show the similarities and differences between years before performing the co-inertia analysis and which therefore correspond to interstructures from the point of view of each dimension and sub-dimension (separately): environment, human rights, employees, stakeholders and ethics.

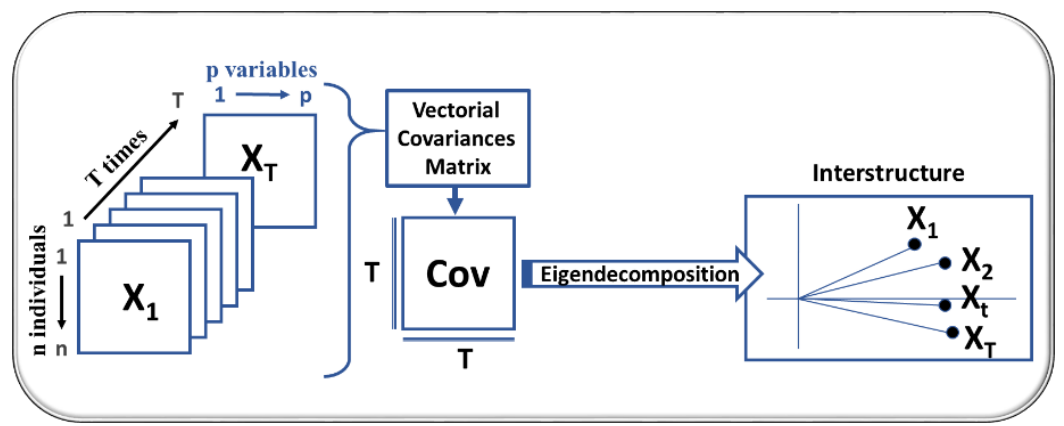

Figure 2. Outline of the Interstructure (X-STATIS analysis)

(ii) Compromise (see Figure 3): The next stage of the method is to create, from the initial $T$ matrices, a matrix $Z$ that is constructed in the following way: It starts from the $T$ matrices, each with $n$ rows (individuals) and $p$ columns (variables), and is constructed a new matrix $\mathrm{Z}$ where each column vector is one of the $T$ matrices extended; that is, where the $p$ columns are stacked in a vector column $X_{t}$. So we have the vectors $X_{1}, \ldots, X_{t}$ that make up the matrix $Z$. The $Z$ matrix will consist of $n x p$ rows and $T$ columns. The next step is to apply a principal component analysis to the created $Z$ matrix, which we will call $Z V$. In this table, each column represents a principal component, and these components are linear combinations of the $Z$ columns - therefore, they contain the common information and stable of the original matrices-. In this way, by unfolding the first column of $Z V$ which is the one with the greatest variability, we will obtain a matrix that returns to obtain the dimensions of the original matrices $X_{t}$ with $n$ rows x $p$ columns. This matrix $X_{c}$ is called 'compromise' and is a global summary of the set of tables. Therefore, the compromise matrix summarizes all the information provided by all the configurations over time. 
The objective of this method is to calculate the compromise matrix of each succession of tables: environment, human rights, employees, stakeholders and ethics. Thus, each of the compromises will synthesize the information of the $n=10$ industries analysed on $p$ CSR practices (the number of practices depends on the succession chosen) during the $T=11$ years of study (2004-2014), filtering the noise and representing the stable information.

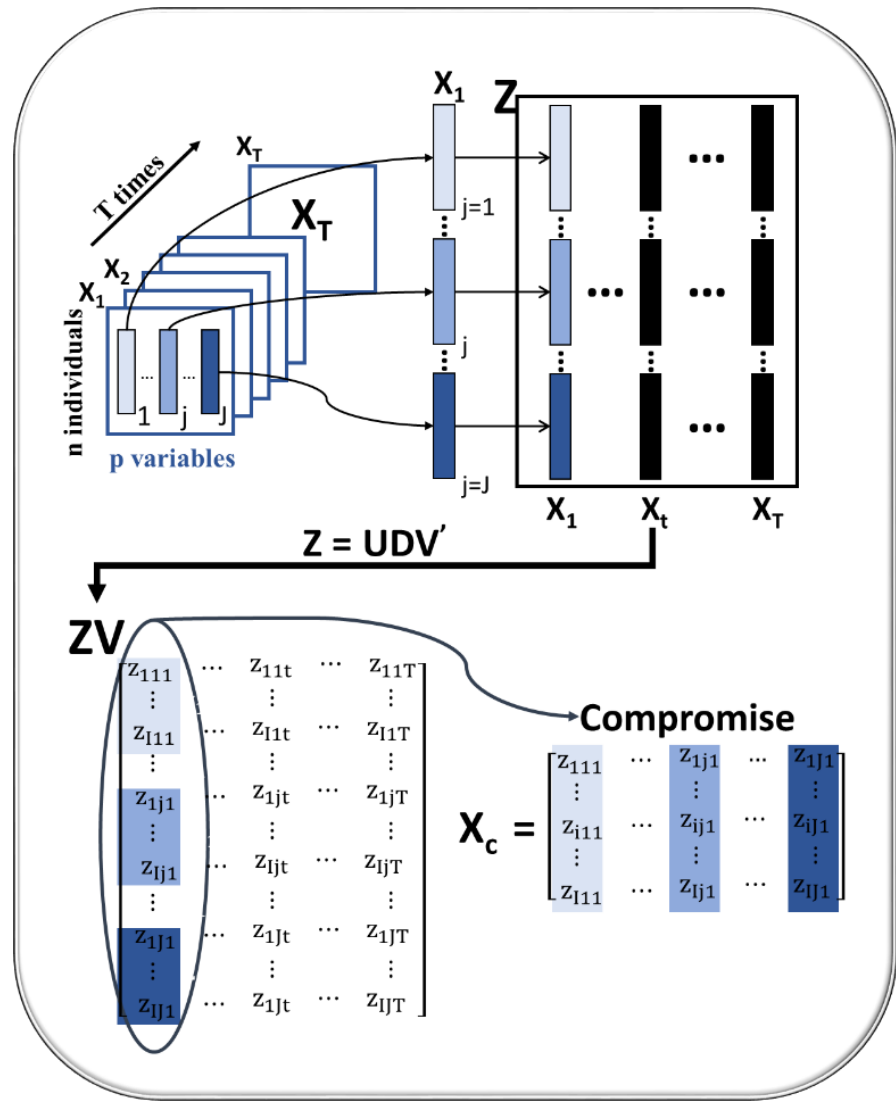

Figure 3. Outline of compromise analysis (X-STATIS analysis)

The next step of the CO-X-STATIS method is a co-inertia analysis of these compromises, taking into account these in pairs. That is, we will highlight the relationships between two 'stable structures'. The analysis of co-inertia 
Factor of Companies' Social Performance

allows us to find the common structure between two groups of variables (Dolédec and Chessel, 1994). This technique aims to find a pair of co-inertia axes - that is, a vector $a_{1}$ of the first set of variables and a vector $b_{1}$ of the second - on which to project the individuals with maximum co-inertia. If the data is centered, this analysis will maximize the covariance squared between the projections of the individuals on the said co-inertia axes (see Figure 4).

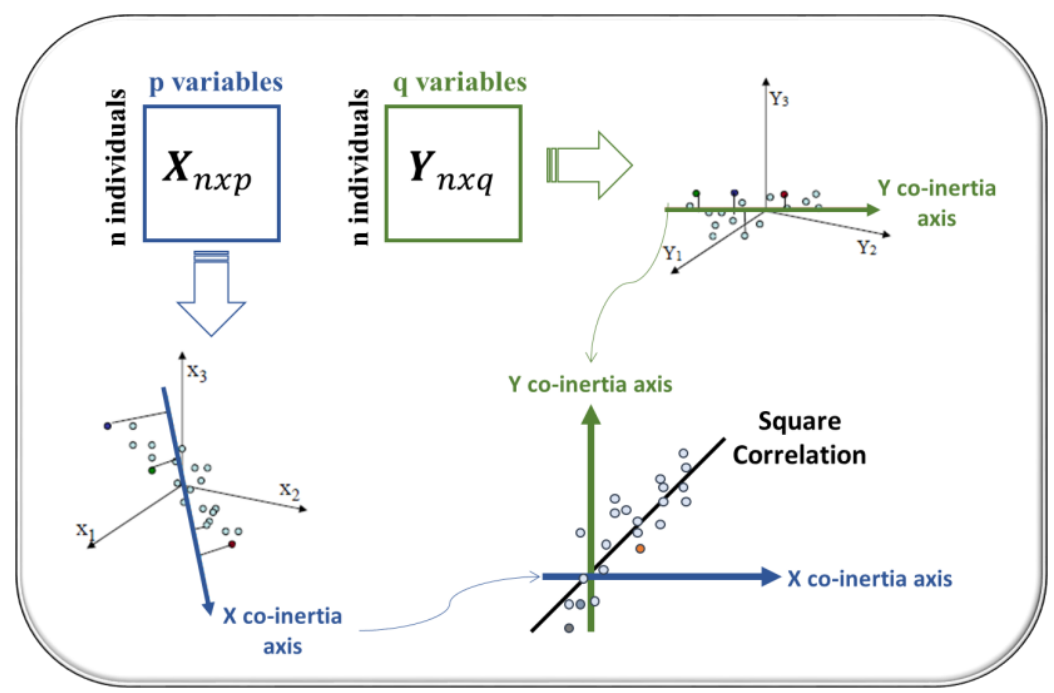

Figure 4. Outline of Co-inertia Analysis

Let $X_{n x p}$ represent the first table and let $Y_{n x q}$ represent the second tabletwo data matrices with the same $n$ individuals according to which $p$ and $q$ variables are measured, respectively. Let $D_{n}$ represent the diagonal matrix $n \times n$ of the weights of the rows:

$$
D_{n}=\operatorname{diag}\left(\omega_{1}, \cdots, \omega_{n}\right)
$$

and let $D_{p}$ and $D_{q}$ represent two metrics in $\mathbb{R}^{p}$ and $\mathbb{R}^{q}$, respectively.

Before carrying out the co-inertia analysis, it is necessary to analyse each table separately. If $D_{n}$ is the uniform row weights matrix $\left(\omega_{1}=1 / n\right)$, and if $D_{p}$ and $D_{q}$ are identities (Euclidean metrics), then these will be simple principal component analyses. Considering the columns of both tables are 
centered, the total inertia of each table will simply be the sum of the variances:

$$
\operatorname{Iner}_{X}=\sum_{j=1}^{p} \operatorname{Var}\left(X_{j}\right) \quad \operatorname{Iner}_{Y}=\sum_{k=1}^{q} \operatorname{Var}\left(Y_{k}\right)
$$

Inertia is a measure of the variability in the data, and is defined as being the distance between an element and its average profile, taking into account the weight of each element. In the context that concerns us, the expression of inertia is:

$\operatorname{Iner}_{X}=\operatorname{traza}\left(X D_{P} X^{\prime} D_{n}\right) \quad \operatorname{Iner}_{Y}=\operatorname{traza}\left(Y D_{q} Y^{\prime} D_{n}\right)$

The co-inertia between $X$ and $Y$ is, in this case, a sum of squares of covariances:

$$
\begin{aligned}
{\text { Co }- \text { Iner }_{X Y}=} & \sum_{j=1}^{p} \sum_{k=1}^{q}\left(\operatorname{Cov}\left(X_{j}, Y_{k}\right)\right)^{2}=\sum_{j=1}^{p} \sum_{k=1}^{q}\left(\frac{1}{n} \sum_{i=1}^{n} x_{i j} y_{i k}\right)^{2} \\
& =\sum_{j=1}^{p} \sum_{k=1}^{q}\left(\frac{1}{n} \sum_{i=1}^{n}\left(X^{\prime}\right)_{j i}(Y)_{i k}\right)^{2}= \\
& =\sum_{j=1}^{p} \sum_{k=1}^{q}\left(\left(X^{\prime} D_{n} Y\right)_{j k}\right)^{2} \\
& =\sum_{j=1}^{p} \sum_{k=1}^{q}\left(Y^{\prime} D_{n} X\right)_{k j}\left(X^{\prime} D_{n} Y\right)_{j k}=\sum_{k=1}^{q}\left(Y^{\prime} D_{n} X X^{\prime} D_{n} Y\right)_{k k} \\
& ==\operatorname{traza}\left[Y^{\prime} D_{n} X D_{p} X^{\prime} D_{n} Y D_{q}\right]
\end{aligned}
$$

Therefore, the co-inertia analysis is the analysis of eigenvectors and eigenvalues of $Y^{\prime} D_{n} X D_{p} X^{\prime} D_{n} Y D_{q}$ and $X^{\prime} D_{n} Y D_{q} Y^{\prime} D_{n} X D_{p}$ and it is possible to graphically represent both the rows and the columns of the two original matrices in a subspace of dimension $r$ obtained with the analysis, calculating the different coordinates:

rows of $X: \quad X D_{p} V_{r}$

columns of $X: \quad X^{\prime} D_{n} Y D_{q} U_{r}$ rows of $Y: \quad Y D_{q} U_{r}$

columns of $Y: \quad Y^{\prime} D_{n} X D_{p} V_{r}$ 
with $U_{r}$ and $V_{r}$ representing the first $r$ columns of the eigenvector base of the decompositions of $Y^{\prime} D_{n} X D_{p} X^{\prime} D_{n} Y D_{q}$ and $X^{\prime} D_{n} Y D_{q} Y^{\prime} D_{n} X D_{p}$, respectively.

The co-inertia analysis maximizes the covariances between the coordinates of the rows of the two tables. If both structures covariate in a similar way (either directly or inversely), co-inertia will be high, otherwise; we will obtain a low value. This is the meaning of the co-structure between the two data tables. The results can be represented as their own name indicates, in the form of graphs of co-structures that greatly facilitate the interpretation of the analysis. We show the following figure as an example (see Figure 5).

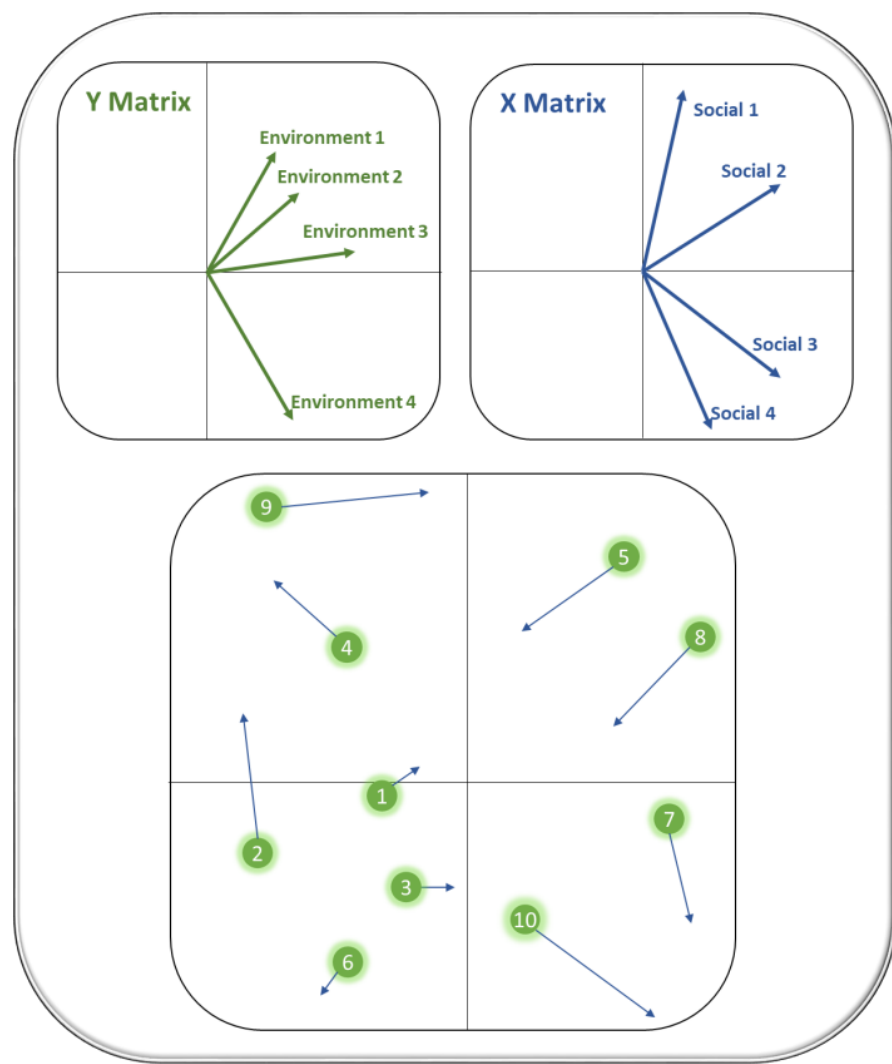

Figure 5. Co-structure graph of a hypothetical study with information on 10 individuals in relation to two sets of variables 
In this figure, it is possible to observe the projection of two new sets of standardized coordinates of a study with information on 10 individuals in relation to two sets of variables on their axes of co-inertia. We can extrapolate this example to our context, so that individuals would correspond with $n=10$ industries measures on $p$ social variables and $q$ environmental variables. Thus, each industry is represented as a circular number accompanied by a vector. The circle in green tone marks the position according to the order of the matrix of environmental practices $\left(Y_{n x q}\right)$. And the end of the blue vector marks the position according to the order of the matrix of social practices $\left(X_{n x p}\right)$. Therefore, individuals with short vectors indicate that, for those individuals, the variables of the $Y$ matrix explain the structure found in the $X$ matrix (and vice versa) well. Applied to the present context, those industries that obtain short vectors will grant similar importance to their social practices in relation to their environmental commitment (e.g., industries 1, 3, and 6). In addition, with this information we will characterize each one of the industries according to their relative position in the plane by observing the quadrants. Thus, for example, industry ' 10 ' prioritizes the practices of 'Environment 4' and 'Social 3 and 4'; and we can also observe with respect to the variables, a positive relationship between 'Environment 4' and 'Social 3 and 4'.

In synthesis, the CO-X-STATIS is a co-inertia analysis of the compromise between two analyses of $T$ tables. Therefore, it highlights the relationships between two stable structures and is easy to interpret (as a standard coinertia analysis), because it retains the optimality properties of the commitments of two X-STATIS analyses. In this research, we use it with the objective of knowing the importance that each industry gives to social concerns as compared to its environmental commitment. More specifically, we study the variation of our $n$ industries measured on $q$ environmental variables and $p_{1}$ human rights variables, $p_{2}$ of employees, $p_{3}$ stakeholders, and $p_{4}$ ethics referencing social sub-dimensions-that is, four different analyses - . To suppress the time dimension, we perform X-STATIS threeway analysis and we work with the matrix called "commitment" that synthesizes all that information. So, through four co-structure graphs on these compromises (environment with human rights-employeesstakeholders-ethics) we verify the importance that each industry gives individually to social practices in relation to its environmental practices. 


\section{Results of Empirical Analysis}

Through the application of a CO-X-STATIS analysis, a comparison of the environmental dimension with each of the social sub-dimensions is carried out in order to assess the importance that each industry attaches to social practices in reference to environmental commitment. The data for this analysis are arranged in five 10-row cubes (the industries), with 11 repetitions (the years 2004-2014): a cube with 4 columns, corresponding to environmental practices; another cube with 3 columns, related to human rights; another with 6 variables that refer to labour rights; another composed of 8 practices concerning stakeholders; and the last, formed by 5 practices in relation to business ethics (Figure 6).

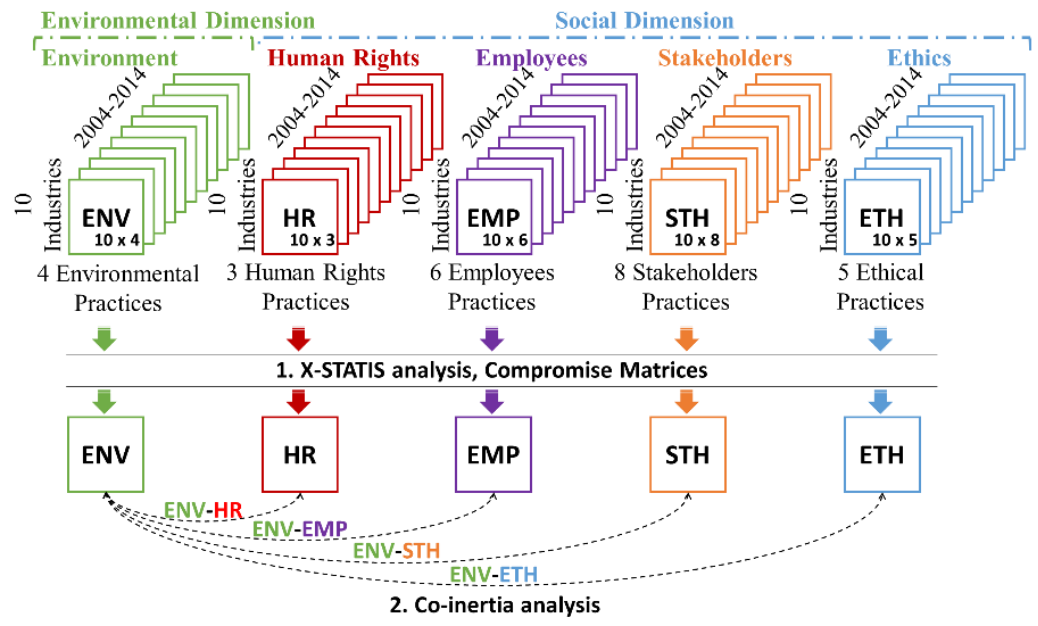

Figure 6. Outline of CO-X-STATIS Analysis

As a first point, an X-STATIS analysis is performed on each of the cubes with the main objective of building the compromise matrix of each of them-a matrix that synthesizes and summarizes the information during the 2004-2014 decade, 'filtering the noise' and keeping the information more stable- L Likewise, through its study of the interstructure, the ordering of the years will be shown from the point of view of each type of variable, separately. As a second point, a co-inertia analysis is performed on the compromise matrices obtained through the X-STATIS, taking into account these in pairs. That is, the relationships between two 'stable structures' are highlighted. This information is presented through co-structure graphs. 
The study of the interstructure of the X-STATIS analysis shows the similarities and differences between years before the analysis of co-inertia for each of the cubes: environment, human rights, employees, stakeholders, and ethics (Figure 7). The relationships between the years occur gradually - the first and the last year of study being the ones with the greatest differences - showing constant growth in CSR practices during this period in each of the dimensions. The arrangement of the years in the different practices shows a strong degree of similarity. Thus, the 'average years' vary between the years 2008-2010. That is, in all of them, one of the intermediate years of the study is the one that most closely approaches the abscissa axis. However, we find some differences. Human rights and ethics practices divide the study decade into two groups, accentuating a jump in this sustainable growth from 2009 to 2010 and from 2008 to 2009, respectively. In the case of the practices of employees or stakeholders, this growth occurs more gradually. Finally, for the environment, very strong relationships occur during most years, separating the latter two (2013-2014) from the rest.

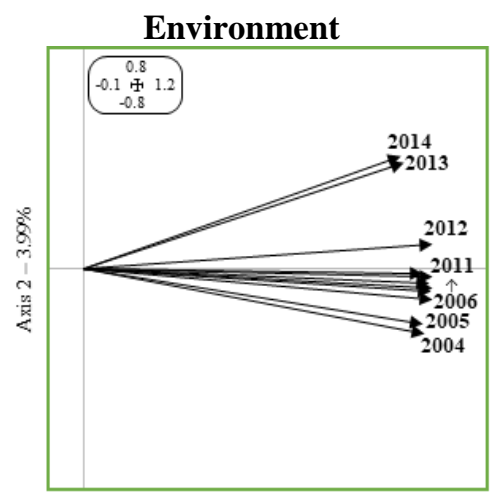

Axis $1-91.85 \%$

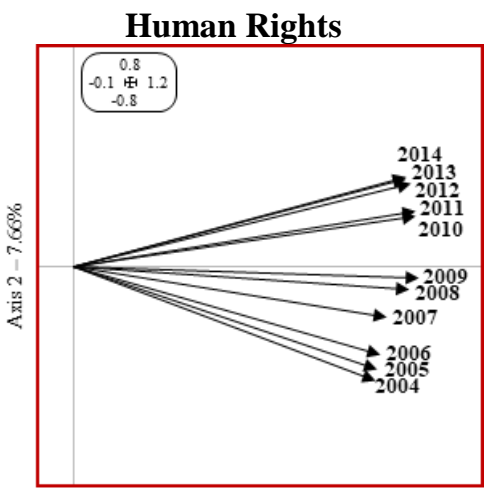

Axis $1-82.88 \%$ 
Factor of Companies' Social Performance

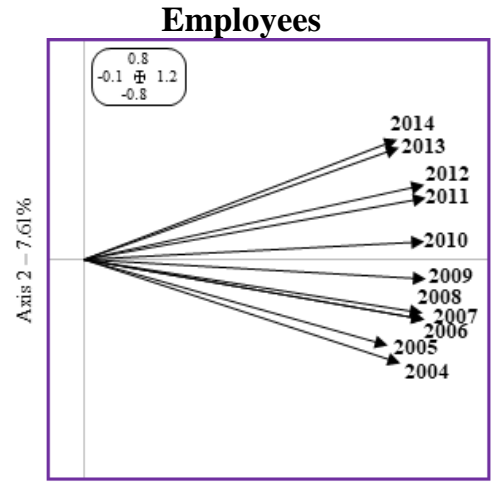

Axis $1-86.07 \%$

Ethics

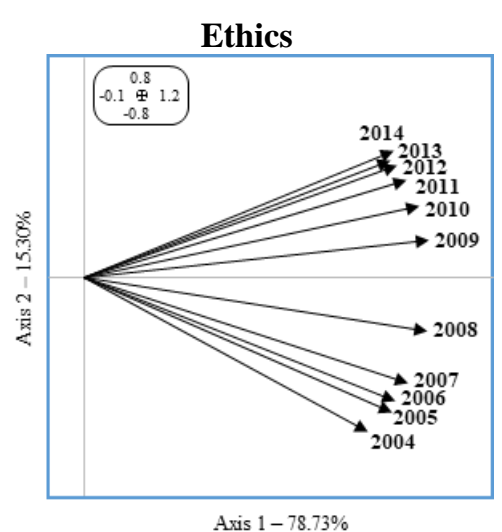

Axis $1-78.73 \%$

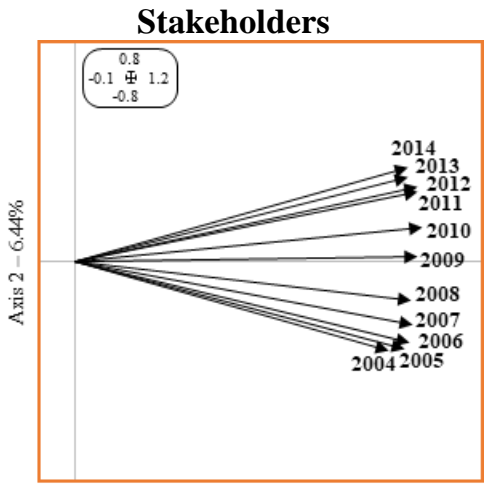

Axis $1-87.54 \%$

Figure 7. Study of the Interstructure for each type of CSR practice (XSTATIS analysis)

Given that the objective is to compare social sub-dimensions with environmental commitment, a co-inertia analysis is carried out between the environmental compromise matrix and each of the social commitment matrices obtained through the X-STATIS analysis. This information is presented through co-structure graphs, where it is possible to observe the projection of two new sets of standardized coordinates, referring to the industries on the co-inertia axes of the two data sets. Thus, we represent four figures: the first corresponds to environmental practices with those of human rights; the second, environment-employees; the third, environmentstakeholders; and, the fourth, environment-ethics. In the co-structure graphs, each industry is represented by a vector, where the circle or start of 
the vector marks the position according to the order of the first compromise matrix, and the vector arrow marks the position according to the ordering of the second matrix.

Prior to the presentation of the said graphs, we show some measures of absorbed inertia and correlations that provide us with the information absorbed by the co-inertia axes of each pair of matrices. Table 3 shows these values, so its last two columns 'Iner1' and 'Iner2', correspond to the maximum inertias resulting from the separate analyses, of which 'Varian1' and 'Varian2' represent the inertia projected on the co-inertia axes. Thus, comparing these values, it can be seen that the first factorial plane (axes 1 and 2) of co-inertia extracts a quantity of variability that is similar to that of the analyses separately. The 'Correlation' column gives us a value of the correlation between the first co-inertia factor of the first matrix and the first co-inertia factor of the second matrix (equal to the second axis). In this way, we can see how each of the social sub-dimensions receives a strong relationship with the environment.

Table 3. Absorbed inertia and correlations with the co-inertia axes (CO-X-STATIS analysis)

\begin{tabular}{ccccccc}
\hline \multicolumn{7}{c}{ Environment - Human Rights } \\
\hline Axis & Covariance & Varian1 & Varian2 & Correlation & Iner1 & Iner2 \\
\hline Axis 1 & 2.330 & 3.576 & 2.701 & 0.750 & 3.624 & 2.713 \\
Axis 2 & 0.093 & 0.145 & 0.199 & 0.486 & 0.165 & 0.216 \\
\multicolumn{7}{c}{ Environment - Employees } \\
\hline Axis 1 & 2.242 & 3.589 & 2.619 & 0.731 & 3.624 & 3.787 \\
Axis 2 & 0.200 & 0.108 & 0.568 & 0.807 & 0.165 & 1.041 \\
\multicolumn{7}{c}{ Environment - Stakeholders } \\
\hline Axis 1 & 3.386 & 3.575 & 5.156 & 0.789 & 3.624 & 5.357 \\
Axis 2 & 0.409 & 0.138 & 1.295 & 0.806 & 0.165 & 1.705 \\
\multicolumn{7}{c}{ Environment - Ethics } \\
\hline Axis 1 & 2.933 & 3.607 & 3.927 & 0.779 & 3.624 & 4.047 \\
Axis 2 & 0.203 & 0.165 & 0.511 & 0.700 & 0.165 & 0.554 \\
\hline
\end{tabular}


Next, we show the corresponding co-structure graphs through which we can make a multivariate characterization of each industry in relation to its social and environmental practices. The first represents the relationship between environmental and human rights practices (Figure 8). All of them are positioned in the right semi-plane (quadrants I and IV), so that they maintain a positive relationship. In reference to the industries, the figure on the left represents, through circles highlighted in green, its environmental position; and the prolongation of the red-coloured vectors marks their position according to human rights practices. In the figure on the right the situation is the opposite. The circles highlighted in red show the position according to human rights practices and the green vectors mark their position according to the environmental variables. In this way, industries that present short vectors give similar importance to both practices.

The practices of both dimensions are located in the right semi-plane, so that the abscissa axis orders the industries according to their commitment to all practices. The basic materials and utilities industries present the highest environmental levels. In human rights, only these industries and the one dedicated to oil and gas are positioned on the right side, showing notable differences with the rest of the industries. Although it is possible to observe long vectors, most of them are produced vertically - which explains the correlation value of the second axes of co-inertia (see Table 3) - However, it is important to highlight the difference in the practices of the industry dedicated to oil and gas, which obtains medium-high values with regard to the environment and very strong in human rights. These companies adhere to CSR practices as a way to legitimize their operations, since its actions have a strong impact on human health, an impact that clearly threatens the rights of citizens. The opposite is found in the telecommunications and consumer goods industries, which prioritize their environmental commitments; although the latter have high levels of disclosure on human rights (foreseeably so for companies dedicated to the manufacture and distribution of tobacco). 


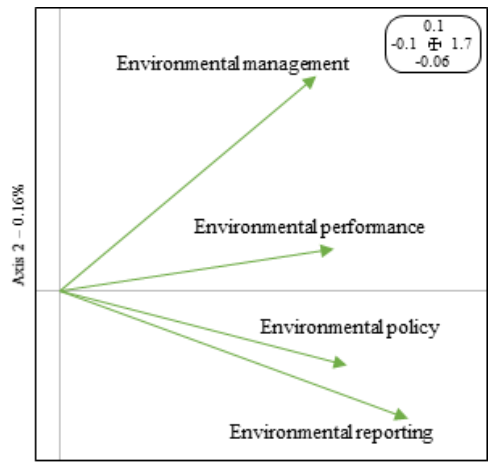

Axis $1-99.84 \%$

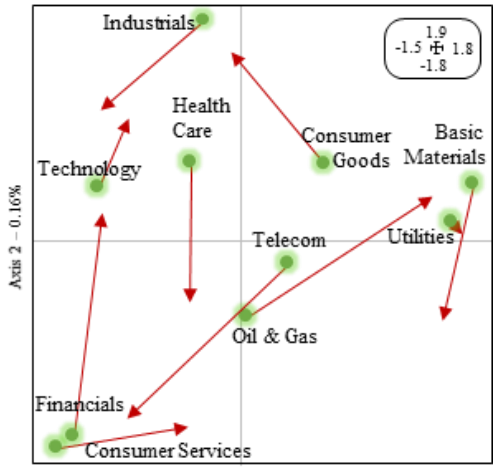

Axis $1-99.84 \%$

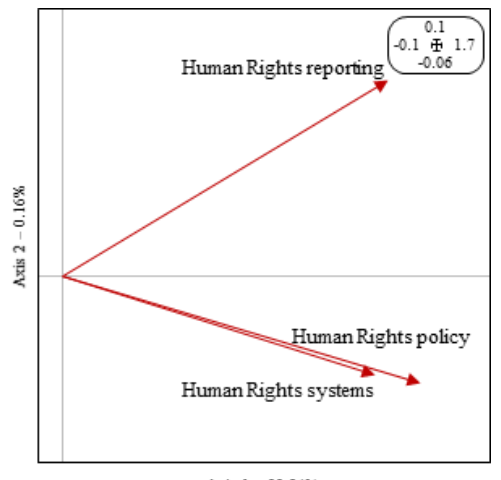

Axis $1-99.84 \%$

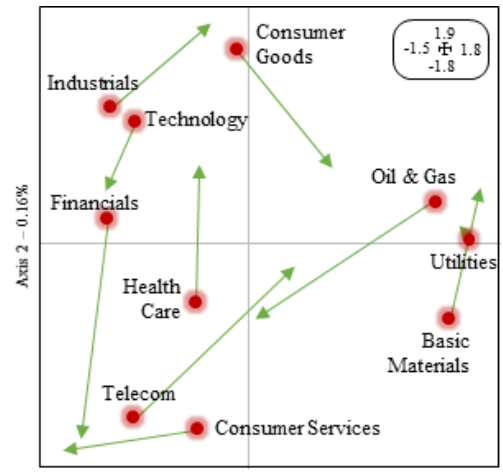

Axis $1-99.84 \%$

\section{Figure 8. Environment-Human Rights co-structure (CO-X-STATIS analysis)}

The following co-structure graphic (Figure 9) represents the relationship between environmental and employee practices. All of them are positioned on the right side, obtaining a strong correlation value (see Table 3), in large part due to the practice directed towards the health and safety systems, which presents the greatest variability and relationship with the abscissa axis.

Regarding the industries, utilities (with greater orientation towards the policies of equal opportunities), telecommunications (more oriented to the training and participation of its employees), and basic materials (oriented towards the systems of equal opportunities) present the highest levels of 
Factor of Companies' Social Performance

employee practices, highlighting their systems' orientation towards health and safety. It should be noted that the telecommunications, consumer services and financial services industries give higher priority to their employee practices than to their environmental commitment. The opposite situation is found in consumer goods and basic materials.
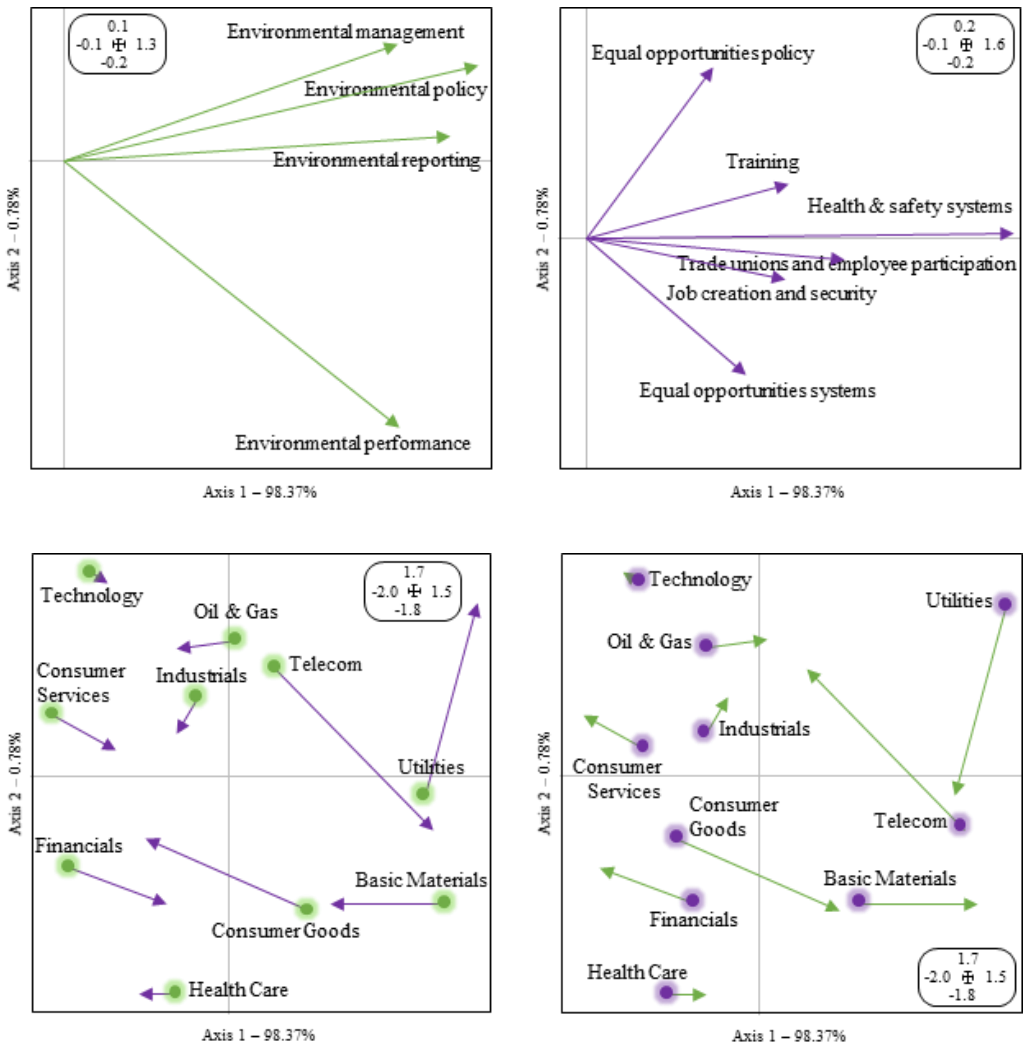

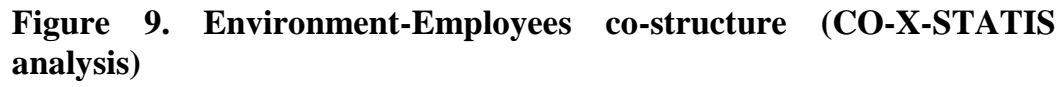

The relationship between stakeholder practices and environmental commitment is a relationship represented in the following co-structure graph (Figure 10), where we found a strong relationship (somewhat less so with the practice related to policies to maintain good relations with customers/suppliers). 
Telecommunications, utilities and basic materials industries are presented as the strongest in stakeholders practices. It should also be noted that the telecommunications, financial services and consumer services industries attach greater importance to these practices than to those related to the environment. The reverse situation is found in the consumer goods and basic materials industries. Likewise, the technology, health care and industrials industries (quadrant II) emphasize their practices in community relations and environmental management; and the consumer services, financial services, and oil and gas (quadrant III) prioritize community involvement.

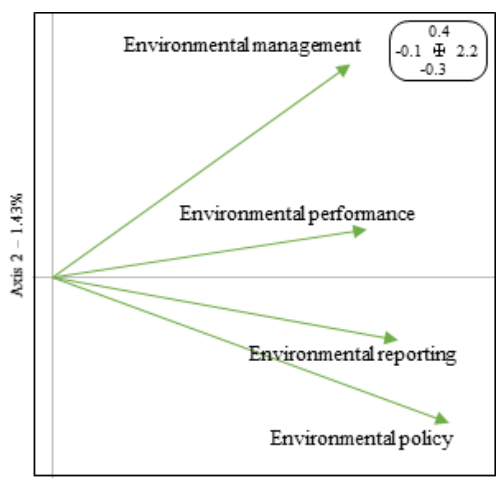

Axis $1-98.51 \%$

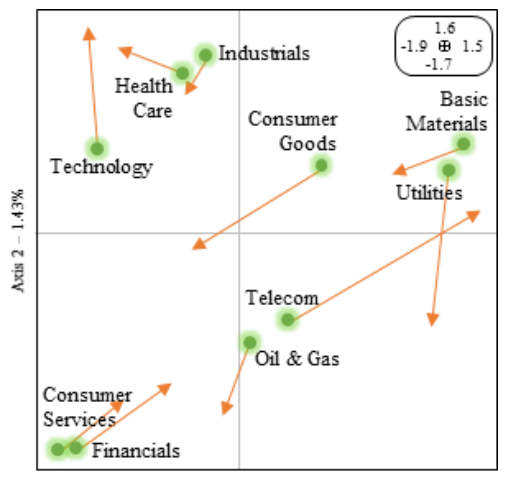

Axis $1-98.51 \%$

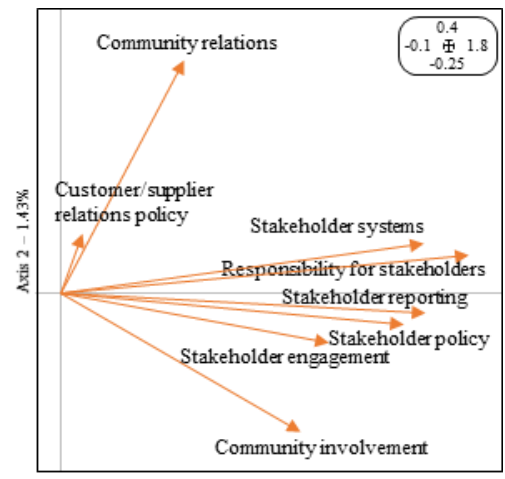

Axis $1-98.51 \%$

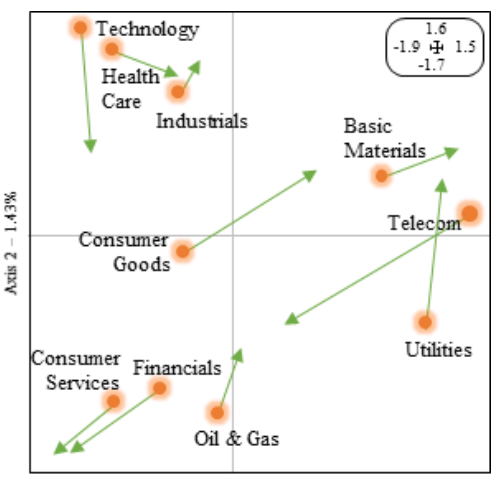

Axis $1-98.51 \%$

Figure 10. Environment-Stakeholders co-structure (CO-X-STATIS analysis)

Finally, in relation to ethical and environmental practices (Figure 11), we find a relationship between environmental policies and the countering 
Factor of Companies' Social Performance

bribery, as well as with the systems for the implementation of a code of ethics, where the oil and gas and telecommunications industries stand out (quadrant I). Likewise, we find another relationship between the environmental reports and the countering bribery, highlighting the industries dedicated to utilities and basic materials (to a lesser extent, Health Care) (quadrant IV). It is worth highlighting the commitment of the consumer goods industry to the environment - a commitment which is far superior to the rest of the non-environmental practices of that same industry. The industrials' industry presents a similar importance with average values for all practices (values somewhat smaller for human rights). Financial services and consumer services present the lowest values of the study; increasing these values in human rights for consumer services and in employees for financial services.
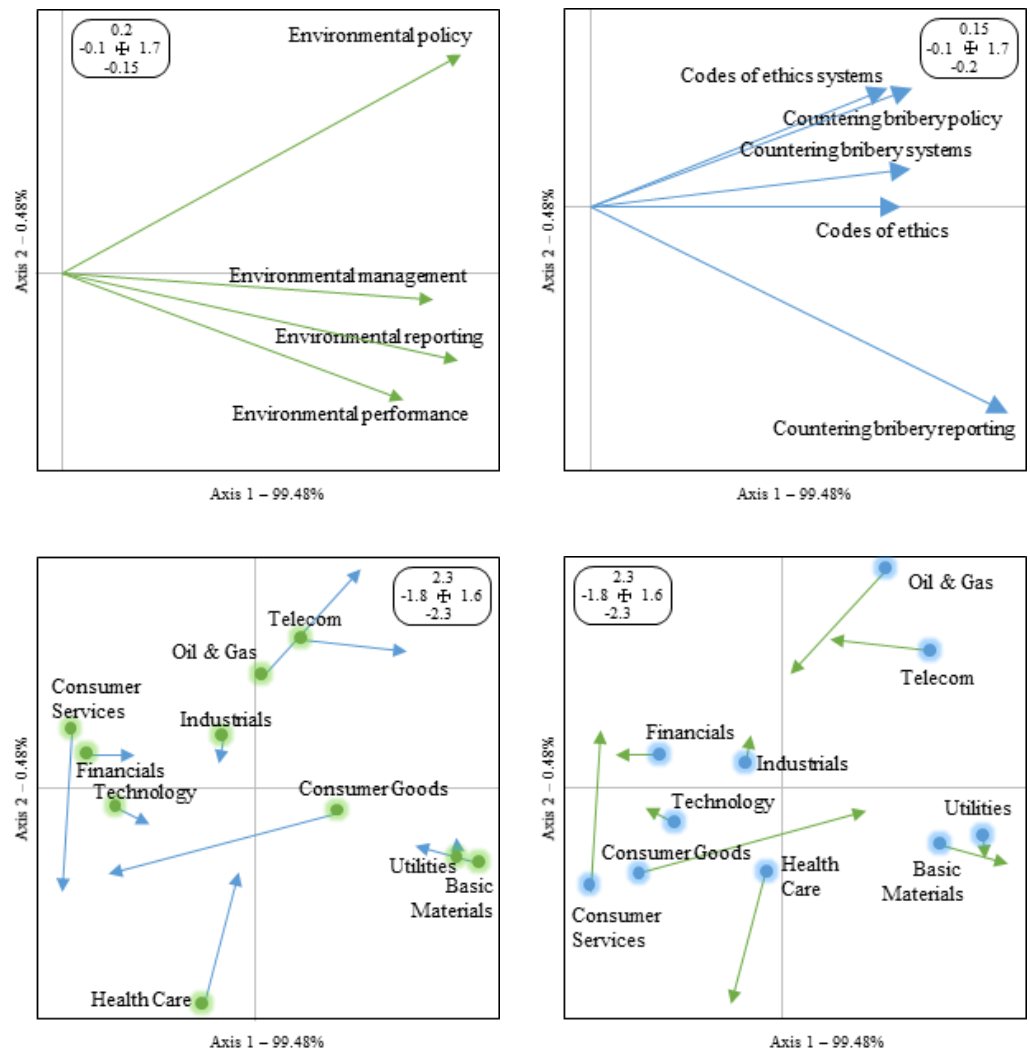

Figure 11. Environment-Ethics co-structure (CO-X-STATIS analysis) 


\section{Discussion}

This research is aimed at answering one of the oldest questions in the debate on CSR: the question of whether it is worthwhile for organizations to pay attention to social demands. For addressing this question, this study works with the environmental and social dimensions of sustainability and evaluates the behaviour of companies with regard to the protection of the environment; the preservation of human rights; the defence of employees' rights; the treatment and relations with stakeholders; and business ethics. Following the results obtained, it is possible to verify the existence of important industrial discrepancies. This is due to the fact that the specific interest groups of each industry, and the society in general, perceive different social and environmental risks according to the economic activity developed by the organizations. This is a fact that is reflected in the CSR policies and initiatives adopted by them. So, the companies adopt more codified and explicit CSR policies and systems of the industry in which they operate. This is done with the aim of improving their image by controlling the standards they must meet in order to be considered proactive and thus to increase their benefits (Jackson and Apostolakou, 2010).

The differences found between industries lead to determining the industry as an institutional factor with an explanatory capacity in terms of CSR practices, thus demonstrating that companies vary their behaviour according to the risks, pressures, and specific expectations of each industry. Following this line of reasoning, we can point out how the industries directed towards basic materials and utilities are presented as leaders in CSR, with notable differences over the rest in terms of their environmental and human rights levels. These industries are made up of polluting companies - producers and distributors of chemical products; mining (including coal extraction); and generators and distributors of electricity or natural gas - considered as being high risk and impactful on the environment. Therefore, due to the social pressure of disclosing unfavorable environmental news, such companies seek to increase the confidence of users by managing the company's risks through engaging in CSR practices (Semenova and Hassel, 2008; Casey and Grenier, 2014).

The industry dedicated to oil and gas presents its highest levels in terms of human rights, because its actions have a strong impact on human health that clearly undermines the rights of citizens. Their companies - being engaged in efforts ranging from the extraction to the supply of oil and gas products - are considered as being high impact, since their activity has a great risk in 
Factor of Companies' Social Performance

terms of pollution or degradation. These companies adhere to CSR practices by adopting broader policies responding in this way to the pressures of their stakeholders (Young and Marais, 2012; Ekelenburg, 2016; Halkos and Skouloudis, 2016).

Other companies which are considered to have a lower impact -companies such as those employed in telecommunications services- present social concerns that are greater than those of the environment. In fact, these companies, intensive in personnel, prioritize their practices towards the labour rights of their employees and good relations with their stakeholders, such as their participation and responsibility in decision-making. Involving stakeholders in corporate activities results in an improvement in sustainable development, since the basis of this process is the dialogue aimed at getting to know each other's expectations and possibilities from all interested parties (Salem et al., 2017).

The industries dedicated to financial services -banks, insurance companies, investment funds ...- and consumer services -travel companies, media, retailers ...- show the lowest levels, slightly increased in employees for financial services and in human rights for consumer services, they are considered to be the most delayed in terms of CSR. Their companies are less controlled by the public and therefore less competitive in terms of sustainable practices (Belu, 2009; Scholtens, 2011; Weber, 2014).

\section{Conclusions}

The 2004-2014 decade shows steady growth in terms of sustainability, highlighting that this growth was more noticeable in the first half of the period, and lower in the second, the years 2010-2014 show greater similarities. More specifically, separating by dimensions, there are some differences, human rights and ethics practices divide the study decade into two groups, highlighting a jump in this sustainable growth from 2008 to 2010; in the case of the practices of employees or stakeholders, this growth occurs more gradually; and, finally, for the environment very strong relationships are produced during most years, separating the last two 20132014 from the rest.

This research responds to one of the oldest questions in the debate on CSR, corroborating that social demands are a main point to take into account, since in certain companies, social concerns outweigh environmental concerns. Thus, it is possible to specify as: 
- The industries whose business focus is directed towards basic materials and utilities are presented as leaders in the sustainability of the company, demonstrating best practices in this regard. Together with oil and gas, their record with regard to their environmental and human rights levels is outstanding. showing notable differences over those of the rest. In addition, it highlights the commitment of both towards health and safety systems.

- Companies dedicated to oil and gas -due to their high impact on human health- give preference to human rights practices, though without forgetting their environmental commitment. They also encourage community participation and the implementation of an ethical code.

- Industrials focus on practices related to systems and environmental performance; practices related to the health and safety of employees; and practices aimed at maintaining good community relations.

- Consumer goods prioritizes its environmental practices over the rest of its other existing practices, and presents high levels of reports on human rights, foreseeably by companies dedicated to, for instance, the manufacture and distribution of tobacco.

- Technology and health care emphasize their practices in terms of community relations and environmental systems due to these sectors being composed of manufacturing companies and distributors of electronic equipment or those employed in the research and development of biological substances. In addition, health care companies disclose information in the fight against bribery.

- Telecommunications, in companies of this industry, social concerns exceed environmental concerns. Thus, they prioritize their practices in the training and participation of their employees and in everything related to external relations-presenting the highest levels in these fields. At the same time, they emphasize systems for the implementation of a code of ethics and the fight to counteract bribery.

- Financial and consumer services show the lowest environmental levels. They comprise companies with fewer concerns for society. They present themselves as the least progressiveindustries in terms of sustainability, slightly increasing their levels with regard to human 
Factor of Companies' Social Performance

rights as it relates to services to the consumer and with regard to employees of financial services.

This study addresses the importance of the industrial root of the socially responsible behaviour of companies and contrasts this with the finding of important industrial discrepancies in sustainability. It defines the industry as being an institutional factor with explanatory capacity in terms of the sustainability of the company. This occurs since different interest groups and society in general perceives, different social and environmental risks according to the economic activity developed by organizations between such industries. This is reflected in the CSR policies and initiatives adopted by such organizations.

\section{Bibliography}

Aerts, W., Cormier, D., Magnan, M., 2006. Intra-industry imitation in corporate environmental reporting: An international perspective. J. Account. Public Policy 25, 299-331.

Aguilera, R.V., Williams, C.A., Conley, J.M., Rupp, D.E., 2006. Corporate governance and social responsibility: A comparative analysis of the UK and the US. Corp. Gov. Int. Rev. 14, 147-158.

Amor-Esteban, V., García-Sánchez, I.-M., Galindo-Villardón, M.-P., 2017. Analysing the Effect of Legal System on Corporate Social Responsibility (CSR) at the Country Level, from a Multivariate Perspective. Soc. Indic. Res. 1-18.

Bayoud, N.S., Kavanagh, M., Slaughter, G., 2012. Factors Influencing Levels of Corporate Social Responsibility Disclosure by Libyan Firms: A Mixed Study. Int. J. Econ. Finance 4. https://doi.org/10.5539/ijef.v4n4p13.

Belu, C., 2009. Ranking corporations based on sustainable and socially responsible practices. A data envelopment analysis (DEA) approach. Sustain. Dev. 17, 257-268.

Boiral, O., Gendron, Y., 2011. Sustainable development and certification practices: Lessons learned and prospects. Bus. Strategy Environ. 20, 331-347.

Boudt, K., Cornelissen, J., Croux, C., 2013. The impact of a sustainability constraint on the mean-tracking error efficient frontier. Econ. Lett. 119, 255-260. https://doi.org/10.1016/j.econlet.2013.03.020. 
Branco, M.C., Rodrigues, L.L., 2008. Factors influencing social responsibility disclosure by Portuguese companies. J. Bus. Ethics 83, 685-701.

Campbell, J.L., 2007. Why would corporations behave in socially responsible ways? An institutional theory of corporate social responsibility. Acad. Manage. Rev. 32, 946-967.

Casey, R.J., Grenier, J.H., 2014. Understanding and contributing to the enigma of corporate social responsibility (CSR) assurance in the United States. Audit. J. Pract. Theory 34, 97-130.

Chen, S., Bouvain, P., 2009. Is Corporate Responsibility Converging? A Comparison of Corporate Responsibility Reporting in the USA, UK, Australia, and Germany. J. Bus. Ethics 87, 299-317. https://doi.org/10.1007/s10551-008-9794-0.

Deegan, C., Gordon, B., 1996. A study of the environmental disclosure practices of Australian corporations. Account. Bus. Res. 26, 187-199.

Deegan, C., Rankin, M., Tobin, J., 2002. An examination of the corporate social and environmental disclosures of BHP from 1983-1997: A test of legitimacy theory. Account. Audit. Account. J. 15, 312-343.

Demirbag, M., Wood, G., Makhmadshoev, D., Rymkevich, O., 2017. Varieties of CSR: institutions and socially responsible behaviour. Int. Bus. Rev. 26(6): 1064-1074.

DiMaggio, P.J., 1991. The iron cage revisited: institutional isomorphism and collective rationality. Organ. Anal. Univ. Chic. Press Chic. Lond.

Dolédec, S., Chessel, D., 1994. Co-inertia analysis: an alternative method for studying species-environment relationships. Freshw. Biol. 31, 277294.

Ekelenburg, M.V., 2016. Determinants of voluntary external assurance on corporate sustainability reports: A comparison between Europe and North America. Netherlands: Radboud University.

Escoufier, Y., 1976. Opérateur associé à un tableau de données, in: Annales de l'INSEE. JSTOR, pp. 165-179.

Esteban, V.A., Villardón, M.P.G., Sánchez, I.M.G., 2017. Cultural values on CSR patterns and evolution: A study from the biplot representation. Ecol. Indic. 81, 18-29. https://doi.org/10.1016/j.ecolind.2017.05.051.

Frías-Aceituno, J.V., Rodriguez-Ariza, L., García-Sánchez, I.M., 2013. The role of the board in the dissemination of integrated corporate social reporting. Corp. Soc. Responsib. Environ. Manag. 20, 219-233.

Frías-Aceituno, J.-V., Rodríguez-Ariza, L., González-Bravo, M.-I., 2013. The Effect of Societal Values on Local Government Transparency: Applying Hofstede's Cultural Dimmensions. Lex Localis 11, 829. 
Factor of Companies' Social Performance

García-Sánchez, I.-M., Cuadrado-Ballesteros, B., Frías-Aceituno, J.-V., 2016. Impact of the Institutional Macro Context on the Voluntary Disclosure of CSR Information. Long Range Plann. 49, 15-35. https://doi.org/10.1016/j.1rp.2015.02.004.

García-Sánchez, I.-M., García-Meca, E., 2017. CSR engagement and earnings quality in banks. The moderating role of institutional factors. Corp. Soc. Responsib. Environ. Manag. 24, 145-158.

García-Sánchez, I.-M., Rodríguez-Ariza, L., Frías-Aceituno, J.-V., 2013. The cultural system and integrated reporting. Int. Bus. Rev. 22, 828838. https://doi.org/10.1016/j.ibusrev.2013.01.007.

Gjølberg, M., 2009. Measuring the immeasurable? Scand. J. Manag. 25, 1022. https://doi.org/10.1016/j.scaman.2008.10.003.

Gray, R., Owen, D., Maunders, K., 1987. Corporate social reporting: Accounting and accountability. Prentice-Hall International.

Habisch, A., Jonker, J., Wegner, M., Schmidpeter, R., 2005. Corporate social responsibility across Europe. Springer Science \& Business Media.

Halkos, G., Skouloudis, A., 2017. Revisiting the relationship between corporate social responsibility and national culture: A quantitative assessment. Manag. Decis. 55, 595-613. https://doi.org/10.1108/MD12-2016-0868.

Halkos, G., Skouloudis, A., 2016. National CSR and institutional conditions: An exploratory study. J. Clean. Prod. 139, 1150-1156. https://doi.org/10.1016/j.jclepro.2016.07.047.

Hess, D., 2008. The three pillars of corporate social reporting as new governance regulation: Disclosure, dialogue, and development. Bus. Ethics Q. 447-482.

Hofstede, G., 2001. Cultural consequences. Sage Publ. Thousand Oaks CA. Jackson, G., Apostolakou, A., 2010. Corporate Social Responsibility in Western Europe: An Institutional Mirror or Substitute? J. Bus. Ethics 94, 371-394. https://doi.org/10.1007/s10551-009-0269-8.

Jaffrenou, P.-A., 1978. Sur l'analyse des familles finies de variables vectorielles: bases algébriques et application à la description statistique. Ph.D. Thèse, Université de Lyon, Lyon, France.

Kolk, A., 2005. Environmental reporting by multinationals from the Triad: convergence or divergence? MIR Manag. Int. Rev. 145-166.

Kolk, A., Perego, P., 2010. Determinants of the adoption of sustainability assurance statements: An international investigation. Bus. Strategy Environ. 19, 182-198.

KPMG, 2011. KPMG international survey of corporate responsibility reporting 2011. The Netherlands: KPMG. 
Larrinaga, C., 2007. Sustainability reporting: insights from neo-institutional theory. Routledge.

León, J.Á.P., 2015. Análisis de la relación causal de la responsabilidad social corporativa y la performance financiera de las empresas. Ph.D. dissertation, Universitat Politècnica de València, València, Spain. https://doi.org/10.4995/Thesis/10251/48517.

Mar Miras-Rodríguez, M., Carrasco-Gallego, A., Escobar-Pérez, B., 2015. Are socially responsible behaviors paid off equally? A Cross-cultural analysis. Corp. Soc. Responsib. Environ. Manag. 22, 237-256.

Martínez-Ferrero, J., García-Sánchez, I.-M., 2016. Coercive, normative and mimetic isomorphism as determinants of the voluntary assurance of sustainability reports. Int. Bus. Rev. https://doi.org/10.1016/j.ibusrev.2016.05.009.

Mizruchi, M.S., Fein, L.C., 1999. The social construction of organizational knowledge: A study of the uses of coercive, mimetic, and normative isomorphism. Adm. Sci. Q. 44, 653-683.

Ortas, E., Álvarez, I., Jaussaud, J., Garayar, A., 2015. The impact of institutional and social context on corporate environmental, social and governance performance of companies committed to voluntary corporate social responsibility initiatives. J. Clean. Prod. 108, 673-684. https://doi.org/10.1016/j.jclepro.2015.06.089.

Park, B.I., Chidlow, A., Choi, J., 2014. Corporate social responsibility: Stakeholders influence on MNEs' activities. Int. Bus. Rev. 23, 966-980.

Parsa, S., Deng, L.X., 2008. Capital markets' reactions to social information announcements. Int. J. Account. Finance 1, 107-120.

Perego, P., 2009. Causes and consequences of choosing different assurance providers: An international study of sustainability reporting. Int. J. Manag. 26, 412.

Ringov, D., Zollo, M., 2007. The impact of national culture on corporate social performance. Corp. Gov. Int. J. Bus. Soc. 7, 476-485. https://doi.org/10.1108/14720700710820551.

Salem, M.A., Shawtari, F., Shamsudin, M.F., Hussain, H.B.I., 2017. The Consequences of Integrating Stakeholder Engagement in Sustainable Development (Environmental Perspectives). Sustain. Dev. https://doi.org/10.1002/sd.1699.

Scholtens, B., 2011. Corporate social responsibility in the international insurance industry. Sustain. Dev. 19, 143-156.

Semenova, N., Hassel, L.G., 2008. Financial outcomes of environmental risk and opportunity for US companies. Sustain. Dev. 16, 195-212. 
Sethi, S.P., Elango, B., 1999. The influence of "country of origin" on multinational corporation global strategy: A conceptual framework. J. Int. Manag. 5, 285-298.

Wanderley, L.S.O., Lucian, R., Farache, F., de Sousa Filho, J.M., 2008. CSR information disclosure on the web: a context-based approach analysing the influence of country of origin and industry sector. J. Bus. Ethics 82, 369-378.

Weber, J.L., 2014. Corporate social responsibility disclosure level, external assurance and cost of equity capital. Boulder, $\mathrm{CO}$ : University of Colorado at Boulder.

Welford, R., 2005. Corporate social responsibility in Europe, North America and Asia: 2004 survey results. J. Corp. Citizsh. 17: 33-52.

Wood, D.J., 1991. Corporate social performance revisited. Acad. Manage. Rev. 16, 691-718.

Young, S., Marais, M., 2012. A multi-level perspective of CSR reporting: The implications of national institutions and industry risk characteristics. Corp. Gov. Int. Rev. 20, 432-450.

Zhou, S., Simnett, R., Green, W., 2013. The effect of legal environment and corporate governance on the decision to assure and assurance provider choice: Evidence from the GHG assurance market. UNSW Aust. Sch. Bus. Res. Pap. A, 5. 





\section{Capítulo VII}

\section{El Isomorfismo Mimético en la Sostenibilidad Empresarial}

La responsabilidad social de las corporaciones es un estilo de gestión empresarial que incorpora, en el proceso de toma de decisiones, además de los objetivos económicos tradicionales, los impactos que las actividades de las empresas generan en sus clientes, empleados, accionistas, comunidades locales, medioambiente y en la sociedad en general. La teoría institucional postula que los diferentes entornos institucionales establecen unas reglas de comportamiento para las empresas, imponiendo unas expectativas que deben satisfacer para recibir la aprobación de la sociedad en la que están inmersas.

En general, los autores se centran en analizar el país como el factor institucional con mayor capacidad explicativa en el comportamiento sostenible de las empresas. Sin embargo, varias investigaciones han revelado que el sector de la actividad es un campo organizacional del que surgen presiones institucionales que llevan a las empresas a adoptar prácticas de RSC. Las empresas probablemente desarrollarán regulaciones y políticas comunes sobre responsabilidad social cuando operen en el mismo sector de actividad, ya que enfrentan presiones y riesgos similares. Estas presiones sectoriales pueden producir isomorfismo entre compañías que operan en el mismo sector a nivel internacional, lo que se conoce como isomorfismo mimético.

El isomorfismo mimético es adoptado por compañías con baja tolerancia a la incertidumbre que, en lugar de diseñar un plan de acción propio, deciden imitar las prácticas empresariales de aquellas compañías líderes y reputadas, considerando que la simple imitación conduce a la legitimación social de sus actividades. Es probable que las empresas que operan en el mismo sector desarrollen o adopten un comportamiento similar con respecto a los estándares de RSC, ya que enfrentan desafíos similares, lo que obliga a un cierto grado de convergencia en las políticas de RSC implementadas por las empresas. De esta manera, muchas organizaciones adoptan o mejoran sus prácticas de RSC debido a las presiones a nivel del sector industrial.

En este capítulo se considera el efecto que las fuerzas miméticas del sector pueden tener sobre los compromisos corporativos en materia de RSC. El interés en analizar el efecto sectorial deriva de la base teórica de los grupos de interés, que argumenta que tienen intereses diferentes, generalmente asociados con las características de cada sector, como resultado de lo cual cada sector es percibido de manera diferente por la sociedad debido a los riesgos sociales y ambientales de la actividad desarrollada. Por lo tanto, las empresas que operan en sectores más contaminantes, como el petróleo y el gas, mostrarán un mayor compromiso con los impactos ambientales que las empresas que operan en sectores intensivos en personal, como por ejemplo el sector financiero, donde prevalecerán políticas laborales más sostenibles que promuevan la conciliación personal y laboral, la igualdad, etc.

Para su estudio contamos con una muestra de datos de panel de 6600 observaciones de 600 empresas cotizadas durante la década 2004-2014. A diferencia del capítulo anterior, en lugar de trabajar con las practicas individuales de sostenibilidad, éstas son agrupadas en cinco indicadores sintéticos de RSC -medioambiente, derechos humanos, empleados, stakeholders y ética- 
asociados con las dimensiones social y ambiental. La agregación de las prácticas de RSC proporciona una mayor simplicidad en el análisis de los resultados, lo que permite una determinación más precisa de las implicaciones que puedan derivarse. Además, contamos con dos medidas que evalúan el impacto de las actividades de la compañía en las dimensiones ambiental y social, clasificando éstas como de alto, medio o bajo impacto. Con el objetivo de determinar el efecto general y así resaltar las diferencias y similitudes entre las empresas y sectores en referencia a su impacto global, creamos la variable 'Mimetic'; a partir de la cual fragmentamos la muestra en cuatro tipologías o niveles de impacto: (i) bajo impacto ambiental y social; (ii) bajo impacto ambiental e impacto social medio, o viceversa; (iii) impacto ambiental alto o medio y bajo social, o viceversa, o impacto medio en ambas dimensiones; y (iv) alto impacto ambiental y social.

Mediante el uso de técnicas estadísticas multivariantes exploratorias, perseguimos los dos objetivos siguientes. Estudiar los patrones de comportamiento de estas empresas durante el periodo mencionado en relación con sus prácticas de RSC; consideramos el uso del análisis XSTATIS como el método óptimo para capturar esta estructura multivariante, ya que esta técnica nos permite analizar la relaciones entre los diferentes años de estudio y la construcción y representación de una matriz que combina la estructura consenso de todas las tablas de datos. Esta matriz se denomina compromiso y resume las tablas de datos originales en una matriz única de la misma naturaleza, la cual proporciona un valor por empresa en cada uno de los indicadores de RSC que sintetiza sus valores durante todo el periodo. Su representación se recoge en un único plano. Una vez hecho esto, separamos las empresas según su nivel de impacto (tipologías variable mimetic) y buscamos diferencias en los patrones de comportamiento con respecto al compromiso en sostenibilidad. A nivel sector, agrupamos las empresas por su pertenencia a los diferentes subsectores de actividad -codificadas en 39 sub-sectores de actividad según la categoría 'sector' del 'Industry Classification Benchmark (ICB) system'- y, para analizar cómo las fuerzas miméticas influyen en las prácticas de RSC y clasificar los sub-sectores de actividad donde operan las empresas de acuerdo con estas medidas, seleccionamos el método HJ-biplot; ya que nos permite representar sub-sectores, prácticas de RSC y fuerzas miméticas con la misma calidad de representación en el mismo plano factorial $\mathrm{y}$, de esta forma, es posible visualizar qué fuerzas miméticas (impacto ambiental y social) presentan una mayor influencia sobre el desarrollo sostenible y específicamente sobre qué indicadores de RSC tienen mayor relevancia. Además, es posible observar qué sub-sectores se ven más o menos afectados por todas estas medidas de manera simultánea, tanto los indicadores de RSC como las fuerzas miméticas.

Los resultados de nuestro estudio muestran que las empresas, independientemente del sector de actividad al que pertenecen, adoptan patrones similares de prácticas de RSC, pero el grado de su desarrollo es muy sensible a las presiones miméticas. Este estudio designa al sector de actividad como un factor institucional con capacidad explicativa de las prácticas de RSC, siendo el impacto de sus actividades, particularmente sus riesgos y preocupaciones ambientales, el mejor indicador de la presión generada por los actores para la implementación y desarrollo de prácticas de RSC que promuevan el desarrollo sostenible. Este enfoque es bastante importante para toda la industria, especialmente para aquellas relacionadas con sectores más contaminantes o con mayor intensidad de mano de obra, para comprender el efecto que la legislación, la regulación y la economía tienen en su supervivencia sobre el control ambiental, el trabajo y los derechos humanos.

Más concretamente es posible puntualizar que las empresas que operan en sectores más contaminantes, como minería, productos químicos o petróleo, otorgan mayor prioridad a la protección ambiental y defensa de los derechos humanos, mientras que otras empresas menos contaminantes involucradas en el sector de las comunicaciones se preocupan en mayor medida por problemas sociales como la ética empresarial o los derechos de sus empleados. Y dado que las empresas que operan en el mismo sector de actividad enfrentan riesgos y desafíos similares, probablemente desarrollen políticas y regulaciones comunes sobre responsabilidad social, dicho isomorfismo puede producirse entre competidores del mismo sector a escala internacional.

Estos hallazgos pueden ser muy útiles para los inversores, las empresas, los gerentes y los responsables de la formulación de políticas. Para los inversores, el conocimiento de las discrepancias en las prácticas de diferentes contextos institucionales a escala internacional puede ser de gran utilidad para una correcta selección del enfoque y el nivel de compromiso de la RSC. Con respecto a las empresas, estos datos facilitan la comprensión de las diferentes presiones del 
comportamiento ambiental y social, por lo que su inversión en la RSC puede condicionarse a las prácticas de RSC demandadas en las industrias que conllevan la diversificación de sus actividades empresariales o su ingreso en nuevos mercados extranjeros. Para los gerentes, cuando la atención se centra en ser aceptados como actores legítimos de las actividades empresariales en nuevos mercados, la comprensión de los factores institucionales limitantes les ayudará a modificar sus prácticas de RSC de acuerdo con estas condiciones. Para los legisladores y reguladores, una apreciación del comportamiento empresarial de la RSC y sus determinantes -identificar los sectores que presentan mayores deficiencias- les ayudará a superar sus deficiencias, facilitando así la orientación de los procesos regulatorios hacia la promoción de políticas que mejoren el comportamiento sostenible de la empresa. Estos problemas pueden guiar a los gerentes en los procesos de toma de decisiones para evaluar los impactos de las actividades empresariales.

A continuación, presentamos toda esta información detallada de manera extensa en el artículo de investigación "Industry mimetic isomorphism and firm's sustainability based on the $X$-STATIS and HJ-biplot methods" actualmente en prensa en la revista Environmental Science and Pollution Research (2016: Q2 - JIF: 2.741; 2017: Q2 - JIF:2.800). 


\section{Research paper in press:}

Title: Industry mimetic isomorphism and firm's sustainability based on the X-STATIS and HJ-biplot methods

Authors: Víctor Amor-Esteban

Ma-Purificación Galindo-Villardón

Isabel-María García-Sánchez

\section{Journal: Environmental Science and Pollution Research, 1-17}

\begin{tabular}{c|c|c|c|c} 
Year & Category Name & $\begin{array}{c}\text { Total Journals } \\
\text { in Category }\end{array}$ & $\begin{array}{c}\text { Journal Rank } \\
\text { in Category }\end{array}$ & $\begin{array}{c}\text { Quartile } \\
\text { in Category }\end{array}$ \\
\hline 2016 & Environmental Sciences & 229 & 79 & Q2 \\
\hline 2017 & Environmental Sciences & 241 & 82 & Q2
\end{tabular}

* Journal Impact Factor: 2016 - 2.741; 2017 - 2.800; 5 Year Impact Factor: 2.989.

* Publisher: Springer Heidelberg

* Google scholar cites:

\begin{tabular}{c|l} 
APA & $\begin{array}{l}\text { Amor-Esteban, V., Galindo-Villardón, M. P., \& García-Sánchez, I. M. (2018). } \\
\text { Industry mimetic isomorphism and sustainable development based on the X-STATIS } \\
\text { and HJ-biplot methods. Environmental Science and Pollution Research, 1-17. }\end{array}$ \\
\hline ISO & $\begin{array}{l}\text { AMOR-ESTEBAN, Víctor; GALINDO-VILLARDÓN, Ma-Purificación; GARCÍA- } \\
\text { SÁNCHEZ, Isabel-María. Industry mimetic isomorphism and sustainable } \\
\text { development based on the X-STATIS and HJ-biplot methods. Environmental Science } \\
\text { and Pollution Research, 2018, p. 1-17. }\end{array}$ \\
\hline MLA & $\begin{array}{l}\text { Amor-Esteban, Víctor, Ma-Purificación Galindo-Villardón, and Isabel-María García- } \\
\text { X-STATIS and HJ-biplot methods." Environmental Science and Pollution Research } \\
\text { (2018): 1-17. }\end{array}$
\end{tabular}

*The paper is numbered independently and includes pages 215-231 (17) of the global document. 



\title{
Industry mimetic isomorphism and sustainable development based on the X-STATIS and HJ-biplot methods
}

\author{
Víctor Amor-Esteban ${ }^{1}$ • Ma-Purificación Galindo-Villardón ${ }^{1}$ • Isabel-María García-Sánchez ${ }^{2}$
}

Received: 9 January 2018 / Accepted: 26 June 2018

(C) Springer-Verlag GmbH Germany, part of Springer Nature 2018

\begin{abstract}
Based on both neo-institutional theory and comparative institutional analysis, this paper studies the role that mimetic forces play in the patterns and evolution of behavior concerning company sustainability. The panel data is composed of 6600 observations of 600 international large listed companies belonging to 39 different activity sectors for the period 2004-2014. Through employing the multivariate statistical methods HJ-biplot and X-STATIS, which provide a useful visualization of a complex data structure in a low-dimensional space, it can be observed that mimetic forces indicate that firms operating in high-impact sectors - sectors that operate under greater pressure from interest groups - face greater social and environmental risks and have higher corporate social responsibility (CSR) scores than companies from other sectors. The adoption or development of CSR practices depends largely on the type of industry in which the company operates, as stakeholder engagement in different industry sectors has different areas of concern. Therefore, companies operating in more polluting sectors, such as mining, paper, chemicals, or oil, give higher priority to environmental protection and defense of human rights, while other, less polluting companies involved in the communication sector are concerned to a greater extent by social issues, such as business ethics or the rights of their employees. Finally, this paper evidences that firms operating in similar contexts, in industries that face analogous risks and challenges, probably develop common policies and regulations with the aim of mitigating the pressures applied by their major stakeholder groups.
\end{abstract}

Keywords Corporate social responsibility (CSR) - Mimetic forces · X-STATIS · Sustainable development · HJ-biplot . Environmental management $\cdot$ Stakeholder engagement

\section{Introduction}

The aim of this paper, based on both neo-institutional theory and comparative institutional analysis, is to determine how mimetic isomorphism influences corporate social responsibility (CSR) practices across different industries.

Responsible editor: Philippe Loubet

Víctor Amor-Esteban

victor_aes@hotmail.com

Ma-Purificación Galindo-Villardón

pgalindo@usal.es

Isabel-María García-Sánchez

lajefa@usal.es

1 Department of Statistics, University of Salamanca, Campus Miguel de Unamuno, c/ Alfonso X El Sabio s/n, 37007 Salamanca, Spain

2 Department of Business Administration, Faculty of Economics, University of Salamanca, Campus Miguel de Unamuno, 37007 Salamanca, Spain
Institutional theory establishes that companies operating in institutional environments establish rules of behavior for these economic units, while imposing on them expectations that they must satisfy in order to receive the approval of the society in which they are immersed. These rules and expectations cause companies operating in similar institutional environments to show isomorphic or homogeneous behaviors that guarantee their legitimacy and favor their long-term survival (Campbell 2007).

The rules and expectations of behavior that produce business isomorphism, according to DiMaggio and Powell (1983), can come from three forces or pressures: normative, coercive, and mimetic. Normative isomorphism (Matten and Moon 2004) comes from formal and informal pressures exerted by supra-organizations or imposed by the cultural values of the business environment (García-Sánchez et al. 2013; GallegoÁlvarez and Ortas 2017). Coercive isomorphism emanates from the standards, laws, or rules that define the professional and legal framework of business practices (Amor-Esteban et al. 2017; Demirbag et al. 2017). Mimetic isomorphism is adopted by companies with low tolerance for uncertainty 
which, instead of designing a plan of action of their own, decide to imitate the business practices of those leading and reputed companies, considering that simple imitation leads to legitimization of the follower company (Matten and Moon 2004).

Comparative studies approaching CSR issues have found substantial differences in CSR practices across countries, explained systematically by institutional coercive and normative pressures (e.g., Colwell and Joshi 2013; Duran and Bajo 2014; Mar Miras-Rodríguez et al. 2015; Garcia-Sanchez et al. 2016; García-Sánchez and García-Meca 2017). However, there is a huge lack of knowledge about the role of mimetic pressures, traditionally associated with industries (Martínez-Ferrero and García-Sánchez 2016).

Mimetic pressure importantly occurs when companies in situations of uncertainty are inclined to imitate the behaviors of other organizations that are considered models in their activity sector: for this, the type of industry can influence the CSR practice development as a firm factor. The following question appears to relate to this pressure: can organizations take part in a CSR strategy as a means of mimicking or resembling the behavior of leading companies or models in their industry? Following the arguments of DiMaggio and Powell (1983) on the process of mimetic isomorphism, we consider that firms operating in industries that face analogous risks and challenges probably develop common policies and regulations with the aim of mitigating the pressures from their major stakeholder groups (Patten 1992). Nevertheless, in this respect, the question has not been widely investigated in the literature.

In this paper, in order to evidence the mimetic force influences on CSR practices during the decade 2004-2014, we employ a sample of 6600 observations of 600 listed firms from 18 different countries. We use 26 items to evaluate the CSR performance regarding the ethical, social, and environmental dimension of sustainability. In addition, we propose a measure of industry mimetic forces based on the environmental and social risks and pressures of each industry.

Through the use of statistical exploratory multivariate techniques, we pursue the following two aims. To study the behavior patterns of these companies during the mentioned period in relation to their CSR practices, we consider the use of the X-STATIS (Jaffrenou 1978) as the optimal method to capture this multivariate structure, since this method allows us to analyze the relationships among the different years of study and the construction and plot of a matrix that combines the consensus structure of these data tables. This matrix is called compromise or consensus and summarizes the $\mathrm{k}$ original data tables in a single matrix of the same nature. The representation of this table allows us to view a global summary of all tables. To analyze how industry mimetic forces influence CSR practices and classify the sectors of activity where the companies operate according to these measures, we select the HJ-biplot
(Galindo 1986) method, since it allows us to represent the sectors, CSR practices, and mimetic forces with the same quality of representation.

Our results allow firms, especially those that operate in a more polluting or labor-intensity industry, to understand the effect that the legislation, regulation, and demands in relation to environmental, work, or human rights has on their reputation.

The paper is organized as follows. In the next section, we describe the institutional theoretical framework that refers to the influence of institutional environments on the companies' sustainable behavior and the previously related evidence. The second section focuses on the impact that mimetic pressures have on CSR practices. In the third section, we summarize the method in terms of the sample, models, and statistical techniques used. We continue with a section on the empirical results obtained, a discussion on the results, and, finally, we present the main conclusions of our analysis.

\section{CSR and isomorphism: from theoretical background to the state of the art}

CSR is a business managerial style that incorporates in the decision-making process, in addition to the traditional economic aims, the impacts that companies' activities generate on their customers, employees, shareholders, local communities, the environment, and society in general. Although CSR may be of a global nature, recent research suggests that it is applied differently in different social, economic, cultural, legal, and political contexts (Matten and Moon 2004; Habisch et al. 2005). This is due to the fact that the institutional pressures that characterize these contexts impose different expectations regarding business behavior, so companies need to develop these CSR practices according to the specific demands in order to guarantee their survival (Campbell 2006).

In this sense, organizations are more likely to behave in a socially responsible way when they operate in a strong normative and coercive institutional environment because this defines whether companies have to comply with the professional guidelines and current norms of their environment, and these different pressures on companies could lead to variations in their behavior (Lenssen et al. 2006).

Comparative studies that address CSR have found substantial differences in CSR practices between countries, systematically explained by normative pressures, stemming from the cultural values of the business environment or imposed from formal and informal pressures exerted by supra-organizations and coercive, laws or rules emanating from standards that determine the legal system for the development of sustainability practices. Ringov and Zollo (2007), in their study of public companies, develop theoretical links between the national culture and the general level of social responsibility of the 
companies, finding that distance of power and masculinity have a negative influence on the quality of corporate behavior. Perego (2009), looking at the quality of assurance statements and providers in his international research and, 2 years later, Boiral and Gendron (2011), in their theoretical study, defend the fact that the legal environment at country level acts as a key determinant of coercive isomorphism, influencing the variability of sustainability assurance between countries. Kolk and Perego (2010), with an international panel of 212 Fortune Global 250 corporations for the years 1999, 2002, and 2005, show that firms operating in countries that are more oriented towards interested parties are more likely to adopt a declaration of sustainability assurance. Zhou et al. (2013), in their study of the emerging international greenhouse gas (GHG) assurance market and using a sample of 2194 disclosures of companies from 32 countries in the period 20082011, show that the preference for accounting profession assurance from stakeholder-oriented countries is more prevalent among companies with a stronger governance structure.

In terms of normative pressures, Skouloudis and Evangelinos (2012), based on the previous theory, propose the design of an investigation to map national CSR fields that broadens the existing set of knowledge about national CSR patterns, contributing to a greater identification of the relationship between cultural specificity and responsible business behavior. But, in general, studies have evidenced the effect that national culture, through the dimensions of Hofstede (2001), has on CSR development. García-Sánchez et al. (2013), in their analysis of the dissemination of integrated reports of the 1590 largest international companies of Forbes Global 2000 list for the years 2008-2010, show that companies located in collectivist and feminist societies are in the vanguard of information integration. Mar Miras-Rodríguez et al. (2015) through a meta-analysis study the moderating role of the national culture in the relationship between CSR and the performance of the company, showing a positive relationship in societies oriented towards the future, institutional collectivism, and a human orientation. Based on a sample from 20 different countries of 1598 international organizations for the period 2004-2010, Garcia-Sanchez et al. (2016) show that those firms located in societies with long-term orientation, collectivists, feminists, avoidance of uncertainty, and a low power distance, and in countries with a legal civil law environment, strong enforcement of the law, and concentration of ownership are more sensitive to the publication of CSR reports. Martínez-Ferrero and García-Sánchez (2016) study the influence of normative, coercive, and mimetic isomorphism in the voluntary assurance of sustainability reports and demonstrate with a panel of 696 companies in the years 2007-2014 that an assurance statement is more likely to be issued by companies in countries with a greater legal system and development cultural and especially in industries concerned with sustainability, and highlight normative isomorphism as the factor with the greatest explanatory power followed by the coercive. García-Sánchez and García-Meca (2017) study the moderating role of institutional factors in CSR commitment and the quality of incomes in 159 banks in 9 countries during the years 2004-2010, evidencing the effect of CSR in countries with higher levels of investor protection and banking regulation, and suggest that socially responsible banks have better income quality in a stricter regulatory environment. Gallego-Álvarez and Ortas (2017), based on a sample of 3917 largest public international companies operating in 59 different countries, test the influence of the cultural characteristics of communities on the practices of corporate environmental sustainability reporting (CESR), concluding that communities with low values in the distance of power and individualism and a high degree of pragmatism present a proactive attitude towards the participation of the interested parties and a commitment to CESR practices. Demirbag et al. (2017) evaluate the relationship between the legal origin of 98 countries focusing on socially responsible investment and voluntary charitable giving of a set of correlated indicators of social responsibility, where they find that companies operating in civil law contexts are more likely to make socially responsible investments.

All these investigations show that the normative and coercive pressures of the institutional context in which the company operates offer a series of advantages and barriers in the adoption and development of CSR practices, so firms coming from different countries, as a result of discrepancies in the institutional efficiency between them, adopt different levels of sustainable behavior and, more specifically, show that a strong macro institutional context which is the same as the development of cultural values and the legal system of the country improves CSR practices (Welford 2004, 2005).

Taking into account that companies that operate in a common scenario, with analogous institutional characteristics, exhibit similar sustainable behaviors, which is known as normative (similar cultural values) and coercive (analogous legal systems) isomorphism, several authors - Lenssen et al. (2006), Gjølberg (2009) and Skouloudis et al. (2016) -adopted a new approach, analyzing the effect that the institutional context has on the CSR penetration through the creation of a national CSR index. Focusing on the most recent of these, the Skouloudis et al. (2016) index provides a global CSR perspective composed of 86 countries based on national data on participation, subscription, or inclusion in different international CSR initiatives. Their ranking shows a deficient penetration of CSR and a wide variation between countries, in which the majority are still lagging in the support of these initiatives. These findings offer a fertile ground for theorists in search of a deeper investigation into the national specificity of CSR. In this sense, Halkos and Skouloudis (2016) investigate the relationship between CSR penetration and national institutional conditions, concluding that regulatory effectiveness, competitive conditions, and civic 
engagement are very important factors and influence CSR penetration with macro-economic conditions; in addition, Halkos and Skouloudis (2017) explore the relationship between the national CSR index at the macro level and the dimensions of the national culture of the Hofstede framework, indicating that societies with a long-term orientation, indulgence and uncertainty tolerance are positively affected in the index.

In general, the authors focus on analyzing the country as the institutional factor with the greatest explanatory capacity in the sustainable behavior of companies. However, several investigations have revealed the sector of activity as an organizational field from which institutional pressures arise, which lead companies to adopt CSR practices (Aerts et al. 2006; Venanzi and Fidanza 2006). Companies will probably develop common regulations and policies on social responsibility when they operate in the same sector of activity, since they face similar pressures and risks. These sectoral pressures can produce isomorphism between companies that operate in the same sector internationally (Jackson and Apostolakou 2010), which is known as mimetic isomorphism.

Although we know the relevance of industry pressures associated with the media impact that a firm's irresponsible actions have on public opinion, the academia only considers the role of the industry in relation to the economic opportunities that the sector of activity offers by the analysis of the role of munificence vs. hostile environments. In this respect, Staw and Szwajkowski (1975) found that when organizations compete in a context of lesser munificence, they are more likely to take illicit and irresponsible actions to access external resources that support their survival. Goll and Rasheed (2004) and Antolín-López et al. (2015) argue that higher munificence firms are more likely to engage in socially responsible behavior than companies that are in environments with scarce resources whose economic conditions are deteriorating. That is, a hostile industrial context that reduces the marginal profit that companies can obtain (Miller and Friesen 1983) and offers fewer opportunities for growth will cause companies to be less focused on being socially responsible, even to the minimum degree expected by stakeholders, since positive economic returns are not guaranteed (Chen et al. 2017).

\section{Mimetic isomorphism}

In mimetic isomorphism, organizations could behave in a similar way to their counterparts in situations of uncertainty. That is, organizations, in as much as their competitors adopt a CSR initiative, can be motivated to follow such behavior with the aim of acquiring social legitimacy. In this respect, not only the level of success but also the level of social acceptance defines the productive efficiency (Ortas et al. 2015). According to Larrinaga (2007), the CSR, in the sense that organizations mimic their competitors' practices, presents a certain level of mimetic convergence.

Companies operating in the same industry are likely to develop or adopt similar behavior regarding CSR standards, as they deal with similar challenges, forcing a degree of convergence in the CSR policies implemented by companies. In this way, many companies adopt or improve their CSR practices due to pressures at the level of the industrial sector (Venanzi and Fidanza 2006); or-which is ultimately the same - an important boundary for institutional fields is represented by the industrial sectors (DiMaggio and Powell 1991).

Several authors - e.g., Branco and Rodrigues (2008), Parsa and Deng (2008), Wanderley et al. (2008), Bayoud et al. (2012), Young and Marais (2012)_-have evidenced differences in levels of transparency for CSR across sectors of activity, indicating that sustainability reports differ substantially between firms operating in different industries as a consequence of pressure exerted by the major interest groups of each sector and the existence of more demanding regulations specific to some industries. In addition, the market characteristics of certain industries may explain possible differences in CSR practices associated with the preferences that consumers may display regarding CSR (Park et al. 2014).

The results discussed for corporate transparency have not been tested for other CSR practices reported in sustainability reports. In this article, we extend the previous literature considering the effect that the mimetic forces of the sector can have on the corporate commitments in CSR matters. The interest in analyzing the sectoral effect derives from the theoretical foundation of the stakeholders, which argues that interest groups have different interests, generally associated with the characteristics of each industry, as a result of which each sector is perceived differently by the society due to the social and environmental risks of the activity developed. Thus, companies operating in more polluting sectors such as oil and gas will show a greater commitment to environmental impacts than companies operating in personnel-intensive sectors - e.g., the financial sector - where more sustainable labor policies will prevail that promote personal and labor conciliation, equality, etc.

According to previous arguments, we hypothesize that companies operating in industries with similar risks, standards of behavior, and pressures, adopt, regarding their CSR practices, homogeneous behavior patterns, and these mimetic pressures influence the degree of business compromise with CSR and the companies' evolution.

\section{Methodology}

\section{Population and sample}

To contrast the established hypotheses, we selected as the target population the companies quoted in the economic-financial 
database Thomson ONE Analytics. The merger of these companies with those from the EIRIS database for sustainability provided a sample of 600 firms for the period 2004-2014, having a balanced panel of 6600 observations. These are the largest listed firms of 18 countries, although the geographical distribution presents a bias in favor of those companies that operate in Europe, North America, Japan, and Australia. In Table 1, it can be seen that they represent 50.50, 25.83, 16.67 , and $7 \%$, respectively.

The consideration of the largest internationally listed companies is a consequence of the fact that they are the most active companies in terms of sustainability (Martínez-Ferrero and García-Sánchez 2016). The consideration of this time period corresponds to the timeframe in which companies have made greater commitments in terms of sustainability, being considered as the most relevant period of corporate and academic CSR (Martínez-Ferrero and García-Sánchez 2016).

Aiming to find differences between industrial sectors, the companies of the sample were grouped into 39 categories, following the Industry Classification Benchmark (ICB) system. This system is a full and detailed structure of industrial sectors, providing a simple comparison of firms across 4 levels: 104 subsectors, 39 sectors, 19 supersectors, and 10 industries. After coding each of the sample firms in reference to the ICB sector, the sample analyzed corresponded to 39 sectors, as shown in Table 2, with a low level of dispersion.

\section{Variables}

According to the information contained in the EIRIS database, CSR business practices will be determined from 26 items weighted $0-4$, which identifies inadequate, weak, moderate, good, and exceptional levels of practice of CSR. These 26 items correspond to measures of the results of CSR in relation to environmental and social dimensions. Within the social dimension, we group actions related to the preservation of human rights, the employees' labor rights, the external relations of companies with their stakeholders, and business ethics. Table 3 shows in greater detail the composition of CSR practices and dimensions, as well as the main descriptive statistics.

Analyzing the CSR practices grouped in their dimensions and subdimensions aims to control, within the same line of action, the divergence in business behavior that might not be observed if the items were analyzed individually, providing more simplicity in the analysis of the results and allowing us to determine with more precision the implications that could derive from the individual items (Garcia-Sanchez et al. 2016; Martínez-Ferrero and García-Sánchez 2016).

For mimetic forces, we used two variables that measure the impact of the activities of the company on the environmental and social dimensions: "environmental impact" is an indicator of the overall impact of the industry activities on the environment; it equals 1 if the industry has low impact, 2 with medium impact, and 3 with high impact. "social impact" is an indicator of the overall impact of the industry activities on social issues; it equals 1 if the company has low impact, 2 with medium impact, and 3 with high impact. The justification for these measures is that the greatest impact of the activities of the company is a useful indicator of the pressure resulting from the stakeholders to adopt or improve CSR practices and the development of institutionalized forms of CSR policies. With the aim of determining the overall effect and so highlight the differences and similarities between sectors in reference to their global impact on environmental and social factors, we created the "Mimetic" variable; for this, we applied the methodology used in the book The Business Case for Corporate Social Responsibility: Understanding and Measuring Economic Impacts of Corporate Social Performance (Schreck 2009), illustrated in Fig. 1.

Regarding Fig. 1, the "Mimetic" variable fragments the sample into four types or impact levels as follows: the fourth type is composed of those companies that are classified having a high environmental and social impact; the third contains firms with low or medium environmental impact and high social impact or vice versa, or medium impact in both
Table 1 Distribution of companies by their country of origin

\begin{tabular}{|c|c|c|c|c|c|c|c|}
\hline & Countries & Observations & $\%$ & & Countries & Observations & $\%$ \\
\hline 1 & Australia & 462 & 7.0 & 10 & Japan & 1100 & 16.6 \\
\hline 2 & Austria & 44 & 0.7 & 11 & Netherlands & 165 & 2.5 \\
\hline 3 & Belgium & 77 & 1.2 & 12 & Norway & 66 & 1.0 \\
\hline 4 & Canada & 440 & 6.7 & 13 & Portugal & 44 & 0.7 \\
\hline 5 & Denmark & 121 & 1.8 & 14 & Spain & 165 & 2.5 \\
\hline 6 & Finland & 110 & 1.7 & 15 & Sweden & 275 & 4.2 \\
\hline 7 & France & 429 & 6.5 & 16 & Switzerland & 220 & 3.3 \\
\hline 8 & Germany & 407 & 6.2 & 17 & UK & 1067 & 16.1 \\
\hline \multirow[t]{2}{*}{9} & Italy & 143 & 2.2 & 18 & USA & 1265 & 19.1 \\
\hline & & & & & Total & 6600 & 100.0 \\
\hline
\end{tabular}


Table 2 Distribution of companies following the Industry Classification Benchmark (ICB) system

\begin{tabular}{|c|c|c|c|c|c|c|c|}
\hline & Activity sectors & Obs & $\%$ & & Activity sectors & Obs & $\%$ \\
\hline 1 & Aerospace and defense & 88 & 1.3 & 21 & Industrial metals and mining & 165 & 2.5 \\
\hline 2 & Alternative energy & 11 & 0.2 & 22 & Industrial transportation & 165 & 2.5 \\
\hline 3 & Automobiles and parts & 176 & 2.7 & 23 & Leisure goods & 66 & 1.0 \\
\hline 4 & Banks & 418 & 6.3 & 24 & Life insurance & 198 & 3.0 \\
\hline 5 & Beverages & 143 & 2.2 & 25 & Media & 231 & 3.5 \\
\hline 6 & Chemicals & 363 & 5.5 & 26 & Mining & 132 & 2.0 \\
\hline 7 & Construction and materials & 297 & 4.5 & 27 & Mobile telecommunications & 88 & 1.3 \\
\hline 8 & Electricity & 121 & 1.8 & 28 & Nonlife insurance & 176 & 2.7 \\
\hline 9 & Electronic and electrical equipment & 88 & 1.3 & 29 & Oil and gas producers & 308 & 4.7 \\
\hline 10 & Financial services & 121 & 1.8 & 30 & Oil equipment, services and distribution & 143 & 2.2 \\
\hline 11 & Fixed line telecommunications & 176 & 2.7 & 31 & Personal goods & 198 & 3.0 \\
\hline 12 & Food and drug retailers & 165 & 2.5 & 32 & Pharmaceuticals and biotechnology & 275 & 4.2 \\
\hline 13 & Food producers & 132 & 2.0 & 33 & Real estate investment and services & 99 & 1.5 \\
\hline 14 & Forestry and paper & 44 & 0.7 & 34 & Real estate investment trusts & 132 & 2.0 \\
\hline 15 & Gas, water and multi-utilities & 165 & 2.5 & 35 & Software and computer services & 154 & 2.3 \\
\hline 16 & General industrials & 132 & 2.0 & 36 & Support services & 176 & 2.7 \\
\hline 17 & General retailers & 132 & 2.0 & 37 & Technology hardware and equipment & 165 & 2.5 \\
\hline 18 & Health care equipment and services & 220 & 3.3 & 38 & Tobacco & 66 & 1.0 \\
\hline 19 & Household goods and home construction & 110 & 1.7 & 39 & Travel and leisure & 264 & 4.0 \\
\hline 20 & Industrial engineering & 297 & 4.5 & & Total & 6600 & 100.0 \\
\hline
\end{tabular}

dimensions; the second contains companies with low environmental impact and medium social impact or vice versa; and the first type is composed of companies with low environmental and social impact. However, for the first type, no data was available, since none of the evaluated companies have low impacts on both dimensions.

\section{Research methods}

\section{X-STATIS analysis}

The X-STATIS analysis, proposed by Jaffrenou (1978), is a suitable exploratory technique for three-way data analysisi.e., the information pertaining to the decade 2004-2014 for 600 companies' commitment to CSR practices. This technique comes from the STATIS family method (Escoufier 1976; L'Hermier des Plantes 1976) and comprises three stages: the interstructure, the analysis of the compromise, and the intrastructure. For this paper, we will focus only on the first two.

The first stage is the study of interstructure. A matrix is built of scalar products between tables (the vector covariance matrix), where the element in row $k$ and column 1 is $\operatorname{Covv}\left(X_{k}\right.$, $\left.X_{1}\right)=\operatorname{Tr}\left(X_{k}^{t} D_{n} X_{1} D_{p}\right)$, where $X_{k}$ is the kth table of the sequence, and $\mathrm{D}_{\mathrm{p}}$ and $\mathrm{D}_{\mathrm{n}}$ are the two metrics for the columns and rows, respectively. This way, we can determine if the matrices have similar structures. This is done via Euclidean representation, where each matrix is represented as a point, in our case representing different years, where similarity (positive correlations are visualized by small acute angles between variables) indicates that the CSR indicators (variables) maintain stable behavior with respect to the companies (individuals) during the study period.

The second stage is the analysis of the compromise, which follows the procedure in Fig. 2, where a linear transformation of each data table is performed so that each matrix becomes a column vector, stacking their variables one on top of another. Thus, we build the $\mathrm{Z}$ matrix, in which each column vector refers to each original matrix. This process is known as the vectorization of the $\mathrm{k}$ matrices. From the singular value decomposition of this matrix, we get the matrix $\mathrm{ZV}$. This matrix is composed by the eigenvectors extracted, and through unfolding its first column, we construct the compromise matrix. This matrix (compromise) combines the consensus structure of the $\mathrm{k}$ data tables representing the common structure of the variables in these tables. So, through the application of a factorial analysis with the principal components method to this matrix, we can plot the structure to interpret the representation of the averages for the variables and individuals.

In terms of this study, remember that we studied the decade 2004-2014 corresponding each year with a matrix; therefore, we have $\mathrm{k}=11$ matrices and, each of these matrices gives us the information of 600 companies (rows) measured on 5 variables (columns) in reference to the 5 CSR indicators, so that each $X_{k}$ matrix will be of $600 \times 5$ dimensions $\left(X_{k_{600 \times 5}}\right)$. To 
Table 3 Composition and descriptive of items that measure the CSR practices

\begin{tabular}{|c|c|c|c|}
\hline Environmental dimension & & Mean & $\mathrm{SD}$ \\
\hline Environment & & 1.74 & 1.11 \\
\hline How does EIRIS rate the Company's environmental policy and commitment? & Environmental policy & 2.25 & 1.29 \\
\hline How does EIRIS rate the Company's environmental management system? & Environmental management & 2.40 & 1 \\
\hline How does EIRIS rate the Company's environmental reporting? & Environmental reporting & 1.29 & \\
\hline What level of improvements in environmental impact can the Company demonstrate? & Environmental performance & 1.04 & \\
\hline Social dimension & & Mean & $\mathrm{SD}$ \\
\hline Human rights & & 0.98 & 0.8 \\
\hline What is the extent of policy addressing human rights issues? & Human Rights policy & 1.37 & 1.1 \\
\hline What is the extent of systems addressing human rights issues? & Human Rights systems & 1.00 & 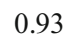 \\
\hline Does the Company report on human rights issues? & Human Rights reporting & 0.58 & . \\
\hline Employees & & 1.09 & \\
\hline How good is the Company's policy on equal opportunity and diversity issues? & Equal opportunities policy & 1.94 & \\
\hline $\begin{array}{l}\text { How clear is the evidence of systems and practices to support equal opportunities and } \\
\text { diversity? }\end{array}$ & Equal opportunities systems & 1.00 & \\
\hline How clear is the evidence of health and safety systems? & Health and safety systems & 1.27 & \\
\hline How clear is the evidence of systems to manage employee relations? & Trade unions and employee participation & 0.89 & \\
\hline How clear is the evidence of systems to support employee training and development? & Training & 0.81 & \\
\hline How clear is the evidence of systems and practices to advance job creation and security? & Job creation and security & 0.64 & 0.0 \\
\hline Stakeholders & & 1.55 & \\
\hline How clear is the Company's commitment to community or charitable work? & Community relations & 1.70 & 0.6 \\
\hline $\begin{array}{l}\text { Does the Company have policies on maintaining good relations with customers and/or } \\
\text { suppliers? }\end{array}$ & Customer/supplier relations policy & 1.38 & \\
\hline $\begin{array}{l}\text { How clear is the evidence of systems to maintain good relations with customers and/or } \\
\text { suppliers? }\end{array}$ & Community involvement & 1.47 & \\
\hline How many stakeholder issues have been allocated to board members? & Responsibility for stakeholders & 1.25 & 1.2 \\
\hline What level of engagement with stakeholders is disclosed by the Company? & Stakeholder engagement & 1.46 & 1.0 \\
\hline How good are the Company's policies towards its stakeholders overall? & Stakeholder policy & 1.93 & \\
\hline How good are the Company's management systems for stakeholders overall? & Stakeholder systems & 1.84 & \\
\hline How good is the Company's quantitative reporting on stakeholder relationships? & Stakeholder reporting & 1.66 & \\
\hline Ethics & & 1.76 & \\
\hline Does the Company have a code of ethics and, if so, how comprehensive is it? & Codes of ethics & 3.12 & \\
\hline $\begin{array}{l}\text { Does the Company have a system for implementing a code of ethics and, if so, how } \\
\text { comprehensive is it? }\end{array}$ & Codes of ethics systems & 2.76 & \\
\hline What is the extent of the Company's policy for countering bribery? & Countering bribery policy & 2.07 & 1.1 \\
\hline What is the extent of the Company's system for countering bribery? & Countering bribery systems & 1.75 & \\
\hline What is the extent of the Company's reporting on countering bribery? & Countering bribery reporting & 0.87 & \\
\hline
\end{tabular}

study these, we unite all of them in a single matrix, which we call $\mathrm{Z}$ (Fig. 2), those dimensions are $3000 \times 11$, that is, the columns of $Z$ refer to the original 11 matrices and each column is made up of 3000 rows, i.e., the 600 companies measured in each of the 5 CSR indicators-human rights (HR), ethics (Eth), stakeholders (Sth), employees (Emp), and environment (Env) - therefore, $Z_{(600 \times 5) \times 11}$. To this matrix Z, we apply a decomposition in values and singular vectors and we obtain the matrix $\mathrm{ZV}$ of the same dimensions as Z but now, it contains the values of the 11 components obtained in its decomposition, in decreasing order. The components are linear combinations of the variables of $\mathrm{Z}$, which referred to each of the original matrices; therefore, they all contain common information about them. If we select the first component, which is the one that collects the most information, it will provide us with the structure and information that all the matrices have in common; thus, unfolding the first column of ZV, which has 3000 rows $(600 \times 5)$, we obtain the compromise matrix, since we are going to place 600 individuals per column until completing the 3000 , so that this matrix manages to return to the dimension of the original matrices with 600 rows $\times 5$ columns. This matrix summarizes the $\mathrm{k}$ original data tables in a single table of the same nature, and its representation allows us to visualize a global summary of all tables.

In its representation, it is possible to visualize the position of the 600 companies — represented as points in the plane - in 
Fig. 1 Industry classification and mimetic types

Fig. 2 Compromise analysis flow chart in X-STATIS
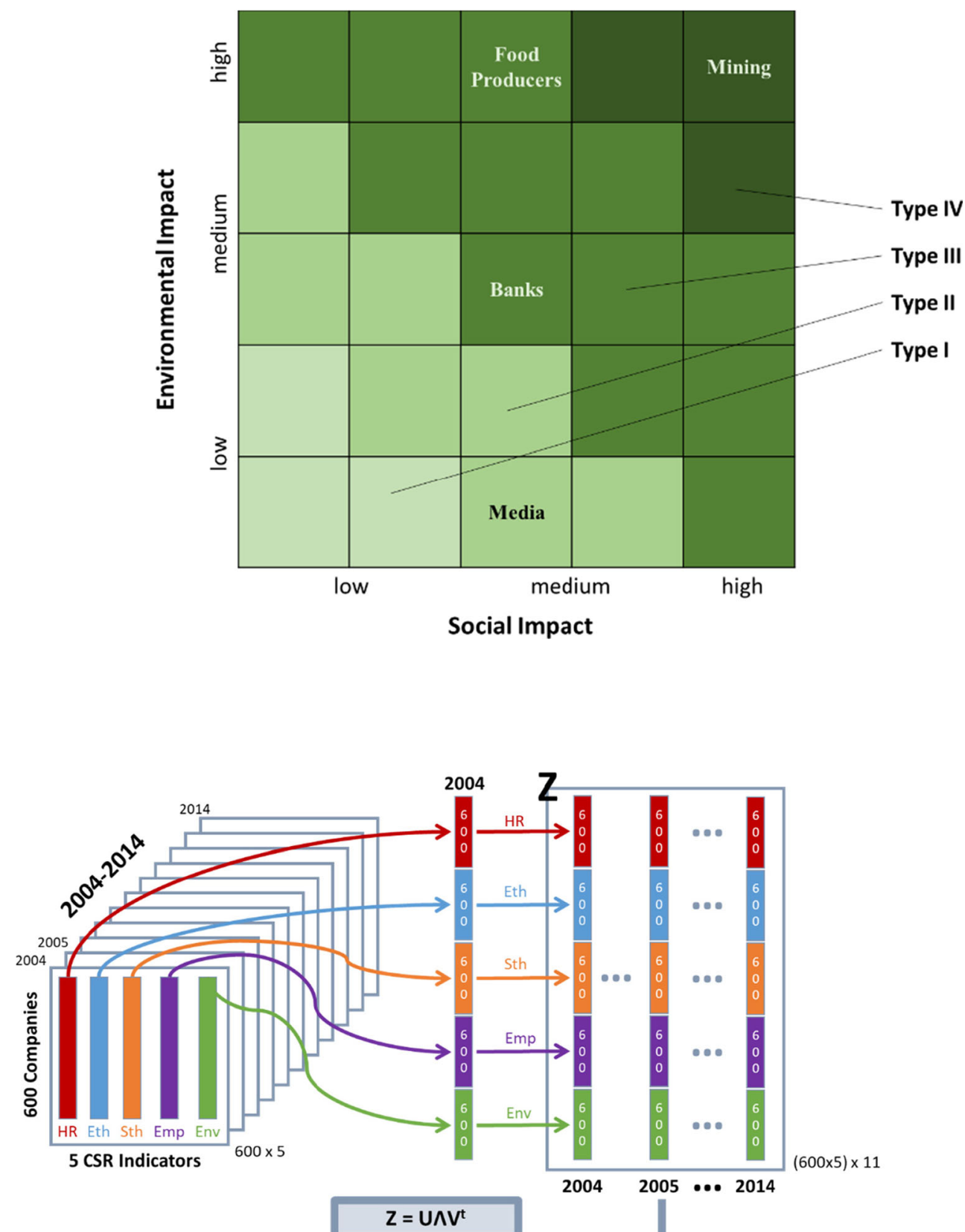

\section{Compromise}

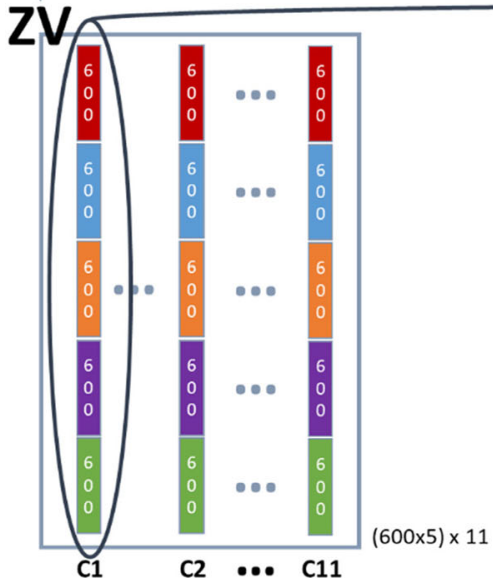

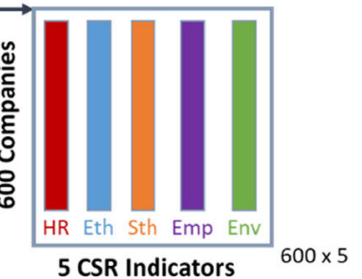

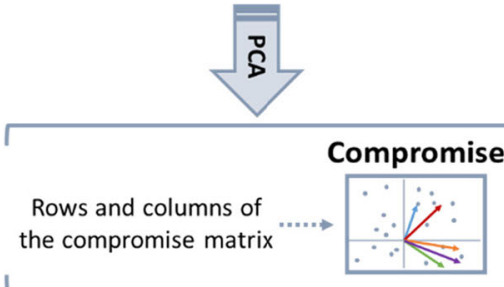


relation to their values in the five CSR indicators - represented as vectors - during the 2004-2014 decade. Following the interpretation guidelines, this method allows us to (1) identify groupings of companies with homogeneous behavior patterns, since the distance between points is associated in terms of similarity, thus two companies that are positioned close on the plane will present similar values in all the indicators and (2) find relationships between CSR indicators, since the angle obtained between two vectors is associated in correlation terms, thus two CSR indicators that form an acute angle will show a positive correlation; the more acute the angle that forms the stronger will be the relationship between those two variables.

All the calculations and graphs involved in this X-STATIS analysis were processed using ADE-4 software (Thioulouse et al. 1997).

\section{HJ-Biplot analysis}

Biplots are useful tools for the inspection of data matrices (Gabriel 1971), allowing us to pick up patterns among individuals (activity sectors of companies) according to their behavior in relation to a set of variables (CSR practices and risks/ pressures of each sector). The HJ-biplot (Galindo 1986) is a statistical exploratory technique to representation of a multivariate matrix $X_{n x p}$, which, by appropriate selection of markers $h_{j}=\left(h_{j}, \ldots, h_{p}\right)$ for its columns and $j_{i}=\left(j_{i}, \ldots, j_{n}\right)$ for its rows, allows the presentation of both markers with optimal quality of representation in the same reference system of low dimension. Let $\mathrm{X}=\mathrm{UDV}^{\mathrm{T}}$ be the usual singular value decomposition (SVD) of $\mathrm{X}$ with $\mathrm{U}$ and $\mathrm{V}$ orthogonal matrices and $\mathrm{D}=$ diag $\left(\lambda_{1}, \ldots, \lambda_{\mathrm{p}}\right)$ containing the singular values. Let $\mathrm{J}$ and $\mathrm{H}$ be the matrices of the first two columns of UD and VD, respectively.

In the HJ-biplot representation, the sectors of activity of companies are represented by points (row markers) and the variables that measure the risks/pressures and CSR practices of sectors by vectors (column markers). Taking into account the rules for interpretation, this method allows us (1) through the observation of the angles formed by variables, to check the relationships between sustainability practices and mimetic forces, since acute angles among variables translate into positive correlations; (2) by the distance among points, to identify sets of sectors with similar behavior, since close points are associated with great similarity; and (3) via the orthogonal projections of the sectors (points) on the variables (vectors), to classify the sectors with respect to CSR practices and mimetic forces by the ordination of the sectors in each variable, it should be noted that only the sectors and variables (row and column markers) with an optimal goodness of fit in the plane can be interpreted correctly. The software used to implement the HJ-biplot was developed by (Vicente-Villardón 2010).

\section{Results of empirical analysis}

In order to analyze the influence of mimetic forces in the 2004-2014 period, we perform as a first point an X-STATIS analysis on 600 firms in relation to their CSR practices, evaluating the indicated period by the study of interstructure comparing the structures found in the years (see Fig. 3). This analysis allows us to visualize the vectorial correlations between the data tables (years), so positive correlations are associated with small acute angles between vectors. We found similar structures among years being produced in a gradual manner - that is, the first and last years of study are the least related, from which we infer a growth or improvement in the adoption of CSR practices in these years. This representation involves approximately $91 \%$ of all information with the first two axes.

As a second point, a matrix that summarizes and synthesizes the common structure of all original matrices is constructed. Thus, in this matrix, each firm receives a value in reference to each variable that synthesizes the information of the 11 years. So, through plotting the structure of the compromise matrix, we capture the multivariate character of data and represent the statistically relevant information: in this way, we can compare and evaluate the companies' behavior in this period. This representation involves approximately $85 \%$ of the data variability with the factorial plane $1-2$; all data tables contribute with a similar weight to the construction of the compromise matrix and obtain a good representation in the subspace created, somewhat smaller for the 2004, 2005, and 2006 years. These values can be seen in the "Weights" and "Cos" ${ }^{2}$ " columns of Table 4.

With this information, we verified that the factorial plane 1-2 approaches the total information, so we move to its representation in Fig. 4, in which we can visualize the commitment to sustainability of our 600 firms by their position with respect to the measures that evaluate the CSR practices in the 2004-2014 period. Companies are positioned in a scattered way, presenting high variability; in reference to the variables, we found two strong relationships, one located in the first quadrant, which refers to ethics and human rights, the other situated in the fourth quadrant in relation to stakeholders, employees, and the environment.

For studying the influence of mimetic forces on company sustainability, we employed two measures, "environmental impact" and "social impact," which are based on the impact of stakeholders on the company. These variables classify companies as having a high, medium, or low impact on environmental and social issues. For this study, we separated the 600 companies according to their global level of impact, using the values of the "Mimetic" variable (see Fig. 1), with the aim of finding differences by levels (mimetic types) (see Fig. 5).

The companies (points) situated in the right part present a greater CSR commitment. This is explained by the horizontal 
Fig. 3 X-STATIS interstructure plot: vectorial correlations between years

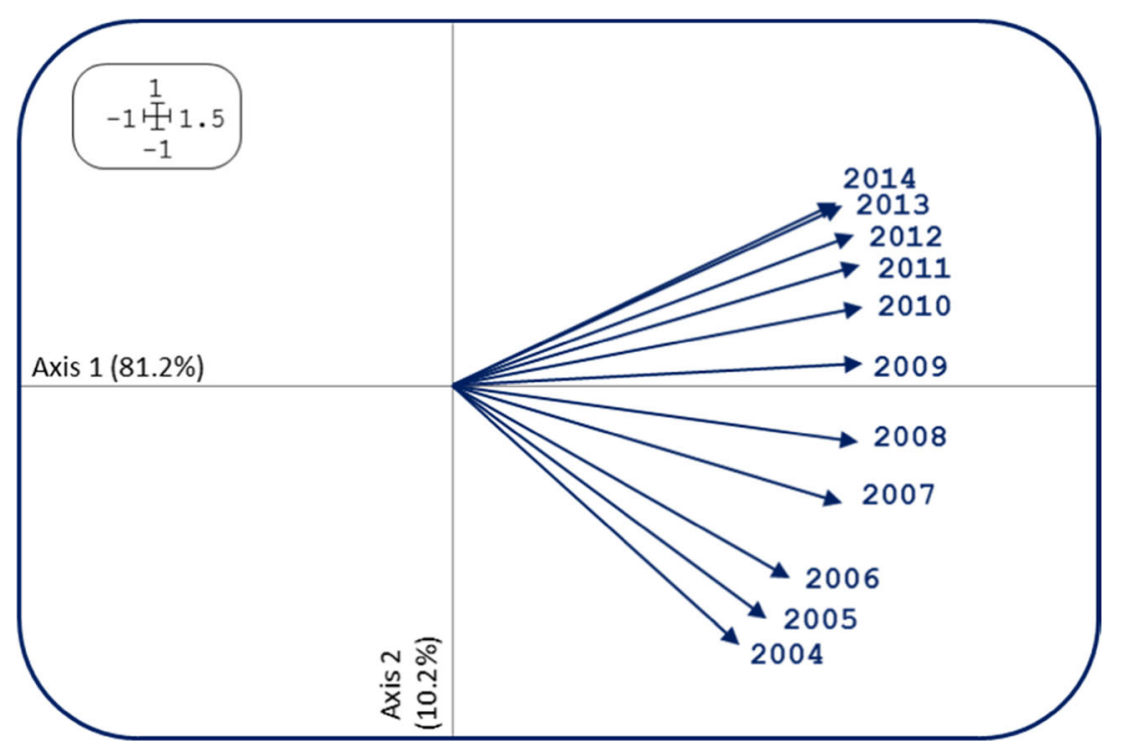

latent axis, which is a combination of the five CSR indicators, since all of them point right; with respect to the vertical latent axis, enterprises provide greater attention to environment, employees, and stakeholders in the lower semi-plane, and to ethics and human rights in the upper semi-plane. In the study of firms, we found these dispersed throughout the plane. Thus, firms regardless of the type (different levels of social and environmental impact) to which they belong adopt a similar CSR commitment. Nevertheless, it is possible to observe differences in the degree of CSR distribution of companies by type, since there is a trend in the centers of the clouds presenting higher average degrees of CSR for firms with higher environment and social impact. Most firms of the fourth type (higher-level impact) are positioned in the right semi-plane, thereby showing a greater commitment to sustainability. Conversely, most firms of the second type (lower-impact level) are positioned in the left semi-plane, showing a lower commitment. Companies of the third type are spread throughout the graph.

To deepen the differences across types in relation to the degree of CSR evolution, we supplemented this information with parallel coordinates graphs (Inselberg 1992), for each CSR indicator. It is a visual technique that allows the representation of k-dimensions in a two-dimensional system, where the dimensions (variables) are represented as our years of study (vertical axes), and the individuals are displayed as horizontal lines, being the mimetic types values for each year (see Fig. 6).

The companies with greater impact show greater commitment to sustainability; note that companies of the fourth type have the greatest impact. This order is maintained in all CSR indicators with significant differences in all the years; however, in the variable "Ethics," the third and second types interleaved the positions, showing similar results in all years of the study. In conclusion, firms worldwide stick to the same CSR practices (common behavior patterns) but, regarding the level of social and environmental impact, present a greater or lesser commitment to them (different development degrees of CSR evolution). These differences are constant over time - that is, the evolution of CSR patterns differs with levels of impact; however, it is common within them during the years of study.

Consequently, we evaluated the mimetic types with a HJbiplot representation, using data at the sector level. We projected the sectors of activity belonging to companies on CSR variables and variables that measure the impact level in order to find relationships between these variables, characterizing the sectors according to their impact level and their commitment to sustainability at the same time. For a correct interpretation of the HJ-biplot, several measures are necessary;
Table 4 Compromise matrix weights and quality of representation on compromise subspace

\begin{tabular}{|c|c|c|c|c|c|c|c|}
\hline & Year & Weights & $\operatorname{Cos}^{2}$ & & Year & Weights & $\operatorname{Cos}^{2}$ \\
\hline 1 & 2004 & $2.30 \mathrm{E}+02$ & 0.523 & 7 & 2010 & $3.28 \mathrm{E}+02$ & 0.757 \\
\hline 2 & 2005 & $2.48 \mathrm{E}+02$ & 0.590 & 8 & 2011 & $3.26 \mathrm{E}+02$ & 0.750 \\
\hline 3 & 2006 & $2.56 \mathrm{E}+02$ & 0.620 & 9 & 2012 & $3.21 \mathrm{E}+02$ & 0.736 \\
\hline 4 & 2007 & $3.16 \mathrm{E}+02$ & 0.695 & 10 & 2013 & $3.12 \mathrm{E}+02$ & 0.699 \\
\hline 5 & 2008 & $3.25 \mathrm{E}+02$ & 0.734 & 11 & 2014 & $3.06 \mathrm{E}+02$ & 0.676 \\
\hline 6 & 2009 & $3.28 \mathrm{E}+02$ & 0.757 & & & & \\
\hline
\end{tabular}




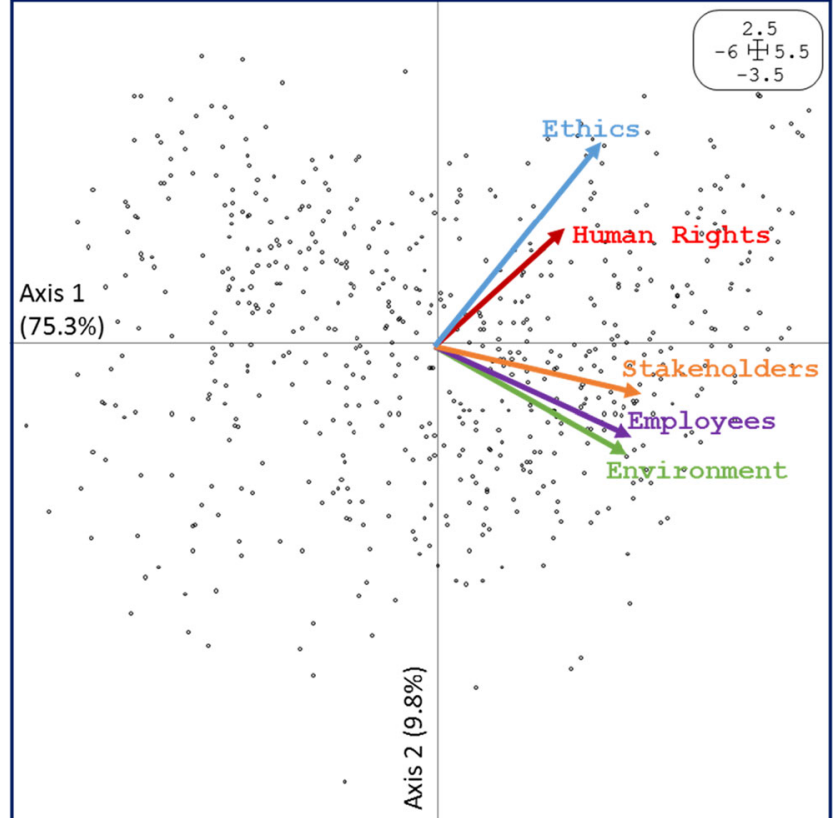

Fig. 4 X-STATIS compromise subspace: position of 600 companies regarding the five CSR indicators

specifically, the proportion of explained variance and eigenvalues, as well as the relative contribution of the factor to the element, which identify the relevance of each measure for the horizontal and vertical axes (Table 5).
This analysis obtains $75 \%$ of explained variance with the factorial plane 1-2, as represented in Fig. 7.

Triangle, circle, and square forms show the position of the 39 sectors in relation to CSR practices and the measures that evaluate the company impact. The position of each sector is obtained by the average value of companies that form it for each of the variables in the years 2004-2014. The triangle forms refer to the sectors with the greatest impact (fourth type), circles correspond to the third type, and squares to the sectors with less impact (second type). It should be noted that all sectors achieved a good-quality representation in the plane, albeit somewhat smaller for technology hardware and equipment (37), banks (4), industrial engineering (20), and industrial metals and mining (21).

In reference to the variables, we observe how all of themthe 5 CSR indicators and the 2 variables that assess the impact - constitute the horizontal axis, obtaining greater strength the CSR indicators; this information is provided by the values of Table 5. Thus, the sectors will be ordered from left to right according to the value of their CSR practices. In relation to the vertical axis, the highest value is obtained by the "environmental impact" variable, which is located in the lower semi-plane, and the next value is obtained by the "social impact" variable positioned in the upper semi-plane, so that sectors with the greatest environmental impact will be positioned in the lower semi-plane, those with the greatest social
Fig. 5 X-STATIS compromise subspace: position of 600 companies, fragmented by their global level of impact (mimetic types), regarding the five CSR indicators

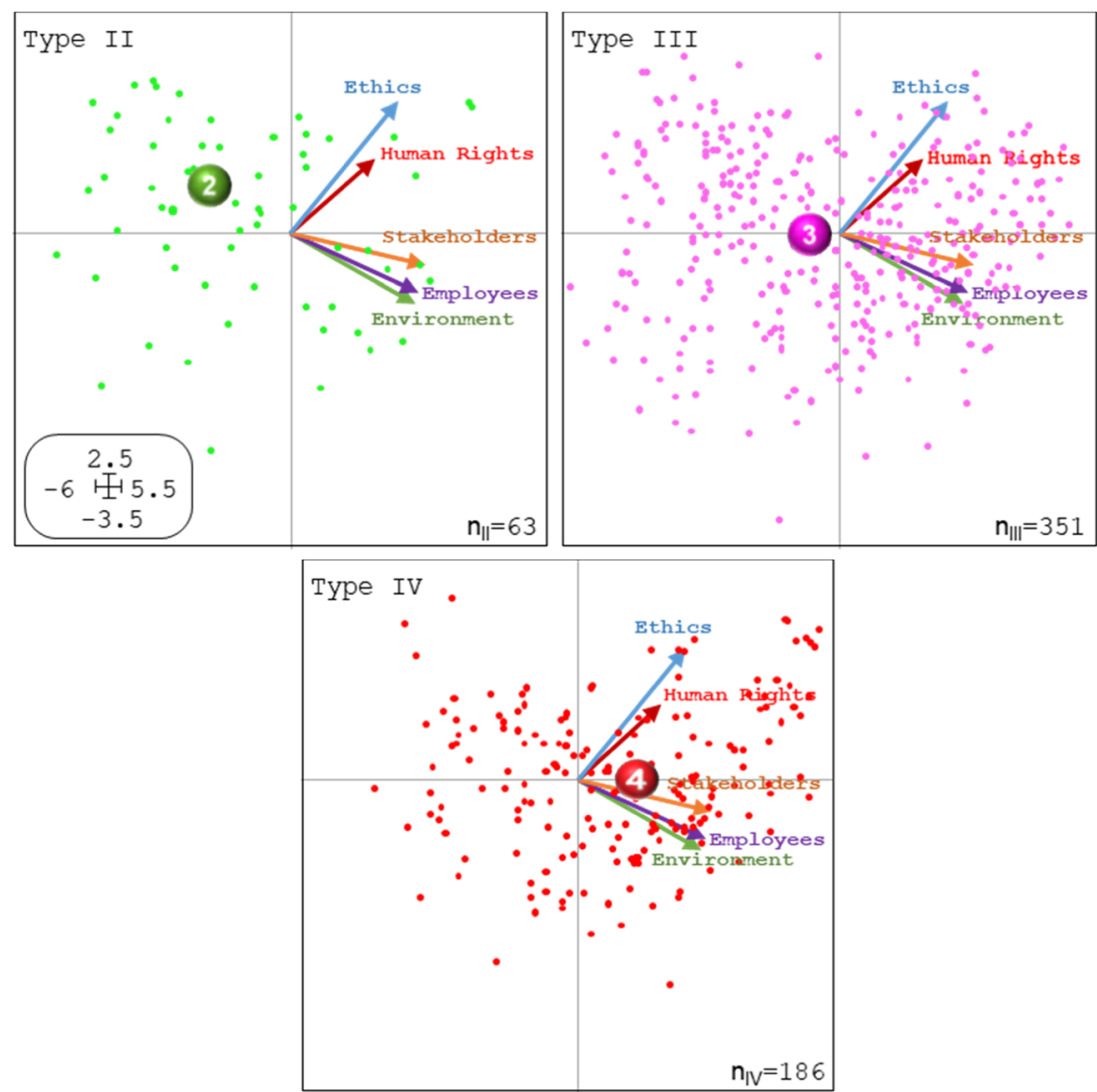




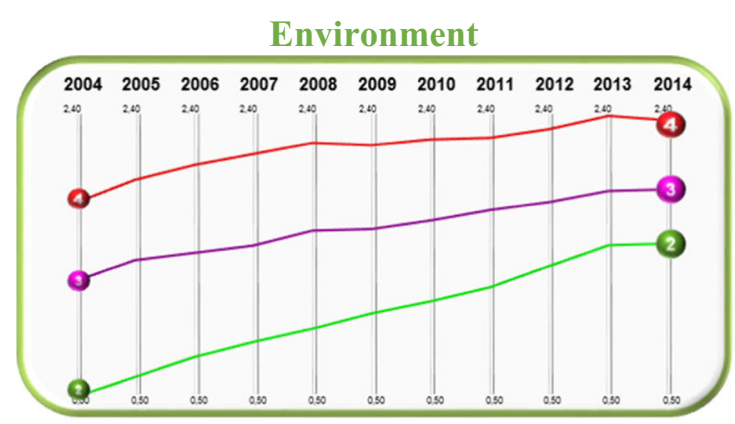

Employees

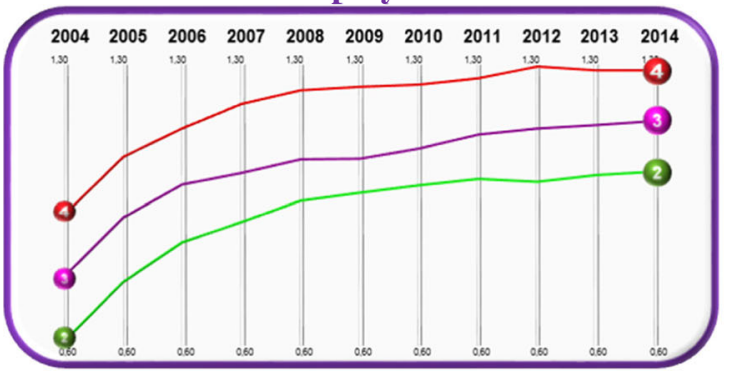

Ethics

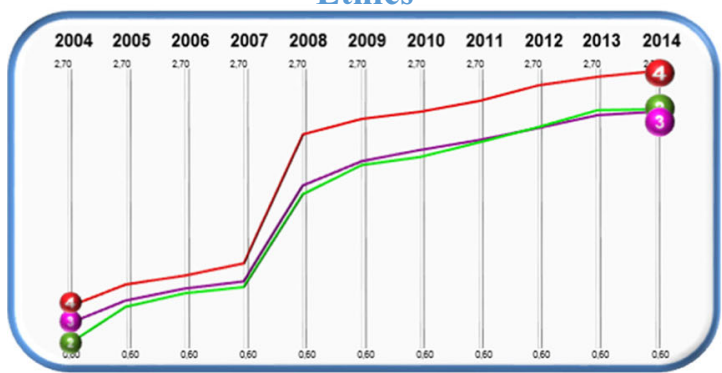

\section{Stakeholders}

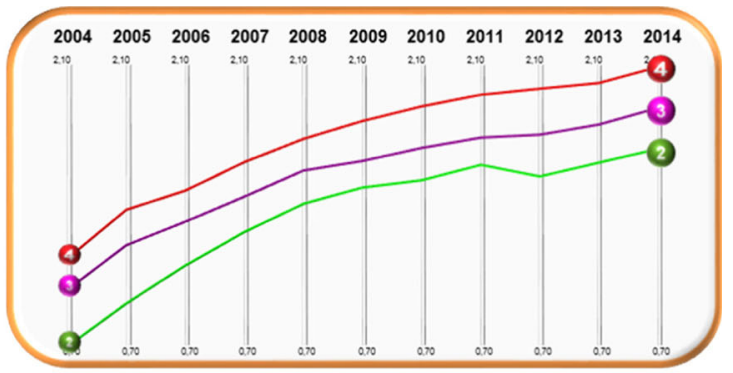

Human Rights

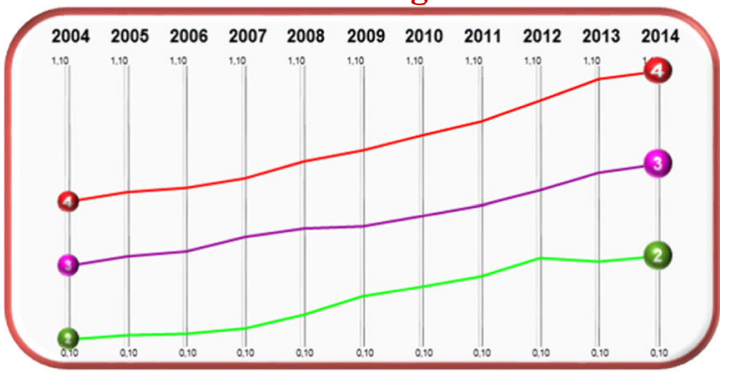

Fig. 6 Evolution of mimetic types (global level of impact) in the 2004-2014 period for each CSR indicator visualized by graphs of parallel coordinates

impact in the upper semi-plane, and those with high impact in both dimensions will be located between these two variables, occupying the right semi-plane.

The variables that assess the impact of stakeholders on environmental ("environmental impact") and social ("social impact") dimensions have a positive relationship with the variables that quantify the commitment to sustainability: therefore, sectors classified as having the most impact (fourth type, triangles) are all located on the right side near these variables, showing a greater commitment. These results translate into companies from higher impact sectors showing higher levels

Table 5 Relative contribution of the factor to the element

\begin{tabular}{lcc}
\hline Variables & Axis 1 & Axis 2 \\
\hline Social impact & 322 & 143 \\
Ethics & 686 & 105 \\
Employees & 717 & 44 \\
Stakeholders & 821 & 11 \\
Environment & 831 & 36 \\
Human rights & 624 & 45 \\
Environmental impact & 310 & 548 \\
\hline
\end{tabular}

of CSR. By contrast, sectors considered to have the least impact (second type, squares), and sectors that are less scrutinized by the public, such as those dedicated to finances (e.g., life Insurance (24), financial services (10), or real estate investment and services (33)) located on the left side far from CSR dimensions, are found to be less competitive in terms of sustainable practices.

From the above, it should be noted that the interests of businesses depend largely on the type of industry in which they operate. We therefore observe that the composition of the fourth type (see Table 6) is formed by sectors with high impact on the environment - i.e., more exposed to environmental riskssuch as mining (26), chemicals (6), electricity (8), pharmaceuticals and biotechnology (32), construction and materials (7), oil and gas producers (29), and industrial metals and mining (21); other polluting sectors of the third type, such as forestry and paper (14), tobacco (38), industrial engineering (20), and automobiles and parts (3) are located in similar positions, and therefore give higher priority to environmental protection and defense of human rights. This is mainly because the variable "environmental impact" obtains a stronger relationship with the variables "Human Rights" and "Environment," and these sectors have high scores in these variables. These results show 
Fig. 7 HJ-biplot: position of all the sectors belonging to companies with respect to the CSR indicators (continuous vectors) and the level of impact (discontinuous vectors)
Table 6 Composition by mimetic types (global level of impact) of the 39 sectors according to the Industry Classification Benchmark (ICB) system

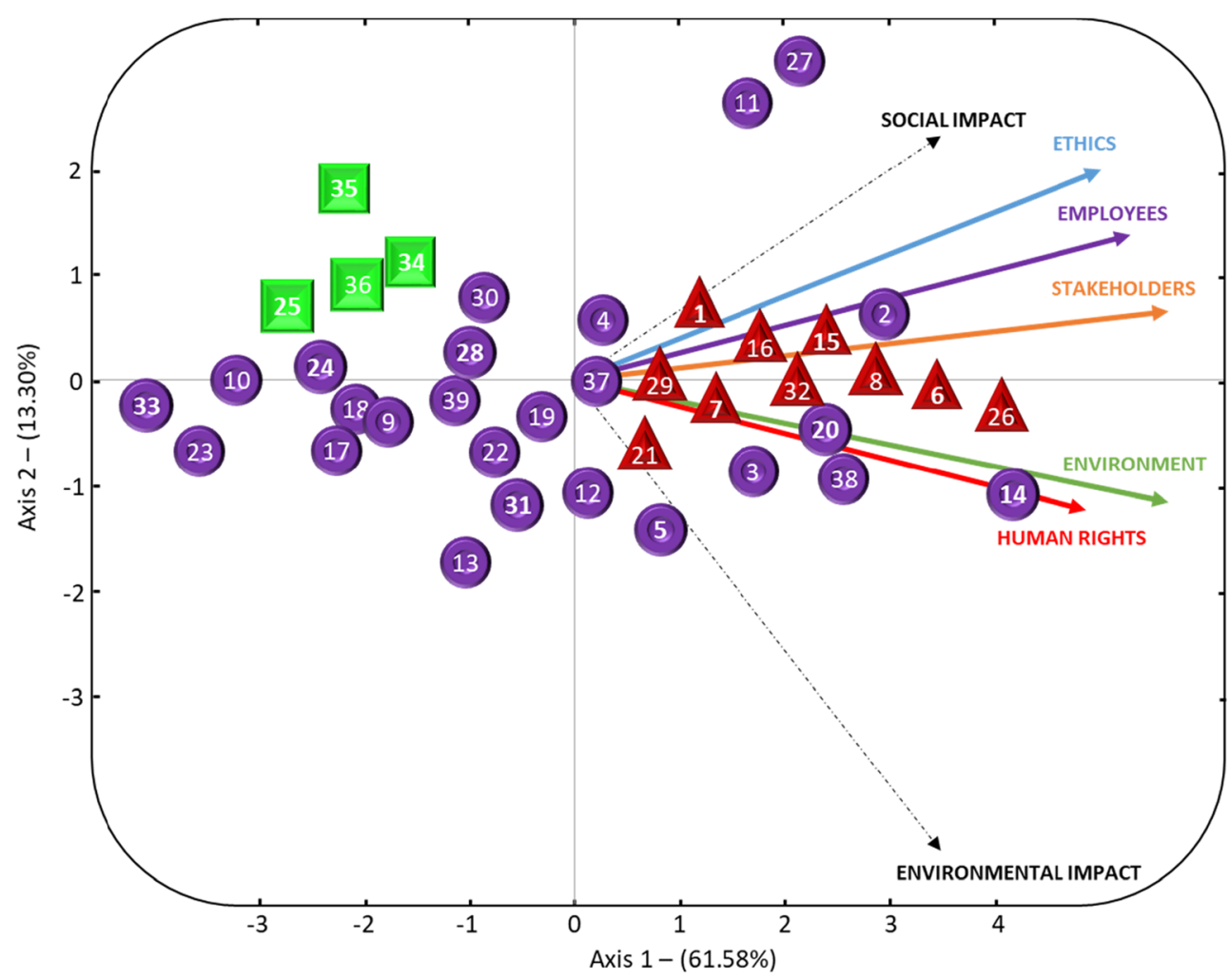

Fourth type (triangle): high environmental and social impact

1. Aerospace and defense

16. General industrials

6. Chemicals

21. Industrial metals and mining

7. Construction and materials

26. Mining

8. Electricity

29. Oil and gas producers

15. Gas, water and multi-utilities

32. Pharmaceuticals and biotechnology

Third type (circle): low or medium environmental impact and high social impact or vice versa, or medium impact in both dimensions
2. Alternative energy
20. Industrial engineering
3. Automobiles and parts
22. Industrial transportation
4. Banks
23. Leisure goods
5. Beverages
24. Life insurance
9. Electronic and electrical equipment
27. Mobile telecommunications
10. Financial services
28. Nonlife insurance
11. Fixed line telecommunications
30. Oil equipment, services and distribution
12. Food and drug retailers
31. Personal goods
13. Food producers
33. Real estate investment and services
14. Forestry and paper
37. Technology hardware and equipment
17. General retailers
38. Tobacco
18. Health care equipment and services
39. Travel and leisure

19. Household goods and home construction

Second type (square): low environmental impact and medium social impact or vice versa
25. Media
35. Software and computer services
34. Real estate investment trusts
36. Support services 
that the leading companies in sustainable commitment belong to sectors with greater environmental risks and present the best practices of the study, prioritizing environment preservation and the defense of human rights.

Other less polluting sectors, such as fixed line telecommunications (11) and mobile telecommunications (27) located in the upper area of the plane - of the third type, give higher priority to business ethics, the rights of employees and stakeholders, since the "social impact" variable obtains stronger relationships with the variables "Ethics," "Employees," and "Stakeholders", and these sectors score highly in these variables. These results tell us that these sectors, with fewer environmental concerns, prioritize the ethics of the company, the labor rights of their employees, and external relations (stakeholders). Most of the remaining sectors are located in the left semi-plane showing the lowest CSR levels.

\section{Discussion}

As we indicated in "Introduction" section, previous papers have focused their aims on the analysis of the effect that normative and coercive institutional pressures of each country has on the company's decision to behave in a socially responsible way (Ringov and Zollo 2007; Boiral and Gendron 2011; Zhou et al. 2013; Mar MirasRodríguez et al. 2015; Garcia-Sanchez et al. 2016). Our results reinforce the importance of institutional forces, showing the relevance that mimetic isomorphism at industry level has on business attitude towards being more likely to make socially responsible investments and, in consequence, to be more sustainable firms. So, we extend the idea of Jackson and Apostolakou (2010), evidencing that common regulations and policies on social responsibility are internationally similar in the same industry, provoking a mimetic isomorphism that could have a similar effect as those generated by national coercive and normative pressures. Moreover, as McWilliams and Siegel (2000) argue, industry factors can make it difficult for companies to enter an activity sector, and we observe that the effect of CSR pressures that exist in each industry could be to create stronger barriers to firms' diversification decision-making.

More concretely, organizations in high-impact sectors obtain higher CSR scores than organizations in other sectors (Jackson and Apostolakou 2010; Young and Marais 2012). Our results agree with those found by Martínez-Ferrero and García-Sánchez (2016), who state that firms that operate in industries with greater environmental risks or concerns, that is, with greater stakeholder pressure are more likely to issue sustainability reports. This is due to the specific stakeholder groups of each industry influencing business CSR practices, in other words, the greater integration of these groups in sustainable development results in less damage to the environment (Park et al. 2014; Salem et al. 2017). These results evidence that the level of environmental sustainability developed is positively tied to the industry imitation tendencies - i.e., firms with the aim of providing social legitimacy can adopt a CSR initiative imitating the behaviors of other organizations that are considered models in its activity sector, so they adhere to CSR policies as a way to manage their reputation and thus respond to stakeholders' expectations (Ekelenburg 2016). Companies in these sensitive industries seek to improve their commitment to sustainability in order to manage their risks and increase user confidence. Such risks occur because of the societal pressure of disclosing bad environmental news (Casey and Grenier 2014; Ekelenburg 2016).

Companies from sectors with a strong social and low environmental impact, such as those dedicated to the telecommunications sector, present social concerns above environmental concerns. They are staff-intensive companies, which focus on the development of policies aimed at favoring personal conciliation and labor, promote diversity, and fight for equal opportunities and the training of their employees, as well as focusing on the maintenance of good relations with their stakeholders and business ethics. Companies lagging behind in sustainable terms correspond to companies considered to have low impact, are less studied by the public, and are from less polluting sectors, such as those dedicated to financial services (Belu 2009; Weber 2014).

Among other factors, the activities in the CSR categories depend on the sector in which the company operates, since stakeholders have different areas of concern according to their industry sector (Halkos and Skouloudis 2016). Companies operating in high-impact sectors respond by adopting more extensive CSR practices; this may be because companies use CSR to legitimize their business practices, as this commitment can be very useful to companies in order to achieve vital social goals such as prestige or a good reputation and therefore, economic advantages associated to growth, survival, or performance (González-Rodríguez et al. 2015). Companies operating in the same activity sector probably develop common policies and regulations on social responsibility since they face similar risks and challenges. These pressures at the sectorial level can produce isomorphism between companies operating in the same industry on an international level (Jackson and Apostolakou 2010).

In addition, our paper could be a complementary view of the results obtained in previous papers that analyze the impact that the economic future opportunism of industry has on CSR investment (i.e., Staw and Szwajkowski 1975; Goll and Rasheed 2004; Antolín-López et al. 2015; Chen et al. 2017). In this context, we observe that stakeholders' specific pressure within each industry plays an important role in CSR patterns and development, which these authors have ignored. 


\section{Conclusions}

Our study determines the role of mimetic institutional pressures in the sector of activity in which the companies operate in the development of CSR practices. Previous papers have been shown that companies that operate in similar normative and coercive countries have adopted the same types of CSR practice as other companies, although there is a more positive evolution, with significant differences in the level of development of these social and environmental practices. However, there is a lack of knowledge about the effect of mimetic forces, pressures, or isomorphism.

Our paper expands previous evidence by firstly analyzing in a comparative manner the role that industry isomorphism plays in the evolution of CSR. This research designates the sector of activity as an institutional factor with explanatory capacity in CSR practices, since interest groups and society in general perceive different social and environmental risks according to the economic activity carried out by companies. The impact of their activities, particularly their risks and environmental concerns, is the best indicator of the pressure generated by the stakeholders for the implementation and development of CSR practices that promote sustainable development. This thematic is quite important for all industry, especially those relating to more polluting or labor-intensity sector, in order to understand the effect that the legislation, regulation, and economy on environmental control and work and human rights has on their survival.

Our main conclusion is that mimetic forces have an important effect on the companies' CSR commitment. More concretely, the mimetic forces are influential factors in the commitment of companies in terms of social and environmental issues. The analysis of these forces indicates that firms in high-impact sectors - sectors that operate under greater pressure from interest groups and face greater social and environmental risk - have higher CSR scores than companies from other sectors. This may be because companies use CSR to legitimize their business practices, so they adhere to CSR policies as a way to manage their reputation and thus respond to stakeholder expectations. Here, CSR practices depend largely on the type of industry in which they operate, as stakeholders in different industry sectors have different areas of concern. Therefore, companies operating in more polluting sectors, such as mining, paper, chemicals, or oil, give higher priority to environmental protection and defense of human rights, whereas other, less polluting companies involved in the communications sector are concerned to a greater extent with social issues such as business ethics or the rights of their employees. As companies operating in the same activity sector face similar risks and challenges, they probably develop common policies and regulations on social responsibility. These pressures from the sector should not be considered strictly national pressures in terms of scope, but can produce isomorphism between competitors in the same industry internationally.

Moreover, our evidence contributes to the academic literature in the following ways. Firstly, our international approach to 18 countries allows us to extrapolate the arguments of institutional theory to a wider geographic spectrum, traditionally limited to comparing one Anglo-Saxon country with another opposing institutional framework (Xiao et al. 2005; Hodge et al. 2009; Weber 2014). Secondly, the consideration of the period 2004-2014 allows us to control unobservable heterogeneity and the annual bias of cross-sectional studies methodologically (Hodge et al. 2009; Perego 2009), besides showing the continuity of institutional isomorphism in different economic periods that can carry different commitments to CSR (Simnett et al. 2009; Kolk and Perego 2010; Tower and Rusmin 2012). In addition, the use of statistical exploratory multivariate techniques provides an innovative methodological contribution, which allows us to capture the multivariate data structure for the 2004-2014 decade in reference to company sustainability through their CSR practices, studying behavior patterns of companies and classifying the activity sectors based on their commitment to CSR practices and mimetic institutional characteristics. Accordingly, the results of our study show that firms, regardless of the sector of activity to which they belong, adopt similar patterns of CSR practices, but the degree of their development is highly sensitive to the mimetic pressures.

These findings can be very useful to investors, companies, managers, and policy-makers. For investors, the findings are useful for a correct selection of the approach and level of CSR commitment, and knowledge of discrepancies in CSR practices in different institutional contexts on an international scale. With respect to companies, these data facilitate comprehension of the different pressures for environmental and social behavior, so that their CSR investment may be presented consequentially when diversifying their business activities or entering foreign markets. For managers, when the focus is on being accepted as legitimate actors in business activities in new markets, an understanding of the constraining institutional factors will help them to modify their CSR practices according to these conditions. For policy-makers and regulators, an appreciation of the CSR business behavior and its determinants-identifying the sectors which present more deficiencies - will help them to overcome their deficiencies, so facilitating the orientation of regulatory processes towards promoting policies that improve company sustainable behavior. These issues may guide managers on decision-making processes to evaluate the impacts of business activities.

This paper presents limitations that will be considered by the authors in future lines of research. Specifically, we only analyze the effect that mimetic pressure at industry level has on CSR patterns and evolution, without taking into account the role that the firms' managers, especially the CEO, could 
play in the CSR decision-making. Accordingly, future work will be oriented to analyzing the impact of mimetic industry isomorphism associated with the personality of the CEO of each company, and especially those traits associated with the tolerance of uncertainty, one of the main determinants of mimetic isomorphism. The ablest CEOs have a greater willingness to undertake long-term investments due to the professional opportunities that they enjoy and their consideration in the labor market, so the most talented CEOs could have a greater incentive to invest in the long long-term CSR practices that lead to improvements in the sustainability of business actions, fostering strengths, and correcting social and environmental deficiencies derived from economic activity.

\section{References}

Aerts W, Cormier D, Magnan M (2006) Intra-industry imitation in corporate environmental reporting: an international perspective. J Account Public Policy 25:299-331

Amor-Esteban V, García-Sánchez I-M, Galindo-Villardón M-P (2017) Analysing the effect of legal system on corporate social responsibility (CSR) at the country level, from a multivariate perspective. Soc Indic Res:1-18

Antolín-López R, Céspedes-Lorente J, García-de-Frutos N, Martínez-delRío J, Pérez-Valls M (2015) Fostering product innovation: differences between new ventures and established firms. Technovation 41:25-37

Bayoud NS, Kavanagh M, Slaughter G (2012) Factors influencing levels of corporate social responsibility disclosure by Libyan firms: a mixed study. Int J Econ Finance 4. https://doi.org/10.5539/ijef.v4n4p13

Belu C (2009) Ranking corporations based on sustainable and socially responsible practices. A data envelopment analysis (DEA) approach. Sustain Dev 17:257-268

Boiral O, Gendron Y (2011) Sustainable development and certification practices: lessons learned and prospects. Bus Strateg Environ 20: 331-347

Branco MC, Rodrigues LL (2008) Factors influencing social responsibility disclosure by Portuguese companies. J Bus Ethics 83:685-701

Campbell JL (2006) Institutional analysis and the paradox of corporate social responsibility. Am Behav Sci 49:925-938. https://doi.org/10. $1177 / 0002764205285172$

Campbell JL (2007) Why would corporations behave in socially responsible ways? An institutional theory of corporate social responsibility. Acad Manag Rev 32:946-967

Casey RJ, Grenier JH (2014) Understanding and contributing to the enigma of corporate social responsibility (CSR) assurance in the United States. Audit J Pract Theory 34:97-130

Chen L, Zhao X, Tang O, Price L, Zhang S, Zhu W (2017) Supply chain collaboration for sustainability: a literature review and future research agenda. Int J Prod Econ 194:73-87. https://doi.org/10.1016/ j.ijpe.2017.04.005

Colwell SR, Joshi AW (2013) Corporate ecological responsiveness: antecedent effects of institutional pressure and top management commitment and their impact on organizational performance. Bus Strateg Environ 22:73-91

Demirbag M, Wood G, Makhmadshoev D, Rymkevich O (2017) Varieties of CSR: institutions and socially responsible behaviour. Int Bus Rev 26(6):1064-1074
DiMaggio PJ, Powell WW (1983) The iron cage revisited: collective rationality and institutional isomorphism in organizational fields. Am Sociol Rev 48:147-160

DiMaggio PJ, Powell WW (1991) The new institutionalism in organisational analysis. New Institutionalism Organ Anal (Vol. 17) Chicago, University of Chicago Press

Duran JJ, Bajo N (2014) Institutions as determinant factors of corporate responsibility strategies of multinational firms. Corp Soc Responsib Environ Manag 21:301-317

Ekelenburg MV (2016) Determinants of voluntary external assurance on corporate sustainability reports: a comparison between Europe and North America. Radboud University, Netherlands

Escoufier Y (1976) Opérateur associé à un tableau de données, in: Annales de l'INSEE. JSTOR, pp 165-179

Gabriel KR (1971) The biplot graphic display of matrices with application to principal component analysis. Biometrika 58:453-467

Galindo MP (1986) Una alternativa de representacion simultanea: HJBiplot. Qüestiió 10(1):13-23

Gallego-Álvarez I, Ortas E (2017) Corporate environmental sustainability reporting in the context of national cultures: a quantile regression approach. Int Bus Rev 26:337-353

García-Sánchez I-M, García-Meca E (2017) CSR engagement and earnings quality in banks. The moderating role of institutional factors. Corp Soc Responsib Environ Manag 24:145-158

García-Sánchez I-M, Rodríguez-Ariza L, Frías-Aceituno J-V (2013) The cultural system and integrated reporting. Int Bus Rev 22:828-838. https://doi.org/10.1016/j.ibusrev.2013.01.007

Garcia-Sanchez I-M, Cuadrado-Ballesteros B, Frias-Aceituno J-V (2016) Impact of the institutional macro context on the voluntary disclosure of CSR information. Long Range Plan 49:15-35. https://doi.org/10. 1016/j.lrp.2015.02.004

Gjølberg M (2009) Measuring the immeasurable? Scand J Manag 25:10 22. https://doi.org/10.1016/j.scaman.2008.10.003

Goll I, Rasheed AA (2004) The moderating effect of environmental munificence and dynamism on the relationship between discretionary social responsibility and firm performance. J Bus Ethics 49:41-54

González-Rodríguez MR, Díaz-Fernández MC, Simonetti B (2015) The social, economic and environmental dimensions of corporate social responsibility: the role played by consumers and potential entrepreneurs. Int Bus Rev 24:836-848

Habisch A, Jonker J, Wegner M, Schmidpeter R (2005) Corporate social responsibility across Europe. Springer Science \& Business Media

Halkos G, Skouloudis A (2016) National CSR and institutional conditions: an exploratory study. J Clean Prod 139:1150-1156. https:// doi.org/10.1016/j.jclepro.2016.07.047

Halkos G, Skouloudis A (2017) Revisiting the relationship between corporate social responsibility and national culture: a quantitative assessment. Manag Decis 55(3):595-613. https://doi.org/10.1108/ MD-12-2016-0868

Hodge K, Subramaniam N, Stewart J (2009) Assurance of sustainability reports: impact on report users' confidence and perceptions of information credibility. Aust Account Rev 19:178-194

Hofstede G (2001) Cultural consequences. Sage Publ, Thousand Oaks

Inselberg A (1992) The plane R2 with coordinate parallel. Comput Sci Appl Math Dep Tel Aviv, University Israel

Jackson G, Apostolakou A (2010) Corporate social responsibility in Western Europe: an institutional mirror or substitute? J Bus Ethics 94:371-394. https://doi.org/10.1007/s10551-009-0269-8

Jaffrenou P-A (1978) Sur l'analyse des familles finies de variables vectorielles: bases algébriques et application à la description statistique. The'se de Troisie'me Cycle, Universite' de Lyon

Kolk A, Perego P (2010) Determinants of the adoption of sustainability assurance statements: an international investigation. Bus Strateg Environ 19:182-198

L'Hermier des Plantes, H (1976) Structuration des tableauya trois indices de la statistique. Thése de 3 eme cycle, Université Montpellier II 
Larrinaga C (2007) Sustainability reporting: insights from neoinstitutional theory. Routledge, London

Lenssen G, Gasdparski W, Rok B, Lacy P, Midttun A, Gautesen K, Gjølberg M (2006) The political economy of CSR in Western Europe. Corp Gov Int J Bus Soc 6:369-385

Mar Miras-Rodríguez M, Carrasco-Gallego A, Escobar-Pérez B (2015) Are socially responsible behaviors paid off equally? A cross-cultural analysis. Corp Soc Responsib Environ Manag 22:237-256

Martínez-Ferrero J, García-Sánchez I-M (2016) Coercive, normative and mimetic isomorphism as determinants of the voluntary assurance of sustainability reports. Int Bus Rev 26(1):102-118. https://doi.org/ 10.1016/j.ibusrev.2016.05.009

Matten D, Moon J (2004) Implicit and explicit CSR. A conceptual framework to understand CSR in Europe ICCSR Res Pap Ser 29

McWilliams A, Siegel D (2000) Corporate social responsibility and financial performance: correlation or misspecification? Strateg Manag J 21:603-609

Miller D, Friesen PH (1983) Strategy-making and environment: the third link. Strateg Manag J 4:221-235

Ortas E, Álvarez I, Jaussaud J, Garayar A (2015) The impact of institutional and social context on corporate environmental, social and governance performance of companies committed to voluntary corporate social responsibility initiatives. J Clean Prod 108:673-684. https://doi.org/10.1016/j.jclepro.2015.06.089

Park BI, Chidlow A, Choi J (2014) Corporate social responsibility: stakeholders influence on MNEs' activities. Int Bus Rev 23:966-980

Parsa S, Deng LX (2008) Capital markets' reactions to social information announcements. Int J Account Finance 1:107-120

Patten DM (1992) Exposure, legitimacy, and social disclosure. J Account Public Policy 10:297-308

Perego P (2009) Causes and consequences of choosing different assurance providers: an international study of sustainability reporting. Int J Manag 26:412

Ringov D, Zollo M (2007) The impact of national culture on corporate social performance. Corp Gov Int J Bus Soc 7:476-485. https://doi. org/10.1108/14720700710820551

Salem MA, Shawtari F, Shamsudin MF, Hussain HBI (2017) The consequences of integrating stakeholder engagement in sustainable development (environmental perspectives). Sustain Dev 26:255-268. https://doi.org/10.1002/sd.1699

Schreck P (2009) The business case for corporate social responsibility: understanding and measuring economic impacts of corporate social performance. Physica-Verlag, Heidelberg
Simnett R, Vanstraelen A, Chua WF (2009) Assurance on sustainability reports: an international comparison. Account Rev 84:937-967. https://doi.org/10.2308/accr.2009.84.3.937

Skouloudis A, Evangelinos K (2012) A research design for mapping national CSR terrains. Int J Sustain Dev World Ecol 19(2):130-143

Skouloudis A, Isaac D, Evaggelinos K (2016) Revisiting the national corporate social responsibility index. Int J Sustain Dev World Ecol 23(1):61-70

Staw BM, Szwajkowski E (1975) The scarcity-munificence component of organizational environments and the commission of illegal acts. Adm Sci Q 20(3):345-354

Thioulouse J, Chessel D, Dole S, Olivier J-M (1997) ADE-4: a multivariate analysis and graphical display software. Stat Comput 7:75-83

Tower G, Rusmin R (2012) Legitimising corporate sustainability reporting throughout the world. Australas Account Bus Finance $\mathrm{J}$ 6(2): 19

Venanzi D, Fidanza B (2006) Corporate social responsibility and value creation-determinants and mutual relationships in a sample of European listed firms. Social Science Research Network, Rochester. https://doi.org/10.2139/ssrn.939710

Vicente-Villardón JL (2010) MULTBIPLOT: a package for multivariate analysis using biplots. Mathlab Softw Biplot Usal EsClassicalBiplotindex $\mathrm{Html}$

Wanderley LSO, Lucian R, Farache F, de Sousa Filho JM (2008) CSR information disclosure on the web: a context-based approach analysing the influence of country of origin and industry sector. $\mathrm{J}$ Bus Ethics 82:369-378

Weber JL (2014) Corporate social responsibility disclosure level, external assurance and cost of equity capital. Dissertation, University of Colorado at Boulder

Welford R (2004) Corporate social responsibility in Europe and Asia: critical elements and best practice. J Corp Citizsh 13:31

Welford R (2005) Corporate social responsibility in Europe, North America and Asia: 2004 survey results. J Corp Citizsh 17:33-52

Xiao JZ, Gao SS, Heravi S, Cheung YC (2005) The impact of social and economic development on corporate social and environmental disclosure in Hong Kong and the UK. Adv Int Account 18:219-243

Young S, Marais M (2012) A multi-level perspective of CSR reporting: the implications of national institutions and industry risk characteristics. Corp Gov Int Rev 20:432-450

Zhou S, Simnett R, Green W (2013) The effect of legal environment and corporate governance on the decision to assure and assurance provider choice: evidence from the GHG assurance market. UNSW Aust Sch Bus Res Pap A 5 





\section{Capítulo VIII}

\section{Propuesta de Indicador Sectorial de Prácticas de Responsabilidad Social Corporativa}

La responsabilidad social corporativa agrupa un conjunto de prácticas y compromisos empresariales con patrones de comportamiento globalizados, pero cuya evolución varía sustancialmente de acuerdo con las condiciones institucionales en las que operan las empresas. En general, la mayoría de los estudios previos se centran en analizar el país como el factor institucional con mayor capacidad explicativa de las prácticas de RSC. Inclusive, ha surgido una línea de investigación orientada a la creación de indicadores compuestos que permiten observar el nivel de sostenibilidad corporativa a nivel país de manera agregada.

Si bien, existen diferencias a nivel país en el desarrollo de la sostenibilidad corporativa, no se puede ignorar el papel que desempeña la industria, ya que la información y las actividades de RSC dependen en gran medida del tipo de empresa. Así, por ejemplo, el sector manufacturero muestra un alto compromiso con la comunidad, la salud y seguridad de los empleados en relación con las categorías de RSC, mientras que, en el sector de petróleo y gas, los niveles más altos se encuentran en las categorías ambientales y de derechos humanos. En esta línea, hay muchos hallazgos en estudios empíricos que evidencian una relación significativa entre la RSC y el tipo de empresa, como resultado de la presión de los grupos de interés y / o debido a las regulaciones impuestas a ciertas industrias.

Con base en las discrepancias institucionales entre los diferentes tipos de industria, este documento propone un índice de sostenibilidad empresarial a nivel sectorial. Del mismo modo que, como se mencionó anteriormente, ciertos autores han creado índices nacionales de sostenibilidad, este trabajo pretende ser pionero en la creación de un índice sectorial de prácticas de responsabilidad social corporativa, denominado ICSRPI (Industrial Corporate Social Responsibility Practices Index) que determine el nivel de penetración de la RSC en los diferentes sectores de actividad.

Para conocer en profundidad las diferencias de RSC inter-sectoriales, es necesario contar con información social y ambiental completa y confiable, la cual puede estar basada en indicadores que permitan comprender la situación actual y su evolución, ya que brindan un valor útil para la toma de decisiones o para ser utilizado como referencia dentro de los procesos de mejora. Más concretamente, defendemos que los indicadores compuestos aportan un enfoque adecuado para sintetizar y resumir toda la información que representan las diferentes dimensiones del desempeño ambiental y social, proporcionando una comprensión holística del desarrollo de la RSC y sus raíces sectoriales. Los indicadores agregados representan herramientas importantes para la comunicación de información científica y técnica, ya que pueden facilitar el acceso a ella por diferentes grupos de usuarios, permitiendo la transformación de la información en acción. De esta forma, los indicadores compuestos, además de ser útiles para evaluar situaciones o decisiones, 
también pueden desempeñar un papel activo en la mejora de los procesos de formulación, más comúnmente en términos de desarrollo de políticas y planificación por parte de las autoridades, pero también en el diseño de proyectos y estrategias por parte de los gerentes.

Para la construcción del indicador compuesto agregado ICSRPI se parte de las prácticas de sostenibilidad de una muestra de 2789 empresas de todo el mundo pertenecientes a los diez sectores de actividad codificados según la categoría 'industry' del 'Industry Classification Benchmark (ICB) system', considerando cada uno de ellos como un conjunto de factores institucionales. Para ello, estudiamos el comportamiento empresarial sectorial de una serie de 28 prácticas de sostenibilidad categorizadas en las dimensiones ambiental y social, a través de un proceso metodológico estructurado en torno a siete fases, para el año 2014: (i) desarrollamos un marco teórico sobre el contexto institucional sectorial y las dimensiones de la RSC, que describe la interrelación entre los elementos en el contexto; (ii) la selección de las prácticas de RSC que determinan un alto nivel de calidad según su relevancia, accesibilidad y consistencia analítica; (iii) la imputación de datos faltantes; (iv) la eliminación de aquellas prácticas que no reducen la calidad del modelo teórico, basadas en métodos estadísticos multivariantes; (v) la estandarización de los datos; (vi) la ponderación de las prácticas finales que conforman el índice; y (vii) la agregación de los valores de las prácticas de RSC a través de una suma ponderada para derivar las puntuaciones sectoriales de RSC.

El desarrollo del ICSRPI junto a su desglose en las vertientes ambiental y social ha demostrado que los sectores más preocupados por la sostenibilidad son aquellos cuya actividad los lleva a ser considerados de alto impacto ambiental, ya que implementan políticas y sistemas de gestión ambiental más avanzados. Las empresas que operan en estos sectores también tienen un fuerte compromiso con la dimensión social. En este sentido, destacan los sectores dedicados a materias básicas y servicios públicos. En consecuencia, los sectores más expuestos a los riesgos ambientales buscan mejorar su compromiso de sostenibilidad para administrar esos riesgos y aumentar la confianza de las partes interesadas. Aprovechan el uso de la RSC para legitimar sus prácticas empresariales, por lo que se adhieren a las políticas de RSC como una forma de gestionar su reputación y responder a las expectativas de los interesados. En otras palabras, dado que estos sectores operan bajo una mayor presión de los grupos de interés y enfrentan un mayor riesgo social y ambiental, tienen puntuaciones de RSC más altas que las empresas de otros sectores. Por el contrario, las compañías de sectores menos contaminantes, como los servicios financieros o servicios al consumidor, tienen puntuaciones más bajas; sin embargo, presentan altos valores en cuestiones sociales, dando mayor prioridad a la ética empresarial y los derechos de los empleados.

Estos hallazgos ofrecen un nuevo terreno a los investigadores para un análisis más profundo de la especificidad del sector de actividad en la RSC y para identificar aún más los determinantes institucionales que dan forma a la sostenibilidad de los negocios. Además, las discrepancias observadas a nivel sectorial muestran la utilidad del ICSRPI para simplificar y cuantificar las prácticas de RSC y proporcionar un valor útil para ser utilizado como referencia, ya que, a través de los valores del ICSRPI, es posible identificar aquellos sectores que tienen mayores deficiencias en los sistemas de sostenibilidad, lo que facilita la planificación de diversas acciones de mejora y proporciona información relevante sobre temas ambientales y sociales para orientar a los gerentes o partes interesadas en sus procesos de toma de decisiones. Por lo tanto, conocer el nivel de compromiso con la sostenibilidad a nivel sectorial permite a las empresas que comienzan a operar en una nueva industria conocer los estándares mínimos de responsabilidad social corporativa que deben respetar. Asimismo, permite la realización de procesos de benchmarking dirigidos a la mejora continua de las decisiones y acciones empresariales. En referencia a los reguladores / políticos, el ICSRPI evidencia diferencias en temas de sostenibilidad a nivel sectorial que pueden ser considerados en el diseño de regulaciones o políticas públicas que permitan corregir las deficiencias observadas a nivel sectorial: por ejemplo, en este sentido, sería recomendable fomentar un mayor compromiso con el medioambiente en los sectores menos contaminantes.

A continuación, presentamos toda esta información detallada de manera extensa en el artículo de investigación "Useful information for stakeholder engagement: A multivariate proposal of an Industrial Corporate Social Responsibility Practices Index" actualmente en prensa en la revista Sustainable Development (2016: Q1 - JIF: 2.167; 2017: Q1 - JIF: 2.750). 
Research paper in press:

Title: Useful information for stakeholder engagement: A multivariate proposal of an Industrial Corporate Social Responsibility Practices Index

Authors: Víctor Amor-Esteban

Ma-Purificación Galindo-Villardón

Isabel-María García-Sánchez

Journal: Sustainable Development

\begin{tabular}{c|c|c|c|c} 
Year & Category Name & $\begin{array}{c}\text { Total Journals } \\
\text { in Category }\end{array}$ & $\begin{array}{c}\text { Journal Rank } \\
\text { in Category }\end{array}$ & $\begin{array}{c}\text { Quartile } \\
\text { in Category }\end{array}$ \\
\hline 2016 & Planning \& Development & 55 & 12 & Q1 \\
\hline 2017 & Planning \& Development & 57 & 12 & Q1
\end{tabular}

* Journal Impact Factor: 2016 - 2.167; 2017 - 2.750; 5 Year Impact Factor: 3.383.

* Publisher: Wiley

* Google scholar cites:

\begin{tabular}{c|l} 
APA & $\begin{array}{l}\text { Amor-Esteban, V., Galindo-Villardón, M. P., \& García-Sánchez, I. M. (2018). Useful } \\
\text { information for stakeholder engagement: A multivariate proposal of an Industrial } \\
\text { Corporate Social Responsibility Practices Index. Sustainable Development. }\end{array}$ \\
\hline ISO & $\begin{array}{l}\text { AMOR-ESTEBAN, Víctor; GALINDO-VILLARDÓN, Ma-Purificación; GARCÍA- } \\
\text { SÁNCHEZ, Isabel-María. Useful information for stakeholder engagement: A } \\
\text { multivariate proposal of an Industrial Corporate Social Responsibility Practices } \\
\text { Index. Sustainable Development, 2018. }\end{array}$ \\
\hline MLA & $\begin{array}{l}\text { Amor-Esteban, Víctor, Ma-Purificación Galindo-Villardón, and Isabel-María García- } \\
\text { Sánchez. "Useful information for stakeholder engagement: A multivariate proposal } \\
\text { of an Industrial Corporate Social Responsibility Practices Index." Sustainable } \\
\text { Development (2018). }\end{array}$
\end{tabular}

*The paper is numbered independently and includes pages 239-256 (18) of the global document. 



\title{
Useful information for stakeholder engagement: A multivariate proposal of an Industrial Corporate Social Responsibility Practices Index
}

\author{
Víctor Amor-Esteban ${ }^{1}$ (D) | Ma -Purificación Galindo-Villardón ${ }^{1}$ | Isabel-María García-Sánchez ${ }^{2}$
}

\author{
${ }^{1}$ Department of Statistics, Campus Miguel de \\ Unamuno, University of Salamanca, \\ Salamanca, Spain \\ ${ }^{2}$ Faculty of Economics, Department of \\ Business Administration, Campus Miguel de \\ Unamuno, University of Salamanca, \\ Salamanca, Spain \\ Correspondence \\ Víctor Amor-Esteban, Department of \\ Statistics, Campus Miguel de Unamuno, \\ c/ Alfonso X El Sabio s/n, University of \\ Salamanca, 37007 Salamanca, Spain. \\ Email: victor_aes@hotmail.com
}

\begin{abstract}
The aim of this paper is to create an industrial corporate social responsibility practices index (ICSRPI) that allows us to determine the level of sustainable business commitment in the main industries. The ICSRPI allows simplification and quantification of corporate social responsibility (CSR) practices; identification of those industries which present greater deficiencies in sustainability systems to facilitate the planning of various improvement actions; and provision of pertinent information on environmental and social issues to guide stakeholders in their decision-making processes. In this sense, empirically, the ICSRPI reveals that companies from more polluting sectors, such as oil and gas, chemical, paper or mining, are perceived as having high environmental risk and are the leaders in sustainable development. Companies from less polluting sectors, such as the media or financial services, have lower CSR scores; however, they present high values in social issues, giving higher priority to business ethics and the rights of employees.
\end{abstract}

\section{KEYWORDS}

composite index, corporate social responsibility (CSR), industry CSR, stakeholder engagement, sustainable development

\section{1 | INTRODUCTION}

In the last few decades, a stream of research has emerged-Gjølberg (2009), Halkos and Skouloudis (2016), Lenssen et al. (2006) and Skouloudis, Isaac, and Evaggelinos (2016)-oriented to the creation of composite indices at national level that combine the effect that the institutional context has on the corporate social responsibility (CSR) penetration. These aggregate indicators, called the National Corporate Social Responsibility Index (NCSRI), allow us to observe the aggregate variation of CSR explained by the nexus of institutions that determine the national identity of each country. These indices are based on national data on inclusion, participation or subscription in different international CSR initiatives, best-in-class indices, and environmental and social standards.

Although there are differences at the country level in the development of corporate sustainability, the effect that the business has on it cannot be ignored, because CSR information and activities are largely dependent on the type of industry in which a company operates (Waddock \& Graves, 1997). The manufacturing sector shows high commitment to the community and to the health and safety of employees in relation to CSR categories, while in the oil and gas sector, higher levels of CSR are found in the environmental categories (Halkos \& Skouloudis, 2016). In this regard, there are many findings in empirical studies that show a significant relationship between CSR and the type of industry (Branco \& Rodrigues, 2008; Cowen, Ferreri, \& Parker, 1987; Gray, 2002; Newson \& Deegan, 2002; Parsa \& Deng, 2008; Wanderley, Lucian, Farache, \& de Sousa Filho, 2008), because of pressure from interest groups (Patten, 1991) and/or because of regulations imposed on certain industries (Dierkes \& Preston, 1977).

Based on the institutional discrepancies between the different types of industry, this paper proposes an index of business sustainability at the sector level. In the same way that, as mentioned before, certain authors have created national sustainability indices, this paper aims to be a pioneer in the creation of an industrial corporate social 
responsibility practices index (ICSRPI) that determines the level of penetration of CSR in different sectors of activity, allowing a holistic understanding of CSR development and its industrial roots. In addition, it will provide relevant information on environmental and social issues to guide managers or stakeholders in their decision-making processes, facilitating the planning of various improvement actions or benchmarking processes.

This composite indicator is formed from the sustainability practices of a sample of 2,789 companies worldwide belonging to the ten industries established in the Industry Classification Benchmark (ICB) system, considering each of them as a set of institutional factors. To do this, we study the industrial entrepreneurial behavior of a series of 28 sustainability initiatives categorized in environmental and social dimensions, through a methodological process structured around seven phases (Dobbie \& Dail, 2013; OECD, 2008) for the year 2014. We develop a theoretical framework of the industrial institutional context and the CSR dimensions, describing the interrelationship between the elements in the context; the selection of CSR practices that determine a high level of quality according to their relevance, punctuality, accessibility and analytical consistency; the imputation of missing data; the elimination of those practices that do not reduce the quality of the theoretical model, based on multivariate statistical methods; data standardization; the weighting of those practices that make up the final index through the standardized regression weights of a confirmatory factorial analysis of the simplified model, proving the reliability of all CSR practices chosen in the ICSRPI and the validity of the construct; and finally, the aggregation of the CSR practices scores based on a weighted sum to derive the industrial CSR scores.

\section{2 | THEORETICAL BACKGROUND AND RESEARCH HYPOTHESES}

CSR can be understood as the set of voluntary business practices aimed at sustainably managing the impacts that its activity generates on the different interest groups of companies such as clients, employees, shareholders, local communities, the environment and society in general. This business commitment can be a strategic response to pressure from stakeholders who may be adversely affected by company practices, or a proactive decision to move ahead or at least mitigate these pressures and improve the company's reputation and value (Jackson \& Apostolakou, 2010).

CSR groups a set of practices and business commitments with globalized behavior patterns but whose evolution varies substantially according to the institutional conditions in which companies operate (Esteban, Villardón, \& Sánchez, 2017). The evolutionary differences of CSR are because companies are economic units that operate in institutional environments where, to receive the approval of society, they must satisfy the standards of behavior and overcome specific expectations that stakeholders impose on them (Campbell, 2007), so the institutional environment in which the company operates establishes a series of opportunities and barriers in the decision to improve its CSR practices. In fact, there is extensive research that has identified the importance of institutions to explain specific aspects of CSR, such as the management of human resources (Edelman \& Suchman, 1997), environmental performance (Salem, Shawtari, Shamsudin, \& Hussain, 2017; Salomaa \& Watkins, 2011), community relations (MartínezFerrero \& García-Sánchez, 2016) or the quality of CSR reports (García-Sánchez, Rodríguez-Ariza, \& Frías-Aceituno, 2013).

In general, previous studies focus on analyzing the country as an institutional factor with greater explanatory capacity of CSR practices. Therefore, an area of research has emerged oriented toward the creation of composite indicators that allow us to observe the level of corporate sustainability at the country level in an aggregate manner (e.g., Gjølberg, 2009; Halkos \& Skouloudis, 2016; Lenssen et al., 2006; Skouloudis et al., 2016).

However, several authors have revealed that the sector of activity to which a company belongs can be defined as the organizational field from which institutional pressures arise (Aerts, Cormier, \& Magnan, 2006), many of which are aimed at companies adopting CSR practices (Venanzi \& Fidanza, 2006). As companies operating in the same sector face similar challenges, they are likely to develop common CSR rules and standards, with a convergence in levels of commitment to sustainability. In other words, the sectors represent an important institutional framework (DiMaggio, 1991). Organizations can adopt CSR initiatives or the dissemination of social or environmental information because their competitors are doing so, and thus, by imitating the social practice carried out by another company that is accepted as a leader or model in their sector of activity, they try to legitimize their strategies, given that the level of success and also the level of social acceptance defines business success (Ortas, Álvarez, Jaussaud, \& Garayar, 2015).

In this sense, depending on the risk that each sector represents for society, stakeholders will exhibit different behaviors. A good example is oil companies, which stakeholders perceive as high risk in environmental matters, as well as in the health conditions of their employees: these stakeholders tend to pressure the companies to adopt CSR policies or improve them. This could be positive for these companies, either through the impact of society or because of the scrutiny undertaken by stakeholders or the government, because by adopting more codified and explicit CSR policies, they will be considered to be proactive and will control the standards with which they have to comply, improving their image and increasing their profits. Hence, CSR can become an institutionalized feature of sectoral governance structures due to stakeholder demands, regulatory pressures created by different organizations, coercive regulations by government authorities, or through a company's own efforts to proactively imitate competitors in the industry to protect its reputation (Jackson \& Apostolakou, 2010). In this way, the first hypothesis of our work defends that there are significant differences in CSR business commitment/practices between industries. So, Hypothesis $\mathrm{H} 1$ is proposed as follows:

Hypothesis 1. The sector of activity determines the level of commitment and development of CSR practices at the company level.

To know in depth the interindustry CSR differences, it is necessary to have complete and reliable social and environmental information, based on indicators that allow understanding the current situation and its evolution, because they are useful for decisionmaking or can be used as a reference within improvement processes 
(Clerici, Bodini, \& Ferrarini, 2004). More concretely, we propose that composite indicators are an adequate approach to synthesize and summarize all the information that represents different environmental and social performance dimensions, providing a holistic understanding of CSR development and its industrial roots. Aggregated indicators represent important tools for the communication of scientific and technical information, because they can facilitate access to it by different groups of users, allowing the transformation of information into action. In this way, composite indicators, in addition to being useful for assessing situations or decisions, can also play an active role in improving formulation processes, most commonly in terms of policy development and planning by authorities, but also in the the design of projects and strategies by the managers (García-Sánchez, Almeida, \& Camara, 2015). In this vein, we propose our Hypothesis $\mathrm{H} 2$ :

Hypothesis 2. The ICRPI allows us to observe the variation of CSR compromises and practices explained by the nexus of institutions that determine the industry identity of firms.

However, to guarantee their utility, in the initial stage of elaboration of the composite indicator, it is essential to develop a theoretical framework regarding the industrial institutional context and the dimensions of CSR that allow the construction of the index. In addition, we must at this stage describe the interrelationship between the elements in context.

The structure of our model is based on linking environmental and social indicators and serves to lead managers to consider the impacts of business activities in their decision-making processes and guide them toward the promotion of policies that improve sustainable business behavior. The voluntary and proactive practices of CSR constructs-which are part of the broader spectrum of activities related to the interaction between business and society-are fundamentally characterized by the institutional terrain in which a company operates. The institutional terrain includes the link between institutional structures and the efficiency of sectoral conditions by suggesting that CSR is defined by the demands and expectations of society in relation to the economic activity of companies (Searcy, 2016). The CSR constructs have been selected according to the previous literature and are defined below:

- Environmental performance. The environmental indicators include the development of policies and systems for care of the environment, such as reduction in energy expenditure, waste disposal, decontamination or the fight against climate change. They also imply full responsibility for the environmental impact of business processes, products and by-products, and therefore the prevention or remedy of damages that are caused or could be caused.

- Social performance. Social indicators include the development of policies and systems of respect for human and labor rights that emerge from the relationship with employees and transparent dialogue with stakeholders, taking responsibility for the consequences and impacts that arise from the company's actions, as well as the monitoring of ethics and corporate governance.
- Human rights. This entails the adoption of codes of conduct on human rights, working conditions (elimination of forced labor, child labor, discrimination, etc.) and environmental aspects.

- Employees. This construct includes initiatives aimed at improving the quality of work, both physical and contractual, investing in the professionalization and improvement of workers and in safe and hygienic working conditions. The company seeks to harmonize interests and establish a transparent relationship and communication with the union around common goals. It promotes equality of opportunity, nondiscrimination and employment of the disabled.

- Stakeholders. This element references the external dimension, the treatment of the company in relation to the community, suppliers, consumers, customers, contractors, and so on, groups to which the company relates. It entails the practice of information transparency, making known at all times essential aspects and the present and future impact of the organization. Participatory practices, ongoing communication and dialogue are essential when establishing a mutually beneficial relationship and the needs of stakeholders must be known.

- Ethics and governance. This construct values the importance of the company acting in accordance with ethical principles and values in all its areas. It includes the incorporation of ethical practices in business management, such as those aimed at countering bribery systems or the fight against political corruption, seen as an element in decision-making and in improving the reputation of the company.

\section{3 | EMPIRICAL DESIGN}

The design of the ICSRPI composite indicator that synthesizes sustainability practices at the sector level requires the development of a set of theoretical and practical steps that must be applied to real data. Thus, we have information on the CSR practices of the main global companies from the EIRIS (Ethical Investment Research Services) database. The sample for the analysis consists of the sustainability practices of 2,789 listed companies worldwide operating in the main ten industries according to the ICB system in 2014. The selection of the year 2014 is because the development of CSR in the decade 2004-14 was extremely important due to the effect of technological development and freedom of the press and, indirectly, to the ability to access information about corporate behavior and the pressure that different actors can exert (Martínez-Ferrero \& García-Sánchez, 2016).

Table 1 shows that the financial and industrial sectors account for about $40 \%$ of the sample, and consumer goods and services more than $25 \%$. The rest of the industries have individual weights of less than $10 \%$.

With this data structure, the ICSRPI was created. For the construction of the composite index, a methodological process was applied, structured around seven phases (Dobbie \& Dail, 2013; OECD, 2008). The phases are organized as follows: the development of a 
TABLE 1

Industry classification benchmark system

\begin{tabular}{lll} 
Industry & Frequency & $\%$ \\
\hline Basic Materials & 232 & 8,3 \\
\hline Consumer Goods & 350 & 12,5 \\
\hline Consumer Services & 398 & 14,3 \\
\hline Financials & 602 & 21,6 \\
\hline Healthcare & 153 & 5,5 \\
\hline Industrials & 529 & 19,0 \\
\hline Oil \& Gas & 151 & 5,4 \\
\hline Technology & 173 & 6,2 \\
\hline Telecommunications & 84 & 3,0 \\
\hline Utilities & 117 & 4,2 \\
\hline Total & 2,789 & 100 \\
\hline
\end{tabular}

theoretical framework (Section 2); selection of variables (Section 3.1); imputation of missing data (Section 3.2); removal of variables (Section 3.3); data standardization (Section 3.4); weighting (Section 3.5); and aggregation (Section 3.6).

\section{1 | Selection of variables}

In the second phase, the CSR practices are selected: this determines the quality of the composite indicator that is being developed and must be performed according to relevance, punctuality, accessibility and analytical consistency. In this phase, a unique set of all the practices that form the ICSRPI is developed, based on the selection of CSR practices that determine a high level of quality.

To evaluate CSR, 28 international CSR practices representing social and environmental dimensions have been selected, using data at the organizational level. These variables are commonly used in research papers to measure social and environmental performance (e.g., Boudt, Cornelissen, \& Croux, 2013; García-Sánchez \& GarcíaMeca, 2017; León, 2015; Martínez-Ferrero \& García-Sánchez, 2016). In particular, environmental dimension indicators refer to the development of policies and systems to economize natural resources and to control the effects of business activities on the environment in terms of waste, atmospheric emissions and chemical residues. The social dimension is related to the corporate impact in the community and includes support for human rights, philanthropic behavior, equal opportunities, relationships, employee participation and the development of economic and social wellbeing. Each of these practices was obtained from the EIRIS database: the commitment to development and sustainability of each company in each of them is evaluated on a scale of $0-4$, where 0 is insufficient, 1 is weak, 2 is moderate, 3 is good and 4 is exceptional (Table 2).

\section{2 | Imputation of missing data}

According to Horton and Lipsitz (2001), sets of incomplete data can compromise the quality and robustness of results, as the distance among observed and unobserved data can produce bias in the results and complications of data processing and analysis. It is possible, without altering the data structure, to make artificial imputations of these when the lost data do not exceed $15 \%$ of the information (Soto \& Schuschny, 2009).

For this study the data were collected and selected with the requirement that their reports were all complete. Therefore, we do not have missing data and the data imputation phase is not necessary.

\section{3 | Removal of variables: Multivariate analysis}

Multivariate analysis is an essential task that consists of checking and verifying the relations between variables to make the best methodological decisions on their processes of normalization, weighting and aggregation (OECD, 2008); this allows avoiding the error of selecting independent variables that do not present links between them and eliminate those that provide duplicate information since it may distorts the results of the study.

The original set of 28 international CSR practices was analyzed statistically. For this, an analysis of the item response theory (IRT) regarding the discriminative power of the original set of variables and a factorial analysis with the principal components method was implemented to summarize the amount of information from these components. By compiling the two sets of results, it is possible to optimally select the set of significant practices that best summarize and synthesize all the information, and remove those that do not reduce the quality of the theoretical model.

\subsection{1 | IRT: Discriminatory power of CSR practices}

Using IRT we analyze which practices have a greater discriminatory power, because this method allows us to develop a disaggregated analysis of each of the different practices (items) (Embretson \& Reise, 2013). In the IRT framework, the information function of a test-here, the global dimension of the CSR-indicates the information that the test provides for the different skill levels $(\theta)$; the more information, the more accurate the measurement or the less the measurement error.

The information function of the complete test is calculated as the sum of the information functions of each of the items (our practices). The information function of the item determines the amount of information provided by the item and at what level this information is provided, so is greater where there is more information. The item information is the inverse of the variability of the maximum likelihood estimator of $\theta$ at each level (Birnbaum, 1968). The practices with greater power to discriminate have higher information, while those with lower power to discriminate have less information (Muniz, 1997). All these calculations have been processed and plotted using the MultiLog software (Thissen, 1991).

Figure 1 presents the total information function for the 28 CSR practices, the blue line representing the information function and the red line the standard error. The maximum information value is 33.460 , so that 1.195 is the expected average for each of the 28 CSR practices.

The global dimension of CSR is formed theoretically by 28 practices: the information function of each is represented in Figure 2. The information function of items shown in green is above the expected average; those with values close but below the average are in a softer tone; and practices with values below the average are shown without any highlighting. 
TABLE 2 Composition and descriptive of CSR practices
Environmental performance
Environment
ENV1 Environmental policy
How does EIRIS rate the Company's environmental policy and commitment?
ENV2 Environmental management
How does EIRIS rate the Company's environmental management system?
ENV3 Environmental reporting
How does EIRIS rate the Company's environmental reporting?
ENV4 Environmental performance
What level of improvements in environmental impact can the Company demonstrate?

\section{Social performance}

Human rights
HR1 Human Rights policy
What is the extent of policy addressing human rights issues?
HR2 Human Rights systems
What is the extent of systems addressing human rights issues?
HR3 Human Rights reporting
Does the Company report on human rights issues?

\section{Employees}

EMP1 Equal opportunities (policy)

EMP2 Equal opportunities (systems)

EMP3 Health and safety systems

EMP4 Trade unions and employee participation

EMP5 Training

How good is the Company's policy on equal opportunity and diversity issues?

How clear is the evidence of systems and practices to support equal opportunities and diversity?

How clear is the evidence of health and safety systems?

How clear is the evidence of systems to manage employee relations?

EMP6 Job creation and security

How clear is the evidence of systems to support employee training and development?

Stakeholders

STH1 Community relations

How clear is the evidence of systems and practices to advance job creation and security?

STH2 Customer/supplier relations policy

STH3 Community involvement

How clear is the Company's commitment to community or charitable work?

Does the Company have policies on maintaining good relations with customers and/or suppliers?

STH4 Responsibility for stakeholders

How clear is the evidence of systems to maintain good relations with community?

STH5 Stakeholder engagement

STH6 Stakeholder policy

How many stakeholder issues have been allocated to board members?

STH7 Stakeholder systems

STH8 Stakeholder reporting

What level of engagement with stakeholders is disclosed by the Company?

How good are the Company's policies toward its stakeholders overall?

How good are the Company's quantitative systems on stakeholder relationships?

How good is the Company's management reporting for stakeholders overall?

Ethics and governance

ETH1 Codes of ethics

Does the Company have a code of ethics and, if so, how comprehensive is it?

ETH2 Codes of ethics systems

ETH3 Countering bribery policy

ETH4 Countering bribery systems

ETH5 Countering bribery reporting

ETH6 Board practice

ETH7 ESG risk management

Does the Company have a system for implementing a code of ethics and, if so, how comprehensive is it?

What is the extent of the Company's policy for countering bribery?

What is the extent of the Company's system for countering bribery?

What is the extent of the Company's reporting on countering bribery?

How many of the core elements of corporate governance does the Company have?

How well do the board and senior management address Company-wide ESG (environmental, social and governance) risks and opportunities?

FIGURE 1 Total information function and measurement error [Colour figure can be viewed at wileyonlinelibrary.com]

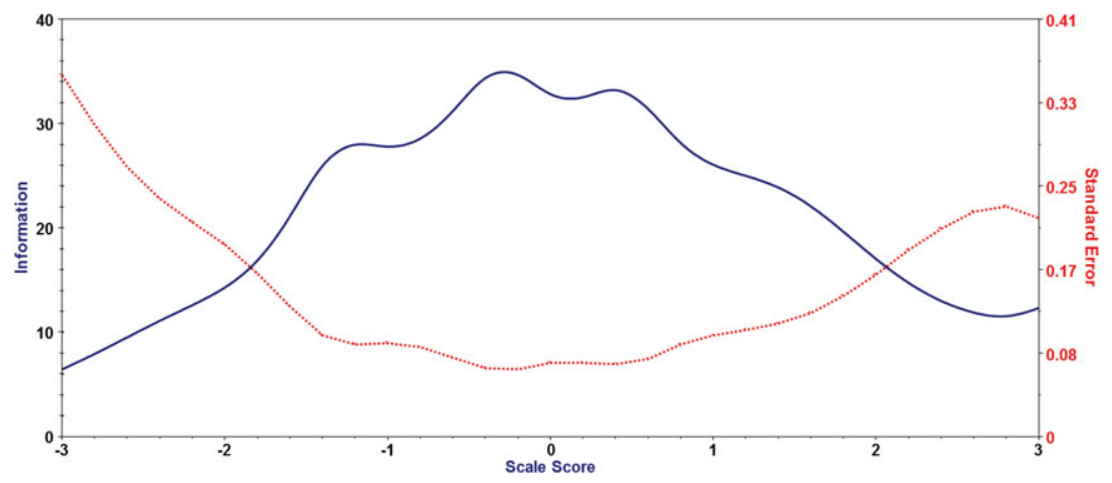

The practices of environmental performance (ENV4), trade unions and employee participation (EMP4), job creation and security (EMP6), community involvement (STH3) and board practice (ETH6) have the lowest values in the information function-that is, they have the lowest discriminatory power and therefore these practices are candidates for elimination from the model. 

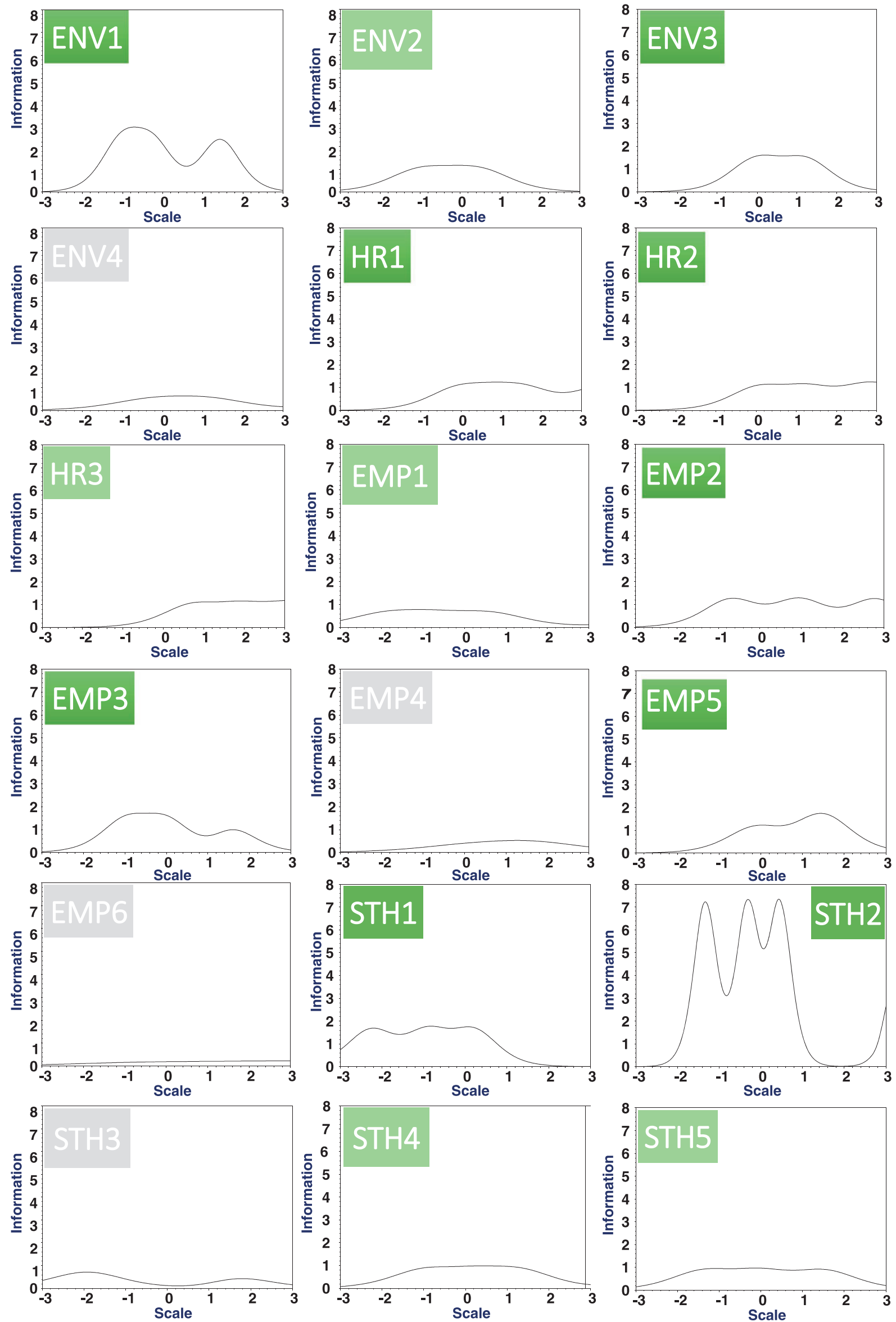

FIGURE 2 Information function of CSR practices [Colour figure can be viewed at wileyonlinelibrary.com] 

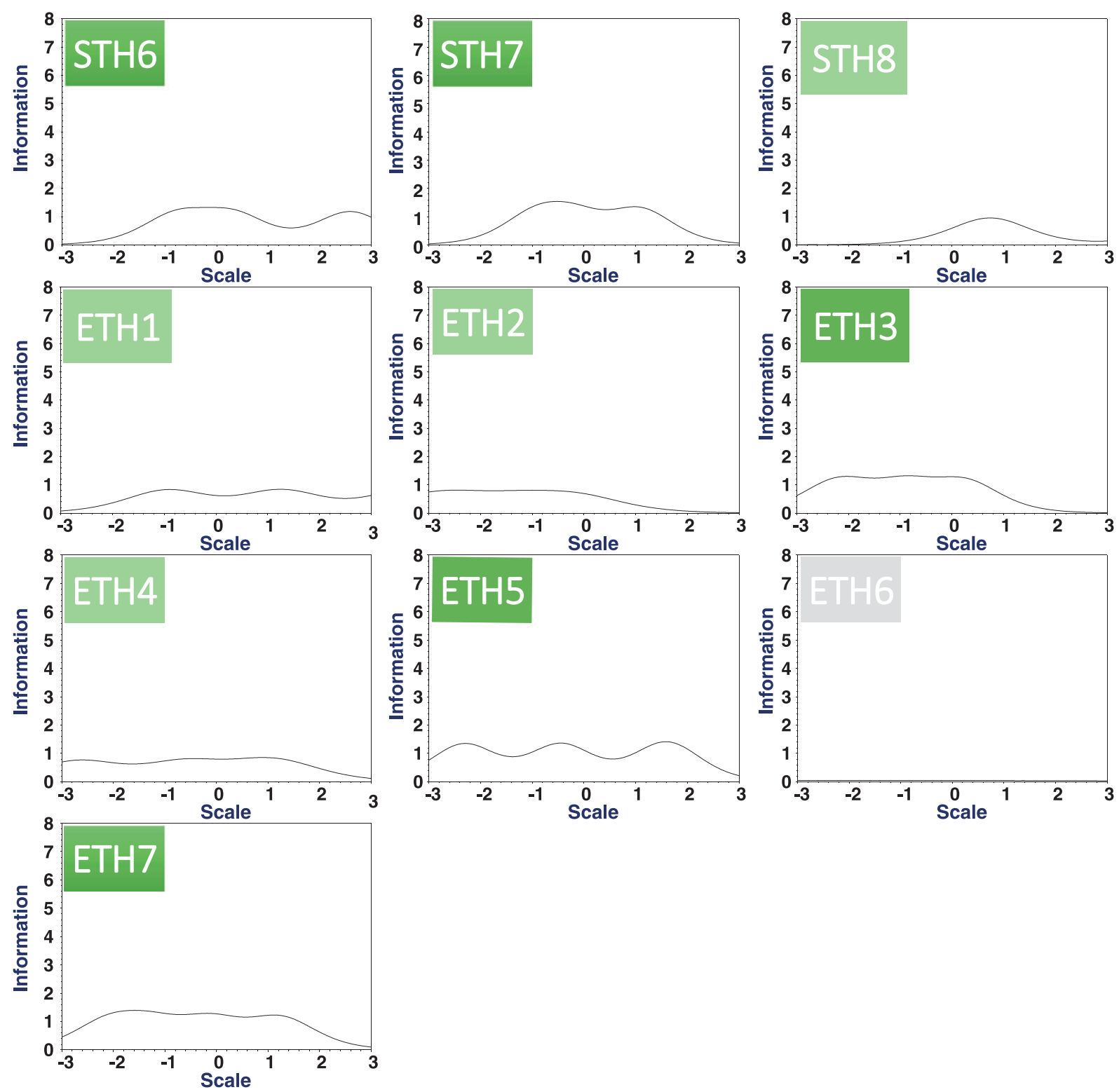

FIGURE 2 Continued.

\subsection{2 | Exploratory factor analysis: Structure of CSR practices}

Before analysis, we use (i) the adequacy index of the KaiserMeyer-Olkin sample $(\mathrm{KMO}=0.943)$ and (ii) the Bartlett sphericity test $(p<.000)$. These measures indicate that the data are adequate for the application of an exploratory factor analysis (EFA) with the principal components method, because they represent a good fit of the sample and an adequate correlation between variables.

The first three axes absorb $56.5 \%$ of the data variability. The first main axis takes $44.3 \%$, and all items have their highest loads on this axis, except for board practice (ETH6), which receives its highest score in Factor 2 with a value of 0.155 . This information means that the practices relate to a single dimension, and therefore it is highly appropriate to combine the results into a single measure, the ICSRPI. Table 3 reflects the factorial loads of the first factor of the EFA. For better reliability of our results, a bootstrap resampling with $n=1,000$ replicates was applied, revealing the stability of the load factors. In addition, a column has been added with the maximum values of the information function of each practice in the IRT. So, by compiling both results, we will be able to select the optimal set of significant practices that best synthesize and summarize all the information (highlighted in bold type).

The results obtained are very consistent even though these techniques express results with different meanings-that is, those practices that obtain the highest loads in the EFA present the higher maximum information values in the IRT, such as the customer/ supplier relations policy (STH2) or the environmental policies (ENV1). By contrast, those practices that present their lowest loads in the EFA $(<0.600)$ have lower information values in the IRT $(<0.700)$, and are excluded from the analysis. Environmental performance (ENV4) measures the level of environmental performance, so it is redundant and consistent with information from the previous environmental variables. With regard to the two variables of the dimension of the rights of employees, trade unions and employee 
TABLE 3 Factorial loadings of factor 1 (EFA) via bootstrap sampling and maximum information values (IRT) for all CSR practices

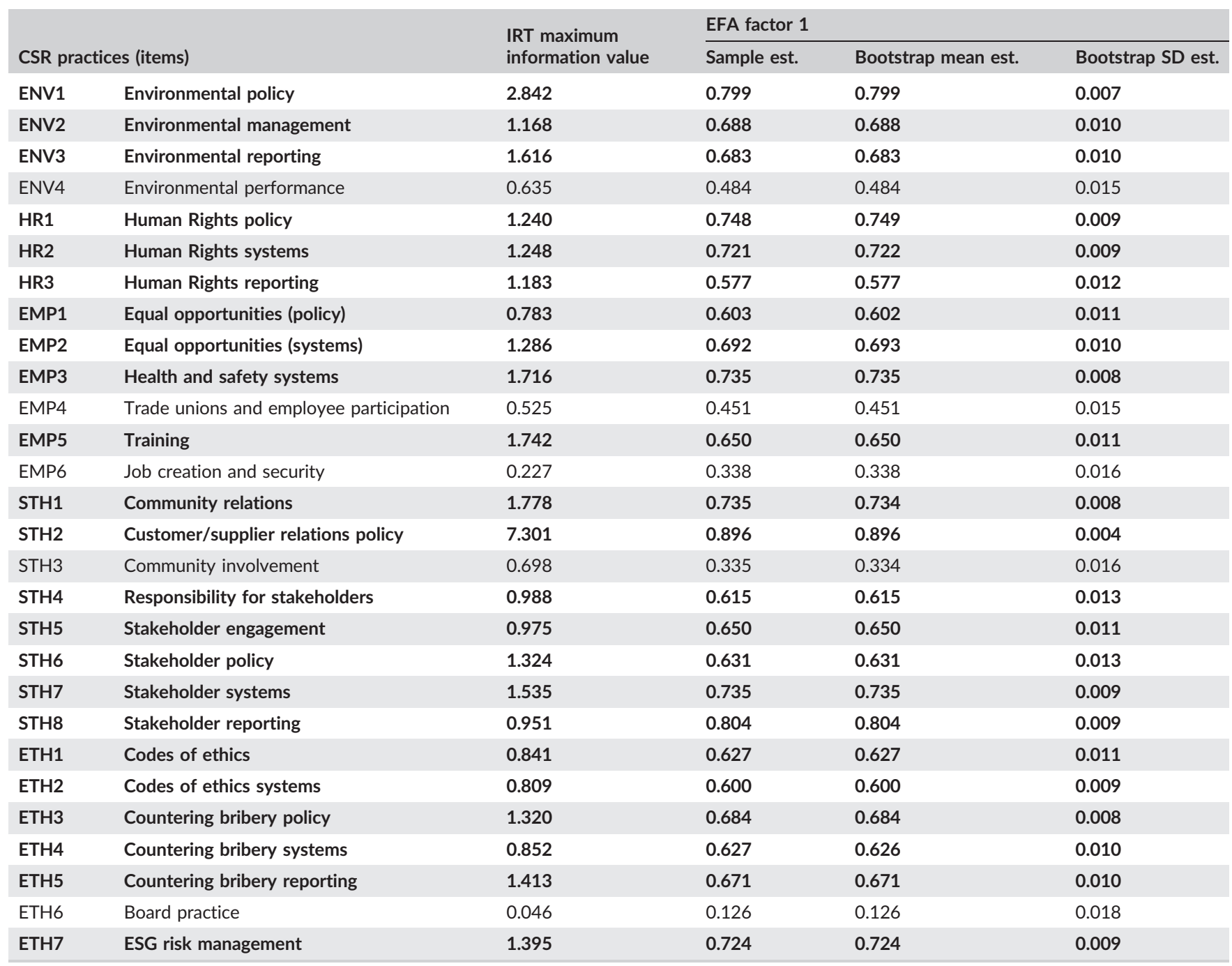

participation (EMP4) and job creation and security (EMP6) measure the level of systems designed to manage relations with employees, work and safety, and have a strong relationship with training (EMP5), which evaluates the support systems for employee training and development, encompassing the two previous items and, according to the statistical analyses, presents a greater explanatory capacity. A similar situation occurs with the other variables: community involvement (STH3) is strongly related to community relations (STH1), as both measure the company's commitment to the community, although the latter presented more variability. Board practice (ETH6) is related to environmental, social and governance (ESG) risk management (ETH7), both evaluating the role of the board. In this sense, the five variables can be eliminated.

TABLE 4 Simplified model: indicators of goodness of fit

\begin{tabular}{|c|c|c|c|c|c|c|}
\hline \multicolumn{5}{|c|}{$\begin{array}{l}\text { Indicators of incremental goodness } \\
\text { of fit }\end{array}$} & \multirow{2}{*}{$\begin{array}{l}\text { Indicators of } \\
\text { residual } \\
\text { goodness of fit } \\
\text { SRMSR }\end{array}$} & \multirow{2}{*}{$\begin{array}{l}\text { Root mean } \\
\text { square error of } \\
\text { approximation } \\
\text { RMSEA }\end{array}$} \\
\hline NFI & TLI & IFI & CFI & RFI & & \\
\hline 0.937 & 0.926 & 0.942 & 0.941 & 0.921 & 0.0499 & 0.069 \\
\hline
\end{tabular}

\section{4 | Data standardization}

The standardization process unifies the range and measures of indicators, because it is possible that the variables are treated with different scales or units. To avoid the influence of atypical values, normalization must be applied before the aggregation process to use a standardized unit (Freudenberg, 2003). In our case, transformation of the data is not necessary, as each of the practices evaluates the commitment to development and sustainability of each company on the same scale of $0-4$, where 0 is insufficient, 1 is weak, 2 is moderate, 3 is good and 4 is exceptional.

\section{5 | Weighting}

This step entails the assignment of weights to each of the variables, in accordance with the researcher's criteria and according to the individual relevance of each to the set. Considering the best weighting methodologies, and considering its importance in the process of creating comparative values, it was decided to give weight to the CSR practices through the standardized regression coefficients of a confirmatory factor analysis of the simplified model-that is, the practices selected in the previous stages. 


\subsection{1 | Simplified model, confirmatory factorial analysis}

With this model, we tested the reliability of all the CSR practices chosen to be combined in the ICSRPI and the validity of the construct (Martínez Arias, Hernández-Lloreda, \& Hernández-Lloreda, 2006). To evaluate the model, researchers use numerous indicators of goodness of fit. Table 4 shows the most common indices.

To validate a model, most authors assert in relation to these indicators that at least three of the five indicators of incremental goodness of fit must exceed 0.9. In our case, all five satisfy this requirement: NFI (Normed Fit Index) $=0.937$, TLI (Tucker-Lewis coefficient, also known as Non-Normed Fit Index) $=0.926$, IFI (Incremental Fit Index) $=0.942$, CFI (Comparative Fit Index) $=0.941$ and RFI (Relative Fit Index) $=0.921$ (Hu \& Bentler, 1999; Yu \& Muthen, 2002). Researchers, with regard to the indicators of residual goodness of fit, have shown that the value must be lower than 0.08. For this model, the standardized root mean squared residuals is 0.0499: this value is an average of the residuals calculated on the correlation matrix, and the lower the value, the better the fit of our model. Finally, authors, in accordance with the mean square error of approximation (RMSEA), affirm that a value lower than 0.08 is required and that a value lower than 0.05 determines a "perfect fit" (Browne, Cudeck, Bollen, \& Long, 1993). Our model must therefore be counted as valid with respect to its RMSEA of 0.069 .

All the indicators of goodness of fit of the simplified model are presented in the direction of good adjustment; thus, our model passes the validation test. We therefore present the standardized regression coefficients of the simplified model as the weights of CSR practices that compose it. Furthermore, we show the estimation and the $95 \%$ confidence intervals of a bootstrap resampling with $n=1,000$ replicates, revealing the stability of these values, as all CSR practices present a highly significant $p$-value lower than 0.01 (Table 5), which means that each has an important role in the ICSRPI proposed.

\section{6 | Aggregation}

This phase considers the individual weight that is assigned to each variable with regard to its importance to the set, and is the last step in the development of a composite index. In this sense, the ICSRPI is based on the fact that for each of the CSR practices, the difference between the average level of sustainability of the companies operating in the selected industry and the average level of sustainability of all the companies included in the qualification is calculated. In the final step of this process of calculation, through a weighted sum by the standardized regression weights (see Table 5), the aggregation of CSR practice scores is realized to obtain an index at the industrial level (Equation 1).

A practical application has been performed to test the utility of the ICSRPI. The results show a comparison of the industries analyzed by this ranking, so that industries with positive scores are associated with a major commitment to sustainability in environmental concerns and social issues, the best CSR practices; scores close to 0 mean that these industries do not stand out in the classification; and those industries with negative values are seen as the slowest in joining this commitment.

\section{I RESULTS OF EMPIRICAL ANALYSIS AND DISCUSSION}

The results summarized in Table 6 reveal important differences between the different industries. Specifically, basic materials and utilities are the most sustainable sectors. At the opposite extreme, the financial and consumer services sectors show less commitment to CSR. In addition, we have decided to disaggregate this indicator in its environmental and social aspects. Appendix 1 provides a synthesis of the ICSRPI values for each country.

We complement these results with radials referenced to the values taken by each of the industries in the five CSR dimensions of the study (Figure 3). The industries that lead the ranking have their highest values in the environmental dimension, as they are formed by companies from polluting sectors with high environmental impacts and risks. Therefore it is possible that these companies use CSR practices to respond to the demands and expectations of stakeholders and manage their reputation. In the central part of the ranking, with values close to 0 , we find technology and healthcare; finally, the telecommunications, financial and consumer services industries present negative values in the study-these are less polluting companies, which give higher priority to business ethics, employee rights and stakeholder concerns.

Basic materials and utilities industries are positioned with similar values, leading the ranking: the former comprises companies dedicated to the production and distribution of chemical products, paper, forest plantation owners and others dedicated to industrial metals and mining, such as exploration and the extraction of coal; the latter, the utilities industry, consists of companies that generate and distribute electricity through the combustion of coal, oil and natural gas or through nuclear energy, as well as distributors of gas, water and multiple services. These companies operate in high impact sectors-that is, they are more exposed to environmental risks and so seek to improve their sustainability commitment to manage those risks and increase user confidence. This is due to the social pressure to disclose bad environmental news (Casey \& Grenier, 2015; Semenova \& Hassel, 2008; van Ekelenburg, 2016).

Companies belonging to the oil and gas sector are engaged in the exploration, extraction, production, refining and supply of oil and gas products, as well as companies that develop or manufacture renewable energy equipment. Companies in this industry are

$$
\text { Industry CSR practices index }=\sum_{i=1}^{23} p_{i}\left(\begin{array}{c}
\text { Sustainability average level of practice } X_{i} \text { from companies belonging industry } A \\
- \\
\text { Sustainability average level of practice } X_{i} \text { from all sample companies }
\end{array}\right)
$$


TABLE 5 Simplified model: standardized regression weights of CSR practices

\begin{tabular}{|c|c|c|c|c|c|c|c|}
\hline \multirow{2}{*}{$\begin{array}{l}\text { CSR practices } \\
\text { Environmental policy }\end{array}$} & \multicolumn{3}{|c|}{ Parameter } & \multirow{2}{*}{$\begin{array}{l}\text { Estimate } \\
0.790\end{array}$} & \multirow{2}{*}{$\begin{array}{l}\text { Lower } \\
0.776\end{array}$} & \multirow{2}{*}{$\begin{array}{l}\text { Upper } \\
0.805\end{array}$} & \multirow{2}{*}{$\begin{array}{l}p \text {-value } \\
0.002\end{array}$} \\
\hline & ENV1 & $\leftarrow$ & CSR & & & & \\
\hline Environmental management & ENV2 & $\leftarrow$ & CSR & 0.683 & 0.660 & 0.703 & 0.002 \\
\hline Human Rights policy & HR1 & $\leftarrow$ & CSR & 0.596 & 0.570 & 0.621 & 0.002 \\
\hline Human Rights systems & HR2 & $\leftarrow$ & CSR & 0.575 & 0.549 & 0.601 & 0.002 \\
\hline Human Rights reporting & HR3 & $\leftarrow$ & CSR & 0.475 & 0.450 & 0.505 & 0.002 \\
\hline Equal opportunities (systems) & EMP2 & $\leftarrow$ & CSR & 0.677 & 0.656 & 0.698 & 0.002 \\
\hline Health and safety systems & EMP3 & $\leftarrow$ & CSR & 0.735 & 0.714 & 0.754 & 0.002 \\
\hline Training & EMP5 & $\leftarrow$ & CSR & 0.642 & 0.620 & 0.664 & 0.001 \\
\hline Community relations & STH1 & $\leftarrow$ & CSR & 0.382 & 0.354 & 0.414 & 0.002 \\
\hline Customer/supplier relations policy & $\mathrm{STH} 2$ & $\leftarrow$ & CSR & 0.637 & 0.611 & 0.662 & 0.003 \\
\hline Stakeholder systems & STH7 & $\leftarrow$ & CSR & 0.878 & 0.868 & 0.887 & 0.001 \\
\hline Stakeholder reporting & STH8 & $\leftarrow$ & CSR & 0.771 & 0.754 & 0.789 & 0.002 \\
\hline Codes of ethics & ETH1 & $\leftarrow$ & CSR & 0.571 & 0.543 & 0.597 & 0.003 \\
\hline Codes of ethics systems & ETH2 & $\leftarrow$ & CSR & 0.676 & 0.654 & 0.696 & 0.003 \\
\hline Countering bribery policy & ETH3 & $\leftarrow$ & CSR & 0.605 & 0.578 & 0.631 & 0.003 \\
\hline Countering bribery systems & ETH4 & $\leftarrow$ & CSR & 0.655 & 0.630 & 0.675 & 0.003 \\
\hline Countering bribery reporting & ETH5 & $\leftarrow$ & CSR & 0.594 & 0.568 & 0.617 & 0.002 \\
\hline ESG risk management & ETH7 & $\leftarrow$ & CSR & 0.717 & 0.698 & 0.737 & 0.002 \\
\hline
\end{tabular}

considered high impact, so they have higher CSR scores than companies in other sectors (van Ekelenburg, 2016) due to their greater environmental impact and the obligation to preserve human rights: hence they have highest scores in these two dimensions (Figure 3).

The industrials industry includes companies dedicated to all types of manufacture and distribution of products (such as vehicles, industrial machinery and aeroplanes), mail services, rail transport, water transport, support services, and construction and materials, such as companies engaged in building construction, infrastructure, and so

TABLE 6 Industrial Corporate Social Responsibility Practices Index (ICSRPI)

\begin{tabular}{lccc} 
Industry & ICSRPI & ICSRPI_ENV & ICSRPI_SO \\
\hline Basic Materials & 4.520 & 1.480 & 3.040 \\
\hline Utilities & 4.478 & 1.434 & 3.045 \\
\hline Oil \& Gas & 3.185 & 0.653 & 2.531 \\
\hline Industrials & 2.085 & 0.587 & 1.498 \\
\hline Consumer Goods & 1.609 & 0.615 & 0.993 \\
\hline Technology & 0.032 & -0.075 & 0.107 \\
\hline Healthccare & -0.103 & -0.328 & 0.225 \\
\hline Telecommunications & -0.654 & -0.637 & -0.018 \\
\hline Financials & -3.645 & -0.964 & -2.681 \\
\hline Consumer Services & -3.659 & -1.099 & -2.560 \\
\hline
\end{tabular}

on. It is clear that industrial activity has an impact on the environment around it, such as degradation or air pollution; the growth of this activity is accompanied by an increase in energy consumption or waste production, among others. These companies adopt broader CSR practices, which may be because they use CSR to legitimize their business practices, so they adhere to CSR policies as a way to manage their reputation and thus respond to stakeholders' expectations (Halkos \& Skouloudis, 2016).

The consumer goods industry comprises firms mainly engaged in the manufacture and transport of food and beverages, vehicles, leisure products (such as TVs and audio equipment) and personal items (such as clothing and cosmetics), and manufacturers and distributors of tobacco. In this industry, more codified and explicit CSR policies are adopted with the aim of being considered proactive and thus controlling the standards with which they have to comply, improving their image and increasing their benefits (Jackson \& Apostolakou, 2010).

In the central positions of the ranking, we find the technology industries, whose companies are dedicated to the manufacture and distribution of electronic equipment, from semiconductors, chips or computers to high technology such as satellites, as well as all types of computer services, software, internet, consulting, and so on. The healthcare industry is also found here, consisting of companies engaged in research and development of biological substances for medicines, other companies dedicated to healthcare services and equipment, and health maintenance organizations (hospitals, clinics, etc.). Both industries have companies considered as high impact, 


\section{Environment}

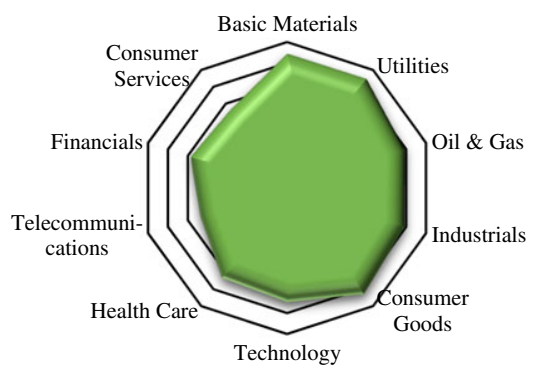

\section{Employees}

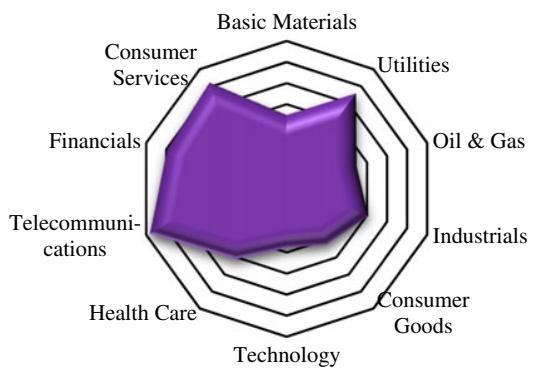

Ethics

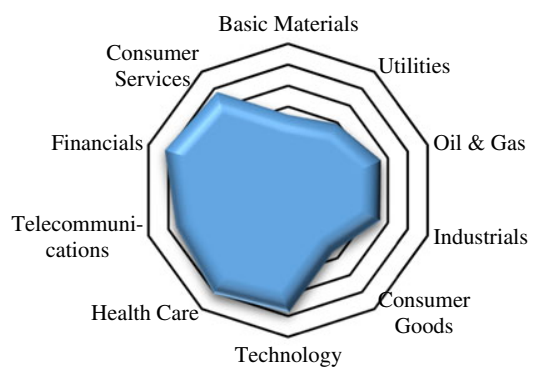

\section{Human Rights}

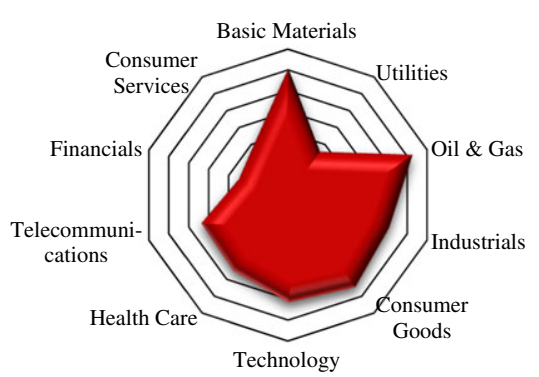

\section{Stakeholders}

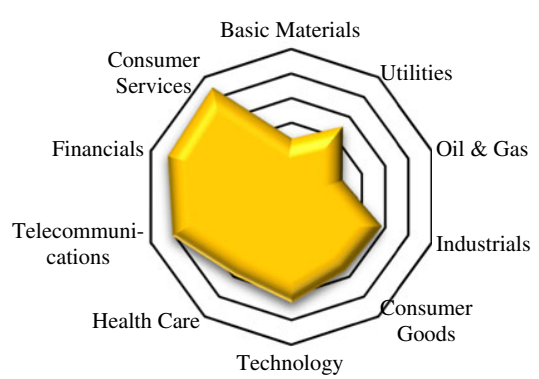

FIGURE 3

Industry values for CSR dimensions [Colour figure can be viewed at wileyonlinelibrary.com]

such as those related to hardware in technology, due to industrial pollution in their manufacture and distribution, and biological substances in healthcare, given their high environmental risk. These companies have higher CSR scores; however, other firms in these industries are not considered high impact and present lower scores, which explains the middle position of these industries.

Finally, we find the industries of telecommunications, comprising companies that provide fixed and mobile telephony services; financials, consisting of insurance companies, real estate services, investment funds and banks; and consumer services, incorporating retail companies, the media, and travel and leisure companies. The companies in these industries are not considered to have a high environmental impact; therefore their low CSR scores indicate less polluting companies that give higher priority to business ethics, employee rights and stakeholders (Belu, 2009; Scholtens, 2011; Weber, 2014) (Figure 3).

To look more deeply into the industries analyzed, we break down each of the countries of origin of the companies with the objective of studying the structure of these according to the industries. To do this, we use bar diagrams, taking as our reference (vertical axis) the average level of sustainability of all companies in each of the industries (Figure 4). In addition, Appendix 2 shows the ICSRPI values synthesized by country and their subcomponents in relation to the average sustainability for each industry.

For correct interpretation of these graphs, we note that, for example, French companies have above average scores in all industries, while Hong Kong companies have below average values, with the exception of companies in the utilities industry, which show values similar to but somewhat above the average.

European Union (EU) countries show positive values with regard to the global average in most industries, showing a greater commitment to sustainability; also included here is Australia, which may be because its regulatory regime is similar to that found in some European countries, especially in relation to corporate transparency (Baughn, Bodie, \& McIntosh, 2007). With regard to nonEU countries, the majority have negative values; nevertheless, Japan in the Asian continent, and Canada and the United States, have values similar to the average in most industries. However, compared to major European countries, they seem to be far behind in sustainability issues, as other researchers have previously found 

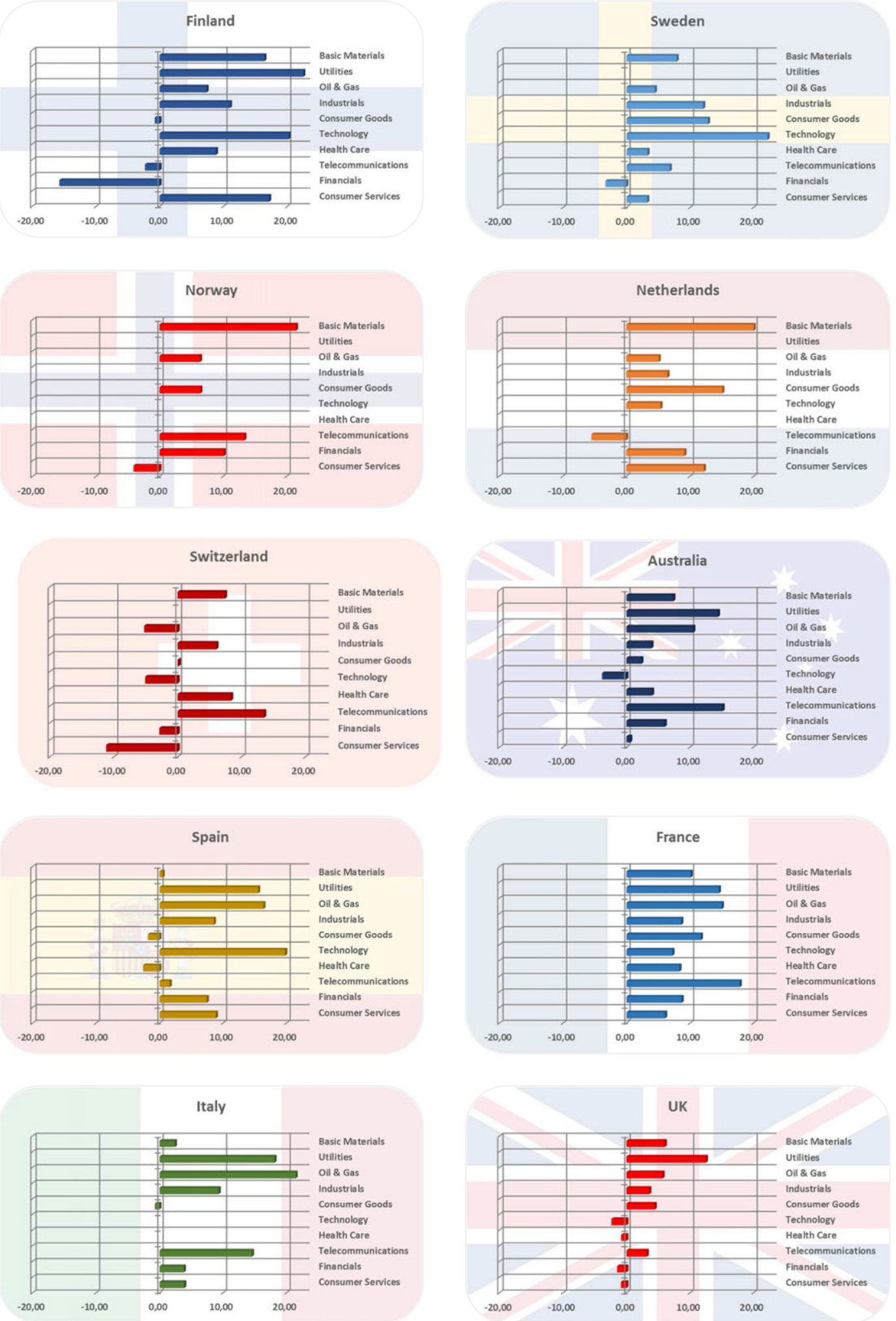

FIGURE 4 ICSRPI values synthesized by country in relation to the sustainability average for each industry [Colour figure can be viewed at wileyonlinelibrary.com]

for microdata (Matten \& Moon, 2008; Purdy, Alexander, \& Neill, 2010). The remaining countries seem to be lagging behind on sustainable issues, South-East Asia, Thailand, Malaysia, Hong Kong and Taiwan having the worst records and so the lowest sustainability commitment. At the country level, Finland stands out in the utilities and technology industries; the latter is also found in Sweden and Spain. Norway and the Netherlands give priority to subjects related to basic materials. France, Italy and Spain present strong CSR practices in the oil and gas, utilities and industrial industries. Switzerland, France and Australia have more developed CSR in the telecommunications industry. Malaysia, Hong Kong and Taiwan show low commitment to CSR in any sector. 

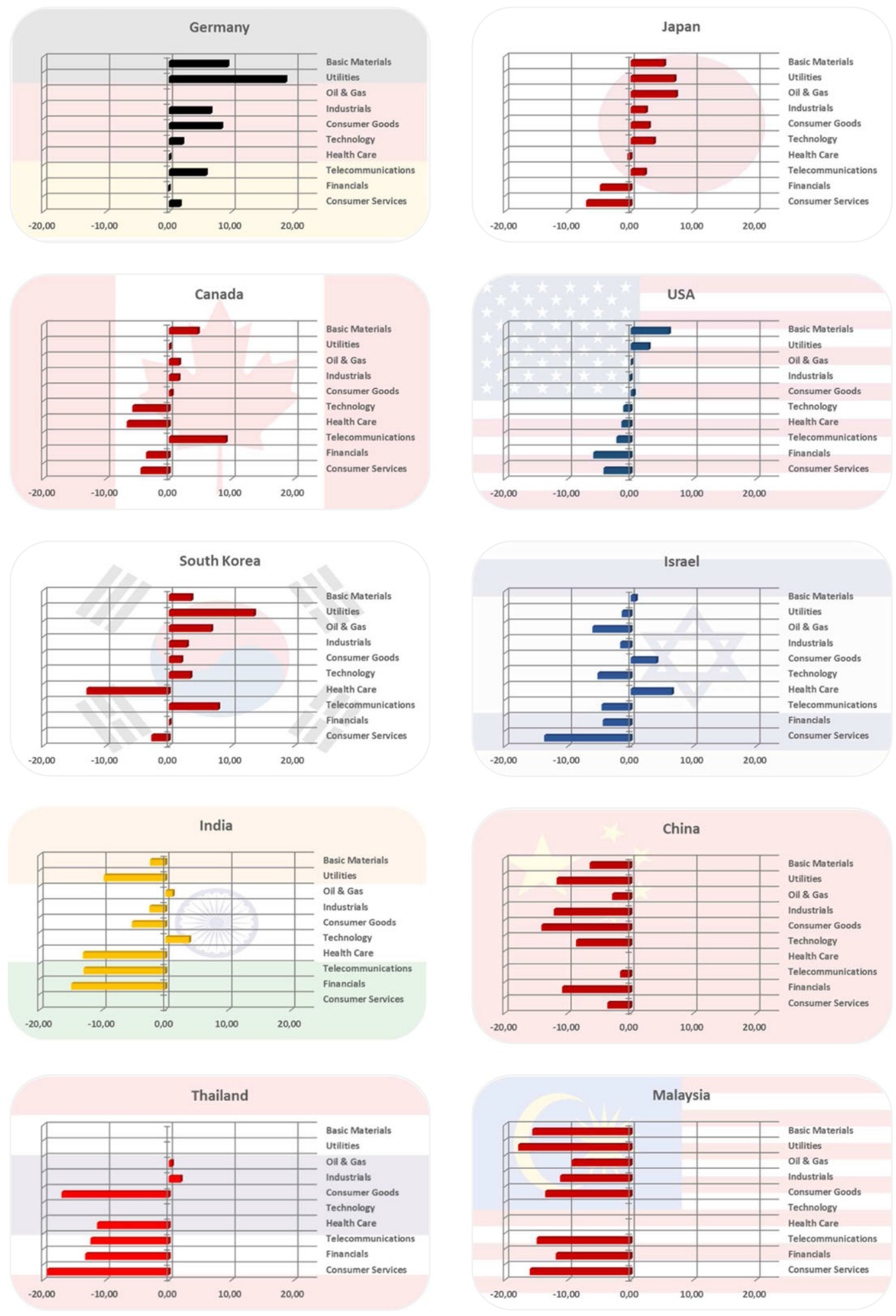

FIGURE 4 Continued.

\section{5 | CONCLUSIONS}

In this paper, an ICSRPI was developed to evaluate the sustainability commitment at the organizational level, consisting of a statistical aggregation process of 23 sustainability business practices categorized in the environmental and social dimensions. The ICSRPI provides an industrial view of the state of commitment to and development of CSR, which will be of value to compare the level of responsible business conduct in industries and in the development of benchmarking processes linked to environmental and social sustainability issues. 
The development of the ICSRPI has shown that the most sustainable industries are those whose activity leads them to be considered as environmentally high impact, as they implement policies and more advanced environmental management systems. The companies that operate in these sectors additionally have a strong commitment to the social dimension of CSR. In this sense, the basic materials and utilities sectors stand out. Thus, those industries most exposed to environmental risks seek to improve their sustainability commitment to manage those risks and increase stakeholder confidence. They can use CSR to legitimize their business practices, so they adhere to CSR policies as a way to manage their reputation and respond to the expectations of stakeholders. In other words, because these sectors operate under more pressure from interest groups and face greater social and environmental risk, they have higher CSR scores than firms in other industries.

Similarly, it is of note in the other sectors that the CSR practices are adapted to the demands that the stakeholders have in the different areas of interest, which are specific to each sector. Thus Finland, considered a strong state of wellbeing, has a strong commitment to CSR in virtually all industries, especially utilities and technology; France, Italy and Spain present strong CSR practices in industries with high environmental risks such as oil and gas, utilities and industrial, highlighting the shortcomings of other countries in the control of oil and gas emissions. In contrast, Malaysia, Hong Kong and Taiwan show the opposite behavior.

Our findings offer new ground to theorists for a deeper analysis of the industry specificity of CSR and to further identify institutional determinants that shape the sustainability of business. Our results indicate that the different characteristics of a sector of activity-competition, economy and other institutional conditionsdetermine a firm's propensity to act in a socially responsible manner.

In addition, the disparities observed at the sectorial level show the usefulness of the ICSRPI to simplify and quantify CSR practices and provide a very useful value to be used as a reference; through the ICSRPI values, it is possible to identify those industries that have higher deficiencies in sustainability systems, facilitating the planning of various improvement actions and providing relevant information on environmental and social issues to guide managers or stakeholders in their decision-making processes. Thus, knowing the level of commitment to sustainability at the sector level allows those companies that start operating in a new industry to know the minimum standards of CSR that they must respect. Likewise, it allows the realization of benchmarking processes aimed at the continuous improvement of business decisions and actions. With regard to regulators/politicians, the ICSRPI reveals differences in issues of sustainability at the sector level that can be considered in the design of regulations or public policies that allow correction of the deficiencies observed at a sectoral level: for example, in this sense, it would be advisable to encourage greater commitment to the environment in those less polluting sectors.

In future research, it would be interesting to go deeper into the different sectors of activity that disaggregate the ten industries considered in this paper. This disaggregation would make it possible to see discrepancies between activity subsectors and to design more precise sustainability actions.

\section{ORCID}

Víctor Amor-Esteban (iD http://orcid.org/0000-0003-0313-0196

\section{REFERENCES}

Aerts, W., Cormier, D., \& Magnan, M. (2006). Intra-industry imitation in corporate environmental reporting: An international perspective. Journal of Accounting and Public Policy, 25(3), 299-331. https://doi. org/10.1016/j.jaccpubpol.2006.03.004

Baughn, C. C., (Dusty) Bodie, N. L., \& McIntosh, J. C. (2007). Corporate social and environmental responsibility in Asian countries and other geographical regions. Corporate Social Responsibility and Environmental Management, 14, 189-205.

Belu, C. (2009). Ranking corporations based on sustainable and socially responsible practices. A data envelopment analysis (DEA) approach. Sustainable Development, 17(4), 257-268. https://doi.org/10.1002/ sd.390

Birnbaum, A. (1968). Some latent trait models and their use in inferring an examinee's ability. Stat. Theor. Ment. Test. Scores, 395-479.

Boudt, K., Cornelissen, J., \& Croux, C. (2013). The impact of a sustainability constraint on the mean-tracking error efficient frontier. Economics Letters, 119(3), 255-260. https://doi.org/10.1016/j.econlet.2013.03.020

Branco, M. C., \& Rodrigues, L. L. (2008). Factors influencing social responsibility disclosure by Portuguese companies. Journal of Business Ethics, 83(4), 685-701. https://doi.org/10.1007/s10551-007-9658-z

Browne, M. W., Cudeck, R., Bollen, K. A., \& Long, J. S. (1993). Alternative ways of assessing model fit. Sage Focus. Educação, 154, 136-136.

Campbell, J. L. (2007). Why would corporations behave in socially responsible ways? An institutional theory of corporate social responsibility. Academy of Management Review, 32(3), 946-967. https://doi.org/ 10.5465/AMR.2007.25275684

Casey, R. J., \& Grenier, J. H. (2015). Understanding and contributing to the enigma of corporate social responsibility (CSR) assurance in the United States. AUDITING: A Journal of Practice and Theory, 34(1), 97-130. https://doi.org/10.2308/ajpt-50736

Clerici, N., Bodini, A., \& Ferrarini, A. (2004). Sustainability at the local scale: Defining highly aggregated indices for assessing environmental performance. The province of Reggio Emilia (Italy) as a case study. Environmental Management, 34(4), 590-608. https://doi.org/10.1007/ s00267-003-0196-x

Cowen, S. S., Ferreri, L. B., \& Parker, L. D. (1987). The impact of corporate characteristics on social responsibility disclosure: A typology and frequency-based analysis. Accounting, Organizations and Society, 12(2), 111-122. https://doi.org/10.1016/0361-3682(87)90001-8

Dierkes, M., \& Preston, L. E. (1977). Corporate social accounting reporting for the physical environment: A critical review and implementation proposal. Accounting, Organizations and Society, 2(1), 3-22. https://doi. org/10.1016/0361-3682(77)90003-4

DiMaggio, P. J. (1991). The iron cage revisited: Institutional isomorphism and collective rationality. Chicago, IL: University of Chicago Press.

Dobbie, M. J., \& Dail, D. (2013). Robustness and sensitivity of weighting and aggregation in constructing composite indices. Ecological Indicators, 29, 270-277. https://doi.org/10.1016/j.ecolind.2012.12.025

Edelman, L. B., \& Suchman, M. C. (1997). The legal environments of organizations. Annual Review of Sociology, 23(1), 479-515. https://doi.org/ 10.1146/annurev.soc.23.1.479

van Ekelenburg, M. (2016). Determinants of voluntary external assurance on corporate sustainability reports: A comparison between Europe and North America. Netherlands: Radboud University.

Embretson, S. E., \& Reise, S. P. (2013). Item response theory. Hove, UK: Psychology Press. 
Esteban, V. A., Villardón, M. P. G., \& Sánchez, I. M. G. (2017). Cultural values on CSR patterns and evolution: A study from the biplot representation. Ecological Indicators, 81, 18-29. https://doi.org/10.1016/j. ecolind.2017.05.051

Freudenberg, M. (2003). Composite indicators of country performance. Paris, France: OECD.

García-Sánchez, I.-M., Almeida, T. A. d. N., \& Camara, R. P. d. B. (2015). A proposal for a Composite Index of Environmental Performance (CIEP) for countries. Ecological Indicators, 48, 171-188. https://doi.org/ 10.1016/j.ecolind.2014.08.004

García-Sánchez, I.-M., \& García-Meca, E. (2017). CSR engagement and earnings quality in banks. The moderating role of institutional factors. Corporate Social Responsibility and Environmental Management, 24, 145-158.

García-Sánchez, I.-M., Rodríguez-Ariza, L., \& Frías-Aceituno, J.-V. (2013). The cultural system and integrated reporting. International Business Review, 22(5), 828-838. https://doi.org/10.1016/j.ibusrev.2013.01.007

Gjølberg, M. (2009). Measuring the immeasurable? Scandinavian Journal of Management, 25(1), 10-22. https://doi.org/10.1016/j. scaman.2008.10.003

Gray, R. (2002). The social accounting project and Accounting Organizations and Society Privileging engagement, imaginings, new accountings and pragmatism over critique? Accounting, Organizations and Society, 27(7), 687-708. https://doi.org/10.1016/S0361-3682(00)00003-9

Halkos, G., \& Skouloudis, A. (2016). National CSR and institutional conditions: An exploratory study. Journal of Cleaner Production, 139, 1150-1156. https://doi.org/10.1016/j.jclepro.2016.07.047

Horton, N. J., \& Lipsitz, S. R. (2001). Multiple imputation in practice: Comparison of software packages for regression models with missing variables. American Statistician, 55(3), 244-254. https://doi.org/ 10.1198/000313001317098266

Hu, L., \& Bentler, P. M. (1999). Cutoff criteria for fit indexes in covariance structure analysis: Conventional criteria versus new alternatives. Structural Equation Modeling: A Multidisciplinary Journal, 6(1), 1-55. https://doi.org/10.1080/10705519909540118

Jackson, G., \& Apostolakou, A. (2010). Corporate social responsibility in Western Europe: An institutional mirror or substitute? Journal of Business Ethics, 94(3), 371-394. https://doi.org/10.1007/s10551-009-0269-8

Lenssen, G., Gasdparski, W., Rok, B., Lacy, P., Midttun, A., Gautesen, K., \& Gjølberg, M. (2006). The political economy of CSR in Western Europe. Corporate Governance, 6, 369-385.

León, J. Á. P. (2015). Análisis de la relación causal de la responsabilidad social corporativa y la performance financiera de las empresas. Retrieved from https://doi.org/10.4995/Thesis/10251/48517

Martínez Arias, R., Hernández-Lloreda, M. J., \& Hernández-Lloreda, M. V. (2006). Psicometría. Madrid, Spain: Alianza Editor.

Martínez-Ferrero, J., \& García-Sánchez, I.-M. (2016). Coercive, normative and mimetic isomorphism as determinants of the voluntary assurance of sustainability reports. International Business Review, 26(1), 102-118.

Matten, D., \& Moon, J. (2008). 'Implicit' and "explicit" CSR: A conceptual framework for a comparative understanding of corporate social responsibility. Academy of Management Review, 33(2), 404-424. https://doi.org/10.5465/AMR.2008.31193458

Muniz, J. (1997). Introducción a la teoría de respuesta a los ítems [Introduction to item response theory]. Madrid, Spain: Pirámide.

Newson, M., \& Deegan, C. (2002). Global expectations and their association with corporate social disclosure practices in Australia, Singapore, and South Korea. International Journal of Accounting, 37(2), 183-213. https://doi.org/10.1016/S0020-7063(02)00151-6

OECD (2008). Handbook on constructing composite indicators: Methodology and user guide. OECD.

Ortas, E., Álvarez, I., Jaussaud, J., \& Garayar, A. (2015). The impact of institutional and social context on corporate environmental, social and governance performance of companies committed to voluntary corporate social responsibility initiatives. Journal of Cleaner Production, 108, 673-684. https://doi.org/10.1016/j.jclepro.2015.06.089

Parsa, S., \& Deng, L. X. (2008). Capital markets' reactions to social information announcements. International Journal of Accounting and Finance, 1(1), 107-120. https://doi.org/10.1504/JJAF.2008.020239

Patten, D. M. (1991). Exposure, legitimacy, and social disclosure. Journal of Accounting and Public Policy, 10(4), 297-308. https://doi.org/10.1016/ 0278-4254(91)90003-3

Purdy, J. M., Alexander, E. A., \& Neill, S. (2010). The impact of national institutional context on social practices: Comparing Finnish and US business communities. European Journal of International Management, 4(3), 234-256. https://doi.org/10.1504/EJIM.2010.033002

Salem, M. A., Shawtari, F., Shamsudin, M. F., \& Hussain, H. B. I. (2017). The consequences of integrating stakeholder engagement in sustainable development (environmental perspectives). Sustainable Development.. https://doi.org/10.1002/sd.1699

Salomaa, E., \& Watkins, G. (2011). Environmental performance and compliance costs for industrial wastewater treatment-an international comparison. Sustainable Development, 19(5), 325-336. https://doi. org/10.1002/sd.440

Scholtens, B. (2011). Corporate social responsibility in the international insurance industry. Sustainable Development, 19(2), 143-156. https:// doi.org/10.1002/sd.513

Searcy, C. (2016). Measuring enterprise sustainability. Business Strategy and the Environment, 25(2), 120-133. https://doi.org/10.1002/bse.1861

Semenova, N., \& Hassel, L. G. (2008). Financial outcomes of environmental risk and opportunity for US companies. Sustainable Development, 16(3), 195-212. https://doi.org/10.1002/sd.365

Skouloudis, A., Isaac, D., \& Evaggelinos, K. (2016). Revisiting the national corporate social responsibility index. International Journal of Sustainable Development and World Ecology, 23(1), 61-70. https://doi.org/ 10.1080/13504509.2015.1099121

Soto, H., \& Schuschny, A. R. (2009). Guía metodológica: Diseño de indicadores compuestos de desarrollo sostenible. Santiago de Chile: CEPAL.

Thissen, D. (1991). MULTILOG: Multiple Category Item Analysis and test scoring using Item Response Theory (Version 7.0. 3). Chicago, IL: Scientific Software International, Inc.

Venanzi, D., \& Fidanza, B. (2006). Corporate Social Responsibility and value creation-Determinants and mutual relationships in a sample of European Listed Firms. Social Science Research Network, Rochester, NY. http://doi.org/10.2139/ssrn.939710

Waddock, S. A., \& Graves, S. B. (1997). The corporate social performancefinancial performance link. Strategic Management Journal, 18(4), 303-319. https://doi.org/10.1002/(SICI)1097-0266(199704)18:4\% 3С303::AID-SMJ869\%3E3.0.CO;2-G

Wanderley, L. S. O., Lucian, R., Farache, F., \& de Sousa Filho, J. M. (2008). CSR information disclosure on the web: A context-based approach analysing the influence of country of origin and industry sector. Journal of Business Ethics, 82(2), 369-378. https://doi.org/10.1007/s10551008-9892-z

Weber, J. L. (2014). Corporate social responsibility disclosure level, external assurance and cost of equity capital. Boulder, CO: University of Colorado at Boulder.

Yu, C. Y., \& Muthen, B. (2002). Evaluation of model fit indices for latent variable models with categorical and continuous outcomes. In Annual Meeting of the American Educational Research Association. LA: New Orleans.

How to cite this article: Amor-Esteban V, Galindo-Villardón M-P, García-Sánchez I-M. Useful information for stakeholder engagement: A multivariate proposal of an Industrial Corporate Social Responsibility Practices Index. Sustainable Development. 2018;1-17. https://doi.org/10.1002/sd.1732 


\section{APPENDIX 1}

\section{ICSRPI VALUES SYNTHESIZED FOR EACH COUNTRY}

ICSRPI values were calculated for each of the countries of study. These values are not comparable: they must be analyzed individually for each country. Positive values translate into CSR practices above the average of the country in question in the selected industry; the reverse is true for negative values. For example, Australian companies prioritize their CSR practices in the telecommunications and utilities industries, and to a lesser extent for oil and gas and basic materials; in contrast, they give less importance to CSR practices in technology and consumer services.

$$
\text { Industry CSR practices index }=\sum_{i=1}^{23} p_{i}\left(\begin{array}{c}
\text { Sustainability average level of practice } X_{i} \text { from companies of country } C \text { belonging industry } A \\
- \\
\text { Sustainability average level of practice } X_{i} \text { from all companies of country } C
\end{array}\right)
$$

\begin{tabular}{|c|c|c|c|c|c|c|c|c|c|c|}
\hline $\begin{array}{l}\text { Country/ } \\
\text { industry }\end{array}$ & $\begin{array}{l}\text { Basic } \\
\text { materials }\end{array}$ & Utilities & $\begin{array}{l}\text { Oil and } \\
\text { gas }\end{array}$ & Industrials & $\begin{array}{l}\text { Consumer } \\
\text { goods }\end{array}$ & Technology & Healthcare & Telecommunications & Financials & $\begin{array}{l}\text { Consumer } \\
\text { services }\end{array}$ \\
\hline Australia & 2.28 & 9.30 & 5.42 & -1.17 & -2.76 & -8.95 & -1.06 & 10.05 & 0.95 & -4.49 \\
\hline Canada & 4.74 & 0.24 & 1.76 & 1.66 & 0.56 & -5.68 & -6.58 & 9.17 & -3.50 & -4.38 \\
\hline China & 2.99 & -2.27 & 6.53 & -2.73 & -4.70 & 0.80 & & 7.81 & -1.40 & 5.78 \\
\hline Finland & 6.87 & 12.99 & -2.20 & 1.47 & -10.33 & 10.67 & -0.73 & -11.86 & -25.30 & 7.62 \\
\hline France & 0.86 & 5.29 & 5.76 & -0.63 & 2.46 & -2.03 & -0.92 & 8.58 & -0.56 & -3.17 \\
\hline Hong Kong & -3.08 & 11.63 & -5.80 & 1.67 & -4.08 & 3.24 & & -1.27 & 1.04 & -1.98 \\
\hline India & 4.27 & -3.08 & 7.86 & 4.17 & 1.39 & 10.48 & -6.40 & -6.29 & -8.27 & \\
\hline Israel & 4.39 & 2.17 & -2.50 & 1.92 & 7.69 & -1.68 & 10.16 & -1.06 & -0.86 & -10.19 \\
\hline Italy & -3.97 & 11.73 & 15.04 & 2.93 & -7.14 & & & 8.15 & -2.56 & -2.51 \\
\hline Japan & 5.07 & 6.69 & 6.95 & 2.15 & 2.63 & 3.44 & -0.78 & 2.00 & -5.15 & -7.36 \\
\hline South Korea & 1.54 & 11.50 & 4.68 & 0.81 & -0.09 & 1.37 & -15.18 & 5.79 & -1.96 & -4.85 \\
\hline Spain & -8.23 & 6.81 & 7.66 & -0.13 & -10.54 & 11.09 & -11.29 & -7.10 & -1.27 & 0.17 \\
\hline Sweden & 2.47 & & -0.96 & 6.66 & 7.41 & 16.80 & -2.10 & 1.39 & -8.75 & -2.17 \\
\hline Switzerland & 5.34 & & -7.27 & 4.01 & -1.88 & -7.11 & 6.30 & 11.48 & -4.91 & -13.23 \\
\hline Taiwan & 5.30 & & -13.68 & -1.64 & -12.35 & 4.62 & & 2.74 & -6.18 & \\
\hline Thailand & & & 9.29 & 10.69 & -8.24 & & -2.59 & -3.66 & -4.50 & -10.56 \\
\hline UK & 4.33 & 10.77 & 3.98 & 1.89 & 2.73 & -4.07 & -2.54 & 1.48 & -3.17 & -2.58 \\
\hline USA & 7.75 & 4.50 & 1.74 & 1.46 & 2.13 & 0.46 & 0.17 & -0.62 & -4.30 & -2.68 \\
\hline
\end{tabular}

\section{APPENDIX 2}

\section{ICSRPI VALUES SYNTHESIZED BY COUNTRY AND ITS SUBCOMPONENTS IN RELATION TO THE AVERAGE VALUE OF SUSTAINABILITY FOR EACH INDUSTRY}

Positive values mean that the country in question presents CSR practices above the global average in the selected industry (average value for each industry in relation to all countries), and the reverse for negative values. These values are comparable: thus Finland is the country of study with the best CSR practices in the utilities industry and, by contrast, Taiwan is the country with the worst CSR practices in the oil and gas industry. Below, we describe one of the countries by way of example.

Australia has above average CSR practices in most industries, notably in telecommunications and utilities; in contrast, it achieves practices below average in the technology industry. Regarding its subcomponents, if we look at the healthcare industry, Australia has a lower than average commitment to environmental issues, and a higher than average commitment to social issues. 


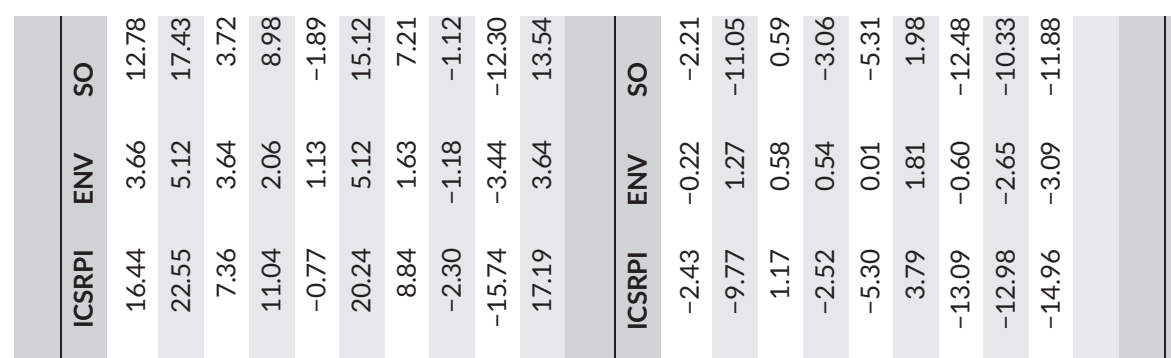

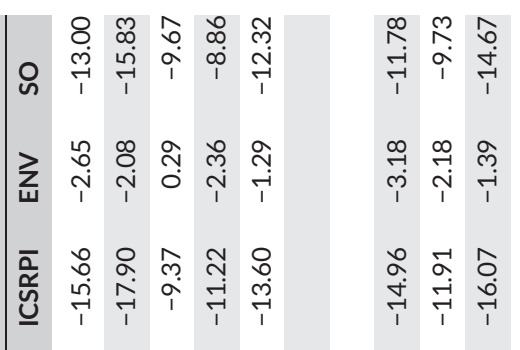

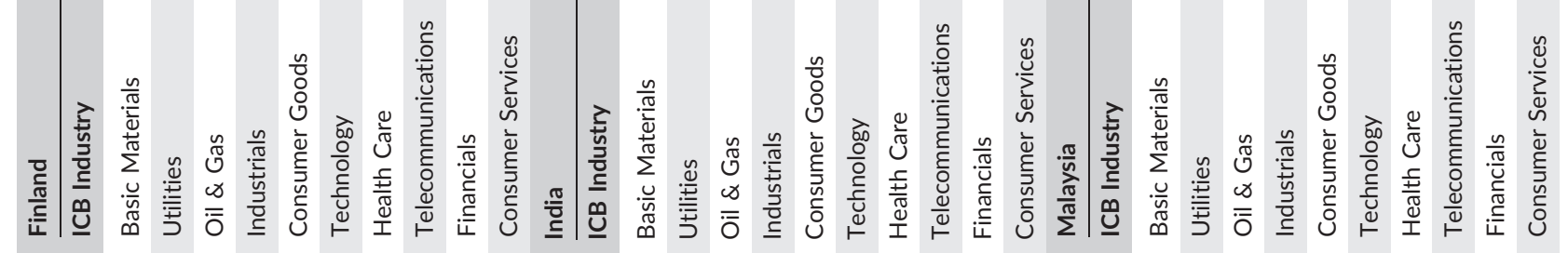

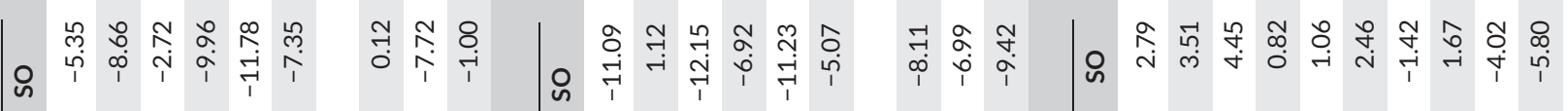

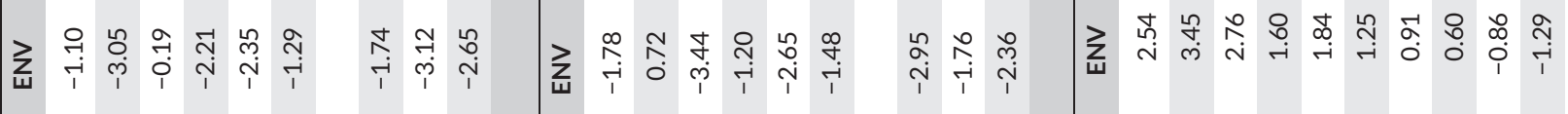

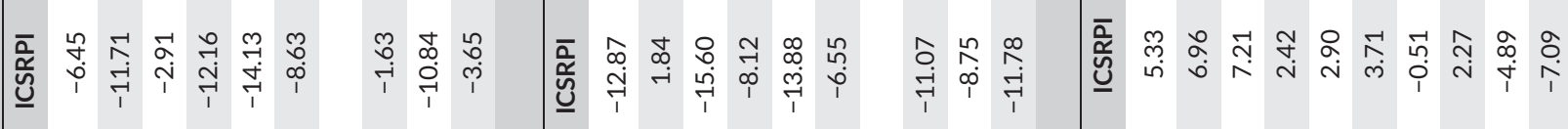

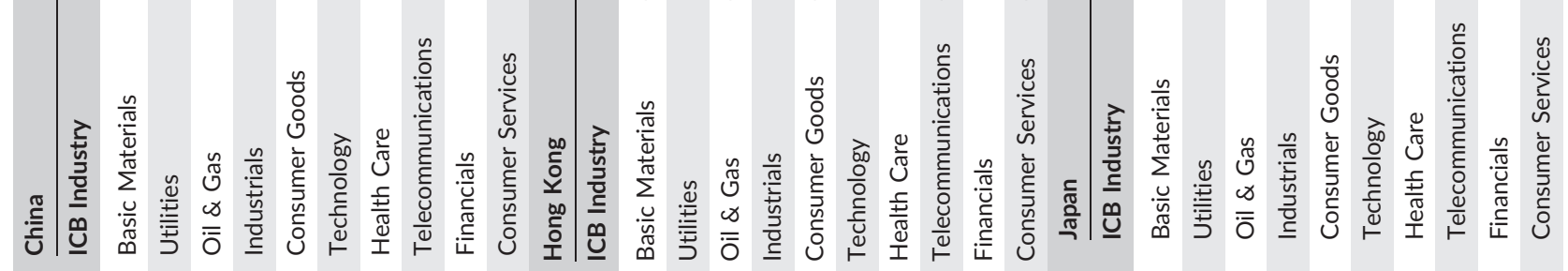

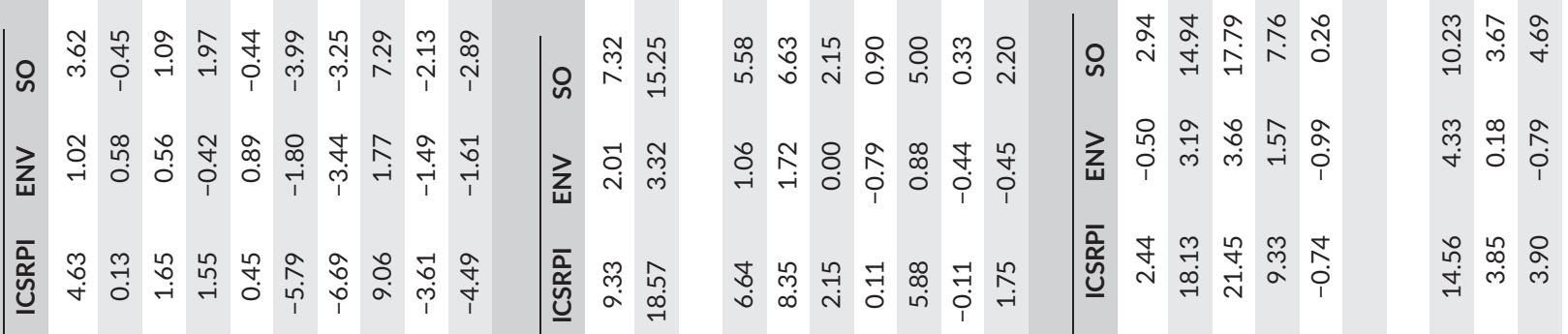

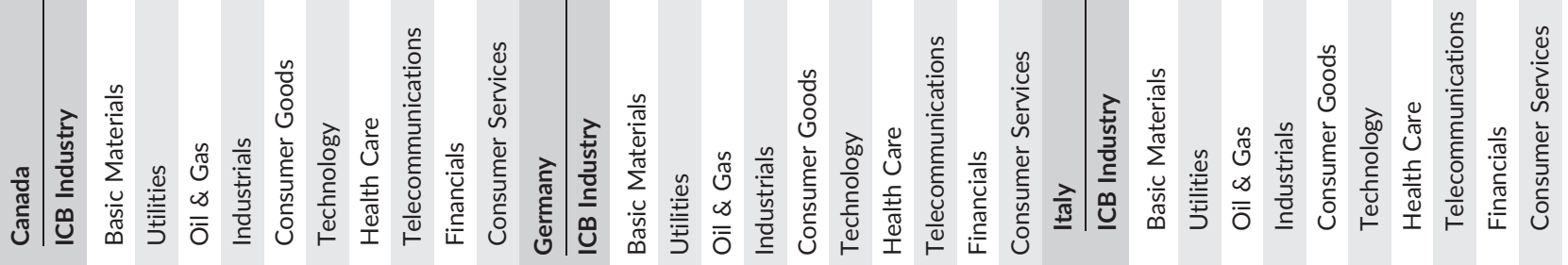

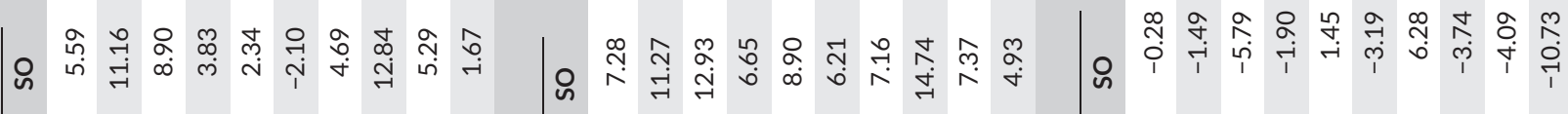

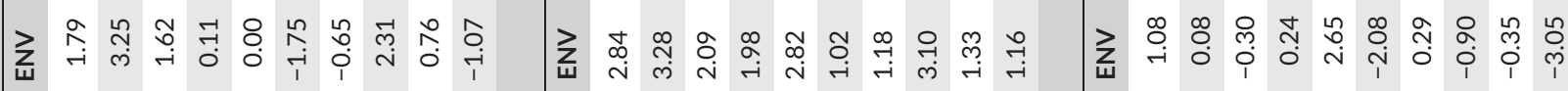

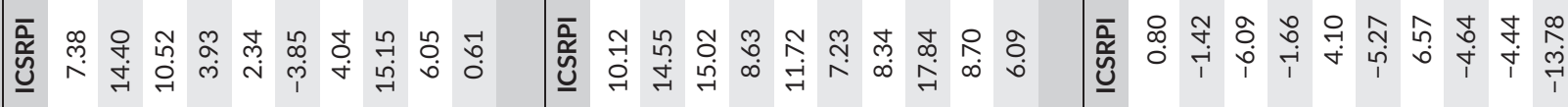

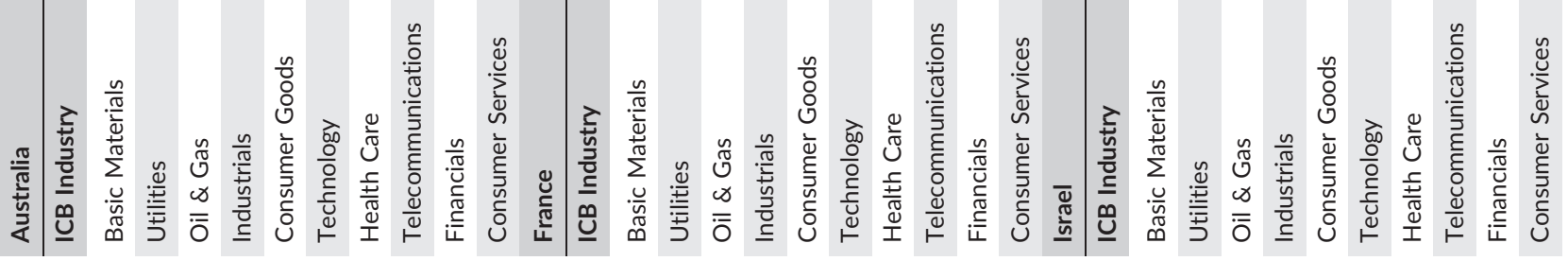




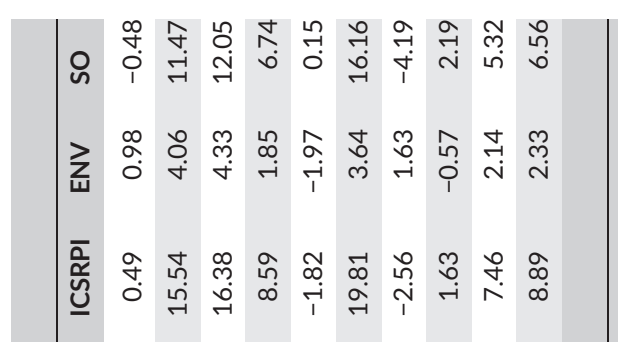

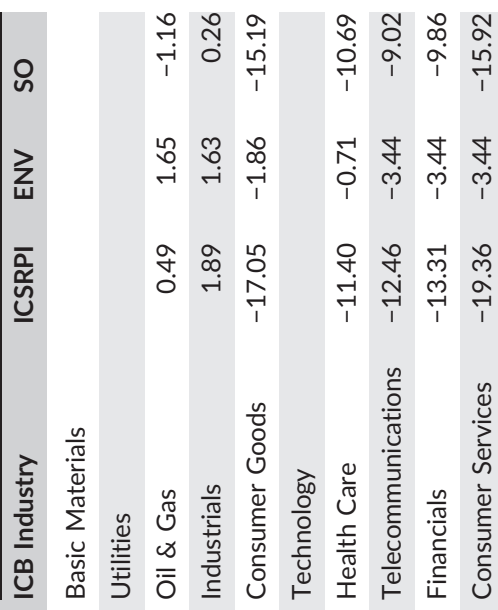

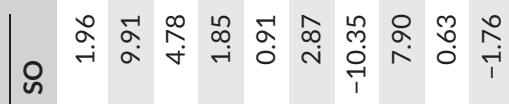

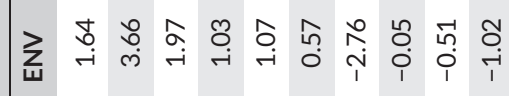

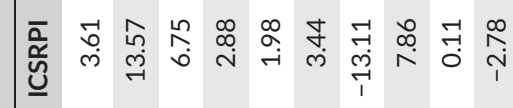

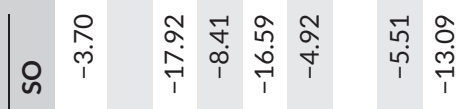

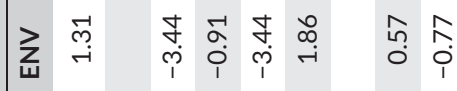

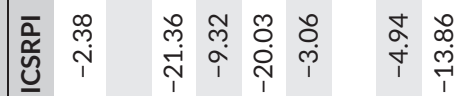

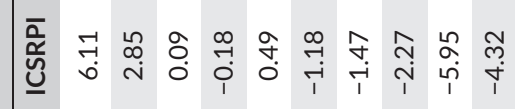

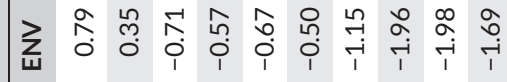

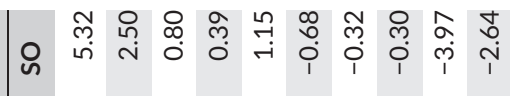

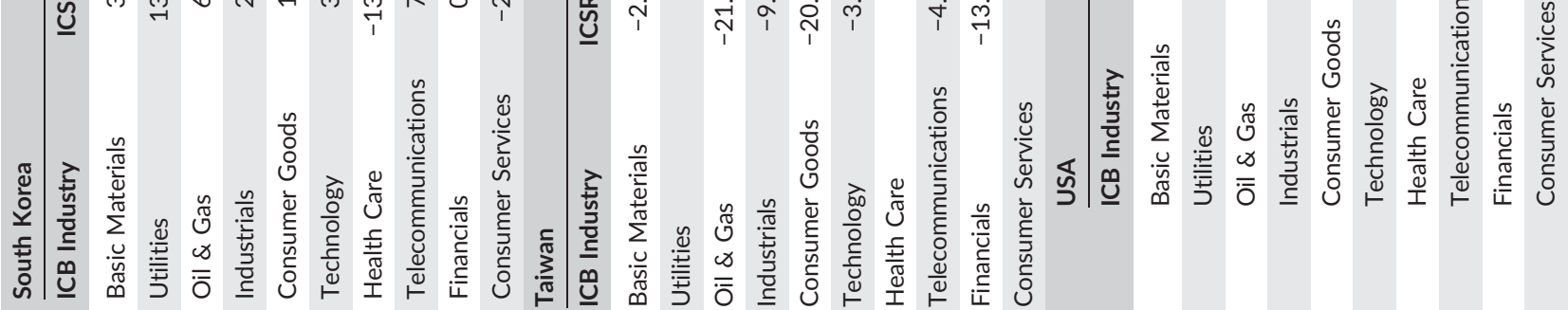

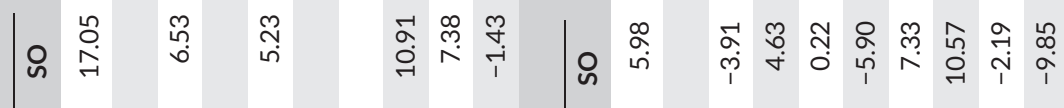

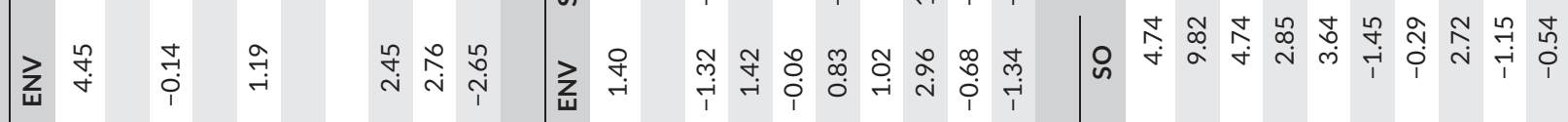

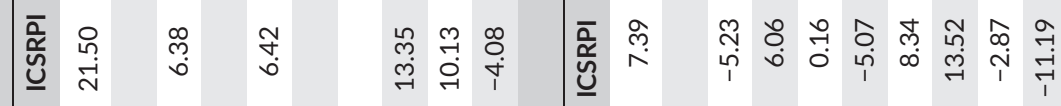

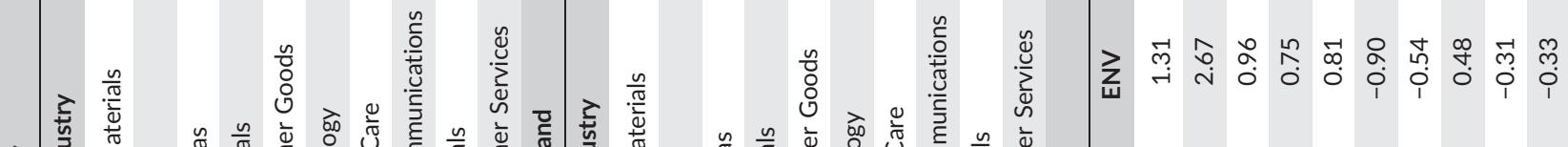

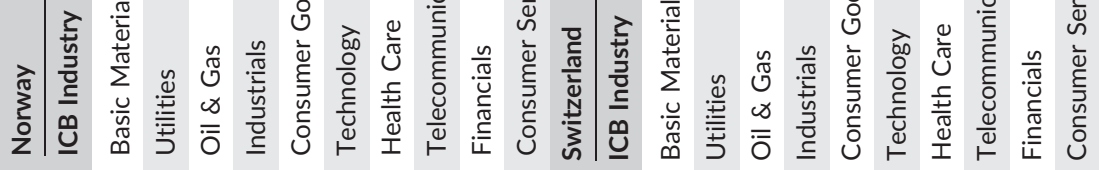

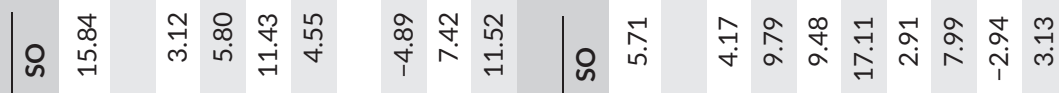

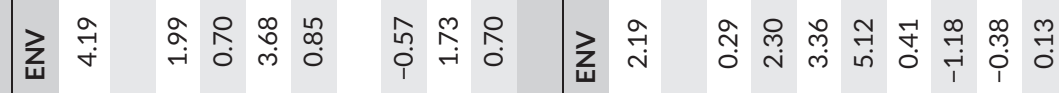

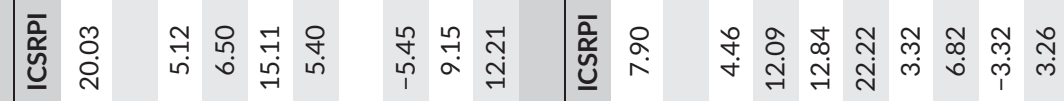






\section{Capítulo IX}

\section{Extensión y Utilidad del Indicador Sectorial de Sostenibilidad}

En las últimas décadas, hemos sido testigos de un importante boom en el comportamiento empresarial sostenible, que incluye una amplia gama de prácticas empresariales que conducen a una gestión más sostenible de los impactos generados por la actividad económica. A pesar de este crecimiento, no podemos hablar de homogeneidad en el estado actual de estas prácticas, lo que muestra que, si bien las acciones emprendidas por las empresas son similares, su desarrollo difiere marcadamente como consecuencia de las presiones institucionales.

Entre las numerosas presiones institucionales que afectan las decisiones empresariales, se destacan aquellas provenientes del campo organizacional o del sector de actividad en el que operan las empresas. Estas presiones organizativas provocan un 'isomorfismo mimético' que implica que las empresas que operan en el mismo sector desarrollen o adopten un comportamiento similar con respecto a los estándares de RSC, ya que (i) las organizaciones en situaciones de incertidumbre tienden a imitar conductas de otras compañías que son consideradas líderes en su sector de actividad; y (ii) enfrentan desafíos similares, forzando un cierto grado de convergencia en las políticas de RSC implementadas por las compañías.

Para determinar las discrepancias en la evolución de la RSC causada por el isomorfismo mimético a nivel sectorial, Amor-Esteban et al. $(2018)^{1}$ proponen el indicador compuesto que se ha descrito en el capítulo previo, el índice sectorial de prácticas de responsabilidad social corporativa, al que denominan ICSRPI (Industrial Corporate Social Responsibility Practices Index), que determina el nivel de penetración de RSC en los diez principales sectores de actividad mundiales. Siguiendo esta línea de investigación, este capítulo se propone un triple objetivo:

(i) el desarrollo y extensión de este indicador para los 39 sub-sectores de actividad que conforman los 10 principales sectores. Para ello, agrupamos las 2789 empresas que conforman la muestra en los 39 sub-sectores de actividad codificados según la categoría 'sector' del 'Industry Classification Benchmark (ICB) system' y, siguiendo el mismo proceso metodológico calculamos las puntuaciones para cada uno de ellos. El ranking obtenido proporciona una visión sectorial más amplia del estado de compromiso y el desarrollo de la RSC. Para evitar confusiones, nombraremos ICSRPI_10 al índice sectorial e ICSRPI_39 al índice sub-sectorial (el término ICSRPI en solitario engloba a los dos).

(ii) demostrar la utilidad del ICSRPI en investigaciones empíricas futuras al determinar el control del impacto que el isomorfismo mimético puede tener sobre el desarrollo de la RSC. Esto lo conseguimos a través de la propuesta de una medida nombrada ICMT (Industry Classification and Mimetic Typologies, este nombre hace referencia a la clasificación de la industria en función de las tipologías miméticas) que determina el impacto general de la compañía en las dimensiones social y ambiental. Esta medida fragmenta las empresas en cinco tipologías o niveles de impacto:

\footnotetext{
${ }^{1}$ Amor-Esteban, V., Galindo-Villardón, M. P., \& García-Sánchez, I. M. (2018). Useful information for stakeholder engagement: A multivariate proposal of an Industrial Corporate Social Responsibility Practices Index. Sustainable Development.
} 
la quinta tipología se compone de aquellas empresas que son clasificadas de alto impacto ambiental y social; la cuarta, contiene empresas de alto impacto ambiental y medio social, o viceversa; la tercera, alto impacto ambiental y bajo social, o viceversa, o impacto medio en ambas dimensiones; la segunda, impacto medio ambiental y bajo social, o viceversa; y la primera, impacto bajo ambiental y social. De este modo, cada empresa recibe un valor de 1-5 en relación al impacto de sus actividades y, por ende, los sub-sectores y sectores de actividad.

Una vez calculadas las puntuaciones de los ICSRPI_10 e ICSRPI_39 y de los ICMT_10 e ICMT_39, se analiza la utilidad de estos índices a través de la cuantificación de la coherencia entre sus puntuaciones, llegando a la conclusión de que el impacto de una empresa, particularmente sus riesgos y preocupaciones ambientales, es el mejor indicador de sus prácticas de RSC, ya que las empresas más expuestas a dichos riesgos, debido a la presión social de divulgar malas noticias ambientales, buscan la adopción o mejora de sus prácticas para gestionar y aumentar la confianza del usuario.

(iii) finalmente, profundizamos en los 10 sectores que conforman la clasificación del ICSRPI, caracterizando éstos a partir de las fortalezas y debilidades de los 39 sub-sectores de actividad que los componen en relación a las prácticas de RSC. Este estudio se realiza mediante un análisis MetaBiplot, que posibilita la obtención de una configuración consenso que integra las configuraciones resultantes de varios análisis biplot. Esto quiere decir que realizamos 10 análisis biplot - uno para cada uno de los principales sectores de actividad-, donde los individuos harán referencia a los sub-sectores que constituyan cada sector y las variables serán las 23 prácticas de RSC con las que se construyeron los indicadores compuestos en todos los casos.

De esta forma, a partir de los análisis biplot individuales caracterizaremos cada sector en función de las fortalezas y debilidades en las prácticas de RSC de los sub-sectores que los forman; $\mathrm{y}$, en un último paso, integraremos todos estos análisis biplot en un biplot consenso que mostrará en un único plano factorial los 39 sub-sectores y las 23 prácticas de RSC conjuntamente, consiguiendo una visión global de la sostenibilidad a nivel sub-sectorial.

Así, las empresas más contaminantes, con mayores riesgos ambientales pertenecientes a los sub-sectores silvicultura y papel, minería, gas, agua y multiservicios, productores de petróleo y gas, tabaco y electricidad, muestran su predilección por las políticas y reportes ambientales, los derechos humanos y la participación de sus grupos de interés; estas empresas adoptan prácticas de RSC más amplias, lo cual puede deberse a que utilizan la RSC para legitimar sus prácticas de negocio, por lo que se adhieren a las políticas de RSC como una forma de administrar su reputación y responder así a las expectativas de las partes interesadas. Las empresas dedicadas a la fabricación y distribución de todo tipo de productos industriales y a la construcción, presentan sus mayores niveles de RSC en el desempeño ambiental, las relaciones con la comunidad y la salud y seguridad de sus empleados; ya que sus actividades suponen un mayor riesgo laboral, y a través de la RSC estas empresas demuestran que su compromiso va más allá de los niveles de protección establecidos por la normativa. Y las organizaciones consideradas de menor impacto, como son las empleadas en servicios financieros, minoristas y telecomunicaciones, se enfocan en las prácticas dirigidas a la formación de empleados y su promoción, políticas de igualdad de oportunidades y fomento de la diversidad, las buenas relaciones con clientes y proveedores y todo lo relacionado en la lucha por contrarrestar el soborno.

Estos hallazgos son útiles para reforzar el conocimiento de las variaciones en las prácticas y el nivel de RSC en diferentes contextos institucionales a nivel internacional; por lo tanto, los resultados son esenciales para el diseño y la elección correcta del enfoque. Estos resultados permiten comprender las presiones sobre el compromiso social y ambiental de los diferentes sectores y sub-sectores, facilitando así la orientación de los procesos regulatorios hacia la promoción de políticas que mejoren el comportamiento empresarial sostenible. Estos datos pueden guiar a los gerentes a evaluar los impactos de las actividades empresariales en sus procesos de toma de decisiones.

A continuación, presentamos toda esta información detallada de manera extensa en el artículo de investigación "An extension of the industrial corporate social responsibility practices index: New information for stakeholder engagement under a multivariate approach" actualmente en prensa en la revista Corporate Social Responsibility and Environmental Management (2016: Q1 - JIF: 2.852; 2017: Q1 - JIF: 4.918). 
Research paper in press:

Title: An extension of the industrial corporate social responsibility practices index: New information for stakeholder engagement under a multivariate approach

Authors: Víctor Amor-Esteban

Ma-Purificación Galindo-Villardón

Isabel-María García-Sánchez

Fátima David

Journal: Corporate Social Responsibility and Environmental Management

\begin{tabular}{c|c|c|c|c} 
Year & Category Name & $\begin{array}{c}\text { Total Journals } \\
\text { in Category }\end{array}$ & $\begin{array}{c}\text { Journal Rank } \\
\text { in Category }\end{array}$ & $\begin{array}{c}\text { Quartile } \\
\text { in Category }\end{array}$ \\
\hline 2016 & Environmental Studies & 105 & 19 & Q1 \\
\hline 2017 & Environmental Studies & 108 & 10 & Q1
\end{tabular}

* Journal Impact Factor: 2016 - 2.852; 2017 - 4.918; 5 Year Impact Factor: 5.856.

* Publisher: Wiley

* Google scholar cites:

\begin{tabular}{l|l} 
APA & $\begin{array}{l}\text { Amor-Esteban, V., Galindo-Villardón, M. P., García-Sánchez, I. M., \& David, F. } \\
\text { (2018). An extension of the industrial corporate social responsibility practices index: } \\
\text { New information for stakeholder engagement under a multivariate approach. } \\
\text { Corporate Social Responsibility and Environmental Management. }\end{array}$ \\
\hline ISO & $\begin{array}{l}\text { AMOR-ESTEBAN, Víctor, et al. An extension of the industrial corporate social } \\
\text { responsibility practices index: New information for stakeholder engagement under a } \\
\text { multivariate approach. Corporate Social Responsibility and Environmental } \\
\text { Management, 2018. }\end{array}$ \\
\hline MLA & $\begin{array}{l}\text { Amor-Esteban, Víctor, et al. "An extension of the industrial corporate social } \\
\text { responsibility practices index: New information for stakeholder engagement under a } \\
\text { multivariate approach." Corporate Social Responsibility and Environmental } \\
\text { Management (2018). }\end{array}$
\end{tabular}

*The paper is numbered independently and includes pages 263-276 (14) of the global document. 



\title{
An extension of the industrial corporate social responsibility practices index: New information for stakeholder engagement under a multivariate approach
}

\author{
Víctor Amor-Esteban ${ }^{1}$ (D) | Ma-Purificación Galindo-Villardón ${ }^{1}$ | \\ Isabel-María García-Sánchez ${ }^{2}$ | Fátima David ${ }^{3}$
}

\author{
${ }^{1}$ Department of Statistics, Campus Miguel de \\ Unamuno, University of Salamanca, \\ Salamanca, Spain \\ ${ }^{2}$ Department of Business Administration, \\ Campus Miguel de Unamuno, Faculty of \\ Economics, University of Salamanca, \\ Salamanca, Spain \\ ${ }^{3}$ Escola Superior de Tecnologia e Gestão, \\ Instituto Politécnico da Guarda, Guarda, \\ Portugal \\ Correspondence \\ Víctor Amor-Esteban, Department of \\ Statistics, Campus Miguel de Unamuno, \\ c/Alfonso X El Sabio s/n, University of \\ Salamanca, 37007 Salamanca, Spain. \\ Email: victor_aes@hotmail.com
}

\begin{abstract}
The aim of this paper is to extend the Industrial Corporate Social Responsibility Practices Index proposed for the 10 main industries in the 39 sectors of activity that comprise them. This extension will provide more detailed information on CSR practices at the industrial level, especially about sustainable development and environmental concerns. In addition, this paper stablishes an aggregate measure of industrial classification and mimetic typologies. It will tabulate the overall impact that the economic activity of a company has on society and environment. Thereby, the relationships between these indicators and the mimetic institutional forces are studied, testing these forces indicate that companies from sectors considered to have greater impact/risk have higher corporate social responsibility (CSR) scores than companies from other sectors. Additionally, using the MetaBiplot statistical multivariate technique, which by the comparison and integration of several subspaces provides a global view of sustainability at a sectoral level, it was found that the most polluting companies with the highest environmental risks-forestry and paper, mining, oil and gas producers, gas, water, and multi-utilities, tobacco and electricity sectors-show their predilection for environmental policies and reports, human rights, and stakeholder participation. Moreover, the less polluting companies-banks, insurance, media, telecommunications, real state, and general retailers-are more intensive on staff and implement policies aimed at favoring: the personal and work-life balance with systems for employee training and promotion; the equal opportunities and participation; the maintenance of good customer and supplier relations; and the fight to counteract bribery.
\end{abstract}

\section{KEYWORDS}

composite index, corporate social responsibility (CSR), environmental policy, industry, multivariate statistics, stakeholder engagement, sustainable development

\section{1 | INTRODUCTION}

In the last few decades, we have witnessed an important boom in corporate social responsibility (CSR), which includes a wide range of business practices that lead to a more sustainable management of the impacts generated by economic activity. Despite this growth, we cannot speak of homogeneity in the current state of these practices, which shows that, although the actions undertaken by the companies are similar, their development differs markedly as a consequence of the institutional pressures (Amor-Esteban, García-Sánchez, \& 
Galindo-Villardón, 2017; Esteban, Villardón, \& Sánchez, 2017). In this sense, the institutional theory postulates that it cannot be ignored that the institutional environments in which companies operate establish rules of behavior that they must fulfill in order to legitimize themselves before the society in which they are immersed (Campbell, 2007).

Among the numerous institutional pressures that affect business decisions, those coming from the organizational field or sector of activity in which the companies operate stand out (Aerts, Cormier, \& Magnan, 2006; Amor-Esteban, Galindo-Villardón, \& García-Sánchez, 2018; Halkos \& Skouloudis, 2016; Salem, Shawtari, Shamsudin, \& Hussain, 2017). These organizational pressures provoke a "mimetic isomorphism" that implies that companies operating in the same sector develop or adopt similar behavior with respect to CSR standards, because (a) organizations in uncertainty situations tend to imitate behaviors from other companies that are considered leaders in their sector of activity and (b) they face similar challenges, forcing a certain degree of convergence in CSR policies implemented by corporations (DiMaggio \& Powell, 1983).

In order to determine the discrepancies in the CSR evolution caused by the mimetic isomorphism at the industry level, AmorEsteban et al. (2018) propose a composite indicator, the Industrial Corporate Social Responsibility Practices Index (hereinafter, ICSRPI), which determines the level of CSR penetration in the top 10 global industries. This composite indicator identifies sustainability at the organizational level through a process of statistical aggregation of business practices analyzed from the social and environmental dimensions. Methodologically, it is developed in seven stages that together establish a theoretical framework of the institutional context and the CSR dimensions; the selection of CSR measures that determine a high level of quality in reference to their relevance, accessibility, and anaIytical consistency; the imputation of missing data; the elimination of irrelevant business practices according to the theoretical model with a methodological basis; the data standardization; the weighting of the practices identified as relevant from the theoretical and methodological point of view; and finally, the aggregation of the scores of the CSR practices by means of a weighted sum that determines the global ones of the ICSRPI.

Following this research, our paper proposes a triple objective: first, the development of this indicator for the 39 sectors of activity that make up the 10 main industries in order to provide a broader industrial view of the state of commitment and CSR development that will be very useful for comparisons in relation to social and environmental sustainability issues, the development of benchmarking processes in the sectors, and their levels of responsible business conduct; second, to demonstrate the usefulness of the ICSRPI in future empirical investigations when determining the control of the impact that mimetic isomorphism can have on CSR development, through a proposal of industry classification and mimetic typologies (ICMT), providing a greater robustness to the results. Finally, in a complementary manner and based on exploratory multivariate statistical methods of the three-way data family, such as the MetaBiplot (Martín-Rodríguez, Galindo-Villardón, \& Vicente-Villardón, 2002), which allows us to compare and integrate the sectors of activity around the 23 sustainability practices that compose the index, we will delve into the CSR practices to characterize the virtues and deficiencies of each of the sectors through an exploratory biplot study of each one of them. Likewise, we will integrate these subspaces, achieving a global vision of sustainability at a sectoral level.

\section{2 | THEORETICAL FRAMEWORK}

CSR, understood as the business practices and commitments with a view toward sustainability, shows widespread behavior patterns worldwide, whose development and evolution vary substantially according to the institutional pressures that characterize the environment in which the companies operate (Amor-Esteban et al., 2017; Esteban et al., 2017; Jones \& Nisbet, 2011). These evolutionary differences of CSR are due to the fact that the institutional environment in which the firm operates establishes a series of opportunities and barriers around these business decisions associated with the specific expectations of the actors and the current standards of behavior in the society in which it acts (Campbell, 2007). Adopting homogenous CSR behavior patterns according to institutional pressures entails a business isomorphism that facilitates the firm's survival.

Thus, faced with the traditional position that CSR is a voluntary business commitment, knowing the institutions that affect CSR development is essential to understand what incentives and restrictions companies have in their environments in order to promote or correct them and achieve greater sustainability (Dennis, 2011; Matten \& Crane, 2005; Windsor, 2004). Expectations and rules of behavior that cause business isomorphism, in accordance with Matten and Moon (2004), come from three forces or pressures: (a) normative, informal, and formal pressures imposed by prevailing cultural values in society or exerted by supra-organizations; (b) coercive pressures, which emanates from the standards, rules, or laws that determine the legal and/or professional framework of business practices; and (c) mimetic pressures, traditionally associated with the practices that leading companies impose in their sector.

In fact, there is a fruitful line of research that has identified the importance of coercive and normative pressures at the country level in the evolution of CSR practices (Demirbag, Wood, Makhmadshoev, \& Rymkevich, 2017; Ferri, Oelze, Habisch, \& Molteni, 2016; GallegoÁlvarez \& Ortas, 2017; García-Sánchez \& García-Meca, 2017; Martínez-Ferrero \& García-Sánchez, 2016). However, there is a great lack of knowledge in relation to the role that mimetic pressures play in CSR practices, traditionally linked with industries (Martínez-Ferrero \& García-Sánchez, 2016).

Mimetic isomorphism is especially relevant in sectors with high uncertainty, causing the follower companies to imitate the behavior of successful and leading organizations, referents in their sector of activity, in order to survive. The selection of competing companies at a sectoral level is determined because both face similar challenges associated with their economic activity and the expectations of their stakeholders. Thus, companies, to the extent that their competitors adopt a CSR initiative, are predisposed to adopt that behavior with the objective of social legitimization and to remain active (Matten \& Moon, 2004). Society in general and, stakeholders in particular, perceive different environmental and social risks depending on the economic activity performed by corporations. 
In other words, each industry determines an environment with standards and pressures about which companies must respond, exerting significant influence on their strategic decisions (Keats \& Hitt, 1988; Walters, Kroll, \& Wright, 2010). Goll and Rasheed (2004), Young and Thyil (2014), and Chen, Zeng, Lin, and Ma (2017) argue that environmental and social corporate performance responds to industrial contexts. Thus, companies that operate in sectors such as oil and gas, considered more polluting, focus on developing policies that reduce their environmental impact, whereas firms that operate in the financial sector, more intensive in personnel, implement more policies aimed at favoring personal and work-life balance, equality, etc. (Jackson \& Apostolakou, 2010). In this sense, various authors-that is, Branco and Rodrigues (2008), Parsa and Deng (2008), Wanderley, Lucian, Farache, and de Sousa Filho (2008), Bayoud, Kavanagh, and Slaughter (2012), Young and Marais (2012), Weber (2014)-have observed that the way of reporting to stakeholders varies depending on the industry in which the company operates. Thereon, companies must achieve a good understanding of the stakeholder's pressures and expectations according to the sector in which they operate because of CSR information on environmental and social dimensions influences purchase, employment, and investment intentions of various stakeholders (Alniacik, Alniacik, \& Genc, 2011; Jenkins, 2004).

In this vein, Amor-Esteban et al. (2018) propose the ICSRPI to determine CSR practices at an industrial level. This indicator provides a value to be used as a reference, making it possible to identify those industries that have the greatest deficiencies in sustainability systems, which facilitates the planning of various improvement actions, guiding stakeholders or managers in their decision-making processes of decisions. Likewise, this indicator should be useful in future academic research to correct the problems of bias associated with the lack of control of the sector as an institutional factor with explanatory capacity in CSR practices. The ICSRPI aggregate composite indicator proposal was made only for the 10 most significant industries worldwide. In this sense, the main objective of this research is the extension and development of this indicator in the 39 sectors that make up these industries, coding companies according to the "Sector" group; this disaggregation will make it possible for us to know the discrepancies between the sectors of activity and design sustainability actions more precisely.

\section{3 | METHODOLOGY}

\section{1 | Population and sample}

In order to achieve the established objectives, the companies included in the EIRIS sustainability database were selected as the target population, providing a sample of 2,789 worldwide companies that were listed on the stock exchange in 2014. Geographically, companies are biased from Europe, America, Asia, and Australia, with percentages of $33.88 \%, 32.52 \%, 29.76 \%$, and $3.84 \%$, respectively. The selected companies are the most active in sustainability terms, the year 2014 being the peak of CSR growth in the decade 2004-2014, extremely important due to freedom of the press and technological development; indirectly, it also responds to the facility for obtaining information about the requirements of the stakeholders and corporate behavior (Martínez-Ferrero \& García-Sánchez, 2016).

EIRIS database comprises different areas, including environmental, human rights, employees, stakeholders, and board social issues; it assigns criterial grades to specific attributes of each item. EIRIS addresses the information that companies disclose online and through questionnaires and surveys sent to companies. Its procedure might involve a subjective assessment of relevant corporate practices, but the topics addressed and the questions posed are designed for achieving a reasonable assessment of the activities evaluated.

Following the Industry Classification Benchmark (ICB), economic activity can be structured around four levels: 104 sub-sectors, 39 sectors, 19 superstructures, and 10 industries; we show the frequency table for both indices. In the ICSRPI, the companies were coded according to the ICB industry (see Table 1) for the 10 main industries, where the financial and industrial industries represent around $40 \%$ of the sample, consumer goods and services more than $25 \%$, and the rest of industries has an individual weight of less than $10 \%$. For the disaggregation and development of this indicator, the companies in the sample were coded according to the ICB sector (see Table 2), giving rise to the 39 sectors of activity that constitute them, with a low level of dispersion. From now on, to facilitate their understanding and comprehension, we will call these indices ICSRPI_10 and refer to its individuals as "industry," and ICSRPI_39 with its individuals as "sector."

\section{2 | Variables}

Based on the information provided by the EIRIS database, CSR practices are specified through 23 items that take values from 0 to 4 , which identify inadequate, weak, moderate, good, and exceptional CSR levels. These items are commonly used in order to measure environmental and social performance in research papers (e.g., Boudt, Cornelissen, \& Croux, 2013; García-Sánchez \& García-Meca, 2017; León, 2015; Martínez-Ferrero \& García-Sánchez, 2016). Table 3 shows the CSR practices and their performance composition by dimensions, ranging from environmental performance and human rights, employees, stakeholders, and ethics to social performance.

TABLE 1 Distribution of companies following the industry classification (ICB system), ICSRPI_10

\begin{tabular}{lcr} 
ICB industry & Frequency & $\%$ \\
\hline Basic materials & 232 & 8.3 \\
\hline Consumer goods & 350 & 12.5 \\
\hline Consumer services & 398 & 14.3 \\
\hline Financials & 602 & 21.6 \\
\hline Health care & 153 & 5.5 \\
\hline Industrials & 529 & 19.0 \\
\hline Oil and gas & 151 & 5.4 \\
\hline Technology & 173 & 6.2 \\
\hline Telecommunications & 84 & 3.0 \\
Utilities & 117 & 4.2 \\
\hline Total & 2,789 & 100 \\
\hline
\end{tabular}

Note. ICB: Industry Classification Benchmark; ICSRPI: Industrial Corporate Social Responsibility Practices Index. 
TABLE 2 Distribution of companies following the sector classification (ICB system), ICSRPI_39

\begin{tabular}{|c|c|c|}
\hline ICB sector & Frq & $\%$ \\
\hline Aerospace and defense & 31 & 1.1 \\
\hline Alternative energy & 6 & 0.2 \\
\hline Automobiles and parts & 79 & 2.8 \\
\hline Banks & 195 & 7.0 \\
\hline Beverages & 41 & 1.5 \\
\hline Chemicals & 104 & 3.7 \\
\hline Construction and materials & 104 & 3.7 \\
\hline Electricity & 72 & 2.6 \\
\hline Electronic and electrical equipment & 70 & 2.5 \\
\hline Financial services & 134 & 4.8 \\
\hline Fixed line telecommunications & 42 & 1.5 \\
\hline Food and drug retailers & 52 & 1.9 \\
\hline Food producers & 82 & 2.9 \\
\hline Forestry and paper & 10 & 0.4 \\
\hline Gas, water, and multiutilities & 45 & 1.6 \\
\hline General industrials & 53 & 1.9 \\
\hline General retailers & 126 & 4.5 \\
\hline Health care equipment and services & 65 & 2.3 \\
\hline Household goods and home construction & 48 & 1.7 \\
\hline Industrial engineering & 101 & 3.6 \\
\hline Industrial metals and mining & 59 & 2.1 \\
\hline Industrial transportation & 67 & 2.4 \\
\hline Leisure goods & 25 & 0.9 \\
\hline Life insurance & 49 & 1.8 \\
\hline Media & 95 & 3.4 \\
\hline Mining & 59 & 2.1 \\
\hline Mobile telecommunications & 42 & 1.5 \\
\hline Nonlife insurance & 74 & 2.7 \\
\hline Oil and gas producers & 101 & 3.6 \\
\hline Oil equipment, services, and distribution & 44 & 1.6 \\
\hline Personal goods & 63 & 2.3 \\
\hline Pharmaceuticals and biotechnology & 88 & 3.2 \\
\hline Real estate investment and services & 77 & 2.8 \\
\hline Real estate investment trusts & 73 & 2.6 \\
\hline Software and computer services & 87 & 3.1 \\
\hline Support services & 103 & 3.7 \\
\hline Technology hardware and equipment & 86 & 3.1 \\
\hline Tobacco & 12 & 0.4 \\
\hline Travel and leisure & 125 & 4.5 \\
\hline Total & 2,789 & 100 \\
\hline
\end{tabular}

Note. ICB: Industry Classification Benchmark; ICSRPI: Industrial Corporate Social Responsibility Practices Index.

For the study of isomorphism or mimetic pressure, we rely on two measures that quantify the risks and pressures of the company based on the impact of its actions on social welfare and the preservation of the environment. These measures, also obtained from the EIRIS database, are called "Social Impact" and "Environmental Impact;" both are indicators of the global impact of the company's activities on environmental and social concerns. They take value 1 if the firm is of low impact, 2 if the firm is of medium impact, and 3 of high impact. Likewise, in order to observe the global effect and highlight the similarities and differences among the organizations, an aggregate measure of ICMT is proposed, which determines the company's overall impact on the social and environmental dimensions. We therefore apply a methodology similar to that applied in the book The Business Case for Corporate Social Responsibility: Understanding and Measuring Economic Impacts of Corporate Social Performance (Schreck, 2009), by means of which we fragmented the sample into five typologies or levels of impact: The fifth typology contains firms that are considered of high social and environmental impact; the fourth typology is composed by companies of high social impact and medium environmental impact, or vice versa; the third is formed by companies of high social impact and low environmental, or vice versa, or even of medium impact in both dimensions; the second is made up of companies of medium social impact and low environmental, or vice versa; finally, the first typology consists of those organizations of low social and environmental impact (see Figure 1).

\section{3 | Research methods}

\subsection{1 | MetaBiplot analysis}

MetaBiplot (Martín-Rodríguez et al., 2002) is a useful technique for the treatment of information from several data matrices, in our case, the 10 main industries, because it makes it possible to obtain a consensus configuration that integrates the configurations resulting from several analyses; in this case, it compares and integrates several biplot analyses (Gabriel, 1971; Galindo, 1986). To obtain the consensus configuration, it seeks the set of orthogonal axes that best match the main directions of inertia.

Therefore, in the case of $g$ groups $X_{g}$, with $g>2$ (in our case, $g=10$ industries), with $n_{i}$ units in each of the groups ( $n_{i}=$ number of activity sectors that make up the industry i), using the same $p$ variables in each of them (23 sustainability practices), and applying the same previous transformation to all groups (standardized by columns), they are subjected to a Biplot analysis, obtaining the decomposition into singular values, such that in the comparison of two or more subspaces defined by the markers of several groups in a CMP-Biplot (GH-Biplot), where

$X(I \times J)$ is the data matrix.

$r$ is the range of $X(r \leq \min (I, J))$.

$U(I \times r)$ is the matrix whose columns contain the eigenvectors of $X X^{\prime}$.

$V(J \times r)$ is the matrix whose columns contain the eigenvectors of $X^{\prime} X$.

$D(r \times r)$ is a diagonal matrix that contains the eigenvalues of $X$.

it must be fulfilled that $U^{\prime} U=V^{\prime} V=I$, that is, the columns of $U$ and $V$ are orthonormal; this property ensures the uniqueness of the factorization.

$$
\begin{gathered}
X=G H^{\prime}=U D V^{\prime} \\
G=U \quad H=V D
\end{gathered}
$$

For the rows, let $b$ be a vector in the original $n$-dimensional space, and $\partial_{t}$ the angle between vector $b$ and the closest vector parallel to it in the space generated by the markers in the group's rows 
TABLE 3 Corporate social responsibility performance composition

Environmental performance

\begin{tabular}{|c|c|}
\hline \multicolumn{2}{|l|}{ Environment } \\
\hline Environmental policy & How does EIRIS rate the company's environmental policy and commitment? \\
\hline Environmental management & How does EIRIS rate the company's environmental management system? \\
\hline Environmental reporting & How does EIRIS rate the company's environmental reporting? \\
\hline \multicolumn{2}{|l|}{ Social performance } \\
\hline \multicolumn{2}{|l|}{ Human rights } \\
\hline Human rights policy & What is the extent of policy addressing human rights issues? \\
\hline Human rights systems & What is the extent of systems addressing human rights issues? \\
\hline Human rights reporting & Does the company report on human rights issues? \\
\hline \multicolumn{2}{|l|}{ Employees } \\
\hline Equal opportunities (policy) & How good is the company's policy on equal opportunity and diversity issues? \\
\hline Equal opportunities (systems) & How clear is the evidence of systems and practices to support equal opportunities and diversity? \\
\hline Health and safety systems & How clear is the evidence of health and safety systems? \\
\hline Training & How clear is the evidence of systems to support employee training and development? \\
\hline \multicolumn{2}{|l|}{ Stakeholders } \\
\hline Community relations & How clear is the company's commitment to community or charitable work? \\
\hline Customer/supplier relations policy & Does the company have policies on maintaining good relations with customers and/or suppliers? \\
\hline Responsibility for stakeholders & How many stakeholder issues have been allocated to board members? \\
\hline Stakeholder engagement & What level of engagement with stakeholders is disclosed by the company? \\
\hline Stakeholder policy & How good are the company's policies toward its stakeholders overall? \\
\hline Stakeholder systems & How good is the company's quantitative systems on stakeholder relationships? \\
\hline Stakeholder reporting & How good are the company's management reporting for stakeholders overall? \\
\hline \multicolumn{2}{|l|}{ Ethics and governance } \\
\hline Codes of ethics & Does the company have a code of ethics and, if so, how comprehensive is it? \\
\hline Codes of ethics systems & Does the company have a system for implementing a code of ethics and, if so, how comprehensive is it? \\
\hline Countering bribery policy & What is the extent of the company's policy for countering bribery? \\
\hline Countering bribery systems & What is the extent of the company's system for countering bribery? \\
\hline Countering bribery reporting & What is the extent of the company's reporting on countering bribery? \\
\hline ESG risk management & $\begin{array}{l}\text { How well do the board and senior management address company-wide ESG } \\
\text { (Environmental, Social, and Governance) risks and opportunities? }\end{array}$ \\
\hline
\end{tabular}

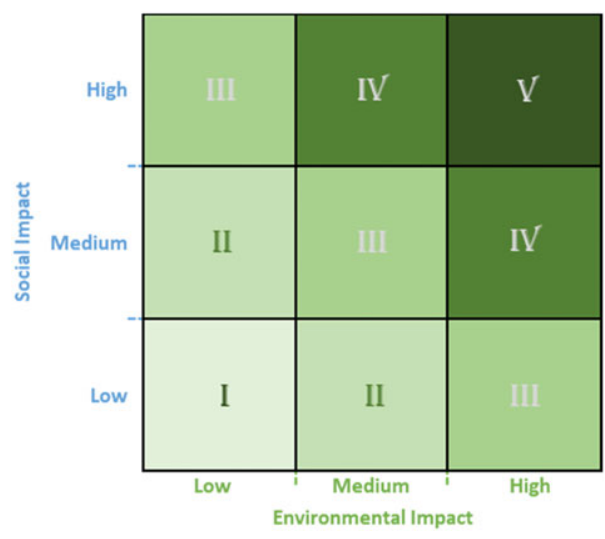

FIGURE 1 Diagram of industry classification and mimetic typologies [Colour figure can be viewed at wileyonlinelibrary.com]

$t(t=1,2, \ldots, g)$. Then the value of $b$ that minimizes the angle $\partial_{t}$ and, therefore, maximizes $V=\sum_{t=1}^{g} \cos ^{2} \partial_{t}$ (sum of squares of the cosines of the angles) is given by the eigenvector $b_{1}$ corresponding to the highest eigenvalue $\mu_{1}$ from the matrix $G=\sum_{t=1}^{g} U_{t} U_{t}^{\prime}$
For the columns, as for the rows but corresponding to the matrix $H=\sum_{t=1}^{g} V_{t} D_{t} D_{t} V^{\prime}{ }_{t}$

For the definition of $\partial_{t} \rightarrow \cos ^{2} \partial_{t}=b^{\prime} U_{t} U_{t}^{\prime} b$; with which we have

$$
V=\sum_{t=1}^{g} \cos ^{2} \partial_{t}=b^{\prime} G b
$$

The development is similar, only changing the corresponding markers.

For this research, the main objective of the MetaBiplot is to obtain a global view of sustainability at sector level, showing in a subspace of low dimension the 39 sectors of activity in which companies are grouped according to the 23 sustainability practices studied. Likewise, these sectors will be fragmented into 10 individual biplot analyses belonging to the 10 main industries, characterizing them around the values in the CSR practices of the sectors that form them. For its correct understanding, we follow the following interpretation guidelines, both for the MetaBiplot and for the individual biplots.

Through the order found in the orthogonal projections of the activity sectors (row markers, points) on CSR practices (column 
markers, vectors), we characterize the different sectors, thus learning the practices most demanded by each one of them; by means of the cosines of the angles formed by the vectors, we evaluate the relationships between CSR practices, because small acute angles are associated with high positive correlations; finally, depending on the distance between points, we identify sectors with similar profiles in relation to their CSR standards, because nearby points are associated with great similarity. The graphs and calculations developed in this research were processed with the MultBiplot software (VicenteVillardón, 2010).

\section{I RESULTS OF EMPIRICAL ANALYSIS AND DISCUSSION}

The results summarized in Table 4 show the ICSRPI scores and their industrial classification and ICMT mimetic typologies, where we found important differences between the 10 main industries, basic materials and utilities being the most sustainable and financials and consumer services the most lagging; and the synthesized results for the breakdown of the 39 sectors of activity that form them.

Companies belonging to the alternative energy sector lead the ICSRPI_39 ranking; these include companies that develop or manufacture renewable energy equipment that uses sources such as solar, wind, tidal, or geothermal energy, among others, and companies that produce alternative fuels such as ethanol, methanol, hydrogen, and biofuels.

The most polluting sectors, with greater environmental concerns, show the highest positive values; these companies therefore adhere to broader CSR policies to legitimize their business practices, and thus focus on reducing their environmental impact and meeting the expectations of stakeholders (Halkos \& Skouloudis, 2016). Hence, we find here companies dedicated to forestry and paper, such as owners and operators of forest plantations, oil and gas producers, chemical products, companies dedicated to the exploration or extraction of coal, fossil fuel combustion, manufacturers and distributors of vehicles, aircraft, heavy machinery, and all kinds of industrial activities. All of these have their impact on the environment (degradation or pollution, waste production, or increase in energy consumption), and therefore, these companies are considered high impact, that is, the enterprises most exposed to environmental risks that attempt to improve their sustainability commitment with the aim of increasing user confidence by managing those risks, as a result of the social pressure to spread bad environmental news (Casey \& Grenier, 2014; Ekelenburg, 2016; Heikkurinen, 2010; Peters \& Romi, 2014; Semenova \& Hassel, 2008; Simnett, Vanstraelen, \& Chua, 2009).

In contrast, in the last positions of the ranking, we find the less polluting sectors with greater preference for the rights of their employees or business ethics, composed of insurance companies, banks, travel and leisure companies, telephony, retailers, consultancy services, producers, operators and broadcasters of radio, television, music, and entertainment, or financial services, among others. Firms in these sectors are not considered to have a high environmental impact, and partly because of this, their CSR scores are low (Belu, 2009; Scholtens, 2011; Weber, 2014).
TABLE 4 Industrial corporate social responsibility practices indexICSRPI_10 and ICSRPI_39-with their industry classification and mimetic typologies-ICMT

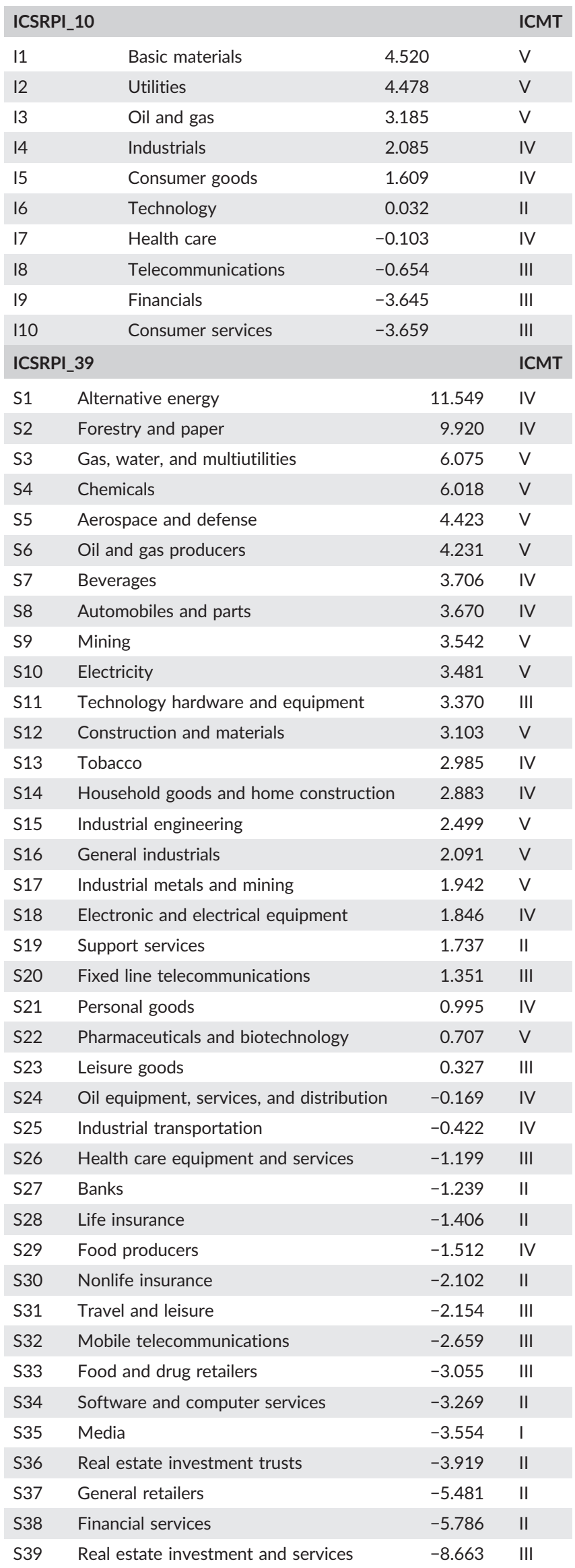


Next, we analyze the utility of these indices through the quantification of the consistency between their scores and their industrial classification and mimetic typologies (ICSRPI-ICMT). This classification fragments the sample into five typologies based on overall impact, the first one having the least impact and the fifth, the most impact. According to this classification, each sector, depending on the companies comprising it, is assigned to one of these typologies, and therefore industries (see Figure 2); as well as their relation to the impact of their activities in an individualized way with social welfare (ICSRPI-Social Impact) and the preservation of the environment (ICSRPI-Environmental Impact).

We show the results of these relationships through the Pearson correlation coefficient between the ICSRPI_10 and ICSRPI_39 indices with the variables that measure the impact of the firm on social and environmental issues and the mimetic typologies proposed in the ICMT classification (Table 5). At first glance, we see that the results indicate strong positive associations between ICSRPI_10 and the impact of the company, the strongest relationship being with the ICMT classification (Pearson's $r=0.788 p$-value $=0.007$ ) that refers to the global impact, which translates into both environmental (Pearson's $r=0.769 p$-value $=0.009$ ) and social (Pearson's $r=0.723$ $p$-value $=0.018)$ issues, and the impact of business activities has an influence on the adoption or improvement of CSR practices of the company, being most notable in those with the greatest environmental impact. This likewise occurs for the ICSRPI_39 index, the relationships being somewhat smaller, but all highly significant. This information verifies that those companies with the greatest environmental and social impacts show a greater commitment to sustainability, which reveals that these measures are useful indicators of the pressure generated by the interest groups for the development of institutionalized forms of CSR policies and the right implementation of CSR practices.

A linear regression analysis was performed to further examine the mentioned relationships. Specifically, the linear association between the ICSRPI_10 and the ICSRPI_39 with the variables that measure the environmental and social impact was investigated through the adjustment of simple linear regression models, where the indices were assigned as dependent variables. Figures 3 and 4 represent the scatter diagrams in which each pair of values $(x, y)$ is labelled by industry and sector, respectively (see Table 4). Also, the prediction line of simple linear regression accompanied by $95 \%$ confidence intervals is shown. The concentration of the different data points in the graph near the regression line is indicative of the importance of the linear association between the pair of variables examined. In particular, $59 \%$ of the variability of the ICSRPI_10 is explained by its impact on the environment ( $p$-value $=0.009$ and $\left.r^{2}=0.551\right)$ and $52 \%$ by its social impact ( $p$-value $=0.018$ and $\left.r^{2}=0.522\right)$; and in reference to the ICSRPI_39, $31 \%$ of the variability is explained by its impact on the environment ( $p$-value $=0.000$ and $\left.r^{2}=0.310\right)$ and $23 \%$ by its social impact ( $p$-value $=0.002$ and $\left.r^{2}=0.235\right)$.

Next, we delve into the 10 industries that make up the ICSRPI classification, characterizing them based on the strengths and weaknesses of the 39 activity sectors they comprise in relation to CSR standards. This study is carried out through a MetaBiplot analysis, which makes it possible to obtain a consensus configuration that integrates the configurations resulting from several biplot analyses, in our case for each of the industries. For a correct application of the biplot methods, several measures are essential, specifically, the eigenvalues and the explained variance (see Table 6). We obtain inertia percentages close to or above $80 \%$ in the individual analyses of the industries,
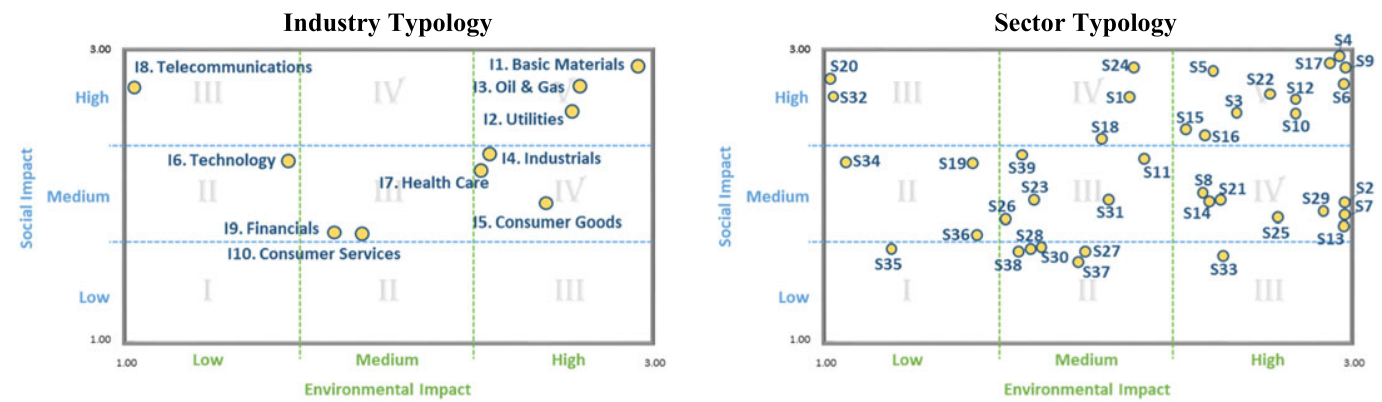

FIGURE 2 Industry classification and mimetic typologies: industry and sector typologies [Colour figure can be viewed at wileyonlinelibrary.com]

TABLE 5 Pearson correlation coefficients between ICSRPI and the variables that measure the impact of the company

\begin{tabular}{lllll} 
& & Environmental impact & Social impact & ICMT \\
ICSRPI_10 & Pearson correlation & $0.769^{* *}$ & $0.723^{*}$ & $0.788^{* *}$ \\
& Sig. (bilateral) & 0.009 & 0.018 & 10 \\
& $N$ & 10 & 0.007 & 10 \\
ICSRPI_39 & Pearson correlation & $0.557^{* *}$ & $0.485^{* *}$ & 0.002 \\
& Sig. (bilateral) & 0.000 & 39 & $0.047^{* *}$ \\
& $N$ & 39 & 39 & 39 \\
\hline
\end{tabular}

Note. ICMT: industry classification and mimetic typologies; ICSRPI: Industrial Corporate Social Responsibility Practices Index.

${ }^{*}$ The correlation is significant at 0.05 level (bilateral).

${ }^{* *}$ The correlation is highly significant at 0.01 level (bilateral). 

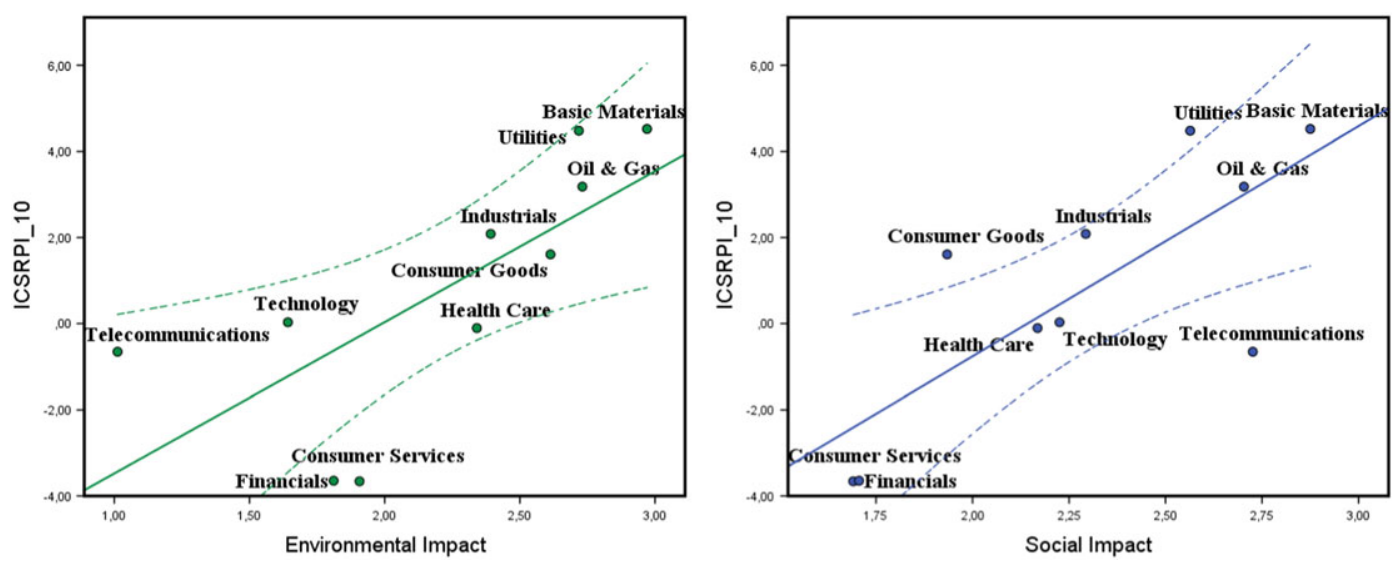

FIGURE 3 Dispersion diagram and regression adjustment between ICSRPI_10 and its environmental and social impact. ICSRPI: Industrial Corporate Social Responsibility Practices Index [Colour figure can be viewed at wileyonlinelibrary.com]
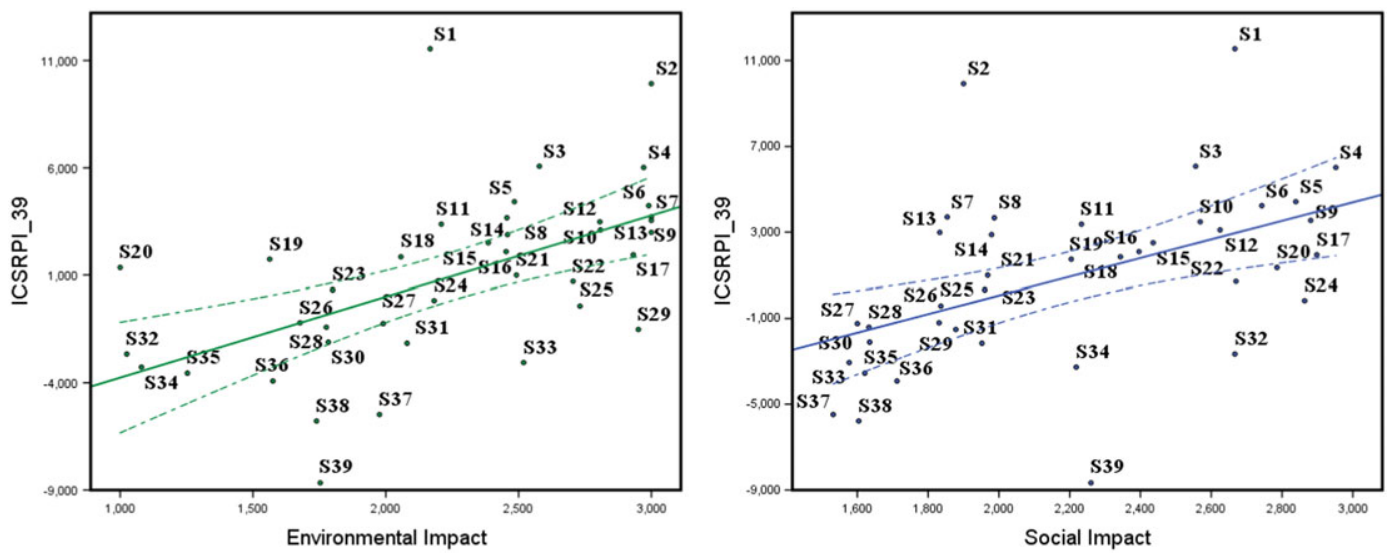

FIGURE 4 Dispersion diagram and regression adjustment between ICSRPI_39 and its environmental and social impact. ICSRPI: Industrial Corporate Social Responsibility Practices Index [Colour figure can be viewed at wileyonlinelibrary.com]

TABLE 6 MetaBiplot analysis, absorbed variance by individual analyses and absorbed variance by consensus analysis

\begin{tabular}{|c|c|c|c|c|c|c|c|}
\hline Industry & $\begin{array}{l}\text { Industry } \\
\text { axis } 1 \text { (\%) }\end{array}$ & $\begin{array}{l}\text { Industry } \\
\text { axis } 2(\%)\end{array}$ & $\begin{array}{l}\text { Industry \% } \\
\text { cumulative }\end{array}$ & $\begin{array}{l}\text { Consensus } \\
\text { axis } 1(\%)\end{array}$ & $\begin{array}{l}\text { Consensus } \\
\text { axis } 2(\%)\end{array}$ & $\begin{array}{l}\text { Consensus \% } \\
\text { cumulative }\end{array}$ & $\begin{array}{l}\text { \%Inertia absorbed } \\
\text { by consensus }\end{array}$ \\
\hline Basic materials & 59.60 & 20.00 & 79.60 & 47.44 & 18.46 & 65.90 & 82.78 \\
\hline Utilities & 78.20 & 21.80 & 100.00 & 51.99 & 9.33 & 61.32 & 61.32 \\
\hline Oil and gas & 54.30 & 27.00 & 81.30 & 11.49 & 13.56 & 25.05 & 30.81 \\
\hline Industrials & 59.70 & 16.00 & 75.70 & 28.12 & 36.38 & 64.50 & 85.20 \\
\hline Consumer goods & 44.10 & 31.90 & 76.00 & 37.06 & 6.48 & 43.54 & 57.29 \\
\hline Health care & 78.20 & 21.80 & 100.00 & 42.72 & $14.73 \%$ & 57.45 & 57.45 \\
\hline Telecommunications & 90.70 & 9.30 & 100.00 & 38.33 & $6.66 \%$ & 44.99 & 44.99 \\
\hline Financials & 56.30 & 21.30 & 77.60 & 44.50 & $12.92 \%$ & 57.42 & 74.00 \\
\hline Consumer services & 76.50 & 16.20 & 92.70 & 61.86 & $16.46 \%$ & 78.32 & 84.49 \\
\hline
\end{tabular}

of which consensus absorbs a large part, and they are lowest for the oil and gas industry; and the relative contribution of the factor to the element, and therefore, we have only highlighted those CSR practices that characterize each sector within the industry analyzed, all of them with optimal representation quality.

All these representations are shown in Figure 5, where we show each industry through a biplot representation, in which the sectors of activity that make up each of them are represented as points and the CSR practices that characterize them are highlighted.
The basic materials industry leads the ranking of ICSRPI_10, partly due to the forestry and paper sector (second position of ICSRPI_39), composed of forest plantation owners and operators, merchants and paper distributors of all grades, companies that present their highest CSR levels in policies and systems toward the defense of human rights, greater presence of the number of stakeholders as members of the board of directors and environmental reports. Other sectors of this industry, such as mining, chemicals, or industrial metals and mining, present companies dedicated to the exploration or extraction 
Basic Materials

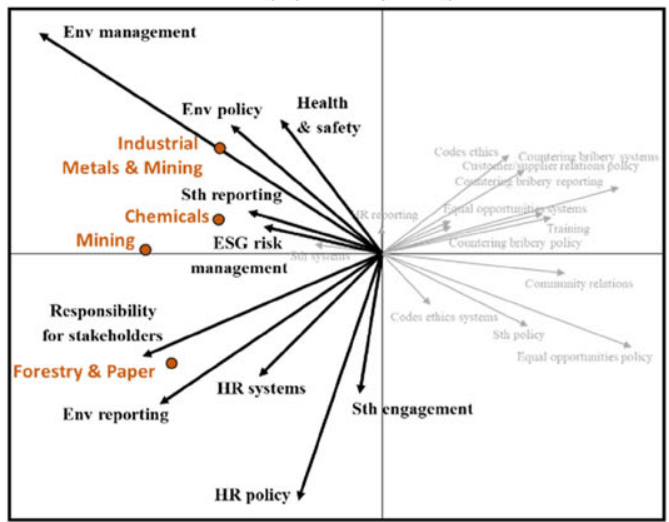

Oil \& Gas

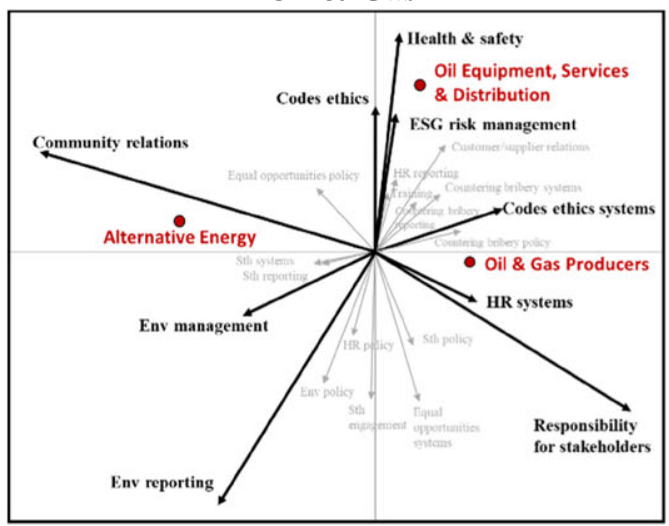

Consumer Goods

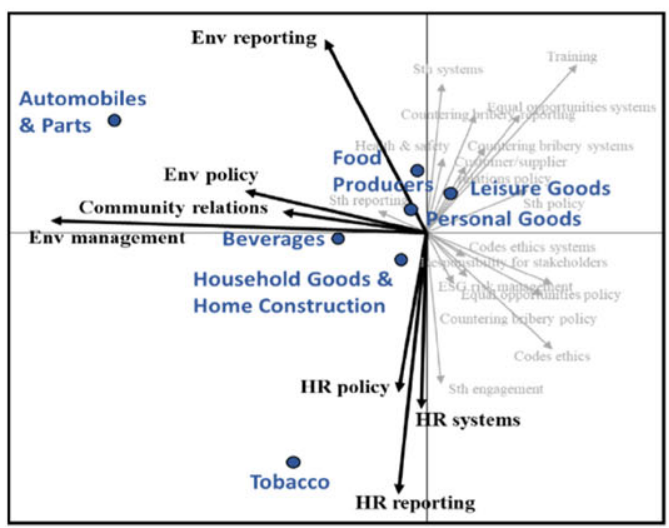

Health Care

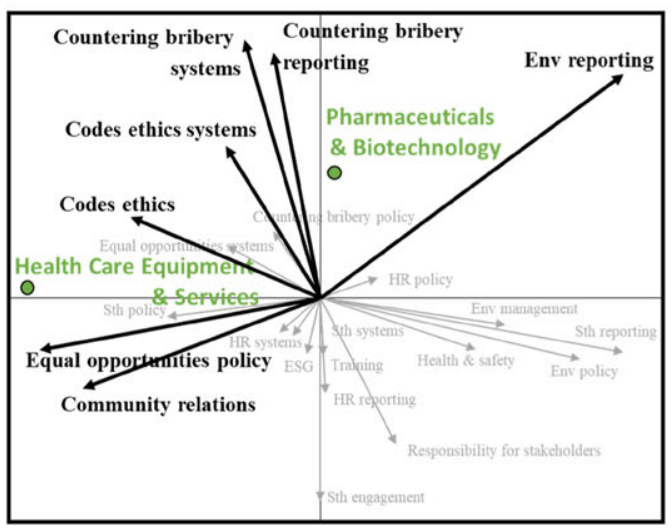

\section{Utilities}

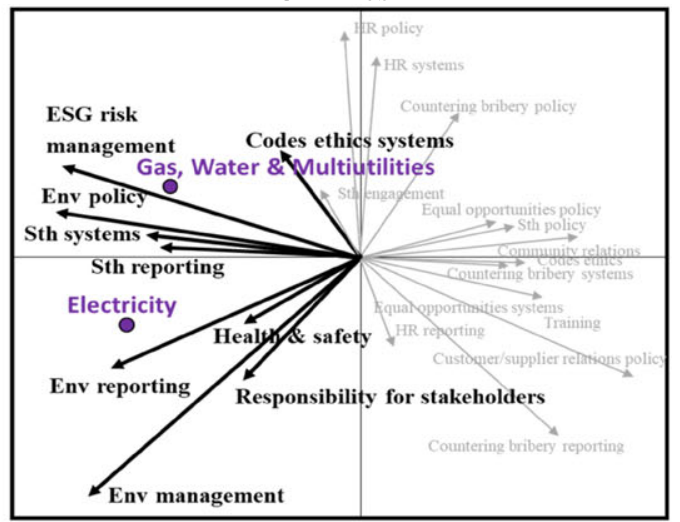

Industrials

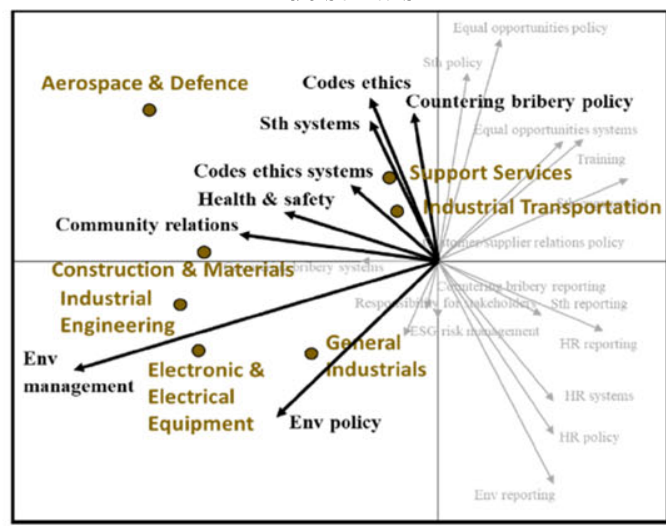

Technology

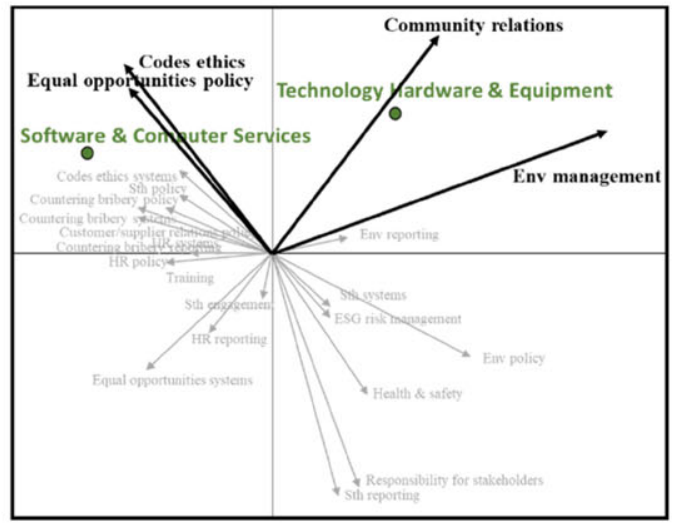

Telecommunications

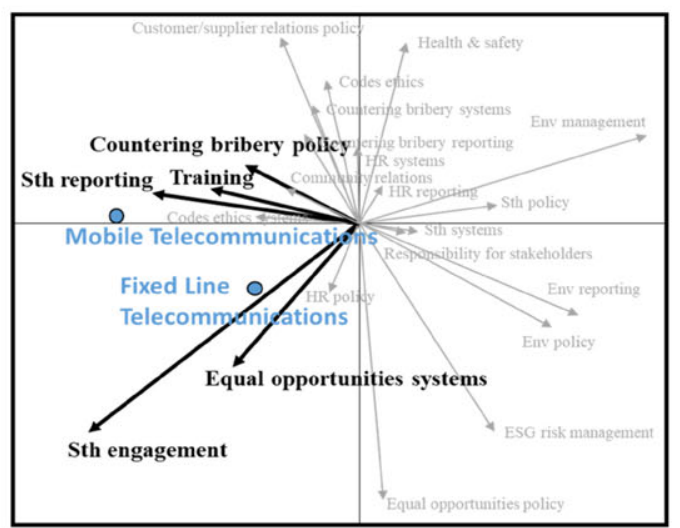

FIGURE 5 MetaBiplot analysis, individual biplot analysis, industry representations according to their activity sectors [Colour figure can be viewed at wileyonlinelibrary.com] 
Financials

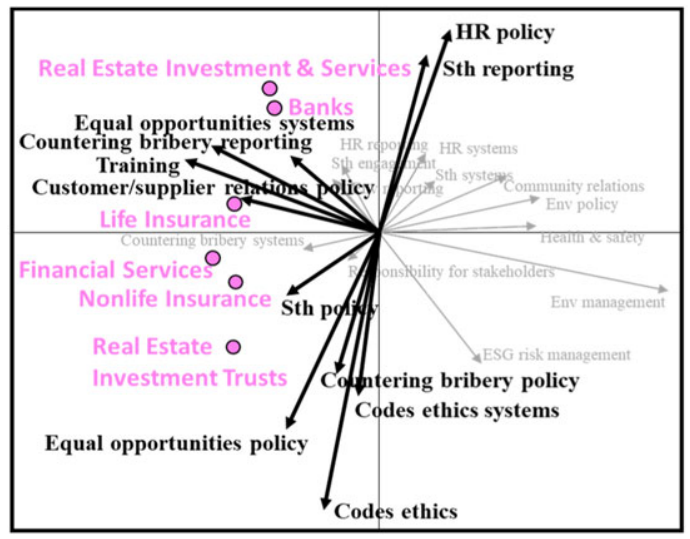

Consumer Services

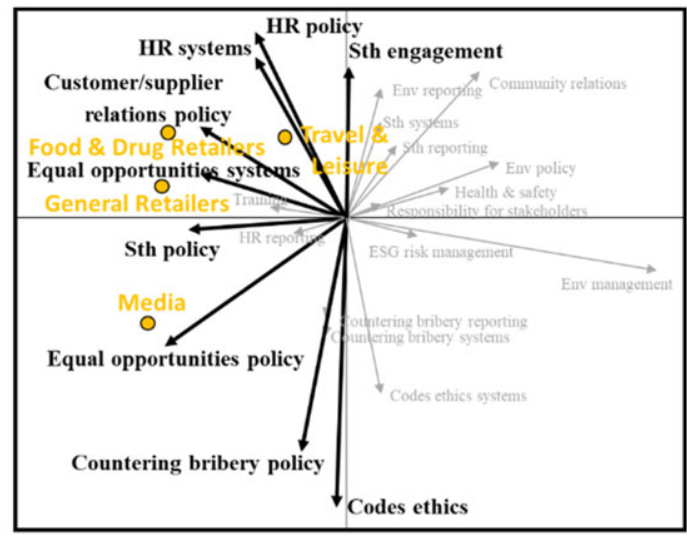

FIGURE 5 Continued.

of coal, producers and distributors of chemical products, metals, etc. These companies also employ the aforementioned practices, but prioritize performance and environmental policies and systems oriented to the health and safety of their employees.

The utilities industry shows behavior similar to the previous one; it is formed by companies that generate and distribute electricity through the combustion of fossil fuels such as coal, oil, and natural gas, and through nuclear energy for electricity, which focuses its practices on performance and environmental reports due to the high risk of contamination for stakeholders and the health and safety of its employees. Utilities also include gas, water, and multi-utilities distribution companies, which highlight environmental policies and ESG risk management in the management systems and reports to their stakeholders.

For the organizations of the oil and gas industry, we find greater differences between their sectors of activity. The companies dedicated to the development, manufacture, or production of alternative energy (sector that leads the ICSRPI_39) give preference to performance and environmental reports, such as systems to maintain good relations with the community; companies dedicated to exploration and extraction, production, refining, and supply of oil and gas products prioritize human rights management systems, give greater responsibility to stakeholders and show greater concern for codes of ethics; and companies destined for distribution give preference to the health and safety of their employees, to codes of ethics and to ESG risks.

In the case of industrials, the sectors that constitute it show a great concern for the health and safety of their employees and for relations with the community. In particular, the manufacturers and distributors of general industrial products, electrical equipment, producers of materials used in the construction and renovation of buildings and structures, and all types of industrial engineering (vehicles and machinery) emphasize their CSR standards in environmental performance and policies. Aircraft manufacturers, assemblers, and distributors, as producers of components and equipment for the defense industry, highlight part of the aforementioned relationships with the community and employee safety, with their systems for the implementation of a code of ethics, management systems for interest groups, and the fight against bribery. Finally, the companies involved in industrial transportation (delivery services, maritime transport, railways ...) and support services do not stand out within the industry, hence their average and low positions in the ICSRPI_39 ranking; if we observe Figure 5, these sectors are positioned in the center of the graph, obtaining similar values in CSR practices.

The consumer goods industry is made up of manufacturers of all types of automobiles and distributors of new parts and spare parts (engines, carburettors, tires ...), which have a preference for environmental performance, policies, and reports and good relations with the community; manufacturers and distributors of cigarettes, cigars, and other tobacco products (including tobacco plantations) prioritize everything related to human rights; the rest of the companies in this industry, such as those involved in beverages, household goods and home construction, food producers, or leisure/personal goods, do not stand out in this study, obtaining similar values in CSR practices.

In relation to the technology industry, the hardware and equipment sector, made up of companies conducted to the distribution and manufacture of electronic equipment, ranging from chips, computers, or semiconductors to high technology such as satellites, show their highest levels in environmental performance and community relations; the software and computer services sector, formed by companies that provide all types of computer services, such as software, internet, and consultancies, stand out in codes of ethics and policies to support equal opportunities and solve diversity problems.

The health care industry differentiates its companies between those destined for the development and research of biological substances, which highlight their environmental reports due to the threat they present, their systems and reports to counteract bribery, and their implementation systems of a code of ethics; and those aimed at health care equipment and services such as hospitals, clinics, and dentists and manufacturers and distributors of medical devices, which stand out in the policies of equal opportunities and promotion of diversity, good relations with the community, and codes of ethics.

In the telecommunications industry, organizations active in fixed line telecommunication services give preference to systems to support equal opportunities and diversity and encourage the participation of interest groups, whereas the companies devoted to mobile telecommunication services prioritize the systems for employee training and promotion, policies to counteract bribery, and reports with information about their relations with interest groups. 
In the financial industry, real estate investment and services sectors and banks give preference to human rights policies, to reports on relations with stakeholders, the fight against bribery, the equal opportunity systems, and the training of employees. The sectors dedicated to life insurance, non-life insurance, and financial services stand out for their policies toward maintaining good relations with customers and/or suppliers and interest groups and the training and development of employees. The sector dedicated to real estate investment/trusts stands out in policies toward equal opportunities and the fight against bribery and systems for the implementation of a code of ethics.

In the consumer services industry, the sectors formed by retail food, clothing, medicines, household, and those employed in travel and leisure emphasize policies for maintaining good relations with customers and/or suppliers, human rights, and their systems, greater participation of interest groups and systems of support for equal opportunities. The media sector emphasizes policies toward its stakeholders, equal opportunities, the fight against bribery, and codes of ethics.

The industries have been individually characterized according to the sectors of activity to which they belong, starting with the most sustainable according to the ICSRPI values. The next step seeks the integration of these subspaces through the set of orthogonal axes that best match the main directions of inertia to obtain a consensus configuration, with the aim of obtaining a global vision of sustainability at a sectoral level (see Figure 6). The sectors that make up the first industries described are located on the left side of the chart. If we focus on the third quadrant, the sectors dedicated to industrials, such as those aimed at the manufacture and distribution of all types of industrial products and construction, show their highest levels of CSR in environmental performance, relations with the community, and the health and safety of their employees, because their activities involve a higher labor risk, and through CSR, the companies show that their commitment goes beyond the levels of protection established by regulations. The sectors with greater environmental risks are positioned in the fourth quadrant. The most polluting ones are forestry and paper, mining, gas, water, and multi-utilities, oil and gas producers, tobacco, and electricity, which show their predilection for environmental policies and reports, human rights, and stakeholder participation. All these sectors show the highest positive values in the ICSRPI_39, which means that the environmental impact or risk of a company is the best indicator of its CSR practices, because the companies most exposed to these risks, due to the social pressure to disclose bad environmental news, seek to adopt or improve their practices in order to manage and increase user confidence (Casey \& Grenier, 2014; Ekelenburg, 2016; Jackson \& Apostolakou, 2010; Peters \& Romi, 2014; Simnett et al., 2009). In these sectors, organizations can use CSR as a key factor in their corporate reputation because of its potential to foster a competitive advantage that is difficult to duplicate (Hoque, Rahman, Molla, Noman, \& Bhuiyan, 2018; Melo \& Garrido-

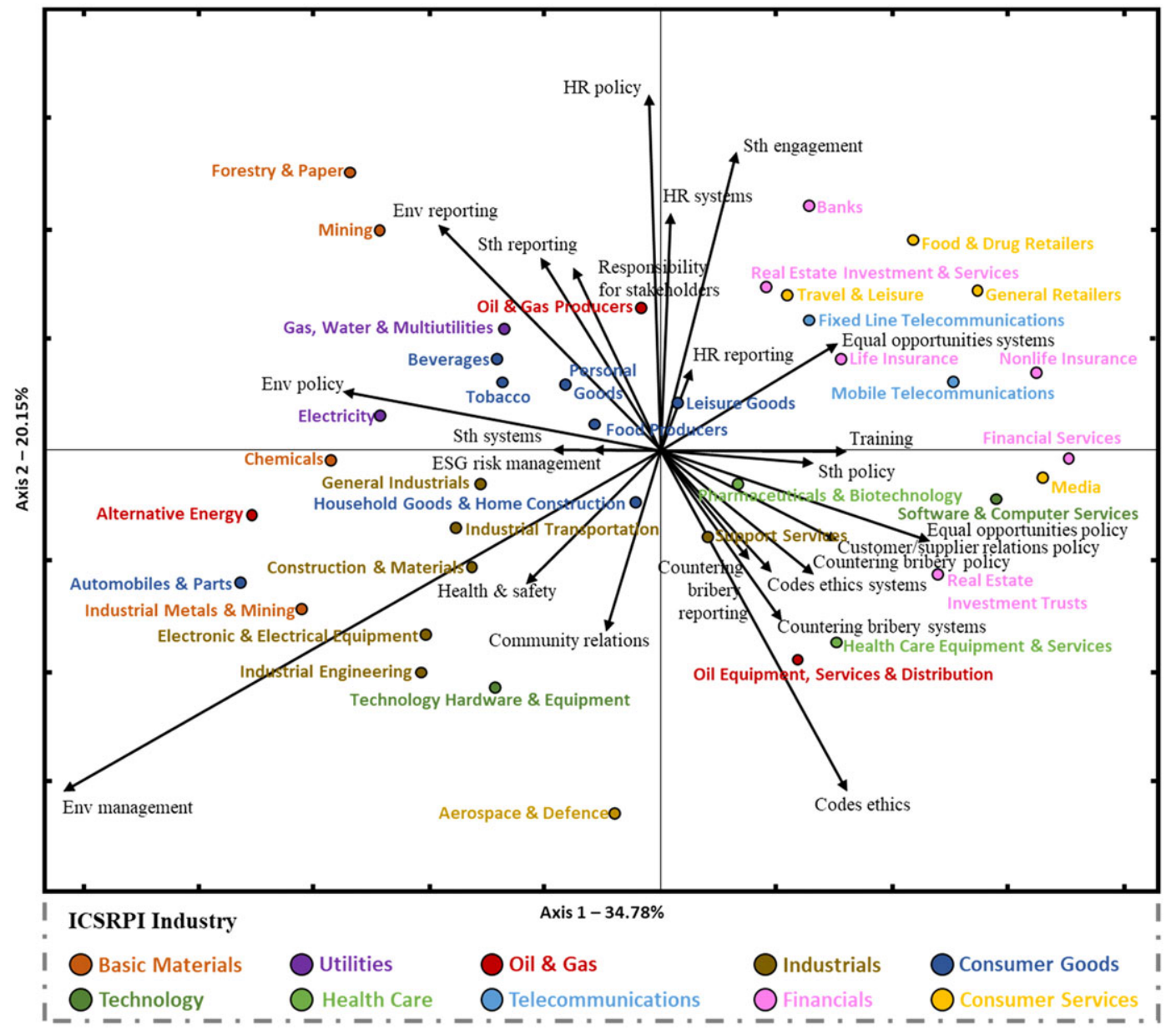

FIGURE 6 MetaBiplot analysis, consensus representation for a global vision of sustainability at a sectoral level [Colour figure can be viewed at wileyonlinelibrary.com] 
Morgado, 2012). In addition, several firms, instead of designing their own action plan, decide to imitate those reputable and leading companies in the sector; they adopt the commercial practices carried out by them to achieve fundamental social objectives like a good image or prestige and, accordingly, benefiting from the economic advantages linked with survival, growth, and performance (Blomgren, 2011; González-Rodríguez, Díaz-Fernández, \& Simonetti, 2015).

In reference to the rest, we find that the less polluting sectors are located on the right side of the graph. In the first quadrant, we find sectors focused on consumer services, finance, and telecommunications, oriented toward systems for employee training and promotion, equal opportunities, and the participation of interest groups, and to a lesser extent human rights policies and systems. Finally, in the second quadrant, we find the sectors dedicated to various services, finance, software, real estate investment, oil support, and distribution, which demand systems for the implementation of a code of ethics, equal opportunity policies, maintenance of good customer, and supplier relations, and everything related to the fight to counteract bribery.

\section{5 | CONCLUSIONS}

This paper extends the ICSRPI proposed by Amor-Esteban et al. (2018) to the 39 main sectors of activity worldwide. This disaggregation provides a more useful and comprehensive view of CSR, developing benchmarking processes related to social and environmental sustainability issues that specify responsible business conduct in each of the sectors. All of this leads to identifying the most relevant discrepancies, making it possible to design more precise sustainability actions at the business and institutional level.

In addition, this research proposes an aggregate measure of ICMT that determines the overall impact generated by the economic activity of the company in reference to its social and environmental impact. The study of these typologies and the extension of the ICSRPI for the 39 sectors shows that the impact of a company, particularly its environmental concerns and risks, is the best indicator of its CSR practices, because the companies most exposed to these risks, due to the social pressure to disclose bad environmental news, seek to adopt and improve their practices to manage and increase user confidence.

This study is based on multivariate statistical techniques such as the MetaBiplot, which by comparing and integrating several subspaces created for different industries provides a global view of sustainability at sector level. It shows that the type of sector plays an important role in the CSR development, because, according to the risk that each sector represents, stakeholders present different areas of interest, and consumers show different behaviors. Thus, the most polluting companies, with greater environmental risks, belonging to the forestry and paper, mining, gas, water, and multi-utilities, oil and gas producers, tobacco and electricity sectors, show their predilection for environmental policies and reports, human rights, and the participation of their stakeholders. These companies adhere to broader CSR policies to legitimize their business practices and focus on reducing their environmental impact, managing their reputation and meeting stakeholder expectations. The firms conducted to the manufacture and distribution of all types of industrial products and to construction show their highest levels of CSR in environmental performance, community relations, and employee health and safety, because their activities involve greater on-the-job risk, and through CSR, companies show that their commitment goes beyond the levels of protection established by regulations. The companies considered to be less risky, such as those employed in financial, retail, and telecommunications services, focus on practices aimed at the training of employees and their development, policies of equal opportunities, and promotion of diversity, good relations with customers and suppliers, and everything related to the fight to counter bribery.

These findings are useful for reinforcing the knowledge of variations in CSR practices and level in different institutional contexts at international level; therefore, results are essential for a right design of the approach. These results make it possible to understand the pressures on the social and environmental commitment of the different sectors, identifying those that show the greatest deficiencies, thus facilitating the orientation of the regulatory processes toward the promotion of policies that improve sustainable business behavior. These issues can guide managers to evaluate the impacts of business activities in their decision-making processes.

In addition, the extension of the ICSRPI is an essential tool for corporations and public administration. The availability of a reference value for each industry about their CSR practices can be useful in decision-making processes for public managers and politicians. More concretely, the ICSRPI scores provides a vision of reality of business; it allows to observe for each industry their environmental, social, and economic progress that improves their projection in the medium and long term. In addition, the handling of these data allows us to identify the priorities and structural drivers of their growth. It also allows to know the design of more precise and effective sustainable development impulse policies and, in this vein, that industries with more deficient business behavior around CSR could choose the specific policies to overcome those deficiencies.

Likewise, the information obtained allows us to realize a benchmark analysis in the different industries of the environmental, social, and economic performance, favoring processes oriented to reinforce the knowledge of the practices that conduct toward a greater CSR commitment. These analyses can be useful for companies' managers in their strategic CSR decisions; moreover, they can also be useful for comprising the existing pressures of those new industries in which they decide to diversify their business activities; they can include them into their environmental and social commitment.

Moreover, we have indicated that our paper suffers several limitations that could be addressed in future research. The first is relating to the scores shown by the ranking of ICSRPI industries refer to the development of CSR practices of companies. The bias of companies by industry that we have discussed where we define the empirical sample suggests the possible existence of limitations in the construction of this indicator. Future analysis will allow us to verify its functionality by comparing the obtained scores. Once the robustness of the ICSRPI will be validated, we aim to proceed to address the second limitation of this paper. We will explain the differences found between industries according to their institutional environment. This complementary objective will allow us to guarantee the coherence of the information provided by the indicator with results previously obtained; 
it also allows the generalization of its use in decision-making processes and around the academic researches.

\section{ORCID}

Víctor Amor-Esteban (10) http://orcid.org/0000-0003-0313-0196

\section{REFERENCES}

Aerts, W., Cormier, D., \& Magnan, M. (2006). Intra-industry imitation in corporate environmental reporting: An international perspective. Journal of Accounting and Public Policy, 25, 299-331.

Alniacik, U., Alniacik, E., \& Genc, N. (2011). How corporate social responsibility information influences stakeholders' intentions. Corporate Social Responsibility and Environmental Management, 18, 234-245.

Amor-Esteban, V., Galindo-Villardón, M.-P., \& García-Sánchez, I.-M. (2018). Useful information for stakeholder engagement: A multivariate proposal of an Industrial Corporate Social Responsibility Practices Index. Sustainable Development, 1-17. https://doi.org/10.1002/sd.1732

Amor-Esteban, V., García-Sánchez, I.-M., \& Galindo-Villardón, M.-P. (2017). Analysing the effect of legal system on corporate social responsibility (CSR) at the country level, from a multivariate perspective. Social Indicators Research, 1-18.

Bayoud, N. S., Kavanagh, M., \& Slaughter, G. (2012). Factors influencing levels of corporate social responsibility disclosure by Libyan firms: A mixed study. International Journal of Economics and Finance, 4. https://doi.org/10.5539/ijef.v4n4p13

Belu, C. (2009). Ranking corporations based on sustainable and socially responsible practices. A data envelopment analysis (DEA) approach. Sustainable Development, 17, 257-268.

Blomgren, A. (2011). Does corporate social responsibility influence profit margins? A case study of executive perceptions. Corporate Social Responsibility and Environmental Management, 18, 263-274.

Boudt, K., Cornelissen, J., \& Croux, C. (2013). The impact of a sustainability constraint on the mean-tracking error efficient frontier. Economics Letters, 119, 255-260. https://doi.org/10.1016/j.econlet.2013.03.020

Branco, M. C., \& Rodrigues, L. L. (2008). Factors influencing social responsibility disclosure by Portuguese companies. Journal of Business Ethics, 83, 685-701.

Campbell, J. L. (2007). Why would corporations behave in socially responsible ways? An institutional theory of corporate social responsibility. Academy of Management Review, 32, 946-967.

Casey, R. J., \& Grenier, J. H. (2014). Understanding and contributing to the enigma of corporate social responsibility (CSR) assurance in the United States. Auditing: A Journal of Practice \& Theory, 34, 97-130.

Chen, H., Zeng, S., Lin, H., \& Ma, H. (2017). Munificence, dynamism, and complexity: How industry context drives corporate sustainability. Business Strategy and the Environment, 26, 125-141.

Demirbag, M., Wood, G., Makhmadshoev, D., \& Rymkevich, O. (2017). Varieties of CSR: Institutions and socially responsible behaviour. International Business Review, 26(6), 1064-1074.

Dennis, W. J. Jr. (2011). Entrepreneurship, small business and public policy levers. Journal of Small Business Management, 49, 92-106.

DiMaggio, P., \& Powell, W. W. (1983). The iron cage revisited: Collective rationality and institutional isomorphism in organizational fields. American Sociological Review, 48, 147-160.

Ekelenburg, M. V. (2016). Determinants of voluntary external assurance on corporate sustainability reports: A comparison between Europe and North America. Netherlands: Radboud University.

Esteban, V. A., Villardón, M. P. G., \& Sánchez, I. M. G. (2017). Cultural values on CSR patterns and evolution: A study from the biplot representation. Ecological Indicators, 81, 18-29. https://doi.org/10.1016/j. ecolind.2017.05.051
Ferri, L. M., Oelze, N., Habisch, A., \& Molteni, M. (2016). Implementation of responsible procurement management: An institutional perspective. Business Strategy and the Environment, 25, 261-276.

Gabriel, K. R. (1971). The biplot graphic display of matrices with application to principal component analysis. Biometrika, 58, 453-467.

Galindo, M. P. (1986). Una alternativa de representacion simultanea: HJ-Biplot. Qüestiió, 10, 1.

Gallego-Álvarez, I., \& Ortas, E. (2017). Corporate environmental sustainability reporting in the context of national cultures: A quantile regression approach. International Business Review, 26, 337-353.

García-Sánchez, I.-M., \& García-Meca, E. (2017). CSR engagement and earnings quality in banks. The moderating role of institutional factors. Corporate Social Responsibility and Environmental Management, 24, 145-158.

Goll, I., \& Rasheed, A. A. (2004). The moderating effect of environmental munificence and dynamism on the relationship between discretionary social responsibility and firm performance. Journal of Business Ethics, 49, 41-54.

González-Rodríguez, M. R., Díaz-Fernández, M. C., \& Simonetti, B. (2015). The social, economic and environmental dimensions of corporate social responsibility: The role played by consumers and potential entrepreneurs. International Business Review, 24, 836-848.

Halkos, G., \& Skouloudis, A. (2016). National CSR and institutional conditions: An exploratory study. Journal of Cleaner Production, 139, 1150-1156. https://doi.org/10.1016/j.jclepro.2016.07.047

Heikkurinen, P. (2010). Image differentiation with corporate environmental responsibility. Corporate Social Responsibility and Environmental Management, 17, 142-152.

Hoque, N., Rahman, A. R. A., Molla, R. I., Noman, A. H. M., \& Bhuiyan, M. Z. $H$. (2018). Is corporate social responsibility pursuing pristine business goals for sustainable development? Corporate Social Responsibility and Environmental Management.

Jackson, G., \& Apostolakou, A. (2010). Corporate social responsibility in Western Europe: An institutional mirror or substitute? Journal of Business Ethics, 94, 371-394. https://doi.org/10.1007/s10551-009-0269-8

Jenkins, H. (2004). Corporate social responsibility and the mining industry: Conflicts and constructs. Corporate Social Responsibility and Environmental Management, 11, 23-34.

Jones, B., \& Nisbet, P. (2011). Shareholder value versus stakeholder values: CSR and financialization in global food firms. Socio-Economic Review, 9, 287-314.

Keats, B. W., \& Hitt, M. A. (1988). A causal model of linkages among environmental dimensions, macro organizational characteristics, and performance. Academy of Management Journal, 31, 570-598.

León, J. Á. P. (2015). Análisis de la relación causal de la responsabilidad social corporativa y la performance financiera de las empresas. https://doi.org/10.4995/Thesis/10251/48517

Martínez-Ferrero, J., \& García-Sánchez, I.-M. (2016). Coercive, normative and mimetic isomorphism as determinants of the voluntary assurance of sustainability reports. International Business Review, 26(1), 102-118. https://doi.org/10.1016/j.ibusrev.2016.05.009

Martín-Rodríguez, J., Galindo-Villardón, M. P., \& Vicente-Villardón, J. L. (2002). Comparison and integration of subspaces from a biplot perspective. Journal of Statistical Planning and Inference, 102, 411-423.

Matten, D., \& Crane, A. (2005). Corporate citizenship: Toward an extended theoretical conceptualization. Academy of Management Review, 30, 166-179.

Matten, D., \& Moon, J. (2004). Implicit and explicit CSR. A conceptual framework to understand CSR in Europe. ICCSR research paper series 29.

Melo, T., \& Garrido-Morgado, A. (2012). Corporate reputation: A combination of social responsibility and industry. Corporate Social Responsibility and Environmental Management, 19, 11-31.

Parsa, S., \& Deng, L. X. (2008). Capital markets' reactions to social information announcements. International Journal of Accounting and Finance, 1, 107-120. 
Peters, G. F., \& Romi, A. M. (2014). The association between sustainability governance characteristics and the assurance of corporate sustainability reports. Auditing: A Journal of Practice \& Theory, 34, 163-198.

Salem, M. A., Shawtari, F., Shamsudin, M. F., \& Hussain, H. B. I. (2017). The consequences of integrating stakeholder engagement in sustainable development (environmental perspectives). Sustainable Development https://doi.org/10.1002/sd.1699, 26, 255-268.

Scholtens, B. (2011). Corporate social responsibility in the international insurance industry. Sustainable Development, 19, 143-156.

Schreck, P. (2009). The business case for corporate social responsibility: Understanding and measuring economic impacts of corporate social performance. Heidelberg: Physica-Verlag.

Semenova, N., \& Hassel, L. G. (2008). Financial outcomes of environmental risk and opportunity for US companies. Sustainable Development, 16, 195-212.

Simnett, R., Vanstraelen, A., \& Chua, W. F. (2009). Assurance on sustainability reports: An international comparison. The Accounting Review, 84, 937-967. https://doi.org/10.2308/accr.2009.84.3.937

Vicente-Villardón, J. L. (2010). MULTBIPLOT: A package for multivariate analysis using biplots. Mathlab software. ${ }^{*}$ biplot.usal.es/ClassicalBiplot/ index.html.

Walters, B. A., Kroll, M., \& Wright, P. (2010). The impact of TMT board member control and environment on post-IPO performance. Academy of Management Journal, 53, 572-595.
Wanderley, L. S. O., Lucian, R., Farache, F., \& de Sousa Filho, J. M. (2008). CSR information disclosure on the web: A context-based approach analysing the influence of country of origin and industry sector. Journal of Business Ethics, 82, 369-378.

Weber, J. L. (2014). Corporate social responsibility disclosure level, external assurance and cost of equity capital. University of Colorado at Boulder.

Windsor, D. (2004). Global corporate social responsibility: International regimes and the constellation of corruption, poverty, and violence. In International corporate responsibility: Exploring the issues (pp. 43-67).

Young, S., \& Marais, M. (2012). A multi-level perspective of CSR reporting: The implications of national institutions and industry risk characteristics. Corporate Governance: An International Review, 20, 432-450.

Young, S., \& Thyil, V. (2014). Corporate social responsibility and corporate governance: Role of context in international settings. Journal of Business Ethics, 122, 1-24.

How to cite this article: Amor-Esteban V, Galindo-Villardón M-P, García-Sánchez I-M, David F. An extension of the industrial corporate social responsibility practices index: New information for stakeholder engagement under a multivariate approach. Corp Soc Resp Env Ma. 2018;1-14. https://doi.org/ 10.1002/csr.1665 




\section{PARTE III}

\section{COMPORTAMIENTO \\ EMPRESARIAL SOSTENIBLE A NIVEL EMPRESA}




\section{Capítulo X}

\section{Propuesta de Indicador de Prácticas de Responsabilidad Social Corporativa a Nivel Empresa}

En los últimos años ha habido un creciente interés en la Responsabilidad Social Corporativa (RSC), que ha generado un número cada vez mayor de investigaciones académicas sobre el tema. De este modo, los gobiernos, los activistas y los medios se han vuelto hábiles para responsabilizar a las empresas por las consecuencias sociales de sus actividades y muchas instituciones han comenzado a clasificar a las empresas en su desempeño de RSC, atrayendo una considerable publicidad. Como resultado, la RSC se ha convertido en una prioridad para las empresas de todo el mundo.

Desde su comienzo hasta la actualidad han existido muchas definiciones y una gran cantidad de investigaciones tanto teóricas como empíricas, aun así, la RSC significa algo, pero no siempre lo mismo a todo el mundo. Definir lo que es la RSC es una tarea ardua y compleja porque no es una realidad física sino una construcción social, en la que cada individuo mira desde la óptica de sus conocimientos, capacidades e intereses. Como resultado de la proliferación de diversas y diferentes definiciones de RSC, cada investigación se ha basado en su propio enfoque incorporando diversas dimensiones o temas para cubrir la RSC, lo que dificulta la posibilidad de estudios comparativos. Estos estudios evalúan el comportamiento organizacional desde diferentes enfoques, con construcciones multidimensionales, utilizando una amplia gama que incluye la medición del comportamiento interno, la inversión sostenible y las inversiones en equipos de control de la contaminación; o empleando una amplia gama de procesos que tratan programas filantrópicos, las relaciones con los clientes, la comunidad y las minorías. Cuantificar toda esta información es un aspecto de vital importancia para la RSC, ya que permitiría su medición y, por lo tanto, la comparación de resultados entre empresas, países o sectores de actividad, dando lugar a una completa comprensión del tema en cuestión.

En los últimos años ha aparecido un creciente interés por parte de las compañías en la presentación y divulgación de informes de RSC, traduciéndose en diversos modelos de reportes, indicadores, estándares, etc. Hay literalmente cientos de principios y códigos de conducta en todo el mundo. Asimismo, hay muchas iniciativas internacionales, relevantes y de gran prestigio como the Global Reporting Initiative (GRI); normas ambientales como Carbon Disclosure Project o Greenhouse Gas Protocol; rankings best-in-class como Global 100, FTSE4Good, DJSI o ESI, entre muchas otras. La principal debilidad que identificamos es que las iniciativas y pautas nombradas para la medición de la RSC son solo estándares, de los cuales ninguno es ejecutable por una agencia reguladora gubernamental. Como regla general, en la mayoría de los países, el informe es voluntario y no existen estándares ampliamente aceptados y uniformes. El resultado de todo esto es que la información no es confiable ya que las empresas pueden seleccionar arbitrariamente qué, cuánto y cómo informar, y solo muestran aquellas actividades o estándares que las ubican en un umbral positivo. Por lo tanto, hoy en día es muy complicado utilizar medidas 
directas de prácticas corporativas de RSC porque las divulgaciones de estas prácticas son voluntarias $\mathrm{y}$, en consecuencia, son incomparables porque no divulgan datos similares.

En este sentido, a lo largo de la literatura, se han propuesto numerosos indicadores para aproximar el compromiso o el desempeño de la RSC. Entre ellos, han prevalecido las medidas agregadas que permiten el examen de diferentes dimensiones de RSC en un solo proxy. Numerosos autores han evaluado el compromiso en la RSC atendiendo a diferentes áreas tales como medioambiente, comunidad, derechos humanos, relaciones con empleados, diversidad, producto y gobierno corporativo. Ciertos autores utilizan para el cálculo una suma no ponderada de los ítems, otros emplean la suma del número de 'strengths' (fortalezas) totales menos el número de 'concerns' (debilidades), puntuaciones z, etc.; utilizando diversas bases de datos como ASSET4, KLD o Bloomberg.

Por lo tanto, nuestra pregunta es: ¿existe una medida agregada con mayor poder explicativo? ¿hay alguna medida universal? ¿existen problemas metodológicos que afectan al indicador agregado?. Para responder a esta pregunta, este documento proporciona una nueva medida agregada a nivel empresa del rendimiento de RSC. Para su construcción, se utiliza un método novedoso de selección de individuos en el manejo de grandes cantidades de datos conocido como descomposición matricial CUR, enmarcado en el entorno del big data. Este método utiliza un procedimiento automático y objetivo otorgando a cada empresa un valor o puntuación conocido como leverage que hace referencia a su influencia estadística dentro del conjunto de datos y, a mayor leverage, mayor nivel de desarrollo sostenible. Al usar este procedimiento, superamos algunas de las limitaciones de estudios previos, por ejemplo, algunos estudios han analizado los 'strengths' y 'concerns', pero solo para determinadas dimensiones de la RSC con varias limitaciones de medición.

Esta investigación mide el desempeño de la RSC de 2675 compañías internacionales que cotizan en bolsa en base a unas medidas o prácticas de sostenibilidad procedentes de una agencia reguladora gubernamental de calificación externa de gran prestigio internacional conocida como EIRIS (Ethical Investment Research Services). EIRIS es un proveedor global líder de investigación independiente sobre el desempeño ambiental, social y de gobierno (ESG). Se analizan diferentes perspectivas de sostenibilidad: medioambiente, derechos humanos, empleados (RSC interna), stakeholders (RSC externa) y códigos éticos. Además, el uso de estos datos para la medición de la RSC ha sido probado y verificado en la literatura, siendo estas medidas de común uso para evaluar el desempeño empresarial ambiental y social.

A pesar de que la literatura anterior no ofrece una medida generalizada, se han utilizado múltiples medidas como un indicador agregado del nivel de RSC por empresa. Los resultados obtenidos muestran la alta correlación y similitud de los leverage CUR -como indicador agregadocon el resto de los indicadores utilizados por la literatura. Esto respalda y corrobora el funcionamiento del índice propuesto. Lo cual lo posiciona como una técnica novedosa para identificar el comportamiento sostenible por parte de la empresa. Este indicador es consistente con el resto previamente analizado, por lo tanto, nos permite seguir avanzando con los objetivos del estudio y analizar el compromiso empresarial por país y sector analizando los leverage CUR.

Dentro del contexto de la sostenibilidad, el método utilizado puede ser muy útil para proporcionar un valor global a cada empresa, un leverage, en relación con un conjunto de prácticas de RSC. De este modo es posible conocer las compañías que sobresalen por país o sector de actividad, las empresas punteras en desarrollo sostenible como Norsk Hydro para la industria minera y metalúrgica en Noruega; Stora Enso en silvicultura y papel de Finlandia; Akzo Nobel para productos químicos en Países Bajos; BMW de automóviles y repuestos en Alemania; Generali en finanzas de Italia; Novartis en farmacéuticas de Suiza; BT Group en telecomunicaciones de Reino Unido; o Inditex en textiles para España, entre otras.

Esta información es estudiada y contrastada con otros índices agregados de la literatura a nivel nacional y sectorial, corroborando su funcionamiento y utilidad como herramienta esencial para los políticos y los gerentes públicos en los procesos de toma de decisiones. La disponibilidad de estos datos permite conocer las empresas modelo tanto a nivel nacional como sectorial, lo que proporciona un espejo donde mirarse a aquellas compañías que se encuentran en situaciones de incertidumbre, imitando el comportamiento de estas organizaciones líderes en el desarrollo sostenible. Por otro lado, la información brindada permite un análisis de referencia del desempeño 
económico, ambiental y social en diferentes sectores, favoreciendo procesos que buscan conocer las acciones que conducen a un mayor compromiso con la RSC como resultado del estudio de las empresas más potentes a tal respecto. Estos análisis pueden ser utilizados, además de por políticos y líderes empresariales, por los gerentes de las compañías en sus propias decisiones estratégicas sobre RSC y comprender las presiones existentes sobre los compromisos sociales y ambientales de los mercados extranjeros en los que deciden diversificar sus actividades empresariales.

A continuación, presentamos toda esta información detallada de manera extensa en el artículo de investigación "Proposal for an Aggregate International Sustainability Index at the Organizational Level from CUR Matrix Decomposition" en proceso de elaboración. 
Research paper in elaboration process:

Title: Proposal for an Aggregate International Sustainability Index at the Organizational Level from CUR Matrix Decomposition

Authors: Víctor Amor-Esteban

Jennifer Martínez Ferrero

Ma'-Purificación Galindo-Villardón

Isabel-María García-Sánchez

Journal: in elaboration process 



\title{
PROPOSAL FOR AN AGGREGATE INTERNATIONAL SUSTAINABILITY INDEX AT THE ORGANIZATIONAL LEVEL FROM CUR MATRIX DECOMPOSITION
}

\begin{abstract}
The main objective of this research is to propose an aggregate index of corporate sustainability at the organizational level in addition to examining its consistency with other aggregate measures of corporate social responsibility (CSR). For its construction, a novel method of selecting individuals is used in the management of large amounts of data, known as CUR matrix decomposition, framed in the big data environment. As the second objective, and with the information provided by the aggregate index, the purpose is to identify the most powerful companies in each country or sector of activity, analysing the commitment to CSR at the country and sector levels. The data used compose an international sample of 2,675 large listed companies from all sectors of activity. The results show the consistency of the CUR leverage as an aggregate measure of CSR, confirming its coherence with other aggregated measures of CSR by means of a correlation analysis. Moreover, the results of the study confirm that companies adapt to the demands or pressures from the stakeholders in different areas of interest, which are specific to each country and industry. Thus, we reveal how European countries are a step above the rest of the countries in sustainability terms. With reference to the analysis by industry, this study shows that the most sustainable companies are in industries considered to be of high environmental risk; companies use CSR to legitimize their business practices and as a way to manage their reputation and respond to the expectations of their stakeholders.
\end{abstract}

Keywords: corporate social responsibility (CSR); sustainability of the company; CUR; environmental management; social performance; business stakeholders.

\section{Introduction}

In recent years, there has been growing interest in corporate social responsibility (CSR), which has generated an increasing amount of academic research on the subject (Mahoney and Thorne, 2005). Porter and Kramer (2006) noted that the media, activists and governments have become adept at holding corporations accountable for the social consequences deriving from their activities. Therefore, many institutions have begun to classify corporations based on their CSR performance, arousing important publicity. Accordingly, CSR has become a priority for companies around the world.

There is no consensus on what exactly should be included in the social responsibility of corporations (Frederick, 1994; Griffin, 2000; Hess, 2014). Today no single definition exists (Weber, 2008; Rahman, 2011). CSR has been understood as corporations' obligation to be accountable beyond simple financial aspects, considering their impacts on their stakeholders and the environment (Gössling and Vocht, 2007). One of the first definitions was established by Carroll (1979) and has been used extensively by several academics in this field: 'The social responsibility of business encompasses the economic, legal, ethical, and discretionary expectations that society has of organizations at a given point in time' (p. 500). Another relevant definition, which places the concept in a broad but understandable perspective, was presented at the World Business Council for Sustainable Development: 'Corporate Social Responsibility is the continuing 
commitment by business to behave ethically and contribute to economic development, while improving the quality of life of the workforce and their families as of the local community at large' (Holme and Watts, 1999, p. 3). According to the study by Sehic and Sabanovic (2008), all authors or organizations present their own definition or concept of CSR; everyone has their own point of view on the subject.

As a result of the proliferation of different and diverse definitions of CSR, each study, based on its own approach, incorporates dimensions or themes to cover CSR, which makes comparative studies difficult (Rahman, 2011). Thus, previous research has followed different approaches. These studies evaluate organizational behaviour with wide-ranging multidimensional constructions that include the measurement of internal behaviour, sustainable investment and investments in pollution control equipment or employing a wide variety of processes treating philanthropic programmes and the relationships with clients, the community and minorities (Waddock and Graves, 1997; Van Beurden and Gössling, 2008). Quantifying all this information is an aspect of vital importance for CSR, since it would allow its measurement and therefore the comparison of results between companies, countries or sectors of activity, giving rise to a complete understanding or an understanding of the subject in question (Hess, 2014).

However, there is no single globally accepted measurement instrument. It is precisely the existence of numerous indicators on CSR that leads the authors to propose the creation of a new aggregate CSR indicator using a novel method of selecting individuals in the management of large amounts of data, known as CUR matrix decomposition (Mahoney and Drineas, 2009). This method provides each company with 'leverage' (a value or score) in relation to its variables (CSR practices), which emanates from the sum of the factorial loads in each of the components obtained in the decomposition of the data matrix originals. Each company receives 'leverage' that indicates its level of statistical influence within the data set; if we arrange the 'leverages' in decreasing order, we obtain an aggregate index at the company level. Subsequently, an additional objective of the creation of the indicator is to study its coherence with some of the indicators previously used in the literature. With this, we offer evidence of the coherence and consistency of our CUR indicator.

Furthermore, making use of the new CUR indicator, the objective of the study is to analyse the commitment to CSR at the country and sector levels. Employing the 'CUR leverage' created as an indicator of CSR performance, our aim is to provide a comparison by company at the country and sectoral levels and infer differences between firms.

This research measures the CSR performance of 2,675 international companies listed on the stock exchange based on sustainability measures or practices from an international rating agency of great international prestige known as EIRIS (Ethical Investment Research Services) - a leading global provider of independent research on environmental, social and government performance (ESG). Different perspectives of sustainability are analysed: environment, human rights, employees (internal CSR), stakeholders (external CSR) and ethical codes.

The paper is structured as follows. After this introduction, section two analyses the theoretical background of the measurement. The third section describes the sample, the measure of the variables and the CUR technique used to obtain the aggregate CSR 
indicator. The fourth section presents the results and the last the conclusions of the study.

\section{Theoretical Background of CSR Measurement}

Carroll (1979) presented the first conceptual model of corporate social performance (CSP). This term was chosen because it was thought that 'responsibility' denotes motivation and is not measurable; therefore, it was replaced by 'performance', a term used for the operational part of CSR. He emphasized CSR in four domains - legal, economic, discretionary and ethical. In addition, he interspersed them in a matrix manner with social issues in which businesses should be interested - the environment, occupational safety, consumerism, product safety, shareholders and discrimination. He also added a third dimension - philosophies of the response capacity (proaction, reaction, accommodation and defence) - which made up the CSP cube. This cube consisted of 96 cells (which, depending on the number of subjects studied, could increase or decrease), through which CSP presumably could be evaluated (Wood, 2010).

The treatment of CSR, one of the earliest and greatest contributions during the 1990s, was conducted by Wood in 1991 when he covered the Carroll model in a CSP study. The model presented by Wood, although he credited and discussed the many contributions to the increasingly popular notion of CSP, was essentially based on the three dimensions of Carroll (1979) and the model of Wartick and Cochran (1985). Following the approach of Wartick and Cochran (1985), he converted the dimensions of Carroll's model (1979) into policies, processes and principles. Wood (1991) restated these principles. Specifically, he identified the principle of CSR proposed by Carroll with its four domains (legal, economic, discretional and ethical) and determined how they are linked to the CSR principles of managerial discretion, public responsibility and social legitimacy. In addition, he established the processes of social response capacity, highlighting processes such as problem management, stakeholder management and environmental evaluation (Carroll, 1999).

There are literally hundreds of principles and codes of conduct around the world. Although there is a proliferation of these codes, they rarely position themselves in relation to the past or establish what advances or differentiates the new code from previous ones (Hopkins, 2004). Likewise, there are many international initiatives, the most relevant being listed in Annex A (for example, in 1997 the Global Reporting Initiative (GRI), environmental standards such as the Carbon Disclosure Project or the Greenhouse Gas Protocol and best-in-class ratings such as the Global 100, FTSE4Good, DJSI or ESI).

The main weakness that we identify is that the initiatives and guidelines developed for the measurement of CSR are only standards, of which none is enforceable by a governmental regulatory agency. As a general rule - in most countries - the report is voluntary and there are no widely accepted and uniform standards. The result of all this is that the information is unreliable, since corporations can arbitrarily select what, how much and how to inform and only reveal those activities or standards that place them at a positive threshold. Therefore, today it is very complicated to use direct measures of corporate CSR practices, because the disclosures of these practices are voluntary. Consequently, they are incomparable because they do not disclose similar data (Boiral and Henri, 2017). 
Mattingly and Berman (2006) encouraged academics to use the different available categories of CSR measures and avoid combining irrelative and opposite dimensions to generate accurate and meaningful results. In addition, the review by Wood (2010) further emphasizes the need for academics to redirect their attention to stakeholders and society when measuring CSR. Wood (2010) urged academics to pay close attention to the relevance of the indicators incorporated into the CSR measure to obtain meaningful and connected results. These should show the direct and less confusing effect of CSR on the results of the organization, such as business performance.

In this regard, throughout the literature, numerous indicators have been proposed to approximate the CSR commitment or performance. Among them, the aggregate measures that allow the examination of different CSR dimensions in a single proxy have prevailed (Cheng et al., 2014; Fabrizi et al., 2014; García-Sánchez and García-Meca, 2017).

Numerous authors have evaluated the commitment to CSR attending to different areas, such as the environment, community, human rights, relations with employees, diversity, products and corporate governance. Analysing these areas, authors such as Chatterji et al. (2007) calculated their proxy using the total strengths minus the total concerns of the five CSR dimensions (environmental, community, employee relations, diversity and products); a positive score indicates a positive overall CSR performance. Recent studies have used this approach repeatedly (Graves and Waddock, 1994; Waddock and Graves, 1997; Le Breton-Miller and Miller, 2006; Campbell, 2007; Pomering and Johnson, 2009; Arora and Dharwadkar, 2011; Wang and Choi, 2013; Cruz et al., 2014; Peake et al., 2015; Oh et al., 2016; Petrenko et al., 2016). On the other hand, other researchers have analysed CSR commitment using an average score in this respect, for instance by using a scale from 0 to 100 about environmental, social and governance performance provided by the ASSET4 database (Cheng et al., 2014; Sassen et al., 2016; García et al., 2017; Gutsche et al., 2017) or by Bloomberg (Marquis et al., 2011; Wang et al., 2018). For Bouten et al. (2017), the CSR measure should be gathered along multiple dimensions, including negative screens (controversial issues) but also looking for both negative (concerns) and positive (strengths) practices in specific CSR categories. For example, Cheng et al. (2014) used the annual standardized scores (z-scores) for the pillars and constructed a composite CSR index by assigning equal weights to each of three pillars (environmental, social and governance). The z-score expresses the value in units of the standard deviation of that value from the mean value of all companies.

Thus, our questions are the following. Does an aggregate measure with greater explanatory power exist? Is there any universal measure? Do methodological issues that affect the aggregated indicator exist? To answer these questions, this paper provides a novel aggregated measure of CSR performance. This measure is aggregated at the company level and is obtained by employing a technique with an automatic and objective procedure known as CUR matrix decomposition - described later in the methodology. Following this procedure, we overcome some of the limitations of previous studies. For instance, some studies have analysed strengths and concerns but only for determined CSR dimensions, with several measurement limitations (Chatterji et al., 2007).

In addition, the use of these data for the measurement of CSR has been tested and verified in the literature. There are studies that have evaluated the role that companies' managers, especially the CEO (Chief Executive Officer), could play in the decision 
making on CSR (Fabrizi et al., 2014); others have studied the influence of the cultural or legal values of the countries of origin of the companies (Martínez-Ferrero and García-Sánchez, 2016), the relevance of the industry to sustainable behaviour (AmorEsteban et al., 2018) and so on. However, no study has shown the commitment of these companies in an individual and comparative way. The availability of these data would allow the identification of the structural drivers of their growth and the establishment of priorities that allow the design of more effective sustainable development promotion policies. As a consequence, the second objective of our study is to deepen the analysis of companies, investigating them individually at the sectoral and country levels. To achieve this, based on the value obtained in relation to their global sustainable behaviour, following an aggregated approach, it will be possible to evaluate and compare their business commitment within their countries of origin or their different industries, highlighting the most powerful ones in sustainable development.

\section{Research Methods}

\subsection{Sample and Population}

The target population for this research is the largest international companies listed on the stock market, as these are the most active organizations in terms of corporate social responsibility (Martínez-Ferrero and García-Sánchez, 2016). For their selection, we rely on only two criteria. First, we select the companies for the year 2014, since it is of great importance to take into account the time factor. We choose this year due to the strong development produced during the 2004-2014 decade, a time period affected by technological progress, which boosted the ability to access information about corporate behaviour and, given the freedom of the press, increased the pressure from different interest groups; consequently, to legitimize their practices and meet the expectations imposed by their stakeholders, companies developed CSR policies and practices, maintaining some stability in the last years of this period. Thus, the evaluation of the year 2014 implies the measurement of the accumulation of all commercial efforts made at that time. Second, we select only companies with complete information on each of the measures chosen to evaluate their sustainable commitment. The variables selected correspond to the 27 CSR practices most commonly used to measure such performance, which are detailed in the next section. With this information, we obtain a total sample of 2,675 large listed companies from 29 countries in developed economies (see Table 1 Panel A) and belonging to the top 10 industries according to the Industry Classification Benchmark (ICB) system (see Table 1 - Panel B).

Table 1. Sample Distribution

\begin{tabular}{|c|c|c|c|c|c|c|c|}
\hline \multicolumn{8}{|c|}{ Panel A. Distribution of companies by country } \\
\hline & Country & Companies & $\%$ & & Country & Companies & $\%$ \\
\hline 1 & Australia & 97 & 3.6 & 16 & Malaysia & 14 & 0.5 \\
\hline 2 & Austria & 12 & 0.4 & 17 & Mexico & 20 & 0.7 \\
\hline 3 & Belgium & 13 & 0.5 & 18 & Netherlands & 31 & 1.2 \\
\hline 4 & Brazil & 26 & 1.0 & 19 & Norway & 13 & 0.5 \\
\hline 5 & Canada & 88 & 3.3 & 20 & Russia & 19 & 0.7 \\
\hline 6 & China & 52 & 1.9 & 21 & Singapore & 39 & 1.5 \\
\hline 7 & Denmark & 20 & 0.7 & 22 & South Korea & 113 & 4.2 \\
\hline 8 & Finland & 18 & 0.7 & 23 & Spain & 39 & 1.5 \\
\hline 9 & France & 88 & 3.3 & 24 & Sweden & 45 & 1.7 \\
\hline 10 & Germany & 86 & 3.2 & 25 & Switzerland & 49 & 1.8 \\
\hline 11 & Hong Kong & 90 & 3.4 & 26 & Thailand & 11 & 0.4 \\
\hline
\end{tabular}




\begin{tabular}{|c|c|c|c|c|c|c|}
\hline India & 27 & 1.0 & 27 & Turkey & 10 & 0.4 \\
\hline Israel & 31 & 1.2 & 28 & United Kingdom & 452 & 16.9 \\
\hline Italy & 38 & 1.4 & 29 & United States & 666 & 24.9 \\
\hline Japan & 468 & 17.5 & & Total & 2675 & 100.0 \\
\hline
\end{tabular}

\begin{tabular}{|c|c|c|c|c|c|c|c|}
\hline \multicolumn{8}{|c|}{ Panel B. Distribution of companies by industry } \\
\hline & Industry & Company & $\%$ & & Industry & Company & $\%$ \\
\hline 1 & Basic Materials & 217 & 8.1 & 6 & Industrials & 517 & 19.3 \\
\hline 2 & Consumer Goods & 343 & 12.8 & 7 & Oil \& Gas & 144 & 5.4 \\
\hline 3 & Consumer Services & 382 & 14.3 & 8 & Technology & 168 & 6.3 \\
\hline 4 & Financials & 574 & 21.5 & 9 & Telecommunications & 73 & 2.7 \\
\hline \multirow[t]{2}{*}{5} & Health Care & 150 & 5.6 & 10 & Utilities & 107 & 4.0 \\
\hline & & & & & Total & 2675 & 100.0 \\
\hline
\end{tabular}

\subsection{CSR Measures}

The measures selected to quantify sustainable business behaviour come from the EIRIS database (Ethical Investment Research Services). EIRIS is a leading global provider of independent analysis focused on environmental, social and governance policies and practices that provides detailed analysis of nearly 3,000 companies worldwide through more than 110 individual criteria. Many of these criteria are oriented towards certain industries or countries and therefore are not available for all companies; other criteria are repeated by changing only the response levels. However, there are certain practices that are common to companies in all industries and countries, measures that are commonly used to assess environmental and social business performance by researchers today (Fabrizi et al., 2014; León, 2015; Martínez-Ferrero and García-Sánchez, 2016; Amor-Esteban et al., 2017; Cuadrado-Ballesteros et al., 2017; Esteban et al., 2017; García-Sánchez and García-Meca, 2017). Given that they are the measures used on a recurrent basis by other researchers, we select them for our study with the aim of building an aggregate measure of sustainability at the company level. These measures are composed of 27 CSR practices that quantify the commitment in sustainable terms of the companies from different perspectives - the environment, human rights, employees, stakeholders and ethics ${ }^{1}$ - with a scale from 0 to 4 on which 0 denotes non-existent, 1 weak, 2 moderate, 3 good and 4 exceptional (see Table 2).

\footnotetext{
${ }^{1}$ These practices give us accurate information about a company's commitment in sustainable terms, since they do not simply provide us with information about the strengths and weaknesses of the company but also inform us of level at which that commitment is produced. In addition, it is reliable information - used by numerous investigations - that is complete and balanced, since it evaluates sustainability through different approaches: (i) the preservation of the environment: its practices refer to the care of the environment in relation to energy expenditure, decontamination, climate change or waste disposal by evaluating the policies, systems and reports of the company as well as the impact of its business processes and therefore the repair or prevention of the damage that it may cause; (ii) the defence of human rights: the independent agency EIRIS quantifies the policies, systems and reports of the company aimed at the adoption of codes of conduct corresponding to working conditions, including discrimination, the elimination of child or forced labour and so on; (iii) internal CSR addressing the labour rights of employees, implying initiatives aimed at improving the quality of work, both contractual and physical, the promotion of equal opportunities - employment for the disabled and nondiscrimination-practices directed towards good working conditions, health and safety, employee training and participation; (iv) external CSR aimed at maintaining good relations with stakeholders - the community, consumers, contractors, suppliers, customers and so on, including initiatives aimed at information transparency, informing the present and future impacts of the organization, with participatory practices seeking dialogue and fluid communication to identify the needs of the interested parties and establish a mutually beneficial relationship; and (v) business ethics, corresponding to policies aimed at countering political corruption or bribery systems. It is important that the company acts in accordance with ethical values in all its areas.
} 
Table 2. Environmental, social and governance performance

Environment

ENV1 Environmental policy

ENV2 Environmental systems

ENV3 Environmental reporting

ENV4 Environmental performance

Human Rights

HR1 Human Rights policy

HR2 Human Rights systems

HR3 Human Rights reporting

Employees

EMP1 Equal opportunities (policy)

EMP2 Equal opportunities (systems)

EMP3 Health \& safety systems

EMP4 Trade unions and employee participation

EMP5 Training

EMP6 Job creation and security

Stakeholders

STH1 Community relations

STH2

Customer/supplier relations policy

STH3 Community involvement

STH4 Responsibility for stakeholders

STH5 Stakeholder engagement

STH6 Stakeholder policy

STH7 Stakeholder systems

STH8 Stakeholder reporting

Ethics and Governance

ETH1 Codes of ethics

ETH2 Codes of ethics systems

ETH3 Countering bribery policy

ETH4 Countering bribery systems

ETH5 Countering bribery reporting

ETH6 ESG risk management
How does EIRIS rate the Company's environmental policy and commitment?

How does EIRIS rate the Company's environmental management system?

How does EIRIS rate the Company's environmental reporting?

What level of improvements in environmental impact can the Company demonstrate?

What is the extent of policy addressing human rights issues?

What is the extent of systems addressing human rights issues?

Does the Company report on human rights issues?

How good is the Company's policy on equal opportunity and diversity issues?

How clear is the evidence of systems and practices to support equal opportunities and diversity?

How clear is the evidence of health \& safety systems?

How clear is the evidence of systems to manage employee relations?

How clear is the evidence of systems to support employee training and development?

How clear is the evidence of systems and practices to advance job creation and security?

How clear is the Company's commitment to community or charitable work?

Does the Company have policies on maintaining good relations with customers and/or suppliers?

How clear is the evidence of systems to maintain good relations with community?

How many stakeholder issues have been allocated to board members?

What level of engagement with stakeholders is disclosed by the Company?

How good are the Company's policies towards its stakeholders overall?

How good is the Company's quantitative systems on stakeholder relationships?

How good are the Company's management reporting for stakeholders overall?

Does the Company have a code of ethics and, if so, how comprehensive is it?

Does the Company have a system for implementing a code of ethics and, if so, how comprehensive is it?

What is the extent of the Company's policy for countering bribery? What is the extent of the Company's system for countering bribery?

What is the extent of the Company's reporting on countering bribery?

How well do the board and senior management address Companywide ESG (Environmental, Social and Governance) risks and opportunities? 


\subsection{Multivariate Analysis: CUR Decomposition}

One of the main objectives of researchers is applying dimension reduction techniques that allow extracting the signal, eliminating noise and explaining in the best possible way the behavior of the data set in a space of reduced dimension. One of the most popular techniques to reduce-dimensionality is the principal components analysis; however, the components are always linear combinations of all the original variables, because of the use of Singular Value Decomposition (SVD) (Eckart and Young, 1936), and are not easily interpretable as latent factors of the original processes (Mahoney and Drineas, 2009).

The CUR matrix decomposition constitutes a low rank approximation of the original data set, expressed in a small number of the rows and/or columns of the data matrix. The aim of CUR is to obtain a decomposition with optimal properties even in the most unfavorable cases, with a natural statistical interpretation associated with its construction and that works well in practice (Mahoney and Drineas, 2009). Formally, it is defined as: $\mathrm{X}$ is a data matrix of order IxJ, where I represents the number of individuals and $\mathrm{J}$ the number of variables, the decomposition $C U R$ of $\mathrm{X}$ is given by:

$$
X_{I x J} \approx C_{I x c} U_{c x r} R_{r x J}
$$

where $\mathrm{C}$ consists of a small number of actual columns of $\mathrm{X}, \mathrm{R}$ consists of a small number of actual rows of $X$, and $U$ is a small carefully constructed matrix that guarantees that the product CUR is close to $\mathrm{X}$.

It is clear that the decomposition obtained is interpretable in terms of the original data given that the matrices $\mathrm{C}$ and $\mathrm{R}$ are some of their own rows and columns (Mahoney and Drineas, 2009). This method is a more interpretable alternative to Singular Value Decomposition (Eckart and Young, 1936), since it works with a small proportion of rows and columns of the original data set. Can be used in place of the eigencolumns and eigenrows, with the added benefit of improving interpretability in terms of the original data.

The theory that underlies CUR matrix decompositions works in the following way (Drineas et al., 2008). To determine which rows and columns to include in R and C, an "importance score" is calculated for each row and column of $\mathrm{X}$ and then a small number of them are selected. This importance score called leverage depends on the matrix $X$ and an input rank parameter $k$. In formal terms, if $v_{j}^{\xi}$ is the $\mathrm{j}$-th element of the $\xi$-th singular vector of $X$, the normalized statistical leverage scores equal:

$$
\pi_{j}=\frac{1}{k} \sum_{\xi=1}^{k}\left(v_{j}^{\xi}\right)^{2}
$$

For all $j=1, \ldots, n$, these scores are the statistical influence factors for each original observation or variable, known as leverage, are interpreted as sensors of the influence of each row/column in the best lowest rank approximation of the data matrix.

Logically, it depends on the input parameter $\mathrm{k}$, that is, the number of dimensions to be retained. Once the leverage has been defined for all the rows and / or columns of X, 
Mahoney and Drineas (2009) defined different method to construct the R and C matrices. Naturally, those observations and/or variables with the highest score are more likely to be selected. This is known as top.scores method (Bodor et al., 2012).

In addition, unlike the SVD in CUR, the vectors chosen are exactly vectors rows and columns of the data matrix. Therefore, within the context of sustainability, this method can be very useful in providing a global value to each company - a leverage - in relation to a set of CSR practices.

In addition, in certain cases we have found that the leverage scores themselves can be used directly, which involves using the statistical leverage scores as a "ranking function". In this study with a total sample of 2,675 companies the CUR decomposition will provide a 'leverage' -a value or score- for each company that will indicate its level of statistical influence within the data set; companies with a greater leverage will correspond with the organizations that present the strongest levels in the set of CSR practices, the most sustainable. Ordering the leverage in a decreasing way we get an aggregate index at company level.

All the calculations processed with these method as well as in the graphs were performed using the R software with the rCUR package, which is freely available, open source R implementation of the CUR matrix decomposition method (Bodor et al., 2012).

\section{Results}

\subsection{Results I: Analysis of the Consistency of the Aggregate CSR Measures Proposed in the Literature through the Aggregate CUR Indicator}

The first objective of the study was to create an aggregate CSR indicator that would later be compared with other indicators to examine and guarantee its consistency. For this reason, as previously described, the creation of the indicator was based on CUR matrix decomposition. This allowed us to obtain the 'CUR' leverage as an indicator of the commitment to sustainability of each company. Having created this indicator, the next objective of the paper was to study its coherence with respect to other indicators that have previously been used in the literature and to check its correlation with other aggregated indicators of CSR.

Table 3 shows the results of the existing bivariate correlations between the CUR leverage indicator as an aggregate measure of CSR and six of the indicators that have previously been used in the literature. These indicators are described in the footnote. As can be seen in Table 3, the bivariate correlation between the CUR leverage and the different CSR measures is especially high (with values higher than 0.87 in all the cases and greater than 0.94 in almost all of them). The high correlation between them, besides being significant ( $p$-value $=0.000$ ) at the $90 \%$ level of significance, confirms our idea of coherence and consistency between the different CSR measures (for $n=2,675$ companies).

Even though the previous literature does not offer a generalized measure or definition, multiple studies have used an aggregate indicator of the CSR level per company as a proxy. The aggregate indicator proposed in this paper, making use of the CUR methodology, does nothing but offer a novel technique to identify the sustainable 
behaviour of a company. This indicator is consistent with the others previously analysed. Therefore, it allows us to continue advancing with the objectives of the study and analyse the business commitment by country and sector through the CUR leverage. The measure is consistent and perfectly comparable to the rest of the indicators. However, within the context of sustainability, the method used can be very useful in assigning a global value to each company - its leverage - in relation to a set of CSR practices.

Table 3. Firms' Ranking - Different measures of aggregated CSR

\begin{tabular}{|c|c|c|c|c|c|c|c|}
\hline & \multirow{2}{*}{$\begin{array}{c}\text { Sum or } \\
\text { Average }^{1} \\
\text { Unweighted } \\
\text { Sum of Items }\end{array}$} & \multicolumn{3}{|c|}{ Strengths and Concerns $\left(n^{0} 1 \text { and } n^{0} 0\right)^{2}$} & \multicolumn{2}{|c|}{$\begin{array}{c}\text { Sum for } \\
\text { dimensions }^{3}\end{array}$} & \multirow{2}{*}{$\begin{array}{c}\mathbf{Z}^{\mathbf{4}} \\
\text { score } \\
\text { CSR Z } \\
\text { score }\end{array}$} \\
\hline & & $\begin{array}{l}\text { 1) Sum of } \\
\text { Strengths }\end{array}$ & $\begin{array}{l}\text { 2) Ratio of } \\
\text { Strengths }\end{array}$ & $\begin{array}{l}\text { 3) Strengths } \\
\text { - Concerns }\end{array}$ & $\begin{array}{l}\text { 1) CSR } \\
\text { Dim } \\
\text { (Max- } \\
\text { Data) }\end{array}$ & $\begin{array}{l}\text { 2) CSR } \\
\text { Dim } \\
\text { (Max- } \\
\text { Scale) }\end{array}$ & \\
\hline $\begin{array}{c}\text { Leverage } \\
\text { CUR }\end{array}$ & $\begin{array}{l}. \mathbf{9 8 2}^{* *} \\
.000 \\
2675\end{array}$ & & $\begin{array}{c}\mathbf{. 9 6 8}^{* * *} \\
.000 \\
2675\end{array}$ & & $\begin{array}{c}\mathbf{. 9 7 8}^{* *} \\
.000 \\
2675\end{array}$ & $\begin{array}{c}\mathbf{. 8 7 5}^{* *} \\
.000 \\
2675\end{array}$ & $\begin{array}{l}\mathbf{. 9 4 1}^{* * *} \\
.000 \\
2675\end{array}$ \\
\hline
\end{tabular}

1. García-Sánchez and García-Meca, (2017) use the unweighted sum of all the analyzed items as an aggregate measure of CSR, applying the same scale in all of them (from 0 to 4). Other authors make use of an indicator based on the average of the indicators. The performance of CSR is measured on a scale of 0 to 100 using data from the ESG database of Thomson Reuters ASSET4 (Cheng et al., 2014; Sassen et al., 2016; García et al., 2017; Gutsche et al., 2017).

2. Other authors refer to strengths and concerns of CSR practices. The value of the practices measured is recoded in a range of $0-4$ to a range of $0-1$. Thus, the values ' 0 -Inadequate' and '1-Weak' receive the value '0-Concerns' while the values '2-Moderate', '3-Good', and '4-Exceptional' receive the value of '1-Strengths'. To calculate the CSR value of each company they have different options. Some authors add the number of strengths (2.1) and the company receives values between 0 and 27. Other authors use the ratio strengths to total possible strengths (2.2) and the company receives a value between 0 and 1 (Arora and Dharwadkar, 2011; Oh et al., 2016). Authors such as Wang et al. (2018), later calculate an aggregate CSR index as the subtraction between strengths and concerns based on five CSR dimensions (2.3).

3. Fabrizi et al. (2014) choose to obtain a CSR performance proxy through a sum by dimensions. According to this methodology, a value is calculated for each company per dimension (Environment, Human Rights, Employees, Stakeholders and Ethics), which is then added to get a global aggregate measure of CSR. Each practice evaluates with the same 0-4 range that is recoded to 1-5 and each dimension is composed of a different number of practices.

CSR $($ Dimension $)=[($ Dimension - Min $) /($ Max - Min $)] \rightarrow$ will be a standardized sum for each dimension receiving a value between 0 and 1 .

$\mathrm{CSR}=[($ Environment -4$) /(20-4)]+[($ Human Rights - 3) / (15 - 3) $]+[($ Employees - 6) $/(30-$

$6)]+[($ Stakeholders - 8) / (40 - 8) $]+[($ Ethics - 6) / (30 - 6) $]$

Our aggregate measure of social responsibility (CSR) is the sum of the 5 scores that have each standardized in a score of 0 to 1 , therefore, it varies from 0 to 5 .

Two indicators should be noted.

\subsection{CSR Dim (Max-Data)}

3.2 CSR Dim (Max-Scale)

The difference is found in the maximum values chosen.

In 3.1 we select as the Maximum values the largest values obtained by dimension

In 3.2 we select as the Maximum values the largest values by scale

4. Cheng et al. (2014) propose as measure the CSR Z score. $Z$ scores as calculated as $\left(z=\frac{X_{i}-\bar{X}}{S D}\right)$ for each firm by practice and then, its average. 


\subsection{Results II: An Analysis of CSR Practices Following the CUR Aggregate Indicator Approach}

Created the CUR leverage for each firm, Figure 1 shows the distribution of leverage for all the companies, calculated by applying the CUR decomposition to the data matrix, made up of 2,675 companies measured on 27 CSR practices. It can be seen that the higher the value of the leverage, the lower the number of companies. The leverage provides information on the statistical influence of each company in the total data set in the context of sustainability; those companies with greater commitment stand out. Thus, it is possible to observe that only around 40 companies of the 2,675 exceed a value of 1.00 for the leverage; these are reflected in the lower part of the figure. We can highlight some, such as Norsk Hydro from Norway in the metals and mining industry; Pirelli, from the automotive industry in Italy and others from Germany, such as BMW, Volkswagen or Daimler; Akzo Nobel (Netherlands) and BASF and Bayer (Germany) among the chemical products industries; BG (UK), Total (France) and ENI (Italy) as oil and gas producers; Enel (Italy) and Fortum (Finland) stand out among the electric companies; in relation to food products, well-known companies such as Nestle (Switzerland) and Danone (France) are prominent; among those focusing on pharmaceuticals and biotechnology are Novartis (Switzerland), GlaxoSmithKline (UK) and Novo Nordisk (Denmark); as general industries there is Siemens (Germany) and in telecommunications there are the BT Group (UK) and Deutsche Telekom (Germany); in terms of finance, several companies stand out, such as ANZ, Westpac or NAB in the banking sector in Australia, UniCredit in Italy and Barclays in the United Kingdom, as well as insurance companies such as Generali (Italy), Aviva (UK) and Allianz (Germany).

Figure 1. Leverage of firms according to CUR decomposition

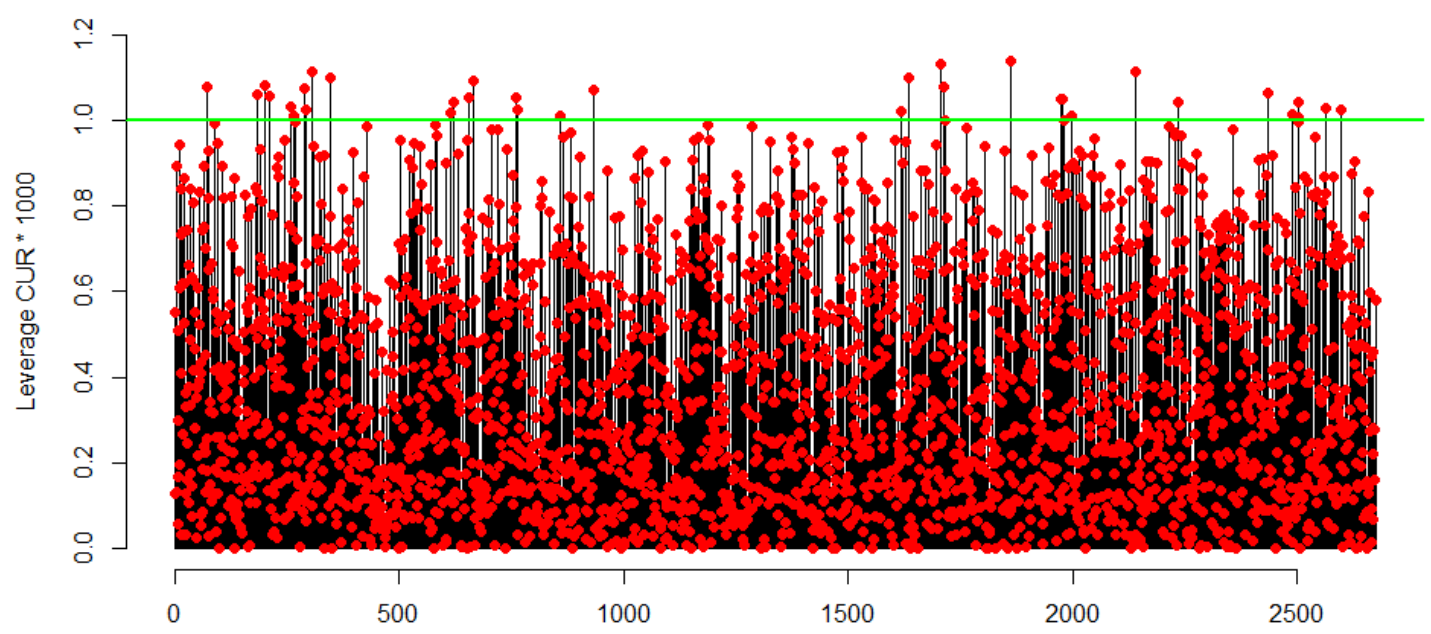




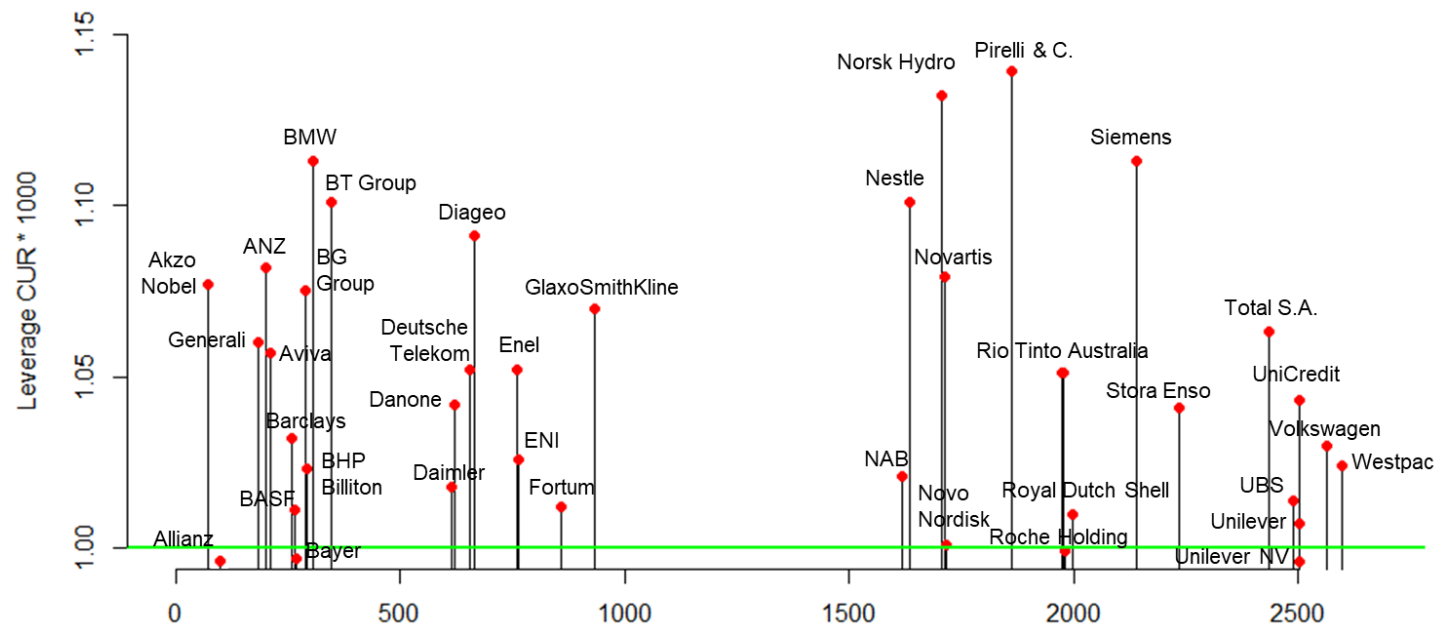

Next, we select the fifty percentile as the sustainability threshold; that is, we will consider those with a leverage above p50 as sustainable companies and those with a value greater than $\mathrm{p} 75$ as the leading organizations in social responsibility. To study this information, we separate the companies by their country of origin and calculate their proportions based on these criteria. Thus, for example, in Australia we have 97 companies, of which $63 \%$ are considered to be sustainable (61 companies with leverage above p50 of the 2,675 companies) and $10 \%$ considered as leaders of this commitment (10 companies with leverage above p75 of the 2,675 companies). In addition, this information is contrasted with the national sustainability practices index called NCSRPI (proposed in chapter four), which show low penetration of the CSR and a great variation between countries. All these data are summarized in Table 4, in which the last column, 'NCSRPI' - the National Corporate Social Responsibility Practices Index -, represents the values of the named national sustainability index.

Table 4. Proportion of sustainable enterprises by country based on leverage CUR

\begin{tabular}{lccccc}
\hline Country & Companies & $>75 \%$ & $50 \%-75 \%$ & $>50 \%$ & NCSRPI \\
\hline Finland & 18 & 27.78 & 50.00 & 77.78 & 21.00 \\
Denmark & 20 & 10.00 & 45.00 & 55.00 & 11.25 \\
Sweden & 45 & 8.89 & 51.11 & 60.00 & 10.27 \\
Norway & 13 & 15.38 & 46.15 & 61.53 & 9.56 \\
Netherlands & 31 & 22.58 & 54.84 & 77.42 & 5.81 \\
Switzerland & 49 & 16.33 & 32.65 & 48.98 & 5.06 \\
Australia & 97 & 10.31 & 52.58 & 62.89 & 3.81 \\
Spain & 39 & 15.38 & 56.41 & 71.79 & 3.33 \\
France & 88 & 18.18 & 63.64 & 81.82 & 1.80 \\
Italy & 38 & 31.58 & 34.21 & 65.79 & 1.04 \\
United Kingdom & 451 & 7.98 & 41.24 & 49.22 & 0.94 \\
Belgium & 13 & 0.00 & 61.54 & 61.54 & 0.86 \\
Germany & 86 & 19.77 & 40.70 & 60.47 & 0.82 \\
Japan & 468 & 3.42 & 40.60 & 44.02 & 0.23 \\
Canada & 88 & 1.14 & 42.05 & 43.19 & 0.10 \\
Unites States & 666 & 1.35 & 34.23 & 35.58 & -0.18 \\
Brazil & 26 & 0.00 & 23.08 & 23.08 & -0.35 \\
South Korea & 113 & 1.77 & 52.21 & 53.98 & -0.58 \\
Austria & 12 & 8.33 & 41.67 & 50.00 & -0.64 \\
Israel & 31 & 3.23 & 25.81 & 29.04 & -0.68 \\
India & 27 & 0.00 & 14.81 & 14.81 & -0.83 \\
& & & & &
\end{tabular}




\begin{tabular}{lccccc} 
China & 52 & 0.00 & 5.77 & 5.77 & -0.84 \\
Mexico & 20 & 5.00 & 50.00 & 55.00 & -2.33 \\
Turkey & 10 & 0.00 & 0.00 & 0.00 & -3.06 \\
Russia & 19 & 0.00 & 5.26 & 5.26 & -3.30 \\
Thailand & 11 & 0.00 & 18.18 & 18.18 & -4.93 \\
Malaysia & 14 & 0.00 & 0.00 & 0.00 & -16.48 \\
Singapore & 39 & 0.00 & 7.69 & 7.69 & -21.93 \\
Hong Kong & 90 & 0.00 & 8.89 & 8.89 & -29.17 \\
\hline
\end{tabular}

The data shown in Table 4 are arranged according to the NRSCPI. We can verify that the proportions obtained from the leverages show a high degree of similarity to these values (companies $>50 \%$, Pearson correlation coefficient of $0.681-\mathrm{p}$-value $=0.000$, and companies $>75 \%$ coefficient of $0.562-p$-value $=0.002)$. In general terms, we find important discrepancies between countries, attributed by various researchers to the variability of institutional efficiency (Chen and Bouvain, 2009; Jackson and Apostolakou, 2010). According to the arguments of Campbell (2006, 2007), companies define their behaviour according to the expectations or pressures imposed on them by their main interest groups due to the institutional characteristics where they operate; organizations must comply with the professional standards and the existing standards of their environment. In Annex B, it is possible to determine the distribution of companies by country, knowing the most sustainable in each of them.

European countries show themselves to be one step above the rest of the world in sustainable terms. Thus, the majority of the companies in all of them are considered to be sustainable. That is, more than $50 \%$ of their organizations are above p50 (with the exception of Switzerland with 49\%). These results coincide with those found from microdata by other researchers (Welford, 2004; Matten and Moon, 2008). In northern Europe, Finland stands out, with $78 \%$ of its companies considered to be sustainable, and $28 \%$ of them are leaders in this commitment. We can highlight Stora Enso and UPMKymmene (forestry and paper), Warstsila (industrial engineering), Nokia (technology) and Fortum (electrical). Together with Finland, the Nordic countries have high percentages, with Novo Nordisk and Novozymes (drugs and biotechnology) in Denmark; Norsk Hydro (raw materials) and Statoil (oil and gas) in Norway; and Svenska Cellulosa (consumer goods), SKF and Sandvik (industrial engineering) and Ericsson (technology) from Sweden.

In Central Europe, we also find strong CSR levels. The highlighted companies include Akzo Nobel and DSM (chemical products), Unilever and Heineken (consumer goods), Elsevier (media) and ING (banking) in the Netherlands and the Swiss companies Nestle (food producers), UBS and Credit Suisse (banking), Novartis and Roche (drugs and biotechnology) and ABB, Sulzer and SGS (industrial products). Germany has been considered a laggard country among its European counterparts in sustainability terms; its high level of social integration and the favourable economic climate at the national level have contributed to reducing the demand for CSR in the country, which is why German companies have maintained a widely ambivalent position towards CSR practices (Jackson and Apostolakou, 2010). As we can see, it presents companies with strong levels of CSR and many others below the sustainability threshold, with very low levels (see Annex B). Among the most powerful, we can point out BASF and Bayer (chemical products), BMW, Volkswagen and Daimler (automobiles and spare parts), Siemens, Fraport and MAN (industrial products), Allianz (insurance), SAP (technology) and Deutsche Telekom (telecommunications), as well as OMV (oil and gas) of Austria. Finally, Belgium presents approximately $62 \%$ of companies that are considered to be 
sustainable; however, none of them is presented as a leader in the study. This information leads us to the same conclusion (Welford, 2004), that is, that companies respond to what is important in their own countries, since institutional characteristics pose an advantage or a barrier when adopting or improving their CSR practices (Esteban et al., 2017).

In southern Europe, we find levels that are similar or superior to the previous ones. Thus, $82 \%$ of French companies are considered to be sustainable, which is an increase of $18 \%$, and among these are Danone, L'Oreal and Peugeot (consumer goods), BNP Paribas (banking), Total (oil and gas), STM (technology) and Suez, Veolia and Engie (gas, water and multiple services). In Spain, Inditex stands out (textile design), along with Acciona (construction and materials), Repsol (oil and gas), Indra (technology) and Iberdrola and Enagas (utilities). Finally, in Italy, we see a high percentage of leading companies. However, those that do not exceed the sustainability threshold have very low levels, a situation similar to that in Germany. We highlight some of the strongest Italian companies: Pirelli (automobiles and spare parts), Generali (insurance), UniCredit, Intesa-Sanpaolo and Mps (banking), CNH (industrial engineering), ENI and Saipem (oil and gas), Enel and Terna (electrical) and Snam (gas, water and multiple services).

More than half of companies are below the threshold of sustainability in most countries that are not part of the European Union, with a few exceptions, such as Australia, where $63 \%$ of companies exceed this threshold. This may be due to the fact that its regulatory regime is similar to that found in some European countries, especially in relation to corporate transparency (Kimber and Lipton, 2005; Baughn et al., 2007). Among its leading companies in sustainable development are Rio Tinto and BHP Billiton (mining), Qantas Airways (travel and leisure), ANZ, Westpac, NAB and CommBank (bank), Amcor (industrial products) and Woodside Petroleum and Santos (petroleum and gas). It should be noted that, in the United Kingdom, only $49 \%$ of companies exceed the sustainability threshold. We find large companies that are known throughout the world, such as Diageo (drinks), Aviva and Barclays (finance), GlaxoSmithKline (drugs and biotechnology), CRH and Marshalls (construction and materials), BG and Royal Dutch Shell (oil and gas), BT (telecommunications) and Centrica (gas, water and multiple services). A similar situation is evident in the United States, where only $36 \%$ of companies exceed this threshold. However, we find several leading multinationals in sustainability, such as Alcoa (industrial metals and mining), Coca-Cola (beverages), Citigroup (banking), Johnson \& Johnson and Merck (drugs and biotechnology), 3M (general industrial products) and Hewlett-Packard, Intel and Symantec (technology). In addition, we can point out that, in general terms, Canadian companies are slightly superior to their American counterparts. However, both appear to be far behind in relation to the sustainability problems of European companies, as other researchers have previously discovered from microdata (Welford, 2004; Matten and Moon, 2008; Purdy et al., 2010). In Canada, the company Suncor Energy (oil and gas) stands out. Of the rest of the countries, we highlight LG (leisure items) and SK Hynix (technology) from South Korea; OMV (oil and gas) of Austria; Bank Hapoalim (banking) of Israel; and Cemex (construction and materials) of Mexico. The remaining countries show small percentages of sustainable companies - Brazil (23\%), Thailand (18\%), India (15\%), Hong Kong (9\%), Singapore (8\%), China (6\%) and Russia (5\%) - and Turkey and Malaysia do not present any organizations that are considered to be sustainable. 
Next, in a similar way to the previous analysis, we separate the companies into different industries and calculate for each of them, based on their leverages, the percentages of companies considered to be sustainable (those that exceed the threshold of sustainability imposed, leverage > p50) and leading companies (leverage > p75). Following the industry classification system of the ICB (Industry Classification Benchmark), we codify the companies according to the 'industry' category in the 10 main sectors of activity - basic materials, consumer goods, consumer services, financials, health care, industrials, oil and gas, technology, telecommunications and utilities. Subsequently, we contrast the information obtained with the industrial sustainability index proposed by Amor-Esteban et al. (2018); they showed that companies belonging to industries with greater social and environmental risks, such as basic materials or oil and gas, have stronger CSR levels than the rest of the industries. In this way, both our results and the scores of ICSRPI (Industrial Corporate Social Responsibility Practices Index), which is what the authors' proposed index is named, are synthesized in Table 5.

Table 5. Proportion of sustainable enterprises by industry based on leverage CUR

\begin{tabular}{lccccc}
\hline Industry & Companies & $>75 \%$ & $50 \%-75 \%$ & $>50 \%$ & ICSRPI \\
\hline Basic Materials & 217 & 5.99 & 59.45 & 65.44 & 4.52 \\
Utilities & 107 & 14.02 & 49.53 & 63.55 & 4.48 \\
Oil \& Gas & 144 & 9.03 & 42.36 & 51.39 & 3.19 \\
Industrials & 517 & 5.80 & 47.00 & 52.80 & 2.09 \\
Consumer Goods & 343 & 7.87 & 43.44 & 51.31 & 1.61 \\
Technology & 168 & 7.14 & 33.93 & 41.07 & 0.03 \\
Health Care & 150 & 6.67 & 31.33 & 38.00 & -0.10 \\
Telecommunications & 73 & 5.48 & 35.62 & 41.10 & -0.65 \\
Financials & 574 & 4.18 & 26.66 & 30.84 & -3.65 \\
Consumer Services & 382 & 2.09 & 25.39 & 27.49 & -3.66 \\
\hline
\end{tabular}

The data shown in Table 5 are arranged according to the ICSRPI. We can verify that the proportions obtained from the leverages show a strong degree of similarity to these scores (companies $>50 \%$, Pearson correlation coefficient of $0.973-$ p-value $=0.000$, and companies $>75 \%$, coefficient of 0.745 - p-value $=0.014$ ). It is possible to observe that more than $50 \%$ of the companies in the industries with positive scores in the ICSRPI are considered to be sustainable. In the development of an industrial sustainability index, the authors show that the industries in which the most sustainable companies are located are those of which the activity leads them to be considered to have a high environmental impact. These companies implement more advanced environmental management policies and systems. Organizations use CSR to legitimize their business practices, so they adhere to CSR policies as a way to manage their reputation and respond to the expectations of their stakeholders (Amor-Esteban et al., 2018). In Annex C, we show the differences between industries graphically based on the leverage of all the companies distributed by industries and graphs, known as 'solar projection'. We break down the joint values of each industry in relation to the 27 individual practices of CSR distinguished into 5 dimensions - environment (ENV), human rights (HR), stakeholders (STH), ethics (ETH) and employees (EMP).

The industries that lead the ICSRPI - basic materials, utilities, oil and gas, and industrial products - present the strongest levels in most practices. These industries stand out remarkably above the rest in environmental performance, human rights and systems aimed to ensure the health and safety of their employees, because their actions have a strong impact on human health that clearly undermines the rights of citizens. Basic materials and utilities are more complete, while oil and gas companies, in relation 
to their stakeholders, prioritize their responsibility as members of the board and industrial products' relations with customers and suppliers. In ethical dimension, oil and gas show greater interest than industrial products in the implementation of an ethical code (Annex C, solar projections). Basic materials account for $65 \%$ of companies that are considered to be sustainable, which are dedicated to forestry and paper, chemical products, mining and industrial metals. In addition, $6 \%$ of its companies are presented as leaders in sustainable development. We name the 5 most powerful: Norsk Hydro (industrial metals and mining, Norway), Akzo Nobel (chemical products, the Netherlands), Stora Enso (forestry and paper, Finland) and Rio Tinto and BHP Billiton (mining, United Kingdom and Australia). In relation to the organizations used in utilities, they focus their activities mainly on electricity, gas and water services. Of these, $64 \%$ surpass the sustainability threshold and $14 \%$ stand out in sustainable development. These companies are Enel, Fortum and Terna (electricity, Italy, Finland and Italy) and Centrica and E.ON (gas, water and multiple services, the United Kingdom and Germany). More than $50 \%$ of the companies in the industry for the extraction, production and distribution of oil and gas are sustainable, and $80 \%$ of them perform production activities. In addition, $9 \%$ of all companies are prominent regarding this commitment - of which $92 \%$ corresponds to production. These companies are BG Group and Royal Dutch Shell (the United Kingdom), Total (France), ENI (Italy) and OMV (Austria), all aimed at production. In industrial products, 53\% of companies surpass the sustainability threshold, including companies focusing on the aerospace and defence sub-industry and on construction for industrial or transport engineering, the production of electrical equipment or support services. Of these, $6 \%$ are conspicuous, including Siemens (general industrial products, Germany), CRH (construction and materials, the United Kingdom), Fraport (industrial transport, Germany), Alstom (industrial engineering, France) and Airbus (aerospace and defence, France). The companies in these industries are considered to have a high environmental impact; therefore, they seek to improve their commitment to sustainability through CSR to manage those risks and increase the trust of their users, which is largely due to social pressure to disclose bad environmental news (Semenova and Hassel, 2008; Casey and Grenier, 2014).

In some industries - consumer goods, technology and health care - the percentage of sustainable companies decreases, because the impact of their activities is smaller. However, in these industries, environmental levels predominate over the rest of their practices, without forgetting their commitment to the community and systems aimed at maintaining good relations with customers and suppliers. This is due to the fact that, in the consumer goods industry highlights the companies with the greatest impact, those aimed at manufacturing and repairing automobiles as well as those addressed to the manufacturers and distributors of tobacco, above the companies aimed at the development of personal and leisure items and producers of beverages and food, of less impact. Among them, Pirelli and BMW stand out (cars and spare parts, Italy and Germany), Nestle and Danone (food producers, Switzerland and France) and Diageo (drinks, the United Kingdom). In technology, the number of sustainable companies corresponds to $63 \%$ of companies employed in the manufacturing and distribution of hardware and high-technology equipment which have a greater impact or environmental risk and, about $37 \%$ dedicated to software. Among them we can highlight Fujitsu, STM and LM (hardware, Japan, France and Sweden) and SAP and Indra (software, Germany and Spain). A similar situation is found in the health care industry, in which companies dedicated to the research, development and manufacture of drugs and biotechnology 
account for $67 \%$ of sustainable companies over $33 \%$ aimed at services and equipment to care for health, such as hospitals or clinics. Among the most sustainable are Novartis and Roche Holding (Switzerland) and GlaxoSmithKline, Novo Nordisk and Merck (the United Kingdom, Denmark and Germany), all focusing on drugs and biotechnology. These organizations adopt more codified and explicit CSR practices in the industry in which they operate with the objective of improving their image by controlling the standards that they must meet to be considered proactive and thus increase their benefits (Jackson and Apostolakou, 2010).

The reverse situation is found in the telecommunications industry - fixed line or mobile - in which the environment is not the central focus of sustainability. In this industry, social concerns outweigh environmental concerns, and companies focus on promoting equal opportunities and the training and participation of their employees. Externally, they prioritize the maintenance of good relations with customers and suppliers and the participation of their stakeholders and transparency in the disclosure of information (Annex C, solar projections). Involving stakeholders in corporate activities results in an improvement in sustainable development; the basis of this process is the dialogue aimed at learning the expectations and possibilities of all the interested parties (Salem et al., 2017). Of this industry's companies, $41 \%$ exceed the sustainability threshold and $5 \%$ are prominent: BT and Orange (landline, the United Kingdom and France) and Deutsche Telekom and Vodafone (mobile, Germany and the United Kingdom).

The last two industries, financial services and consumer services, have the lowest environmental levels, since their companies represent a minor concern for society. Both are positioned as the most backward industries in sustainable terms, presenting levels below the average in all practices. These industries focus their efforts on working conditions - job creation, training and employee participation - and external relations clients, suppliers and the community. In finance, they are more concerned with counteracting bribery and consumer services for human rights. Only $31 \%$ of companies in financial services are considered to be sustainable, of which $42 \%$ correspond to banks, surpassing other companies dedicated to life insurance and other insurance, investment or real estate investment funds, among others. Only 4\% stand out among all companies: ANZ, Unicredit and Barclays (banking, Australia, Italy and the United Kingdom) and Generali and Aviva (insurance, Italy and the United Kingdom). The consumer services industry is made up of organizations operating in the media, travel and leisure, general retail, food and medicines. Only $28 \%$ of these companies exceed the threshold of sustainability, and only $2 \%$ are among the leading companies in sustainable development. These companies are Kingfisher and Inditex (general retailers, the United Kingdom and Spain), Reed Elsevier and WPP (media, the United Kingdom) and Qantas Airways (travel and leisure, Australia). Companies in these industries are less controlled by the public and therefore less competitive in terms of sustainable practices (Belu, 2009; Scholtens, 2011; Weber, 2014).

\section{Conclusions}

Making use of an international database, this research proposes an aggregate index at the organizational level based on a novel method of selecting individuals when handling large amounts of data, known as CUR matrix decomposition, to highlight the companies with the strongest levels of sustainability. In addition, the aggregate indicator proposed is contrasted with the main measures used in previous studies to check their coherence 
and their consistency with the literature. Secondly, as an additional objective, the proposed index is disaggregated at the national and industrial levels.

The results obtained show the high correlation and similarity of leverage CUR - as an aggregate indicator - with the rest of the indicators used in the literature. This supports and corroborates the operation of the proposed index. On the other hand, the results of the study confirm that companies adapt to the demands or pressures from the stakeholders in different areas of interest, which are specific to each country and industry. Thus, this study reveals how European countries show themselves to be a step above the rest of the countries in sustainable terms. The Nordic countries stand out, more specifically Finland. Among the non-European countries, Australia is one of the strongest, given that its regulatory regime is similar to that found in some European countries.

With reference to the analysis by industry, this study shows that the most sustainable companies are in industries considered to involve high environmental risk. Therefore, companies use CSR to legitimize their business practices, so they adhere to CSR policies as a way to manage their reputation and respond to the expectations of their stakeholders. The most polluting industries with the highest social risks, basic materials, utilities, oil and gas, and industrial products, show the strongest levels of environmental performance, human rights and systems relating to the health and safety of their employees. The consumer goods, technology and health care industries are one step below the previous ones, and their environmental levels predominate over the rest of their practices, without forgetting their commitment to the community, customers and suppliers. Finally, in the remaining industries, we find the reverse situation, in which social concerns exceed environmental concerns. Companies in these industries are less controlled by the public and therefore less competitive in terms of sustainable practices.

The results obtained in this study offer a series of practical implications. Thus, an aggregate indicator of CSR practices at the company level is an essential tool for politicians and public managers in decision-making processes. The availability of these data allows the identification of the structural drivers of their growth and the establishment of priorities that allow the design of more effective sustainable development promotion policies. These data enable the identification of the model companies both nationally and industrially, providing a mirror to look at those companies that are in situations of uncertainty, imitating the behaviour of the leading organizations in sustainable development. On the other hand, the information provided allows a benchmark analysis of economic, environmental and social performance in different industries, favouring processes that seek to know the actions that lead to greater commitment to CSR as a result of studying the most powerful companies. These analyses can be used, in addition to politicians and business leaders, by company managers in their own strategic decisions on CSR and to understand the existing pressures on the social and environmental commitments of those foreign markets into which they decide to diversify their commercial activities.

This article presents limitations that will be considered by the authors in future lines of research. More concretely, we only analysed the scores obtained in the aggregate index at the national and industrial levels, leaving aside the role or function of the managers of companies, especially the CEO, in CSR decision making. Consequently, research will be conducted in the future to analyse the score or sustainable development linked with the CEO personality of each corporation. The most prestigious CEOs, due to their 
consideration in the labour market and the larger number of professional opportunities that they enjoy, are more willing to undertake long-term investments; thus, they could have a greater incentive to conduct the company towards the correction of environmental and social deficiencies derived from economic activity, foster strengths and improve the sustainability of commercial actions through investment in CSR practices in the long term.

\section{References}

Amor-Esteban, V., Galindo-Villardón, M.-P., García-Sánchez, I.-M., 2018. Useful information for stakeholder engagement: A multivariate proposal of an Industrial Corporate Social Responsibility Practices Index. Sustain. Dev. https://doi.org/10.1002/sd.1732

Amor-Esteban, V., García-Sánchez, I.-M., Galindo-Villardón, M.-P., 2017. Analysing the Effect of Legal System on Corporate Social Responsibility (CSR) at the Country Level, from a Multivariate Perspective. Soc. Indic. Res. 1-18.

Arora, P., Dharwadkar, R., 2011. Corporate Governance and Corporate Social Responsibility (CSR): The Moderating Roles of Attainment Discrepancy and Organization Slack. Corp. Gov. Int. Rev. 19, 136-152. https://doi.org/10.1111/j.1467-8683.2010.00843.x

Baughn, C.C., (Dusty) Bodie, N.L., McIntosh, J.C., 2007. Corporate social and environmental responsibility in Asian countries and other geographical regions. Corp. Soc. Responsib. Environ. Manag. 14, 189-205. https://doi.org/10.1002/csr.160

Belu, C., 2009. Ranking corporations based on sustainable and socially responsible practices. A data envelopment analysis (DEA) approach. Sustain. Dev. 17, 257268.

Bodor, A., Csabai, I., Mahoney, M.W., Solymosi, N., 2012. rCUR: an R package for CUR matrix decomposition. BMC Bioinformatics 13, 103. https://doi.org/10.1186/1471-2105-13-103

Boiral, O., Henri, J.-F., 2017. Is sustainability performance comparable? A study of GRI reports of mining organizations. Bus. Soc. 56, 283-317.

Bouten, L., Cho, C.H., Michelon, G., Roberts, R.W., 2017. CSR Performance Proxies in Large-Sample Studies: 'Umbrella Advocates', Construct Clarity and the 'Validity Police'. http://dx.doi.org/10.2139/ssrn.3107182

Campbell, J.L., 2007. Why would corporations behave in socially responsible ways? An institutional theory of corporate social responsibility. Acad. Manage. Rev. 32, 946967.

Campbell, J.L., 2006. Institutional Analysis and the Paradox of Corporate Social Responsibility. Am. Behav. Sci. 49, 925-938. https://doi.org/10.1177/0002764205285172 
Carroll, A.B., 1999. Corporate social responsibility: Evolution of a definitional construct. Bus. Soc. 38, 268-295.

Carroll, A.B., 1979. A Three-Dimensional Conceptual Model of Corporate Performance. Acad. Manage. Rev. 4, 497-505. https://doi.org/10.5465/AMR.1979.4498296

Casey, R.J., Grenier, J.H., 2014. Understanding and contributing to the enigma of corporate social responsibility (CSR) assurance in the United States. Audit. J. Pract. Theory 34, 97-130.

Chatterji, A.K., Levine, D.I., Toffel, M.W., 2007. Do corporate social responsibility ratings predict corporate social performance? Division of Research, Harvard Business School.

Chen, S., Bouvain, P., 2009. Is Corporate Responsibility Converging? A Comparison of Corporate Responsibility Reporting in the USA, UK, Australia, and Germany. J. Bus. Ethics 87, 299-317. https://doi.org/10.1007/s10551-008-9794-0

Cheng, B., Ioannou, I., Serafeim, G., 2014. Corporate social responsibility and access to finance: CSR and Access to Finance. Strateg. Manag. J. 35, 1-23. https://doi.org/10.1002/smj.2131

Crilly, D., Zollo, M., Hansen, M.T., 2012. Faking it or muddling through? Understanding decoupling in response to stakeholder pressures. Acad. Manage. J. $55,1429-1448$.

Cruz, C., Larraza-Kintana, M., Garcés-Galdeano, L., Berrone, P., 2014. Are family firms really more socially responsible? Entrep. Theory Pract. 38, 1295-1316.

Cuadrado-Ballesteros, B., García-Sánchez, I.-M., Martínez-Ferrero, J., 2017. The impact of board structure on CSR practices on the international scale. Eur. J. Int. Manag. 11, 633-659.

Drineas, P., Mahoney, M.W., Muthukrishnan, S., 2008. Relative-error CUR matrix decompositions. SIAM J. Matrix Anal. Appl. 30, 844-881.

Eckart, C., Young, G., 1936. The approximation of one matrix by another of lower rank. Psychometrika 1, 211-218.

Esteban, V.A., Villardón, M.P.G., Sánchez, I.M.G., 2017. Cultural values on CSR patterns and evolution: A study from the biplot representation. Ecol. Indic. 81, 1829. https://doi.org/10.1016/j.ecolind.2017.05.051

Fabrizi, M., Mallin, C., Michelon, G., 2014. The Role of CEO's Personal Incentives in Driving Corporate Social Responsibility. J. Bus. Ethics 124, 311-326. https://doi.org/10.1007/s10551-013-1864-2

Frederick, W.C., 1994. From CSR1 to CSR2: The maturing of business-and-society thought. Bus. Soc. 33, 150-164. 
Freeman, R.E., Harrison, J.S., Wicks, A.C., Parmar, B.L., De Colle, S., 2010. Stakeholder theory: The state of the art. Cambridge University Press.

García, A.S., Mendes-Da-Silva, W., Orsato, R.J., 2017. Sensitive industries produce better ESG performance: Evidence from emerging markets. J. Clean. Prod. 150, 135-147. https://doi.org/10.1016/j.jclepro.2017.02.180

García-Sánchez, I.-M., García-Meca, E., 2017. CSR engagement and earnings quality in banks. The moderating role of institutional factors. Corp. Soc. Responsib. Environ. Manag. 24, 145-158.

Gössling, T., Vocht, C., 2007. Social role conceptions and CSR policy success. J. Bus. Ethics 74, 363-372.

Graves, S.B., Waddock, S.A., 1994. Institutional Owners and Corporate Social Performance. Acad. Manage. J. 37, 1034-1046. https://doi.org/10.2307/256611

Griffin, J.J., 2000. Corporate social performance: Research directions for the 21st century. Bus. Soc. 39, 479-491.

Gutsche, R., Schulz, J. F., \& Gratwohl, M. (2017). Firm-value effects of CSR disclosure and CSR performance. In EFMA-Conference proceedings (pp. 1-31). EFMA.

Hess, D.W., 2014. The framework for CSR assessment, measurement, and reporting. In Christian ethics and corporate culture (pp. 177-192). Springer, Cham.

Holme, R., Watts, P., 1999. Corporate social responsibility. Geneva World Bus. Counc. Sustain. Dev.

Hopkins, M., 2004. Corporate social responsibility: an issues paper. International Labor office. Geneva.

Jackson, G., Apostolakou, A., 2010. Corporate Social Responsibility in Western Europe: An Institutional Mirror or Substitute? J. Bus. Ethics 94, 371-394. https://doi.org/10.1007/s10551-009-0269-8

Kang, J., 2013. The relationship between corporate diversification and corporate social performance. Strateg. Manag. J. 34, 94-109.

Kassinis, G., Vafeas, N., 2006. Stakeholder pressures and environmental performance. Acad. Manage. J. 49, 145-159.

Kimber, D., Lipton, P., 2005. Corporate governance and business ethics in the AsiaPacific region. Bus. Soc. 44, 178-210.

Le Breton-Miller, I., Miller, D., 2006. Why Do Some Family Businesses Out-Compete? Governance, Long-Term Orientations, and Sustainable Capability. Entrep. Theory Pract. 30, 731-746. https://doi.org/10.1111/j.1540-6520.2006.00147.x

León, J.Á.P., 2015. Análisis de la relación causal de la responsabilidad social corporativa y la performance financiera de las empresas. Ph.D. dissertation, 
Universitat Politècnica de València, València, Spain. https://doi.org/10.4995/Thesis/10251/48517

Liesen, A., Hoepner, A.G., Patten, D.M., Figge, F., 2015. Does stakeholder pressure influence corporate GHG emissions reporting? Empirical evidence from Europe. Account. Audit. Account. J. 28, 1047-1074.

Mahoney, L.S., Thorne, L., 2005. Corporate social responsibility and long-term compensation: Evidence from Canada. J. Bus. Ethics 57, 241-253.

Mahoney, M.W., Drineas, P., 2009. CUR matrix decompositions for improved data analysis. Proc. Natl. Acad. Sci. 106, 697-702. https://doi.org/10.1073/pnas.0803205106

Marquis C, Beunza D., Ferraro F., Thomason B., 2011. Driving Sustainability at Bloomberg L.P. Harvard Business School Case, 411-025.

Martínez-Ferrero, J., García-Sánchez, I.-M., 2016. Coercive, normative and mimetic isomorphism as determinants of the voluntary assurance of sustainability reports. Int. Bus. Rev. https://doi.org/10.1016/j.ibusrev.2016.05.009

Matten, D., Moon, J., 2008. "Implicit" and "explicit" CSR: a conceptual framework for a comparative understanding of corporate social responsibility. Acad. Manage. Rev. $33,404-424$.

Mattingly, J.E., Berman, S.L., 2006. Measurement of corporate social action discovering taxonomy in the Kinder Lydenburg Domini ratings data. Bus. Soc. 45, $20-46$.

Oh, W.-Y., Chang, Y.K., Cheng, Z., 2016. When CEO Career Horizon Problems Matter for Corporate Social Responsibility: The Moderating Roles of Industry-Level Discretion and Blockholder Ownership. J. Bus. Ethics 133, 279-291. https://doi.org/10.1007/s10551-014-2397-z

Peake, W.O., Davis, P.E., Cox, M.Z., 2015. Being good for goodness sake: The influence of family involvement on motivations to engage in small business social responsibility. J. Small Bus. Strategy 25, 1-25.

Petrenko, O.V., Aime, F., Ridge, J., Hill, A., 2016. Corporate social responsibility or CEO narcissism? CSR motivations and organizational performance. Strateg. Manag. J. 37, 262-279. https://doi.org/10.1002/smj.2348

Pomering, A., Johnson, L.W., 2009. Advertising corporate social responsibility initiatives to communicate corporate image: Inhibiting scepticism to enhance persuasion. Corp. Commun. Int. J. 14, 420-439.

Porter, M.E., Kramer, M.R., 2006. The link between competitive advantage and corporate social responsibility. Harv. Bus. Rev. 84, 78-92.

Purdy, J.M., Alexander, E.A., Neill, S., 2010. The impact of national institutional context on social practices: Comparing Finnish and US business communities. Eur. J. Int. Manag. 4, 234-256. 
Rahman, S., 2011. Evaluation of definitions: ten dimensions of corporate social responsibility. World Rev. Bus. Res. 1, 166-176.

Salem, M.A., Shawtari, F., Shamsudin, M.F., Hussain, H.B.I., 2017. The Consequences of Integrating Stakeholder Engagement in Sustainable Development (Environmental Perspectives). Sustain. Dev. https://doi.org/10.1002/sd.1699

Sassen, R., Hinze, A.-K., Hardeck, I., 2016. Impact of ESG factors on firm risk in Europe. J. Bus. Econ. 86(8), 867-904.

Scholtens, B., 2011. Corporate social responsibility in the international insurance industry. Sustain. Dev. 19, 143-156.

Sehic, D., Sabanovic, J., 2008. Corporate Social Responsibility of B \& H Companies in Globalization, in: 5th International Scientific Conference Business and Management.

Semenova, N., Hassel, L.G., 2008. Financial outcomes of environmental risk and opportunity for US companies. Sustain. Dev. 16, 195-212.

Stuart, H., 2002. Employee identification with the corporate identity-Issues and implications. Int. Stud. Manag. Organ. 32, 28-44.

Su, P.-F., Chen, X., Chen, H., Shyr, Y., 2012. Statistical aspects of omics data analysis using the random compound covariate. BMC Syst. Biol. 6, S11. https://doi.org/10.1186/1752-0509-6-S3-S11

Van Beurden, P., Gössling, T., 2008. The worth of values-a literature review on the relation between corporate social and financial performance. J. Bus. Ethics 82, 407.

Waddock, S.A., Graves, S.B., 1997. The corporate social performance-financial performance link. Strateg. Manag. J. 303-319.

Wang, H., Choi, J., 2013. A new look at the corporate social-financial performance relationship: The moderating roles of temporal and interdomain consistency in corporate social performance. J. Manag. 39, 416-441.

Wang, Z., Hsieh, T.-S., Sarkis, J., 2018. CSR Performance and the Readability of CSR Reports: Too Good to be True?. Corp. Soc. Responsib. Environ. Manag. 25, 66-79. https://doi.org/10.1002/csr.1440

Wartick, S.L., Cochran, P.L., 1985. The evolution of the corporate social performance model. Acad. Manage. Rev. 10, 758-769.

Weber, J.L., 2014. Corporate social responsibility disclosure level, external assurance and cost of equity capital. University of Colorado at Boulder.

Weber, M., 2008. The business case for corporate social responsibility: A companylevel measurement approach for CSR. Eur. Manag. J. 26, 247-261.

Welford, R., 2004. Corporate social responsibility in Europe and Asia: Critical elements and best practice. J. Corp. Citizsh. 13, 31. 
Wood, D.J., 2010. Measuring corporate social performance: A review. Int. J. Manag. Rev. 12, 50-84.

Wood, D.J., 1991. Corporate social performance revisited. Acad. Manage. Rev. 16, 691-718. 


\section{Annex A. Description and operationalization of the most important initiatives, standards and guidelines for CSR}

CSR initiatives

ISO 14001

OHSAS 18001

SA8000

Global Reporting Initiative Guidelines

Global Compact

Principles

World Business

Council for

Sustainable

Development

Carbon Disclosure

Project

Greenhouse Gas

Protocol

KPMG Int. Survey of Corporate Resp. Reporting

Ethibel

Sustainability Index

\section{Description and operationalization}

The ISO 14001 standard is an international environmental management standard developed by the International Organization for Standardization (ISO) that lays out a framework that an organization can follow to establish an effective environmental management system. It can be used by any organization regardless of its activity or sector. It can provide security to the company management, employees and external stakeholders that the environmental impact is being measured and improved.

The OHSAS 18001 standard is a standard of occupational health and safety management systems developed by the Occupational Health and Safety Advisory Services Project Group (OHSAS). Its objective is to help organizations to control occupational health and safety risks. It was developed in response to the widespread demand for a recognized standard against which health and safety performance can be evaluated and certified.

The SA8000 certification is an auditable certification standard for workplaces developed by the International Social Responsibility (SAI - Social Accountability International). It reflects a management system approach by establishing policies and procedures that protect the basic human rights of employees and maintain socially acceptable practices in the workplace.

The Global Reporting Guidelines (GRI) offer a set of reporting principles, standard disclosures and an implementation manual for the preparation of sustainability reports by organizations, regardless of their size, sector or location. This initiative also offers an international reference for all those interested in the dissemination of the governance approach and the environmental, social and economic performance and impacts of the organizations.

The Global Compact, developed by the United Nations, is a strategic policy initiative that invites companies to adopt, support and enact, within their sphere of influence, a set of ten universally accepted principles for the protection of human rights, labour standards and benign environmental management and anti-corruption measures.

The World Business Council for Sustainable Development (WBCSD) is a global association of companies that aims to promote strategic issues related to sustainable development and corporate responsibility. It offers a platform for companies to share knowledge, experiences and best practices and to defend commercial positions on these issues between various forums, in cooperation with government agencies, NGOs and intergovernmental organizations.

The Carbon Disclosure Project (CDP) is an international non-profit organization that works in cooperation with market forces to motivate companies to measure, manage and disseminate vital environmental information regarding their emissions of greenhouse gases and finally to take measures to reduce them.

The Greenhouse Gas Protocol (GHG) is an accounting tool to quantify and manage greenhouse gas emissions with the overall objective of contributing to credible and effective programmes to address climate change. It offers the accounting framework for almost all GHG standards and programmes in the world, as well as hundreds of GHG inventories prepared by individual companies.

KPMG's international corporate social responsibility report survey (Klynveld Peat Marwick Goerdeler) is a detailed analysis of non-financial corporate reports and includes a descriptive assessment of the current state of CSR disclosure practices among the 100 largest companies in the countries selected (N100).

The Ethibel Sustainability Index (ESI - Ethibel Sustainability Index) of global excellence contains a variable number of actions, bringing together the best 
Excellence Globa

FTSE4Good Global Index

Dow Jones

Sustainability World

Enlarged Index

ECPI Global ESG

Alpha Equity Index

Ethisphere WME

MSCI World ESG

Index

Global 100 companies in its class with respect to CSR/sustainability in all sectors and regions of Europe, North America and Pacific Asia. It is a weighted index of free float or 'free float' - the part of the social capital of a company that is freely quoted on the stock exchange - designed to approximate the weightings of the sector in the S\&P Global 1200 (Standard \& Poor's Global 1200 Index, which provides efficient exposure to the global equity market, captures approximately $70 \%$ of the global market capitalization and is constructed as a composite of 7 major indices, many of which are accepted leaders in their regions).

The FTSE4Good global index, created by FTSE International (the Financial Times Stock Exchange; the securities represented here are $70 \%$ of the London Stock Exchange market) and EIRIS (Ethical Research Services), has been designed to measure objectively the performance of companies around the world that comply with the corporate responsibility standards recognized worldwide. It is one of the world's leading indices for socially responsible investment.

The Dow Jones Global Sustainability Index (DJSI World Enlarged) tracks the performance of the top $20 \%$ of the 2,500 largest companies in the S\&P Global Broad Market Index, which lead in terms of corporate sustainability. These companies are evaluated by RobecoSAM (it is an international investment company with a specific focus on sustainability investments) using an annual corporate sustainability assessment.

The ECPI Global ESG Alpha Equity Index is made up of the 100 highest market capitalization companies and the highest in their environmental, social and governance ratings.

The designation of the most ethical companies in the world (WME - World's Most Ethical), developed by Ethisphere Institute, recognizes companies that promote ethical corporate standards and practices internally, exceed the legal minimums of compliance and shape the future standards of the industry by promoting best practices.

The MSCI World ESG Index, a member of the MSCI Global Sustainability Indexes (MSCI - Morgan Stanley Capital International), is formed by medium and large capitalization companies and offers exposure to companies with high environmental, social and government performance in relation to its peers in the sector.

Global 100 refers to the 100 most sustainable companies in the world in a sustainability equity index, maintained by the Corporate Knights advisory group and calculated by Solactive, a German index provider. 
Red dotted line: sustainability threshold. Companies above this threshold are considered sustainable. It corresponds to the p50 of the leverage CUR of the 2,675 companies analyzed.

Dashed green line: leading sustainability threshold. Companies above this threshold are considered to be leaders in sustainable development. It corresponds to the p 75 of the leverage CUR of the 2,675 companies analyzed.

\section{Annex B. Firm Leverage CUR by country and activity sector.}

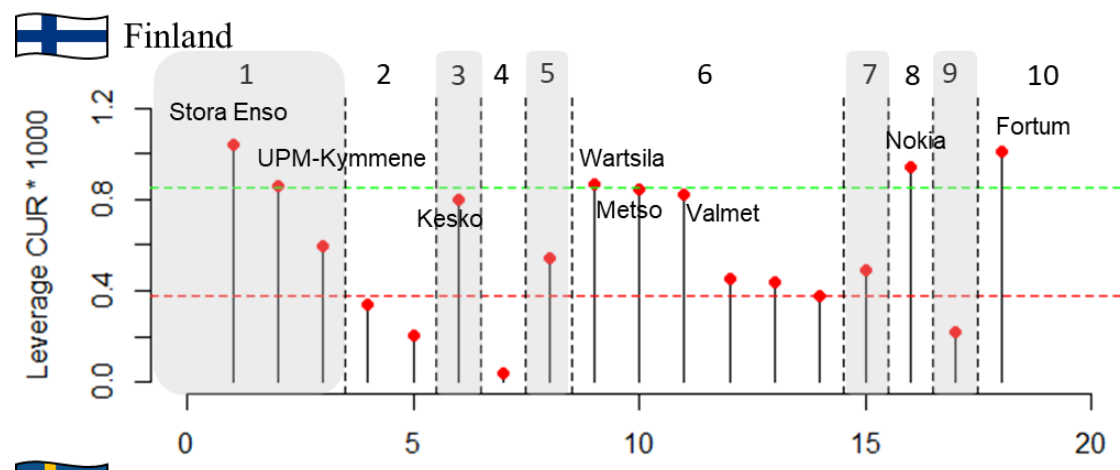

\section{Eveden}
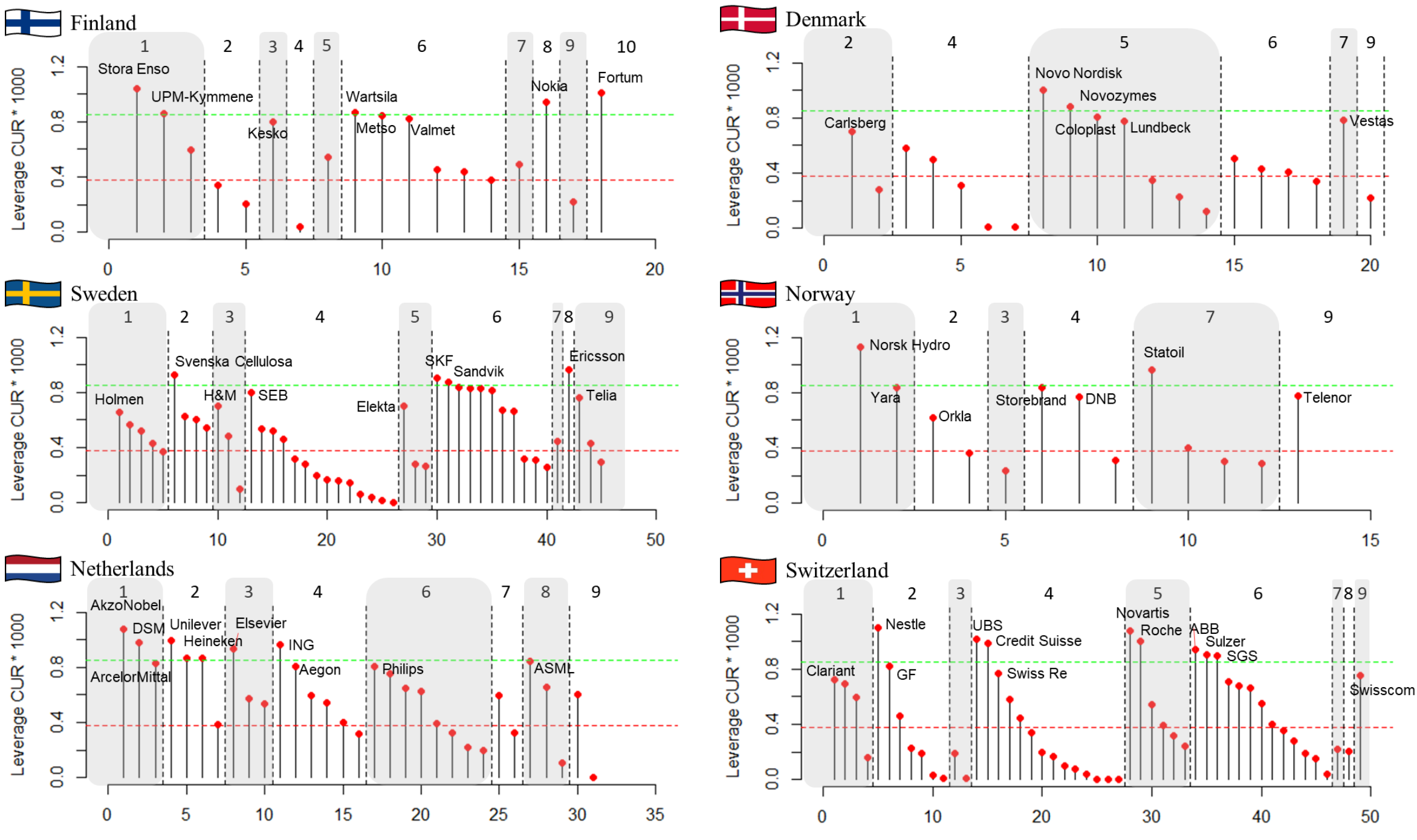
Red dotted line: sustainability threshold. Companies above this threshold are considered sustainable. It corresponds to the p50 of the leverage CUR of the 2,675 companies analyzed.

Dashed green line: leading sustainability threshold. Companies above this threshold are considered to be leaders in sustainable development. It corresponds to the p 75 of the leverage CUR of the 2,675 companies analyzed.
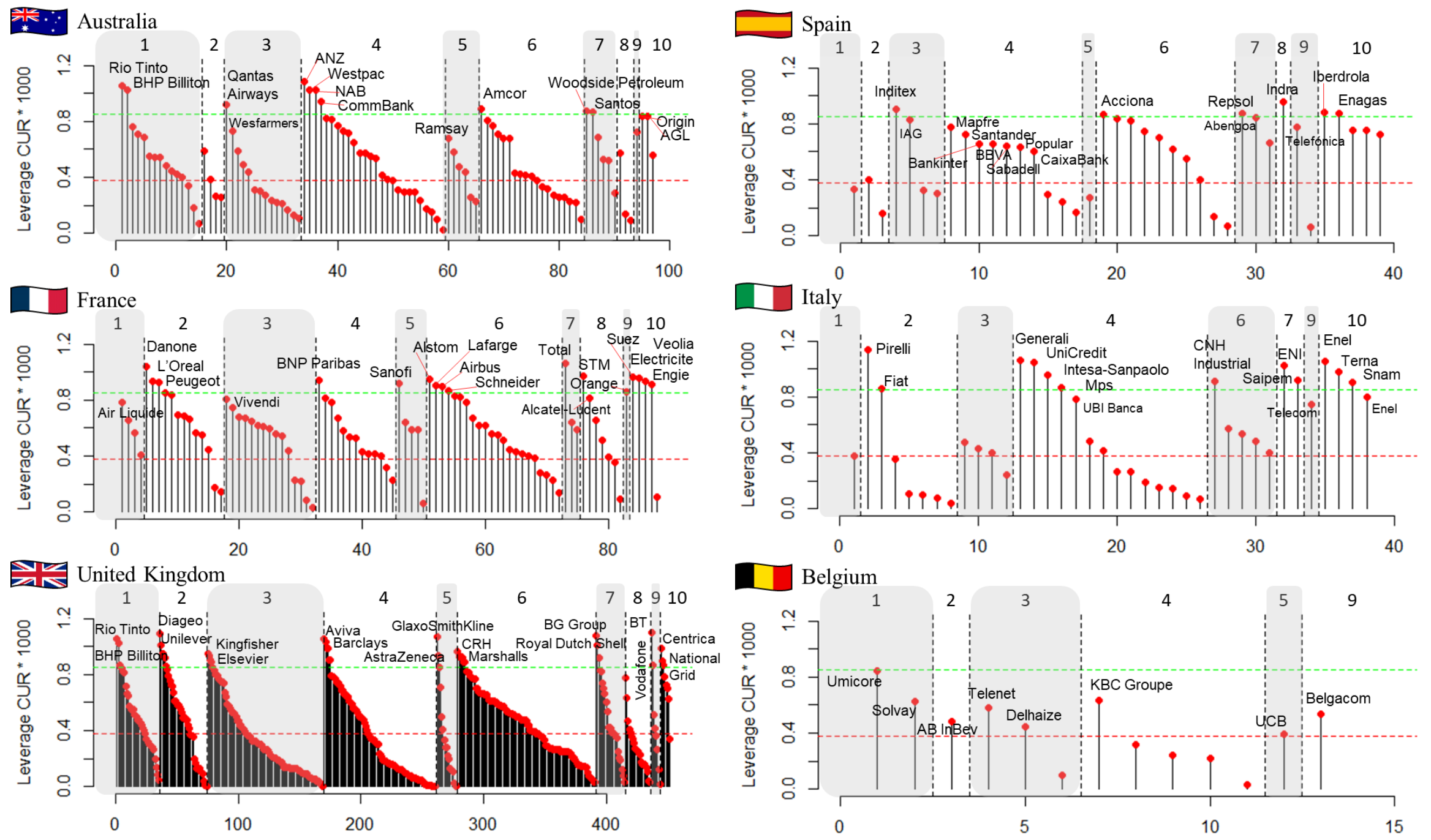
Red dotted line: sustainability threshold. Companies above this threshold are considered sustainable. It corresponds to the p50 of the leverage CUR of the 2,675 companies analyzed.

Dashed green line: leading sustainability threshold. Companies above this threshold are considered to be leaders in sustainable development. It corresponds to the p 75 of the leverage CUR of the 2,675 companies analyzed.

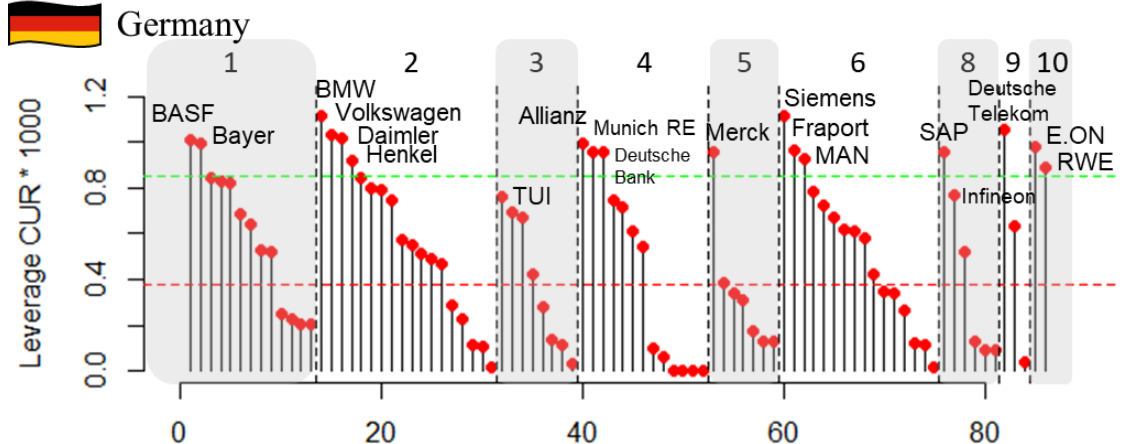

Canada
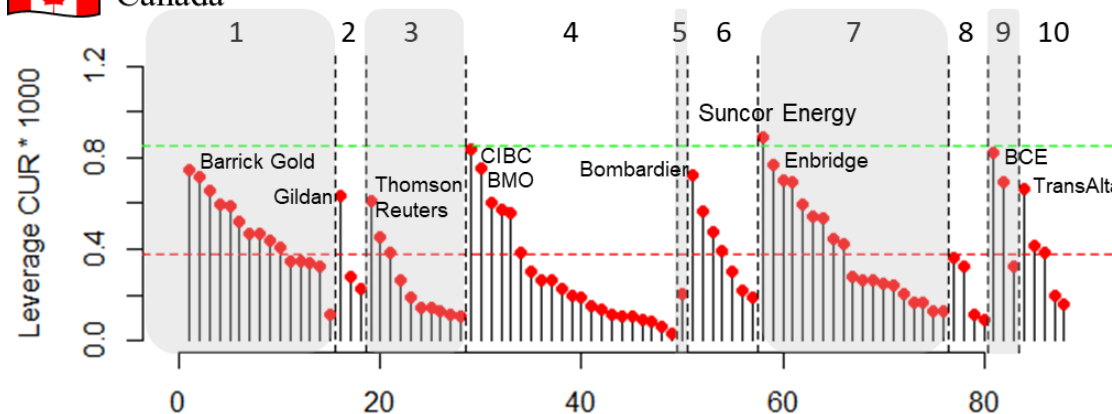

4

$\begin{array}{lll}8 & 9 & 10\end{array}$

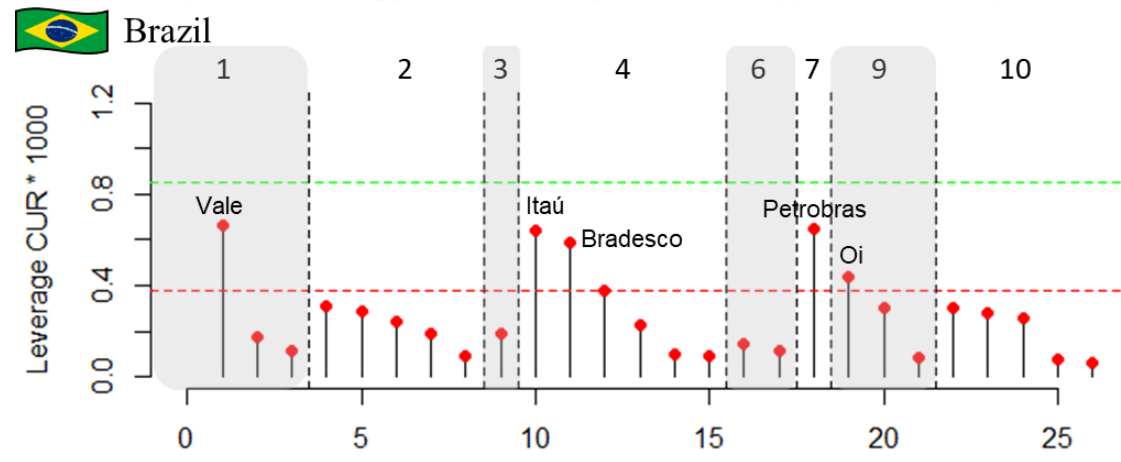

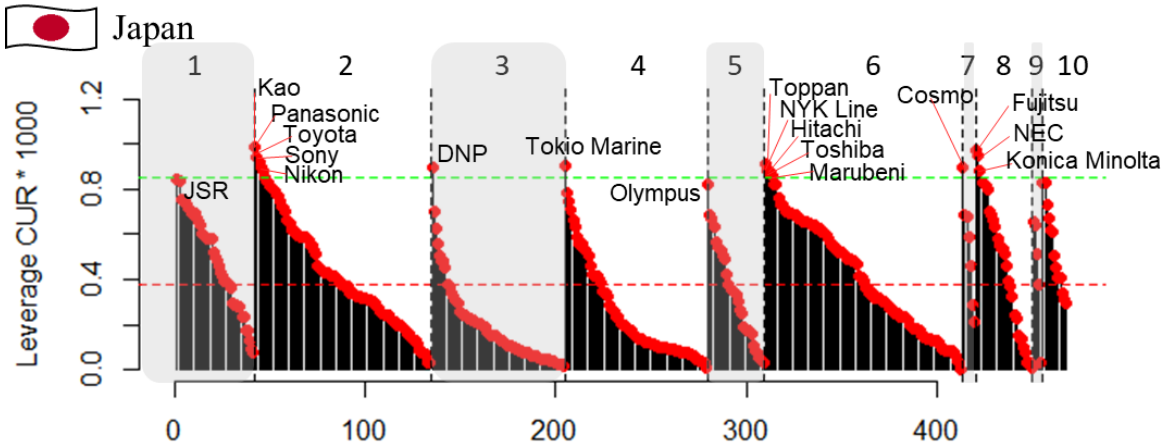

United States

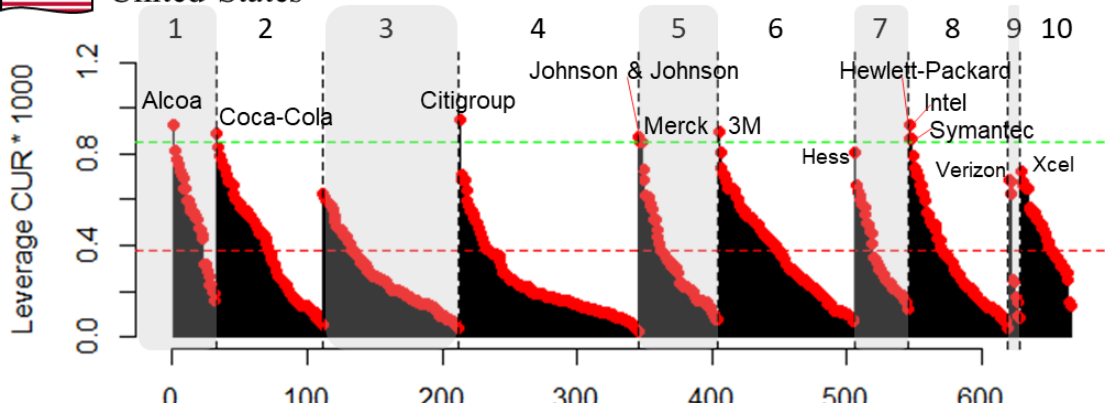

III South Korea

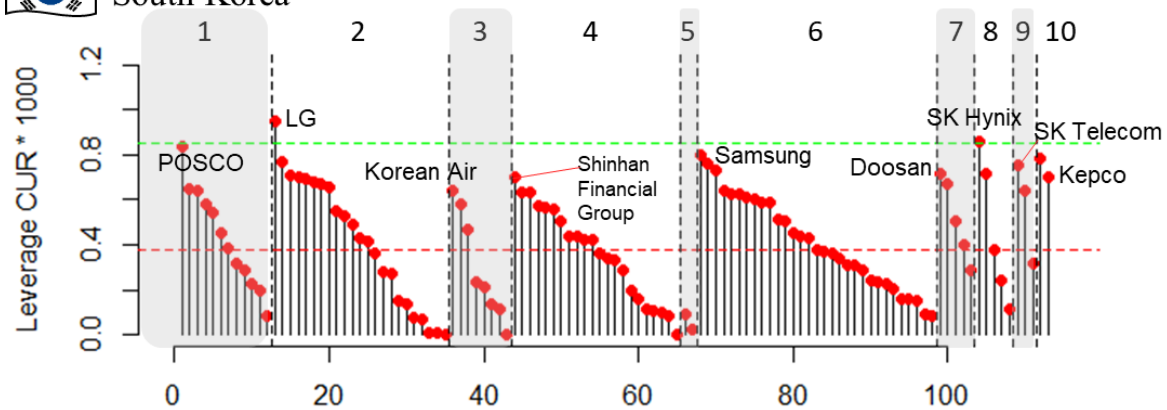


Red dotted line: sustainability threshold. Companies above this threshold are considered sustainable. It corresponds to the p50 of the leverage CUR of the 2,675 companies analyzed.

Dashed green line: leading sustainability threshold. Companies above this threshold are considered to be leaders in sustainable development. It corresponds to the p 75 of the leverage CUR of the 2,675 companies analyzed.
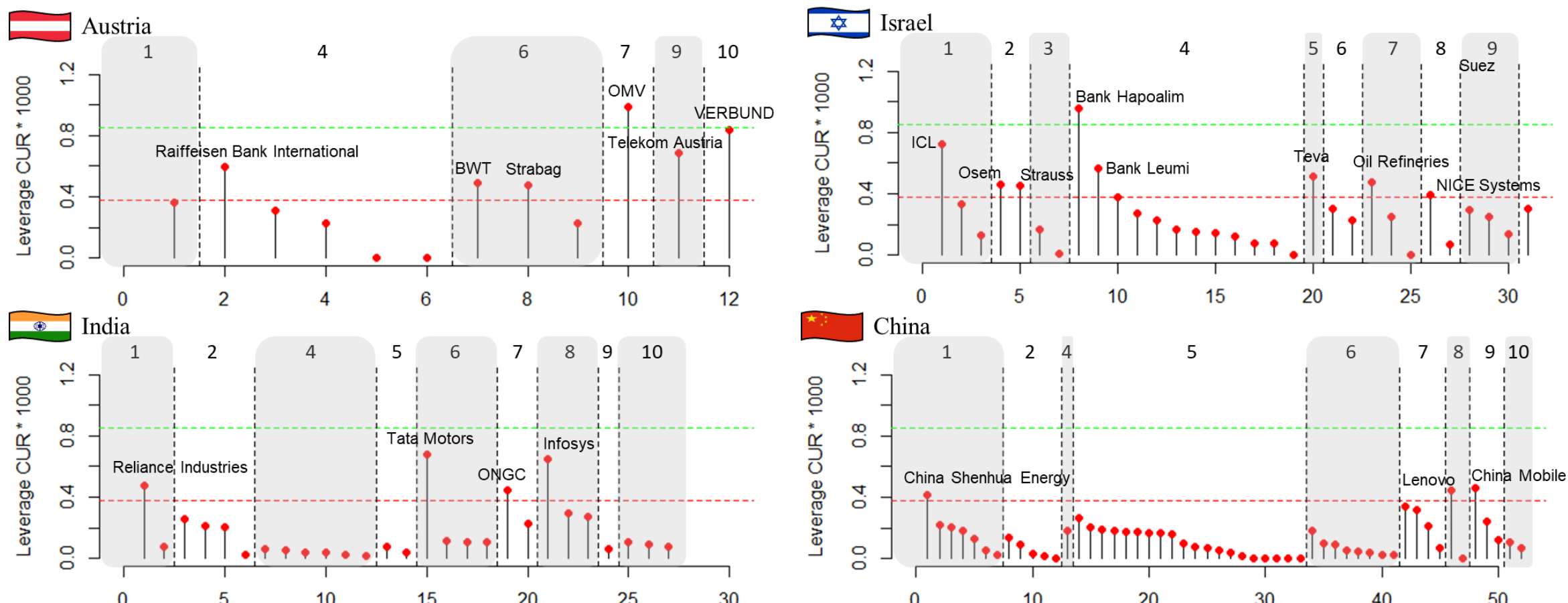

(3) Mexico
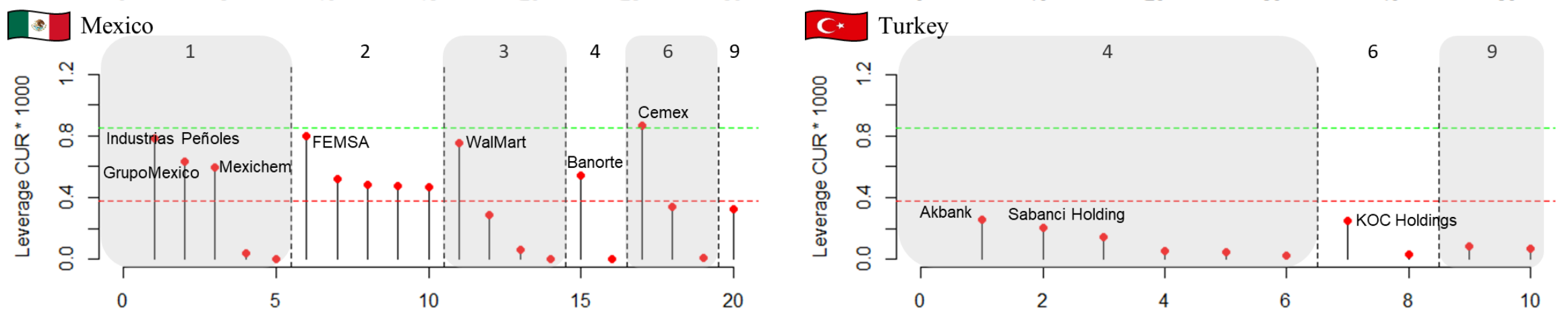
Red dotted line: sustainability threshold. Companies above this threshold are considered sustainable. It corresponds to the p50 of the leverage CUR of the 2,675 companies analyzed.

Dashed green line: leading sustainability threshold. Companies above this threshold are considered to be leaders in sustainable development. It corresponds to the p 75 of the leverage CUR of the 2,675 companies analyzed.

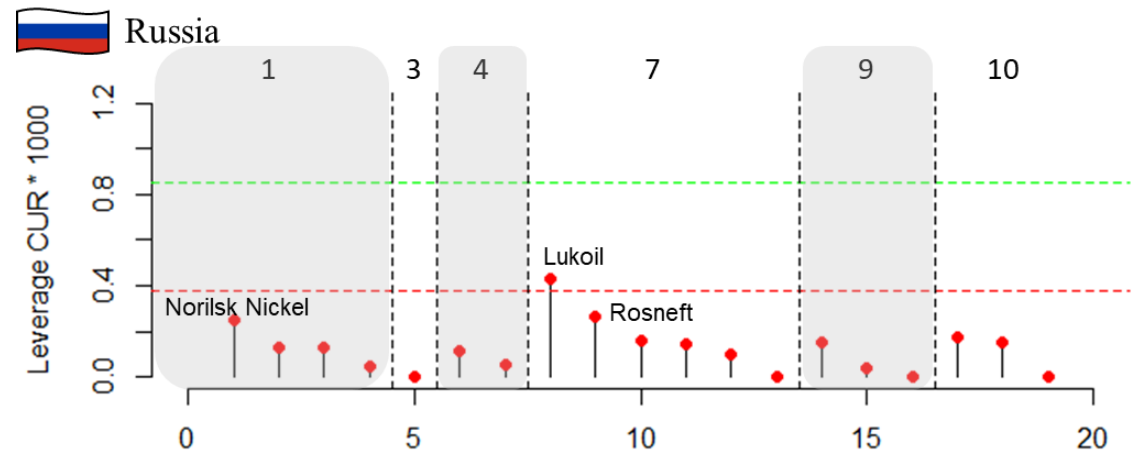

\section{(* Malaysia}

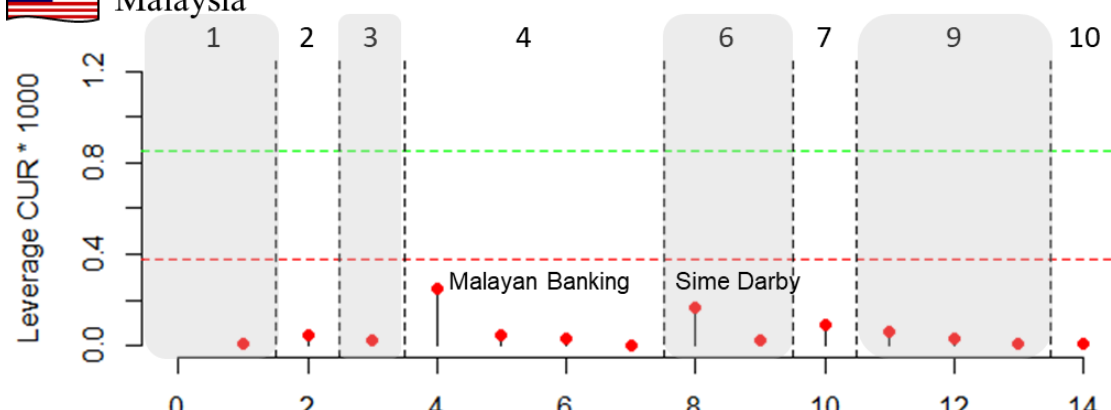

Hong Kong
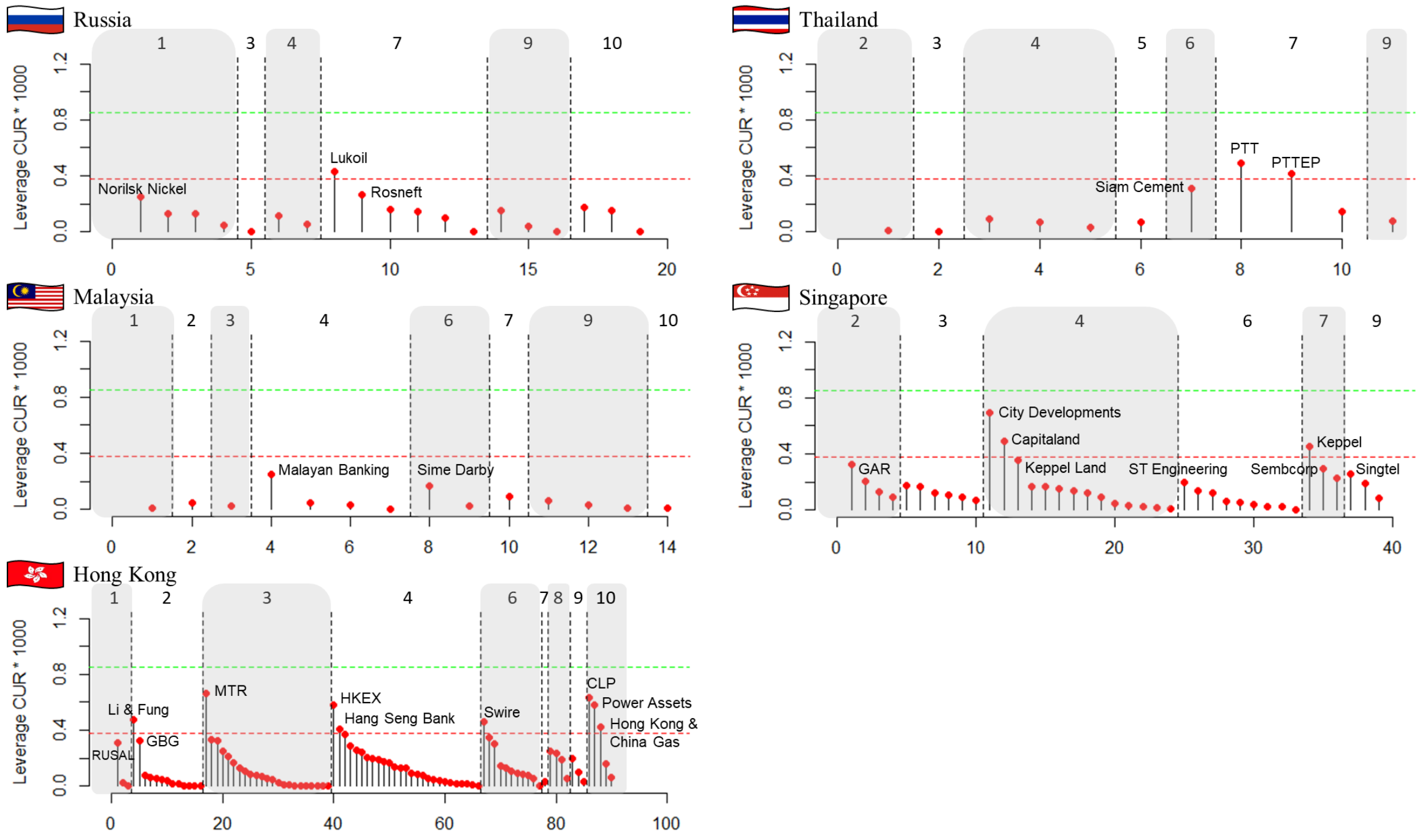
CUR Decomposition Graph:

o Red dashed line: sustainability threshold. Companies above this threshold are considered sustainable. It corresponds to the p50 of the leverage CUR of the 2,675 companies analyzed.

$o$ Green dotted line: leading sustainability threshold. Companies above this threshold are considered to be leaders in sustainable development. It corresponds to the p75 of the leverage CUR of the 2,675 companies analyzed.

\section{Annex C. Firm Leverage CUR by activity sector and solar projection graph with its values in the 27 individual CSR practices}

\section{Basic Materials}
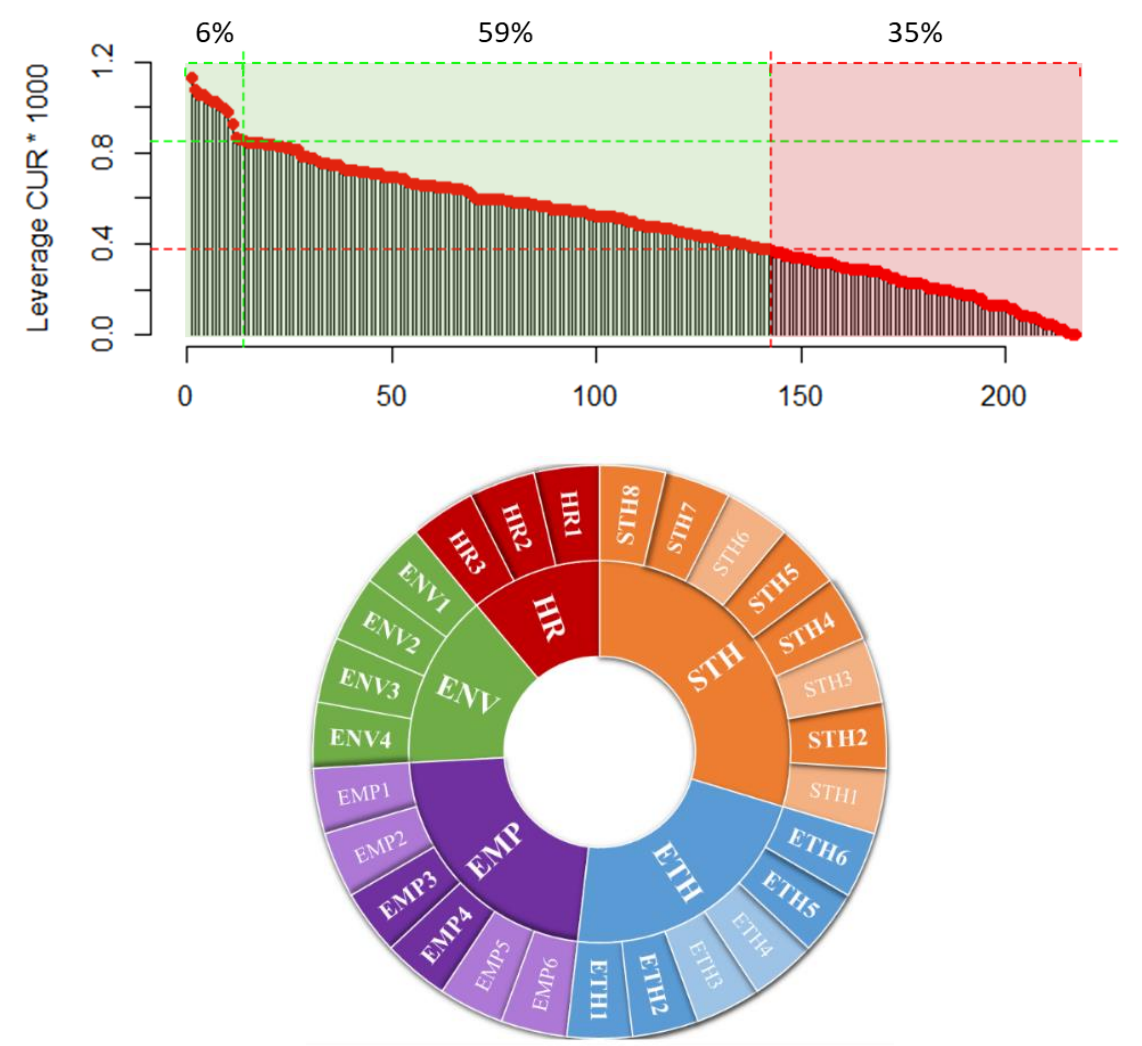

\section{Utilities}
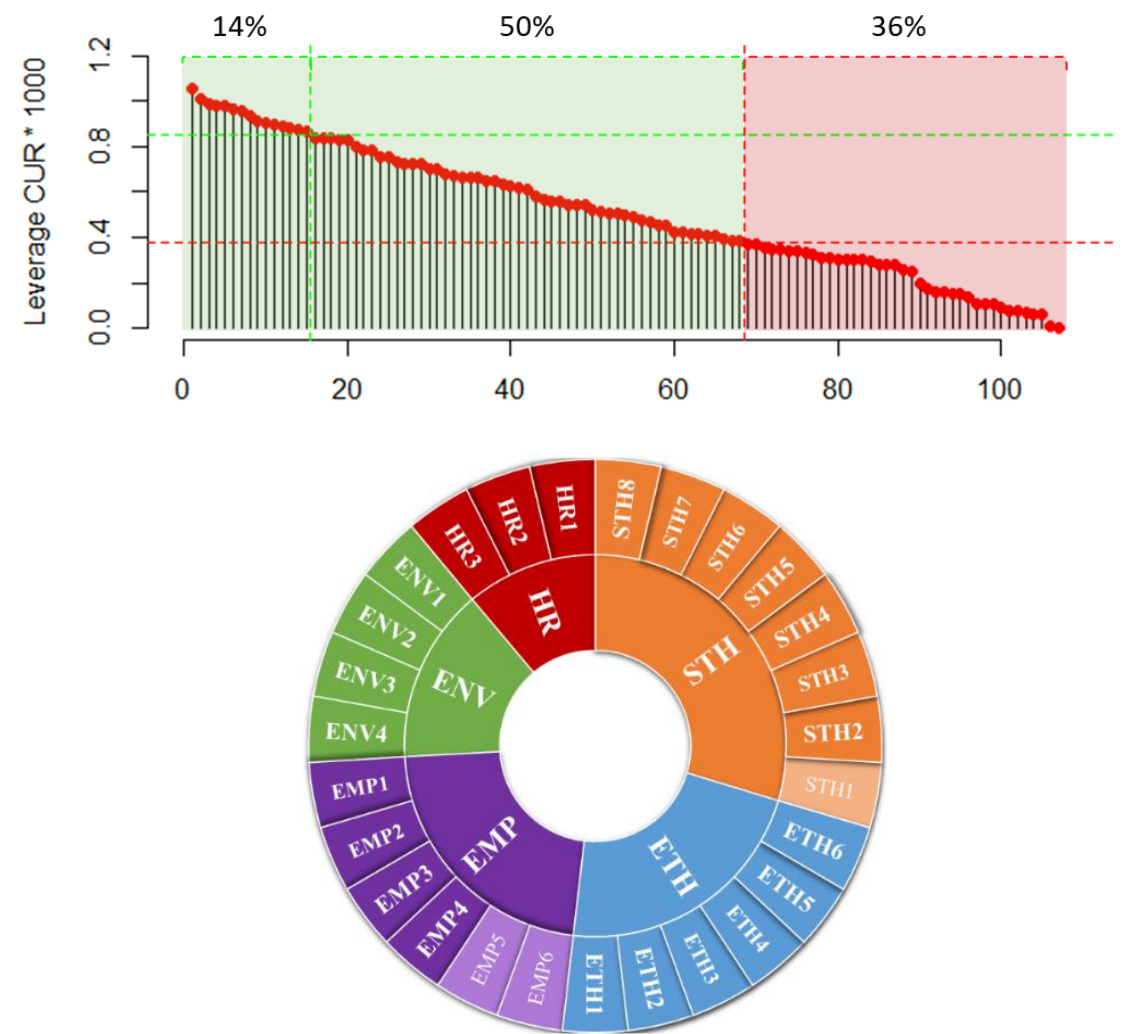

Solar Projection Graph:

We break down the joint values of each industry in relation to the 27 individual practices distinguished in 5 dimensions - Environment (ENV), Human Rights (HR),

Stakeholders (STH), Ethics (ETH) and Employees (EMP) -.

o Practice in a strong tone (same shade of color as the dimension): the values of the industry in that practice surpass the average values corresponding to the 2,675 companies.

o Practice in soft tone (color tone more clear than dimension): the values of the industry in that practice are close to the average.

o Missing practices (blank holes in the pie chart): industry values in that practice are positioned well below the average. 
CUR Decomposition Graph:

o Red dashed line: sustainability threshold. Companies above this threshold are considered sustainable. It corresponds to the p50 of the leverage CUR of the 2,675 companies analyzed.

$o$ Green dotted line: leading sustainability threshold. Companies above this threshold are considered to be leaders in sustainable development. It corresponds to the p75 of the leverage CUR of the 2,675 companies analyzed.

Oil \& Gas
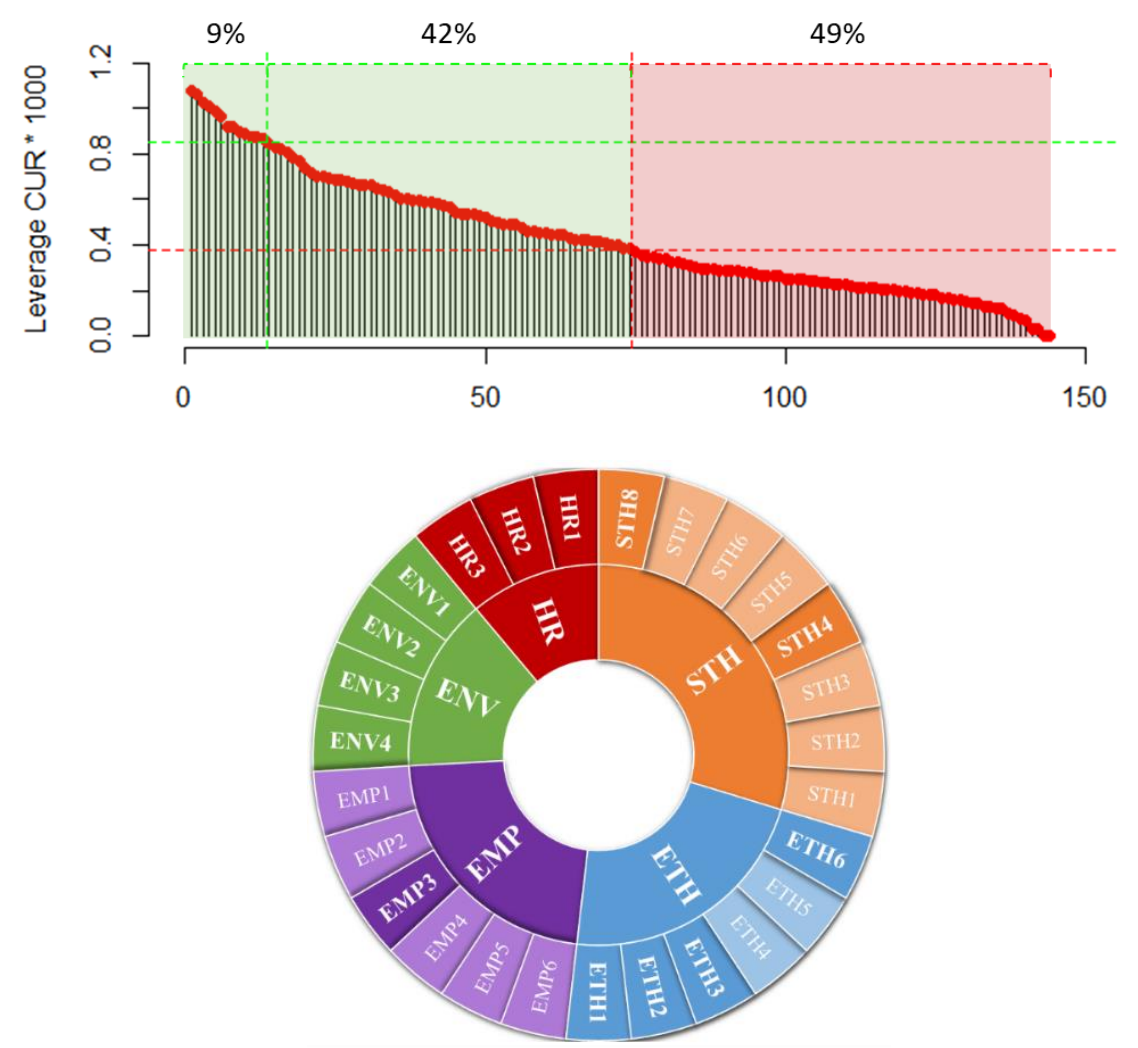

Industrials
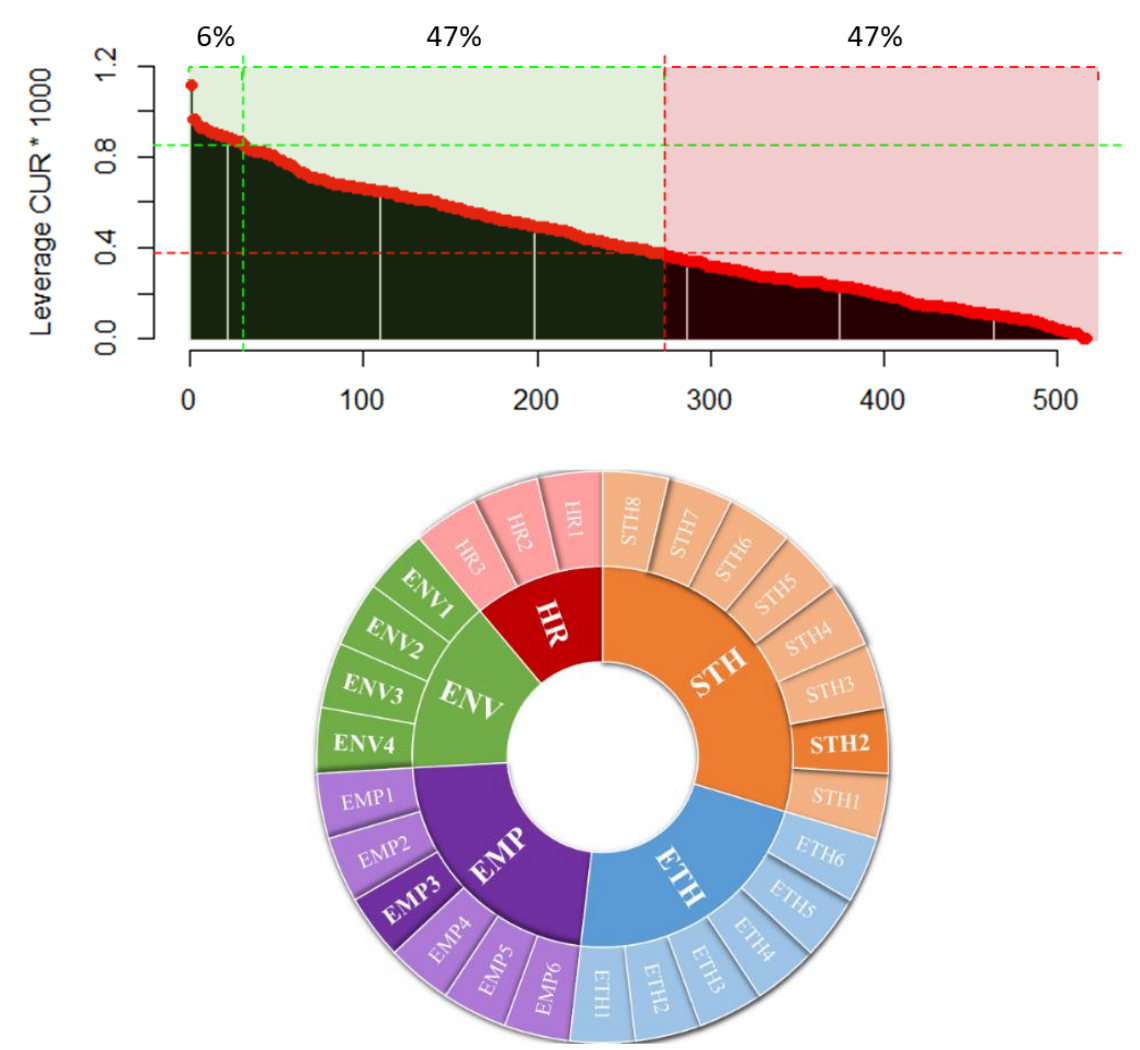

Solar Projection Graph:

We break down the joint values of each industry in relation to the 27 individual practices distinguished in 5 dimensions - Environment (ENV), Human Rights (HR),

Stakeholders (STH), Ethics (ETH) and Employees (EMP) -.

o Practice in a strong tone (same shade of color as the dimension): the values of the industry in that practice surpass the average values corresponding to the 2,675

companies.

o Practice in soft tone (color tone more clear than dimension): the values of the industry in that practice are close to the average.

$o$ Missing practices (blank holes in the pie chart): industry values in that practice are positioned well below the average. 
CUR Decomposition Graph:

o Red dashed line: sustainability threshold. Companies above this threshold are considered sustainable. It corresponds to the p50 of the leverage CUR of the 2,675 companies analyzed.

$o$ Green dotted line: leading sustainability threshold. Companies above this threshold are considered to be leaders in sustainable development. It corresponds to the p75 of the leverage CUR of the 2,675 companies analyzed.

\section{Consumer Goods}
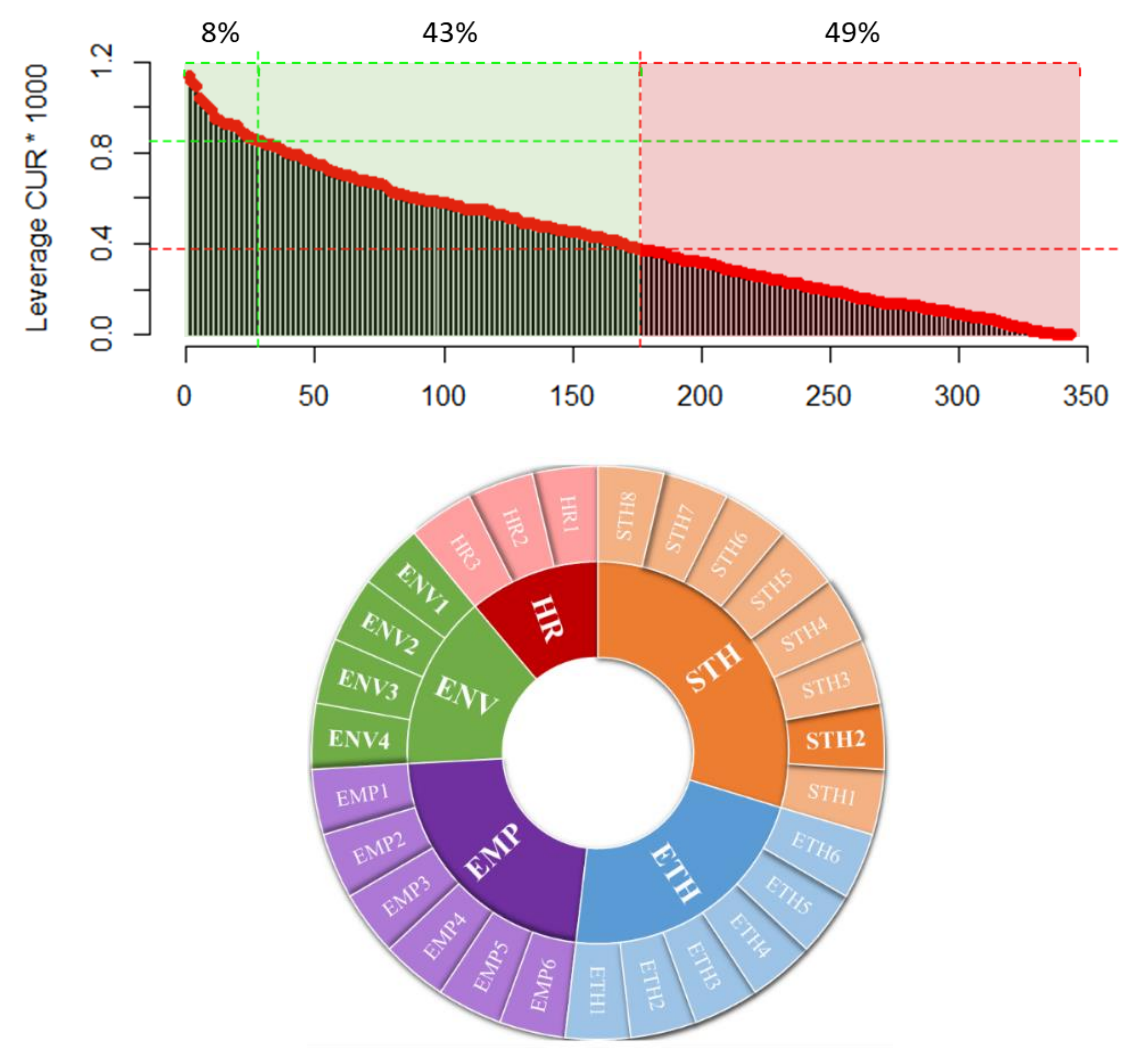

Technology
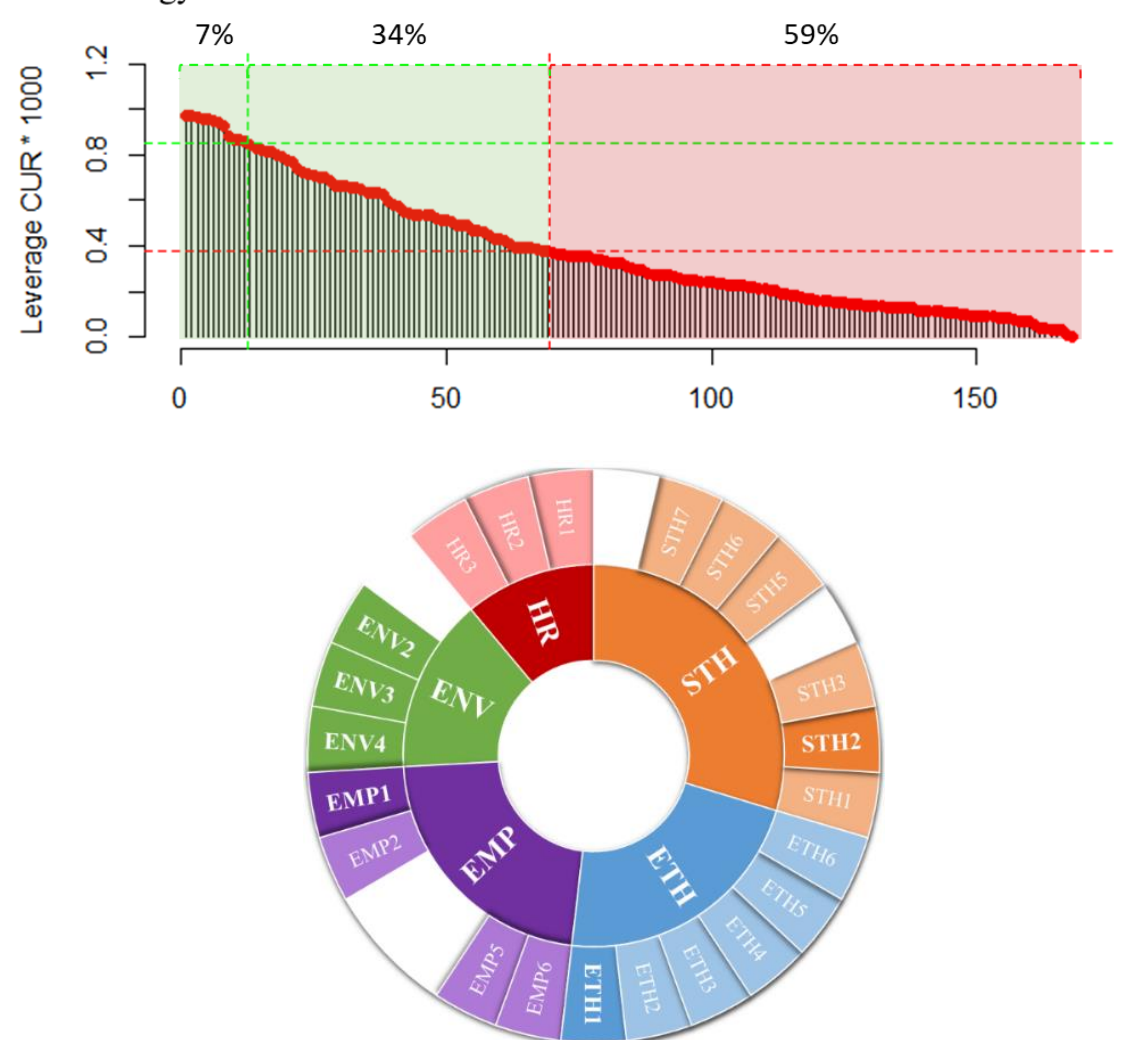

Solar Projection Graph:

We break down the joint values of each industry in relation to the 27 individual practices distinguished in 5 dimensions - Environment (ENV), Human Rights (HR),

Stakeholders (STH), Ethics (ETH) and Employees (EMP) -.

o Practice in a strong tone (same shade of color as the dimension): the values of the industry in that practice surpass the average values corresponding to the 2,675

companies.

o Practice in soft tone (color tone more clear than dimension): the values of the industry in that practice are close to the average.

$o$ Missing practices (blank holes in the pie chart): industry values in that practice are positioned well below the average. 
CUR Decomposition Graph:

o Red dashed line: sustainability threshold. Companies above this threshold are considered sustainable. It corresponds to the p50 of the leverage CUR of the 2,675 companies analyzed.

$o$ Green dotted line: leading sustainability threshold. Companies above this threshold are considered to be leaders in sustainable development. It corresponds to the p75 of the leverage CUR of the 2,675 companies analyzed.

\section{Health Care}
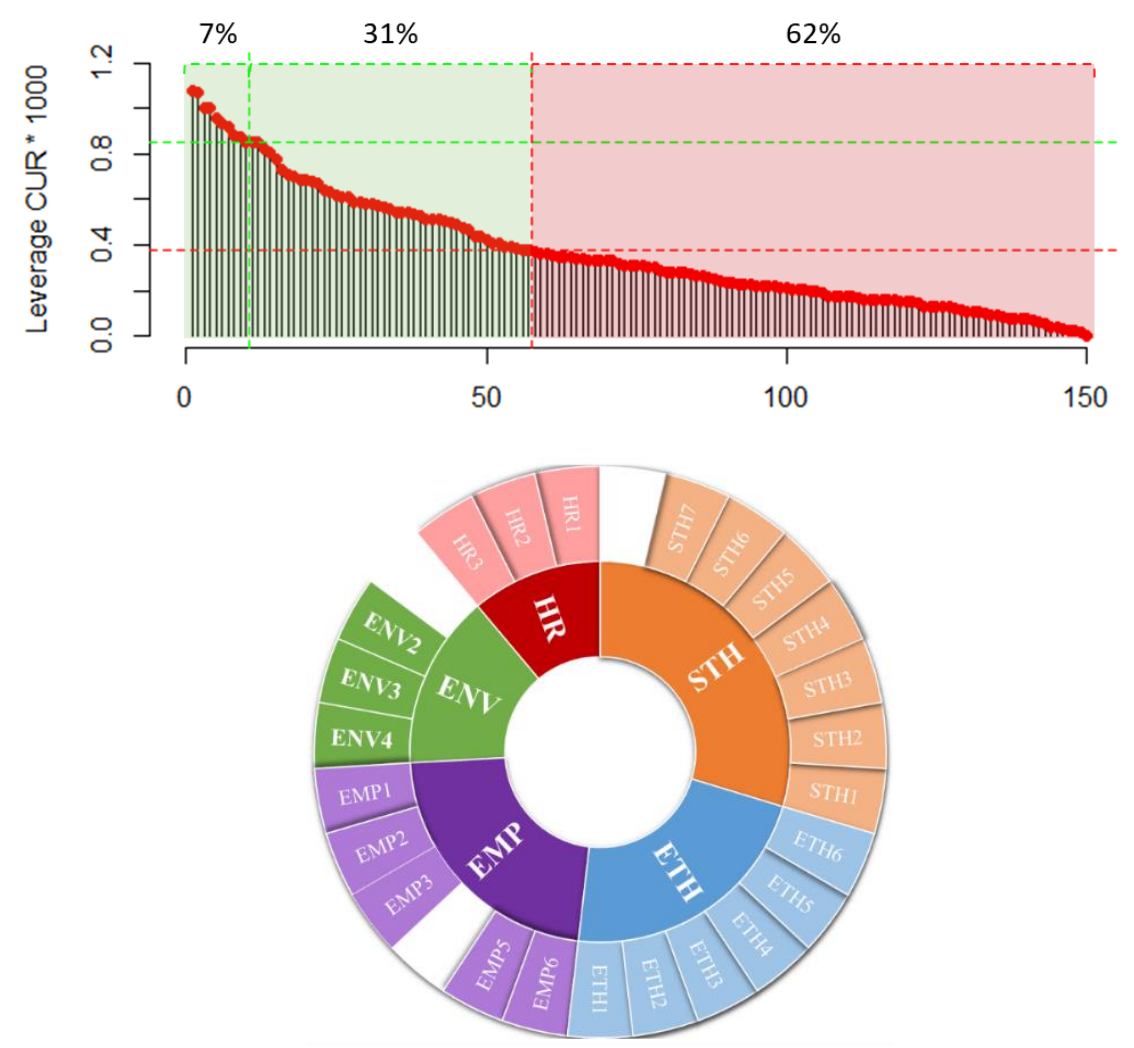

Telecommunications
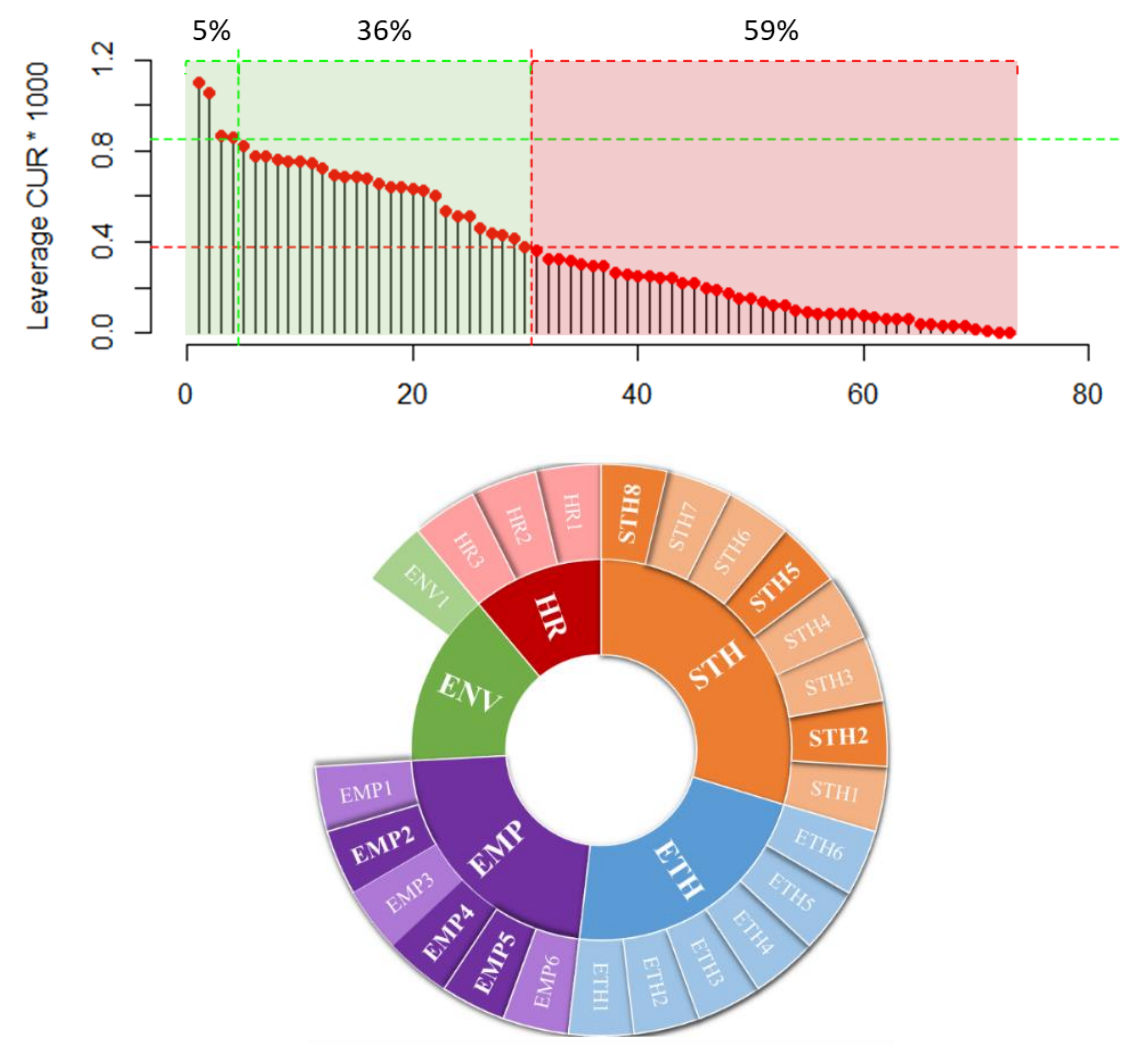

Solar Projection Graph:

We break down the joint values of each industry in relation to the 27 individual practices distinguished in 5 dimensions - Environment (ENV), Human Rights (HR),

Stakeholders (STH), Ethics (ETH) and Employees (EMP) -.

o Practice in a strong tone (same shade of color as the dimension): the values of the industry in that practice surpass the average values corresponding to the 2,675

companies.

o Practice in soft tone (color tone more clear than dimension): the values of the industry in that practice are close to the average.

$o$ Missing practices (blank holes in the pie chart): industry values in that practice are positioned well below the average. 
CUR Decomposition Graph:

o Red dashed line: sustainability threshold. Companies above this threshold are considered sustainable. It corresponds to the p50 of the leverage CUR of the 2,675 companies analyzed.

$o$ Green dotted line: leading sustainability threshold. Companies above this threshold are considered to be leaders in sustainable development. It corresponds to the p75 of the leverage CUR of the 2,675 companies analyzed.

\section{Financials}
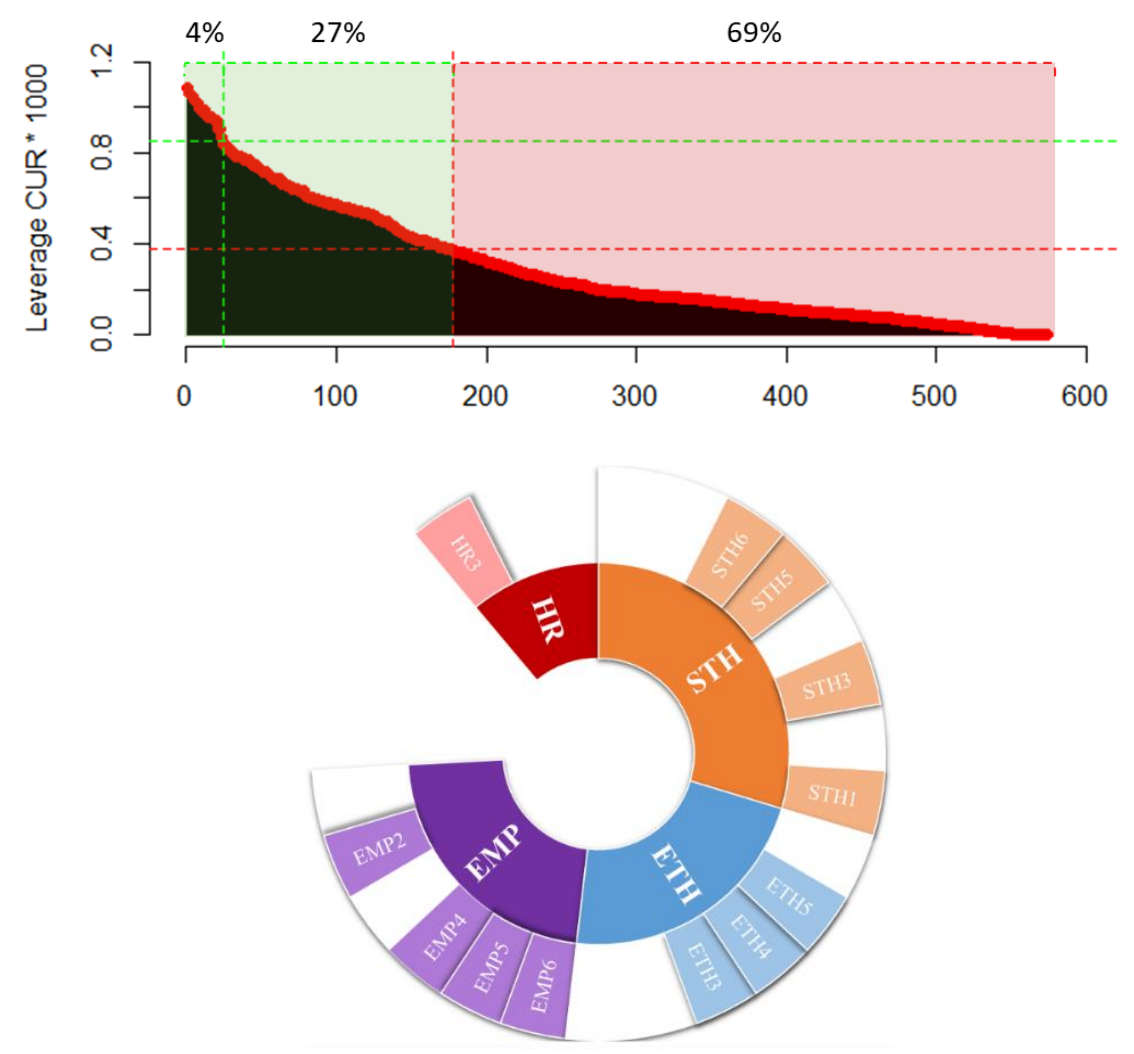

Consumer Services
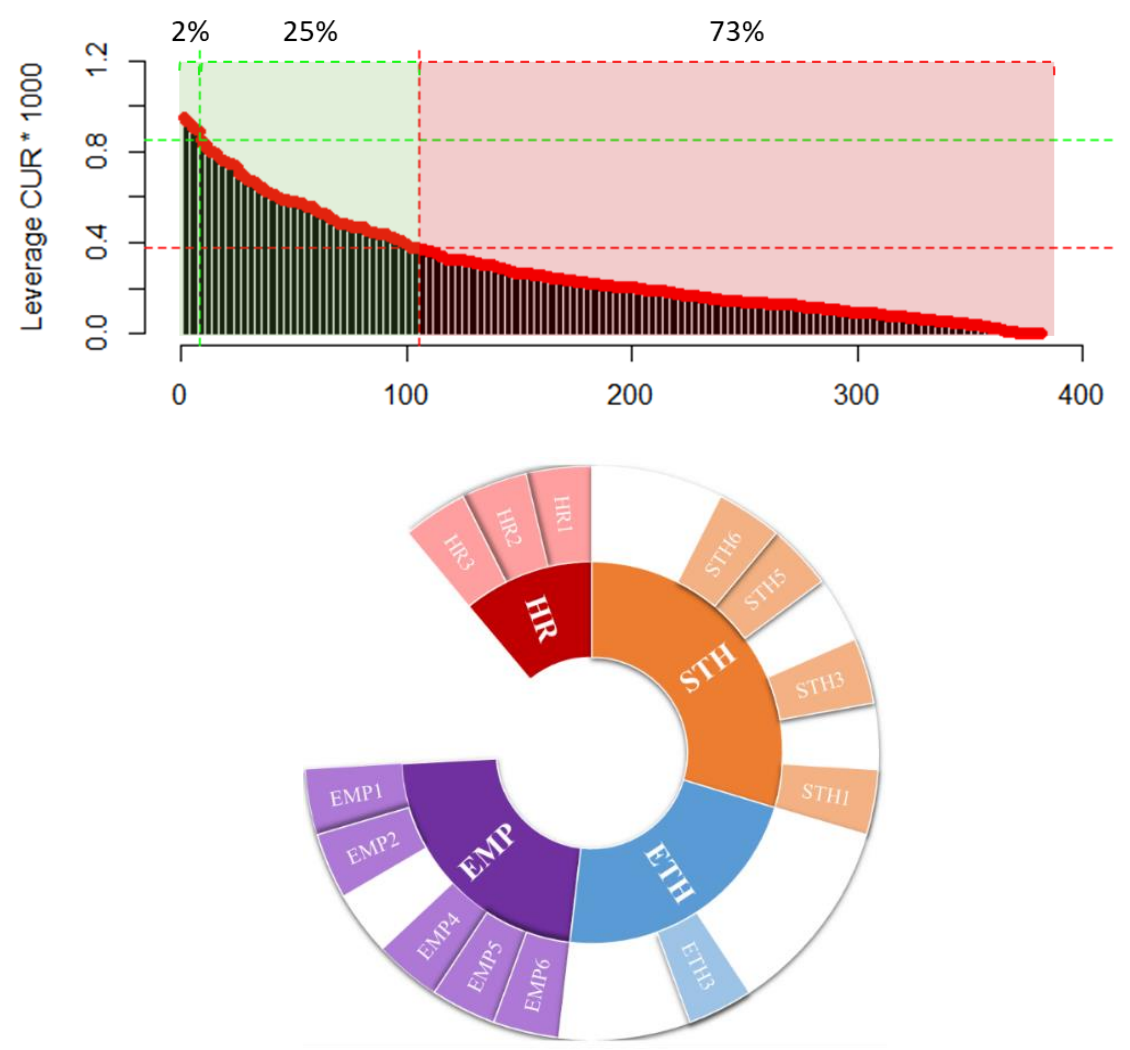

Solar Projection Graph:

We break down the joint values of each industry in relation to the 27 individual practices distinguished in 5 dimensions - Environment (ENV), Human Rights (HR),

Stakeholders (STH), Ethics (ETH) and Employees (EMP) -.

o Practice in a strong tone (same shade of color as the dimension): the values of the industry in that practice surpass the average values corresponding to the 2,675

companies.

o Practice in soft tone (color tone more clear than dimension): the values of the industry in that practice are close to the average.

$o$ Missing practices (blank holes in the pie chart): industry values in that practice are positioned well below the average. 




\section{Conclusiones}

1. En esta investigación se evalúan los patrones del comportamiento empresarial sostenible a nivel internacional y su evolución dentro de la década 2004-2014, con empresas pertenecientes a todos los sectores de actividad. Tras la exhaustiva revisión bibliográfica llevada a cabo sobre estudios de Responsabilidad Social Corporativa (RSC), se pone de manifiesto una clara discordancia entre el crecimiento de las técnicas estadísticas multivariantes para la inspección de datos de tres vías y su uso en estas investigaciones, a pesar de que claramente los datos presentan esa estructura: empresas - prácticas sostenibles años de estudio. Este trabajo rellena pues, un vacío en la literatura mediante la adopción de un enfoque multivariante a partir de un análisis institucional comparativo.

2. Las empresas de todo el mundo adoptan patrones similares de prácticas de RSC, pero su grado de desarrollo está fuertemente determinado por las características institucionales. Un macro contexto con fuertes presiones normativas y coercitivas mejora las prácticas de RSC; países regidos por el derecho civil y con una orientación hacia la protección de las partes interesadas, ponen mayor énfasis en temas sostenibles. Las compañías que actúan en sociedades colectivistas y, más aún en las feministas, muestran las mejores prácticas de RSC.

3. Las organizaciones que operan en contextos nacionales similares, es decir, en entornos con características institucionales parejas adoptan un comportamiento empresarial homogéneo en términos de RSC. Este proceso, denominado 'isomorfismo normativo' en referencia a valores culturales análogos e 'isomorfismo coercitivo' en relación a sistemas legales equivalentes, mejora la estabilidad, la supervivencia de la empresa y la legitimidad institucional.

4. El compromiso empresarial sostenible está positivamente ligado con el desarrollo y la orientación de los sistemas legales nacionales hacia los derechos laborales. Los países de América del norte priorizan las cuestiones éticas, muy por detrás de los europeos. En Asia, Japón es el país con mejores prácticas, únicamente preocupado por el medioambiente. El compromiso más bajo y las peores prácticas se localizan en los países del sudeste de Asia. Los países europeos son los líderes de este compromiso.

5. El isomorfismo mimético es adoptado por compañías con baja tolerancia a la incertidumbre que, en lugar de diseñar un plan de acción propio, deciden imitar las prácticas comerciales de aquellas compañías líderes y reputadas, considerando que la simple imitación conduce a la legitimación social de sus actividades.

6. El sector de actividad se corrobora como el factor institucional con mayor capacidad explicativa en las prácticas de RSC, ya que, los grupos de interés y la sociedad en general perciben distintos riesgos sociales y ambientales según la actividad económica desarrollada por las empresas. 
7. Las empresas líderes en compromiso sostenible pertenecen a sectores con mayores riesgos ambientales, como las dirigidas a materias básicas, servicios públicos, productores de petróleo y gas, o todo lo relacionado con los productos industriales. Estas empresas adoptan políticas de RSC más codificadas y explícitas focalizadas en las prácticas ambientales, sistemas e informes de derechos humanos, salud y seguridad de sus empleados y, participación y responsabilidad de sus grupos de interés. Debido a la presión social de divulgar malas noticias ambientales, se adhieren a las políticas de RSC demostrando que su compromiso va más allá de los niveles establecidos por la normativa, con el fin de alcanzar objetivos sociales vitales como el prestigio o una buena reputación.

8. Las empresas procedentes de sectores menos contaminantes como servicios financieros, telecomunicaciones o servicios al consumidor, se ven menos afectadas por la opinión pública y, por ende, son menos competitivas en términos de prácticas sostenibles. En estos sectores las preocupaciones sociales superan las ambientales.

9. En esta investigación se ha propuesto un índice nacional y un índice sectorial de prácticas de responsabilidad social corporativa que determinan la penetración de la RSC, proporcionando una comprensión holística del desarrollo de la RSC y sus raíces nacionales y sectoriales. Las discrepancias entre sus puntuaciones se estudian en relación a la idoneidad institucional del contexto en el que operan, de modo que, cuanto mayor sea el valor del índice, más apropiado será el entorno del país o sector para las prácticas de RSC.

10. Estos hallazgos son útiles para reforzar el conocimiento de las variaciones en las prácticas y el nivel de RSC en diferentes contextos institucionales a nivel internacional. La disponibilidad de estos datos permite la identificación de los impulsores estructurales de crecimiento y el establecimiento de prioridades que permitan el diseño de políticas más efectivas para el desarrollo sostenible de la empresa. Estos conocimientos permiten a las empresas que comienzan a operar en una nueva industria conocer los estándares mínimos de RSC que deben respetar o las presiones existentes de esos mercados extranjeros en los que deciden diversificar sus actividades comerciales.

11. En un lenguaje asequible para los investigadores del campo de la sostenibilidad mundial, priorizando los resultados visuales, el estudio comparado entre los métodos de análisis de datos de tres vías X-STATIS, X-STATICO, CO-X-STATIS, Tucker3 y MetaBiplot, ha permitido poner de manifiesto las ventajas y limitaciones de estas técnicas y, simultáneamente proporcionar soluciones de gran impacto social en un tema de trascendencia a nivel internacional. Además, se ha propuesto el uso de la descomposición CUR como una técnica novedosa para el reconocimiento del comportamiento sostenible de la empresa, corroborando su fiabilidad para la identificación de las empresas punteras en desarrollo sostenible. 


\section{Conclusions in English}

1. In this research, the patterns of sustainable business behaviour in the international level and their evolution within the 2004-2014 decade are evaluated, with companies belonging to all sectors of the activity. After an exhaustive literature review carried out on Corporate Social Responsibility (CSR) studies, a clear mismatch is found between the growth of multivariate statistical techniques for the inspection of three-way data and its use in these investigations, although clearly the data presents that structure: companies - sustainable practices - years of study. This work fills an existing gap in the literature by adopting a multivariate approach based on a comparative institutional analysis.

2. Companies around the world adopt similar patterns of CSR practices, but their degree of development is strongly determined by the institutional characteristics. A macro context with strong normative and coercive pressures improves CSR practices; countries governed by civil law and with an orientation towards the stakeholders protection place greater emphasis on sustainable topics. Companies that act in collective societies, and even more in pro-feminists, show the best CSR practices.

3. Organizations that operate in similar national contexts, that is, in environments with similar institutional characteristics, adopt a homogenous business behaviour in CSR terms. This process, called 'normative isomorphism' in reference to analogous cultural values and 'coercive isomorphism' in relation to equivalent legal systems, improves the stability, the survival of the company and the institutional legitimacy.

4. Sustainable business commitment is positively linked to the development and orientation of national legal systems towards labour rights. The countries of North America prioritize ethical issues, far behind Europeans. In Asia, Japan is the country with best practices, only concerned about the environment. The lowest commitment and the worst practices are located in the countries of Southeast Asia. The European countries are the leaders of this commitment.

5. The mimetic isomorphism is adopted by companies with low tolerance to uncertainty that, instead of designing their own action plan, decide to imitate the commercial practices of those leading and reputed companies, considering that the simple imitation leads to the social legitimization of their activities.

6. The activity sector is corroborated as the institutional factor with the greatest explanatory capacity in CSR practices, since interest groups and society in general perceive different social and environmental risks according to the economic activity developed by the companies. 
7. The leading companies in sustainable commitment belong to sectors with greater environmental risks, as those aimed at basic materials, utilities, oil and gas producers or everything related to industrial products. These companies adopt more codified and explicit CSR policies focused on environmental practices, systems and reports on human rights, health and safety of their employees and, participation and responsibility of their stakeholders. Due to social pressure to disclose bad environmental news, adhere to CSR policies demonstrating that their commitment goes beyond the levels established by the regulations, in order to achieve vital social objectives such as prestige or a good reputation.

8. Companies from less polluting sectors such as financial services, telecommunications or consumer services, are less affected by public opinion and, therefore, are not as competitive in terms of sustainable practices. In these sectors, social concerns overcome environmental concerns.

9. This research has proposed a national index and a sectoral index of corporate social responsibility practices that determine the CSR penetration, providing a holistic understanding of the CSR development and their national and sectoral roots. The discrepancies between their scores are studied in relation to the institutional suitability of the context in which they operate, so that, the higher the value of the index, the more appropriate the environment of the country or sector for CSR practices will be.

10. These findings are useful to reinforce the knowledge of the variations in the practices and the level of CSR in different institutional contexts at the international level. The availability of these data allows the identification of the structural drivers of growth and the establishment of priorities that allow the design of more effective policies for the sustainable development of the company. This knowledge allows companies that start operating in a new industry to know the minimum standards of CSR that they must respect or the existing pressures of those foreign markets in which they decide to diversify their commercial activities.

11. In a practical language to researchers in the field of global sustainability, prioritizing visual results, the comparative study between three-way data analysis methods X-STATIS, XSTATICO, CO-X-STATIS, Tucker3 and MetaBiplot, has made it possible to highlight the advantages and limitations of these techniques and, simultaneously, provide solutions of great social impact in a topic of international importance. In addition, the use of the CUR decomposition as a novel technique for the recognition of the sustainable behaviour of the company has been proposed, corroborating its reliability for the identification of the leading companies in sustainable development. 

